THE INVASION OF NEPAL.

John Company at War $1814-1816$.

by

John Pemble. 
ProQuest Number: 10752690

All rights reserved

INFORMATION TO ALL USERS

The quality of this reproduction is dependent upon the quality of the copy submitted.

In the unlikely event that the author did not send a complete manuscript and there are missing pages, these will be noted. Also, if material had to be removed, a note will indicate the deletion.

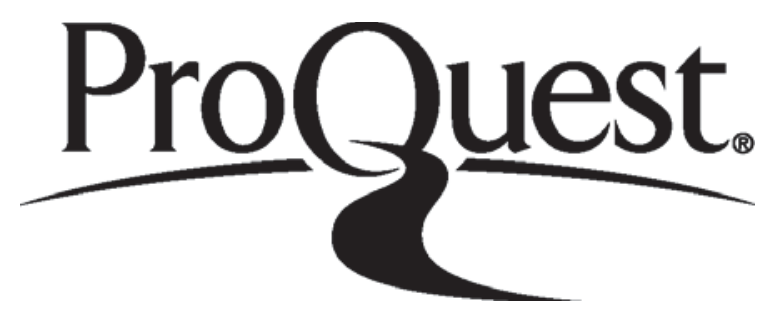

ProQuest 10752690

Published by ProQuest LLC (2018). Copyright of the Dissertation is held by the Author.

All rights reserved.

This work is protected against unauthorized copying under Title 17, United States Code Microform Edition (C) ProQuest LLC.

ProQuest LLC.

789 East Eisenhower Parkway

P.O. Box 1346

Ann Arbor, Ml $48106-1346$ 
A Thesis submitted for the degree of Doctor of Philosophy in the University of London, June, 1968. 
Abstract

The Nepal War symbolized an attempt by the East India Company to preserve its territorial income and to end the anarchy which the collapse of the Mogul empire had engendered in north India, by asserting the rights it had inherited from the Mogul vassals. The attempt involved a war against Nepal because the Gurkha dynasty, having already profited by the prevailing chaos to extend its domination over the whole of the eastern Himalayan region, had an interest in the perpetuation of that anarchy. The War did not symbolize an attempt by the East India Company to open the trans-Himalayan countries to British trade. It came about at a time when the Company's old interest in trade with Tibet had been replaced by a paramount concern to propitiate China. As both Nepal and Tibet were now theoretically Chinese vassals, the War was fought not because of, but in spite of a concern to avoid, Himalayan policies of the old type. From a military point of view, the War is interesting because it shows the Bengal army in operation at the beginning of a new stage in its existence: a stage marked on the one hand by a process of structural rationalization, and on the other by the increasing involvement in remote and difficult theatres of war produced by the establishment of British paramountcy in north India. With its inchoate commissariat, intelligence, and organizational machinery, and its new responsibilities, the army required exceptional qualities in its officers. This War eloquently demonstrated the type of leader that the army now needed; but at the same time it revealed that this was the type of leader it was incapable of producing. Humiliating setbacks were suffered as a result of inept command. out of the four Company major-generals employed, three were dismissed for professional incompetence; and of the three commanders who can be called successful, only one was a Company officer. This was Ochterlony, and even he would have had no opportunity to exercise his talents had it not been for the unforeseeable death of Gillespie, a King's officer. The deterioration of the quality of command was a consequence of the parsimonious application of the system of seniority advancement. None of the dismissed generals was pensioned, and each was subsequently promoted. Ochterlony, because he was a few years their junior, was never promoted, and by the time he died, nine years after the War, was liable to be commanded by both the officers he had, during the course of the War, been appointed to supersede. 
CONTENTS

Part 1

Chapter One: The Growth of the Gurkha Empire page 6

Chapter Two: The Quarrel with the British 36

Chapter Three: The Matter of Himalayan Trade 66

Chapter Four: The Bengal Army 109

Chapter Five: Preparations for War 153

Part 11

Chapter Six: Fiasco in Garhwal

Chapter Seven: Stagnation in Sirmur 216

Chapter Eight: The Collapse of the Eastern offensives

Chapter Nine: The Triumph of Ochterlony 324

Chapter Ten: The Conquest of Kumaun 376

Chapter Eleven: Interlude 407

Chapter Twelve: The Final Campaign 425

Part 111

Epilogue

Appendix: Treaty of Peace between the Honourable East India Company and Maharaja Bikram Shah, Rajah of INipal

Reference Notes

Bibliography

Maps: a) North India in 1814.

b) Sketch Hap to illustrate the Operations in Garhwal \& Sirmur in 1814 and 1815

c) Shetch Map to illustrete the Campaigns in the Eastern theatre in 1814, 1815, \& 1816

d) Sketch Map to illustrate Ochterlony's operations in 1814 and 1815

e) Sketch Map to illustrate the operations in Kumaun in 1815 
PART 1. 
Chapter One

The Growth of the Gurkha Empire

The most stupendous mountain range in the world separates India from Tibet. In Sanskrit it is called himalaya, or region of snow. Its northern peaks are lifeless, and wasted by eternal arctic winter; yet along $i$ ts southern skirt, never more than a hundred miles away, sultry jungle abounds with game and tropical vegetation. Lifting abruptly at the edge of the vast Gangetic plain, this long misshapen massif suggests the interrupted work of some mythological god, who once cleared the north of India smooth and left the debris heaped in peripheral drifts and piles: a deposit of primordial fabric excavated and pushed aside, it seems, for some future cosmographic sculpture, but then neglected; left to be carved during aeons by glaciers, the weather, and the buried rivers which thrust from beneath and drain back to the plains. The Himalayas have been likened in form to the back of a human hand with the fingers pointing towards India; but there is no more real pattern in their contours than there are true configurations in the moon and stars. It is as if the ridges which jut southwards from the puckered spine of snowy peaks are crumpled for ever into foetal convolution by the constricting girdle of foothills. Deep crevices divide the ridges, and there are a few level spaces where men swarm, like microbes. The most considerable are the vale of Kashmir to the far west; the duns or straths of Kayarda and Dehra more to the centre; and the valley of Nepal, in the east. Shielded from the icy winds of the Tibetan steppes by the northern flange of mountains, yet preserved from the cauterizing heat of the plains by their elevation, and from the violence of the tropical monsoon by the filtering foothills, they all enjoy a temperatuffe climate and favour arable husbandry. European fruits and timbers flourish in them; and there is an abundance of English garden flowers, prodigal of intoxicating perfumes and colours of prismatic purity.

Much of the early history of the Nepal Valley is apocrypha of fable and romance. Buddhist legend avers (and this much geological evidence confirms ${ }^{l}$ ) that the valley was once a lake. The 
mythical saint Manjusri, coming down from China, drained it dry by opening the southern rocks with a blow from his sword, and allowing the water to flow down to India as the Baghmati river. The earliest inhabitants were probably members of the Kirata tribe: a short, flatfaced people of Indo-Mongolian stock and Tibeto-Burman tongue, who came from Assam and north east India. Several centuries before the Christian era, they were joined by the people who still inhabit the valley in considerable numbers, the Newars. Their provenance is uncertain; but their language, which is similar to that of the Kiratas, and their features, which of ten even now betray Mongolian ancestry, have led it to be supposed that they were a second north Indian group, or possibly a tribe from Tibet. The Newars were a literate race, with an advanced culture. Their industry and artistry have given the valley its distinctive architecture and sculpture; and their language has preserved its folklore and early history. In the earliest stages, Buddhism was probably the main religion of Nepal, but when a system of monarchy replaced the old tribal republican form of government, the kings were invariably Hindu, and modelled themselves on the monarchs of the plains. Another north Indian people, the Licchavis, founded the first recorded Hindu dynasty in Nepal; and Aryan or not (they could have been Mongolian) they adopted titles used by the Rajputs,* introduced the classical Hindu institution of varna, or the division of society into four immutable categories, and even persecuted the Buddhists. The Kiratas, apparently displaced by the Licchavis, moved into the hills east of the valley, where their descendents are still to be found. The Newars, however, submitted passively to the

*Rajputs (literally: royal progeny) were a Hindu caste of the Ksatriya or military category - the second in the four varna of the brahminical system. They were first heard of, and probably constituted after the invasion of north India by the Gujars and Huns in the sixty century. In medieval times they were widespread in Rajputana, Gujarat, and Hindustan. Rajput kings claimed mystical descent either from the sun (suryavansi Rajputs) or the moon (chandravansi). The Licchavi kings of Nepal used the suffixes Varman (= protector) and Deva (= lord, or divine) which are those of the solar line. Lunar sufixes were Chandra (= moon), Pala (= protected) and Sena (= army). 
rule of Hindu monarchs, and of ten became converted themselves. They are still divided into worshippers of the Hindu deity Shiva (Shivamargis) and worshippers of the Buddha (Buddhamargis). The Licchavis, who were in Nepal from the first until the eighth century, built a powerful empire and extended their dominion even beyond the Himalayas. Soon Nepal became the client of a kingdom whose real centre was Tibet, but she exercised a strong cultural influence, passing on her own artistic idioms to Tibet and mediating the transfer thither of Buddhism from north India. In 704, Nepal broke away from Tibet, and a few decades later the Nepalese Licchavi dynasty came to an end, with the accession of a king called Amsu Varman, who according to one chronicle at least was not of royal blood, but a noble, or thakur, who married into the royal family. ${ }^{2}$ Almost nothing is known about the history of the first two and a half centuries of the Thakuri dynasty. The only facts which emerge with clarity are that it had three lines, and that during some two hundred years the valley was divided in to two kingdoms, in one of which there was a relapse to the Mongolian institution of joint rule by a pair of monarchs. Unity was ephemerally regained at the end of the eleventh century under King Sankara Deva, who ruled from Patan; but the valley reverted to anarchy when he died. In an interlude of darkness and confusion, for which native chronicles, concerned to purify the genealogies of later monarchs, are no source of enlightenment, the Thakkuri dynasty faded into oblivion and the final of the 'Newar' dynasties, the Malla, took its place. The period was an unhappy one, with raids from north India, especially from the kingdom of Tirhut. Nanya Deva of that country made a predatory ascent into the valley about 1100 , and further excursions followed; but in 1324 it was as a refugee that Hari Sinha of Tirhut made his way there, fleeing the army of the Muslim Sultan of Delhi, who had invaded Bengal. Hari Sinha was a patron of Sanskrit letters, and exercised a strong influence on the development of Hinduism in the valley; but there is no record that he ever became its king. This was a tragic time in the history of Nepal. Hordes of Muslims shattered its solitude on two occasions at least in the middle years of the fourteenth 
century, and probably it is these proselytizing visitations which account for the disappearance of all temples of older date than the fifteenth century. From a background obscured by this chaos, a strong man, Jaya Sthithi Malla, emerged - deliverer and unifier of the Nepal Valley, and one of the most notable rulers in its history. He sought to give legitimacy to his succession by marrying the daughter of Hari Sinha and then having the chroniclers record his father-in-law as a king, but was not content to justify his claim to power with spurious pedigrees alone. Nepalese society long bore the imprint of his sagacious administration. His system of weights and measured remained in use until recent times, and his legal codes are theoretically still valid. He made his kingdom a sanctuary for the laws and traditions of Hinduism. They were recorded and codified by pundits from India, and the valley of Nepal became the repository for a way of life menaced with extinction by the Muslims on the plains. Even the Buddhist society of Nepal, while tolerated, was carefully graded as an hierarchy of castes. The early Malla kings combined zealous Hinduism with an interest in local culture. Jaya Yaksha Malla, grandson of Jaya Sthithi, patronized native letters, and raised Newari to the status of an official language. Unhappily, these halcyon days were but the prelude to another long trial of internal strife. The kingdom's precarious cohesion was lost when Jaya Yaksha, on his deathbed, divided his realm between his three sons, who soon fell to quarrelling and fighting among themselves. The valley remained divided into the warring principalities of Bhatgaon, Patan, and Kathmandu until an adventurer from the west, Prithvi Narayan Shah of the little hill state of Gurkha, took advantage of the jealousies separating each from the others to establish his own authority over all, and to found the dynasty which still endures. 3

The Gurkhas are not a tribe or a caste, but a miniature nation of several tribes and castes. The only features which they all share are descent from the original subjects of Gurkha state, and a dialect called Gurkhali or, nowadays, Nepali. The martial energy which enabled the Gurkhas to conquer the Nepal Valley and then forge a huge empire in 
the hills was the attribute of one group in their community - the Chetris. The word chetri is a vernacular distortion of the sanskrit ksatriya, meaning warrior, and designating the second of the four divisions of Hindu society; but in the Himalayan hills it has lost $i t s$ generic quality and acquired special significance. The Chetris have the basic characteristic of a caste, which is endogamy with no smaller endogamous subdivisions. 4

Ethnologically, the Chetris are related to the ancient Khas tribe of north-west India. The Khas migrated up into the Panjab hills and the central Himalayas early in their history. They appear to have been among the original Aryan settlers in north-west India, and tradition links them with the five sons of Pandu (the Pandavas) who are featured in the epic poem Mahabharata (1000-500 B.C.) Some hill dynasties still claim descent from the Pandavas. 5 There is undoubtedly a basis of truth to such assertations. One of the social institutions of the modern Khas is polyandry, which they almost certainly contracted as a result of early contacts with the aboriginal populations of north India, ${ }^{6}$ and a society with such a non-Aryan custom was clearly known to the authors of the poem, since all the sons of Pandu were married to the same wife. It is also a fact that by the time the Law Book of Manu was drawn up (200 B.C. -200 A.D.) the Khas had lost all high status. They were therein listed among the vrishalas, or outcastes, as a race of ksatriyas who had fallen by the wayside from seeing no brahmins. ${ }^{7}$ It is probable that they were ostracized because of their polyandry, and other habits derived from aboriginal societies, which the brahmins now despised as perverse. ${ }^{8}$ A modern view is that the great war in the Mahabharata symbolizes the conflict between early Aryan settlers of debased blood and unorthodox customs and later, purer-bred arrivals. It may well be that the Khas' movement northwards into the western and central Himalayas was part of a retreat of older settlers before the new waves of immigration, represented in the Mahabharata by the withdrawal of the Pandavas into the mountain fastnesses after the destruction of their power. The certainty is that by the dawn of the Christian era the Khas had been banished to 
both the social and geographic periphery of the Hindu cosmos, and had dispersed throughout the Himalayan hills from Kashmir to Nepal, They adhered to the simpler, or Vedic, forms of religious code and ritual which, on the plains, were becoming obscured by alterations and refinements introduced by the brahmins. ${ }^{9}$

At some time about the eleventh century, two groups of Khas migrated into western Tibet and established themselves as ruling cadres in Purang and Guge. Later, these dominions were united under a single family which adopted the popular title Malla (literally, wrestler). 10 They proved very troublesome to the rulers of the Nepal Valley, making several depredations in that direction at the end of the thirteenth and the beginning of the fourteenth centuries. ${ }^{11}$ This family's power reached its zenith in the middle of the fourteenth century under King Prithvi Malla, who ruled over an extensive empire. It included Guge, Purang, and territories in the hills as far as the west of modern Nepal. This dominion seems to have disintegrated after Prithvi Malla, for no record of his successors has been found, and raids into the Nepal Valley ceased; but it is possible that the Mallas who came into prominence in the valley at this time were scions of the western dynasty. ${ }^{12}$ The suggestion receives a measure of support from the fact that it was in the time of the early Malla kings in the valley that a Khas dialect was introduced there. One was in official use at the durbar of Kathmandu before the end of the seventeenth century. ${ }^{13}$ The reasons for the demise of the empire in the west are not ascertained; but newly discovered records and lapidary inscriptions mention both the advent of a new aristocracy from the plains, and the Rajput city of Chitor which, after the heroic resistance much sung in Rajput minstrelsy, fell to the Muslims in 1303. This leads to the supposition that the collapse of the Mallas was caused by the advent of Rajput exiles from India, who carved principalities for themselves out of the family's dominions. Many subsequent hill rajas claimed descent from the Chitor Rajputs. ${ }^{14}$

These fugitives found in the hills extensively dispersed settlements of Khas, ranging in size from minor principality to sub- 
stantial empire, using variants of what had at one time been a distinct Khas language. The Chetri caste was the result of miscegenation between the immigrants and the resident hill societies. Its members were born of Khas mothers and spoke a Khas dialect, but were recognized as ksatriyas, and allowed to wear the sacred thread, the emblem of the two highest varna, in deference to their Rajput or brahmin paternity. Many Khas conceded the right of spiritual jurisdiction to the brahmins who came with the Rajputs from the plains, and in return were admitted to the Chetri caste and allowed to wear the thread. In the area of Gurkha, to the north west of the Nepal Valley, there lived the Magars, a Mongolian people. They reacted to the influx of Rajputs and brahmins in much the same way as the Khas. Many were converted to Hinduism; and many of their women gave birth to the children of the immigrants. Both converts and illegitimate progeny were accepted into the new caste; and so in this area it came to include Magar names (such as Burathoki, Gharti, Thapa) as well as Khas, Rajput and brahmin ones. At first the authentic Rajputs from the plains probably held aloof from this new hybrid caste; but given the situation where their own clans were of ten exogamous, where their choice of marriage partners was very circumscribed, and where common ksatriya status made intermarriage less reprehensible, we can readily accept that the Rajputs were soon assimilated by the Chetris. In this way the new caste became a crucible for all the ethnic elements of the hills - Magar, Khas, brahmin and Rajput. Chetris still vary considerably in appearance. Most have a pronounced Indo-Aryan bias; but they tend to be small and very slight. Others retain unmistakably Mongolian features, and are more robust and muscular. Linguistically, they are more akin to the speakers of the Khas dialects of the hills than the Hindi speakers of India. ${ }^{15}$

At the beginning of the eighteenth century, the country between the valley of Nepal and Kumaun was fragmented into 46 lordships, grouped into two loose confederations. In the basin of the Karnali* river system

* Called the Gogra when it reaches India. 
were the Baisi, or Twenty Two Rajas; and further east, in the Narayani* basin, which comprises the seven branches of the Gandak, were the Chaubisi, or Twenty Four. All paid theoretical allegiance to the Mogul Emperor in Delhi; but the arm of Imperial authority, never having proved long enough to control the hill states effectively, was becoming even more enfeebled as the life blood of the Mogul body politic drained away and rival heirs contended for its legacy; and the intractable hill lords were left to themselves. The resulting background of turbulence was propitious for the ambitions of the Shah family of Gurkha, a little state among the Twenty Four. This family, like most nobility in the hills, claimed descent from the Rajputs of Chitor. They designated themselves Thakuri - a Rajput title - and considered themselves to be a cut above the Khas, whom they affected to scorn. ${ }^{16}$ In fact, they were almost certainly Chetris - ethnic mongrels of the type we have been describing. This proud people gradually enlarged and marshalled their resources; and in the middle of the eighteenth century, under the leadership of Raja Prithvi Narayan Shah, they set about conquering the Nepal Valley, an ambition which it took nearly twenty five years to accomplish. Kathmandu fell to Prithvi Narayan in 1768, and Patan and Bhatgaon the following year. ${ }^{17}$ These conquests marked the birth of the Nepalese state as it is known today. It was a state conceived and nurtured by a minor martial aristocracy of Chetris, who made their particular Khas dialect the official language of the kingdom, and their particular caste the sole repository of political power. The intriguing thing about the Chetri caste is that while it was in itself a product of the brahmins' accommodating adjustment to the pressures of local necessity, it soon ceased to practise the hospitality by the grace of which it had itself been born. Quite when is not sure; but at some time it ceased receiving converts from the hill tribes into its fold, and Magars who had become Chetris began to distinguish themselves from those left outside the caste by the designation "Chetri" after their name (e.g. Thapa-Chetri). The Gurungs, another Mongolian tribe domiciled north of Gurkha, who with the Magars formed the bulk of the Gurkha army, were excluded altogether from the new caste and denied the privilege 
of calling themselves ksatriyas even when professed Hindus. Khas who found themselves outside the caste when it became closed had to be content with an inferior status. Such were, apparently, the Khratis of Gurkha. The Newars were excluded without exception. This state of arrestation was quite foreign to the empiricism of the brahmins, whose practice in effect, if not in theory, was to draw up an hierarchy of castes designed to embrace all the Hindus of a community, and then arrange such a distribution of those castes between the four varna as would describe its social and political organization. In Nepal, the brahminical system was not and is not a reflection of the Hindu community. Religiously orthodox groups of Gurungs, Magars, Newars and Khas having been excluded from the Chetri caste despite the sanction which precedent would appear to give for their inclusion, have found no allowance made for their political or military qualifications in the national order of precedence. Their status was defined only in negative terms. They could not claim parity with the Chetris, and had no acknowledged right to wear the sacred thread. When we remember that this state of petrification favoured the hegemony of the Chetris, by making it impossible for these groups to acquire the social status which might justify their pretensions to power and influence, we have perhaps a clue at hand to help explain the characteristic anomaly of Nepalese society. It may well be that the development of the caste system was prevented from working itself out with its accustomed logic as a result of a determination on the part of the Chetris of Gurkha to maintain political control. It is at any rate indisputable that the legal system which they introduced rigorously perpetuated the existing hierarchy of castes and made further development impossible; ${ }^{18}$ and it is equally certain that they made political initiative the perquisite of a narrow oligarchy of Chetri families. 19

The Gurkhas were an uncouth people with few pretensions to culture or the arts of peace. As Hindus, they generally respected the shrines and temples of the Newars; but they evinced little inclination to imitate their industry or their sophisticated urban style of life. As the new capital the Gurkhas chose the relatively drab town of Kathmandu, 
in preference to the more opulent centres of Patan and Bhatgaon; and they showed reluctance to abandon their small-holdings and mud huts. 20 Their interests were almost exclusively martial, but they waged war neither in response to a crusading impulse nor from economic necessity. They were driven to it because they saw prestige only in self-aggrandizement; because conquest was the only form of self-assertion, and valour the only shibboleth which they knew. Prithvi Narayan paused only briefly to consolidate his position in the valley before resuming his career of acquisition. He made a feint at the Twenty Four Rajas, but his main interest at this stage was in the east, the country of the Kiratas in the basin of the Kosi river. The objective was Vijaypur, a town in the foothills across the Kosi in that portion of the lowland called the Morang. It was the eastern capital of a Rajput family whose three branches controlled a far-flung empire extending from the Kosi basin to Makwanpur, the territory just to the south, of the Nepal Valley. Makwanpur was already in the Gurkha Raja's grasp, andhis generals now attacked Vijaypur. The Morang had for some years beden fermenting with civil war, its Raja having been murdered and the throne become the object of rival claims from his uncle and his dewan, so it fell an easy prey. The Morang was overrun, the regicide dewan ferreted out and killed, and the remains of the royal family expelled into India. ${ }^{21}$ The Gurkha Raja's next concern was the state of Sikkim, whose boundaries in those days stretched in the south west to Baikantpur on the plains, and in the north west to the Arun river in the hills. Sikkim was a colony of the Lepcha tribe, a Himalayan people who were unique in that they acquired for rulers not Hindus from the plains but Buddhist princes from Tibet, or Bhot. The Sikkim Rajas also exercised a tenuous authority over the Limbu tribe on the eastern bank of the Arun river. In the middle 1770's the Gurkhas made preparations for an invasion of Sikkimese territory. A warning from Tibet, who considered Sikkim a protege, and the death of Prithvi Narayan Shah (1775) temporarily upset the plans; but skirmishing along the Arun frontier continued until the Tibetan government ransomed peace by consenting to move the frontier further east, making the Kankai river the 
boundary in the lowlands but leaving Sikkim with Ilam and Taplejung in the hills. The Gurkhas had no intention of honouring the treaty, and barely waited for it to be signed before launching a two-pronged attack, driving into Sikkim by the two passes of Taplejung and Ilam. But the Lepchas were a virile race, of the same mountain stock as the soldiers in the Gurkhas' own army. They resisted vigorously, fighting with swords, poisoned arrows, and a few muskets which, being too big for these thickset but diminutive people to handle conventionally, they tied to trees and fired with a match. At Namchi, just north of Darjeeling, they soundly defeated their antagonists; and in the Morang effectively checked their other division. The Gurkhas were now held up for nine years. ${ }^{22}$ Only in 1788 were they able to renew their onslaught, defeating the prince in an obstinate battle fought near his capital (probably Namchi) and compelling him to flee to Tibet, where he was provided with men to continue the struggle. With additional reinforcements from the Raja of Bhutan, he returned to raise the siege of his capital. He drove the Gurkhas out, but could tempt good fortune no further. His Bhutanese troops became mutinous from want of pay, and the Gurkhas were able to take refuge in the fort of Nagri, to the south, where they awaited reinforcements. Soon they were strong enough to reconquer all Sikkim west of the Tista and compel the Raja, his infant son, and his loyal Lepcha general to withdraw into the hilly fastnesses east of that river. This defiant band ensconced themselves in the town and fort of Gangtok, whence they were still harassing the Gurkhas when the British went to war against Nepal in 1814. By then the old Raja had died, and his nineteen year old son, Chogyal Namgyal, was governing the truncated patrimony in close association with troops and advisors from Tibet. West of the Tista, the Lepchas continued to prove refractory, and the Gurkhas found it wise to humour their pretensions by allowing one of their own leaders to continue as civil governor and collector at Nagri. This was Yuk Namchu, a nephew of the loyal Lepcha general. His other nephew, brother to Yuk Namchu, remained at Gangtok as chagzod, or chief minister, to the Raja. ${ }^{23}$ A large civil and military station 
was constructed at Dhankuta, north of the old provincial capital of Vijaypur, and became the administrative centre of all Gurkha conquests in this part of the hills. The new masters wisely conciliated their fierce and recalcitrant Kirata and Limbu subjects by being satisfied with token submission. The revenues were lightly assessed, and allowed to be collected by the tribal societies' own representatives.* They took pains to appease the brahmins hitherto attached to the Vijaypur royal family by confirming and even increasing their free grants of land. 24

Meanwhile the hill states to the west of the Nepal Valley had not been ignored. It was in this direction, indeed, that the main thrust of Gurkha expansion was directed. At first it was not a career of conquest by the sword alone, but rather a scheme of aggrandizement implemented by an opportunist mixture of attack, alliance, stratagem and marriage diplomacy. Force was used with discretion, care being taken to avoid precipitating antagonistic coalitions before the Gurkha hegemony was consolidated. The crucial diplomatic necessity was to avoid provoking the Raja of Palpa, who not only enjoyed pre-eminence among the hill chiefs, but was a favoured client of the Nawab of Oudh, whose tenant he was for certain territories on the plains. A marriage match was arranged between the Palpa Raja's daughter and the regent of Nepal during the minority of Prithvi Narayan's grandson, and it was the subsequent connivance of the Palpa family which enabled the Gurkhas to impose their authority over all the Twenty Two and Twenty Four Rajas. By 1790, all the mountain rulers as far west as the Kali river were either enfeoffed by the Gurkhas or replaced by their agents. Palpa alone remained unannexed, but henceforth its independence was more symbolic than real. The Kathmandu durbar manipulated the Raja, Prithvi Pala, more or less as. it pleased, though he was more the victim of his own vanity and cupidity than of $i$ ts strength. It played with him as a cat with a mouse, twice inveigling him to come to Kathmandu on pretexts which flattered his

"Rais in the case of the Kiratas; subbas in that of the Limbus. 
conceit and then keeping him in close confinement for a time, but hesitating as yet to kill him for fear of possible reprisals by the Nawab of Oudh. 25

Beyond the Kali river lay Kumaun. Once the prosperous kingdom of the Hindu Chand dynasty, it had, since the rule of a feckless raja in the early eighteenth century, been suffering from malignant anarchy. Nominating and controlling kings had become the privileges of the highest bidder, and two factions of zemindars had been bidding for years without either offering a price in blood and ruthlessness which the other was not prepared to match. As the contention dragged on, rich provinces in the lowlands had been lost to oudh; a rash of castles and fortresses had spread across the surface of the land; trade and agriculture had languished; and the last legitimate Chands, helpless pawns, had been exterminated. The most prominent member of the Mara faction was Harak Deva Joshi, a restless, scheming supporter of the Chands who had turned king-maker and sponsored two pretenders since the extinction of the royal family. In 1790 he was in exile on the plains. The Phartiyal faction, his mortal enemies, had seized power by playing his own trick and invoking the support of neighbouring Garhwal. Lal Singh was the strong man of the moment, and on the throne was Mahendra Singh, nephew to himself and son to the regicide. When the legitimate dynasty had been destroyed, so too had the common receptacle of fealty. There was no alternative abstract notion to contain dispersing loyalties and bind the fragmenting hierarchy of the state. It would be unrealistic to look for some idealistic patriotism, for allegiance to anything beyond personal ambition and self-preservation in a feudal chaos, where the only sanction of power was the strength to exercise or sieze it. Summoning the aid of external powers was common practice in such situations, and Kumaun had been the stamping ground of foreign armies for decades. It was venial for Harak Deva Joshi to connive at the Gurkhas' plans to invade Kumaun. In 1790, dividing their force into two divisions, the Gurkhas crossed the Kali river and defeated Mahendra Singh in Gangoli province in the north, and Lal Singh in Kali Kumaun 
province in the south. Both fled to the plains, and the victors occupied Almora, the capital, with no resistance from a populace weary after generations of anarchy. The Gurkhas hesitated to trust the wily Harak Deva Joshi too far, and planned to send him to Kathmandu, where he could do no mischief; but he fled west to Garhwal, his old refuge. Here he plotted as actively as ever, and attempted to build an antiGurkha coalition. He hawked his cause around the courts of north India, with many crocodile tears and fluent stories of Gurkha atrocities, but found little active support until the British were preparing to invade the hills in $1814 .^{26}$

Once they had advanced beyond the Kali, the Gurkhas began to be perplexed by the problem of how to combine military occupation with an equitable colonial administration. In conformity to their usual practice, the land was divided and assigned in separate parcels to the officers and troops of the army; but the necessity of maintaining a large military establishment meant that the income from each portion was rated too high, and the troops, who had no permanent interest in the welfare of the peasants and landholders made accountable to them, used brutal treatment and confiscated private property in order to increase the revenues to the estimated level. Even the wives and children of cultivators were seized and sold as slaves. 27 The subsequent depopulation, with large numbers of farmers emigrating to India, ${ }^{28}$ alarmed the durbar at Kathmandu, which made efforts to improve the local administration and revise the land settlement. ${ }^{29}$ Brahma Shah, the member of the royal family who succeeded to the Governorship of Almora in 1806, was congenial and just. Under his rule Kumaun became the object of special solicitude and favour. Orders were issued for the protection of private property; the enslavement of subjects was prohibited; rent-free grants of land were confirmed; and a special influence was conceded to the brahmins and zemindars of the Phartiyal faction, who had been in power when the Gurkhas arrived. 30

To promulgate injunctions was one thing; to have them obeyed, especially in areas outside the capital, another. The welfare of the 
peasantry would only be assured when troops and officers in the outlying districts were made fully accountable for their misconduct towards the civilian population. ${ }^{31}$ But instead of pausing now to attend to this and other pressing problems concerning internal government, the Gurkhas drove on still farther west, accumulating territories in a fever of aggrandizement. They were partly impelled by the sheer momentum of their own military advance; partly drawn by the political vacuum in the hills ahead; and partly stimulated by a revolution in Kathmandu, which brought to power the aggressively imperialist Thapa party.

For twenty years, from the death of Prithvi Narayan Shah until the coming of age of his grandson in 1795, a Chetri family of noble extraction, called Panre, replaced the marchy as the true source of authority within the state. It was Damodar Panre, prime minister during the regency, who carried the work of Prithvi Narayan to its logical conclusion, consolidating and extending the Gurkha empire without relinquishing due diplomatic discretion and political moderation. Rana Bahadur Shah came of age in 1795, but resigned the throne to his infant son four years later, in deference to the wishes of his morganatic favourite queen. Soon after, this queen died; and Rana Bahadur was distracted to the point of insanity by grief. He began to perpetrate the most atrocious cruelties and profanities, and Damodar Panre, with the support of the brahmins, most of the durbar, and all the vassals of the western hills, compelled him to withdraw to the holy city of Benares, on the plains of India, in the guise of a pilgrim. His youngest queen was left as regent. For the next few years, Damodar continued as prime minister, secure from the intrigues of the regent while he had the support of Brahma Shah, Rana Bahadur's illegitimate brother. This member of the royal family enjoyed the prestige and influence of an elder statesman. In a durbar whose members so often feature in the pages of history as monstrous allegories of perfidy, cruelty and greed, he was remarkable for his diffidence, sobriety, and decorum. He regarded the wanton adultery of the queen regent with extreme distaste, and was disgusted when she raised her paramour to the rank of counsellor. 
But a situation now evolved in which even all his good will was insufficient to save the Panres. Their inveterate rivals, the Thapas, were working for the return of Rana Bahadur. The doyen of the clan, Amar Thapa, had been imprisoned by Damodar Panre; but at Benares his young son, Bhim Sen Thapa, was pouring schemes into the unbalanced Rana Bahadur and ingratiating himself with the frustrated and jealous senior queen; while in the west his brother, Amar Singh Thapa,* was rapidly becoming prominent for his generalship. In 1803, the senior queen staged a coup de theatre. She suddenly left her profligate husband and travelled up to Kathmandu alone, nonplussing the prime minister, but impressing the general populace by her courage and determination. She made herself regent, released Amar Thapa, and admitted him to the council of state. The following year Rana Bahadur followed her to Nepal. Prompted, no doubt, by Bhim Sen Thapa, who was at his elbow, he challenged the troops sent to oppose him as their true liege lord; and they, perhaps spontaneously, probably not, went over to him with enthusiastic protestations of loyalty. Damodar Panre was arrested and beheaded, and Bhim Sen Thapa made prime minister. The melodramatic denoument of this operatic chapter in Nepalese palace politics came when Rana Bahadur was assassinated in the open durbar by one of his uncles. Bhim Sen Thapa retaliated to what he claimed was a Panre conspiracy by energetically purging the administration of the Panres and their coadjutors. Some 50 heads are said to have rolled in the prime minister's orgy of blood. 32

The main beneficiaries and probably the chief protagonis ts of this Iurid interlude were the Thapas, a Chetri clan who had never quite lost the stigma of their mongrel origin. Chetris who prided themselves on their own purer Rajput extraction spurned the Thapas, and even treated them as a separate and inferior caste by refusing to eat with them. ${ }^{33}$ The Thapas had become embittered, and nursed secret pretensions.

* Both were called Amar Singh Thapa. The middle cognomen is omitted in the case of the one in Kathmandu in order to make distinction easier. 
Their jealousy was directed in particular against the Panre family, whose control of all political appointments since the death of Prithvi Narayan had thwarted their ambitions. When their opportunity for selfassertion came, they exploited it with all the customary truculence of the newly-emancipated. Bhim Sen Thapa, to be master of Nepal for the next 35 years, was only twenty-five when he became prime minister in 1804. He was tall and sinewy, with fine Rajput features whose constant animation betrayed great energy and a certain nervousness. His manner was in strange contrast to the vacant stare and mute incomprehension of the young roi faineant, whose intellectual and physical development he purposely retarded by constant confinement and defective education. For the next 150 years, the Gurkha monarchy was to be no more than a vestigial embellishment. While in Benares, Bhim Sen had carefully observed European manners and customs, especially those relating to military organization, and he subsequently attempted to introduce some of them into his own country; but he had imbibed neither fondness for the English, nor respect for their mode of political conduct. $^{34}$ After his accession, Gurkha policy became suddenly more intransigent and rash. One of his first acts was to execute Prithvi Pala, the vain and selfish Raja of Palpa. Then his father, Amar Thapa, raised to the English rank of general, was sent with a large force to occupy all the Palpa estates. These were measures in marked contrast to the circumspection shown by the Panres in their dealings with this family. General Amar Thapa fixed his heddquarters at Tansing and assumed the functions of Govemor of Palpa, which he discharged very pugnaciously. Most free grants of land were resumed and their brahmin possessors insulted. Brahma Shah, despite his sympathy for the Panres, did not perish in the purge of 1804 . He was saved by his popularity, venerability and affability; but soon after the palace revolution, he was banished, on administrative business, to far distant Kumaun. He went tormented by sorrow and worry. The Thapas he detested as low-born upstarts, and their acquisition of power he lamented; but he knew that if his behaviour gave cause for the slightest suspicion, his family, kept in Kathmandu as hostages, would answer for it. ${ }^{35}$ 
In Garhwal, and beyond to the Sutlaj river, the softly contoured hills of Kumaun give place to a more wild and angular topography, in which there are many precipices and chasms. There is no scattered distribution of small fertile valleys, as in Kumaun. The province's whole measure of open space is concentrated into one or two extensive tracts. In comparison with the barrenness of the rest of the country, the valley or dun of Dehra seems extravagantly favoured. It is a delectable strath, varying from eight to ten miles in breadth, and nearly 40 miles long, stretched between the Ganges and the Jumna in the first tier of hills, and well-watered by a filigree of rills and rivulets. In those days it was generously wooded. Stately forests of sal, sissu, pine, and all the familiar European timbers interspersed fields of lavish fertility. But tragedy was ever wont to attach to beautiful things; and for three generations this idyllic grove had been a source more of chagrin than of joy to the Rajas of Garhwal. The valley's riches, and its proximity to the plains, had combined to make it a favourite plundering ground for Sikh brigands from the Panjab, and Rajput, Gujar and Afghan rulers from Rohilkhand. The Raja had been compelled to cede villages and whole sections of the territory as blackmail to various external princes and chieftains. In 1786 the dun was actually annexed to the Rohilla kingdom of Saharanpur, and the Raja only regained it by a judicious marriage contract in $1800 .^{36}$ The Gurkhas made preparations to march into this distracted kingdom as soon as they had subdued Kumaun; but their plans were interrupted by the arrival of news of a war with Tibet and China on their northem frontier, and all available troops had to be withdrawn eastwards to deal with this danger. Meanwhile the Raja of Garhwal in vain hopes of redemption, agreed to pay a tribute and keep a vakil at Kathmandu. He demonstrated his sincerity by refusing to compound Harak Deva Joshi's scheme for a coalition against the Gurkhas. But even with all his inoffensiveness he could not purchase good fortune. In 1801, the dun was ravaged by an invasion of Marathas from Saharanpur; in 1803, an earthquake devastated his capital, Srinagar; and later the same year the Gurkha army returned in new force to the west and crossed 
the Ganges into his territory. The Raja retreated to Dehra town, but the Gurkhas followed and defeated him. This slight and nervous young man showed courage in his hour of trial. He collected a mercenary force on the plains, and returned to challenge the invaders in January, 1804. It was a brave but futile gesture, and it cost him his life. His sons fled back to India, and sought asylum in the territories of the East India Company. ${ }^{37}$

The Gurkhas regarded the already devastated condition of Garhwal, and the barbarity of much of the population, more as justifications for plunder than as incentives to constructive administration. The land revenues were grossly overrated, and the occupationary troops left to squeeze from their assigned estates rents which bore no relation to their yield. Arrears increased, and there was armed resistance, followed by brutal retaliation, depopulation, and an alarming increase in the trafficking of human slaves, used as a supplementary currency. ${ }^{38}$ But the difficulties of colonial government, no matter how urgent, were now insufficient to deter the Gurkhas from devising even more ambitious schemes of conquest. About this time Amar Singh Thapa, uncle to Bhim Sen, was raised to the rank of kaji, the highest for which those of non-royal birth were eligible. ${ }^{39}$ It was this man's strong will which thenceforth dominated the fortunes of his country in the west. Amar Singh Thapa, now nearly sixty, had spent his life soldiering, but like most of his clan had hitherto been allowed few hopes of high rank and influence. He came suddenly into prominence after the Thapas' coup d'etat in 1803, and immediately sought to add lustre to his reputation and to exalt his prince by pushing back the frontiers of the Gurkha empire still farther, perhaps even to Kashmir. ${ }^{40}$ Had his judgement been commensurate with his ambitions, he might well have gone far towards accomplishing his aim, But his self-confidence overmatched even his aspirations, and was ever leading him onwards when he should have stayed to question and deliberate. Perhaps there was some anxiety to make up for lost time in all this: the urgency of an old man in a hurry; but there was also a strong trait of superstition in his character, which caused him to place trust in religious 
portents and prophecies, but to be otherwise unamenable to counsel. He was accompanied in these years by Shiva Dat Rai, the son of a Bhotiya, or Tibetan, of oracular pretensions, whose predictions of success and recounting of legends foretelling the advent of the Gurkhas as victors seem to have determined the Kathmandu durbar to carry the western campaign to the Sutlaj and beyond. ${ }^{41}$ The pusillanimous confidence which he derived from such sources enhanced Amar Singh's courage as a soldier; but it made him more dreaded than popular as a commander, and blighted his judgement as a tactician and a diplomat.

The country between the Jumna and the Sutlaj is not a particularly extensive area, when measured by the scale of distances which proportions the Indian sub-continent. It comprises some five and a half thousand square miles, of which perhaps three thousand are inhabitable. Yet at the beginning of the nineteenth century this modest tract was divided into no less than 30 separate states and principalities. The inaccessibility of the territory, and the reluctance of the Moguls to undertake the subjugation of the hills, had always combined to preserve it as a sanctuary for political refugees and ascetic fakirs. Many Rajput princes had founded kingdoms here after the great exodus from north India in the thirteenth and fourteenth centuries, and had remained undisturbed in their tumultuous feudal way of lifeever since. Centuries of seething and untended fever had caused a fortress to erupt on almost every rise in the country's broken surface. The original amorphous multiplicity had, by 1803 , begun tocrystallize into a recognizable political pattem. Four states had achieved power and growth at the expense of all the rest. They were Sirmur, adjoining Garhwal on the west; Hindur, partly on the plains and partly in the hills where the Sutlaj curves north to enter the mountains; Bilaspur above it, lying across the Sutlaj on its loop; and Basahar, straddling the river further up, and separated from Bilaspur by 12 tiny states forming a distinct group called the Twelve Lordships (Bara Thakuri), dispersed along the south bank of the Sutlaj*. The

*Hindur was also known as Nalagarh; Bilaspur as Kahalur; Basahar as Kunawar. The capital of Sirmur was Nahan; of Hindur, Palasi; of Bilaspur, the town of the same name; and of Basahar, Rampur. 
remaining fourteen principalities were scattered in the basins of the Tons, Pabar, and Giri rivers. ${ }^{42}$ All these states had in theory owed tribute, or nazarana, to the Emperor of Delhi: but the liability had never been much more than a license for the strongest states to levy exactions on their weaker neighbours. Collected ostensibly on behalf of the Emperor, the tribute/seldom found its way into his treasury. The practice of accepting military service in lieu of pecuniary contribution was widespread, so the armies of these little states were often disproportionately large. But they were bedraggled, undisciplined and protean bodies. ${ }^{43}$ An Englishman who passed through Bilaspur in 1783 described its army as "about three hundred horse and eight thousand footmen, armed with matchlocks, swords, spears and clubs, huddled together on two sides of a hill in a state of deep confusion and filth". ${ }^{44}$

The dynasties of Hindur and Bilaspur were cognate, and had for some centuries lived amicably side by side. Of late, however, Hindur had been ruled by a particularly energetic and ambitious raja, called Ram Saran Sen, who had been able to exploit the state of perpetual jealousy among the various royal houses to extend his own power at the expense of his cousin of Bilaspur, without precipitating a coalition against himself which was permanent enough to be dangerous. By usurping Bilaspur's suzerainty over the Twelve Lordships, and annexing large chunks of her cis-Sutlaj possessions, he had gone a long way towards mastering the whole tract of territory between the Jumna and the Sutlaj. Now he was meddling in the domestic politics of Sirmur, abetting a group of rebellious barons who detested their own Raja, Karman Prakash, as a bully, and despised him as an imbecile. Karman Prakash despaired of being able to retain his throne without outside help, and implored Amar Singh Thapa to intervene on his behalf. Amar Singh sent a detachment of 700 men to quell the rebels, but it was encircled by a Hindur force at Jampta, and forced to capitulate and withdraw. This was in May, 1804. Meanwhile, in his picturesque little palace of frescoed stucco, slothful Maha Chand of Bilaspur was stirring indignantly. The combined encroachments of his kinsman, Ram Saran, and/Ram Saran's 
ally, the Raja of Kotoch across the river, had of late deprived him of the richest portions of his kingdom. Now, Amar Singh Thapa's talisman and religious mentor, Shiva Dat Rai, was a native of Bilaspur; and it seems that he used his powerful influence to arouse the Gurkha Kaji's interest in the plight of Maha Chand. Feeble and unheroic though he was, it was this raja whom Amar Singh Thapa selected to be his special protege. The Gurkha crossed the Jumna in person in October 1804, and entered the territory which a decade later was to be the stage of his crucial struggle against the British. He gave battle, and defeated the Hindur troops at Ajmaigarh, and invested the forts of Ramgarh and Nalagarh. The garrisons were bribed to surrender, and Ram Saran Sen fled south to the fort of Palasi. Karman Prakash was restored to the throne of Sirmur as a Gurkha vassal; and Maha Chand was given nominal trust of all the territories he had recently lost to Hindur, including the Twelve Lordships. But it was Shiva Dat Rai who was made the real agent of Amar Singh in the new puppet state of Bilaspur. ${ }^{45}$ He now urged the Kaji to advance still farther, and attack the Raja of Kotoch, who had robbed Bilaspur of her possessions on the west bank of the Sutlaj. Kotoch included the most renowned stronghold in the Himalayas - Kangra. Long after their authority had disappeared on the plains, the Moguls had preserved a garrison in Kangra. Its strength had become proverbial. The fort had been re-annexed to the patrimony of Kotoch in 1786 , by vigorous young Sansar Chand, who aspired to the leadership of a revived confederation of hill states, and who was even strong enough to cause perturbation among the Sikhs, now rising to pre-eminence on the Panjab plain. His durbar was brilliant, the resort of bards, adventurers and artists from all over Hindustan. ${ }^{46}$ Flushed by the prospect of the prestige which its conquest would confer; encouraged by his first easy victories; flattered by fresh prognostications of success; and seduced by promises of alliance from the variaus trans-Sutlaj monarchs, Amar Singh Thapa had little heed for the weakness of his present position. He gave no thought to that perfidy of the hill rajas, which alone had enabled him to march so easily across the Jumna; was barely concerned even by the 
Hindur troops who still occupied Chamba, Taragarh, Malaun and Surajgarh strong forts within the territory freshly acquired by his army. Arrogant and self-assured, the kaji overreached himself. In April, 1806, he committed what he later admitted was a capital error, and crossed the Sutlaj with his main army, en route for Kangra. He carried Maha Chand with him, but had barely restored him to his old estates, when he learned that a thousand troops from Kangra had crossed the river in the opposite direction further south, had joined Ram Saran Sen, and were attacking the Gurkha garrisons in Nalagarh and Ramgarh. The kaji was forced to pause and send back a strong detachment to expel the intruders, but, impenitent, ${ }^{k}$ still disdained to ponder the wisdom of his ambition. The march against Kangra was resumed, and after a preliminary victory over Sansar Chand's troops at Barahati, the fort was reached in July. Attempts to take the place by storm miscarried, and Amar Singh was compelled to raise the siege. 48

For three long years the futile enterprise endured. Meanwhile the irrepressible Ram Saran Sen conspired and schemed, and with shrewder appreciation and longer experience than his adversary of the fickle friendship and inconstant enmity of the chameleon hill rajas, was soon able to stir up an anti-Gurkha movement. It involved not only the Twelve Lordships, who began to withhold supplies from the Gurkha Army before Kangra, but Ram Saran's own quondam victim, Karman Prakash of Sirmur, as well. 49 Distracted by this treachery and dismayed at the sight of his army wasting away, ${ }^{50}$ Amar Singh was at length forced to consider the bitter expedient of a compromise. He sent a messenger to Sansar Chand; but the tall proud Rajput curled his lip and refused to treat with the agent of a Thapa. He demanded to treat with Rudra Vir Shah, brother of Brahma, whom alone he considered his equal in rank. Furious at this insulting allusion to his birth, Amar Singh dashed off a letter to Kathmandu, urging that Rudra Bir's treaty (which recognised Sansar Chand's right to Kangra in return for the payment of tribute) be not ratified. He insisted that the fort was on the point of surrender. Amar Singh never forgave the Shah brothers forthis humiliation. He used his 
influence to have Hast Dal Shah removed from the govermorship of Garhwal, and to have Rudra Vir relieved of his command with the field army - though Brahma Shah remained beyond the effect of his vengeance in Kumaun. ${ }^{1}$ Amar Singh's petulance ruined his chances of withdrawing from Kangra with some semblance of dignity. Sansar Chand, who had already rejected one offer of aid from the leader of the Sikhs, Ranjit Singh, out of preference for the treaty of Rudra Vir Shah, now called on the Sikh again. He escaped from Kangra and made a treaty with Ranjit Singh - signed, it is said, in blood. He continued to humour the Gurkhas, hoping to imbroil them with Ranjit Singh and keep the fort himself; and Amar Singh Thapa, unable to acknowledge, because of his ruinous pride, that he was being double-crossed, dallied with Sansar in the vague hope that he could either win over Ranjit Singh or take the fort in alliance against him. Ranjit Singh prevaricated until his time was ripe, and then, in July 1809, put an end to all this clumsy intriguing by thrashing the Gurkha army, occupying Kangra, and making it perfectly clear that he intended to share it with no-one. Grumbling and affecting to claim that he had been duped by the Sikh, Amar Singh Thapa led the remains of his army, diminished by famine and decimated by disease, in ungainly retreat across the Sutlaj, having undertaken never to pass it again. ${ }^{52}$

He vented his vexation by chastising the contumacious princelings who had plotted in his absence. The ungrateful Karman Prakash of Sirmur was peremptorily ejected,

several of the Twelve Lords were constrained to flee for their lives. Only now that he came to subdue it, perhaps, did Amar Singh realise how tenuous had been his hold over this wild and inaccessible region. His troops had to tackle the frustrating and arduous task of reducing numerous hill castles in remote principalities, of whose existence they had hitherto hardly been aware. The Thakur of Balsan proved especially refractory, and the Gurkhas suffered three repulses when trying to reduce his fort, Nagana. He joined with several of his neighbours and called on the Raja of Basahar for assistance. This raja obliged with 10,000 men. Amar Singh dealt with this new threat from the north in person. In May, 1811, 
he marched from Subhathu with a large force, finally took Nagana, and pushed on to the more hospitable and smiling landscape of the valley of the middle Sutlaj, where stood the Basahar capital, Rampur. The kaji had chosen his time well. The durbar, confused after the recent death of the Raja and the accession of an infant to the throne, fled across the river on hearing of the Gurkhas' approach. After lengthy negotiation an agreement was concluded whereby the Raja was left in unmolested possession of his trans-Sutlaj territories in return for a tribute. The Basahar minister henceforth formed part of Amar Singh's growing and impressive retinue of retainers and clients. 53 In cis-sutlaj Basahar, the Gurkha administration again partook of the character of the country on which it was engrafted. While in Garhwal, whose population was untamed and defiant, the Gurkha rule was cruel and unmerciful, in Basahar, which lay astride the broad trading highway of the Sutlaj and whose denizens had derived culture and probity from a long tradition of commerce, it was considerably more mild and congenial. 54

On the eve of the war with the British, the Gurkha empire was at $i$ ts zenith. It stretched from the Tista river in the east to the Sutlaj in the west, a distance equivalent to that between the southern coast of England and the northern tip of Scotland; and its average breadth was not much less than that of Great Britain. In the space of half a century, the Gurkhas had unified, for the first time in history, a belt of territory which was the most beautiful, the most inaccessible, and, until then, the most politically fragmented in Asia. There seems no reason to suppose that, had the war with the British not intervened, this empire would not have proved viable. Its great strength was the army by which ithad been won and by which it was held, for no rival among the Himalayan states had a force more efficient and more loyal. Among the native states of north India, only the Sikhs had an army which could compare, but their energies and interests were centred more on Kashmir than the Nepalese territories.

The regular army of Nepal was officered by Gurkha Chetris, but composed in the main of Mongolian hill tribes - Magars, and to a lesser extent, Gurungs. 55 These hill people, diminutive, thick muscled and 
with the distinctive features and isabelline complexion of the oriental, first showed their worth as fighting men in the army raised by the Gurkhas, and for this reason were thought by the British to be Gurkhas themselves.* They were ideal soldiers: immensely strong, loyal, and tractable; and with a perfunctory religion which left them free of the restrictions which ritual normally imposed on Hindu soldiers, even in time of war. While the orthodox Hindu shed all his dress and washed his whole body before eating, these hillmen made do with removing their headgear and washing faces and hands. They were cheerful, agreed to carry their own provisions, and were not fastidious about what they ate. ${ }^{56}$ The peace establishment of the army was between six and eight and a half thousand, but by a system of rotation the full potential strength was about double this. ${ }^{57}$ It was exclusively an infantry force, and during the half century of $i$ ts existence had gradually been brought into conformity with thepattern of the East India Company's Bengal army. Initially, it was organised in companies; but when Bhim Sen Thapa returned from Benares he regrouped some troops into battalions, using the English title of captain for their commanding officers. This gave the Nepalese army much the same sort of organization which the Bengal army had had in the days of Clive. ${ }^{58}$ The involutions of British drill were mimicked from the beginning, and in Kathmandu the troops were paraded daily to English words of command, achieving such an efficiency in their exercises as would not have shamed the East India Company's own battalions. ${ }^{59}$ These routines were leamed from British deserters who took service with the Gurkha Raja. In 1814 there were still two of these individuals in Nepal, Byrnes and Bell by name, deserters from the Company's European regiment and foot artillery respectively. Bymes was made a schoolmaster, and taught the officers English, while Bell was made a colonel of artillery. ${ }^{60}$ They even seem to have given some musical instruction, for in 1816, at Makwanpur, the Nepali fifers entertained the astonished British troops with their own versions of

*The misconception still persists. The so-called Gurkha regiments in the British and Indian armies are composed not of Gurkhas but of the various tribes of the Nepalese hills whom it was the special policy of the Gurkhas to keep distinct from themselves. 
The Lass of Richmond Hill, The Soldier's Wife, and half-a-dozen other English marching tunes. ${ }^{62}$ After the middle 1790 's the dress of the regular soldiers was in quaint imitation of the Company's uniforms. There were red jackets with facings and white cross belts for the men; ${ }^{62}$ and fantastic outfits for the officers, concocted with little heed for the exact symbolism of British army dress. The rank of general was held by the commander-in-chief alone in the Nepalese army; yet the subba, or provincial governor, killed by John Shipp in 1816 was dressed in the old fashioned full uniform of an English general, frog lace and all. ${ }^{63}$ Prithvi Narayan Shah had himself distrusted Europeans and had been reluctant to take them into his service; ${ }^{64}$ but even he had been obliged to have recourse to Frenchmen to instruct his artisans in the arts of smelting native ores and casting and boring cannon. A Frenchman called Neville was in Prithvi Narayan's service and he appears to have been joined by two others, one named Vincent and the other called Dil Bensi* by the Gurkhas. ${ }^{65}$ These three were in charge of the Nepalese artillery until the middle 1790 's, and kept very busy supervising the casting of guns, howitzers and mortars, and the manufacture of gun powder. Dil Bensi's pay was stopped when the Gurkhas fancied they had learned all that he could teach them; and when he endeavoured to leave the country he was killed. The others, however, apparently escaped. ${ }^{66}$ Bymes and Bell also caston in Kathmandu; and by the outbreak of the war with the British there must have been four or five hundred guns of all descriptions in Nepal. Even quite sophisticated artillery devices were adopted. The British discovered shrapnel shells and howitzers with tangent scales at Makwanpur in 1816. 67 The Gurkhas did not only copy the Europeans. When the Chinese invaded Nepal in 1792, their army was provided with very light leather guns, which fired five or six rounds before bursting. ${ }^{68}$ Their antagonists promptly adopted the idea, and after the British had occupied Garhwal, they found guns "made of leather pretty thick, lined throughout with clay and an iron hoop rudely twisted round." They were so light that one man could easily carry two; used shot of about one pound; and could be fired three or four times before bursting. 69 *The derivation is not clear. Dil is a common Chetri cognomen, and means"heart" Bensi is possibly a sobriquet deriving from bhanse (cook). 
European muskets were imported from Calcutta by Prithvi Narayan Shah; but subsequently the Gurkhas set up their own manufactories, with the help of English deserters, and produced relatively efficient weapons. They were spoiled only by inaccurate balance and defective locks. The severest disadvantage suffered by Gurkha musketeers was the poor quality of their flints. These frequently snapped or missed fire, and it was essential to import flints from India to make the firearms function properly. 70 With this, and the single other exception saltpetre, the Nepalese territories provided all the raw materials essential to satisfy the Gurkha passion for military appurtenants: good quality iron for muskets, swords, and khukuris (short curved knives famous as the characteristic weapon of the hill tribes); copper and zinc for brass guns; lead for shot; and sulphur for gunpowder. 71

Having said so much, it must be emphasised that,for all its apparent sophistication, when actually in the field the Gurkha army neither acted like a European force nor owed its victories to European science. Of the regular army, half was (perhaps) organised in battalions, and these were kept in Palpa and in the Nepal Valley to provide for defence and furnish ceremonial corps d'elite. The remainder, still divided into independent companies, was dispersed throughout the wide length of the empire. 72 It was very thinly spread, and recourse had to be made to irregular troops to thicken the texture of the military presence in the provinces. The greater part of the Gurkha field army consisted of local troops. In the west large numbers of the inhabitants of Kumaun and Garhwal were embodied as militia, officered by Gurkhas and supplied with muskets by the government, but with no uniform and with regular pay only when on foreign service. Otherwise they were paid a retaining fee in land. Of a force of between six and seven thousand men west of the Kali, between a half and two thirds were locals. 73 In the eastern provinces, Kiratas and Limbus were enlisted. They received no pay, but were allowed to keep all they might obtain, specie excepted, by plunder. 74 These tatterdemalion bands were very different from the trim English-style soldiers who manoeuvred with clockwork precision on 
the Tundikhel, the vast and pretentious parade ground laid out in Kathmandu by Bhim Sen Thapa. Furthermore, the Gurkha officers, although they knew English words of command, gasconaded in English uniforms, and instructed the rudiments of English discipline, had very little grasp of the fundamental principles of which all these were but the superficial expression. The daily parades in Kathmandu were little more than a decorative choreography, inspired by a love of ostentation and designed to give an air of martial circumstance to the capital. In the field, the strength of the army resided less in $i$ ts collective discipline and in the training of its officers, than in the powers of endurance and courage of its individual members, who were all natural guerilla fighters. Tactics were elementary, and seldom involved more than the Gurkhas' favourite expedient of attacking simultaneously from two or three directions. Usually a volley of musket fire was sufficient to terrify the enemy into surrender or flight; but in cases of resistance they would surround their antagonist, and starve him into submission. The Gurkhas were past masters in the art of stockade warfare. Within a few hours a force could be almost ineradicably ensconced behind a high abatis made of two parallel screens of wickered branches and filled between with stones, mud, sticks, and any available rubbish. From these safe retreats they would harass the enemy with daring assaults, usually nocturnal. ${ }^{74}$ The scientific refinements, like the drill and the polish, were reserved for Kathmandu. Guns were so difficult to transport, that their use was very limited. Apart from the light leather ordnance, the Gurkhas had only about three dozen small brass cannon in the west, and these had to be carried on slings or dragged along the ground. They roared impressively with their rough hand-beaten shot, but did little damage, because there was no means of aiming them. Carriages were very few, and often the guns were merely laid on the ground and fired by a trail. ${ }^{76}$ Far more important to the army than these cumbersome engines was its agility. There were no pack animals. All stores and supplies were carried by non-combatant camp servants. There were large numbers of these, for every soldiers had his woman slave and his 'boy' 
(keti). Baggage was reduced to an absolute minimum. The troops had no tents, but slept under low makeshift shelters of blankets and sticks. An officer's camp equipage could be carried by one man, and the whole tentage of the commander required only six bearers. Supplies sufficient for three days only were normally carried. The army expected to provide itself from the country, and agents were stationed in all the principal towns and villages to buy and forward grain. ${ }^{77}$

Its slippery mobility enabled the Gurkha army to exploit fully the features of the hill country. It could come and go with the stealth of a fish in water. As well as suddenness and savagery, $i$ ts attribute was mystery. It could evoke terror in the heart of an antagonist; vitiate his judgement, and confound his assessments merely by concealing its identity in the dissembling landscape and remaining undefined by number or formation. Because the inaccessibility of the country was an important factor in its defence, the few roads which existed in the conquered territories were allowed to decay. To facilitate communication with Kathmandu a road was made linking Srinagar in Garhwal to Almora in Kumaun, and going thence eastwards to the Kali river. Here it joined a road extending from the Nepal Valley. But the whole was little more than a narrow bridle path and would hardly have qualified as a military road by European standards. ${ }^{78}$ 


\section{Chapter Two}

The Quarrel with the British

As the Gurkhas advanced westwards, they were paced on their southern flank by the British, who were simultaneously pushing back the frontiers of their lowland empire. The first half of the eighteenth century was the age of the decline and fall of the Indian empire of the Mogul Emperors of Delhi. Internal decadence enabled the Emperor's powerful provincial governors - such as the Nawabs of Bengal and Oudh in the north, and the Nizam of the Decean in the south - to assert their independence; while assaults from the predatory Muslims of Persia and Afghanistan hastened the demise of Imperial authority without providing an alternative hegemony. The chief contenders for the Mogul legacy were Hindu and European. The Hindus who took advantage of this ferment to demonstrate new political initiative were the Sikhs, the Gurkhas, and the Marathas. Their European rivals were the French and the British, The Sikhs were a martial sect of Jats, $/$ reformed Hindus $\not$ were
pantheism, once of/idolatry, caste, and asceticism. They laid claim to the Panjab and Sirhind, which they successfully preserved against the Afghans. The Gurkhas seized the hills, with little opposition from anyone. The Marathas were the heirs to the rest, but were cheated by fate and the British of their inheritance. They were a west Indian tribe, who in the first decade of the eighteenth century became agents of Imperial authority in the Deccan and south west India. From Poona, the Peshwas or hereditary ministers (the Maratha monarchy was otiose from an early stage) directed imperialistic expeditions which, by about 1770, had made them masters of all central India, Rajputana, Malwa, and Berar, and custodians of the person of the Emperor himself. But the extent of these dominions was out of proportion to the strength of the bonds of Maratha unity, and the polity split into five independent portions. The states of Gwalior, Indore, Berar (or Nagpur), Gujarat, and Poona became separate sovereign powers, each with its own army. They all continued to acknowledge the titular suzerainty of the Peshwa, and historizks have chosen to retain the term 'Maratha confederacy'; but it was in fact 
the inability of all to cooperate under a single leadership in times of crisis that was the ruination of each.

The territorial power of the East India Company, a corporation of merchants trading under charter from the British Crown, germinated, like that of the Marathas, in south India. Its first factories were at Bombay, on the west, and Madras on the east, or Coromandel, coast. But the Company's wars in the south, in the second half of the eighteenth century, were less against the Marathas than against the French, for even after the last French colonies had been captured (1761) a powerful gallic influence persisted both at Poona and at the independent Muslim court of Mysore. The war fought by the English with Poona, and the three fought against Mysore between 1779 and 1799 were in large measure projections into Indian politics of the Anglo-French rivalry in Europe. The Company's real struggle against the Marathas took place in central and northern India.

The Company had trading posts in the area of modern Calcutta from the end of the seventeenth century, but with no territorial possessions and no army at first. Harassment by the Marathas from Berar and from capricious Nawabs of Bengal led Robert Clive to form an army and claim a share of influence in the internal politics of Bengal. The share soon grew into a monopoly, and the Company began to control the Nawabs. It acquired tenant rights to certain territories, and in 1765 suddenly became a landed potentate in its own right when the Emperor of Delhi made the Company Dewan (fiscal administrator in theory; farmer of revenues in fact) of the three provinces of Bengal, Bihar, and Orissa. With these new responsibilities the Company began to develop an administrative, as well as a mercantile identity. Once started, the process of growth was difficult to stop. It became necessary to expand in order to consolidate and preserve what was already possessed; and there was, besides, little inclination at first to eschew aggrandizement, for both public revenues and opportunities for private enrichment increased with every augmentation of the Company's territory. In 1772, the the fertile province of Kuch Bihar, wedged between the northern frontier 
of Bengal and Bhutan, was re-incorporated into the territory of Bengal, after a long independence. Its Raja appealed to the Company for help against the ferocious mountaineers of Bhutan, who had come down and attacked histerritories, and Warren Hastings, Governor of Bengal at the time, was glad of the excuse to re-annex the territory, thereby completing the outline of the Company's dominions and adding to its income - though he firmly disclaimed 'remote projects of conquest'. 1 A policy of self-defence, mixed with greed, led Hastings to turn his attentions to the Muslim state of Oudh, long independent of Delhi, but now in its turn effete. To protect Bengal against the Afhgans in Rohilkhand and the Marathas in Delhi, Oudh was made a buffer state and provided with a protective force, for which it was compelled to pay an enormous annual subsidy. The Marathas and the English remained in uneasy truce until the arrival of Lord Wellesley as Governor General in 1798. Wellesley, brother of the Duke of Wellington, was a little man with panoramic vision and olympian aspirations. He viewed Indian politics in relation to those of Europe, and conceived an elaborate scheme of alliances with the native states designed to preclude the subversion of the Company's position in India by Napoleon. Oudh was constrained to disband its own army, accept an increased force of Company troops, cede Rohilkhand and all territory between the Ganges and Jumna rivers in lieu of subsidy, employ no Europeans, and leave the Company in general control of its foreign policy. The weakest of the independent rulers, the Nizam of the Deccan, meekly submitted to similar terms; but Mysore, whose ruler Tipu Sultan flaunted his sympathy for the French in an attempt to preserve his independence, had to be forced into submission. It was Wellesley's attempt to bring the Marathas into this grand system of British hegemony which finally precipitated the long pending clash between them and the Company. Poona and Gujarat agreed to accept troops, pay subsidies, and forgo the employment of Europeans: but the other three Maratha states vigorously demurred at this betrayal of Maratha independence. Gwalior and Berar were at war with the Company from 1802 to 1804 , but were ultimately forced to submit. Only Berar accepted a subsidiary force, 
but each received a British Resident at its court and agreed not to employ Europeans. All Maratha territory in the Doab, or tract between the Jumna and the Ganges, was annexed by the Company. It was combined with the estates in the same area ceded by Oudh in 1801, and the whole was made an integral part of the Bengal Presidency under the designation 'Ceded and Conquered Provinces'. Holkar of Indore then took up arms against the Company, prolonging the contest until 1805, and causing unexpected discomfort to the British commanders, Lake and Monson. On receiving news of this, the home authorities, who had been prepared to let Wellesley have his head while he did not stumble, pulled in the reins sharply. There was a growing disapproval in England of Wellesley's lofty manner and pretensions; of his humiliation of illustrious dynasties; and of his blatant contravention of the clause in the Company's charter which deprecated schemes of conquest; as well as an increasing apprehension lest the structure he was building should become too unwieldy to control. So, with his plans but half-realised in the coucial area of central India, Wellesley was obliged to resign; and his successors were instructed to follow a policy of retrenchment and neutrality. The protection afforded by Wellesley to the states of Rajputana was withdrawn; and Indore and Gwalior, dangerous as wounded wasps, were left to conspire uncurbed. The territories of the British and their protected clients had by this time assumed roughly the configuration of a huge question mark, following the western contour of the sub-continent. The Ceded and Conquered Provinces, Oudh, and the provinces of Bihar and Bengal formed the hook; Madras, the Deccan and Mysore the thickened tail; and Ceylon* the stop. In the open ended space of central India were the Maratha states and the unprotected Rajputs.

In the years between Wellesley's resignation and the arrival of Lord Hastings, when Barlow and Minto were Governors General, the Company was drawn into serious diplomatic confrontations with the two remaining members of the trio of Hindu phoenix which hademerged from

* Ceylon was British territory, but since 1798 had been adminis tered by the crown, not by the Company. 
the ashes of the Mogul empire:- the Sikhs and the Gurkhas. It seemed possible that the Company would find itself in conflict with one or both of these powers while Gwalior and Indore still remained sufficiently strong to seek revenge. This was the nightmare of a Hindu confederacy which alarmed Lord Hastings. The Sikh communities straddled the Sutlaj river, divided between the Panjab and the old Mogul province of Sirhind. Raja Ranjit Singh of Lahore had become the most powerful Sikh monarch in the Panjab, and he sought to extend his control to the Sikhs on the other side of the river. To prevent this, Minto was compelled to act against the letter of his instructions and grant British protection to the Sirhind Sikhs, thus pushing further west, to the left bank of the Sutlaj, the starting place of the hook in the question mark of British territory. The Gurkha empire was contiguous throughout its whole length to territories either administered or protected by the Company. Before long, both the Company and its hill neighbour found that with their new dominions they had inherited local disputes about borders.

There existed no greater contrast than that between the country occupied by the Gurkhas, where the surface of the earth appeared to have been petrified in the full violence of its primeval fermentation, and that in north India under the English Company's sway, which was an immense plain, level like an unrippled lake. The flatness of the terrain, its mango groves, its ponds and creeks, and the intense luminosity of its amosphere recalled the classical landscapes of claude le Lorrain and Poussin. From the Jumna eastwards these provinces were separated from the Himalayan foothils by a belt of forest, averaging from five to fifteen miles in depth, where the swampy soil and torrid climate forced sal, elephant grass and etiolated bamboo in to excessive luxuriance. The vegetation varied in density from area to area: sometimes thinning to expose large tracts of arable land; elsewhere so thickening that the light was excluded and passage impossible. The ground was intersected by innumerable soupy nillas; and the dank, close atmosphere ceaselessly vibrated with the noises of mosquitoes, cicadas and frogs. This fringe, called Tarai along most of the Nepalese border, 
Morang in extreme south east Nepal, and divided into sections called duars on the frontier of Bhutan, was intensely malarial during the summer and monsoon months, from April to October: a place of dread to be avoided at all cost, save by the Tharus and other indigenous tribes, which were immune to the infection. The mosquito's responsibility being then unknown, the awl of malarial fever was reckoned to be caused by some noxious miasma. According to the natives this emanated from the mouths of large serpents who inhabited the northern mountains. The European view was that it derived from putrifying vegetation or stagnant water. ${ }^{2}$ Its effects were swift and horrifying: fever and vomiting, followed in a few hours by raving madness and death. The Company's northern territories, which stretched into this inhospitable region, were bisected by the Kingdom of Oudh. West of Oudh there were the Ceded and Conquered Provinces, of which Rohilkhand and Saharanpur were the most northern; and east of Oudh there were the districts of Gorakhpur, Saran, Tirhut, Pamia, and, in the extreme north east of Bengal across the Tista river, the district of Rangpur. These were the moffussil - the 'interior' or 'up country' areas, as opposed to the Presidency capital, Calcutta, which might be up to three month' journey away. Europeans were few and far between. Besides the handful of magistrates, revenue collectors and military men, there were only those few who had managed to secure settlers' licences - essential for anyone who wished to live more than ten miles from Calcutta. They were mostly indigo planters, brutish and boisterous individuals, whose handsome villas with spacious verandas were becoming numerous in Gorakhpur, Tirhut, and Parnia. European life centred around the civil and military stations. The former, composed of district Judge, Collector, Registrar, Surgeon and Postmaster, with an army officer or two in charge of the jail guards and escorts, were remote pockets of British society in country where the British had barely been heard of, and where the sight of a white face could still provoke constemation and amazement. There were no allweather roads. Consequently, the main stations - Dinapur, Ghazipur, Chunar, Campare, Meerut - were situated close to the river Ganges, $h$ the 
principal highway of travel. From these centres troops were distributed among the numerous outposts and frontier pickets.

The districts of Saran, Tirhut, Pamia, and Rangpur formed part of the territories of which the fiscal administration was granted by the Emperor to the Company in $1765 . *$ They were divided into the estates of various rajas and barons who by the terms of Lord Cornwallis's land settlement were recognised as the proprietors or zemindars (literally, landholders) of their lands, and made responsible, for the payment of the rents (to the company). The amount for which they were liable was fixed in perpetuity. When the land settlement was made, the Company's officials were reluctant to concem themselves with defining the boundaries of the estate for which each zemindar contracted to pay the revenues. Interference in matters of this nature was held to be an infringement of the sacrosanct principle of privacy. This was not the province of revenue administrators, but of the magistrates and judges, should zemindars feel disposed to make use of their services in cases of uncertainty. The result was, in the words of Sir George Campbell, that "even the very first step towards the roughest settlement of modern days, the definition of boundaries, was not taken...There was a mere register of rent-paying estates, with the names of the proprietors, but no means of identifying the lands." ${ }^{3}$ Quarrels concerning boundaries therefore inevitably arose. When two disputing zemindars were tenants of the same government, no grave issue was involved; but when one was a tenant of the Company, and the other a tenant or agent of a neighbouring sovereign power, then a small domestic problem was transformed into an international border dispute. In the days of feckless Mogul rule, the zemindars in these districts $"$ continuously (had) disputed with the hill rajas about possession of the rich lowland border areas; and after the Company made them $i t s$ clients and revenue contractors, its officers were soon faced with an avalanche of claims and complaints. Villages and tracts were reported to have been seized either by the Bhutanese or

"Gorakhpur was ceded by the Nawab of Oudh in 1801. 
by the people of the Raja of Nepal. It was often impossible to make a satisfactory settlement. A collector or magistrate might be expected to form a judgement on the basis of quite preposterous evidence. The altercation between the Raja of Bhutan and the Company's zemindar of Baikantpur, whose mutual boundary meandered back and forth across the river Tista, was typical. When the Magistrate of Rangpur went to inspect the border of an estate belonging to Bhutan on the westem bank of the river, he found that its distinguishing features were occasional streams, rivulets and ridges of earth. Elsewhere his only direction was the memory of his guide, who professed to recognise the frontier by the different colourings of the grass "and other marks of the like nature which seemed to exist nowhere but in the fertility of the imagination." ${ }^{4}$ The Raja of Kuch Bihar was in incessant dispute with the Bhutanese authorities concerning the villages in the area of their common frontier. In 1809, the Company set up a commission to examine the claims and counterclaims in question, and even sent military assistance to its vassal when the enquiry indicated his complaints against Bhutan to be justified. 5 Sometimes, encroachments were flagrant. The Bhutanese, for example, seized the estate of Bidyagong, in the extreme north east of Rangpur, and asserted their right to nominate a successor when the adjacent zemindari of Bijni became vacant. But such remote and complex contests were more tiresome than important to the British officials. The Magistrate of Rangpur reported the Bidyagong affair, but the government decided that an annual rent of 40 elephants was too trivial a loss to warrant giving offence to Bhutan. Bijni, way over on the Manas river, was the remotest ramification of the province of Bengal, and virtually nothing was known about the country and the nature of $i$ ts connection with the Mogul empire. When the Bhutanese appointed their own candidate as zemindar, in 1791, the British authorities made a desultory enquiry, but forbore to press their own right, as it transpired from the investigation, to nominate a successor. ${ }^{6}$

Company zemindars in areas farther west accused the Gurkhas of usurpation. Their complaints were numerous, elaborate, insistent, 
and often totally without foundation. They were bothersome to the collectors, busy with the administration of districts of vast extent; harassing to the magistrates, who had enormous backlogs of cases; and embarrassing to the government, which wished to avoid offending Nepal, and which, because its revenues had been settled on a permanent basis, was not the loser in cases of encroachment. ${ }^{7}$ At first there was no problem. The Gurkhas showed themselves anxious to have these disputes settled peaceably; and the Company seemed prepared to make concessions at the expense of its own clamouring zemindars. In 1795 Cornwallis assured the Raja of Nepal that he was willing to define the long uncertain border between the Morang and the district of Parnia in exact conformity with his representations; ${ }^{8}$ and writs and petitions from cheated zemindars of Tirhut were allowed to gather dust in the files of the Collector's office without any determined attempt being made to deal with them. In the zone to the east of oudh, the boundary between the Ceded and Conquered provinces and the Gurkha colonies of Kumaun and Garhwal had been made so uncertain by the collusion and inefficiency of the Oudh officers who had preceded the British, and accurate records and surveys were so wanting, that the Company's servants were perplexed as to how to react when they saw the Gurkhas move into a fresh frontier area. In some instances, incursions were not even noticed until long after they had taken place. In the early years of British occupation, the Company's authority was so tenuously established and its vigilance so strained, that the advance of a few Nepalese troops into remote villages, or the loss of uncultivated and unhealthy tracts near the border, were the incidents least likely to attract the notice of $i$ ts officers. Furthermore, in these areas there were no zemindars to complain, the revenue contracts being made, according to an experimental system, directly with village headmen. Rohilkhand had declined into a state of anarchy under the combined effects of Maratha invasions and maladministration by Oudh. Cultivators and farmers had relapsed into a state of instinctive resistance to all revenue collectors. Organized brigandage was rife, exacerbated by the continued existence of the small independent states 
of Rampur and Sirdhana, which were sancturies for fugitives from British justice. 10 One of the first Company collectors in Moradabad felt so insecure that he threw elegance to the winds and made an incongruous moat and mud rampart around his handsome cutchery. 11 To the west, across the Ganges in the district of Saharanpur, almost every village was surrounded by a wall or ditch - testimonies to a long torment inflicted by Sikh raiders from across the Jumna. 12 The large new military station of Meerut, outside the old town, had to be built on land reclaimed from the jungle; and crime was so rampant in the area that it was quite common to stumble across the corpse of a murder victim even on the plain between the city and the cantonments. 13 With so much else to distract them, it is scarcely surprising that the tiny number of British officials gave only perfunctory attention to the settlement of the northern regions, and only scant notice to the subsequent Nepalese incursions. Indeed, the marauding raids of the Mewati and Amir tribes had made alarums and excursions along the northem frontier so unexceptional, that such intrusions were often lost in the general confusion. ${ }^{14}$ Then again, British officers were scared by the climate of the Tarai, and tended to avoid it, save for a few weeks in the healthy season, when they might hunt big game. 15 It was quite by accident that the Magistrate of Bareilly noticed, in 1811, that the Gurkhas had built a fort in Kheri. This was a remote appendix of territory east of the Kali, wedged between oudh and the hills. It had been assessed as part of the ceded and Conquered Provinces, but its revenue had never actually been realised by the Company. 16 The Magistrate was sure that the Gurkhas had not been in occupation of the tract two years previously, but, as he pointed out, no one could be sure that they were not entitled to it. "Such is the undefined boundary between the two governments", he wrote, "and our want of local information of the extent of our territories in the unexplored tract of country along the foot of the hills, that doubts may be entertained whether even the acquisitions of the Nepalese which are stated to appertain to the pargana of Kherigarh can be pronounced encroachment on our territories." 17 
Obviously, such a state of affairs could not be permitted to continue. The Directors of the Company wrote from London to censure the "want of vigilance" or the "defect in the system of management" which allowed boundaries to elude definition and anarchy to persist. "It is unnecessary for us to insist upon the importance of having the limits of our dominions accurately defined", they pronounced, in February $1814 .^{18}$ But the boundary question had already boiled to a crisis before the ship carrying this despatch reached Calcutta. Long even before it was written, both the British and the Gurkha governments had changed their attitude towards the frontier problem. When the Thapas acceded to power, the Gurkha durbar became pusillanimous and uncompromising. At the same time, the Company's government decided that its own laxity and complaisance in these matters had gone on long enough. The border must be clearly defined, once and for all, even at the risk of displeasing Kathmandu.

In one area, at least, defining the border was as simple as drawing a line on a map, and then warning the Gurkhas that they would cross it at their peril. This could be done in the frontier regions adjacent to the recent Gurkha conquests in the western hills. Where the Gurkhas had had no time to establish themselves in the lowlands. As they held Kumaun and the territory beyond only by right of conquest, they had no a priori right to parts of these provinces which they did not actually occupy. Seizure of the hilly part of a raja's kingdom gave them no claim to the lowland portion if the raja had not formally resigned it and was able to defend it. Now the rajas expelled from the western hills were able to defend their lowland possessions, because the Company decided that it would support them in their determination to do so. It was indicated to the Gurkhas that they could invade these tracts below the hills only on pain of war with the British. Because the Gurkhas were not yet established below the hills, and because they had no treaty rights, it proved a simple and effective way of fixing boundaries. The Calcutta government, however, did not dispute the Gurkhas' claim to the mountain territories, and resisted considerable 
pressure to reinstate the rajas in the hills. Early in 1810, Amar Singh Thapa announced his intention of occupying certain villages on the plains of Sirhind on the justification that they belonged to Sirmur and Hindur, all of whose territories were now his by right of conquest. ${ }^{19}$ Colonel David Ochterlony, at Ludhiana, was Agent for the affairs of the Sirhind Sikhs brought under the protection of the Company by Minto in 1809. He had already been given clear instructions for such a contingency. He was to inform the Gurkha commander that all territories below the line of the foothills, whether previously attached to hill states or not, were now under the protection of the Company; but at the same time he was to make it clear that the Company had no interest whatever in the fate of territories within the mountains. ${ }^{20}$ But Ochterlony was spoiling for a fight to He urged that the Gurthas be requested not only to relinquish possessions in the plains, but also to restore the Dehra and Kayarda Duns, in the first range of foothills, to the Garhwal and Sirmur royal families respectively. This, he claimed, would create a useful buffer region between the Gurkha and the British spheres of interest, besides enhancing the Company's prestige in the view of all the native states of Hindustan. He anticipated little resistance from the Gurkhas, whom he disdained as "a body of ill-armed and undisciplined barbarians, who affect a wretched imitation of the dress, accoutrements and constitution of a British native battalion and who might have been successfully resisted in such a country by less than a third of their numbers." ${ }^{21}$ Government patiently pointed out that it would be futile and discreditable to make such a demand, for it was most unlikely that the Gurkhas would spontaneously comply: and the expediency of using compulsion was "more than questionable". ${ }^{22}$ In the event, Amar Singh did not act on his claim to the lowland villages, and the use of force even in the plains was unnecessary.

In the middle of 1813 there was a second frontier crisis. Amar Singh Thapa's men seized six villages which two of Ochterlony's Sikh protégés, Patiala and Hindur, affirmed belonged to their lowland possessions. Amar Singh claimed that they belonged to Sirmur and Kionthal, states in the hills which he had conquered and to all of whose 
estates he had right; but he asked for time to make reference to Kathmandu before relinquishing them. ${ }^{23}$ ochterlony agreed to the delay: but only because the season was not yet fit for military operations. He was convinced, or affected to be convinced, that Amar Singh had no intention of abandoning the villages. Briskly, and with obvious enthusiasm, he set about making preparations for a punitive expedition, whose object was to be the expulsion of the Gurkhas from all the hill areas west of the Ganges. This brought him into contact with Captain Hyder Hearsey, a half-caste who had made his fortune by fighting as a mercenary with various native princes in the turbulent years before 1804, and by marrying a muslim princess of cambay. Hearsey had in his pocket his own plan for an invasion of the Western hills. It had been concocted in consultation with Harak Deva Joshi, the quondam King-maker of Kumaun, and Hearsey had a special interest in its implementation, because in his other pocket he had a deed of right to Dehra Dun. He had bought this for a few thousand rupees in 1811, from the impoverished and exiled heir to the Kingdom of Garhwal. ${ }^{24}$ Ochterlony proceeded on the assumption that the Govemor General, Lord Minto, would be of the opinion "that the best way of enforcing the restitution of the disputed villages ... would be to show our ability to do much more ${ }^{25}$; and his own "firm persuasion" was "that Amar Singh Thapa will compel us to dislodge his troops from below the hills". ${ }^{26}$ But his assumption and his persuasion were wrong, and both his ambitions and Hearsey's hopes were for the moment to remain unsatisfied. "It is...far from being the wish or intention of the Governor General in Council to engage in any extended scheme of operations such as that contemplated I by you_T. His Lordship ...is, on the contrary, desirous of maintaining the existing relation of friendship with the Nepalese Government, and of effecting an adjustment of all disputed points by amicable negotiation, if practicable", wrote the Political Secretary. At the very most, and then only as a last resort, force might be used to eject them from the lowlands. ${ }^{27}$ Meanwhile Amar Singh Thapa, confuting Ochterlony's confident assertion that he had been bluffing, did make reference to Kathmandu. The durbar made 
it plain that as far as it was concerned the issue was not to be settled according to whether the villages were or were not below the hills, but according to whether the Company or the Gurkhas had been in possession of them first. His government, in fact, was far more intransigent than the Kaji himself, who was embarrassed by these injunctions. He appealed to Ochterlony to spare his dignity. He had occupied the villages in the sincere belief that they belonged to the Gurkhas by right, and he could not now withdraw without losing Could not the Gurkhas and the Company share the contested territory? ${ }^{28}$ But Ochterlony was obdurate, and issued an ultimatum. ${ }^{29}$ Though peevish and insistent as to his right, the old kaji had no intention of risking a conflict with the Company, and he directed his officers to withdraw. ${ }^{30}$ Only when he actually inspected the disputed areas, several weeks later, did Ochterlony discover that two of the villages were decidedly in the hills. 31

Amar Singh Thapa had made a genuine concession because he was eager to try again to capture Kangra. He was convinced that the British were preparing to cross the Sutlaj and conquer the Panjab, and his idea was to use the occasion, with British acquiescence, to march once more against the fortress and avenge his previous humiliation. Ochterlony peremptorily disavowed such intentions; but once this Gurkha had formed his own interpretation of a situation, he was loath to change it. He continued to press for an alliance, and being persuaded of the selfevident correctness of his own assessment of British ambitions, regarded all protestations to the contrary as policy or artifice. He refused to concede the merit of sincerity - thereby divulging, no doubt, his own disingeniousness - and fancied he could penetrate Ochterlony's tactics of dissemblance. Ochterlony, like most, was ever the first to discem and detest his own faults in others, and was exasperated by this obstinacy. He complained of Amar Singh's obtuseness and duplicity. ${ }^{32}$ In fact, the Gurkha's supposition that the British had only advanced thus far in order to prepare for an assault on the Panjab was not so bsud as Ochterlony insisted. According to the Indian way of thinking it seemed obviously to be so. Sansar Chand of 
Kangra drew the same conclusion. ${ }^{33}$ Ochterlony's refusal to respond to Amar Singh's overtures made the Kaji feel that the Agent was deliberately seeking to humiliate him, and his aversion for the British became something near detestation. But he knew not to goad them beyond a certain point. Almost in spite of himself, he sensed the profound unwisdom of a war with the East India Company, and the expression ofhis hostility was ever tempered by an instinctive respect for its power. Others of his race were not so circumspect, and in negotiations over disputed borders further east, words and actions of uncontrolled impetuosity led to the collapse of conference and the declaration of war.

In the frontier areas in the zone east of Oudh it was much more difficult to define a boundary. It was too late now for the Company to draw an imaginary line along the base of the foothills and forbid the Gurkhas to cross it. With the consent of earlier governments and, in the case of Gorakhpur, with the connivance of the Nawab of Oudh's officers, they had become firmly established in the Tarai and Morang, effective inheritors of all lowland territories formerly owned by the hill rajas they had displaced. These hill rajas, unlike those in the west, had not been able to protect their estates in the plains, because the Company had not felt disposed to assist them. The Gurkhas could therefore legitimately claim the $h^{\text {astates }}$ fruits of conquest. Now if the British and Gurkha governments were to honour the limits of their respective dominions, it was essential to know exactly what lands and villages those lowland estates had comprised. Such knowledge was not easy to obtain, because in many cases the hill rajas were not the proprietors of their lowland tracts, but merely tenants in them of the Nawabs of Bengal and Oudh. In this area, then, resolving the problem was a great deal more difficult than drawing a line on a map. Here, the frontier had not to be created, but discovered: and this involved unpicking a complicated knot of precedents, rights, and legalities.

Such a task demanded patience, good faith, and a compromising attitude of both sides. Until the fall of the Panres, the durbar of Kathmandu had reciprocated the spirit of concession shown by the Company 
in matters relating to the border. The political trio which was pre-eminent in Nepal in the last decade of the eighteenth century had been anxious to preserve the benevolence of Calcutta. This group had consisted of Damodar Panre, the prime minister; Brahma Shah, who was a chautarya or royal hereditary counsellor; and Gajraj Misr, the guru or spiritual mentor of the royal family. All three had fallen from power after 1803. Damodar Panre had been executed; Brahma Shah removed to Kumaun; and Gajraj Misr made persona non grata and constrained to make a prolonged pilgrimage to India. The new royal favourites, prime minister Bhim Sen Thapa, his father General Amar Thapa, and the new guru, Raganath Pandit, considered themselves as rivals rather than as vassals of the East India Company; and in imitation of it, they began to adopt imperious language and ambassadorial diplomacy. Contacts were made with the various native states; Nepal's relationship with China was turned to special advantage; and in exchanges with the British the old tone of cautious mistrust gave place to one of cavalier independence. When, in 1804, General Amar Thapa was sent to annex the territories of the Raja of Palpa, he did it with little ceremony, and did not stop at the hills. He sent officers down into the department in Gorakhpur called Butwal to collect the revenues, ignoring the fact that the Raja of Palpa had held this district as a tenant of the Nawab of Oudh, to whose rights in Gorakhpur the Company had now succeeded. ${ }^{34}$ The Gurkhas could argue from precedent, for they had been in possession of Siuraj, an adjacent department whose situation was similar, for sixteen years before the Nawab of Oudh ceded Gorakhpur to the Company. But Butwal was very fertile, and its revenues, because it formed part of the ceded and Conquered Provinces, where the Permanent Settlement did not apply, were not commuted into a fixed rent, but collected directly by the Company. This being the case, the Governor General was very reluctant to relinquish the region, and he requested the Gurkhas to evacuate it immediately. He even offered to leave British rights to Siuraj in a state of lapse, as a compromise. But the Gurkhas were equally loath to abandon such a rich acquisition, and would go no 
further than offering to pay the Company a rent for it. This offer was refused; but the Company refrained from pressing its claims, and as year succeeded year Amar Thapa's men occupied more and more of the Butwal villages with impunity, taking British quiescence as tacit recognition of their right. 35

In the district of Saran, next to Gorakhpur in the east, one of the Company's permanently settled zemindars, the Raja of Betiya, decided that he could wait no longer for the Company to investigate and secure redress for the losses he had suffered as a result of Gurkha encroachment. In 1811, he took the law into his own hands and sent a large body of armed men to seize some villages occupied by the Gurkhas as part of the inheritance of the conquered hill state of Makwanpur, but claimed by the Raja as part of the estates for which he had contracted to pay rent to the Company. There was an affray, and a Nepalese subba, or governor, was killed. The Gurkha Raja professed himself outraged, but delayed retribution in order to appeal to the Senior Judge at Patna, who was requested to punish the culprits. The Judge promised that impartial justice would be done. He passed the matter on to his subordinate, the Judge at Saran, who came to the conclusion that the subba had been as much to blame as the Betiya Raja. The authorities in Calcutta decided that provocation had been too strong to warrant the chastisement of the Company's zemindar. Nevertheless, in view of the fact that the Butwal issue was still unresolved, it was thought expedient to propose the institution of an Anglo-Nepalese commission to investigate the whole question of border disputes. The Gurkhas chafed at what they considered to be the Company's prevarication in favour of its own zemindars, but agreed to depute agents. ${ }^{36}$ For good measure they seized more villages in Saran, making 22 in all, pending the convening of the commission. 37

The Company's chief commissioner was Major Paris Bradshaw, Head Assistant at the Lucknow Residency. He began by investigating and presenting the Company's claim to the Butwal and Siuraj tracts, while Mr. Young, the Saran Magistrate's Assistant, conducted preliminary 
enquiries in Saran. No-one could pretend that Paris Bradshaw was a good diplomat. Fifty years old, small and slight, unspectacular and moderately successful, he was, when on official business at least, self-conscious and shy, seeking refuge from spontaneity in frigid punctiliousness and archaic mannerisms - unusual in an Irishman. He declined to abandon hair powder and pigtail, despite the fact that these had been abolished as part of the military uniform in 1810. To the thinking of his young brother-in-law, John Hearsey, * he was very much "a gentleman of the old school...exceedingly prosaic." 38 His despatches, tortuous and laboured even by comparison with the normal congested prose of official documents, betrayed a diffidence which made it impossible for him to cultivate any flair for management - a flair essential in oriental diplomacy. But having said so much, it must be added that the ultimate collapse of negotiations was not simply the result of defective negotiation at commission level. The Company, like the Gurkhas, no longer had any real intention of compromising, and it would have been impossible for anyonein Bradshaw's position to carry out the instructions from Calcutta without incurring unpopularity and being accused of bad faith. Bradshaw was instructed not only to demand the surrender of Butwal, but in addition to revive the lapsed claim to Siuraj, which the Company had professed itself willing to waive in 1805.39 He produced sanads and rent rolls to show that both belonged to the Company, but the Gurkhas were extremely unwilling to recognize such evidence, however conclusive. The Tarai lowlands were of vital importance in the economy of Nepal. Their revenues formed the only income from land which the Gurkha exchequer received, because all other territory was allotted to the army in lieu of payment. 40 Vainly, Krishna Pandit, one of the Gurkha commissioners and well-disposed towards the English after several years spent as resident Nepalese vakil at Calcutta, suggested a compromise. If the Raja admitted British sovereignty in the lowlands, would the Company be prepared to grant him on lease a "Later Major-General Sir John Hearsey. He was Hyder's half-brother. 
tract along the foot of the hills? Triumphantly, Calcutta asserted this to be an implicit admission of British claims, and the Raja was sent an ultimatum by Minto. Either he gave up the lands, or they would be taken by force. ${ }^{41}$ Here the matter rested for a few months: the hot season of 1813 was at hand, and any military movements would have to be postponed until the autumn. Krishna Pandit fell from favour for his well-intentioned but apparently unwarranted initiative, and was recalled. ${ }^{42}$

Bradshaw now proceeded to Saran, where Mr. Young had begun an enquiry concerning the 22 villages. His first act was to renew an initial condition laid down by the Calcutta government - namely, that these villages be surrendered to the Company pending any investigation concerning the question of right. The Gurkhas demurred, and were suspicious; but finally they consented, and the Company's officers occupied the hamlets and their fields. Major Bradshaw then announced that there would be no inquiry. Mr. Young's evidence was conclusive enough, and had already established the right of the Company to the lands. ${ }^{43}$ There was no point in conducting another laborious investigation, because the Gurkhas, judging by their intransigent attitude in Butwal,were bound to reject its findings in any case. ${ }^{44}$ Now this was a blunder. The British had laid themselves fully open to accusations of guile and deception. Bradshaw had given the Gurkha commissioners every assurance that a full investigation would be opened once they had surrendered the villages ${ }^{45}$; and the calcutta government, although it claimed that he had never been authorized to give such an impression, should have accepted the consequences of his mistake and allowed the inquiry to proceed. Furthermore, in asserting that the Gurkhas had rejected the findings of the Butwal investigation, the government were making an over-hasty anticipation of Kathmandu's reaction to that enquiry. The Gurkha commissioners had rejected nothing, but had merely asked for time to refer to the durbar, and the Raja's refusal to evacuate the contested territory was not in fact known at Calcutta until the end of $1813 .^{46}$ The British were also inconsistent in their treatment of precedents. While willing to regard their own 
long effective occupation of the 22 villages as "sufficient ground, if there had been no other, for immediately resuming the $\mathrm{m}^{\prime \prime}$, they refused to admit similar arguments in favour of the Gurkhas, who pleaded 25 years' possession of Siuraj. ${ }^{47}$ But then Gurkha tactics were equally dubious. The commissioners made a great show of indignation, and claimed that Bradshaw had tricked them shamefully, but at the same time betrayed their own insincerity by claiming that Young's enquiry had established their right to the villages ${ }^{48}$; and when Bradshaw produced additional documents to reinforce the Company's claim, they refused to accept them on the ground that they had not been produced at Young's enquiry, whose findings they regarded as final. ${ }^{49}$

Relations between Bradshaw and the Gurkha commissioners deteriorated to petty bickering. At the beginning of April, 1814, the latter suddenly broke off negotiations and returned to Nepal. Bradshaw, in a plaintive tone of self-justification, expressed his conviction that all their previous rudeness and intransigence had been designed to provoke him into some indiscretion which would make him appear responsible for what was in fact a predetermined cessation. ${ }^{50}$ It appears that the commissioners were summoned to Kathmandu to give their opinions in a debate which the Raja was holding to determine whether the Gurkhas should take a stand against the British. After the Raja's refusal to evacuate Butwal and Siuraj had been received in Calcutta in December, 1813, a fresh demand, in the form of an ultimatum, had been sent for the relinquishment of those lands. General Amar Thapa had no intention of yielding to such insolent and domineering representations. To humiliate the haughty British, by turning against them the model soldiers he had drilled and rehearsed with solicitude and pride, was the paramount ambition of this ailing but ferocious old war lord. At the end of March he summoned his energies for the journey to Kathmandu, and there used all his eloquence to urge resistance and disparage supine concession. ${ }^{51}$ Opinion was divided in the state. Bhim Sen Thapa was in favour of defiance; but Brahma Shah, his brother Hasti Dal, and Amar Singh Thapa 
counselledy restraint and concession. They feared that armed resistance to the British would engender full-scale war, and

they knew/ to be too weak. to embark on military enterprises of that magnitude without risking annihilation. Urgently, they stressed the difference between the hill rajas and the East India Company: fighting the one was like hunting deer, but engaging in battle with the other would be like fighting tigers. But the party of resistance carried their case; and General Amar Thapa, now back in Palpa, was sent instructions to prepare the military defence of the territories under his command. 52 In reply to the Governor General's protestation at the unceremonious interruption of negotiations with Bradshaw, the Raja retorted that Bradshaw had been rude and offensive, and that the Gurkhas had no intention of restituting lands to which $\mathrm{Mr}$. Young's enquiry had established their incontrovertible right.

On April 22nd, 1814, the ultimatum for the formal surrender of Butwal and Siuraj having expired, the Magistrate of Gorakhpur ordered seventeen companies of native infantry to take possession. They met with no resistance, Amar Thapa's men withdrawing as they advanced. But at this time of the year, when the malaria was becoming virulent, it was impossible to allow the troops to remain in the disputed territory. The regular soldiers had to be withdrawn almost as soon as they had advanced, and defenses was entrusted to the native personnel of a few thanas, or police posts. On May 29 th the Gurkha troops moved back into the now virtually unprotected territory, and attacked a thana in Butwal. Eighteen of the Company's policemen were killed and six wounded. The daroga, or chief officer, was wounded, and surrendered. The Gurkha commanding officer ordered him to be tied to a tree, and he was then shot dead with arrows. Two other police posts were attacked at the same time, and put to flight. ${ }^{53}$

When the news of this atrocity reached Calcutta, early in June, the Governor General and Council were in conclave on normal business. The council chamber in Fort William was not a place of harmony and relaxed cooperation. Suppressed animosity intensified the natural 
discomforts of the scorching Bengal summer. The Governor General, the Marquis of Hastings* was not popular with his colleagues. The mode of his appointment and the nature of his policies were both causes of resentment and hostility. Hastings, now in his sixtieth year, was a soldier by education and experience. As Lord Rawdon he had fought with distinction in the American War of Independence, and then in the Revolutionary Wars in the Low Countries, where Wellington served under him. Between his foreign assignments, he had fitted uneasily into domestic politics. A committed follower neither of Fox nor of Pitt, he had too few of the skills of management and insufficient taste for the furtive arts of Parliament to form a party independent of them both to give voice to his independent liberal views on leading issues such as Catholic emancipation and the government of India. His firm loyalty to the Prince Regent was generously repaid in 1812 , when in response to the Regent's influence, the Court of Directors of the East India Company elected Hastings not only Governor General, but Commander-in-Chief in India as well. The object of the dual appointment was to give Hastings a chance to recruit his personal finances, crippled by extravagance and a somewhat ostentatious largesse; but, however financially remunerative, it cost him much in terms of popularity and sympathy. The friends of Sir George Nugent, the present Commander-in-Chief, indignantly deprecated an untimely supersession whose only justification was the penury of the new Governor General; and they used their influence to have a special post was created for him, that of Commander of the Forces in Bengal. 54 The new Governor General was repelled by hypocrisy; sincerely hated giving offence; and was never happier than when dispensing praise and favour and generally inducing gratification. Among the traits which he fancied he saw within himself, that which he took most seriously and of which he was most proud was his ability to conciliate; his flair for soothing hurt feelings and calming ruffled pride. But to create this

*At this stage he was in fact still the Earl of Moira; but as he is better known by his later title, it is probably in the interests of clarity to use it throughout. 
opinion of himself in others required art, and art was something which Hastings neither had nor understood. Consequently, while among subordinates his condescension was esteemed and his joviality and benevolence made him popular, to colleagues nearer his own station his manner could seem absurdly self-infatuated. Unaware of his own proneness to give an impression different from the one he had intended, and therefore always at a loss to understand any coldness towards himself, Hastings could interpret unsympathetic responses only as displays of malice or jealousy, and, under the blight of such incomprehension, few of his official relationships blossomed into friendships.

In an interview given soon after his arrival in India in October 1813, Hastings fancied he had induced Nugent, who was made unhappy and embarrassed by his new situation, to relinquish thoughts of resignation. He consequently felt on excellent terms with himself. ${ }^{55}$ In fact, that very same interview had so depressed and annoyed Nugent, that he finally determined to resign. ${ }^{56}$ He delayed his departure until December the following year, and in the meantime continued as Senior Member of the Council. His decision being known, it both made Hastings feel that he had been gratuitously slighted by one he had sought to conciliate, and increased his unpopularity. He was now at odds with the majority of his council. That body consisted of two other members besides Nugent, Archibald Seton was a background figure, occasionally asserting himself in an attempt to preserve harmony, but more often overshadowed by Neil Benjamin Edmonstone, who was openly sympathetic towards the erstwhile Commander-in-Chief. But there were far more fundamental points of difference between Hastings and the self-assured Edmonstone than Nugent's supersession. Edmons tone was rigidly opposed to the style of policy pursued by Wellesley, while Hastings was resolved to carry his work to completion. The physical contrast between Wellesley and Hastings was extreme: the one small but naturally imposing energetic, lean, and patrician-featured; the other large, cumbersome, and heavy-jowled - an avuncular figure who could assume dignity only at the price of appearing pompous. But temperamentally they had much 
in common: compassion for the unfortunate and the underprivileged; fondness of display; a tendency to self-exaltation; and prodigious energy. Despite his early criticisms of Wellesley's Indian policy, Hastings had

lately found himself increasingly in sympathy with him, especially on the sensitive issue of Catholic emancipation, of which they were both in favour. It was Wellesley's grand scheme of Indian alliances, designed to obviate French subversion but left unfinished, which Hastings resolved not only to complete but to re-work into the instrument of British paramountcy in India. Where Wellesley had striven to turn the native states into allies, Hastings was avowedly determined to turn them into vassals. In short, his policy was unashamedly imperialistic a term of ten applied to Wellesley but perhaps better reserved for his successor. The East India Company was finally to claim the Mogul inheritance, by dropping the fiction of allegiance to the puppet Emperor in Delhi and assuming the tone and trappings of royalty itself. ${ }^{57}$

It would be wrong, probably, to discount entirely love of imperialism for its own sake; but it does seem that Hastings' policy was motivated principally by the genuine fear that unless the British acted first, the native states would combine and drive the Company from India. Only paramountcy could pre-empt destruction. ${ }^{58}$ This way of thinking made it impossible for Hastings to treat the Nepalese encroachments as mere isolated border incidents. He interpreted them as the symptoms of a profounder and more insidious disturbance: the first stirrings of a martial renaissance among the Hindu states, whose apotheosis would be the expulsion of all Europeans from India. It was with a mixture of irritation and relief that he heard the Political Secretary read out the despatch from Butwal, recounting the murder of the Company's police officer: irritation because he had never anticipated that his efforts to resolve the Nepalese problem by diplomacy could fail ${ }^{59}$; relief, because he was beginning to suspect an alliance between the Gurkhas and the Marathas, and considered it wiser that the Gurkhas, obviously the better prepared, be defeated first, in isolation. 60 But whatever Hastings' ulterior motives may have been, his colleagues 
in the Council knew nothing of them, and would certainly never have condoned them if they had. They agreed to make war for one reason only, and that was because retaliation was essential if the Company was to fulfil its most basic function as a government - which was defence of $i$ ts subjects and officers. ${ }^{61}$ Reaction among them was spontaneous and unanimous. No-one disputed the necessity of war, ${ }^{62}$ least of all Nugent, who assented almost mechanically to what he probably assumed would be one of what he had described as "petty warfares on the frontiers of the British territories which rarely last more than one campaign, and which always end successfully." 63 The authorities in London were fully reconciled to the use of force, and a despatch, written even before thelatest atrocity was known, was already on $i$ ts way to India, sanctioning war.

"Should representation and remonstrance fail of obtaining redress for the indignities which have been offered, a recourse to arms for the recovery and protection of the rights of the British Government will become a measure of absolute necessity,"

wrote the Court of Directors. ${ }^{64}$

Military operations could not begin until the hot and rainy weather had passed. The Governor General took advantage of the interval not only to obtain information and to make plans for the invasion, but to call on the Raja to disavow the murder of the daroga and punish its perpetrators. He made it plain that if such atonement was not forthcoming, the two countries would be in a state of war. This was Hastings' last measure in the Nepalese crisis before his departure from the Presidency on a tour of the Upper Provinces. He received the Raja's reply on August 12 th, while at Patna. It evaded all mention of the fracas in Butwal, but made obscure references to the assassination of his own police officers, and accused Bradshaw of trespassing and violence. Its tone the Governor General found "evasive and even implying menace." 65

It is difficult to estimate how far Hastings' suspicions of collusion between the durbar at Kathmandu and the Maraths was justified. There is no doubt that there were diplomatic exchanges; the Thapas had a relish for ambassadors and the appurtenances of empire, and stationed agents at many native courts. It was furthermore later revealed 
that the Peshwa of Poona had given secret encouragement to the Gurkhas with a vague and opportunist view of somehow exploiting any consequent diversion of British energies in the hills. ${ }^{66}$ But the existence of mature conspiracy is unlikely. No reference to aid expected from outside was made in the replies submitted by the state counsellors in the war debate in Kathmandu; and Amar Singh Thapa was so far from being confident of such support that he was aghast at the prospect of war. Later, when the temerity of the durbar had brought him face to face with final defeat and ruin, he bitterly castigated the Raja for his folly at this juncture:

"... if you had, in the first instance, determined upon a pacific line of conduct, and agreed to restore the departments of Butwal and Siuraj, as adjusted by the commissioners, the present contest might have been avoided. But you could not suppress your avarice and desire to retain those places, and having murdered the revenue officers, a commotion arose and war was waged for trifles." 67

His main hopes of support were directed to the Sikhs and to China, ${ }^{68}$ though as the war went on, he also wrote for assistance to Gwalior. 69 His urgent concern, as soon as the affray in Butwal became known to him, was to avert, if possible, British military retaliation by opening a fresh correspondence with Ochterlony, and, through him, with the Governor General. He re-iterated the Gurkha claim to the disputed lands, made excuses for the expulsion of the Company's thanas, and repeated the offer to pay a rent for Butwal. The ambivalent tenor of his letters betokened a struggle between appeasement and defiance going on within him: the one prompted by his exasperation at the durbar's foolhardiness; the other by his pride, and hisobstinate loyalty to his prince, right or wrong. Unbending as far towards actual supplication as his independent spirit would permit, he invoked the precedent of 60 years' friendship between the two governments, and recalled his own concession in the case of the Sirhind lowlands in a plea for agreement. But, his fierce pride rejecting peace at the price of humiliation, he could not resist a note of challenge. Pointedly, he insinuated mention of Nepal's firm friendship with China, and warned all potential aggressors of the military might and iron resolve of his nation: 
"If...prompt injunctions are issued to the officers of the British government who are stationed on the opposite frontier of the Palpa territory to desist from further sedition and contention, it will be proper and just, in as much as mutual litigations will cease. Otherwise, by the favour of God, the troops of the Gurkhas, resembling the waves of the ocean, whose chief employments are war and hostility, will make the necessary preparations to prevent the usurpation of any one place which has been in their possession for years past, and the flame of sedition will daily increase." 70

To this communication the Governor General did not see fit to reply, and Amar Singh's subsequent attempts to negotiate through Ochterlony were firmly discouraged. He was asked to make all his representations to the Resident at Delhi; but the long mooted deputation of an agent there to discuss terms of peace never in fact transpired. 71 Once war had begun, the kaji's tenders of negotiation became no more than subterfuge, designed to distract British attentions from the war and secure delays which he might turn to military advantage.

Nepal's main diplomatic expedient was to exploit her connections with China. As Chinese vassals, the Gurkhas were obliged to send a quinquennial embassy to Peking, 72 and that sent in 1813 was flaunted in a flurry of propagandist rusing. The Gurkha ambassador asked the Imperial authorities for military aid against the Sikkimese, whom he claimed were proving contumacious, and this was apparently promised. It appears that about the same time the Chinese officials in Lhasa sent money, with a large escort, for the repair of a Buddhist temple in Kathmandu. The Gurkha government then propagated the idea that both the promise of military aid, and the remittance of funds were gestures of support against the British. ${ }^{73}$ Bazaar gossip in Lhasa gave further currency to such notions, and it was in this distorted form that the intelligence reached the Company's officers in India. ${ }^{74}$ More likely to yield positive results in the way of military cooperation were the negotiations opened with Bhutan in September, $1814 .^{75}$ The position of the Raja of Bhutan vis-a-vis the Company was not dissimilar to that of his Gurkha neighbour, for he too had his uncomposed border quarrels. 
When the Governor General announced his intention to make war, the immediate concern of the Kathmandu durbar was to gauge his sincerity, ascertain the measure of his preparations, and delay their implementation as long as possible. To this end, it pretended to have no realization that a state of hostility existed, and in the naive hope of persuading the British of its innocence,

presents and sent him down to Calcutta. His ostensible purpose was to submit the Gurkha Raja's formal congratulations to the new Governor General on his accession, and to resume negotiations concerning the frontier dispute. He was instructed to restate yet once more the Gurkha case, and to accuse the Company's officers, Bradshaw especially, of forging evidence and provoking dissension. The tempting prospect of an Anglo-Gurkha alliance against the Sikhs was to be proffered to the Governor General, and as a token of the Gurkhas' good faith, some of the 22 villages were to be offered as the ransom of peace. He was always to bear in mind that it was his business to "conciliate and establish friendship", and was told: "You must at first assume a bold tone; afterwards, in order to preserve peace, you may agree that some concessions shall be made on both sides." His eyes and ears were to be kept open; "every particle of information, whether important or not... respecting the probability of war" was to be transmitted to the durbar; and attempts to learn secretly what terms the Company would agree to concerning the Tarai were to be made. ${ }^{76}$ Bhim Sen Thapa instructed Parsa Ram Thapa, a commander on the frontier, to supply escort and bearers, and urged the agent to proceed speedily. "Delay is improper. Whatever may pass in conversation, or whatever you may observe, hear and understand, do not write openly, but secretly and under disguise."77

Bradshaw took advantage of the rainy months of July and August to occupy the 22 villages on the Saran frontier, whence the Gurkhas tried to dislodge him by poisoning the wells. At the end of August the first skirmish of the war took place, with the capture of a Gurkha thana called Kachurwa. It was therefore with some astonishment that Bradshaw learned of the arrival at Barharwa, a village on the west bank of the 
Baghmati serving as Parsa Ram's headquarters, of a Gurkha vakil with gifts of gold, silks, trinkets and elephants for the Governor General. On instructions from Headquarters he refused to allow him to proceed further. No friendly missions could now be received; only agents with plenary powers to sue for peace. The agent, called Chandra Sekhar Upadhyaya, was told that he was at liberty to return to Kathmandu. ${ }^{78}$ But Chandra Sekhar ignored the intimation, and tried surreptitiously to obtain a passport. He was unsuccessful, ${ }^{79}$ but still remained on the frontier, with the ostensible design of meeting the Govemor General, then touring the Upper Provinces, and the real purpose of observing the activities of the British and transmitting intelligence to Kathmandu. The durbar, after such a long sequence of unimplemented threats was probably still unconvinced of the sincerity of the Governor General's determination to invade Nepal, and even less assured of the practicability of his intention, if such it was. It seems that at the most, it regarded the threat of war as the promise of an attempt to resume by force the lands so long contested on the plains. So Chandra Sekhar dallied, endeavouring to clarify the situation, and he was still at Barharwa, in a state of half-doubt and mounting disquiet, when Bradshaw began his march in earnest, at the end of November. Only then, perhaps, were his lingering illusions finally dispersed and his government finally convinced of the seriousness of British intentions.

In Palpa, the arch-sponsor of Gurkha defiance prepared for the pending trial with the febrile enthusiasm of the moribund. Alone among men of military experience in the state, General Amar Thapa had been flagrantly averse to compromise. With his son, Bhim Sen Thapa, determination to resist derived more from youthful impulsiveness and vanity than reflection and experience. But with the general himself, it was reasoned conviction which urged him to canvass war. He had supreme confidence in his carefully nurtured Palpa battalions, which were in truth fully equal to the most brilliant corps d'elite in Kathmandu. 80 He coveted the influence and the prestige which would accrue to the Gurkhas in the eyes of every native power in India, if they could but 
successfully resist the legendary might of the East India Company; and he remained assured that the option of peace would always remain the prerogative of the Gurkhas, who could never be defeated outright if they sought the refuge of their mountains. ${ }^{81}$ The war all but vindicated his prognostication, and very nearly justified his daring. But he did not live to know it. He died at the end of October, 1814, almost as the first bugles were sounding. ${ }^{82}$ 
Chapter Three

The Matter of Himalayan Trade

On December 2nd, 1814, the Governor General was at Moradabad, on the plains near the border of Kumaun. A heavy shower had just cleared the air, and looking northwards Hastings could see quite clearly the Himalayas, incandescent in the sunlight. He was moved by the view, and wrote in his diary:

There was an odd sensation in contemplating a spot in the globe where the foot of man never trod, nor was ever likely to be planted. This immense barrier would seem sufficient to limit the concerns of India; yet at this moment I am speculating on the trade which may be carried on beyond it, should the present war with the Gurkhas leave us in possession of Kumaun. From that province there are valleys between the hills which afford a passage of not much difficulty, and greatly frequented, into Tartary. The holding of Kumaun would give us the exclusive purchase of the shawl wool, to be paid for in cutlery, broadcloth, and grain.1

The ambition to trade across the Himalayas, and thereby link the

British territories in India with the vast regions of Tibet and China beyond, was not new, and had, at its inception, been connected with the idea of a war against Nepal.

In 1767, when Prithvi Narayan Shah of Ghurkha led his army in to the Kathmandu Valley and set about destroying its three kingdoms, the Calcutta government decided that $i$ ts own commercial interests were sufficiently menaced to justify an attempt to contain the Gurkhas by military intervention. Consequently, in June of that year Captain Kinloch marched to the assistance of the Raja of Kathmandu with a force of 2,400 men. The government's more immediate reason for sanctioning this step was because it wanted to preserve the local trade between north Bengal and contiguous districts of Nepal - a trade which the Gurkha career of conquest was upsetting; but wider ambitions were stirring even then. It was not only reasoned that old patterns of trade would be preserved, but speculated that new ones might be created. Why should not Nepal be used as a channel to Tibet? ${ }^{2}$ So the notion was born, conceived of need and ignorance; need for new sources of precious metals, to counterbalance 
the drain from India caused by the demands of the East India Company's establishments in China; ${ }^{3}$ ignorance of almost everything relating to Nepal and Tibet, the inevitable consequence of the fact that British experience of north Bengal was but a few years old. Thus it was that a force was sent into the hills at the deadliest season of the year, quite insufficient in numbers, ill-equipped with provisions, and totally innocent of the topography of $i$ ts route and destination. Not surprisingly, the expedition was a failure, not to say a disaster, with only a third of the troops returning. ${ }^{4}$ The immediate en thusiasm for a conflict with Nepal diminished, and Kinloch was not permitted a second try. However, the attractive assumption that a trans-Himalayan trade was possible persisted, grew, and flourished. The idea soon became the subject of discussion in India, and of enquiry in despatches from London. ${ }^{5}$ Why should not the looms of Halifax provide woollens for the inhabitants of windswept Tibet and hither China? There was something epic in the conception. As the idea became familiar, so it seemed more natural; and soon it seemed so natural that the Company's statesmen in India began to wonder why the Himalayan passes were not thronged with merchants carrying up English broadcloth and metals into Tibet, and returning with wool from the mountain goat, gold, musk, and borax. It seemed ordained by the logic of commerce that mutual needs should be so satisfied. From the premis that a particular state of affairs naturally should exist, it is only a short step to the inference that such a state of affairs at one time did exist; so it comes as no surprise to find a famous enthusiast of the cause of trans-Himalayan trade, Brian Houghton Hodgson, later referring to "that great commerce which naturally ought to, and formerly did subsist between the vast cis and trans-Himalayan regions." 6 The idea that new trading connections might be created had become transformed into the argument that old ones should be revived. Because the Gurkhas were building their empire across the eastern Himalayas at the time when the thinking of the British was evolving in this fashion, it was inevitable that they should be held responsible for the obstruction which the British theory postulated. By the time 
Warren Hastings* became Governor of Bengal in 1772, the rationalization of the East India Company's commercial problem had been neatly completed. Formerly (according to the theory) the trade between Bengal and Tibet had been very considerable. All Hindu and Muslim merchants had been allowed to trade in Nepal, which was the main entrepot of trade between the two countries. But with the wars and oppressions of the Gurkhas, the rhythm of interchange had been broken, merchants deterred, and the trade all but destroyed. ${ }^{7}$ This was the interpretation which Warren Hastings adopted with eagerness, because the outflow of treasure from Bengal was unabated, ${ }^{8}$ and he was something of a visionary where lost horizons were concerned. Armed with this well-rehearsed argument, and with some presents of English produce to enhance its attractiveness in the eyes of the Tibetans, an amiable Scotsman called George Bogle was sent to Tibet in 1774, travelling by way of Bhutan. His object was to promote commercial intercourse between Bengal and Tibet by arranging for merchants from both places to meet regularly in Bhutan. ${ }^{9}$ He was particularly instructed to acquire specimens of the goat which provided the wool for the famous shawls of Kashmir, and of the Himalayan yak, the fibres of whose tail were used in Europe to make lace. ${ }^{10}$

In a word, Warren Hastings was essaying the policy of bypassing the Gurkhas. The idea of attacking them and forcing open a pasage for trade was still canvassed, ${ }^{11}$ but events occurring since the abortive Kinloch expedition had offered the chance to try an alternative route. The Bhutanese had come down from their mountains and attacked Kuch Bihar; and the molested Raja having solicited aid, Warren Hastings, as we have seen, sent a force to help him, determining at the same time to use the opportunity to acquire Kuch Bihar for the Company. ${ }^{12}$ Captain Jones's men had a hard time of it, what with the disease in the malarial foothills and the ferocious resistance of the Bhutanese; but by April, 1773 , the enemy had been sufficiently alarmed to seek outside help. ${ }^{3}$

Not to be confused with the Marquis of Hastings, Governor General at the time of the 1814-16 Nepal War. 
Bhutan, as a Buddhist country, had a close religious and cultural affinity with Tibet, and ethnographically was at one with that country. ${ }^{14}$ While the Deb Raja* dealt with mundane administration, the Dharma Raja concemed himself with affairs of religious and transcendent interest, professing a state of spiritual vassalage to the Dalai Lama of Tibet. ${ }^{15}$ It was natural, therefore, that in her plight Bhutan should look to Tibet for support. The most important pontiff in that country after the Dalai Lama was the Panchen Lama, whose see was at Tashilunpo*** in southern Tibet. It was the Panchen Lama who now intervened, by sending to the Governor at Calcutta a letter in which he suggested the expediency of clemency towards the truculent Bhutanese. With great diffidence he offered a few presents. These were most interesting. They included sheets of Russian gilt leather; talents of gold and silver; bulses of gold dust; bags of musk; Tibetan woollen cloth; and Chinese silk. The gifts were conveyed in chests of professional workmanship, with dovetailed joints. Speculation and rumour had been vindicated. Here were proofs of "an extensive commerce, internal wealth, and an advanced knowledge of the arts of common life."16 The opening afforded by the Lama's address was not to be missed; and Bogle was sent to return the compliment and at the same time blaze a trail for merchants and traders. The opening of Bhutan would be the British ripos te to the Gurkhas' closure of Nepal.

Thus, at first glance, it appears that the sentiments expressed by Lord Hastings at Moradabad in 1814 betoken the survival of a policy which was half a century old; they would seem to indicate that it was the persistence of the desire to open channels for commerce through the Himalayas which contributed to cause a second, and much more serious war against the Gurkhas in 1814. An attractively simple theory - but dangerous: a sure enticement to error. There are flashes, which warn of dangerous rocks beneath the calm surface.

\footnotetext{
* Deba is a Tartar title, corresponding to governor, or viceroy. ** For this reason he was often referred to by English writers as the 'Teshoo' Lama.
} 
In the first place, events had come to pass in that halfcentury which made it quite unrealistic to suppose, in 1814, that a war with Nepal could facilitate access to Tibet. Even in Warren Hastings' time, indeed, it had been unrealistic to suppose so much. Had the Company's servants been less predisposed in favour of convenient assumptions, they would have sensed the futility of their aspirations. Warren Hastings implied that his scheme for a trans-Himalayan trade was in no way revolutionary. All that was involved was the removal, or the circumvention, of artificial obstructions which the Ghurkhas had put in the way of the commerce which under normal conditions would circulate across the Himalayas, linking central Asia and Hindustan. But on closer inspection it seems that he had no grounds for such an assumption. The idea of a flourishing antecedent trade through the eastern part of the Himalayas, at least, was probably chimerical.

There can have been little to suggest that Nepal, previous to the Gurkha conquest, had been a great and thriving entrepot of trade between Bengal and Tibet. Some interchange had been carried on, of course. Since the mid-seventeenth century Patna, the biggest town in Bihar, and the most renowned for commerce, ${ }^{17}$ had attracted merchants who carried on a trade with Tibet through the passes of Nepal. There was always someone at Patna who would barter gold, borax, yaks' tails or musk from Tibet, against coral, betelnut, nutmeg, cottons and woollens; ${ }^{18}$ but probably the volume of such trade never exceeded a feeble trickle. It was a peddling business in luxury goods, carried on mainly at the behest of the wealthy and the curious. In the experience of Francis Tavernier, Court Jeweller to the Delhi Emperor and a keen observer of mid-seventeenth century Hindustan, Nepal had little claim to a reputation as a busy thoroughfare. He wrote of the Raja of Nepal: "There is precious little commerce and wealth in his country, which is nothing but woods and mountains." 19 Few people knew anything about the country apparently even Tavernier did not know that there were in fact three Rajas in the Nepal Valley - and prevailing ignorance hardly betokens thriving commerce. Nobody knew that Nepalese gold really came from 
Tibet, and few would gainsay obscure travellers when they spun tales about the opulence and fabled wealth of the kingdom in the hills. Occasionally, a prince of the plains, his lust for treasure aroused by such idle romancing, would send off in quest of a mountain Golconda; but the obstructions of the way and the resistance of the hillmen would compel retreat, and Nepal would remain still preserved in its mystery and remoteness. 20

The severest discouragement to a direct intercourse between the high Tibetan plateau and the plains was the dramatic contrast in climate between the two regions. The mountain passes were open only in the months of summer, when the lowlands of India were either seared by heat, or drowned by the equinoctial monsoon. Nothing could then draw down the Tibetan mountaineers, who dreaded the climate of Hindustan at the best of times. ${ }^{2 l}$ If contact was to be made at all, they were therefore best met half way, at a place where the climate was not too extreme for either party. The eastern area of the Himalayas was the least suitable for such a meeting. Because of the malaria, merely to walk in the Tarai during the hot and rainy seasons was death; so at the very time when the mountain passes into Tibet were open and busy, the southern belt of jungle was silent and deserted. There were no roads leading into Nepal, and the rivers, deceptively broad and slow near the plains, soon led travellers back to a pristine confusion of chasms, gorges, and cataracts. No wide river valleys formed natural highways here. When Francis Hamilton went to Nepal with the British Embassy in 1802, he followed a route to Kathmandu which was reckoned to be one of the most practicable. Even so, the difficulties were formidable, and in one defile eighteen miles long the winding Rapti river had to be forded no less than twenty two times. ${ }^{22}$ Such topography was typical of the whole southern slope of the eastem Himalayan range, from Bhutan to Kumaun in the west. Roads were rare and where they did exist, as in Kumaun, they were intendedonly for pilgrims. Breasting acclivities in flights of steps and coming to an abrupt termination at shrines and temples, they were quite useless to pack animals and traders. ${ }^{23}$ The natives of Bengal, smothered in the carress of a sultry climate and enervated by 
the spontaneous fertility of their soil, were loath to endure the rigours of cold and danger in the mountains, and only a few intrepid speculators undertook the whole journey to Tibet themselves. Such were the Kashmirians and Armenians who had establishments at Patna. ${ }^{24}$ Their expeditions were fraught with alarming hazards - wild elephants and precipitous mountain pathways - as well as the great expense incurred by the unavoidable use of human carriers. ${ }^{25}$ The peripatetic gossains*, or Hindu pilgrims, also found their way into Tibet through the Nepalese hills, and peddled in drugs, spices, dried fruits, precious stones, pearls, coral, and perhaps a little cloth - "articles of great value and small bulk". ${ }^{26}$ otherwise, the inconvenient coinciding of the seasons and the natural difficulties of the way meant that any trade between Bengal and Tibet had to be carried on by the agency of middle men, like the Newar entrepreneurs in Nepal and the hill peasants in Kumaun. In Kumaun, indeed, the trade had to pass through two agencies, the migratory peasants of the southern slopes acting as a medium between the fairs on the plains and the Bhotias, who inhabited the high hollows of the ghats, or passes, leading into Tibet. By ancient usage, only the Bhotias had the privilege of direct communication with traders from beyond the passes. $^{27}$ Tobacco, glass beads, hardware, coarse local textiles and grain, were loaded by the hill people on to short-legged goats and mountain sheep, who alone could manoeuvre the rugged pathways with confidence. Fine manufactures and expensive articles were brought up only when previously bespoke. From the Bhotias they received the usual trans-Himalayan products - borax, salt, musk, and various drugs and spices. ${ }^{28}$ Checks, obstructions and risks not only tended to restrict commerce to articles of smallest bulk and greatest value; they also raised retail prices to a prohibitive level and confined demand to a small circle of rich individuals and officials. Coral beads from Bengal had always been notoriously expensive in Tibet, and by the beginning of the nineteenth century were being undersold by imports from Russia.

From the Sanskrit goswamin, owner of cows. 
European commodities from Bengal suffered a similar fate; Russian traders could sell cloth from France, for example, at a rate below the cost of English woollens from India. Such were the consequences of goods from the plains having to pass through so many pairs of hands. 29 Additional inhibitions of a political nature prevented the development of a trade in shawl wool across the eastern Himalayas. By a treaty dating from the end of the seventeenth century, the state of Ladakh, an erstwhile province of Tibet situated in the valley of the upper Indus, and separating Tibet from Kashmir, was possessed of a strict monopoly in this commodity; and the Kashmirians in turn had the unique right of purchase from the Ladakh dealers. It was consequently very difficult for strangers to buy wool, or to obtain specimens of the shawl wool goat. $^{30}$

Trade through the eastern Himalayas before the Gurkha conquests cannot, then, have been a "great commerce". The very fact that it came to a halt under the slight pressures imposed by the Gurkhas betokened but feeble antecedent circulation in these constricted arteries. A healthy trade would have survived much more than that. The truth would seem to be that Bengal, Oudh, and Rohilkhand had never had welldeveloped direct trading connections with Tibet. The Tibetan commercial cosmos had always included Kathmandu, certainly. Tibet relied on the Kathmandu mint for her coinage; Nepalese artisans and traders settled in considerable numbers in Lhasa; ${ }^{31}$ and the route from the valley to the passes into Tibet was well trodden by traders from the north. 32 Similarly, the scope of the trade of north India extended to the Nepal lowlands, and a considerable interchange in timber, rice and other local produce was carried on between the Tarai, the Morang, and neighbouring districts in India. 33 But it was as if these two points the Valley of Kathmandu and the Nepal lowlands - were the extremities of two separate commercial systems, divided by a watershed which neither at that stage retained sufficient pressure to break down completely.

The British were looking at things from the wrong standpoint. 
Having familiarised themselves with the eastern sea approaches, built up Calcutta, and come to know Bengal, they did not at first appreciate that the trade of north India was traditionally orientated towards the west, the natural emporium of Hindustan being where its political and cultural focus had always been - in the Panjab and Rajputana. The plains of the northwest were the meeting place for merchants who came by land from Tibet and Kandahar, or by sea to the ports of Gujarat. If we would know how India got her shawls, her salt, and the borax and musk of which Tibet was the richest source in the world, we should look towards the western Himalayas, where the valley of the river Sutlaj provided a broad natural highway directly linking the Panjab with the plateau of western Tibet. ${ }^{34}$ The small state of Basahar,* in the Panjab hills, had acquired great importance as a convenient half-way stage on the route from Ladakh and Tibet; and it was at Rampur, the capital of that state, that sellers from Kashmir, Ladakh and Yarkhand came down to meet the lowland traders and exchange the precious merchandise of central Asia for the wheat and manufactures of the plains. ${ }^{35}$ The inhabitants of Basahar betrayed by their politeness and probity a long tradition of commercial experience. In the words of an English traveller of the second decade of the nineteenth century, they had become the "commercial carriers between Hindustan and Tartary, as also between Tartary and Kashmir, frequenting the routes from Leh in Ladakh to Lhasa and Shigatse and Nepal, on trading speculations." ${ }^{36}$ It was by the Sutlaj route, no doubt, that Indian merchants travelled, when they went to the great annual fair at Gartok, capital of western Tibet, where every September traders from Ladakh, Kashmir, Tartary, Yarkhand, Tibet and China haggled, bartered and bargained, filling the streets with cacophany and colour. ${ }^{37}$ This was the area where the very best shawl wool was produced ${ }^{38}$ - a fact which, together with the monopoly enjoyed by Ladakh and Kashmir, made the western Himalayas the natural centre of the trade in this immensely profitable commodity. The Panjab

* Known alternatively as Kunawar. 
hills between the Indus and the Sutlaj were laced with roads, pathways, and river valleys - a plexus of ramifications from arteries of commerce which led to the Panjab in the south, to Attock and Peshawar in the west, to Kashmir and Ladakh in the north, and to Tibet in the east. A convincing testimony to the drawing power of this vortex is given by Tavernier. He describes how altercations with the Imperial customs officers at Gorakhpur would be sufficient to induce the Patna merchants to abandon the route through Nepal in favour of a journey far to the west, where they could meet merchants from all quarters at Kabul. ${ }^{39}$ The commerce pursued through Nepal by the Kashmirians at Patna was in any case but of ancillary importance: a digussion from the main east-west orientation of their trade. The principal caravans plied the lateral valleys which run between the Himalayan ranges and link Ladakh and Kashmir with east Tibet, taking made-up shawls mostly, and bringing back raw wool and Tibetan produce. ${ }^{40}$ Certain subsidiary enterprises had inevitably germinated by the way. The Patna merchants were only minor agents, engaged principally in collecting otter skins for the China market from Dacca and the maritime provinces in the Ganges and Brahmaputra deltas. ${ }^{41}$

So, the anxiety of the British, in Warren Hastings' time, to vindicate the policy of promoting trade with Tibet through the eastern Himalayas, ledich to invoke a precedent which was illusory. The idea of a great antecedent commerce linking Tibet, Nepal, and Bengal, was merely a mirage, conjured from the haze of unexplored historical distance by the very needs it promised to assuage. The same anxiety was also creating what we might call the traditional view of the part played by the Gurkhas in this phase of Himalayan history, which attributes to their pusillanimity a state of affairs created in reality by quite separate influences.

In the final analysis, the Gurkhas in Nepal and the British in north India were pursuing parallel policies with regard to Tibet. The ultimate aim of both was to foster their own commercial contacts with that country. Just as the British were convinced that the opening 
of the trans-Himalayan markets was vital to their commercial welfare, so the Gurkhas realized that the prosperity of Nepal

war hiked. to the advantages deriving from a close economic involvement with Tibet. A glance at the Nepalese economy will illus trate the point. The exchequer derived very little income from the land, because by the Gurkha system the greater part of land and landed income was transferred as payment to the army. ${ }^{42}$ The state therefore relied all the more on the Tibetan trade for its money income. Not only was this a vehicle for taxation; it was also a source of direct profit because returns were made largely in bullion, which merchants were compelled to exchange for Nepalese currency at the mint in Kathmandu. The government secured a clear profit of some eight percent on these transactions. ${ }^{43}$ Further profits were derived from the privilege which Kathmandu had acquired of minting currency for circulation in Tibet. ${ }^{44}$ The Nepalese crafts of refining and working the precious metals depended for their sustenance on the custom and raw materials of Tibet; and many were the Nepalese residing in Lhasa as goldsmiths and silversmiths, plying their trade in dim-lit basement workshops, beneath the sign of the sun and crescent moon. ${ }^{45}$ Finally, the Gurkhas depended on Tibet for their salt, a vitally important commodity, which was not found in their own dominions. ${ }^{46}$

It was therefore of great importance to the rulers of Nepal not only that Tibet be kept open for a free commercial interchange, but that what trade there was from the plains to Tibet be confined to the channels through Nepal. ${ }^{47}$ There was not sufficient to be shared, and far from obstructing such a commerce, the Gurkhas did their utmost to encourage it. The very beneficial treaty which had given Kathmandu the right to mint Tibet's currency had also closed the Sikkim route to the plains by levying heavy customs duties on goods going that way. ${ }^{48}$ It was with considerable concern that the Gurkha Raja heard of Mr. Bogle's expedition to Bhutan and Tashilunpo, for it was obvious that its object was to divert traffic from his own country. He straight away wrote a stern letter to all the chiefs of 
Tibet, including the erring Panchen Lama, requiring them to have nothing more to do with the feringis [Europeans_T, but to "follow the ancient custom". He desired marts for the sale of Bengal goods to be built on the northem borders of his own kingdom, indicating that he would offer noobstruction to "the common articles of commerce". It is quite clear from his letter how seriously he viewed this attempt to side-step Nepal. He declared that he had no wish for war, but reminded the Tibetans that he was a Rajput, and well-prepared. ${ }^{49}$ It is true that the Gurkhas' efforts to enhance their kingdom's importance as an entrepot of trade were not all calculated to have the desired effect. The new rulers in Kathmandu had but primitive notions concerning the wealth of nations, and considering trade as a vehicle of taxation rather than as a means to national wealth in itself, tended to favour a system of trading monopoly which facilitated the levying and collection of imposts. ${ }^{50}$ The taxes were often high - but this was nothing new. Musk had been subject to a duty of $25 \%$ at Gorakhpur in Tavernier's day. Compared with states such as Tibet and Bhutan, whose govemments reserved all trade to themselves, Nepal under the Gurkhas appears in fact to have been relatively favourable to commerce. ${ }^{51}$ Certainly the intention to encourage foreign trade was there, even if the monopolies system and the inadequacies in the dispensation of justice tended to hinder its full realization. ${ }^{52}$ If the Gurkha state was reluctant to welcome British merchants as residents, the Calcutta government had only itself to blame. By invading Nepal in 1767, when the Gurkha empire was intheimpressionablestages of infancy, it had created an anti-European complex,

which thenceforth always had the edge over the desire to receive European traders and residents. The Kinloch expedition caused an abrupt cessation of Raja Prithvi Narayan Shah's tolerant attitude towards the Capuchin missionaries in Nepal, and they went the way of the gossains - expelled in disgrace as foreign spies. ${ }^{53}$ Thereafter the Gurkha durbar could never overcome the fear that any encouragement to British merchants might open the way for the Company's army; 
but there is nothing to suggest that it was averse to facilitating trade by means of Nepalese agencies.

British attempts to open other routes to Tibet merely

served to complement mistrust with apprehensions for Nepalese commercial interests. Bogle's mission was not an isolated instance, but was followed by several more embassies, the last being Captain Samuel Turner's of $1783 . .^{54}$ Such perseverance gave cause to fear that the English would ultimately seize by force what they could not win by diplomacy; and it is not unlikely that a determination to forestall a similar move by the East India Company was partly responsible for the Gurkha decision to invade Tibet in 1788. It is a fact that in 1814 Amar Singh Thapa evinced such a way of thinking, by declaring that only by conquering Tibet once and for all could Nepal hope to put an end to British ambitions in that direction, for Tibet had ever been the true object of their cupidity. 55 But Gurkha commercial interests in Tibet were not being threatened by the British alone. Developments in Tibet itself had long been working to frustrate the customary intercourse with Nepal; and these developments are important because they confute both the idea of an earlier eighteenth century Himalayan trade and the contention that the Gurkhas were the main impediment to the existence of such a trade after the middle of the century.

Access to Tibet from the south had never been easy. In addition to the natural obstacles of the journey up from the plains, there were the Tibetans' mistrust of aliens and pagans, and their inveterate dread of smallpox, to make entry difficult for the lowlander. ${ }^{56}$ The indications are that for many years before the Gurkha conquest of Nepal, Tibet was becoming increasingly indisposed to have contacts with foreign nations all foreign nations, that is to say, except China. Ever since the extinction of the Buddhist dynasties of north India by the Muslims, in the twelfth century, and the attempts by the pagans to penetrate even to Tibet itself, she had shunned intercourse with Hindustan. ${ }^{57}$ As contacts with India weakened, so Tibet's awareness of her cultural and religious identity with China grew, ${ }^{58}$ fostered by the 
conciliatory policy of successive Chinese dynasties towards the lama hierarchy. When the Manchu dynasty was established in 1655, an unwritten concordat was created between the new Emperor and the doyen of the reformed sect of Buddhists, the Dalai* Lama. This rapprochement enabled the reformed** Buddhists to complete their spiritual victory in Tibet, and facilitated the Emperor's political control of Mongolia. ${ }^{59}$ Henceforth Chinese Emperor and Dalai Lama existed on a relationship of symbiosis, each in large measure dependent on recognition by the other.

Seditroisa influences from Mongolia soon compelled the Emperor to exercise the temporal functions of defender of the faith, and in 1720 Imperial forces enthroned the Sixth Dalai Lama at Lhas a and excluded a pretender. In 1728, civil war in Tibet caused a second Chinese military expedition, and this time when the tide withdrew it left an alluvium in the form of two Chinese residents Iamban $T$ and a permanent garrison. The revolutionary activities of certain political groups still persisting, an Imperial force marched into Tibet a third time in 1750. The position of the residents was consolidated, and the Dalai Lama and state council thenceforth had to consult them on all questions concerning temporal government. ${ }^{60}$ As the Chinese hegemony intensified, so Tibetan policy began to betray a Chinese outlook. For example, the notorious Manchu jealousy of Europeans was clearly behind the expulsion of the Capuchin missionaries from Lhasa in $1745 .^{61}$

It would seem that closer political control over Tibet was accompanied by an increase of Chinese influence in Tibet's commercial life. Tibet had always relied almost exclusively on China for the things she did not produce herself - a trading connection which had its origin in the regular tribute caravans from Lhasa to Peking, which would return ladenwith rich reward from the Emperor. Tibetans had also

* Dalai,from the Tartar word talé, means ocean. Its use signifies the omiscience and unlimited wisdom of the Lama. $* *$ :

The reformers were called the Yellow Sect, after the colour of their dress. The old Buddhists wore red vestments. 
bartered their horses for Chinese tea, from very early times. 62 Later, it was from China, rather than India, that they obtained even goods of European provenance, 63 and by the end of the eighteenth century the greater proportion of Tibet's trade was carried on via the garrison town of Siling, on the borders of western China. 64 Furthermore, the Tibetans themselves, although possessing a flair for barter, tended to trade on an ad hoc basis to serve personal needs, and were so lacking in the spirit of association that members of the same family would often

pursuen their commercial interests independently. Consequently organized trade came to be almost exclusively in the hands of Chinese merchants and retailers. 65

Chinese control of Tibet's economy and trade relations naturally followed the assumption of political power, since commerce was traditionally a prerogative of the government, and no trade existed but by privilege or sufferance. This was why the Chinese presence was constantly invoked by the Tibetans as an obstacle to any closer commercial ties with outside countries. Bogle grumbled that this was a stumbling block which crossed him in every path. 66 That fostering trade was not as simple as bypassing the Gurkhas was shown by the failure of the experimental fair at Rangpur, in north east Bengal, which, in the 1790's, was established as a mart for the Tibetan trade. Both Bogle and Turner had been satisfied that the arrangements concluded with Tibet and Bhutan had removed all serious impediments, and that nothing remained to hinder the trade. 67 But the merchants did not come: Despite the Company's abolition of all duties and $i$ ts willingness to pay the expenses of the caravan, the spark of life was never there, and the fair soon languished into insignificance. 68 Turner especially should have realized that such expectations were futile, for it had been made quite clear to him that similar attempts by the Russians had been thwarted by the jealous Chinese. 69 So long was the Chinese shadow, that it was whispered in the bazaars of Nepal and Tibet that the Panchen Lama, who had died of smallpox while paying his respects to the Emperor 
in Peking in 1780, had in fact been deliberately disposed of because of his friendship for the English. 70

It was surely not entirely a coincidence that about the time of Bogle's mission the currency arrangement between Nepal and Tibet began to suffer difficulties. It appears that the authorities in Tibet suddenly insisted that the Tibetan coinage, which was debased with copper, should be considered as equal in value to the purer silver currency issued by the Kathmandu mint. The Gurkha government demanded that the debased coinage be recalled, as it was a source of disadvantage to $i$ ts own merchants, or that, at least, a fair rate of exchange be established between the two currencies. Negotiations were protracted for nine or ten years, but the Tibetans would not yield. A period of crisis followed, when Nepalese coin was withdrawn altogether, and trade between the two countries suffered a great decline. ${ }^{71}$ In addition, the Gurkhas were exasperated by the Tibetan habit of selling salt adulterated with earth, and by their levying of excessive and arbitrary duties on Nepalese merchandise. ${ }^{72}$ That their complaints had been justified in the latter instance was fully confirmed later, when a member of the Tibetan council of state evinced his culpability by committing suicide to escape the effects of Imperial displeasure. ${ }^{73}$ The situation must have borne the appearance of an urgent crisis to the Gurkhas because, although their field army was fully occupied in the western hills, they decided to risk Chinese retribution and make a punitive expedition into Tibet. This was in $1788 .^{74}$ The gamble was not so ill-advised as it might seem. Their attack was unexpected, and the principal of the three generals sent by the Emperor to advise the importunate Tibetans preferred not to press the issue to a trial of strength. Instead, he came to a secret understanding with the Gurkhas and sent a false report to the Emperor. The Nepalese were promised a yearly tribute from the monastic authorities. The bond was not honoured, and in 1791 the Gurkhas invaded again. The Chinese resident withdrew the new infant Panchen Lama from Shigatse; the treasurer of the Tashilunpo Monastery fled, and the lamas, pleading divine injunction, 
refused to resist. While the Gurkha army sacked and pillaged the monastery, the Imperial reinforcements ordered from Szechwan dallied; the principal Chinese general drowned himself; and all Tibet was in commotion.

When the Emperor learned what had happened, he had the timorous resident of Shigatse shackled with a cangue, and sent his best Manchu general, Fou-kang-an, to chastise the Gurkhas at the head of an immense expeditionary army. Meanwhile, the Gurkha force, gorged with plunder, had withdrawn into Nepal, leaving detachments to guard the passes. During June, 1792, the Chinese army expelled the last Gurkhas from Tibet, and prepared to invade Nepal. The Kirong pass was negotiated by Fou-kang-an himself, while detachments on either flank diverted the enemy's attention. The Gurkhas had truly brought down upon themselves all the might of the Son of Heaven. They were pursued to the banks of the river Tadi, only twenty miles from Kathmandu, where they turned and made a desperate stand. It is said that the Chinese general, in a fury, drove forward his men by turning his own guns on them from the rear, and overwhelmed his adversary with a human avalanche. 75 The Gurkhas, dismayed by their failure to secure aid from the British, 76 had no resource save submission. They surrendered their plunder and their prisoners, and agreed to send a regular tribute to Peking, as vassals of the Celestial Empire. The old economic dispensation was cancelled, and money struck in Kathmandu was thenceforth banned in Tibet, where a new mint with Chinese experts was set up. All foreign trade with Tibet was subjected to the strictest regulations, and Tibetans were allowed to trade with outsiders only under licence and by approved routes. The Chinese residents were made the sole medium of communication with other countries; and measures were taken which subjected ingress by foreigners to close official control. 77 The Gurkhas' attempt to frustrate the closure of Tibet by the Chinese had merely precipitated its consummation, and reduced Nepal herself to the ranks of the humble petitioners. The Gurkhas did not relinquish hopes of retrieving their old privilege of minting currency for Tibet, but the tone of their solicitations in 
1814 was markedly different from their earlier pugnacious demands. ${ }^{78}$ The Gurkhas had received the painful and unequivocal warning that Tibet was claimed territory; but the admonition was clearly intended for the British as well. The military successes of the Company in India had made it an object of apprehension and mistrust even in Bogle's day, ${ }^{79}$ and now its failure to afford assistance to Fou-kang-an when so requested did not go unnoticed at Peking. Unknown to the British, the Gurkhas had completed the vitiation of the Company's reputation by their practice of dressing their own soldiers in red uniforms. ${ }^{80}$ Misled by the costume of the Nepalese, the Chinese general reported to the Emperor that not only had the British refused to help, they had also sent troops to aid the enemy. ${ }^{81}$ Lord Macartney was on an embassy at the Court of Peking when the Emperor received this intelligence, and shortly after was given an audience of leave. ${ }^{82}$. A letter was written by the King of England to the Emperor in 1795, explaining that in fact the British had attacked the Gurkhas in the rear. ${ }^{83}$ This did not impress the Chinese, who apparently assumed it to mean that the Company had taken advantage of the situation to further their own plans for conquering Nepal. ${ }^{84}$ A close watch was kept on English activities in north India from now on, ${ }^{85}$ and officers on the Tibetan frontier were ordered to admit no Europeans. The Chinese Deba, or viceroy, of Gartok who was responsible for allowing the expedition led by the English traveller Moorcroft to enter Tibet in 1812, was summoned to Lhasa in disgrace. ${ }^{86}$ Irritating though it was to the British, in the eyes of the Chinese both Europeans and Gurkhas were tarred with the same brush. Nor perhaps were they so unjustified in their refusal to differentiate. The Gurkhas were emulating the British in every way; not only in the discipline and dress of their army, which, again like the British, they flaunted so as to create an aura of invincibility, but also, in this instance, in determining to preserve economic privileges by force of arms. The war fought against Tibet by the Gurkhas in 1788 had not a little similarity to the one fought by the British at the other end of the Chinese Empire in 1842. 
While, therefore, in the 1770 's it had seemed that a war against Nepal could open access to Tibet, by 1814 it had become quite clear that it would be unrealistic to suppose that any form of military activity in the Himalayas could achieve that object. Events in the meantime had demonstrated that the principal artificial obstacle to trans-Himalayan trade was not the presence of the Gurkhas in Nepal, so much as the jealousy of the Chinese guardians of Tibet. The fact had been brought home with startling clarity to the British in Calcutta by "the extraordinary spectacle of a numerous Chinese force occupying a position which probably afforded it a distant view of the valley of the Ganges and the richest of the East India Company's possessions." 87 There were, moreover, no grounds for supposing that the Chinese would have been less hostile towards the British had the Gurkhas not aroused their resentment. The Manchus' suspicion of outsiders was inveterate and it was obvious that Europeans were the last in favour of whom they would discriminate. In the final analysis, the consequences of the Gurkhas' efforts to open Tibet had served less to embarrass the British than to enlighten them as to the inevitable outcome of a similar policy on their own part.

As the British became more powerful in India, they became more knowledgeable; but sometimes knowledge came too late to be of positive use. Such was the case with facts about the shawl wool trade, which came to light after British sway had been extended westwards to the Sutlaj river. Textiles were the oldest and most important of the industrial arts of India, and the artisans of Kashmir were second to none in skill and fame as weavers. The gossamer softness, the beauty and durability of the long decorated wraps produced by the looms of Kashmir were admired by emperors of India, sovereigns of Persia, and not least by merchants of England - who were no bad judges when it came to something made of wool. From the eighteenth century the word used to describe them, 'shawl', passed into the English language. It was known that the great secret of the shawls lay in their raw material, which was more a down than a wool, being protected by the exterior coarse hair of 
the animal. The shawl-wool goat was found only in Tibet, and early attempts to introduce it into India and Persia failed. ${ }^{88}$ As we have seen, Warren Hastings was particularly anxious that Bogle should bring back some specimens of the animal. In the event it was Turner who managed to send some emasculated goats to Calcutta, but the unfortunate creatures languished in the suffocating heat, shed their coats, developed cutaneous eruptions, and finally expired. ${ }^{89}$ The trade would obviously have to be tapped at its natural source; but full facts concerning the commerce were not available until 1812, when William Moorcroft went to western Tibet.

Moorcroft, Superintendent of the East India Company's Stud, was thinking how best to improve the strain of the indigenous cavalry horse of Hindustan. This had become necessary because political events (the consolidation of Sikh power in the Panjab; and the withdrawal, after 1806, of British protection from the petty states below the Panjab in Rajputana) had made it difficult to continue acquiring horses from west of the Indus where, in Kabul especially, fine-blooded animals were bred. For some years the Company had been compelled to rely on horses from $i$ ts own territories for $i$ ts cavalry mounts, and these beasts were small, weak, and vicious. ${ }^{90}$ In 1812 Moorcroft, in company with Hyder Hearsey, made a journey into Western Tibet, travelling through the Gurkha province of Garhwal, ostensibly in search of better horses for breeding purposes; but in reality also because his enquiries concerning the origin of the shawl wool goat had drawn his attention to this area. 91 It was the beginning of a private crusade for Moorcroft, a solitary, restless man, prone to untempered speculation, who appointed himself chief promoter in the cause of opening to British enterprise the trade and resources of trans-Himalayan Asia. He was to pursue his vision with an evangelistic tenacity and intrepidity, embarrassing to his government and ruinous to himself. During his journey of 1812 he gathered information concerning the Kashmirian-Ladakh monopoly, the location of the best wool growing areas, and the orientation of the trade. He brought back upwards of 50 shawl wool goats to Moradabad, 
with hopes of introducing the breed into Scotland or Wales, ${ }^{92}$ and, even more of a triumph, succeeded in buying wool in markets which were the preserve of the Ladakhis. This, he decided, was the beginning of a new epoch in British trade. ${ }^{93}$ But it was not so. Moorcroft's revelations came too late to draw the interest of his employers to the western hills, because while they had been dallying with Nepal and Bhutan in the east, Ranjit Singh had been forging a Sikh empire in the Panjab which took the shawl wool trade into its embrace. He had made his intentions towards Kashmir obvious, and had so far established his eligibility to participate in the trade that merchants from Amristar were allowed to buy wool in Gartok. ${ }^{94}$ Roads had been built, leading direct from Ladakh to Amritsar, which were causing the decline of the old route along the Sutlaj valley through Rampur and drawing the bulk of the shawl wool trade through Sikh territory. ${ }^{95}$ Shawl manufactories even were established in Amritsar. ${ }^{96}$

It seemed obvious, then, in 1814, that any attempt by the British to capture a share of the shawl wool trade would prove objectionable to Ranjit Singh; and the political situation at this time made it something of a priority to avoid offending the Sikhs. British statesmen were having to reconsider all old ideas on the subject of the defence of India. In the time of Warren Hastings they had felt secure, confined as they were to Bengal and the Deccan, bounded by the sea in front and the territories of the Moguls and Marathas behind. Since then however, frontiers had been pushed back, and states under British protection were found as far west as the left bank of the Sutlaj. Sea power alone could no longer defend the Company's possessions from external aggression, and thought had to be devoted to the problem of protecting the land routes which debouched into north west India. ${ }^{97}$ The Hindu Kush passes were as the wings of a vast theatre, through which the prominent actors in Indian history had made their entry onto the ancestral stage of the Panjab plain. Conciliating the power which had control of the Panjab was an essential first step to preventing the drama of another invasion. Napoleon Bonaparte, fascinated by India, had definite plans to make the attempt in alliance first with Russia, then with Persia; and it 
became the primary object of British diplomacy to thwart his designs by making treaties with Persia, Afghanistan, Baluchistan and the Sikhs - all of vital strategic importance to any defence system designed to bar land armies from Turkey or Turkistan. This policy inspired the first political mission to Lahore, Ranjit Singh's capital, in 1809. The Sikhs were the object of British vigilance thereafter, the more especially as Moorcroft had discovered that Russian agents were active in Kashmir and helping to discipline Ranjit Singh's infantry. 98 This caught the attention of the court of Directors, which asked to be regularly informed of developments across the Sutlaj. 99

So far, we have examined political developments in India and Tibet which by 1814 would seem to have compelled a drastic modification, not to say the reversal, of the Himalayan policy conceived by early Governors of Bengal such as Verelst and Warren Hastings. But politics are only one side of the coin. Being primarily a trading concem, the East India Company might have risked the impolitic to secure the economically beneficial. It is therefore important to demonstrate that simultaneously with political developments, changes had occurred in the economic interests and outlook of the Company, which made trans-Himalayan trade commercially unimportant.

The East India Company had originally been interested in transHimalayan trade for three reasons:

First, because the drain of treasure from India was a cause of great concern, and Tibet was known to be a rich source of precious metals.

Second, because Tibet and the trans-Himalayan countries promised a natural and unlimited market for English woollen cloth, whose appeal in the tropical and sub-tropical peninsula was obviously limited. In 1774, the manufacture of woollen cloth was still England's staple industry, and on the prosperity of that industry the national welfare was believed to depend. Take this with another precept of the prevailing system of economic thought (often loosely called mercantilism), namely, that foreign trade should justify itself by creating an increase in the national store of treasure, and it will be appreciated why the East India Company was regarded as being under a special obligation to meet 
its liabilities in India as far as possible by the sale of English staple produce, rather than by the exportation of specie. In 1708 the United Company of Merchants trading to the East Indies had accepted the obligation to export goods to the value of $£ 100,000$ annually, in return for its monopoly of the East Indian trade. The first war with Nepal and the early attempts to open Tibet were products of the Company's mercantilist tradition: the tradition of opening new markets and fostering new demands for English staples by exercising the power of arms and taking the risks which the privilege of monopoly postulated. Such quasi-scientific, quasi-commercial expeditions as those undertaken by Bogle and Turner were expressions of a type of enterprise which traced its origins back to the time when the old Merchant Adventurers first weighed anchor. Warren Hastings expressed this attitude when he wrote:

"...it is impossible to point out the precise advantages which either the opening of new channels of trade, or in obtaining redress of grievances, or in extending the privileges of the Company, may result from such an intercourse; like the navigation of unknown seas which we explored not for the attainment of any certain or prescribed object, but for the discovery of what they may contain. In so new and remote a search, we can only propose to adventure for possibilities. The attempt may be crowned with the most splendid and substantial success; or it may terminate in the mere gratification of useless curiosity."100

Third, and finally, because a trans-Himalayan commerce would provide access to the shawl wool trade. Such a unique and profitable commodity would have attracted the attention of a trading government under any circumstances, but from the 1770's the East India Company had a special reason for being interested. It was finding it increasing difficult to transfer funds from India to England. Large sums of money were required in London. After paying dividends on East India stock, the Court of Directors needed funds to cash bills of exchange drawn on them in the possession of creditors and servants who wished to remit their assets from India to England; to provide for the upkeep of the Company's various establishments at home; to pay retirement pensions to the Company's servants; and to buy the 
English goods sent out to India and China as exports. ${ }^{101}$ As profits from the China trade, which were realized in London, were insufficient to meet these requirements, it became necessary to remit to England part of the assets which the Company realized in India. The export of bullion from India was deprecated, 102 and the usual mode of remittance, that of buying goods in India and selling them in England, was becoming inefficient and unprofitable. The produce brought from India, which constituted the Company's annual investment, was mainly cotton piece goods, which the Company manufactured itself in its own factories. But from the $1770^{\prime}$ s, the growth of the English cotton industry was reducing the home market for Indian cotton goods, and as a vehicle of remittance the trade in piece goods was transferring money to London only inefficiently, and running at a loss as a purely commercial enterprise. ${ }^{103}$ It is not possible to ascertain the exact state of the import trade from India, because the liabilities incurred on account of the India and China trade were not kept separate in the Company's books; 104 but even according to the Company's estimates the import trade from India occasionally indicated a deficit, 105 and it is probable that in fact the immense profits of the China trade were disguising a more considerable loss on the Indian. 106 What nobody could dispute was the fact that funds realized in London from all sources did not meet expenses, and that the English establishment was running at a loss. 107 Under such circumstances, a new Indian article of investment which promised to be not only a vehicle of remittance but also a means to profit, was bound to arouse a lot of interest. This explains in great measure the sustained interest in the shawl wool trade and in plans to manufacture shawls for the English and European markets.

Here are three reasons then, as they existed in the last decades of the eighteenth century, to explain the prevailing concern to extend the limit of British commercial interest across the Himalayas. In 1814 , these reasons no longer existed.

By the outbreak of the Nepal war in 1814, the main channel by 
which treasure had been flowing out of India - the channel to China had been blocked. Sending Indian bullion to china to pay for the Company's tea investment had latterly been an annual practice, dating from 1757. 108 The procedure had been necessary because few English commodities could be sold profitably enough in China to make it possible to pay for tea with exports alone. The practice continued for some 30 years, before it was realized that the produce of India could be used to finance the China investment. Indian raw cotton found a ready market in China, and by exploiting the demand for this commodity the flow of bullion out of India was soon stopped. The other product of India which the Chinese needed was opium, and this they absorbed with insatiable voracity. ${ }^{109}$ Its importation was illegal, but private merchants did not scruple to carry on a pirate trade, and in a short time the exploitation of this black market swung the balance of the trade from China's advantage to India's. The opium being paid for largely in Bullion, 110 treasure was soon flowing from China to India a trend which was well established before the end of the first decade of the nineteenth century. In 1814, the outflow from the Bengal exchequer had by no means ceased, and the Governor General complained of the demands for bullion from England, Mauritius, Ceylon, Java, and the embassy in Persia; ${ }^{111}$ but shortages were transitory and the problem was by no means as urgent as it had been in the 1770's. Treasure was no longer scarce in India: So much is shown by the fact that loans could easily be raised to provide the government with cash - in excess even of its needs. 112

Eagerness to open new markets for English woollens had languished by 1814. Economic thinking still placed importance on the prosperity of the old staple industry, it is true. British woollens enjoyed preferential tariffs in Indian ports until $1845,,^{113}$ and the prohibition on the export of raw wool from England was not repealed until 1825. 114 But the East India Company had made it quite clear that their share of the good work would continue only so long as they retained their monopoly and privileges. "If the private traders under new 
regulations should interfere with the Company's regular trade...the Company must be obliged to reduce their exports of the raw materials of the country, and the woollens of the country, in some degree..." Thus spoke the Company's Accountant General in $1813,{ }^{115}$ and his reasoning is evident. The successful promotion of the sale of English goods in India depended on a careful nurturing of the market, and this was made possible only by the instruments of monopoly and privilege. Yet faith in monopoly and privilege was increasingly sapped by the spreading popularity of a new gospel - that according to Adam Smith - which preached the ethic of free enterprise. The Company wes forced to make its first concessions in 1793, when undertook to supply freight to a certain amount each year for private traders; and thencafler the clamour of private merchants, who wanted to trade to India on their own terms and in their own ships, became loud and persistent. The question of the renewal of the Company's Charter, due to expire in 1813 , engrossed the attention of Parliament for a period five years before the event, during which the Company's apologists fought a protracted and eloquent defence; but there was no disguising the fact that the whole system of restriction, monopoly and privilege was moribund, and it is no wonder that a decline in the old eagemess to open markets beyond the Himalayas accompanied its demise. After 1813, when the Indian trade was finally made open to all private traders, to have invoked the principles of Warren Hastings - intellectual curiosity; moral obligation; adventure - would have appeared quaint and outmoded. The opening of the Indian market registered a change in outlook among the British concerned with affairs of India. The servants of the Company were becoming more involved in collecting revenues, guarding frontiers and dispensing justice than in trading; and the men who inherited the legacy of commerce knew no debt to the old traditions of exploration, pioneering, and willingness to risk all for the tale of an eldorado beyond. They acted more as merchants, less as adventurers, exploiting already established markets, calculating maximum profit and minimum risk, and treating the whole idea of 
trans-Himalayan trade with increasing scepticism. ${ }^{116}$

So the inspiration, and the sense of obligation to pen new markets in India was fading; but, let it be at once admitted, so too was the necessity. The fact is that British woollens had not been faring too badly in India, though one would never think so, to hear the witnesses who gave evidence before the House of Commons in 1813. One after another they asseverated that the Indian market for British goods was glutted and incapable of further extension; that Indians had neither the inclination nor the means to buy European goods; that all efforts to stimulate new interest in them had failed; and that the warehouses were already overflowing with unsold imports from England. 117 They spoke impressively, and from experience; but a brief glance at the figures reveals a different situation:

\begin{tabular}{ccc} 
Date & $\begin{array}{l}\text { Value of European goods } \\
\text { imported into India.118 }\end{array}$ & $\begin{array}{l}\text { Value of European goods } \\
\text { left unsold in Indian } \\
\text { warehouses at the end of } \\
\text { the year.119 }\end{array}$ \\
\hline $1791-2$ & $\begin{array}{l}£ 206,791 \\
1808-9\end{array}$ & $£ 15,982$ \\
$£ 1,181,718$
\end{tabular}

This single comparison of two years discloses a state of affairs that was typical. The proportion of goods remaining unsold at the end of successive years stayed in almost constant relation to the amount of goods imported. This means that the Indian markets for English woollens - which comprised the bulk of the imports - was steadily expanding. This is not surprising, for more and more sections of the Indian population were coming into the sphere of British influence, and more native princes seemed to be dressing their soldiers, after the British fashion, in red broadcloth. 120 Probably the agency of private traders helpos, between 1793 and 1813, reduce the price of English goods and extend their sale, but their shipments consisted mostly of wine and beer. ${ }^{121}$ It was the Company which, even after its monopoly was withdrawn in 1813, continued to export by far the greater part of the English 
woollens which found their way to India, and which were sold for increasingly higher profits as mechanization reduced the prime cost. The Company finally stopped exporting English commodities in the 1820's, but only because it did not wish to continue realizing assets in India while it remained so difficult to transfer them to London, and because its ships were becoming too full of troops and stores to carry goods for sale as well. ${ }^{122}$ The situation was, then, that a new fashion in economic thought, and a spontaneous extension of the Indian Market had changed the whole nature of England's trade with India in the period between George Bogle's mission to Tibet and Lord Hastings' reverie in December 1814. The profoundest change - the supersession of woollens by cotton goods as the staple British product - was yet to come; but still, enough had happened by 1814 to make the attitude of Warren Hastings outmoded, and his Himalayan policy no longer relevant.

On the other hand, the export trade to China was a cause of grave concern. The Company still felt an obligation to push the sale of British staples in China, because Parliament continued to allow it an unmitigated monopoly of the trade with that country. ${ }^{123}$ But it was proving a vexatious duty. The company seems to have experimented persistently and diligently with new varieties of woollens and metals, ${ }^{124}$ and the amount of English goods actually exported to Canton steadily increased. ${ }^{125}$ They were sold, too - but only at a considerable loss. In the books of the Company's factory at Canton for the 17 seasons from 1792 to 1809 the accounts of only three show a net profit, and the total deficit over the whole period amounted to close on a million sterling. ${ }^{126}$ Even then, the profits on tea were disguising losses incurred by selling British produce. Until 1810, the Company's agents at Canton had got rid of their woollens by bartering them for tea- this being the only way of inducing Chinese merchants to accept them. Such a way of dealing in effect increased the price of tea, because the Chinese naturally expected a favourable exchange when accepting goods which were so difficult to sell on the Chinese market. So a thousand pounds' worth of woollens bought much less tea than a thousand pounds in cash. By 
paying partly in goods, the Company were foregoing a portion of their profits on tea, and affording a subvention to British staples which did not show on the accounts, where the woollens sold were rated at their barter price, and not at their market money value. ${ }^{127}$

By 1814, the port of Canton had become the focus of the East India Company's trading activities, and the economic priority of the day was to widen the Chinese market for British and Indian goods, and improve the conditions under which English merchants operated in China. English interests in the China trade were at this time of crucial importance. India's potentiality as a tea-growing country was unknown, and the United Kingdom relied exclusively on China for its supplies of what had become its national beverage. An approximate average of one and a half million sterling was invested in tea every year, and the returns hovered around the two and a half million mark. These were astronomical sums in those days. ${ }^{128}$ Yet, to carry on a commerce of such magnitude, the agents of the East India Company were allowed access to only fouteen chinese merchants, who were specially licensed by the Chinese government; and their sole establishment on Imperial territory was a modest factory at Canton, where they were suffered to reside only during the season of business. The buying and selling, the bartering and chaffering once finished, and the ships once laden and under weigh for England, the Supracargoes, as the Company's agents were called, were obliged to retire to the Portuguese island colony of Macao, where they carried on their affairs until the opening of the ensuing season. ${ }^{129}$ They were forced to trade under the most frustrating and vexatious conditions. The benefit of open market competition was precluded by associations of Chinese merchants; and the local officials denied the English all access to the machinery of legal redress, manipulating the commerce in a spirit of private interest and petty despotism. ${ }^{130}$ The Supracargoes complained that artificial barriers were constantly put in the way of the sale of British goods, and it was a rankling thought that the prohibition of opium had reduced the guarantee of security for an essential trade to the corruptibility 
of local mandarins. ${ }^{131}$ The problems of the British merchants trading to China were matters of national concerm, requiring to be handled by royal ambassadors rather than emissaries from a mere trading corporation. Thus it was that Lords Macartney and Amherst journeyed to Peking, the first in 1792 and the second in 1816, to plead the case of British merchants before the Celestial Emperor, by authority of credentials from the King. The war with Nepal, intruding upon this delicate and crucial process of ingratiation, was an inconvenience and an embarrassment. Sir George Staunton, one of the Supracargoes, affirmed in 1813 that the trade with China was on a precarious footing, and "liable to be disturbed by provocations which might be considered of a slight nature". ${ }^{132}$ It was not forgotten that Nepal was now, in theory at least, a vassal of China, and it seemed that an attack on her might well qualify as such a provocation and jeopardize Britain's most vital commercial interests in the East. Lord Hastings took care that the Supracargoes were given full details concerning the causes of the war and the attitude of the Calcutta government, so that an equitable case might be presented to the Chinese authorities. ${ }^{133}$ Major Bradshaw, Political Agent with the main invading force, was instructed to inform any Chinese officers who might confront the army that the British objectives were entirely punitive and not acquisitive; ${ }^{134}$ and it was his reluctance to offend the Chinese which contributed to determine Lord Hastings not to annex Nepal after her defeat. ${ }^{135}$ When the war was over he showed considerable anxiety to mollify any offence it might have given to China. Recognizing that the maintenance of peace and amity with Peking was of "such vast consequence to the commercial interests of the Company and indeed of the United Kingdom", he was prepared to withdraw the British Residency established in Kathmandu, and even give tacit acquiescence to an Imperial occupation of Nepal, if genuine Chinese resentment was to be thereby mitigated. ${ }^{136}$ Lord Castlereagh, the Foreign Secretary, took pains to brief Lord Amherst on the British position vis-a-vis Nepal before the departure of the Ambassador for China, and enjoined "great 
circumspection and discretion" if the topic should be raised. ${ }^{137}$ It was all a rather unfortunate distraction, at this time when it was so essential to secure the favourable disposition of the Chinese Emperor; and it would require diplomatic adroitness and even retraction to contain its harmful effects - such seems to have been the prevailing attitude towards the war. The only way in which it was suggested it might help improve British commerce was by opening a trans-Tibet access to Peking, whereby direct representation might be made to the Emperor and the agency of the Canton officials superseded when necessary. This notion was proffered by the Supracargoes, but only after they had heard that plans for the invasion of Nepal had been made. ${ }^{138}$ There is no question of its having influenced the government's determination to go to war. The idea seems to have gained no currency in Calcutta, where there was so little reason to expect that Imperial officials in Tibet would be any less obstructive than those in Canton that the possibility was subsequently never even put to the test.

So far we have shown that of the three reasons which induced the Calcutta government to adopt a Himalayan policy in Warren Hastings' day, two had been superseded by 1814. The flow of treasure had been reversed by the development of the China trade; and the need to extend the Indian market for British staples had been eclipsed by the urgent necessity of removing obstacles which were impeding the sale of British and Indian produce in China. The shift of interest away from India to China not only made it seem less important to breach that mighty wall of snow and ice which separated India from Tibet; it made it seem prejudicial to commercial interests to try to, because the risk of offending China was involved. The third reason why the East India Company became interested in Himalayan trade was, it will be remembered, because it offered the possibility of making available another Indian commodity - shawl wool - which the Company would be able to use as a vehicle for transferring funds from India to England profitably. The days of cotton piece goods as a means of remittance, numbered even in Warren Hastings' time, were virtually over in 1814. English cottons 
had captured the home market, ${ }^{139}$ and the re-export trade, having enjoyed a brief prosperity after the 1799 Warehouse Act,* when almost all the calicoes from India were re-exported, had been killed by the Berlin Decrees, by which Napoleon closed almost all Europe to goods from England. ${ }^{140}$ Even private traders, after giving a slight stimulus to the import trade from India, ${ }^{141}$ had lost interest, and it became difficult to remit funds to England by buying, in India, bills of exchange on the London agents of private merchants. The latter, it seems, just were not desirous enough of buying Indian goods to require large advances from the Company in India. ${ }^{142}$ The Company continued to import raw silk and indigo at a loss, solely because there was no other way (apart from exporting bullion) of transferring resources directly from India to England. ${ }^{143}$ Under these circumstances, interest in the shawl wool trade did persist: to gain a share of it, to establish shaw 1 manufactories, and to send a new and exotic luxury for sale in England seemed just the treatment to galvanize a jaded commerce. In 1815 it was decided to build a factory at Kotgarh on the Sutlaj, designed to attract some of the trade which was traditionally confined to Ladakh and Kashmir - though without success, it appears, until the final subjugation of Kashmir by the Sikhs in 1819 sent a number of refugee weavers into British territory, and even then obtaining wool remained an almost insuperable problem. ${ }^{144}$ However, the remittance problem had also been transformed and diminished by the pressure of commercial developments. True, it was still difficult enough to transmit funds directly from India to London; but since 1774 a way of remitting indirectly had been discovered. This involved selling the Indian investment in China, buying tea with the proceeds, and realizing the profit on tea in London, in the usual way. In other words, assets were remitted to England via the agency of Canton. ${ }^{145}$ Thus while the sale of Indian opium in China by private merchants brought great quantities

This exempted goods destined for re-export to Europe from all but a small warehouse duty. 
of treasure into India, the sale of Indian cotton by the Company provided the alternative solution to another problem which at first had aroused interest in the shawl wool trade. After all its other factories had been closed, an establishment was kept in operation at Bombay by the Company for the provision of cotton wool for the China market. ${ }^{146}$ The sale of Indian cotton became so important as a means of buying tea, that, later, it even began to be feared lest any increase in the sale of English twist and piece goods at Canton might adversely affect this means of remitting funds from India. ${ }^{147}$

So, for the third and final time we find that a problem which in 1774 had led people to regard trans-Himalayan trade as desirable, led them in 1814 to be more concerned about the security of the East India Company's commerce with China. The trade routes linking London with Canton were the spinal nerves of the body economic, and upon their soundness depended its whole health and robustness. Free access through all the high passes into Tibet would have been less valued than was a passport to China and an audience vouchsafed by the Son of Heaven. No journeys through the frozen wastes of central Asia were as momentous as those to Peking in a palanquin, pertaining as the latter did to the fate of a commercial empire, and involving as they did the harshest of all privations - that of an Englishman of his dignity. Whether or not Lord Amherst should kotow to the Chinese Emperor was an issue of much more import than whether William Moorcroft was dead or alive somewhere out in Turkestan. Wherever men pondered the issues of the day - in brown-panelled rooms in London; behind fluted white columns in Calcutta; and over madeira and cheroots in English houses in Macao on one point they were always agreed, namely, that the China trade must not be jeopardized. The English were in no position to bargain or blackmail, because the Chinese did not, in their own view, depend at all on foreign trade, and they made it clear that trading facilities were in the interest only of those to whom they were granted; They were no acknowledgement of Chinese need, only a token of Imperial 
magnanimity. No, the only way to retain trading privileges was to avoid studiously all policy which might give umbrage to the Imperial court; and to extend those privileges required conciliation and cajolery.

By 1814, then, British Indian diplomacy was being dictated by two priorities: first, the necessity of good relations with the Sikhs; second, the indispensability of a benevolent Chinese court. A Himalayan policy was incompatible with the fulfilment of both requirements, and if we glance over British diplomacy in the quarter century before the Nepal war, we can see how such a policy was abandoned as the political and economic processes which we have been describing developed.

In 1792 the Gurkhas agreed to sign a commercial treaty with the Company, probably in the expectation that they would in return receive help against the Chinese, who were at that time hammering at the walls of Kathmandu itself. ${ }^{148}$ However, the Governor General of the time, Lord Cornwallis, made it clear to the Nepal government that he could not endanger the Company's commercial interests by fighting the Chinese. The most he dared do by way of exploiting the situation was to insinuate a British agent as peace maker. This was Captain William Kirkpatrick, the first English official to visit Kathmandu. Peace was made before he arrived, but he went on just the same in order to spy out the land and to supervise the implementation of the commercial treaty. The commerce in question was the purely local one between the Nepalese lowlands and northern India; the treaty made no mention of Tibetan trade. ${ }^{150}$ A subsequent native agent, Abdul Qadir, sent to Kathmandu by $\operatorname{Sir}$ John Shore in 1795, gathered useful information about it and suggested setting up marts for Tibetans in the coldest parts of the Company's dominions. It was soon after this that the Government took measures to encourage the resort of Tibetan merchants to Rangpur; but no further effort was made to implement Abdul Qadir's proposal. ${ }^{151}$

In 1800 , after the palace revolution in Nepal, the Raja, Rana Bahadur, was obliged to have recourse to the age-old expedient of the 
Bahadur, was obliged to have recourse to the age-old expedient of the personae non gratae of Indian politics - a pilgrimage to Benares, on the Ganges, the holiest shrine in South Asia. Exiled ex-rajas were irresistable playthings to the new Governor General, Lord Wellesley, who had a penchant for intrigue, and he sent off an agent, Captain Knox, to Benares. Wellesley's idea was to act as arbiter in the political quarrel in Nepal, and restore Rana Bahadur as a puppet of the Company. ${ }^{152}$ There was no hope of this being accomplished, because the quondam Raja had no intention of being manipulated by the British; but the interest shown by the Company in the fugitive at Benares had a useful effect on Damodar Panre's government in Kathmandu, which agreed to a new treaty and an exchange of residents with Calcutta. It seemed that the Company had at last acquired a foothold in Nepal. ${ }^{153}$ But the whole affair smacks of opportunism, and was really no part of a consistent Himalayan policy. Although the Nepalese durbar signed the treaty from a fear that the British would forcibly reinstate Rana Bahadur if it refused, the Governor General had no such intention; ${ }^{154}$ and he was particularly careful that all clauses which might offend the Chinese were deleted from the treaty. 155 Captain Knox went to Nepal as the first British Resident in 1801, and was instructed to obtain the maximum amount of information while arousing the minimum amount of suspicion. The very comprehensiveness of his instructions betrays extempore and opportunist thinking. He was required to investigate the possibility of facilitating commerce with Tibet through Nepal; but the injunction was given no particular emphasis, and was rather lost among the detailed instructions designed to promote local trade, especially in timber, between the Nepalese Tarai and north India. ${ }^{156}$ As it happened, the embassy was rather a shambles. From fear of offending China, Knox was enjoined to use no threats to secure compliance with the treaty, ${ }^{157}$ and, helpless before the obstruction and the prevarication of the durbar after the sudden and dramatic return of the senior queen from Benares, was left no resource save that of withdrawing with some show of pique. Had the British been sincerely interested, they could have retaliated instead 
by setting up their own government in Nepal. The occasion had never been more propitious for the extension of British hegemony into the eastern Himalayas. The political confusion in Kathmandu was such that even prominent Gurkhas desired to become vassals of the Company, ${ }^{158}$ and about the same time the Raja of Sikkim appealed to the British for aid in expelling the Gurkhas from his country. ${ }^{159}$ But the Calcutta government took no heed of these opportunities. Knox withdrew, the treaty was dissolved, and Sikkim was left to its fate. Had China been offended, the advantages would just not have been worth the price. Thereafter, the Company's government's main concern was to avoid all involvement in Himalayan projects and politics. Calcutta appears to have been somewhat nonplussed by the home authorities' approval of Thomas Manning's plan to voyage to Lhasa from India. Manning was a genuine eccentric of vintage quality, who had learned Chinese at Canton. He seems to have had no motive apart from the satisfaction of idiosyncratic impulse and private curiosity. After a bizarrejourney in the disguise of a Chinese he did in fact become the first Englishman to reach Lhasa and set eyes on the Dalai Lama; but it does not appear that he received any support or assistance from Calcutta. 160 At about the same time, Ochterlony tried to persuade the government to take up the cause of the hill Rajas of Garhwal and Sirmur, who had been dispossessed by the Gurkhas - only, as we have seen, to elicit an emphatically interdictory response from Lord Minto. ${ }^{161}$ Similar circumspection characterized Minto's handling of the border disputes with the Nepalese in north Bengal, where he showed that his inclination was rather to appease than to stand firm. When Moorcroft, footsore but triumphant, retumed from Tibet in 1812 , he did not receive the official acclaim he expected. There had been an unfortunate brush with the Gurkha authorities on the return journey through Garhwal, and his party had been arrested and roughly handled. ${ }^{162}$ The Nepalese Raja, replying to the Calcutta government's representations on Moorcroft's behalf, professed himself offended and disappointed by such an intrusion into his territory by men who were uninvited and in 
disguise. ${ }^{163}$ Minto was all the more irritated by Moorcroft's expedition because it had been undertaken without sanction from Calcutta. Moorcroft was reproved for his cavalier and clandestine conduct, and told that if official permission had been requested it would not have been granted, seeing that such an expedition was dangerous, offensive to Nepal, and directed to objects which were outside the prescribed duties of Superintendent of the Stud. ${ }^{164}$

It might at first seem that the annexation of Kumaun after the Nepal war confutes the argument advanced above. Lord Hastings' interest in the province was undoubtedly stimulated by the fact that it offered access to Tibet and the shawl wool trade; but if we examine the circumstances under which the decision to annex was made, we shall see that the attractions of a trading connection with Tibet were not present in the minds of members of the government when they determined to go to war. Preparations were being made for a conflict from the middle of June, 1814, the plan being to commence operations at the beginning of the ensuing cold season. The idea that the Gurkha territories west of the Kali river might, if captured, offer passages in to Tibet, evolved from the extensive inquiries of the period prior to hostilities. One of the government's informants was Hyder Hearsey, and among memoranda of his which were submitted, through Moorcroft, as possible sources of useful intelligence, there was mention of the Niti and Mana passes, which lead from Garhwal into Tibet. This caught the attention of government, and on July 30 th Hearsey was asked for further details concerning them. ${ }^{165}$ on 24 th August Hearsey wrote supplying more information, and described Garhwal with its rich valley, Dehra Dun, as a potential thriving entrepot for trans-Himalayan trade. ${ }^{166}$ The Governor General was now intrigued by the possibilities which the province offered, and he contemplated annexing Garhwal "not so much with a view to revenue as for the security of commercial communications with the country where the shawl wool is produced." 167 Enquiries were instigated with a view to enabling him to make a definite decision. Soon it became obvious that Kumaun offered even better access to Tibet 
than Garhwal. William Fraser, Assistant at the Delhi Residency, submitted a memoir on the comparative merits of the two provinces, and demonstrated that the Kumaun passes or ghats of Juar and Darma were more frequented than those in Garhwal, and that Kumaun included numerous traditional trade marts. ${ }^{168}$ Knowledge of Kumaun's rich natural resources had already determined as part of the just prize of war, ${ }^{169}$ and as Fraser's report made it clear that Kumaun offered the better trade routes as well, it was no longer necessary to consider annexing Garhwal. ${ }^{170}$ Only Dehra Dun would probably be retained, for purely strategic reasons. ${ }^{171}$

There was no question of the war with Nepal being undertaken in order to secure the trade routes through the western Gurkha provinces. As preparations for war evolved, information came to light, and it became apparent that the war could be given an additional justification by the acquirement of such trading advantages. It became obvious later that Hastings' interest in trans-Himalayan commerce was subordinate to his conception of strategic and political necessities, and it would be quite unconvincing to suggest that he inherited Warren Hastings' willingness to make war for the sake of that commerce. The true object of his war with Nepal was to obviate the risk of an attack from the north when he came to turn his attention to the task of pacifying central India, - a task which he well anticipated would lead to a war with the Maratha states who as yet lay outside the pale of the British hegemony. For this reason he admitted that he was not sorry that the rupture with Nepal came when it did. Nor is his sincerity to be doubted when he claimed that the Company's government was compelled, in order both to save $i$ ts own reputation and to discharge its basic moral obligation of protection to its subjects, to end the alarums and excursions which for twenty years had interrupted the peace of India's frontier with Nepal. ${ }^{172}$ War once decided, it would have been unnatural to forgo such incidental opportunities as promised to make it more worth the trouble and expense. By annexing Kumaun, several such opportunites were realized. Besides a corridor to Tibet, the province 
offered mineral and timber resources of great richness, and a position of major strategic importance. The Sikhs had already shown an inclination to cross the Sutlaj on the plains, and it was arguable that they would not have resisted much longer similar temptations farther up, in the hills, where the Gurkhas had been proving troublesome to them. The Governor General considered that by establishing the Company's military presence in Kumaun, he had removed the threat of the Sikhs invading the cis-Sutlaj hills and "taking in flank one of the most valuable and important positions of our northwest frontier line". ${ }^{173}$ If he tended to expatiate more on the shawl wool theme, it was probably because he appreciated that reasons of commerce were still likely to appear more cogent to the Court of Directors, whose aversion to further annexations had to be borne in mind. If such was his reasoning, it was exact. In reply to a despatch which he wrote to explain the motives for annexation, and in which he emphasised the potential advantages to trade, $^{174}$ the Directors replied:

"We could have wished that the war had ended without any accession of territory on our part; but the peculiar circumstances which....induced you to determine upon retaining Kumaun, appear completely to justify that deviation from the settled course of your policy."175

If we would have a more genuine insight into the Governor General's way of thinking, we should look elsewhere than in his somewhat specious despatches to London. It is significant, for example, that at the outset of the war he told Major Bradshaw that a trade agreement with Nepal was to be considered as a dispensable part of the provisional peace treaty; 176 and that at the end of the war he showed no enthusiasm at all for a commercial treaty with Sikkim, who now found herself freed from Gurkha domination. Sikkim was a natural gateway to Tibet, separated as she was from Bhutan on the east by the Chumbi Valley, a long finger of Tibetan territory which reaches over the Himalayan crest and points down to Bengal. Yet Captain Latter, in charge of negotiations with Sikkim, received no instructions concerning a commercial clause in the Company's pending treaty with that state until he announced that 
he had suggested to the Sikkim officers that they would derive advantage from a trade with north India - "I in order $T$ that by the sale of mangeit, beeswax, ivory and other articles the Raja might be furmished with funds for the payment of his troops."177 The Governor General's reaction to this modest design was very nonchalant. "It might be proper," Latter was informed, "as it seems...t to be expected, that an article should be inserted in the proposed arrangement, for encouraging a free commercial intercourse between the two states."178 Then again, the following extract from a letter to Canton, dated June 1816, has a tone which contrasts strongly with the zeal of his letters to London:

"The approximation of the British territories and of states subject to $i$ ts $\overline{\text { sic }} \bar{T}$ protection $\bar{T} *$ to the dominions of China, will probably lead to a more or less extended commercial intercourse with the provinces of the latter state near the Himala range. It will I? not be $T^{*}$ in the $\bar{T}$ ? nature of $T^{*}$ our policy to endeavour to force this intercourse, but we shall of course feel disposed to give every fair encouragement to it." 179

Actions were in fact even more cautious than the most guarded words; and far from "every fair encouragement", the Governor General displayed a diffidence which must have caused sad disappointment to those who had hoped the war would prune away the encumbrances which had hitherto prevented the full blossoming of the trade through the Himalayas. William Moorcroft could hardly wait for the fighting to end to exploit the openings provided by the acquisition of Kumaun. He was well acquainted with Ahmed Ali, one of the Kashmirian merchants at Patna, who offered his services as gomastha Iagent T should government wish to test the possibilities of a commercial communication with Lhasa. Moorcroft was eager to send him on an experimental expedition there, by way of Kumaun and the Garhwal passes, ostensibly as a private merchant (to avoid suspicion) but in reality under the government's sponsorship. 180 This idea wedelent of the experiment of 1795, when Abdul Qadir was sent to Kathmandu to test the market for British goods. ${ }^{181}$ But the government now, fearing lest the agent should exceed his powers Words omitted in India Office transcript. But the sense is clear. 
and compromise its position, was not at all keen to repeat the device. Ahmed Ali was given permission to go, but only as a private individual. The government undertook to find suitable samples of British merchandise, but only on the understanding that their value should constitute a loan at $6 \%$, without liability on the agent's part for losses incurred. Ahmed Ali chose not to accept these terms, and the project lapsed. ${ }^{182}$

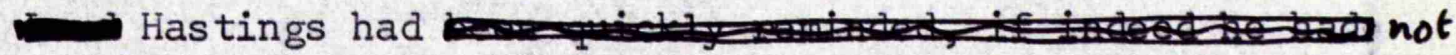
forgotten that any attempt actually to exploit the advantages he had so warmly invoked could easily endanger the success of the more fundamental policy of propitiating China. The Imperial authorities at Lhasa had been manifestly perturbed by the British invasion of Nepal, and Hastings had no intention of deepening their suspicions either by sending agents to Lhasa, ${ }^{183}$ or by hastening to utilize the passes to Tibet in the western hills. When we remember his eagerness to speculate on the facilities for access to the trans-Himalayan countries offered by Kumaun, it comes as something as a surprise to find that Hastings ignored Moorcroft's suggestion that Ahmed Ali should use the route through the newly annexed territory, and recommended instead that he travel by way of Sikkim. ${ }^{184}$ Captain Webbe was even required to suspend his surveying operations on the Kumaun border because they had brought him into contact with the Chinese officials of Tibet. He was told that it had "become peculiarly necessary to observe the strictest caution in all...proceedings on the frontier of China, Tartary, and in...intercourse with the officers and subjects of that Government." 185

Those who looked across the other new frontier, the river Sutlaj, to the west, aspiring to reach out and capture the shawl wool trade plied between Ladakh and Amritsar, had their hopes confounded, too. If the Calcutta government was to retain the goodwill of the Sikhs, there could be little thought of actually realizing the prospects which had been so plausibly elaborated by the Govemor General. Lieutenant Ross, in charge of relations with the cis-Sutlaj hill states afforded British protectionafter the war, suggested that the government should probe the possibilities of a commercial connection with the Raja of Kulu, 
a small state across the Sutlaj which straddled the main trade route from Ladakh to the Panjab. He pointed out that the trade in shawls and shawl-wool could be tapped in Kulu, and drawn off in to the Company's territory. ${ }^{186}$ But in the vew of the Governor General, the plan was "liable to considerable objections...since it might be viewed by Ranjit Singh as an attempt...to form a connection with the countries lying on the other side of the Sutlaj and as justifying any measure on his part to renew his intercourse with the Sikh chiefs on this side..." 187

Perhaps no one was more dismayed by the transience of the revived interest in trade through the Himalayas than William Moorcroft. He brooded over lost opportunities, and resolved either to vindicate his convictions or crucify himself in the attempt. ${ }^{188}$ In 1819 he set off through Kumaun on an expedition to Bokhara, encumbered with British merchandise which he hoped to dispose of in the trans-Himalayan countries, thereby fostering new markets for British goods. The government reluctantly sanctioned the scheme, because again its ostensible object was to procure horses for the stud; but it refused Moorcroft official designation and a letter of introduction to the King of Bokhara. ${ }^{189}$ Fears of offending Ranjit Singh undoubtedly weighed heavy with the government. According to Hyder Hearsey, who refused to accompany Moorcroft on this occasion, it would have been more favourable had he agreed to adopt the route from Bombay, via Persia, as suggested by Hearsey himself ${ }^{190}$ - presumably because this would have avoided contact with the Sikhs. Certain it is, that by subsequently interfering in the affair of Ranjit Singh's claims to Ladakh, Moorcroft brought down upon himself the severest official castigation. ${ }^{191}$ His mission was a failure. He reached Bokhara - disowned by his government, despoiled by bandits, chagrined and exhausted - but never returned. His fate remains mysterious. Trebeck, his companion, who also failed to return, wrote announcing his death in Afghanistan, in September 1825; but the French missionary, Huc, when in Lhasa in the 1840 's, obtained convincing evidence of Moorcroft's arrival in that city, disguised as a Kashmirian, 
in 1826, and of his sojourn there, incognito, for a period of twelve years. ${ }^{192}$ It is just possible that in his mortification he chose to commune in exile with the shades of Warren Hastings, George Bogle, and Samuel Turner, rather than return to the humiliation and disgrace which he had been convinced would await him in India if his expedition failed. 193

British Himalayan policy in 1814 was therefore fashioned by two types of necessity: that created by local border problems; and that deriving from more basic economic and strategic issues; and the two, like the surface and the deeper currents in a river, had ceased to pull in the same direction. The Nepal war was an interesting exercise in the art of diplomatic navigation, because it was an enterprise favoured by superficial but opposed by deeper forces; coming about because of the one set of exigencies, but in spite of the other. It was made acceptable by the need to define and secure the northem boundary of the East India Company's possessions, and to vindicate the Company's raison d'etre as a government by defending the subjects under its protection; but at the same time it was made unwise by the more fundamental requirement of amity with the Chinese and the Sikhs. It was in the profounder forces of necessity that a metamorphosis had been wrought since 1774 , the date of the first British expedition in quest of Himalayan trade. Their direction had ceased to correspond with that of superficial expediency; They now created powerful reasons against fighting another war with Nepal, and made it much more difficult to prevent such a war turning into a diplomatic disaster. 


\section{Chapter Four}

\section{The Bengal Army}

On November momings in 1814 , the roads leading north from the great military stations on the Ganges - Dinapur, Benares, and Meerut were thronged with the divisions of the Bengal army marching to war against Nepal. The long columns streamed like embroidered banderoles through the misty light. Had an Englishman newly-arrived in India seen one of the processions, the sight must have dissolved his sense of exile, and left him momentarily uncertain of time and space. Familiar uniforms, accoutrements, and muskets; the breathy articulation of fifes; and the whirring syncopation of side drums, would have recalled another world: a world where soldiers stirred in village squares, and battalions embarked to fight the French. Only as the light intensified would he have become conscious of a strange aberration disturbing the concord between remembered and present impressions; Only the full brilliance of the day revealed an unfamiliar angularity of features beneath the shakos; a predominance of glossy black whiskers; dusky complexions, lightened to an Iberian olive by the leaping scarlet of the jackets; naked legs, deepened to a burnt umber by the dazzling white of thigh-length shorts. Almost every soldier was an Indian. Here was a British army without Britons. The observer would have seen the occasional European face. The mounted officers, splendidly baroque with swords and lace, gloves and gilt epaulettes, were all British; so were the artillery; and there were detachments of troops from the army of the crown. But blanched and cleanshaven, these had the incongruity of players discovered costumed, but without make-up, among the painted concourse on a harshly illuminated opera stage.

Checked in his drift towards a passive state of reminiscence, the observer would have marshalled his senses to satisfy a curiosity, and savour a new and exotic spectacle. He would have been astonished by the immense train of baggage and camp followers. An Indian army was a cosmos unto itself. When it marched, every requisite article of 
consumption, and many inessential articles of comfort, went with it. The body of non-combatant servants and followers was more than twice the size of the fighting force, and as the army went by the order and measured tread of the troops gave place to the motley and charivari of a long straggling circus cavalcade. There were elephants, camels, buffaloes, bullocks, horses, ponies, carts and tumbrils labouring under the weight of tents and camp equipment; of trunks, barrels, boxes, bags and baskets packed with supplies and provisions of every description; and even of battered drawing room furniture. Perhaps even more surprising than the sight of so much baggage would have been the overheard remarks of officers complaining about having to make do with so little. Normally, he would understand, an army expected to march with five times as much equipment as this. The bazaar people drove herds of oxen, sheep, goats, and poultry. Tireless half-naked bearers carried the sick, the wounded, and high-caste native women on litters; while others were less nimble under the heavier load of curtained palanquins, whence civil servants and less energetic officers leaned lethargically from time to time, to summon a servant or observe the progress of the march. In addition to the officers' domestic establishments there was a legion of public servants - grooms, grass-cutters, cooks, water-carriers, tailors, washermen - many with their wives and children; and finally there was the accumulation of hangers on, clinging like parasites to the line of march: scavengers, jugglers, prostitutes, plunderers - men, women, children and animals, following the army for what they could get and constituting perhaps a third of the non-combatant force. Controlling and manipulating this unwieldy appendage was the responsibility of the Baggage Master, whose mounted troopers cantered up and down $i$ ts length, cracking long whips and trying to lash it into something like order. Only if he had followed the division to its next ground of encampment would the observer have appreciated in full the difference between a European and an Indian army. British officers in India enjoyed a standard of luxury in the field, as well as in the cantonment or garrison, which amazed those accustomed to the rigours of service in 
Europe. All officers had been requested to reduce the scale of their establishments for service in the mountains; but even so, infantry captains still required up to two dozen servants, and most had baggage sufficient to occupy half a dozen camels. The entourages of field officers were even larger; and the commanding officer's reached a quite viceregal scale. Officers tended to be isolated by these bevies of acolytes, and such evidence of communal existence as mess tents was not to be seen. They breakfasted and dined either alone, or as guests in the tents of other officers, but always in some state, with cut glass, china, plate, condiments, and wine. European soldiers were indulged to a degree unknown at home. Each corps (normally divided into groups of sixteen sharing a tent, but on the occasion of this war assigned to tents in bodies of 40 , to reduce the burden of camp equipment) had native cooks and attendants of every description attached. The diet of the men consisted of biscuit, soup, meat and rum. The meat, it is true, was sometimes pickled beyond recognition (a consignment of beef for the Dinapur division of the Nepal expeditionary force had been two and a half years in salt); but the ration of spirit was generous - a daily half pint for each man. It was a local liquor called arrack, made from rice and sugar. In some corps the men were allowed to take it undiluted if they chose, despite the fact that it was above proof. By nightfall the European area of the camp must have been easily distinguishable by the din of drunken brawling and the stench of vomit. Never greater contrast than then between the incontinent Europeans and the sober native troops, who sat quietly aside in the shadow, beyond the glare and confusion. The march once finished, camp once pitched, and the day's exercises once over, they lived a lifeapart. When, as now, on foreign service, they were supplied with provisions, comprising flour (ata), lentils (dal), clarified butter (ghiu, or ghee), salt and tobacco. The food they prepared and consumed according to the strict ritual of Hindu or Muslim usage. For Hindus, of whom the great majority of the native infantrymen, or sepoys*, was composed, these were especially elaborate

From the Persian word sipahi, a soldier. 
and solemn processes. Only ritually clean utensils might be employed, so they had no use for the black tin kettles and mugs, and the tin, leather or wooden canteens issued to the Europeans. Complete withdrawal from the contaminating influence of men of lower caste was necessary even the shadow of a European could pollute - and then puja, or worship, had to be made; the blessing of a brahmin invoked; all vestments save a loin cloth discarded; and a symbolic washing performed. The whole ceremony might take three hours, and for this reason the sepoys preferred to eat at night, when they would gather in groups and perhaps prolong their meal with campaigning stories, or with chatter about their homes and families. Normally, when on foreign service they were provided with tents; but on this occasion, again in order to lessen the difficulties of transportation in the mountains, they had been left to improvise their own shelter. While they remained on the warm plains this was no privation. On service, they generally chose to sleep in the open, and the sight of them lying on their mattresses and wrapped in their quilts, dark forms made restless by the unsteady light of camp fires, was a common one to all with experience of military life. The Muslims, who were predominant in the cavalry regiments, also lived according to their creed; but they were found to be less introverted than the Hindus, and numbers could have been seen carousing with the Europeans. They had a pronounced relish for opium - a vice which made them the more sympathetic in the eyes of their fellow British profligates. 1

The East India Company had three standing armies, one at each of the three Presidencies of Madras, Bombay, and Bengal. Each had its own officer corps, /staff, and commander-in-chief; but all were ultimately subject to the head of the Bengal force, who was Commander-in-Chief for all British possessions east of the Cape of Good Hope. These armies were regarded by the Company, and even by many of its critics, as wonders of their time. The high standard of loyalty and discipline inculcated in such large bodies of Asiats by a tiny group of British officers was an object of pride and an habitual theme of self-congratulation. But complacency had outlived its justification. 
Serious flaws had begun to endanger the structure behind the variegated and impressive facade.

In 1814, the Bengal army was the largest of the East India Company's three. Robert Clive had formed the nucleus of a standing force in 1757, when he embodied and drilled a few hundred sepoys according to the European method, in order to protect the Company's trading posts on the Bengal seaboard. Since then, the Company had become a dewan in its own right in north India, with territorial revenues to collect, frontiers to defend, and powerful rivals to intimidate; and the original small band had grown into an army of some 67,000 men. One of the most notable facts about its development was that it had latterly involved a shrinkage not only in the proportion, but in the gross amount of Europeans. When Clive reorganized the army in 1765, he had balanaced a battalion of European infantry against every seven of sepoys, ${ }^{2}$ and in 1786 Cornwallis, convinced that the European contingent was "the foundation upon which all [ the Company's $T$ power and dominion in this country must in many possible cases stand or fall", insisted on increasing the proportion to one to every six, thereby bringing the total of the Company's European infantry to about 6,000 men. $^{3}$ These six single-battalion regiments had been reduced to three in 1796, and later to two; and in 1814 only one of these was serving in Bengal. ${ }^{4}$ Meanwhile the 24 native infantry battalions of $1765^{5}$ had risen to 54 . The European foot artillery had remained constant, at three battalions. The native cavalry had increased from two to eight regiments*, while the only mounted European corps in 1814 was the single regiment of horse artillery. ${ }^{6}$ In terms of numbers, the regular Bengal army on the eve of the Nepal war amounted to roughly 67,250 men of all ranks, of which the corps composed of Europeans accounted for about 3,200 . The European contingent was thus only one twentieth the size of the native army. ${ }^{7}$ In government circles at home this ratio was regarded as quite unacceptable - Castlereagh, when President of the Board of Control, had reckoned that even one seventh

Each of three squadrons or six troops. A troop had 80 horsemen. 
was too $10 w^{8}$ - and over the years since 1788 the relationship had been rectified by the presence of Royal regiments in India.

Partly because of technical difficulties (its recruiting officers did not bear King's commissions, and it had no recourse to martial law), and partly because of negligence and a failure to offer sufficient incentive, the Company's European corps had always been incomplete in numbers and wretched in quality. Comwallis had been so alarmed by their inadequacy that he had adopted the view that all European troops in India should be employed by the King. ${ }^{9}$ The Court of Directors, however, had opposed augmentation of the Royal troops in its territories, first because it would increase the jealousy of their own officers, over whom all Crown officers of the same rank were given precedence; and then because King's men were so much more expensive than sepoys, in whose fidelity the Court always affected to have an unshakable confidence. 10 The consequence had been that in 1788 Henry Dundas, President of the Board of Control, had instigated legislation which compelled the Court to accept and pay for, within a certain limit, such Royal troops as the Board deemed essential for the security of the Indian possessions, at the same time obviating one of the Court's objections by having a local King's brevet granted to all Company officers. ${ }^{11}$ Thereafter, the number and significance of soldiers of the Crown in India had grown in steady proportion to the increase in the size of the native armies. In 1787 there had been only six King's regiments in the peninsula - roughly five and a half thousand officers and men. In 1811 there were twenty regiments, or about 20,000 men, 12 which was the greatest number for which the Company was liable to pay by the terms of the act of 1788 .

That act leaving it no option concerning the employment of a certain proportion of British troops, it is not difficult to understand why the Company chose to fulfil its obligation by receiving Crown regiments rather than by increasing its own European corps (which it was now entitled to do to the extent of 12,000 men). It would have been enormously expensive to maintain such a large European contingent. The 
service life of British troops in India was rapidly terminated by death, debility or insanity. Dipsomania was so rife among them, that they had to be kept constantly sequestered for fear lest they should terrify the native population by their drunken rampaging. But confining them to cantonments and garrisons where clubs, libraries (for the very few who were literate), and organized recreations were unknown, merely hastened their physical and mental deterioration, for they had no diversions save fornication and more drink. Most European soldiers had native concubines, and were reckoned to be responsible for the alarming growth in the half-caste population; ${ }^{13}$ and it was very difficult to prevent their acquiring supplies of "country" liquor in addition to their allotted rum. This was the very crudest spirit, of uncontrolled manufacture, and often made even more noxious by the admixture of drugs. ${ }^{14}$ Their degeneration was consequently appallingly swift. It was estimated that a European soldier in the Company's service was fit only for a pension or a place on the invalid establishment after ten years' service; and in the 1820 's it was considered necessary to deny King's troops the option of remaining with their regiments in India once they had passed the age of thirty. ${ }^{15}$ Many did not even survive that long. The annual death rate among European troops during the first half of the nineteenth century maintained an average of about one in fourteen, as a result more of alcoholic poisoning, disease and suicide than battle casualties. ${ }^{16}$ Even communal suicides were known. ${ }^{17}$ The annual casualty rate from all causes, including invaliding, discharging, and desertion, achieved an average of one in seven. ${ }^{18}$ The advantage of using King's troops under such circumstances is obvious. They were regularly replenished and relieved by fresh consignments from home, and the Company was spared the cost of recruiting and training a constant supply of replacements. This saving undoubtedly more than compensated the expense of the difference between the pay of Royal troops and that of Europeans in the Company's own service. ${ }^{19}$

Consequently, there were in 1814 two cavalry and six infantry regiments of the King's army in Bengal alone - a total of some 7,000 
officers and men. 20 Their presence increased the size of the European force in this Presidency to just over one sixth that of the native; and it meant that that European nucleus with which the final responsibility for the safety of the Indian empire was believed to rest, and which was expected to provide a standard of loyalty and bravery for the natives to emilate, had ceased to be a part of the Company's own army. While this increase in the size of the King's arny in India had done much to mitigate the problem of expense, it had also, as the Directors of the Company had foretold, done much to aggravate the jealousy of their own officers. In Bengal and Madras in 1786 there had been about thirteen officers and men in the Company's pay for every one in the King's; but by the end of the first decade of the next century the ratio was only eight to one. ${ }^{2 l}$ As their numbers and significance had augmented, so too had the self-importance and pretensions of the officers of the Crown. The Company's officers had been made increasingly aware of the panache, the mystique, the prestige attaching to the King's army; and the comparatively low tone of their own status as the servants of a mere trading corporation had made them sullen and disgruntled. Furthermore, the King's officers still enjoyed advantages and privileges which they did not share: such as senior rank at an earlier age, the highest positions, and honourable distinctions and decorations. Company officers were often commanded by King's men ten or fifteen years their junior, because the pace of promotion in their own service was so slow. They were now at last eligible (since 1813) for the rank of lieutenantgeneral; but there was no precedent to suggest that this would afford them access to the principle staff positions and commands in chief at the various Presidencies, all of which had hitherto been the preserve of King's officers. 22 Decorations from the Crown were extremely rare. Sir John Malcolm, of the Bombay establishment, who had been made Knight of the Wilitary Order of the Bath early in 1814, was the only Company officer ever to have received the accolade. ${ }^{23}$ Brooding on their grievances, the Company's men had come to envisage themselves as the victims of a cruel prejudice, like "a kind of Roman Catholic, and subjected 
to disqualification without having undergone the ceremony of conversion". ${ }^{24}$ Many were of the opinion that the Company's armies should be transferred to the Crown; ${ }^{25}$ but the contrary argument - namely, that the Court of Directors could not function if it were deprived of the power of dismissal ${ }^{26}$ - had so far carried the greater weight, and the policy had never got beyond the stage of discussion. So the situation persisted, in Bengal as in the other Presidencies, where the military assignment was shared between two distinct officer corps, divided by tensions which, like the force repelling identical magnetic poles, imposed contact only intensified.

Dissension among the officers was only one of the weaknesses resulting from the type of expansion which the Bengal army had been undergoing. Another arose from the fact that the rate of expansion had failed to keep pace with the accumulation of territory under the Company's administration. Until the early 1780's the growth of the Bengal army had been progressive; but by then a fundamental change was being imposed on the Company's attitude towards its Indian possessions. In Pitt's Regulation Act of 1784, a clause whose preamble affirmed that it was "repugnant to the wish, honour and policy of this nation" to "pursue schemes of conquest and extension of dominion in India" had removed the freedom of the Company's agents in India to make war arbitrarily. ${ }^{27}$ This legislation postulated the existence of a fully grown empire in a state of rest, a conception radically different from the notion (that the British territories in India were trading establishments in search of security) which had hitherto underlaid policies of aggrandizement. A diminution of the Bengal army, and a redefinition of its purpose, had not unnaturally followed this transformation of outlook. Its normal function no longer being conceived as offensive warfare, but defence and internal security, extensive reductions had been made in the army in 1786 and a military peace establishment instituted. ${ }^{28}$ Further increases had been implemented subsequently, in response to the threat or the outbreak of war. There were enlargements on the occasion of the Mysore War in 1790, and during the period 1797-1805, which saw the 
second Mysore War in south India, the threat of invasion from Kabul, and the Maratha War in Hindustan; but the army had not been maintained on a war footing once the crises had passed, and decreases had been made in 1796 and 1806. On the latter occasion, as well as reductions in the size of the regular force, the disbandment of various ad hoc bodies of irregular horse and foot, formed to relieve the regulars of internal duties, had been ordered. ${ }^{29}$ Each reduction being less than the amount of the previous augmentation, even the peace establishment had continued to maintain an overall expansion; but in the years before the Nepal war it had become obvious that this establishment was both unsuited in nature and inadequate in numbers for the functions it was expected to perform.

The reduction of nearly all the irregular levies in 1806 meant that the comparatively small regular army had recently been required to sustain the burden of such tedious and unprofessional duties as guarding jails; escorting stores, treasure, and prisoners; supervising convict working parties; and occupying police outposts. 30 The infantry had had to be broken up into small detachments and dispersed over the whole area of the Bengal Presidency, which had been greatly enlarged in 1806 by the acquisition of extensive territories from the Marathas in Bandelkhand. Most of the men had been kept constantly on duty without regular reliefs or intervals of rest, ${ }^{31}$ and had besides been so thinly spread that whole districts in the north, contiguous to Nepal, had been devoid of regular troops. 32 The cavalry was absurdly inadequate for the demands which had come to be imposed on it. Deterred by the relatively enormous expense of this arm - the monthly upkeep of a trooper's horse alone cost three times the amount of a sepoy's wages ${ }^{33}$ - the Company maintained in all Bengal but 6,000 regular cavalrymen, King's dragoons included. Yet there were now two and a half thousand miles of frontier to defend, of which vast stretches in the south were exposed to the depredations of Pindari chiefs who counted their horsemen in tens of thousands.

Sir George Nugent, Hastings' predecessor as Commander in Chief, 
had warned the Calcutta government that a serious deterioration in the discipline and morale of the army was being caused by such a severe overtaxation of $i$ ts patience and resources. He wrote of "the relaxed habits and occasional irregularities of detached parties, which from the great want of troops cannot be regularly relieved and [which $T$ are therefore kept from under the eyes of their officers much longer than is for many reasons desirable"; and he complained that field exercises had become impossible:

"Of the benefit of acting and manoeuvring in bodies this army is altogether deprived by its limited establishment being incessantly employed in internal duties, leaving no troops disposable for the purpose of forming a large permanent cahtonment or an occasional camp, and by the scattered description of the forces over the surface of a vast territory $\ldots$ and yet the constant or at least frequent assemblage of troops in considerable divisions, or, on the lowest scale, to the extent of a brigade or two, is deemed indispensable to the proper organization of any regular army intended for the defence of great continental dominions".

The sepoys, finding it increasingly difficult to obtain leaves of absence, on which they depended for the settlement of their domestic and legal concerns, had been applying for discharges and, when unsuccessful, deserting in alarming numbers. "Battalions thus become incomplete I and $T$ a constant succession of expensive recruiting and of drills for recruits takes place to supply the loss ... of formed soldiers, many even of the oldest and best of whom are known to seek their discharges or desert." ${ }^{34}$ Nugent had expressed the opinion that the army needed to be increased by eight squadrons of cavalry $(1,280 \mathrm{men})$ and three regiments of infantry

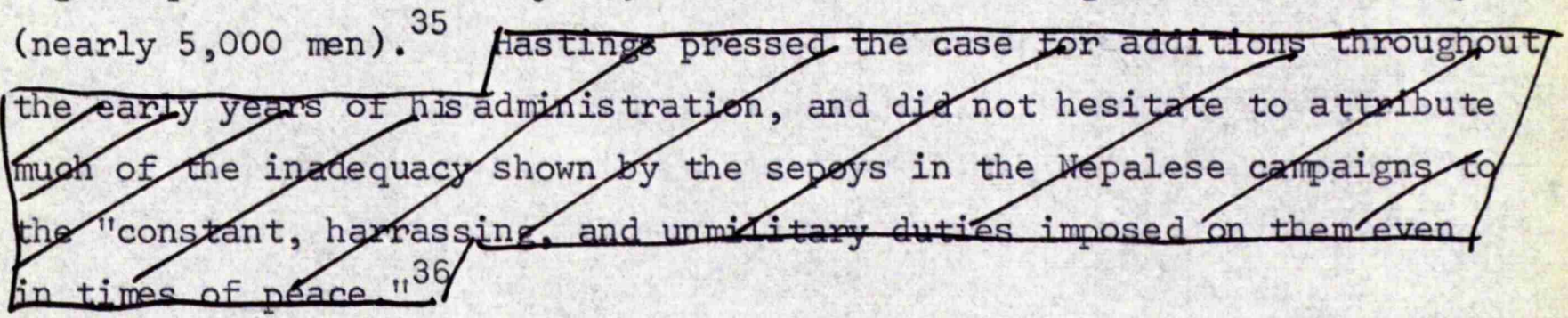

By 1814, certain of the mistakes of 1806 had been rectified, and supplementary irregular corps were again in existence. They totalled some fourteen and a half thousand men, and comprised a few bodies of 
quasi-military police, such as the Delhi Najibs, the Calcutta Militia, and the half-dozen Provincial Battalions - all with only a European commander and adjutant; the Ramgarh Local Battalion, instituted by Nugent on an experimental basis, with a European officer to each company, to help defend the northem border; and two corps of irregular cavalry, constituted after the native manner, with the men supplying their own horses, uniforms and accoutrements in return for a monthly lump sum, and commanded by two of the officers who had come over from the Maratha service on the outbreak of the war in 1803 and who had since been entertained as pensioners by the Calcutta govemment. One was the renowned and dashing half-caste, James Skinner, and the other was an Englishman, William Gardner. ${ }^{36}$ But there were still too few of these bodies for them to be efficient. In a letter to the Magistrate of Patna dated April, 1814, the Commanding Officer of the Patna Provincial Battalion wrote that he had had only between sixteen and twenty men (out of nearly a thousand) present in the lines during a period of five months, and that it had consequently been impossible for him to relieve the outposts in that period. Skinner's Horse was celebrated for its virtuosity as an ensemble; 38 but in February, 1815, Gardner told the Adjutant-General that it had been impossible for him to train his men even in the rudiments of collective discipline:

"They have been dispersed in parties of seldom more than 5 troopers, and such has been, from the first formation of the corps $[$ in $1809 T$, the pressure of duty, that as soon as a recruit was en Iisted he was detached on command, by which many have scarce seen a drill or parade."

As a result, when the horsemen were finally required to work together as a group to defend part of the northern border during the Nepal War, they proved restive and even mutinous and created more havoc than they averted.

To provide for the present emergency, the regular army had been put onto a war footing. Each company of sepoys had been increased from 80 to 90 privates, and the grenadier companies of battalions not actually in the field had been withdrawn and embodied in to seven grenadier 
battalions, preparatory to being replaced by recruits.* By these means it was anticipated that some 9,500 extra men would eventually be available. ${ }^{42}$ Furthermore, the magistrates of frontier districts had been authorized to raise temporary levies of barkandaj, or militiamen, to perform internal guard and police duties while the war was in progress. ${ }^{42}$ Hastings, however, was determined to use the occasion to increase the Bengal army's permanent establishment. He proposed the creation of three new infantry regiments; but the essence of his plan was the augmentation of the irregular part of the force, so that the regular army could be relieved altogether of interior duties and refurbished as a professional instrument. He demanded three more local battalions, nine additional provincial battalions, two new corps of irregular horse, and the expansion of Skinner's Horse from 1,000 to 3,000 men. His proposals became the issue of a strenuous controversy, and while the fighting went on in the mountains, a bitter dispute raged between the Governor General's Headquarters and the Vice-President's circle in Calcutta. Because Nugent had urged their necessity before Hastings' arrival, Edmonstone was prepared to accept the three additional regiments of infantry; but he vigorously jibbed at the policy of permanently increasing the irregulars, and insisted that the proposed corps should be treated as temporary expedients only. ${ }^{45}$ He argued that it was essential to maintain regular troops in the interior; ${ }^{45}$ but his real objections stemmed from a far more fundamental antipathy. Hastings, under the influence of Wellesley's disciples, such as John Adam and Charles Metcalfe, justified his military policy by invoking the indispensability of British paramountcy in India, or the maintenance of a military establishment sufficient to defeat all possible combinations of potential enemies. Military expansion was essential to ensure the preservation of what had already been won. It was an important tenet of this school of thought that paramountcy would in large measure pay for itself by creating a state of stability in which existing revenue

"An old-fashioned practice, which had now ceased in the Royal army. 
assets could be more completely realized; but its adherents did not hesitate to draw the inference that territories and revenues should, if necessary, be expanded in order to provide for the predetermined level of military strength. ${ }^{48}$ Advocates of paramountcy therefore rejected the premis that the British Indian empire was normally in a state of rest - a premis which Edmonstone conceived as hallowed, and which he made it his mission to defend. He questioned the practicability of a combination of all potential enemies, and argued that it was not only unnecessary but gravely impolitic to fix a scale of military strength in order to provide for what was at present a purely theoretical contingency. Such martial demonstration, suggesting eagerness to expand territorial sway, was the one thing which would cause the native rivals of the British to band together. Military augmentations would therefore precipitate the very danger they were designed to obviate. The Nepal War once finished, he saw no reason to apprehend subsequent altercations with any of the native states, provided the Company made it clear that it had no acquisitive ambitions. Security could be guaranteed only by a state of rest, so the regulator of military strength should be the actual extent of dominion and the existing level of income.

But Hastings declined to yield. On the conclusion of the wark rescinded only those increases which he had intended should be temporary, $\$$ and submitted points of difference with Edmonstone to the Court of Directors. Fus mempers were evgn more chary than the

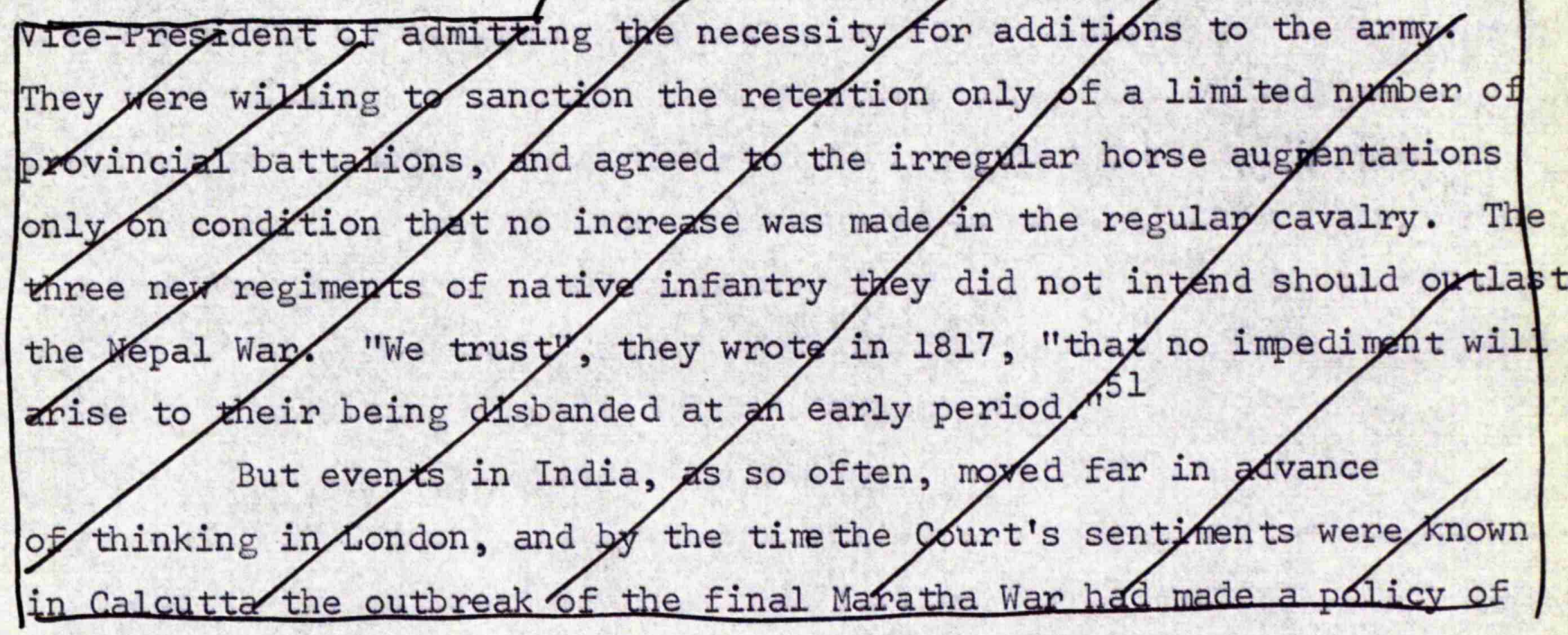




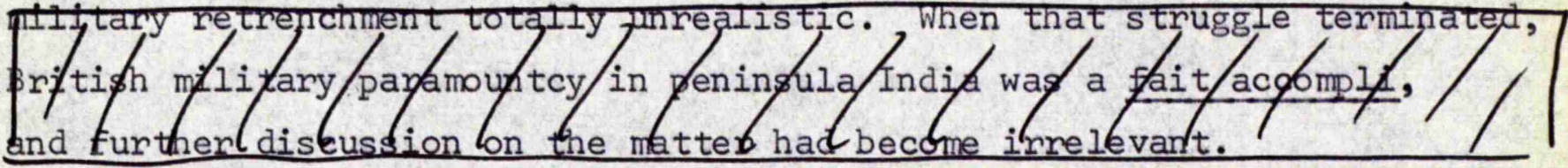

While the process of expansion had been accentuating the intermal weaknesses without alleviating the external pressures which were vitiating the Bengal army's efficiency, other measures, designed to rationalize the army's organization, had begun to be applied. Their success was so far at best dubious or incomplete; and in one important respect their effect had been far more deleterious than beneficial largely because of the jealous and parsimonious way in which they had been conceded by the Court of Directors. By the period of the Nepal War it seemed that the old style, loosely regulated army had been condemed to death, yet that the new rationalized one was still powerless to be born.

The condition wias well exemplified by the state of the commissariat. Until the beginning of the nineteenth century, the army had been clothed, fed, and transported by private contractors - generally civilians. The system had involved individuals' undertaking to provide, on terms specified in contracts, certain articles of supply. It had long proved inadequate and unthrifty. Contractors had been found to fumish inferior materials, and they had frequently failed to meet their obligations. The shortcomings of the system had become especially manifest in the state of the ordnance cattle and their drivers. Contractors would buy the cheapest bullocks, and then confide them to native Sub-contractorhose chief concern was to increase their own profits. Consequently, whenever it had been necessary to send a battering train of heavy artillery with an army in the field, the cattle had been found so emaciated and weak as to be incapable of keeping pace with the infantry. The drivers found by the contractors had been/chedy underpaid aud treated the animals and continually deserted. 51 Delay and frustration from these causes had been so apparent in 1809, when a force was ordered to the west to deter Ranjit Singh from crossing the Sutlaj, that Hewitt, the Commander-in-Chief of the day, had become convinced that essential 
provisions and services must henceforth be supplied by a department of the army itself. 52 A commissariat had therefore been instituted in December, 1809, and given charge of the victualling of all European troops; the purveyance of boats; the provision and feeding of ordnance cattle, and of elephants and camels for camp equippage and stores; the supply and upkeep of horses for the cavalry and horse artillery; and the maintenance of car(i)iage cattle and hackeries sufficient for the transportation of the soldiers' personal effects. ${ }^{53}$ At about the same time attendants for the ordnance cattle had been subjected to military discipline, arrangements being made to have them provided partly by the commissariat and partly by a regular corps of ordnance drivers. 54 So far, the new arrangements had given much cause for satisfaction. Considerable savings had been realized in each department of the commissariat, compared with the cost of similar services from contractors, ${ }^{56}$ and on the occasions of punitive expeditions against the fortresses of Kalinjar and Rewa, in Bandelkhand, the ordnance bullocks had been so much improved that the heavy guns, with their carriages and tumbrils of ammunition, had kept pace with the infantry "on the longest marches, over the worst roads, and in the hottest weather." Resort to the temporary expedients of hired cattle and carriage had not been necessary. Nugent, impressed with these performances, had expressed the opinion that "no single improvement ever introduced into the Indian armies was of greater importance to their efficiency or more conducive to the general interests of the state than the Commissariat."

"I have no doubt," he wrote, "but that experience in India will accord with that of all belligerent countries, and that the establishment of a commissariat under the Presidency will excite the gratitude of future commanders, whose minds it will have relieved from a load of anxiety and perplexing details, and their operations from all those difficulties and embarrassments which have hitherto been wont to clog and delay them". 56

Hastings shared this view. In his estimation the Bengal commissariat had aconsiderable advantage (even) over that at home, because its Commissary General was not a civilian, but a military man familiar, through personal experience, with the nature of the demands he was called 
on to satisfy. By 1814 several assignments had been added to his province, including the provision of tents and camp equippage; the purveyance of hospital and medical supplies; and the hiring and paying of bearers to carry the doolies used for the sick and wounded, drivers for the hackeries, and the various coolies and carriers needed for the paraphernalia of the European and native soldiery.

But in its hours of trial the commissariat did not fulfil all the hopes it had inspired. Its resources bore little relationto the size of the army it was meant to serve. While it was capable of discharging $i$ ts functions in times of peace and desultory warfare, it was unable to supply the needs of large divisions preparing for active service. The native soldiers were almost always left to provide their own carts and bullocks, ${ }^{59}$ and public establishments of coolies and porters were insufficient even for the transportation of provisions and ammunition for campaigns such as those in Nepal, where the difficult ground precluded the use of cattle. Furthermore, the commissariat did not assume even nominal responsibility for the transportation of the baggage of native and European officers. They were required to apply directly to the magistrates for their coolies and hackeries, and were expected to maintain enough bullocks and camels to enable them to move instantly at all times. Few of them did. One major-general of the Bengal army admitted that although an officer was supposed to keep baggage animals, "you never press I ed T him to have them unless he actually requir I ed T them", because they were easily hired. ${ }^{60}$ Even then, another officer affirmed that the Company's were better prepared than King's officers, who "tend Led T not to keep up carriage, which I was T a most expensive article, and rel Iied T on having time to muster animals when orders to march arriv [ $\overline{\text { ed }} \overline{\bar{T}} . "$ " 62 The upshot was, that when orders to march did arrive, no-one was ready, and there was the utmost confusion while officers, men, and commissariat all competed and bargained for animals, coolies, and carts. It was reckoned that, even under normal conditions, detachments of the Bengal army required three weeks to put themselves into motion, 62 and the delay was correspondingly longer when the service, as that in Nepal, demanded 
carriage of an unusual description.

It cannot be denied that part of the blame for the army's dinosaurian ponderousness attached to the Bengal officers' own reluctance to rationalize their habits. They continued to expect to live as luxuriously in the field as in the garrison. One major in the Meerut division of the Nepal force required four camels for his spare liquor alone, "viz: 10 dozen[bottles] of Madiera; as much beer; 6 dozen of port; all the old claret without breaching the new chest that there may be; 2 dozen of brandy; $1 \frac{1}{2}$ of cherry brandy; and half a dozen of French liqueurs." Continuing his letter of instructions to his wife, he added: "a few bottles of sauces, mustard, etc., etc., would also be acceptable. These wants strike me more freshly as I had last night a party of 14 who drank 22 bottles out of my small stock of one liquor or another." This now seems preposterous; but in fact there was a genuine need for enormous quantities of drink, because methods of purifying water were unknown, and drinking wine and beer was the only sure way of avoiding cholera. ${ }^{65}$ Generally speaking extravagance was only half the problem. There were special requirements which the commissariat was incapable of accommodating.

The other main source of supply for the army was the clothing agency - another department which owed its inception to the cause of rationalization, but which was already finding its growth stunted and its efficiency impaired partly by the dead weight of habit, and partly by the inveterate parsimony of the court. The old mode of clothing the army had been to issue contracts to civilian entrepreneurs, who had been paid from the off-reckoning fund. This fund was formed by the stoppages which were made from each soldier's pay. The amount remaining after the contractors' accounts had been settled would be shared among the staff and regimental officers, in amounts varying according to their rank. That the system had led to abuses is readily understandable. The officers had been interested in keeping the cost of contracts as low as possible; and the contractors in their turn had been wont to make up the uniforms as cheaply as they could in order to increase their 
margin of profit. The result had been that when the soldiers received their coats they fitted abominably and were cut so sparingly that they would not meet across the chest and belly, and ended considerably short of the wrist in the sleeves. Contractors had often failed to deliver, and instead of the annual new jerkin to which he had been entitled, the soldier had had to make do with one every two orfhree years. The situation had become particularly deplorable after 1801, when a committee sat at Fort William to devise ways of reducing the price of clothing. Thereafter, entrepreneurs had still remained so anxious to secure contracts and finger the advances, that they took them at quite unrealistic rates. One individual who in his eagerness accepted a contract for three years, had found himself incapable of meeting his obligations, and hadnun away to America with his advances; and later another contractor had had to be released from his bond because of his inability to fulfil its conditions. Others had been ruined by their rashness. Compensation, made available to the troops when they failed to receive the clothing due to them, had been paid out on six occasions between 1801 and 1808. Finally, in 1809, the contract system had been abolished, and the arny's own clothing agencies set up. There had originally been three, administered by a principal Agent and two Deputies, who had each received a fixed salary. But removing the contractors had solved only half the problem. The old method of financing still persisting, the Agents had soon found themselves at loggerheads with the colonels conceming the distribution of the off-reckoning fund. Rather than abolish the whole invidious system whereby the same fund, provided by the troops, was required both to furnish an important emolument of the officers and to pay for the army's uniforms, long term efficiency had been sacrificed as usual on the altar of immediate economy. Compensation for the loss of off-reckonings, in the form of increased pay, being unmentionable even if thinkable, the new system had been modified in order to preserve the old form of perquisite. In 1811 , on the recommendation of the Committee for the Adjustment of off-reckonings, one of the agencies had been abolished,* and for the 
salary attached to the two remaining ones a share of the off-reckoning fund had been substituted, obviously with a view to dissuading the Agents from being too generous when providing for the manufacture of uniforms. Officers' off-reckonings had consequently not been affected by the operation of the agency system, and the uniforms of the men had been but marginally improved, the agency coat having about a sixth more cloth than the contract one. ${ }^{64}$ So the Bengal army remained shoddily dressed. However dashing they might have appeared to the casual glance, closer scrutiny would have shown the sepoys to be cramped in to illfitting coats and tight shorts, which restricted movement so much that it was impossible for them to sit, or stoop to pick anything from the ground, without unbuttoning somewhere. ${ }^{65}$ In 1816 Hastings decided that long pantaloons, must, with a view both to the comfort and the smartness of the troops in the cold weather, be made a permanent part of the Bengal uniform; but in order to preserve the integrity of the off-reckoning surplus the arrangement had to be made whereby they were issued not in addition to the jackets, but in lieu of them every other year. ${ }^{6}$ still in the interest of those who shared the residue of the off-reckoning fund, all articles of dress were made in three sizes only, and fitted to the men as best they could by regimental tailors. It is worth remarking that in the King's regiments virtually every garment was re-made to suit the individual to whom it was issued. The cheap and shab6y turn-out of the Company's Bengal troops was commonly admitted to be the consequence of having the business of clothing administered by those who shared the profits.

Inferior workmanship extended to more vital things than uniforms. Although the Court of Directors would not allow muskets to be made in India, on the ground that neither the timber nor the workmanship was equal to that of Europe, ${ }^{68}$ the small arms which it consigned from home could not be compared to those supplied to the King's army. General Horsford, of the Bengal Artillery, recalled that the locks of the muskets were badly sprung, making the triggers stiff, the aim unsure, and the hammers difficult to re-cock. He considered that the finish of the wood and iron work was inferior. The bayonets he had found too 
short, with points so thickened (for strength and long life) that they would not pierce the quilted jerkins often worn by Indian enemies. Muskets frequently arrived from Europe with flawed barrels and split stocks, and swords with temper so soft that they snapped on trial. 70 A special committee had been appointed to look into the state of the Company's weapons in 1809, but it seems to have contented itself with a perfunctory comparison of the King's and Company's arms in use with the Presidency guard at Fort William. Even so cursory an investigation had confirmed that the locks of the Company's muskets were "rather inferior", but the committee had attributed this to the age of the pieces, finding that those in more recent assignments did not exhibit the same deficiency. They had reported favourably on the general state of the Company's small arms, leading the Commander-in-Chief to conclude that "the arms supplied for the Honourable Company's service appear I ed $T$ to have been much improved of late years, and to be now nearly, if not quite, as good as those supplied for H.M. troops." 72 The state of the weapons received in a consignment from England in 1811 had soon confuted his optimism. The Secretary to the Military Board had reported that numbers of these muskets had injured locks, broken sights, and damaged ramrods. Many of the bayonets were cracked and broken in their weakest parts. The Board had found it impossible to attribute all the damage to the rigours of the journey, because there was no indication that the arms had been inadequately packed; but only guardedly had it dared to hint at "bad workmanship", and to suggest that the arms were "indifferent and liable to injury in a most essential part". It had recalled that the Directors did not take kindly to having bad arms returned, and were extremely sensitive to "animadversions on the conduct of tradesmen under their immediate directions". 72 When giving evidence before the House of Commons in 1832, the Company's Inspector of Military Stores insisted that there was nothing whatever wrong with the muskets provided by Birmingham tradesmen for consignment to India. 73 Such was not the opinion, however, of other witnesses, one of whom (Captain Macon, in the Bengal army since 1806) roundly declared them to be the worst he had ever seen. ${ }^{74}$ In truth, the situation probably was that most of the 
Bengal army was using weapons of indifferent quality made worse by age and shoddy maintenance. In infantry corps, repair of arms was at the discretion of commanding officers, who were supplied with monthly sums for the purpose. As they were allowed to keep any surpluses, it is not really open to question that repair work, when authorised, was of ten carried out with a stricter regard for economy than for efficiency.

In the case of ordnance, the Directors' parsimony had combined with laxity in the upper ranks of the army itself to allow a deterioration in effectiveness. Easy victories had engendered over-confidence, and it had been forgotten that the Company's armies had owed their early triumphs as much to their technology as to their discipline and bravery. Cavalry charges used to be broken with elementary musket vollies; whole battalions had been known to flee before a few well-directed cannon shots. But over the intervening years the standard both of discipline and of scientific expertise in the armies of the native princes had risen. European advisers - usually French or English deserters and adventurers - had become an indispensible part of the military establishment of every ruler with some pretension to importance. The Maratha, Sikh and Gurkha princes had formed forces drilled and armed in close imitation of the English model, and the Company's invincibility could no longer be taken for granted. If its armies were to retain their margins of superiority, they needed to raise their own criteria of efficiency; and this was something which they had failed to do. There was, in the Bengal army especially, a prevailing attitude of swaggering self-confidence; an over-willingness to anticipate victory; and a tendency to preening self-congratulation in advance of the event. The language of the camp knew no reservations, no misgivings regarding the certainty of swift and easy victory. Anyone who voiced a doubt, who counselled caution, was jee red and called a "croaker". ${ }^{76}$ This disposition was especially manifest in the reluctance to make full use of guns, and in the dislike which military men had of being reminded that the English cannon had become proverbial in India. 77 Despite 
the mystique which attached to artillery in the minds of all native soldiers, they preferred to attribute their victories to discipline, valor, and some mysterious innate excellence of the British character. Nevertheless, this disparagement of artillery was undoubtedly also due in some measure to the fact that it was so exasperatingly cumbersome. The guns in the Company's service were generally more accurate and better served than those in the armies of native princes; but they were extremely bothersome. Bengal's establishment of horse artillery was much too small. In 1815 it consisted of one regiment whose total strength was 312 , and the light field pieces or "gallopers" which were attached in pairs to each cavalry regiment. The foot artillery had to rely on teams of bullocks which, although the commissariat had improved their quality, still remained slowand inflexible. They made even light field guns more a hindrance than an aid in the heat of battle, when swift and complex manoeuvring was required. ${ }^{78}$ Elephants, which were also used for the draught of heavy ordnance, were timid and unreliable under fire. They were terrified by the report of small arms, and liable to become unmanageable on difficult or uneven ground. ${ }^{89}$ The poor construction of the gun carriages further complicated the use of artillery. They were of solid teak and sissoo, and had to be made heavier than the gun itself to withstand the repeated shock of recoil. This meant that even a light field piece, a six-pounder, complete with carriage and with ammunition in the $h^{\text {boxes, }}$, weighed about a ton. ${ }^{80}$ The design of the carriages, especially those in use with the six-pounders, and of the ammunition tumbrils, was bad. Nugent had complained that those in use with the horse artillery endangered the drivers and distressed the horses. ${ }^{82}$ Designs do not appear to have been based on standard patterns. One Bengal artillery officer asserted that two guns might be moving side by side in the field without the spare parts of one carriage being able to supply the other. It was often quite impossible to replace wheels and axle trees in cases of accidents. ${ }^{82}$ Until Hastings instituted a transport train, shortly after the Nepal war, native mortar carriages had to be hired for the occasion whenever an expedition was planned. 
These constantly failed under the weight of the pieces, and made them more an impediment than an asset. This circumstance, together with the government's reluctance to make the outlay for expensive shells and platforms, had meant that mortars, which should have been an essential part of any siege train, had seldom been present in sufficient numbers to provide more than a widely spaced, and therefore ineffective, fire of shells.

Scientific knowledge in general, as well as guns in particular, was under-exploited in the Bengal army, because its practitioners laboured under disadvantages accruing from the Directors' stinginess. The engineers were the only officers (besides the artillerists) who were in any sense technical specialists. They were trained with the King's cadets at Woolwich or Chatham, or at the Company's own military seminary at Addiscombe, which had been founded in 1809 primarily for their benefit. These officers were, in the first place, overworked. There were only 31 engineers in the Bengal army at the time of the Nepal war, their number having slightly more than doubled since 1764, while the size of the army itself had more than tripled. One of Hastings' first recommendations on his arrival in India had been that the number of engineers must be increased. ${ }^{84}$ The second disadvantage was releated to the first. Because the corps was so small, the contingent of high ranking officers was minute, and most engineers were only subalterns or captains. It was very rarely indeed that even the chief engineer with a division on service was a field officer. All those with the Nepal divisions were captains. ${ }^{85}$ This was a grave handicap in a service where (as we shall see) commanding officers were invariably old men who, because seniority alone was the qualification for promotion, placed more value on length of service than on expertise and who, because their arrogance had generally increased with theirsenility, felt it intolerably degrading to consult and be guided by officers considerably junior in rank to themselves.

Over-confidence, a shameful inadequacy of artillery, and an impatient disregard of professional guidance had already, by the time of the outhreak of the Nepal war, contributed to cause several costly military failures. The most spectacular had been at Bharatpur, a vast 
fortified town, surrounded by some eight miles of mountainous mud wall, about 100 miles south of Delhi. In 1805 Lord Lake, the Commanderin-Chief, had interrupted his campaign against the Maratha chieftain Holkar in order to attempt to capture this place, because its raja had renounced his allegiance to the British and declared himself an ally of the enemy. Both Lake's force and his ordnance had been absurdly insufficient for the task. He had had less than 8,000 men; and while his heavy artillery had been sufficient to make a breach, his supplementary field pieces and mortars had been far too few to match the artillery which the enemy had been able to bring to bear in their own defence. Yet the premis whence the justification for siege warfare was drawn was that a greater force of artillery can be amassed on the perimeter of the larger than that of the smaller of two/circles. It followed that beseigers could take advantage of their position on segments of the larger circle to destroy the guns of the defenders on the perimeter of the smaller, and thereby enable the processes of breaching and storming to proceed unopposed. Lake's conduct of operations had been marked by precipitation and an aloof refusal to seek the advice of his engineers, the chief of whom was only a lieutenant. As Lake was no engineer himself, the results had been catastrophic. He would not delay to enable the nature of the difficulties to be ascertained, and had harried his engineers with totally unrealistic demands for speed. All the technical operations of the siege had consequently been marred by haste and a disregard for even the most elementary rules of procedure. The wall had been opened three times in different places; but every time, instead of being the final object attained prior to the storm, the breach had been the primary achievement; and, as the mortars and field pieces, firing grape and shells, had been too few and too distant to prevent it being repaired during hours of darkness, pending the completion of other essential measures, on each occasion troops had been sent to the assault before even the most basic preparations and reconnaissance had been carried out. Four attempts had been made to storm the place, and all of them had failed because of these deplorable omissions. Plans to carry Bharatpur by a coup-de-main had finally had to be abandoned, and the 
rebel raja forced into submission by a blockade. The wages of impatience, arrogance, and rashness had been heavy: two and a half thousand men wounded, nearly $450 \mathrm{killed}$, and a severely impaired reputation. ${ }^{88}$

Insofar as the Bengal army had taken the field at all during the period between the end of the Maratha and the beginning of the Nepal war, it had been employed in desultory siege warfare against the strongholds of various recusant zemindars in Bandelkhand, the tract on the southern bank of the Jumna river retained as part of the Bengal Presidency after the peace of 1806. Most of these feudeal fortresses had been stormed successfully; but on three occasions, at Badekh, Komona, and Kalinjar, the mortifying experience of the failures at Bharatpur had been echoed. Each repulse had been on too small a scale to cause great disquiet; and as each had been followed by the surrender of the besieged, on all three occasions the reassuring conclusion had been drawn that the assaults had not so much failed as had a delayed effect. Taken together, however, they constituted an ominous indication that the mode of conducting sieges had been making freakish not defeat, but victory. On each occasion, as at Bharatpur, there had been a proneness to pin hopes less on guns than on men; an eagemess to hurl forward troops to accomplish what the engineers had scarcely prepared for. Kalinjar was a fort on the top of a monumental rock, and in order to gain the breach, the storming party had found themselves required to scale first a perpendicular rock face about twenty feet high, and then thirtyfeet of broken wall. Ladders had been used to climb the rock, but as the men clung to the wall, where ladders could not be placed, fumbling for crevices and projections to gain a footing, they had been flicked off like insects by boulders and shot from above. Only one or two had reached the breach. The survivors had bitterly declared, what should have been obvious without the expensive trial of experience, that such a fort could never be taken; and a later observer, himself a military man, was astonished that it had ever been possible for any of them to climb as far as the breach. "To us", he 
wrote, "who journeyed for amusement up its stupendous sides, the ascent was most difficult and by the time we had gained the summit we were exhausted." 88 The King's 53rd Regiment, now part of the Nepal force had provided the storming party, and had had 14 men killed and 128 wounded in this foolish enterprise. / But perhaps the most baneful consequences of cut-price rationalization were the corrosion of morale and the heightened sense of grievance which it had caused in the officer corps. $\longleftarrow$ - In response to the changing climate of opinion, Indian officers had been given new standards of respectability to observe. The impeachment and trial of Warren Hastings for corruption and oppression, on his return to England in 1788 , had signalled a change in the public attitude towards the government of India. A new solicitude for responsibility, for regularity, and, with the evangelical revival, for Christian propriety, had been evolving, which soon made its influence felt in measures designed to improve the tone and rationalize the position of the East India Company's agents. In the early years, the Company's military, like its civil servants, had been but lightly shackled by codes and rules. They had lived and worked in the wide and convenient penumbra which, in those days of casually focussed moral concepts, had separated probity from corruption, deriving their remuneration more from a process known as "shaking the pagoda tree" than from prescribed salaries and allowances. Commanding officers had been minor despots, dressing and administering their regiments very much as they pleased, and working in close collaboration with their native officers, with whom they shared the irregular perquisites of power. 80 But the new pressures had wrought changes. Officer entry into the army, for a start, had become regularized; and the old-style "country" cadets, who used to come out to India in some civil guise and wheedle their way to commissions after their arrival, had become extinct. Since about 1786 it had been essential for candidates to secure their commissions from the Directors in London, and cadetships in the Company's service had come to be regarded as respectable provisions for younger sons. 90 Regiments had been numbered; uniforms standardized; and regulations drafted to cover almost every aspect of military 
administration, making the army less the expression of the fancies and partialities of its officers and more an institution in itself. A series of measures culminating in the major re-organization of 1796 had been implemented with a view to defining the position of the officers and making them the servants instead of virtually the masters of the army. Salaries and allowances had been prescribed to take the place of illicit gains - such as those secured by faking payrolls - and old-style emoluments such as the bazaar duty.* Furlough arrangements had been introduced in order to strengthen their ties with home and discourage the notion of settlement in India, and pensions provided that they might be freed from the necessity of making private fortunes. To protect officers from abuses of patronage, it had been decreed that promotion was to be strictly by seniority: up to the rank of major in the regiments, and thereafter in a single line. To prevent invidious supersessions, the practice of buying and selling commissions, which prevailed in the King's army, had been forbidden. 91 Much more emphasis had lately been placed on seniority in the promotion of native officers;* especially in the commissioned ranks. 92

Although the European officers had themselves been among the most strenuous advocates of regularizing their position by such expedients as seniority promotion, paid leave, and retirement pensions, it had not been long before they felt that they had made a bad bargain in surrendering their old advantages in exchange The Court of Directors was willing enough to admit the principle of rationalization in the officer corps; but, as in other sections of the army, was not so willing to provide the money necessary to implement the principle effectively. Niggardliness in London had precluded the successful operation of the new regulations from the outset. The scale of pay and allowances had been

"A duty levied on liquor, tobacco, and drugs, which had been a perquisite of commanding officers.

**Native ranks were: naik (corporal); havildar (sergeant); jemadar (3rd commissioned rank); subadar (2nd commissioned rank); and (after 1814) subadar-major (lst commissioned rank). 
pitched too low for the minimum rates to have any realistic relation to the costs actually incurred by young officers. In Bengal, where caste-consciousness was strong, Europeans could not avoid comparatively heavy domestic expenses. Each servant's caste closely limited his function, and large establishments, if extravagant, were therefore ineluctably so. ${ }^{9}$ The cost of military equipment was very high, and almost always beyond the means of newly-commissioned officers. ${ }^{4}$ Most subalterns were consequently forced to borrow money - at rates of interest of up to $24 \%$ if from native usurers - and remained burdened with debt until well into their careers. ${ }^{95}$ It was very rarely that an officer was able to save money before he attained the rank of major; ${ }^{96}$ so although they were now allowed three years' furlough after ten years' service, most officers found that it was not until they had been in the army for 30 years that they could muster the enormous sum required for the passage home. It is a fact that officers were comparatively fortunate if they could contemplate taking their leave after a period of service whichwas supposed to qualify them for a pension. 97 An officer was permitted to retire on the basic pay of his rank after 22 years' actual service; but promotion was so agonizingly slow that he could only expect to be a captain at the most after that time, and certainly in no position to think of retiring. The Court's parsimony was throwing out of gear the whole mechanism of seniority promotion, which could work effectively only if officens had sufficient inducement to retire on reaching age. But retirement was something which few Indian officers, however high their positions, were willing to consider. Aged general and senior field officers clung to service, often long after they had ceased to be fit for command, blocking the channels of promotion to those waiting in the lower ranks. Although 25 years (including three years' furlough) was considered to be the maximum period of effective service, most officers served double that time before they reached the rank of major-general. 98 The general stagnation raised the age and depressed the quality even of lieutenant-colonels and majors to an appalling degree. When Nugent inspected the Bengal army in 1812, he 
had found two infantry lieutenant-colonels who were demonstrably senile, and had had to remove them to the invalid establishment. No less than 15 lieutenant-colonels and majors had appeared "altogether incapable, from age and increasing infirmity, of performing the duties expected of them", but these he had forborne to remove, both from fear of increasing the expense of the invalid establishment, and from reluctance to offend the old officers, "whom an indulgent but pernicious usage I had T hitherto suffered to remain unnoticed in the effective ranks of the army." 291 So they had been left to moulder on, decaying on the job and unable to afford to retire, but deriving solace, no doubt, from the knowledge that every year of mounting decrepitude improved their chances of promotion and increased their qualifications for the pay and responsibility of high command. Death and subsidised retirement were virtually the only modes of egress from the army. The latter was made possible by the merciful fact that the prohibition on the sale of commissions was not rigorously enforced. It was the custom for the junior officers of a regiment to subscribe sums of money to time-expired senior officers to induce them to retire. ${ }^{10}$ But the method could relieve a corps of one or two officers every year at the most, and did little to accelerate promotion. When it was decided, in 1816, to grant the brevet rank of captain to lieutenants of 15 or more years' standing, no less than 59 subalterns qualified for the award, of whom 52 had served 16 years or more. One had been in the army for 19 years. ${ }^{102}$ It must still have taken them several years to qualify for the pay and allowances of their new rank, because on an average it took 23 years to proceed from the rank of cornet or ensign to that of captain; 8 years from captain to major; 6 years from major to lieutenant-colonel; and a further 12 years to full colonel. ${ }^{102}$ Until 1808 cadets had been commissioned at the age of 15 , so in 1814 most of the Bengal army's general officers were in their middle sixties - and this in a climate where Sir Henry Lawrence asserted that Europeans were "old men at forty". 103

Small wonder that the enthusiasm of most young officers soon 
gave way to apathy and despair. It was not long before they were made to realize that they had as good as sold themselves into bondage. For the vast majority a career in the Company's military service meant exile for life. Out of every 100 who went to India, about 40 actually survived 22 years' service, but only six ever returned home to enjoy their pensions. ${ }^{104}$ It was an exile made all the more insupportable by the refusal of the new public opinion to sanction anodyne for even its harshest agonies. Intolerance of the Englishman who tried to reconcile himself to expatriation by seeking a new identity in an Indian way of life was mounting. Lady Nugent had not been able to disguise her disapproval when she met the two young Assistants at the Delhi Residency, Fraser and Edward Gardner (brother of William), because neither shaved (whiskers were an exclusively Indian habit at that time) and both were vegetarian. ${ }^{105}$ Such eccentricities were increasingly rare in the army, and where they did persist were the objects of censure or derision. There was on the Bengal establishment in 1814 a major-general called Charles Stuart, who was known as "Hindu Stuart" because of the enthusiasm with which he studied the languages, manners and customs of north India. A contemporary in the King's army, who published his impressions of a tour of India in the early 1820's, was revolted by such extraordinary habits, and he energetically stigmatized Stuart for adopting them:

"He is not treated as a madman, but would not, perhaps, be misplaced if he had his idols, fakirs, bedas, and shasters in some comer of Bedlam, removed from its more rational and unfortunate inmates."108

Every obstacle was put in the way of officers' strengthening their ties with India. They were not allowed to buy land, and marriage with Indian women was a fact of life whose existence wassimply not acknowledged. Military, like civil servants, who did seek consolation in such liaisons (and they were in the majority) had to endure the unhappiness of seeing their wives and children the objects of a cruel proscription. Native women were ostracized by European society; and the position of Anglo-Indians, or half-castes, was miserable in the extreme. They were barred from Company employment, and denied most 
forms of legal and social recognition. ${ }^{10}$ Many officers spent their lives in a vain attempt to come to terms with the void in which they moved. Denied the right to make themselves Indian, they strove to believe in the simulcra of an English way of life. For an hour or two in the half-light, at the beginning and end of each day, existence became a ritualistic mimicry of one nostalgically recalled. Had that hypothetical observer, images of European graces and pleasures still vivid inhis mind, gone to a social gathering at calcutta or one of the large up-country military stations, real India would have seemed like the dark side of a two-way mirror, invisible behind the reflected brilliance of his memories: memories of Waverley novels; amateur theatricals; backgammon; chess; billiards; breakfast and dinner parties; evening clothes; balls; carriages and grooms; military bands on lawns. But come the day, and the blinding sun would have reversed the balance between light and dark. The dim side of the mirror would have blazed into light, overwhelming the pale glow of his remembrances of home, which in their turn would have faded into darkness and obscurity. Now he would have seen through the glass, and observed the illuminated realities of Indian life. Most saddening of all would have been the spectacle of the Company's military officers. They were exiles abandoned by the past, unreconciled to the present, and aimless for the future; withered by the heat, the dust and the disease; and oppressed by the languor, the pungent smells, and the alien, brazen beauty, of a land that was never purged by frost. They seldom enjoyed even the community of a regimental mess, for such establishments were made impracticable by the dispersed state of corps, and by the absence of most of the few senior officers on staff or political appointments. ${ }^{108}$ Each individual was left to pursue his own monotonous and solitary existence, with few prospects of fortune as consolation for the anguish of nostalgia; and few hopes of comfortable retirement as recompense for the sacrifice of youth.

The Court of Directors, ever seeking ways to economize, had little sympathy for pleas of hardship. It impatiently brushed aside 
the argument that it was impossible for a subaltern to avoid incurring debt, affecting to believe that this was but a false generalisation, based on the extravagance and improvidence of a few. ${ }^{109}$ Already, by the time of the Nepal war, it had drawn up a revised scale of allowances, which would reduce officers at certain stations to half batta (allowance) and abolish most of the perquisites remaining to commanding officers. 110 Not for the first time, the Bengal officers embarked on a long and acrimonious wrangle with their employers, contesting every clause of the new plan in language of unmeasured contumacy. 112 They had reacted in the same way to the regulations promulgated in 1796 , so perturbing the Governor General of the time, Sir John Shore, that he had modified the plan in accordance withtheir protests. In a pique, the court had dismissed him; but had nevertheless been constrained to accept his alterations. 112 Encouraged by the success of their recalcitrance, officers had treated the new regulations with contemptuous disregard. Commanding officers had apparently continued to levy contributions on bazaar liquor and tobacco, despite the new regulation against the practice, for in 1811 the Commander in Chief, Hewitt, had found it necessary to publish an order reiterating the prohibition. ${ }^{113}$ In a private letter to his successor, Nugent, he had expressed the belief that misconduct in this respect had been widespread, and had confessed that he ought to have had one commanding officer at least arrested for the insubordinate tone of his objections to the new order. ${ }^{114}$ Studied defiance and organised protest were becoming part of the way of life of the Bengal officer; and, as one witness remarked before the House of Commons in 1832, "where officers of an army meet, form committees, appoint delegates, subscribe funds, talk of 'rights infringed', 'compacts broken', 'bad faith' of their rulers ... it is idle to talk of military subordination."116 The exasperation of the officers of the Madras army had already simmered to the point of mutiny when, in 1809, they had felt that they were being petulantly victimised by the civil authorities for having objected to various measures of military retrenchment; ${ }^{116}$ and it is possible that a similar trauma would now have convulsed the 
Bengal army, had the latest plan for reductions not been published at a time when the officers' energies were absorbed by the struggle against Nepal, and had Hastings not postponed its implementation and submitted it to an officers' committee for consideration. But on this occasion the effect of resistance was more to delay than modify the scheme, which the Court was obviously determined not to be brow-beaten into abandoning; and its final application in 1828 was to be the signal for a fresh upsurge of virulent indignation. 118

The sense of abandonment and acute despair which was manifest as acerbity and insubordination in times of peace, might take the form of lethargic indifference when the prospect of active service arose. Joseph O'Halloran was a talented and popular officer in the infantry, ${ }^{118}$ and he had completed 34 years' service by 1814. Yet he was still a major, and only 20th in the line of succession to a lieutenant-colonelcy. It was difficult for him to feel much enthusiasm for the pending campaign. He wrote to a friend: "I expect, in a few days, the command of a battalion ... to join the expedition against Nepal - a point about which I am perfectly indifferent, for my zeal has subsided into sullen apathy, from the disappointment of my hopes." 129 Others turned to drink, to gambling, to beating the Indians, and to insulting and fighting each other. Plunged as they were, without preparation or training, into the tense and alien atmosphere of Indian military stations at the age of 17 , 16 or even 15, and allowed responsibility and freedom when they most needed formative discipline and guidance, it is not surprising that many officers throughout their lives showed signs of arrested psychological development. Some never outgrew the adolescent's association of virility with depravity, and gambled, drank, or duelled their way pathetically to disgrace and death. In existences with long periods empty of distraction interest, the most trivial incidents were inflated into dramas, the slightest feelings of irritation were fostered into false rages. Life became a grotesque masquerade of simulated outrage, swaggering defiance, and exaggerated bravado. Animosities were deliberately cultivated to leaven the dead weight of ennui, and fill 
out the vacant hours. Almost all officers, even the most cautious and best tempered, received challenges to duels at some time in their careers, which it was better for them to quit the army than refuse. Many sudden deaths were ascribed to cholera which in fact had less natural causes. 120

Most competent officers found a refuge from regimental life, and a means of adding to their pay, in extra-regimental appointments; and the corps were being drained of their best talent by the growth of the general staff, by the increase in the number of local and provincial battalions, and by the practice of employing military men in political capacities..$^{122}$ Nugent. claimed that an establishment which assigned the same number of officers (45) to an infantry regiment of two battalions as was allowed to a single-battalion regiment in the King's army was even in theory too low. ${ }^{122}$ reckoned that every infantry company and cavalry troop should have a captain at its head, as in Europe; instead of which the ratio in the Bengal army was only three captains to a cavalry regiment of six troops, and four to an infantry battalion of ten companies. ${ }^{12}$ Even this low complement was never full. It was not unusual for more than half of a regiment's lieutenants and captains to be absent on local leave, extra-regimental duty, or sick pay, at the same time. ${ }^{124}$ The reorganization of 1796 had fixed the proportion of just over two European commissioned officers to every hundred men in the native infantry regiments. It was calculated that during the Nepal war the ratio stood in practice at one to a hundred. ${ }^{125}$ This attenuation was all the more permicious because the officers who were left in the regiments were generally the least able, the most inexperienced, and the most discontented. The contrast between the brightest and the dimmest intelligencies in a body of officers was extreme, as must be the case with any group whose unity derives less from common professional aptitude than from similar social background; ${ }^{126}$ and the residue remaining with the regiments after officers had been filtered off for other appointments was liable to contain only the dregs of the commissioned ranks. The consequence was a worsening 
deterioration in the relationship between regimental officers and their men. It was becoming very unusual for any of the former to take personal interest in the welfare of the native soldiers, and most had great difficulty in communicating with them even on parade. None was required, and few bothered, to have knowledge of the native languages. The adjutant of a regiment was supposed to act as interpreter, but even he was not required, at this stage, to undergo an examination to test his linguistic capability. ${ }^{12}$ He generally knew enough Urdu to read orders and translate commands; but as his pronunciation was often bad, and as most sepoys knew Urdu only as a second language themselves, he was hardly a medium by which the officers could know their men or the men their officers. ${ }^{128}$ The regiment was in fact ceasing to have any real significance as a cadre. The junior Europeans were frustrated, indifferent, prefectorial, and incomplete in numbers; while the seniors were mere birds of passage, whose names happened to alight on the paper strength of a regiment only because it offered the vacant rank to which they were entitled.

The essence of the tragedy of the Bengal army is that this deterioration in the quality of its regimental officers happened at a time when other processes were affecting the discipline of the native ranks, and making it imperative to improve that quality. While the administration of the army was being rationalized, the attitude of the mass of the native soldiery was being altered by contrary influences. There is considerable evidence which suggests that the sepoys were becoming more self-conscious about the rules and tenets of their castes, less flexible, and less amenable to even the basic requirements of a European military system.

The East India Company had always preferred to recruit for the Bengal army from among the brahmins and ksatriyas, the highest of the four groups into which the multiplicity of castes in Hindu society is divided; and in particular from among the brahmins and ksatriyas of Bihar and Oudh. Bihar was a province of the Company, and Oudh a protectorate; and in enlisting high caste Hindus whose families comprised the majority of landowners in these territories, the Company was pursuing 
the ideal of a 'yeoman' army whose members would have a personal interest in the preservation of the government they served. ${ }^{129}$

High caste Hindus from these provinces also had the advantages of imposing physique, a keen sense of martial honour, and a sober and tractable disposition. ${ }^{130}$ By 1814 they constituted a large majority of the Bengal sepoys. ${ }^{132}$ Muslims were extremely few in infantry regiments, but tended to predominate in the artillery and cavalry. ${ }^{132}$ As a result of the recruiting techniques of commanding officers, infantry companies were even more homogeneous than the larger divisions. Battalions were usually raised at once in a single area, and when additions were required for the component companies* the sepoys' relatives present at headquarters were generally enlisted. Otherwise, when he wanted a few men, the company commander would tell the sepoys about to go home on furlough to bring back their relations. In May, 1814, Lieutenant Thomas Thackeray, commanding a company of the 2nd Battalion, 26th Native Infantry, had written an interesting letter to his brother, describing both the consequences and the purpose of this type of recruitment:

"I am at great pains to fill up the vacancies which occur in my company by brothers of the best sepoys, and seldom entertain a recruit who is not in some way related to a man already in the company. I have succeeded so well that I have now four full brothers of one family, three of another, and out of ninety men I have not twenty who are not connected, either by consanguity or marriage, with some of their comrades. Men naturally become attached to the service in which they have so many ties".133

The infantry company was therefore developing a double identity: on the one hand it was acquiring new significance as a unit in an institutionalized army (for the forces tended to be distributed in companies rather than in battalions); and on the other, it was developing into something of an institution in itself. The gravity of the situation

*

There were 10 companies in a battalion. 
lay in the fact that the two identities were the results of virtually contradictory processes. The self-perpetuating groups which the infantry companies were becoming were far from being moulded by the rationalization which was being applied to the army as a whole. They were defined by caste regulations and a system of social precedence which were the very negation of the military concepts of rational distribution of labour and the determination of hierachy by rank. A moral dilemma was coming to dominate the native soldier's existence. Military duty and ethical obligation were mutually exclusive and competing for his loyalty. The one demanded compliance with the exigencies of the service and deference to its system of rank; the other forbad travel by sea and the performance of manual labour, and required lower caste native officers to bow in submission to brahmin privates. All the while the advantages of this type of recruitment were considered to outweigh its disadvantages, the predicament was bound to exist, because the sepoys became more self-conscious about their standards of conformity as their companies developed into coteries of their own neighbours and relatives. The crucial problem was how to prevent the Hindu, irrational, personality of the infantry corps from subverting their rational, military one. It was a case of schizophrenia which only two therapies could cure: one was tightening the attachment of the sepoys to their European officers; and the other making battalions and companies more heterogeneous by recruiting from among a more diversified selection of tribes and religious groups.

Rationalization was by its very nature making it increasingly difficult for the first cure to operate. It deprived commanding officers of their old instruments of influence. From princely dispensers of patronage and favour, objects of veneration and propitiation, they had been reduced to mere overseers, enforcers of written regulations. One measure had been particularly derogatory to their ascendency. This was the removal of their power to secure precedence for litigation preferred by their sepoys in the civil courts. Until 1805, a commanding officer had been permitted to address judges on behalf of his men, and 
this enabledthe latter to bypass the cumbersome formalities of the legal machinery and secure swift attention for their suits. The privilege was abolished in 1804 for sepoys residing in the Company's own territories, and in 1815 for those hailing from oudh. The channels of justice were so cluttered, and so jealously guarded by obstructive native acolytes, that now that sepoys had to pursue their claims in the normal way even the most indulgent furlough was insufficient to complete a process. With this dispensation had been removed not only a principal reason for sepoys' deference towards their commanding officers, but one of the fundamental attractions of service with the Company. Landowners large and small had made it a policy to have one son at least in the army precisely as a means of securing this benefit; ${ }^{13 /}$ and it had undoubtedly been a greater incentive to enlistment than a monthly wage of seven rupees (about 14/-) which had been fixed in 1779 and not thereafter significantly altered despite the steady rise in the cost of living, ${ }^{135}$ and a pension which, though available after 15 years' service, was not adequate to live on until 30 or 40 had been completed. ${ }^{13 t}$ This transformation of the powers and status of commanding officers had been bound to produce an introspective tendency among the body of sepoys: a relapse into the more instinctive and less materially inspired sense of attachment to their social and religious leaders. To arrest this process precisely those qualities were needed in the generality of regimental officers which the parsimony of the Court was making impossible. If regimental duties had been made the most instead of the least rewarding aspect of service with the Company; if the best instead of the worst officers had stayed to lead and be in daily contact with the men, the situation might have been retrieved. The conduct of the British Indian armies, more perhaps than that of any others in modern history, was a reflection of the quality of $i$ ts regimental officers. The Hindu soldier, though proud, was most content to manifest his pride in steadfast loyalty to the officer who had won his respect and affection. When serving under such men, sepoys of the Bengal army could be devoted, brave, and eager to a degree incompatible with caste 
conformity. That their behaviour varied according to the quality of their officers is demonstrated by the very unpredictability of their reactions when required to embark for foreign service. On several occasions they had been successfully prevailed upon to undergo sea journeys - to Madras in 1758 and 1768; to Sumatra in 1789 and 1791 which were not only theoretically tabu for Hindus of caste, but revolting physical experiences as well. At other times, certain groups had refused, Between 1782 and 1784, four regiments had had to be disbanded for unsoldierlike conduct when required to embark for Madras; the army had been purged of another battalion for a similar reason in 1795; and in 1824 a regiment mutinied when required to embark for service in Burma. It is significant that the court of enquiry set up to probe the last affair censured the lieutenant-colonel commanding. "He had not the art of gaining esteem, but seemed to have an unhappy factious disposition. On parade he managed ill, got angry, andharassed the men by continually doing the same thing .... and by keeping the corps out unusually long in hot weather." $13 \$$ / The regiments now needed qualities of leadership which were far in advance of those which the average regimental officer could provide. They needed men sympathetic and imaginative enough to manipulate simultaneously the two forms of organization - Hinduism on the one hand, the European military form of embodiment on the other which the army paradoxically represented; who had sufficient skill and knowledge to cause them to mesh and work together as a single entity. Very few officers ever evinced such understanding, mainly because they lacked even basic knowledge about the men with whom they were dealing. It is not that it was omitted to impress officers that they should respect the "prejudices" of the natives. On the contrary, the injunction was reiterated with tireless insistence. It seems to have found its way into every order, every despatch, every commentary, in one form or another. Apparently, what nobody realized was that in order to respect prejudices, it is necessary to know exactly what they are. Cadets were given no formal instruction whatever in the history, culture, or religions, and only the most cursory in the languages, of India, before 
being posted to their regiments. The subjects with which they were expected to have some acquaintance were mathematics, science, classics, topographical drawing, chemistry, swordsmanship, and French. Hindustani (Urdu) was on the curriculum at Addiscombe, but instruction was woefully inadequate, and it was almost unknown for a cadet to be able to express himself intelligibly to his servants on arrival. ${ }^{138}$ The experiment had been briefly tried of giving cadets language training on their arrival in India. A college had been operative for the purpose at Baraset, just outside Calcutta, for seven years.* But the place had been in a state of continuous riot, and had had to be closed for lack of order and discipline. ${ }^{139}$ So ensigns and cornets were now again sent straight to their regiments, with the vague hope that they would somehow acquire essential knowledge on the job. Yet even when with his regiment, there was little in the duties of an officer which made familiarity with the habits and language of the sepoys either imperitive or convenient. Courts martial for sepoys were composed of native commissioned officers, and the main body of Europeans took no part in the trials, which must have been one of the best sources of instruction about the lives, habits and language of the men. ${ }^{140}$ It was easy for the regimental officer to continue to make the same mistakes, to go through his career without accumulating enough knowledge and experience to serve him as a criterion for his own conduct. Those officers who did, from natural curiosity or concern, acquire such knowledge, soon found the opportunity to take off their skills to staff or political appointments. In most cases, the very fact of an officer's having remained long with his regiment was an indication of his deficiency in the sort of aptitude which that regiment most needed. Sir John Kaye, in his History of the Mutiny of 1857, wrote of regimental officers as "men who could scarcely call for a glass of water in the language of

*1802-11, with a break during the Maratha war. 
the country, or define the difference between a Hindu and a IMuslim T."141 They were frustrated, bored and bewildered, and often added unpopularity to their incompetence by affecting to despise the Hindu "prejudices" which in reality they did not understand.

The regimental officer had been the talisman of his sepoys, the receptacle of their loyalty, and their link with authority. His eclipse had left a gap which not only insulated them from the object of their allegiance, but also encouraged private fantasy, speculation, and fear. The sepoys had no sense of devotion to the Company itself, whose nature was too abstract and foreign for them to grasp (though they had at one time endowed it with the personality of an old woman), and their fidelity, in their new isolation, depended increasingly on the satisfaction of their superstitions, on the favourable augury of success, and on cabalistic assurances of the continuing benevolence of fortune (ikbal) 142 The native commissioned officers were not in a position to compensate for the deterioration in the number and quality of European regimental officers. They are curiously shadowy figures in the history of the Indian armies before 1857, because they were denied opportunity to assert themselves. The senior ones were liable to be commanded by the greenest boy subaltern, and it was never even made clear that they had authority over the two European serjeants attached to each native battalion. ${ }^{145}$ With the increase in the number of European officers their opportunities for important independent command had almost vanished; and they found themselves unqualified for staff positions which, in an increasingly institutionalized army, demanded high standards of literacy. Some European officers scomed them as clumsy and uneducated, and it appears that far less courtesy was now shown them than had been the case in the old days. 144 If they were no longer received into officer society, neither were they accepted by the sepoys as being truly in the interests of the men, and consequently in any crisis in the relationship between officers and soldiers, they merely stood aside, and had little part. ${ }^{145}$ The most serious indication that the medium of communication between authority and the ranks was collapsing had occurred not in Bengal, but in Madras. Here, in 1806, attempts to introduce innovations in 
dress and discipline (all in the cause of rationalization) had engendered a panic of fear and resistance. The new Commander in Chief, Sir John cradock, had ordered that whiskers were to be trimmed in a uniform manner; that a leather cap was to be substituted for the turban; that caste marks were not to beworn on parade; that sepoys on guard duty should meven answer the calls of nature in a military fashion, by waiting until enough men were in the same condition and then being marched down in a party - and so on. ${ }^{146}$ The policy had been silly and unnecessary, but hardly exceptional in a military context. In some regiments the new regulations had been enforced without trouble, ${ }^{14 \%}$ but in the garrison at Vellore they had led to open mutiny. More than anything else, the rebellion had been a symptom of the morbid incompetence of officers at regimental level; and it was afterwards suggested that had they been able to communicate with the men in their own language, the innovations would have caused no trouble. Without the necessary assurances from their officers, the sepoys had been bewildered and alarmed by regulations whose purpose they did not understand, a prey to agitators who disseminated the idea that they were part of some sinister plan to enforce mass conversion to Christianity; and the officers, at first unable to communicate and now themselves unable to understand, had succumbed in their turn to exaggerated apprehension and vicious reprisal. 148

The dangers inherent in the practice of restricting recruitment to the high caste Hindus of Bihar and Oudh were not appreciated until it was too late to make changes. It appears that with the decline in the influence and capability of commanding officers, control over recruitment passed out of their hands. When, several years after the Nepal war, the experiment was tried of mixing other groups into the infantry regiments (chiefly Sikhs) the Oudh and Bihar men refused to accept them, and bullied them out of the army. ${ }^{159}$ Bishop Heber mentions the case of a naik who was removed from the army by the government because he had become a Christian. $15 \mathrm{D}$ There seems to be good ground for suggesting that the almost pathological fear of offending native 'prejudices' which prevailed in high quarters after the Vellore mutiny combined with the general ignorance among regimental officers of the exact nature of those 
prejudices to undermine the whole reality of European authority. More than one commentator of the first half of the nineteenth century insinuated that the superficial amenability of the Hindu sepoy was disguising the fact that control not only over recruitment, but also over a much wider aspect of the army's functioning, had ceased to be vested in its nominal masters; and it was complained that many indulgences were allowed the sepoys on the justification of caste precept which in reality had no such sanction. "We should respect their casts", declared one critic in 1821, "but not descend with them to the indulgence of mere childishness - of things not meant or demanded by their faith, but assumed and imposed on our weakness and mistaken liberality."151 "The assumptions of vanity and laziness are too extensively admitted in the Bengal army", wrote another, the following year. ${ }^{152}$ When giving evidence before the House of Commons in 1832, Captain Macon claimed that "the most trifling alteration in dress I was_T frequently made an excuse for discontent, and I that_ T this I was_T artfully worked on by the natives of caste, such as the Brahmins or priests". ${ }^{15}$ Even Sir Henry Lawrence admitted that the ordinary sepoy was "pampered and petted". 154

By trying to treat the rationalization of the Bengal army as the justification for immediate economies instead of the means to long term ones, the Court of Directors had brought that army into what can only be described as a state of arrested transformation. Rationalization had been allowed in principle; had even begun to be applied; but had then found itself stale-mated by parsimony. The financial means and the local initiative necessary to bring it to completion were being denied. In 1814 the tragic paradox which was the gravest result of such myopic policy was already apparent. The quality of regimental officers was becoming seriously impaired by the gruding manner in which rationalization was being applied; yet it was only by means of superior officers at this level that the process itself could hope to be successful. Regimental officers were the only agency which could give meaning, in the eyes of the sepoys, to the injunctions of anonymous authority: they were the nerves essential to interpret the European mind of the army to its Asiatic body . 
Chapter Four

152

As the army marched to war along the highroads leading north to Nepal on those November mornings in 1814, there was little, perhaps, to show that it was tired, demoralized, poorly clothed, indifferently armed and inadequately administered; that the officers with the men were too few and too incompetent, in high command too old, in general too disdainful of native en pies and too preoccupied with grievances, jealousies, and heartache; but it is essential to know that such were its deficiencies. Only if they are borne in mind; and only if it is remembered that the Nepalese expedition was the first major trial for the new-style, quasirationalized, Bengal army, can the strengths as well as the failings revealed by the probation of the war have any meaning. 


\section{Chapter Five \\ Preparations for War}

Hastings' plan for the invasion of Nepal was bold and unorthodox, and he was proud of it. He had had to devise a strategy which took account of the limited time at the disposal of an army based on the plains. He could not send an army across the Tarai until late October at the earliest, and it would have to be back in India by the beginning of the following April. After that time, malaria raged in the lowland jungles and marshes, cutting communications; and to leave a force stranded in the hills, unsupplied, unsupported, and surrounded by hostile guerilla forces, would be to invite catastrophe. The objects of the invasion must therefore be accomplished within the short period of five or at the most, six months. This being the case, both a conventional assault on the enemy capital, and a Napoleonic-style attack on the enemy's field army (leaving their capital as a secondary objective, to succumb more easily or even spontaneously later) $)^{l}$ were out of the question. Hastings reckoned that their mobility, and the ruggedness of the terrain, would enable the Gurkhas to avoid the decisive battle on which a single concentrated attack would rely for its success. Instead, therefore, of choosing between attacking the enemy capital and the enemy field army, he had determined to divide his resources and launch independent but simultaneous attacks against them both. He was confident that the country could thereby be wrested piecemeal from the Gurkhas within the space of a single campaign. The strategy of division would, besides invalidating advantages which would normally enable the enemy to prolong resistance, considerably simplify the manipulation of the offensive forces. It was known that valleys in the mountains were barren, and often too narrow to accommodate a thousand men in a line. ${ }^{2}$ By dividing the army problems of logistics would be minimized, and increased rapidity of advance assured.

Extending the principle of diffusion even further, Hastings decided that each of his two objectives - the Gurkha field army under Amar Singh Thapa and the Gurkha capital, Kathmandu - should be attacked not by a single force, but by two cooperating columns advancing 
simultaneously. This would prevent the blurring of the two areas of operation, by pinning down and keeping separate the respective victims of the invasion. He reasoned that if the advance on Amar Singh Thapa were supplemented by a column on its right, which could occupy the Dehra and Kayarda Duns and block the ghats across the Ganges and Jumna rivers, the field army would be prevented both from retreating towards the capital and from receiving reinforcements from it; while, if the main column advancing on Kathmandu were supported by a thrust on its left, this would bar the way to and from the west, making it impossible for the army in the capital to withdraw into the impenetrable hills of the Gurkha region or receive assistance from the field army or Palpa. ${ }^{3}$ The dispersal of troops for the purpose of mountain war had a respectable precedent, for Napoleon had used just such a strategy when crossing the Alps in 1800 . He had acted on the principle, equally valid in Nepal, that a multi-faceted advance was more likely to confuse the enemy, for when the heads of several columns appear, each on a narrow front, he cannot know which covers the main body. ${ }^{4}$

Hastings selected the river Kali as the line dividing the eastern from the western theatre of war. In the eastern theatre, two columns were to march into the hills. The principal column of six and a half thousand men was to be commanded by Major-General Bennet Marley. His base and rendez-vous was to be Dinapur, and his assignment the capture of the hill fort of Makwanpur, just south of the capital, and of Kathmandu itself. On Marley's left, a much smaller force, comprising somewhat less than 4,000 men, was to advance under Major-General John Sullivan Wood from Gorakhpur and occupy the disputed frontier lands in Siuraj and Butwal. The immediate aim of this force was to create a diversion in favour of the Kathmandu column, but it was to extend its operations as far as circumstances would permit towards the capture of General Amar Thapa's headquarters at Tansen, the occupation of the town of Palpa, and the severing of the lines of communication between Kathmandu and the west. In the western theatre, two forces were to converge on Amar Singh Thapa. The right hand column, under Major-General Rollo Gillespie, 
consisting of about four and a half thousand regulars, was to move from Saharanpur into Dehra Dun and Kayarda Dun, occupy these valleys and the ghats on the Ganges and Jumna, and then veer left to support the activities of the second or left hand column. This was to be under the command of Ochterlony, now promoted Major-General. He was given 6,000 men, and required to push forward from Rupar on the Sutlaj against the main army of Amar Singh Thapa. Once the two columns had coalesced, Gillespie was to assume the overall command. ${ }^{5}$

That, basically, was the plan. It involved the use of four columns of infantry, each organized as a brigade and a reserve and each with supporting artillery, ${ }^{6}$ and the attainment of two objectives. Hastings had it in mind to throw forward yet a third column into the western theatre, to the east of the other two, against Kumaun, but intended to wait until the enemy were too fully occupied in other quarters to attend to the effective defence of that province. ${ }^{7}$ In the meantime, however, a corps of najibs or irregulars was to be raised in Rohilkhand in preparation for the projected operation. Gurkha recruiting agents had already been active among the fierce Muslim Pathan tribesmen of north Rohilkhand, and Hastings judged that enlisting them for the British effort would have the additional recommendation of denying the enemy the benefit of their services. ${ }^{8}$ Who better qualified to raise and command the force than Hyder Hearsey? Moorcroft had brought him to the notice of Government as an informant of local knowledge and military experience; ${ }^{9}$ and Hearsey, overjoyed at the possibilities offered by a war with Nepal for the realization of his secret claim to Dehra Dun, had eagerly solicited a part in the ensuing conflict with the Gurkhas. "It is my most ardent wish to be employed against them in a military capacity", he wrote. ${ }^{10}$ Early in November he was instructed to raise a corps of 1,500 najibs from among the martial populace of Rohilkhand. Il The Governor General's remaining concern was to provide for the defence of the frontier of Parnia and Rangpur, bodering the far eastern provinces of Nepal. This task was entrusted to the new Rangpur Local Battalion, with a few companies of regulars, under the command of Captain Barré Latter. His headquarters were at Titalia, on the flat watery lowlands directly south from Darjeeling. ${ }^{12}$ 
The broad outline of his strategy had been evolving in Hastings' mind for some time before the declaration of war, and he was able to indicate his plans and objectives to the Council with no hesitation when the decision to invade was taken. ${ }^{13}$ He had confidence and pride in his scheme, and was determined not to jeopardize its chances of success by ignoring the peculiarities which the service promised. Information and suggestions from every informed quarter, civilian as well as military, were invited and studied; optimistic assessments were weighed against the cautionary; and no effort was spared to provide for the expected difficulties. To make assurance double sure, Hastings fixed the strength of each column at twice the amount which his advisors estimated as necessary, ${ }^{14}$ and thereby mustered a force of 21,000 men to oppose an enemy whose strength he correctly estimated as 16,000 at the most. ${ }^{15}$ But he realized that numerical superiority, if an essential, would not be a sufficient condition of success. Conventional north Indian battles, with their epic sweep and clash, reverberating to uninterrupted horizons, offered no pattern for those now in prospect. The familiar and reassuring sights and conditions, the large masses of infantry, the swift cavalry, the warmth and the sunlight, would not characterize warfare inNepal. Combat would be close, given by small units of unsupported foot soldiers, in the claustrophobic confines and cold shadows of mountains, where cavalry would have no space to unfold its elaborate formations. The territory was more than unfamiliar: it was all but totally unknown, an undisturbed sanctuary of myth and fable beyond the pale of science. It was not only for the sepoy, with his belief in gnomes, goblins and fabulous serpents, that it retained a mysterious identity. The notion that the unicom was to be found in the unexplored tracts of the Himalayas was propagated by a sober English gazetteer, and even the names of the hill states and their rulers were subjects of conjecture. ${ }^{16}$ Sensing the importance of taking every measure to give the native troops extra encouragement, for fear will engender phantom sound and movement in silence and darkness, Hastings took care to include a good proportion of European troops in the invading columns. It was a common conviction 
that sepoys were most confident and brave when they had a European example to emulate. Generals Marley, John Wood, and Gillespie each had a battalion of King's infantry with their force, besides their European artillery. Ochterlony was not so provided, doubtless because it was planned that his force should be joined by Gillespie's at an early stage. Ordnance was provided on a generous scale, and Hastings advised his generals not to hesitate to make use of it. But he was convinced that mobility would be their most useful attribute, and he personally designed a howitzer carriage which could be dismantled and carried in separate portions. ${ }^{17}$ A similar pattern was adopted for the carriages of light cannon. 18

Appreciating that the morale of the army could only be the highest if the physical discomforts of mountain climate and terrain were reduced to a minimum, Hastings had special clothing prepared, to be issued to the troops at government expense. The customary thigh-length shorts of the sepoys were demonstrably unsuited to the cold weather and rough country of the hills, so both clothing Agents were instructed to make lange quantities of cloth pantaloons, in blue if possible, in the usual three sizes, and according to the pattern of those used by the King's troops in Europe. ${ }^{19}$ But the orders were not placed until the middle of August, and it was only by feverish activity that the second Agent, at Calcutta, was able to produce 7,000 pairs of pantaloons and an equal number of flannel banyans or waistcoats, by the beginning of October. ${ }^{20}$ This was sufficient to supply Marley's column, but John Wood was still waiting for his complement to be made up at the beginning of December. ${ }^{21}$ The provision of the two eastern columns proceeded even more slowly. The first Agent, at Fategarh, had in store cloth sufficient only for 4,000 pairs of pantaloons, and he had to apply to Calcutta for replenishment. ${ }^{22}$ The journey of his application to Calcutta, its screening by the Military Board, and its approval by the Vice-President in Council, consumed weeks of precious time, and the Agent was still awaiting the arrival of fresh cloth in the middle of october. A letter from the Adjutant-General dated October 27 th instructed him to bring the total 
number of pairs of pantaloons to 6,000 , and to send them in all haste to Saharanpur. ${ }^{23}$ They were therefore apparently intended for Gillespie's column, but could not have been ready in time to accompany the force. They were probably sent after it. How Ochterlony's troops were supplied, if they were supplied, is not clear.

One of the Governor General's advisers on matters of clothing was Thomas Rutherfurd, Assistant Surgeon at Moradabad. Surgeons at civil stations had ample leisure to pursue private supplementary interests, and they were notorious for their commercial speculations. ${ }^{24}$ Rutherfurd was no exception, having extensive interests in the enterprises of the hemp cultivators of the Kumaun hills, and holding besides the salaried position of Government Agent for the supply of half wrought timber to the magazines in the Upper Provinces. ${ }^{25}$ He had found life in a civil station so lucrative that he had even declined promotion to the rank of full Surgeon, since that would have compelled reversion to military duty. ${ }^{26}$ Preparations for the war involved the cessation of all commercial intercourse with the Nepal hills, but with the acumen of the true financial opportunist Rutherfurd was quick to exploit new contingent sources of emolument. He wrote to government offering his services as an informant, and had soon exchanged a salary of 500 rupees as Timber Agent for one of 1,000 as Extra-Assistant Commissary General. ${ }^{27}$ He made perspicacious recommendations on the subject of clothing for the troops, emphasising that "a martial air and smart appearance should give place entirely to convenience, comfort, and efficiency." ${ }^{28}$ His advocacy of a pyjama-type pantaloon came too late to be adopted, and the troops were supplied with what were in effect long woollen stockings; ${ }^{29}$ but ${ }^{\text {short }}$ ankle boots, with hobnails, and seams sewn with leather thongs, were manufactured according to his specifications. ${ }^{30}$ Rutherfurd also pointed out that the high precarious shako was thoroughly unsuited to wear in the hills. "Something that will set close to the head (a helmet for instance) and be a defence against stones and not liable to be brushed off in the thickets, should be contrived." 31 The recommendation was evidently adopted, for the preparation of "shoes, caps, I and T pantaloons" was later listed by 
Hastings among those expenses which had been occasioned by the special needs of the Nepal campaign. ${ }^{32}$ In his anxiety to ensure that no physical discomforts impairedthe performance of the troops and endangered the success of the enterprise, Hastings exercised a close personal supervision of all these arrangements, and conducted much correspondence concerning them through his personal Military Secretary, instead of through the Adjutant-General. The practice was in the interests of speed, though it earned the censure of the Court of Directors. 33 But to have the army ready by the end of October still involved a race against time.

Victualling the army presented the thorniest organisational problem. Foraging could not be counted on; lines of communication would be vastly extended and separated over a front of 600 miles; and for transportation no reliance could be placed on bullocks, the traditional means of draught and carriage in Indian armies. The war would obviously be a severe trial for the Bengal commissariat, still in the formative stage of infancy. The service was to be, in Hastings' own words, "of a nature quite novel in India, and demanded preparations such as never came within the expenditure of an army on any former occasion in this country." ${ }^{34}$

Persuaded that the army could not hope to feed itself from the country, ${ }^{35}$ Hastings ordered the formation of frontier depots, each with provisions for six months. Grain was plentiful at that time of year, and by prudent management was purchased cheaply. Each magazine on the frontier was made sufficiently small to avoid creating a local rise in price, and then supplemented by the formation of four similar depots at regular intervals in its rear. On the withdrawal of grain from the frontier, its stock could be made good by a requisition on the depot behind, which in its turn could be replenished from the third, and so on. ${ }^{36}$ To carry provisions into the hills, mules, tanyans or mountain ponies, elephants and camels could be used, but bullocksp would ultimately have to be replaced by human porters, who cost half as much again to hire, and were only perhaps a third as efficient. ${ }^{37}$ For this reason, every effort 
was made to prune the convoys of superfluities. No tents were issued to the sepoys; and in all the columns save the main Kathmandu one, the system was adopted whereby the normal foreign-service ration of the troops, which was over ample, was to be halved in amount but offered free, and whereby provisions for fifteen days, instead of a month, were to be carried. 38 For easier transportation, the salt provisions and spirits were put up in small kegs, better adapted to human carriage. 39 Throughout the five months preceding the commencement of operations, despatches flew by express to and from the itinerant Headquarters of the Governor General, plans were drafted, troops were mustered at their respective rendez-vous, information was sifted, supplies were gathered. Hastings surveyed the bustle and was well pleased.

"I cannot conceal my having formed the highest expectation of a brilliant and rapid termination of the war", he wrote. "The several divisions were, in numerical strength fully equal to any opposition which the resources of the enemy could subject them to encounter, and were, I may venture to say, on a footing of efficiency in every branch of equipment unknown in former wars. In the important article of supplies, for which it appeared probable that the troops would be obliged to depend on our own depots with little assistance from the country, the most able arrangements were made by the Commissariat, and every article of necessary consumption provided on a scale of utmost amplitude." 40

On one issue only, perhaps, did he still have serious misgivings. The defences of the whole Bengal Presidency were going to be dangerously weakened by the withdrawal of troops, who were scarcely sufficient for the task of defence even when present in full strength in times of peace. The war in the hills would naturally be followed with close interest by the Marathas and Ranjit Singh, and the merest hint of British embarrassment might precipitate irresistible attacks on the Company's denuded frontiers. This risk made it doubly essential that the hill campaigns be over as swiftly and as brilliantly as possible.

Remaining doubts about the adequacy of his invading columns to secure their communications and garrison captured forts were removed by the formation of a plan which Hastings was confident would bring hordes of supernumaries flocking to the British standard. All his informants 
assured the Governor General that if he promised them liberation from the Gurkhas and the restoration of their ancient rulers, the subjugated hill peoples would be eager to provide active support for the invasion. ${ }^{41}$ Under this impression, he determined to court the allegiance of all available hill chiefs. ${ }^{42}$ Considerable advantages were anticipated as a result of their adherence, especially in the western theatre, where "the nature of the country and the numerical strength of the force which I could_T be brought to act in it Irendered_T the cooperation of the inhabitants in the expulsion of the enemy and the occupation of the posts from which they $[$ might $T$ be driven an object of peculiar importance in a military point of view."

"From what the Governor General can learn of the nature of the country to be the scene of your operations", wrote the Political Secretary to Ochterlony, "it will be impossible for you to occupy by detachments and parties from your force, the posts and strongholds from which you will expel the Gurkha troops... In these cases the zealous and cordial aid of the inhabitants of the country, excited by the presence of their natural chiefs, will be of essential advantage, and indeed apparently indispensable. It can however only be secured by the expectation on the part of the chiefs, of recovering their former power; and on that of the inhabitants, of permanent emancipation from the tyranny of the Gurkhas."143

From a political point of view, a plan based on the principle of restoration was extremely satisfactory. It would entail the substitution for the overgrown power of the Gurkhas of a multiplicity of tiny states each too weak in itself to re-create a political hegemony and renew the harassments which the Company had lately been experiencing along its northern frontier. ${ }^{44}$ Although the plan had its origins in military considerations, it could not have been better calculated to solve the Governor General's dilemma concerning the disposal of the territories which he expected to conquer in the hills. Their restitution to the Gurkhas would be out of the question if that troublesome race was to be prevented from recommencing their aggressions; yet on the other hand "the annexation of the conquered country to the possessions of the Honorable Company I appeared_ $T$ to be entirely inexpedient in every point 
of view in which the Governor General I had_Tbeen able to consider the question". ${ }^{45}$ The policy of reinstating the exiled hill chiefs offered the acceptable solution, and it was decided to adopt it for all the Gurkha territories with the exceptions of the Nepal valley, the province of Kumaun, and the Tarai lowland. The first the Gurkhas were to be allowed to retain; the last two Hastings resolved the Company should annex, as compensation for the expenses of the invasion. ${ }^{46}$

The person most obviously suited to be an agent of the govermment in its attempt to engender local rebellions was the indefatigable Harak Deva Joshi. Now nearly seventy, he was led at last out of obscurity into the light of official notice by Hyder Hearsey, who described him as "the Earl of Warwick of I Garhwal and Kumaun_T...a perfect instrument whose name the Gurkhas dread." Hearsey claimed that he had 6,000 men at his command in Kumaun, and a great influence over many of the exiled hill rajas. ${ }^{47}$ Hastings was distinctly interested, and hoped that Harak Deva would be able to organise a force to seize the passes on the Jumna above Dehra Dun, thereby thwarting any plans which Amar Singh Thapa might contemplate for retreat to the east by the rugged routes of the north. ${ }^{48}$ Though fully aware of the Government's intention to keep Kumaun, Harak Deva agreedto exert all his influence in favour of the British invasion. ${ }^{49}$ It was feared lest the head of the Phartiyal faction of Kumaun, Harak Deva's old rival Lal Singh, now at Kashipur, should work surreptitiously to sabotage the Company's plans, especially since the Gurkhas in Kumaun had taken pains to conciliate the Phartiyals; but in the event he gave no cause for apprehension, and seems to have abandoned politics for a life of piety. ${ }^{50}$ Once plans to annex Garhwal had been relinquished in favour of the decision to keep Kumaun, the heir to Garhwal (Sudra Sen Shah), now in exile at Farakabad, was invited to join the British force in Dehra Dun "to add his personal encouragement to the popular effort against the Gurkhas". He was assured that his exertions would be rewarded by his restoration, and a proclamation was issued to his erstwhile subjects promising emancipation from Gurkha oppression. ${ }^{51}$ Krishna Singh was a scion of the Sirmur royal family, and had been a leader of the revolt against the imbecile Raja Karman Prakash. 
Hyder Hearsey's private scheme for the invasion of the western hills, the notes for which were submitted confidentially to government by Moorcroft, assigned him a role as a partisan. ${ }^{52}$ Ochterlony was also acquainted with him, and suggested that if he were given money to purchase arms and pay his men, he might raise a considerable body of auxiliaries - 1000 , perhaps, or even $4,000.53$ The proposition was readily agreed to, and the Resident at Delhi was instructed to advance funds to Krishna Singh for this purpose. The political settlement of Garhwal was to involve the perpetual exclusion of Karman Prakash, and the installation of his young son on the gaddi with Krishna Singh as Regent. ${ }^{54}$ Ochterlony was confident that Ram Saran Sen of Hindur, now a Company protége in the lowland remains of his once-extensive kingdom, would provide two or three hundred armed supernumaries and a greater unarmed force to clear roads, carry supplies, and act as guides, if promised a patent of restoration. The pledge was sanctioned, and Ochterlony was furnished with a proclamation addressed to all the hill chiefs of his region, offering reinstatement under British guarantee in return for aid against the Gurkhas. 55 Ochterlony further hoped that Raja Sansar Chand of Kotoch would volunteer to cooperate with the British. Sansar Chand had a considerable body of infantry trained and commanded by a wild and bibulous deserter from one of the King's Irish Cavalry regiments, called O'Brien, who was known to Ochterlony and who now professed to be anxious to help the Company. Ochterlony was sure that Sansar Chand would be eager to advenge the loss of Kangra, indirectly the fault of Amar Singh Thapa, by allowing $0^{\prime}$ Brien to cross the Sutlaj and attack the Gurkhas simultaneously with the British. ${ }^{56}$ The government was enthusiastic at the prospect, seeing that Sansar Chand would be in a position to prevent Amar Singh's retreat westwards across the Sutlaj. But on no account was he to be encouraged to utilize the British invasion as a screen for the recovery of Kangra - a move which would offend Ranjit Singh and possibly furnish him with an excuse to enter the conflict on the side of the Gurkhas. 57

In the eastern theatre, General John Wood was instructed to 
invite the cooperation of the Raja of Tulsipur, whose old hill estate of Dang was now under Gurkha sway, ${ }^{58}$ and supplied with the draft of a proclamation encouraging rebellion among the inhabitants of the lands previously ruled by the Twenty Two and Twenty Four Rajas. The heir to the Palpa dominions was to be contacted, and encouraged to muster and arm as many followers as he could. ${ }^{59}$ Bradshaw was to urge the Raja of Ramnagarh to assert himself for the recovery of his ancient possession of Tanhu in the hills, ${ }^{60}$ but the most sanguine expectations of all were held of the heir to the Makwanpur dominions. In its heyday, the Makwanpur empire had stretched to the border of Sikkim, and included the Kirata settlements of the Kosi basin, but it had then suffered tripartite division among members of the royal family. The prince of Makwanpur was the sole survivor of this family, and heir to the whole of its dominions. The government assumed that Makwanpur subjects now in the Gurkha army would "readily flock to the standard of their ancient princes "; 61 and Captain Latter, in command on the frontier east of the Kosi, was instructed to embody as a corps of auxiliaries all the Kiratas whom it was anticipated would rush to aid the cause of the Company and their legitimate chief. ${ }^{62}$ The Magistrate of Rangpur, was requested to attempt to communicate with the Raja of Sikkim, still defying the Gurkhas from Gangtok. "The endeavours of the Raja of Sikkim to recover the possessions of his ancestors, properly encouraged, may also create and embarrass the Gurkhas by adding to the number of points at which it is possible to assail them." Any result of the war favourable to Sikkim would, moreover, allay the suspicions of the Chinese authorities in Lhasa. ${ }^{63}$

Hastings had great confidence in his strategic and political schemes, and could not conceive the possibility of prolonged Gurkha resistance. Writing to Bradshaw "under the impression that the Gurkhas would not defer that submission which could alone form the basis of a pacification between the two states to so long a period as to draw on themselves their extinction as a substantive and independent government", he outlined a peace treaty which was designed to leave them "a substantive power - however reduced in dignity, character, and resources." The terms 
which Bradshaw, as Political Agent, was to offer were: submission; due atonement for the outrage in Butwal, and surrender of the officers who perpetrated it; relinquishment of all claim to the disputed lands; indemnity for the expenses of the war; recognition of all engagements made by the Company with the hill chiefs; and the abandonment of all rights in lands actually captured by the British. ${ }^{64}$ In the first days of the war, Bradshaw was approached by the two surviving nephews of Damodar Panre, who were living as exiles in India. They hoped to secure the Company's support for an attempt to provoke a revolution in Nepal, and restore the Panres to power; but this much Hastings refused to countenance. The overthrow of the present Kathmandu government would become a project fit for consideration only in the event of protracted resistance - "an extremity", he told the Court of Directors, "which I did not contemplate". 65 Few people anticipated a serious war. "Private advices, on the authority of which considerable reliance is placed, hold out reason to hope that the war will be speedily brought to a satisfactory and bloodless conclusion, by the entire submission of the Raja of Nepal to all the stipulations demanded of him", the Calcutta Monthly Journal assured its readers. ${ }^{66}$ Such was certainly the tenor of opinion at Headquarters. Hastings even envisaged submission on the part of the Gurkhas so hasty as to "prevent the actual commencement of hostilities". 67 The reason given by the Governor General for his forbearance to assume the command of one of the invading columns in person is inadvertently revealing. It derived, he confided to the Prince Regent's Private Secretary, from "a natural repugnance to appear as if I were seeking petty opportunities for distinguishing myself", ${ }^{68}$ - a remark which discloses less about his modesty than about his true assessment of the challenge which the war would present to commanding officers.

Thus the responsibility for putting the master plan into operation was entrusted to the generals of the Bengal army. Hastings exercised little discrimination when choosing his commanders. "I...nominated to the command of each division", he wrote, "the officer already commanding in the district where it was to be assembled, a procedure recommended by obvious faimess where no presumable incapacity could be urged against 
the general."69 This attitude was caused partly by genuine indifference, bred of Hastings' confidence in his plans and preparations, which he apparently considered would render the invasion all but self-operational; but also partly by necessity, because there would have been little room for choice in any case. There were only 30 major-generals in Bengal, of whom fifteen were on furlough and one in Java. ${ }^{70}$ The selection of four who were not obviously disqualified by senility from fourteen would not have been a task affording latitude for discretion. Even among the lieutenant-colonels, who were younger and much more numerous, Nugent had found it difficult to select one fit to command a large force on active service. ${ }^{71}$ By casting as he did, Hastings in fact probably netted the best of the available talent. Only one of his officers, Bennet Marley, was old enough to be a full major-general in the Company's service, and at sixtyone he was a young general officer. Ochterlony was fiftysix, and at the commencement of the service was only a brevet major-general. Both Gillespie and Wood were King's officers, Gillespie in his fortyeighth year, and Wood probably about the same age.

Bennet Marley was an obscure, unobtrusive personality, counted among the millions who, lacking the endowment of originality, have/no legend, have bequeathed not even an anecdote, to pisterity. Sprung from a prominent Durham family, he had spent all his adult years in India as an infantry officer in the Company's service, rising without drama or incident through the ranks as a result of the inexorable workings of the seniority system. His active service appears to have been confined to unspectacular ancillary operations, in which he acquitted himself without brilliance, yet at the same time creditably enough. He was well-regarded in high places, and it was only because of his refusal to accept a situation without extra allowances that he had not assumed command of the Second Division of the Bengal Field Army in 1812, which had been offered him despite his being still only a colonel. His appointment to the general staff had followed swiftly after his promotion to the rank of majorgeneral and the command at Dinapur in $1813 .^{72}$ Sixtyone was no age at which to submit a man to his first full-scale command; but Marley might, 
with the aid of long-dormant talents, have discharged it competently had he not been the victim of adverse circumstances and unfair prejudice.

David Ochterlony had also spent all his adult life in India in the infantry of the Bengal army, but in contrast to Marley was a man of experience and proven ability. Bom in Boston, New England, in 1758, of a Scottish father and Anglo-American mother, he had gone to England at the age of twelve, when his mother was widowed. Mrs. Ochterlony had found powerful friends, and married Isaac Heard, then Lancaster Herald and later Garter King of Arms. The alliance had secured influential connexions for the young David, including, it appears, the family of the Earl of Buckingham. ${ }^{73}$ He had gained a cadetship in the East India Company's service, and left England for Calcutta in 1777. No sooner had he obtained his first commission, than he had been sent with Sir Eyre Coote to Madras, to fight Hyder Ali of Mysore and his Maratha allies. It had been a fatiguing service of seven years. Ochterlony had suffered the loss of an eye, capture, and not a little demoralization under the ordeal. He had quickly developed a sense of grievance, and whole-heartedly associated himself with the Company officers who were agitating for better conditions, faster promotion, and more equitable standing vis-à-vis the King's army. As a major he had commanded a battalion under Lake in the 1803 Maratha campaign, and had so impressed the commander-in-chief that he had been selected for the post of Deputy Adjutant General with the Field Army. After the capture of Delhi in September 1803, Ochterlony had been considered qualified for a political post of the highest importance. Chosen to be Resident at the Court of the Delhi Emperor, he had soon vindicated his appointment and set the stamp of distinction on his career by a brilliant defence of the city against Holkar. As well as being a feat remarkable in itself, involving the defence of some seven miles of city wall with only two and a half thousand men and eleven guns, it had checked the Maratha in the full swell of his jubilance after the discomfiture of Monson. Sir George Barlow, who followed Wellesley as Governor General, had removed Ochterlony from Delhi to make way for a more senior 
civilian, doing his best to assuage any mortification which the measure might cause; but all the anodyne of official consolation and encomium had not been able to palliate Ochterlony's gall. What he regarded as an ignominious supersession had left a permanent strain of bitterness in his character, deepened his mistrust of Calcutta politics, and heightened his sensitivity to adverse criticism. Lord Minto had brought him out of the obscurity of Allahabad, wither he had retired as commandant in 1806, to command the military force sent to the east bank of the Sutlaj in 1808 as support for Metcalfe's mission to the court of Ranjit Singh; and he had remained at Ludhiana thereafter to manage relations with the protected Sikh states. ${ }^{74}$

This appointment had signalled fresh recognition and given him new interests, but increased age had not removed his temperamental instability, and he remained a prey to uncontrolled extremes. In moods of enthusiasm he would show eagerness, independence, and even arrogance; while in moods of depression he would descant on his own foreboding and make a parade of his own despair. On the occasion of the failures at Bharatpur, the Governor General had even felt constrained to admonish him for the querulous tone of his despatches, which ill-became the communications of a public officer, and could have had pernicious effect. ${ }^{75}$ During the administration of Minto, who re-endowed him with political office and who knew how to control his vagaries, firmly but without harshness, Ochterlony had worked in a renewed spirit of harmony with Calcutta and found new confidence in the civilian service. It was a disposition reinforced by the succession of his close friend Charles Metcalfe to his own oldpost of Resident at Delhi. The years at Ludhiana had not been without their upsets and displays of plaintiveness; but in this period Ochterlony had more often been bounding with enthisiasm than abject and morose. He had been, as we have seen, especially eager to march into the hills and chastise Amar Singh Thapa. The relish with which he had devised that particular project naturally leadsus to expect that he was the first to show zealous support for the decision to make full-scale war on the Gurkhas. But, in fact, such was not the case at all. 
When Ochterlony heard of the Governor General's plans for invasion, he registered only apathy and misgiving. He suddenly decided that the restoration of the hill chiefs, (which he had himself previously advocated) was not a good idea after all, and he wrote at length to the government to "deprecate the extension of an expensive and harassing protection to ingrates who, if relieved from their present oppressors or restored to their ancient possessions, will, by their own petty internal disputes in all probability furnish an endless source of trouble and vexation to the government which has exerted itself for their deliverance." It was now his view that it would be much wiser to relinquish the policy of restitution. "If we do attack, it should be avowedly in the first instance to conquer for ourselves." 76 In a private letter to Metcalfe he gave full expression to the despondency which the prospect of going to war for the sake of the squabbling hill rajas aroused in him:

"A new sort of service, my dear friend!! I have not the least objection to a proper vindication of the national honour, and if necessary, an attack on the heart of their empire Kathmandu or some members in this quarter; but to set off with the idea of overthrowing a long established government, and for such unprofitable purpose, seems to me the most quixotic and impolitic measure we have ever at tempted."77

$/ / \overrightarrow{H e}$ expressed his conviction that no material assistance would be obtained frompexiled chiefs, "men who now literally subsist on charity"; ${ }^{78}$ and he soon lost confidence even in Krishna Singh. ${ }^{79}$ He was disturbed by the alacrity with which the government adopted and distorted his suggestion concerning Sansar Chand's cooperation. He had only pointed out, he explained to Metcalfe, that Sansar Chand might volunteer his services against the Gurkhas. He disliked the idea of soliciting his aid, for Sansar was now a vassal of Ranjit Singh and had, besides, never possessed (contrary to the belief of the govermment) any territory on the west bank of the Sutlaj. He feared too that, while a spontaneous offensive by the Kotoch chief in a separate quarter would have been a useful diversion, if closer cooperation were invited his army, commanded as it was by a British deserter, "might have... a very bad effect amongst our own European 
troops. 180 He began to disown his own earlier assessment of the enemy. There was no more mention of "a body of ill disciplined barbarians"; instead, his tone became cautionary and even grudgingly appreciative of the Gurkhas' qualities. He conceded in one letter that if the Gurkhas were given full credit for the reputation they had acquired, then "an officer must make up his mind to contend with a hardy and brave people, by no means uninformed in the arts and stratagems of mountain warfare." 81 Such a moody and pessimistic reaction to a project which he had previously been wholeheartedly committed to was not as paradoxical as it seems. Ochterlony disliked Hastings, for a start, and had been depressed by the departure of his old friend, Lord Minto. "I do not like this new viceroy", he wrote to Metcalfe in January, 1814. "All noise and emptiness, like a drum... believe the old one was worth a dozen such."182 Secondly, he was bitterly disappointed for personal reasons with Haptrigs' for the invasion. Ochterlony was a man on the brink of old age, who had had to contain his talent, energy and ambition for 35 years while he waited in the wings for a senior command; and now, when a project he had made his own, and which he was better placed than any office in India to conduct, was at last put into operation, he found that he was assigned a subordinate role, as second in command to a King's officer nearly ten years his junior. His sourness is not to be wondered at. It typified the state of mind induced in many officers by the frustrations and humiliations of service with the Company. He could not know then that this apparent invitation to end his career as a handmaid to Gillespie was his greatest opportunity in disguise; that what seemed the way to obscurity was in fact the threshold of fame.

John Sulivan Wood was a King's officer who had come out to India with the Eighth Light Dragoons after acquiring the lieutenantcolonelcy of that regiment in 1803. He had served valiantly in the Maratha campaign of 1803 , and had risen to the rank of major-general by 1810 - a speed of promotion in marked contrast to the sluggish progress of the Company's officers through the ranks. In 1814 he was on the general staff of the Bengal army, and commander of the station at Benares. ${ }^{83}$ He was a pleasant man to have dealings with: modest, and in 
Hastings' words, "remarkably gentlemanlike". ${ }^{84}$ As a commander his strength was his flair for administration, and his weakness the usual concomitant of an over-fastidious mind - a lack of imagination. This combination of qualities made him, in Field Marshal Pollock's view, an officer "well-suited to command in cantonments during the piping times of peace, but without a single qualification to lead an army in war". 85 A soldier who had gained all his experience with European cavalry, and who was unimaginative, was, indeed, hardly ideally qualified to lead a column of preponderantly Indian infantry on a novel type of service. But the assignment of Wood's force was the least important among those of the four columns of invasion, and not designed to over-tax his ingenuity.

Robert Rollo Gillespie was at once the most conspicuous and the most controversial military figure in India. Modesty was not one of his attributes, besause $h$ is life was a desperate combat against obscurity.

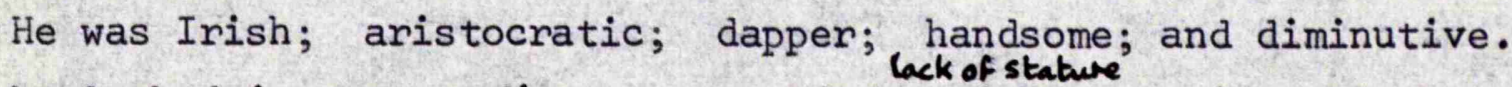
He compensated for $/$ with obtrusive valour, vanity, and bigotry, and by 1814 he had succeeded in making himself known and talked about not only in India, but also in the highest circles at home. But his has proved an ephemeral celebrity, nothing more durable than a product of those conventions which now seem absurd, but which made up the code of behaviour of his day. Gillespie's fame was possible only in an age when fashionable society set great value by hard drinking and the grotesque quixotism of pusillanimous dandies who swaggered around drawing rooms and messes ever ranting about outraged honour and demanding "satisfaction". That Gillespie was brave no-one can deny; but a man's attributes, like his wealth, are only made virtues by the end they serve; and while disinterested courage is noble, reckless and ostentatious temerity whose main purpose is self-glorification is just as surely vicious. Even his admirers conceded that Gillespie would expose himself needlessly in battle, that he was "brave to a fault". ${ }^{86}$ Danger was his harlot, whom he at once disdained and courted shamelessly, both to assuage uncontrolled instinct and to add meretricious lustre to his person. 
He solicited popularity by flourishes of generosity and exhibitions of munificence; but, far too self-centred to be genuinely altruistic, he was hated far more deeply than he was esteemed.

While still a cornet, his violent temper had led him into brushes with the law. On one occasion he had been tried (but acquitted by a jury of fellow-officers) for the murder of a rival, whom he had killed in a duel; and on another had been compelled to go into hiding to escape arrest for assault and battery. He had found a legal outlet for his aggressive instincts in the French West Indies; and the story of his altercation with eight nocturnal desperadoes, who broke into his quarters in San Domingo to murder him, in which he fought them off singlehanded and killed six, had carried his fame to all the drawing rooms of London. He had transferred to the 19th Light Dragoons, who were in India, in 1805; and in the following year had assumed command of the garrison at Arcot, in the Madras Presidency. In July, 1806, within fifteen minutes of the news of the mutiny at nearby Vellore reaching Arcot, Gillespie had roused a squadron of his regiment, saddled, mounted, and set off to the rescue at a furious pace, while the rest were limbering the galloper guns and preparing to follow. The gate of Vellore fort being in the hands of the mutineers, Gillespie had made his entry by climbing a rope let down the wall by the European survivors, then rallied the remnants of the garrison, and kept the enemy at bay until the guns arrived from Arcot and blew open the gates, admitting the relieving force. For this dazzling feat he had been christened the Hero of Vellore.

In 1807, when the 19th were ordered home, Gillespie had changed regiments so that he might stay in India. Life as commander at Bangalore proving uneventful, he had devised the 'sport' of tiger-sticking to relieve the tedium of garrison duty. The opportunity for active service had come again in 1811, with the decision to expel the Dutch, allies of Napoleon, from $\mathrm{J}$ ava. Gillespie had been selected to command a division in the expeditionary force under Sir Samuel Auchmuty. After landing at Batavia (Jakarta) he had distinguished himself in a series of preliminary skirmishes and then in the assault on fort 
Comelis, just outside Batavia. General Janssens' Franco-Dutch colonial force, though numerically superior to the Anglo-Indian, had been no match for it in quality and discipline, and cornelis had fallen under the first coup-de-main on August 26 th. ${ }^{88}$ Auchmuty acknowledged that the success of the assault was due in large measure to Gillespie. ${ }^{89}$ After a campaign of 45 days, Java and all its dependencies had been surrendered to the British, and Gillespie had been appointed commander of the occupationary force. Though battle-scarred and exhausted, he had spared himself no effort while opportunities for action yet remained. In March, 1812, he had led in person an armed deputation to Palembang in Sumatra to demand certain trading concessions, deposed the contumacious raja, and enthroned a more accommodating successor; and on his return had made for Jokyakarta, on the southern coast of Java, and led a spectacular attack on the Sultan's vast keratun, or fortified residential enclosure. He had had less than 3,500 men to oppose the 11,000 defending the place, yet had assaulted by escalade, got possession of the ramparts, and turned their own guns on the enemy. In less than three hours the keratun had been won. 90

A deep aversion to inactivity and an insatiable appetite for glory constantly impelled Gillespie to seek fresh distractions and opportunities for renown. The initial excitements of conquest and pacification once over, the prospect of service in Java had held few attractions. There had been hopes that the island would be made a crown colony, a status which would have given greater scope for King's officers, since it was the custom for such dependencies to be ruled by them; but the weary months had passed while the London authorities pondered, and meanwhile Minto's incorporation of Java into the territories of the East India Company had been allowed to stand. This arrangement had made the military subservient to the civil authority, and Gillespie had found himself merely a second in command, with little more than an advisory power regarding the few thousand troops under his supervision. His irritation had been made worse by the fact that the civilian Lieutenant Governor, Stamford Raffles, was fifteen years younger than himself, a self-made man, and while professedly an admirer of Gillespie, not 


\section{him that showy deference to which the commander considered}

prepared to concede/himself entitled by his profession, renown, birth and seniority. Gillespie scorned Raffles as a churlish upstart, and in the months following the fall of Jokyakarta, the two had been continually at loggerheads, chiefly because of differences about military retrenchment. ${ }^{91}$ Life had become intolerable, and Gillespie had fretted to be free. He had written "repeated and earnest applications" to the Commander-in-Chief, Nugent, to be relieved. ${ }^{92}$ Transfers were not easy to arrange; but Nugent, as Gillespie's old commanding officer, had been anxious to help, and Minto had been equally concemed to relieve Raffles from unbearable vexation. ${ }^{93}$ The upshot had been that Major-General Miles Nightingall was induced to agree to take Gillespie's place in Java, and Gillespie was given command of the Second Division, Field Army, on the Bengal establishment. In the euphrasia of release he had forgotten all his bitterness, and made effusive demonstrations of reconciliation with Raffles. The two had parted in October, 1813, apparently on the best of terms. 94

Now on board the Troubridge, bound for Calcutta, had been Mrs. Blagrave, ${ }^{95}$ wife of an acting Secretary to the Java Government whom Raffles had dismissed for dishonesty, incapability, and insubordination. Blagrave's appointment in Java had in any case only been temporary; but instead of now p roceeding to Amboina, whither he had originally been bound, he had challenged Raffles' power to dismiss him without reference to the Supreme Government, and made his way to Calcutta - presumably to lay his case before the authorities there. ${ }^{96}$ He was in considerable debt, and we can readily suppose that his wife blamed Raffles for the distresses which she and her husband were now experiencing. What had happened on the Troubridge can only be surmised; but it is hardly likely that Gillespie, ever a philanderer, had not paid his respects to Mrs Blagrave; that she had not wept a little, and bitterly reproached Raffles for his base victimisation of a man already in financial straits; and that he, flattered by her confidences, gulled by her lachrimose importuning, and even incensed by backstairs gossip about Raffles' private attitude towards himself, had not preened himself before her with protestations of outraged 
chivalry. It is not difficult to imagine Gillespie avowing, with melodramatic flourish and exaggerated indignation, that Raffles should pay for his dastardly behaviour. He had worked himself into a fury, perhaps sincere, perhaps not, and by the time he reached Calcutta had hardly been able to contain his feelings. Circumstances had then conspired to goad him into open and violent calumny of the LieutenantGovernor. Lord Minto, who knew Raffles and who well understood Gillespie's precipitancy, was gone; and in his place was Lord Hastings, who was not acquainted with Raffles but who knew Gillespie by report as the bravest soldier of the east. Without foreknowledge to temper his interpretation of Gillespie's unguarded language, he had reacted with concern and sympathy and had naturally given Gillespie credit for the justness of his invective. Thus encouraged, Gillespie had either surrendered completely to the egoist's propensity to self-persuasion, and become truly convinced of the validity of his accusations (if he had ever doubted it, that is); or found that he had gone too far to recede without humiliating himself. In concert with Blagrave, who was in Calcutta, and whose position as a government secretary had given him access to necessary "evidence", he had submitted a formal indictment of Raffles' administration, concentrating on the matter of the sale of government lands in Java and the Governor's own participation in the sale as a private purchaser. Gillespie had not only questioned the wisdom of this measure,but impugned Raffles' motives. Raffles had had no difficulty in refuting the charge of venality and in making Gillespie look a fool for good measure. His reply made it obvious not only that Gillespie had not the remotest understanding of the matters he had presumed to make judgements on, but furthermore that he had himself approved and, in one case at least, instigated, measures he now had the audacity to condemn. Raffles had pointed out that Gillespie had been in Java during the whole episode of the sale of lands, had known of it, yet had said nothing. Among the minor heads of indictment, Gillespie had accused Raffles of excessively debasing the new Java coinage; yet the records showed that Raffles had advocated a nearer approximation to the Calcutta rupee, only to be overruled on this point by members of his Council, including Gillespie! ${ }^{97}$ It is difficult to reconcile such 
wild inconsistency with complete mental stability. Probably, the tendency to megalomania which had always existed in Gillespie's character had finally developed into a pathological condition - perhaps as a result of the head wounds he received at Cornelis. Even before their first quarrel, Raffles had remarked: "he does and will take some of the strangest starts and wildest freaks into his head that ever entered the mind of man"; 98 and Lady Nugent, who had "long and many conversations with him" after his arrival in Bengal, was convinced that "his mind was certainly sadly disturbed". "I could not but see", she wrote, "that natural impetuosity and his extraordinary vanity and love of fame had led him into false ideas and errors that would embitter his future life." 99 To the ladies at Meerut he was simply "a pickle" - far too preposterous ever to be taken seriously. ${ }^{100}$

To Raffles and his friends in Java Gillespie's accusations, coming so soon after demonstrations of reconciliation and cordial farewells, seemed utterly despicable. ${ }^{101}$ Raffles, in the flush of his resentment, had not been content to vindicate himself and expose Gillespie as an imbecile. He had made countercharges, vilifying him as a slave-driver and a lecher. The first charge related to Gillespie's impressment of unpaid native labour in Java for the construction of a private house at Chipanas; the second, to the appearance one night, at the orphan school in Samarang, of a man employed by Gillespie, who demanded a virgin. ${ }^{102}$ Raffles had shocked the Calcutta government with these accusations, and Hastings had admonished him for tasteless recrimination. But Raffles was angry, and instead of withdrawing the charges, had added another:

"Where was the indelicacy of my conduct towards the Commander of the Forces when a virgin was forcibly demanded, by his orders, from the orphan school at Samarang? Where was it in a similar outrage perpetrated by military force in the house of Mr Sluyster in Batavia - both of which instances were reported to me?"103

By now the whole sordid affair was an embarrassment to the government, which was anxious to silence Raffles. "After all, what is to 
be done with Gillespie? There is no competent tribunal here to take cognizance of his conduct as a military man", said George Tucker, Government Financial Secretary, to Charles Assey, who had gone to Calcutta on behalf of Raffles. Assey, reporting this to his chief, wrote:

"If we are to judge from the secretaries of the sentiments of the Governor General himself, it is the question of disgrace on the Major-General which forms a great obstacle in the judgement of the present case; it is satisfactory, however, to recollect that if such should be the inclination in Bengal, there is an ulterior tribunal and to use the old adage, magna est ventus etc."104

Such was the posture of his private affairs on the eve of

Gillespie's departure for Nepal. He must have prepared for the campaign with something other than his usual confidence and swagger. Not merely victory, but a victory spectacular even by his own standards of stage management, had become a desperate personal necessity: the only antedote, perhaps, to disgrace and ignominy. Whether or not Raffles' charges were substantial was never established; but Assey's reference to an ulterior tribunal suggests that Raffles' party was reasonably confident of its ability to prove the accusations. Even if judicial scrutiny had revealed Gillespie's moral conduct to be no worse than that of most of his contemporary officers, that, made public, would have been humiliating enough, and must have detracted from the magic of his name. The Nepal campaign offered him the opportunity to add fresh laurels to his crown, to renew his legend, and to so dazzle the world that Raffles would be confounded and his petty charges drowned in the paeans of adultion.

But Gillespie had more enemies than those he had left in Java. He had always been fastidious in matters of discipline; and now that his ill-temper was made worse by the pain of shrapnel wounds and the stress of his feud with Raffles, he had vented his spleen by demanding of the troops at Meerut impossible standards of drill and dress. He seems to have had the cavalry officer's contempt for infantry corps in more than normal measure, and his asperity had therefore been directed especially against the King's 53rd Regiment of Foot. Many had been the times when 
these unfortunate troops were kept stamping burning barrack squares hour after hour in suffocating heat, until the shakos felt like steel bands tightening around their skulls, the broadcloth jackets weighed like yokes across their shoulders, and men dropped dead on the spot from sunstroke. Many had been the curses whispered against him; many the grievances unuttered, but not forgotten. Gillespie had laid up a large debt; and it was to prove his greatest misfortune that the regiment who were his creditors were a part of the column which he was to lead into Nepal. 
PART 11 


\section{Chapter Six}

\section{Fiasco in Garhwal}

After the termination of their so-called military road at Srinagar in Garhwal, the Gurkhas' route from Kathmandu to the west was known to pass through three main points, all fortified. From Srinagar the route went to a ghat on the Song river, which flows across Dehra Dun to join its parent Ganges in the south west comer. This point was protected by the fortress of Kalanga. From Kalanga, the route struck west across Dehra Dun to the Jumna river. On this there were several fords and ferrying places, but all were dominated by the important position of Kalsi, situated in the angle formed by the confluence of the rivers Tons and Jumna. Beyond the Jumna, in Sirmur, the route lay through Kayarda Dun and past the town of Nahan at its western extremity. From there it continued to the Sutlaj river, through hidden alpine byways. .. Before joining Ochterlony, Gillespie was to sever this line of communication. The operation was to be performed in two stages. First, Dehra Dun, Kalanga, and the Jumna passes were to be occupied; then he was to cross the Jumna into Sirmur, and capture Nahan. ${ }^{1}$

Notwithstanding that plans for war had been in preparation for three months, the column was assembled and mobilized with confusion and hurry. In order not to forewarn the enemy, the strictest secrecy had been maintained, and the various corps selected to form Gillespie's division were given only a couple of days to prepare to move to their rendez-vous at Saharanpur. Most of the troops were stationed at Meerut, and, though long tantalized by hints and rumours, were not given marching orders until october 3rd, when they were instructed to move within two days. It was then discovered that the commissariat had insufficient camels to carry the private belongings of the troops as well as the provisions and stores, and the contractors called in to supply the lack detained the army until the 12 th. ${ }^{2}$ Even then, H.M. 53rd marched without enough camels, and when only four miles outside Meerut had to wait two days for an extra supply. ${ }^{3}$ Gillespie was fidgety, and these delays made him 
ill-tempered. He had been told to advance into the hills as quickly as possible, for intelligence had been received that Amar Singh Thapa was contemplating a retreat to the east. ${ }^{4}$ It was just as well that the intelligence proved false, because it was not until late on October 19th that Gillespie's force was complete. ${ }^{5}$ The division assembled on the still sultry plain north of Saharanpur. It consisted of about 4,400 fighting men, 900 of them Europeans. Besides the King's 53rd Regiment of Foot (lst Battalion), the latter consisted of a troop of the 8 th, or Royal Irish, Dragoons, and a detachment of horse artillery. The native complement comprised about 3,000 sepoys, 138 pioneers, some 200 gun lascarstand ordnance drivers, a regiment of native cavalry, and a risala or troop of Skinner's Horse. Cavalry was provided for use on the extended level spaces of Dehra Dun, where it was hoped it might confound the Nepalis, who were unaccustomed to contending with this arm. ${ }^{6}$ Non-combatant public servants swelled the force to some 10,000; and then there were about 5,000 camp followers and officers' private servants. ${ }^{7}$ In response to strong recommendations, officers had reduced their baggage to what they considered to be a minimum: but this was obviously not going to involve any spartan self-denial. Major John Ludlow, commanding a battalion of native infantry, still needed six camels even before he had packed his supply of spare liquor. ${ }^{8}$

Gillespie was not satisfied that the force at his disposal was adequate - especially since Hastings' plan required the establishment of numerous detached posts. The Governor General agreed to provide another battalion of native infantry; but this could not be expected to join the division until Dehra Dun had been occupied. ${ }^{9}$ Gillespie's experience and instincts warned him that Hastings was perhaps under-estimating the difficulties in prospect, and he even privately admitted presages of disaster - an uncharacteristic sentiment. ${ }^{10}$ While waiting for his force

*Each company of European artillery (composing several details, one to each gun) had native gun lascars attached. Their function was to man the drag ropes, guard and serve out the ammunition, and carry the match. They were not supposed, for political reasons, to serve the gun itself. 
to congregate, he was restless and irritable, and he began to put his instructions into operation even before all the troops had arrived at Saharanpur.

There were two principal passes into Dehra Dun through the Siwaliks, as the foothills in this area are called: the Timli pass in the west, and the Mohan pass in the east. On the morning of October 19th, Lieutenant-Colonel Carpenter, already at Saharanpur with his battalion of native infantry, was sent with his sepoys and three pieces of light artillery to force the Timli pass and secure the Jumna. ${ }^{11}$ At daybreak the following morning a detachment of about $1,000 \mathrm{men}$, including two companies of the King's 53rd and the native cavalry, was sent under Colonel Sebright Mawby of the 53rd to march into the Dun via the Mohan pass and seize the fortress of Kalanga. ${ }^{12}$ Hastings had suggested that the Kalanga column be sent without artillery; but Gillespie, more wary, decided to send the two cavalry "gallopers" (six-pounders) with Mawby. ${ }^{13}$ He obviously expected the passes to be heavily defended, because on the 21st the remainder of the 53rd were ordered off to the village of Jaundra below the hills and equidistant from both passes, so that it could support either detachment in case of need. ${ }^{14}$ As it happened, the Timli pass, at least, was not guarded at all. Carpenter cleared it on the morning of the 20th, moved up the Jumna posting pickets at the main ghats, and reached Kalsi unopposed, the Nepali garrison having withdrawn to the fort of Birat, further north.

As Carpenter entered Dehra Dun, Mawby left Saharanpur. He made his way through fine flat country where the rice crop was ripe, to the ruined town of Khiri, on a marshy river-side near the edge of the dense jungle grass which skirted this part of the foothills. Here the detachment camped for the night; and on October 2lst made a four-mile march through the forest, disturbing game of every description. The Mohan* pass was in fact the route of a river bed - now dry, and very stony.

"Sometimes called the Khiri Pass, after the town at its foot. 
The channel lay parallel to the foot of the hills for some distance, before curving and incising a ravine into them. As the soldiers and officers of the 53 nd moved easily along its bank, cool in the shade of imposing trees, the view of the wooded sandstone hills across the river reminded them irresistibly of familiar spots in southern England. The main force halted below the hills while Captain Fast, on his own offer, pushed forward with two companies of sepoys to secure the top of the pass. It was not unguarded. The Nepalis had strongly stockaded the crest, but Fast was easily able to scatter the few defenders. At midnight he sent down word that he had got possession of the top. ${ }^{15}$

The rest of the detachment began to move up an hour before daylight. The pass was only three and a half miles long, but the trees on its banks soon became so thickly crowded that the troops had to march on the river bed itself. This was not only painful, but also dangerous, because the stones and boulders had no hold in the sand, and rolled underfoot. The cavalry were compelled to dismount, and the guns had to be dragged up by men. Progress was further hindered by the increasing narrowness of the pass. It was only nine feet wide half a mile from the top, and on the crest itself there was barely five feet between the high banks. It was eleven $0^{\prime}$ clock before the ascent was completed. ${ }^{46}$ Two hours later, Mawby's force marched into the little town of Dehra, situated in a wilderness of high grass which was interspersed with groves of sal and sissu, and abounding with tigers, elephants, peacocks, and every other variety of game. ${ }^{17}$

Once camp was pitched, the colonel and his staff rode about five miles to the north east to reconnoitre Kalanga fort. By the time they approached the hill on which it was situated, however, the light was failing, and it proved impossible to form a useful impression of the position. ${ }^{18}$ About midnight, a letter was sent to the castellan, Bal Bahadur Singh, demanding the surrender of the fort. Tradition recounts that he tore it up, observing that it was not his custom to deal with correspondence at such - unseasonable hours. $^{19}$ Early on the 23 rd Mawby and his officers, this time with an escort of light infantry and cavalry, 
again went to reconnoitre. Their examination of the ground was very cursory, because Mawby was fearful of being cut off by prowling enemy detachments. He nevertheless felt he had seen enough of the position to plan a full scale attack, to take place the following moming. ${ }^{20}$ That night, ${ }^{2 l}$ Carpenter arrived in Dehra, and his junction increased Mawby's force to 1,3000 infantry, 300 cavalry, and 5 light guns. ${ }^{22}$

Kalanga fort, also called Nalapani, was on the highest point of one of the how spurs which jutted southwards into the Dun from its northern rim of mountains. On its western side, the Kalanga spur plunged almost vertically for 1,000 feet to the valley floor. The eastern flank sloped away more gently until, about a mile from the summit, it suddenly dropped 600 feet to the Song river. The most accessible approach was the southem, which was marked by a proad from Dehra to the fort. This climbed steadily, but not too steeply, for about three miles, before reaching the socalled table land. This was a narrow strip of fairly level ground 200 feet below the summit, and separated from it by/a water course (the Nalapani) which came down from the north, and then turned west in its descent $h$ The summit itself was thus in the form of a knoll naturally moated on two sides. Its slopes formed a glacis for the fort, which perched on its highest point. The whole spur was thickly planted with slender/, save in the vicinity of the fort, where it was clear like a tonsure." The fort was irregular in shape, following the contours of the ground, and, its defences being unfinished, it was surrounded by a hastily constructed palisade. ${ }^{23}$ This rather unimpressive stronghold was reckoned to harbour some 600 people, of whom not more than half could have been in any sense soldiers. ${ }^{24}$

At half past four on the morning of October $24 \mathrm{th}$, Mawby advanced his infantry and guns to the foot of the southern aspect of the spur and sent the cavalry round to the village of Rajpur, north of the fort, to intercept the en emy if they should attempt flight. At dawn, the infantry climbed to thetable land without opposition - save for the harmless fire of a few small cannon from the fort. A fatigue party of the $53 \mathrm{rd}$ then went down for the two six pounders, and dragged them up within an hour. 
The guns were opened on the fort soon after, and continued their fire for several hours: but by eleven o'clock they still had not made any impression on its walls. ${ }^{25}$ Mawby decided that they must be got nearer, and had one pushed up the table land along the road leading to the fort. But it was then discovered that at the end of the table land the road turned sharply left, dipping severely to cross the water course. This obstacle, and the fact that enemy outposts were dispersed over the whole distance, induced him to abandon the operation. His artillery was obviously too light to make a breach, and he considered the place too strong to be attacked without preliminary cannonade. The force therefore returned to camp that same afternoon. ${ }^{26}$ Mawby's decision was in perfect consonance with Hastings' instructions, which strictly enjoined that Kalanga was not to be assaulted without artillery should reconnaissance show its use to be expedient. ${ }^{27}$

When he heard of the safe arrival of Carpenter and Mawby in the Dun, Gillespie was relieved, and imagined the most tricky part of the first stage of his operations to be over. He wrote to Ochterlony, making him a provisional promise of collateral aid in Sirmur about November lst, and ordered the dragoons and three light companies of sepoys to march from Saharanpur to a position on the east bank of the Jumna, near the foot of the Timli Pass, where they would be ready to cross the river. ${ }^{28}$ Leaving Major John Ludlow with the lst Battalion, 6th Native Infantry at Saharanpur, he then took a small escort and briskly followed Carpenter up the Timli pass into Dehra Dun to inspect Kalsi, Birat, and the Jumna ghats. It was on October $25 \mathrm{th}$, while engaged in this examination, that he received Mawby's report of the unsuccessful attempt against Kalanga. He had not anticipated having to give his own attentions in that direction, and was hotly vexed at having his plans interrupted by what he thought was Mawby's timidity. But Kalanga was a stumbling block and would have to be removed - removed quickly, too, if he was to keep his promise to Ochterlony. ${ }^{29}$ On the 25 th he sent word to Mawby that he would join him at Dehra the next day, and ordered those parts of his army still on the plains to march without delay into the Dun. ${ }^{30}$ 
For the dragoons and light infantry on the Jumna, and for Ludlow and his corps at Saharanpur, the journey to Dehra Dun was relatively easy and quickly accomplished. The former were already at the foot of the Timli pass, and the latter had only to follow the main route from Saharanpur to the Mohan pass - well-trodden by now. But for the eight companies of the $53 \mathrm{rd}$ at the march was much more difficult. They had to move eastwards to reach the Mohan pass, and as the nullas draining down from the foothills flow in a southerly direction, the route lay across the numerous water courses, instead of parallel to them, as was the case for the troops moving from Saharanpur. The road was, furthermore, bad and very tortuous. The force broke ground at $5.00 \mathrm{a} . \mathrm{m}$. on October $28 \mathrm{th}$, and trudged 23 miles in the course of the day, crossing no less than five running streams. It was hot, and the column straggled badly, the luggage and sick taking all night to reach the camping ground at Khiri. Here the tents had to be pitched on low marshy ground beside a nulla, where water oozed out of the soil in the footprints of the camels. The troops lay in the damp all night, and the baggage became soaked. Gillespie, not aware of these difficulties, sent liverish/note to LieutenantColonel Buckland (never one of his favourites) on the 29th, telling him to make haste. Camp was struck at one o'clock, but before the march was many hours old many of the men had collapsed by the roadside, unable to continue. Not more than four or five miles had been covered by dusk and that night camp had to be pitched in the pass itself, on the stony river bed where there was no level ground and no place to drive a tent pin. It was nearly noon the next day before the sick and all the stragglers had come up. Because of the heat, and the exhausted state of the troops, it was decided that the march would not be resumed until moonrise: but the officers, fearing that the narrow crest of the pass would become choked when the main part of the detachment entered it, tried to send on their baggage in advance of the regiment. The result was utter chaos. The movement of their private servants provided an impulse to the other bearers and camp followers, and soon the whole force found itself caught up in a general forward motion once more. As the sides of the ravine converged 
to form the narrow summit of the pass, the camels and their attendants were forced together into a suffocating mass. Many animals fell, blocking the road until their loads could be removed and carried over by hand, and the din was stunning. It was night before the baggage was out of the pass, and ten o'clock before the men had followed. The force finally being in some sort of muster order, the march to the main camp at Dehra was then resumed. The distance was about ten miles, and most of the men covered it sleeping on their feet. In addition to fatigue, they suffered from a sudden change of climate, for the cold of the nights at this altitude was in sharp contrast to the broiling heat of the daytime on the plains. The detachment reached Dehra at midnight, bruised, tired and shivering, and feeling very sorry for itself.

There was no warm welcome to console them. There was, in fact, no welcome at all, for Dehra was silent and completely deserted. Fresh tent marks in the ground were clearly visible in the moonlight; but there was no sign of the army and by some extraordinary oversight no guide had been left to indicate where it had gone. For three hours the troops remained in a state of increasing apprehension while the acting quartermaster, Captain Emery, probed around gingerly for signs of the vanished army. Finally he found the new ground,which was three or four miles to the north east, at the base of Kalanga hill. Wearily, the mentrekked forward again , and finally stumbled into camp just as the clocks were striking four. Only the native cavalry were at hand to explain what was happening, becauroperations against Kalanga had already commenced and all the infantry had taken up positions around the fort. A few hours later, just as dawn was breaking, the sound of gunfire echoed around the valley; and then, when the tents had almost been unloaded and as the men were at last savouring the prospect of repose, an urgent order arrived in camp from General Gillespie. Three companies of the $53 \mathrm{rd}$ were to march to the table land immediately. ${ }^{31}$

Gillespie had joined Mawby on the morning of the 26th, in no sweet temper. Early on the 27 th he went out to examine the fort, and spent an exhausting day reconnoitring. He appreciated the strength of the position, but did not doubt his ability to take it. 
"Here I am", he wrote breezily to Major-General Grant Kier, "with as stiff and strong a position as ever I saw, garrisoned by men who are fighting pro aris et focis in my front and who have decidedly formed the resolution to dispute the fort as long as a man is alive. The fort stands on the summit of an almost inaccessible mountain, and covered with an impenetrable jungle, the only approaches commanded, and stiffly stockaded. It will be a tough job to take it; but by the Ist proximo I think I shall have it, sub auspice Deo." ${ }^{32}$

He chose an advanced position for the camp, nearer the foot of the hill, and ordered the preparation of fascines, gabions and scaling ladders in readiness for an assault. By October 29 th, the dragoons and light infantry from Timli, and Ludlow's battalion from Saharanpur had reached Dehra with the rest of the artillery; but there was still no sign of the dilatory remaining companies of the 53rd. Gillespie, determined to have the fort by November lst, refused to delay his operations, and made plans to proceed without them. The available force was divided into four columns and a reserve, which were to attack Kalanga simultaneously from all accessible quarters - the north, the east, and the south. After a preliminary bombardment, Captain John Fast was to close in from the village of Lakhaend, on the north west flank of the spur; Major Kelly from the village of Karsalli, on the crest of the spur about two miles north of the fort; and Captain John Campbell from the hamlet of Asthal, on the eastern ridge near the brink of the Song river ravine. The main force with the scaling ladders, under Carpenter, and the reserve under Ludlow were to attack from the table land. 33 At daybreak on October 30 th, the 53 nd still had not arived; but the major-general, testy and impatient, ordered camp to be struck at once and moved to the advanced position, preparatory to a commencement of operations that very afternoon. At three o'clock, Carpenter's column made for the table land. It arrived at precisely five past four. The Nepalis opened a fire from the fort, but it was ill-directed and erratic, and did little damage. 34 Ludlow then followed with the reserve, and after him came the pioneers and the guns. As the guns were all comparatively light - there were two brass twelve-pounders, two six-pounders and a couple each of small mortars and howitzers - they were taken from their carriages and strapped to the 
backs of elephants. The strength and perseverance of these animals were titanic. They disliked steep or uneven ground; yet they now mounted the pathway to Kalanga carrying loads of six and even twelve hundredweight. 35 By working all through the night, the pioneers had the guns in battery by daybreak, facing the southern defences of the fort across the water course. ${ }^{36}$ Their position was the same as that occupied by Mawby's battery. Evidently Gillespie did not consider Mawby's experience worth profiting by.

At about midnight, while these preparations were going forward, Gillespie at last received news of the approach of the $53 \mathrm{rd}$, and before retiring to his tent he left orders that they were to remain in the camp for its protection. In the early hours of the morning of the 3lst, the first stages of his plan were carried out. Kelly left camp for Karsalli at two $o^{\prime}$ clock, and Fast and Campbell moved to their respective rallying points an hour later. Each had synchronized his watch with the major-general's, and all had been carefully briefed. A signal was to be fired exactly two hours before the assault, the purpose of the time lapse being to give each officer time to correct his distance from the fort - for it was anticipated that the guides might be unreliable. The signal was to be the discharge of five guns preceded by a silence of five minutes; and Gillespie, expecting a breach to be ready by noon, gave his officers to understand that they should listen for the signal at about ten o'clock. ${ }^{38}$ In his field orders he laid great stress on the importance of simultaneity in the various attacks; of compactness in the columns; of judicious use of bayonets; and, above all, of composure:

"Let emulation actuate all; but corrected by steadiness and coolness - no breakings of ranks or running for who is to be foremost in the contest - each column must be a mutual support - and every soldier actuated by the principle of cool and precipitate courage. . $^{39}$ always have the advantage over wild

Never can a man's example have belied his precepts so blatantly as Gillespie's was to do, that day.

He rose at five $0^{\prime}$ clock, and at the first glimmer of day mounted his horse and rode up to the table land. At sunrise, the guns exploded 
into action, and startled fowl spiralled upwards, in an irridescent shower. For an hour and a half the fort's southern defences were smitten with shot and shells; but by half past seven it had again become obvious that the field pieces could do little damage at so great a distance. Shot after shot either fell short, flew over the fort, or struck the stonework with too little impact to damage it. Gillespie became more and more irate. For him, futile activity was more exasperating even than no activity, and his judgement became clouded with dudgeon as he watched the artillerists striving vainly to make some impression on the paltry walls of the fort. Both guns and gunners became the objects of his anger and contempt, and the irresistible urge welled up inside him to make some gesture that would symbolize his sweeping them aside as useless impedimenta. For Gillespie only one gesture could have such meaning: the taking of Kalanga by a coup de main. He was in no mood to assess the practicability of such a measure. The ineffectiveness of $h$ is artillery merely enhanced his conception of his own capacities and fired memories of those occasions in the past when he had established his reputation as a master of the art of daring assault. Resolved to wait no longer for the guns to make an effect, he ordered the signal for the attack to be given. His officers were aghast. It was only eight o'clock, and they besought him to delay until the appointed time, urging that a breach could yet be made in the four hours remaining. But the major-general irascibly waved aside such counsel, and the prescribed discharges had to be made: three at intervals of a minute, and then two in rapid sequence. 40 This was Gillespie's first blunder of the day. The officers with the supporting columns, thinking that they did not need to pay special attention to the pattern of gun fire for another two hours, did not recognise the signal. 41

Just before nine o'clock, a party of Nepalis, which had moved out of the fort during the night to a position on the eastern end of the table land in order to harass the parties working at the batteries, moved up with the obvious intention of taking the guns in flank. In great excitement, Gillespie ordered a howitzer to be turned on them. A dose 
of grapeshot checked the party; and when charged by a group of sepoys at bayonet point, they dispersed and began to retreat. 42 To Gillespie, already devoured by feverish impatience, the retreat of this party was an irresistible cue for action. Keyed up to the pitch of impetuosity, he commanded Carpenter and Ludlow to pursue, and enter the fort on its tail. This was his second, and even more inexcusable error. Only one hour had elapsed since the firing of the signal; and even though it might have been argued that the time of the signal itself had been fixed only approximately and was liable to variation according to circumstances, the lapse of two hours between the signal and the storm was the crucial factor in the whole plan of operations. But this did not deter Gillespie, who fancied he could change the plan, even at this late hour. He sent urgent missives to the officers in charge of the supporting columns, commanding them to attack immediately. ${ }^{43}$ It was to no avail; for as luck would have it, that very contingency which the two-hour lapse had been designed to compensate had materialised, and their guides had led the supporting columns astray. Gillespie's frantic orders, though sent in duplicate by different routes, never reached their destinations. 44 It was at this stage that the major-general sent down for three companies from those of the 53 rd which had just arrived in camp. 45 Here was another capricious order which, conflicting with a previous one, failed to have the desired effect. Instructions having been left that these companies of the 53 rd were to remain in the camp for its protection, dispositions had been made accordingly. The arrival of fresh orders found the regiment quite unprepared, as well as jaded, and the officer designated to lead the detachment to the table land, Captain Wheeler Coultman, could not be found. Three companies were hastily put under arms and paraded, but for about half an hour the utmost confusion prevailed, and no move was made. Part of the summit of Kalanga spur being visible from the camp, the troops were actually the spectators of an action in which they were supposed to be taking part. 46

Once begun, that action unfolded swiftly to a half ludicrous, half tragic, climax. Carpenter's force consisted of about 600 men, including the two companies of the 53 rd which had arrived in the Dun with Mawby, 
and 50 dismounted Royal Irish Dragoons. It was supported by Ludlow's, originally 900 strong, but now reduced to 136 sepoys and 50 dragoons as a result of successive detachments made during the night. 47 The dragoons were put at the front of the combined column of attack, and it soon became obvious that this was a grave emror. They had splendid brio as they sprinted down the table land, veered sharply left to cross the water course and surged up the eastern glacis of the fort in pursuit of the retreating Nepalis; but it was a pace which the infantry, encumbered with knapsacks and muskets, and the pioneers, labouring under the scaling ladders, could not equal. The gap between the blue jackets ahead and the red behind widened ominously. When between 60 and 80 yards from the southeastem corner of the fort, the dragoons reached its surrounding palisade. This they vaulted, and chased the enemy from a cluster of huts just beyond. But now that they were almost up with their prey found themselves much too far in advance, and entirely unsupported. Nepali soldiers were swarming over the walls of the fort to lend support to their retreating comrades. Khukuris unsheathed, they engaged the oncoming dragoons in a fierce hand-to-hand struggle. The Irish cavalrymen, considerably taller than their opponents, and with sabres twice the length of their reach, lunged and lurched clumsily while the diminutive hillmen rippled like squirrels under their feet, thrusting nimbly within the point of the sabres, and parrying every swipe before it could be completed with shields bome on the left arm. These they wielded with dazzling dexterity. "There was no end to the damn pot lid", recalled one dragoon later; "no getting over, nor under, nor round about it. It was like bad luck - everywhere!" To close in with these ferocious manikins was to invite an excruciating puncture in the belly, as a great number of the dragoons discovered. Within a few minutes, 58 were lying wounded and four dead. The onslaught had been checked, and the Nepalis clambered back into the fort, ready to resist the next wave of assailants with shot, arrows and stones. The pioneers and the infantry battled their way grimly through this cascade of missiles. Lieutenant Ellis of the engineers sprangahead, to encourage thepioneers, but was shot dead while placing the first ladder against the 
wall. 49 The pioneers wavered, and then fell back in disorder to the huts, abandoning the ladders as they retreated. The infantry, headed by the two companies of the 53rd, were cruelly scathed as they advanced, and were soon forced to retreat and take cover behind the stockade. At about this time the huts caught fire. The scaling ladders were destroyed in the blaze and all means of entering the fortlost. 50

News of this check galvanised Gillespie into a state of frenetic pertinacity. Notwithstanding that there was no breach in the defences; that none of the supporting columns had made its appearance; and that the three companies of the 53 rd ordered up from the camp an hour ago still had not arrived, he refused to concede the foolhardiness of continuing the assault. It was not in his nature to abandon an enterprise without having brought it to a decisive issue; and he was so egocentric that he fancied everyone was at fault save himself. He blamed the incompetence of his artillery, the treachery of his guides, and the worthlessness of the men and officers of the 53 rd for the frustration of his intention. It cost him no self-reproach; rather it increased his self-infatuation and convinced him that he alone could succeed where all others had blundered and mismanaged. He dashed off a note to Carpenter, ${ }^{51}$ exhorting him to keep his post to the last extremity, for he intended coming up to command operations himself; and sent another furious summons to camp for the dithering three companies of the $53 \mathrm{rd} .^{52}$ Meanwhile all fire was ceased. ${ }^{53}$

It was now about ten o'clock. In the dim forest around the fort, the officers heading the supporting columns, after having led their men all through the night and morning by widely circuitous and almost impenetrable pathways at the behest of guides who were possibly incompetent, but probably treacherous, called a halt, took out their watches, and listened. For half an hour no firing was heard from the batteries; and when it recommenced there was only a confused cacophany of sound. Artillery, musketry, and some unidentifiable explosion could be heard, but nothing recognisable as the anticipated signal. Concluding that Gillespie was not yet ready to forewarn them of the assault, they adjusted their positions and waited patiently. 54 
At half past ten, Wheeler Coultman and the three companies of the 53 rd at last arrived on the table land with two horse artillery six-pounders, drawn up by the men. ${ }^{55}$ Gillespie, in a vile temper, angrily harangued them for their delay. The troops, red-eyed, sunkencheeked and swollen-footed after three days of arduous marching, and now further exhausted by a distressing journey from the camp, were shocked at this reception. They glared sullenly at the noisy little figure before them: trim and carefully manicured as ever, but now jerking like a marionette manipulated by a drunkard. Shouting that he would take the fort or be killed in the attempt, ${ }^{56}$ Gillespie ordered forward the three companies, who advanced morosely, pulling the guns by the drag ropes. They went down the table land to the point where the rodd turned left to cross the water course, proceeded down one side of the channel and up the other to the eastern glacis of the fort, where the two assaulting columns were still sheltering behind the palisade from a heavy fire. Here Gillespie and his staff came up, ${ }^{57}$ and there was a hasty council of war. One of the dragoons of Ludlow's detachment had discovered, f a gateway to the fort, ${ }^{\text {in }}$ which was ${ }^{\text {a }}$ wicket. He offered to guide the general to the spot. ${ }^{58}$ Gillespie eagerly consented; and, accompanied now by Ludlow, the three companies pressed on, leaving one of the guns at the stockade to cover the advance. They had to pick their way among the dead and wounded strewirig the ground; but the huts were still burning, and the smoke provided a screen for the movement. Turning right close under the walls of the fort, the party proceeded round to its north-eastern side. There, sure enough, was the wicket; but Bal Bahadur, expecting an attempt to force it, had left it open, and constructed barricades of stones and wood in the gap. Across this formidable obstacle appeared the menacing nozzle of a cannon. 59 Lieutenant Kennedy of the horse artillery ran on ahead to select a position for the six-pounder, which he managed to bring within 30 or 40 yards of the wicket. 60 One or two rounds were fired and they apparently crippled the enemy gun. Gillespie ordered Ludlow to lead the $53 \mathrm{rd}$ to the assault. They rushed forward. Suddenly there was a flash, a roar and a puff of smoke from the wicket, and a discharge of grape tore 
seven men to pieces and wounded many more, showering the air with blood and lumps of flesh. The troops staggered and recoiled, stunned. Ludlow tried desperately to rally them, while Gillespie sat transfixed by rage, watching them grope and flounder helplessly under an avalanche of shot, arrows, darts and stones, fired and hurled furiously from the defences by children and women as well as men. Ludlow himself was struck by a stone on the thigh. ${ }^{61}$ Then, seizing their opportunity, the Nepalis again clambered out of the fort, rushed up to the six-pounder, and with great aplomb silenced it by cutting the only sponge staff in two. ${ }^{62}$

Gillespie, finally roused from his stupor, ordered a retreat, and violently abused the troops for having failed. He seemed liable to order them to go back once more, but Ludlow hotly remonstrated, insisting that it would be futile to attack again in front. He suggested that the gun might instead betaken in flank, by moving a column obliquely to it, on a line outside the angle of its bearing. Gillespie's reaction was not coherent: but Ludlow saw that he "seemed to approve". The two companies of the 53 rd which had formed part of Carpenter's column had by now arrived from the stockade, and Gillespie ordered Ludlow to lead them down the right flank of the gun while he formed a second detachment to send in from the left. The major mustered his men: but they had already seen too much of the punishment inflicted on their comrades; had already been too long exposed themselves; and detested Rollo Gillespie too intensely to act with any enthusiasm or confidence. To his dismay, Ludlow saw that they had no sooner moved than they edged farther to their right, into the shelter of a depression in the ground. Rather than interrupt the elan of the advance, he tried to accommodate the deviation by inclining with them: but there was no preserving the momentum of the charge. The men had ducked into the depression and started sniping. When Ludlow neared the wicket, he had only four soldiers with him. He turned and pleaded with the others, crying out that if only eight men more would come on he would enter the fort; but he was ignored. "I addressed a serjeant, which was the only person of authority I found in advance," he recalled, "but he turned a deaf ear to all I could say." He was convinced that this 
attempt could have been successful, because the vigour of the defenders' resistance now seemed to be slackening. The men of the 53 rd stubbornly spurned their opportunity. Like the army of the Roman consul Appius, they had determined to destroy their general - even, if necessary, at the price of destroying themselves. The vainglorious martinet was in their power, and they were resolved to have revenge for the long tortures they had suffered on a cauterized parade ground, under the molten suns of Meerut; and for the reckless prodigality with which he now seemed disposed to squander the lives of others to retrieve his own reputation. Only now was it apparent how execrated Gillespie was.

When the major-general witnessed their dogged refusal to follow Ludlow, he went berserk. He had cheated danger so often, that he had come to contemn it, and had lost awareness of his own destructibility. There was no antidote to counteract the impulse of rage and despair. Screaming at the men, he drew his sword and dashed forward into the torrent of fire. A musket ball struck him in the chest, and brought him to the ground. Then he died, before he could utter another word. Lieutenant O'Hara, Ludlow's adjutant, fell almost at the same time; and Captain Byers, Gillespie's aide-de-camp, was wounded in the leg. Both these officers had rushed after the major-general - though whether to support him or restrain him is not clear. 63

It was just before $11.15 .^{64} \mathrm{~A}$ short distance away, in the forest to the rear, Captain John Campbell was at the village of Asthall, still waiting for the signal gun. For some time he had heard confused firing, but, remembering Gillespie's emphatic injunctions, dared not move in anticipation of his cue. He grew increasingly uneasy, however, as the sounds of commotion continued and the signal still was not fired; and finally, fearing that there had been some mistake, decided to advance. He arrived on the scene of action just as Ludlow was giving the order to retire; and if a few minutes too late to be of any use to Gillespie, was at least able to cover the retreat and bring down the gun, which was in danger of being lost. 66

The command now devolved on Mawby, who immediately withdrew the army from the hill, resolved to relinquish all plans for a further attack 
until he had heavy battering ordnance. The most immediate task now was to assess the losses. Bal Bahadur granted permission for the dead and wounded to be brought down from the hill: but many of the corpses had already been stripped of their clothing and were horribly mutilated. 67 When the reckoning was complete, it appeared that of the European officers 5 had been killed, and 18 wounded; of the men and native officers, 30 killed and 210 wounded. 68

Gillespie's body was preserved in spirits, and at four o'clock on the morning of November lst, a small cortege bore it down to Meerut. On November 6 th it was interred with full military honours, and minute guns, one for each year of his life, thundered out at Calcutta. But he was not really lamented. The officers of the $53 \mathrm{rd}$, not surprisingly, were frankly glad that he had gone. "It is the general opinion here", wrote Henry Sherwood, Paymaster to the regiment, "that Gillespie's death has saved the army... As long as he had lived, the Europeans would have remained unresisting to be killed." 69 In Meerut, the ladies could hardly keep from giggling at his funeral, so tickling was the idea of his having been lain in spirits - "a pickle when alive, and a preserve when dead!"70 Sic transit gloria mundi:

When Hastings received news of the disaster, his immediate reaction was to blame Gillespie. "That he should have made so rash an attack is astonishing", he wrote in his journal. Even while making suitably decent acknowledgement of Gillespie's merits, he could not disguise a surge of irritation at the thought of "the discredit to our arms and the baneful influence which this reverse must have upon the future operations" especially as it had apparently been caused by the very impetuosity against which he had so earnestly cautioned the major-general. ${ }^{71}$ on November 10 th, he wrote to Lord Bathurst:

"The good fortune which had attended him in former desperate enterprises induced him to believe, I fear, that the storm of the fortress of Kalanga might be achieved by the same daring valour and readiness of resource whereby he had on other occasions triumphed over obstacles apparently insuperable.

The assault, in which he was killed at the foot of the rampart, involved, as I conceived, no possibility of success; otherwise the courage of the soldiers would have carried the plan notwithstanding the determined resistance of the garrison." 72 
Suchwas the obvious interpretation of the evidence available to Hastings at this stage - that is, his own knowledge of Gillespie's character, and the official despatch submitted by Mawby. Information in the despatch was incomplete, because Mawby had not been a witness of the final assault, Gillespie having ordered him to remain on the table land to receive yet another two companies of the $53 \mathrm{rdsummoned}$ from camp. ${ }^{73}$ In subsequent weeks, Hastings received private accounts of the day's events. His principal informants were Captain John Sparks Byers, of the Royal Artillery, who had been Gillespie's A.D.C., and John Ludlow. Byers had seen the perfidy of the $53 \mathrm{rd}$, and was never likely to forget it. Mawby unsuspectingly referred the Governor General to him for further information, and Byers was soon on his way from Saharanpur (whither he had gone to recuperate from his leg wound) to Headquarters, at Lucknow. ${ }^{74}$ John Ludlow was an intimate of George Fagan, the Adjutant-General, and there is no doubt that through Fagan he made known at Headquarters his own version of events - especially as he knew the official account to be deficient. ${ }^{75}$ When Hastings had heard these reports, his assessment changed, and his high opinion of the $53 \mathrm{rd}$ became transformed into disgust. Henceforth that regiment and its commanding officer, Colonel Mawby, were, as far as he was concerned, on trial. Should they fail or falter again, he was not likely to be indulgent. Rather, he would welcome the opportunity to publicly withdraw the credit he had given them for their courage and vindicate the maligned Gillespie at their expense.

Sebright Mawby was a graduate of the Royal Irish Regiment of Foot: handsome, courteous, brave and experienced. He had served with the 53rd since 1804, when he had been appointed I ieutenant-colonel in that regiment, and had commanded the first battalion during all its ten years' service in India. ${ }^{76}$ That the men esteemed him well enough to follow him even on the most daunting service had been proved by their outstanding behaviour at the storm of Kalinjar in 1812. As a result of this the Governor General had commended the "exemplary exertions, zeal and persevering courage manifested by Lieutenant-Colonel Mawby and the brave officers and men acting under his command." 77 Mawby himself had not had words enough to praise the battalion - "anything he could say on the occasion 
would fall very short of what they deserved, for greater bravery and perseverence never were displayed by men..."78 Mrs. Sherwood, an astute judge of character, always wrote of the colonel and his wife in terms of respect and affection. But the misbehaviour of his regiment at Kalanga naturally reflected on him and his fellow officers, earning them the mistrust and contempt of Company officers like Ludlow, in whose view the King's regiment had betrayed Gillespie and cheated him of the victory he had coveted and deserved. The incident thus served to precipitate the always latent antagonism between King's and Company's officers; and as the campaign proceeded the rift between the two cadres widened until the harmony of the camp was destroyed. In the field, the King's officers, were the dominant group; but the Company's officers had their friends at Headquarters, and by dint of their influence won the sympathy of Hastings. The King's officers soon began to feel that the Governor General was blatantly prejudiced in favour of the native army, and uncharitably vindictive towards Mawby and his regiment. Like that of Julius Caesar, Gillespie's disruptive ghost long brooded unexorcised in the army of his assassins.

Mawby decided to withdraw the camp to a position about a mile and a half in advance of Dehra. He considered that Gillespie's ground, wild and jungly, gave the enemy too many opportunities for ambuscades and night attacks. He also felt compelled to abandon attempts to straiten the fort, because his force was becoming much reduced. News from Lieutenant Lockhart, in command at Kalsi, making him fear for the security of the Jumna ghats, he sent Carpenter there with six companies of sepoys; and a fortnight later, on November 16th, four more companies of light infantry followed. ${ }^{79}$ These detachments, in addition to the battle casualties, reduced Mawby's force by over 1,000 men. The loss of European officers, moreover, had been disproportionately great, and it was impossible to spare even one for the detachment at the Timli pass. Further acquaintance only revealed the great natural strength of the fort. Its water wells were on the glacis itself, almost directly under the walls; and the spur on which it stood, as well as being covered with dense vegatation, was nearly 15 miles in circumference. ${ }^{80}$ The British had 
no maps to speak of, and only the briefest acquaintance with the locality. Furthermore, that assistance from the local populace on which Hastings had taught his officers to reckon, had in the event proved unforthcoming. Dehra Dun itself was virtually deserted - Ludlow affirmed he had never seen a country so devoid of population ${ }^{81}$ - and all the efforts of William Fraser, the Political Agent, to arouse the zemindars of the northern regions of Garhwal had proved abortive. Deprived of their arms and cowed by the threat of Gurkha reprisals, the inhabitants had chosen to await the result of the operations at Kalanga before committing themselves to the British cause. The ensuing fiasco had obviously done nothing to banish their diffidence, and Nepali foraging parties could still roam the northern areas without harassment. Fraser had had the idea of compensating for the lack of spontaneous local support by organising a corps of partisans, including "people employed as guides, deserters from the enemy, and mountaineers volunteering their services." But recruitment was slow, and by the end of November not enough men had been collected even to police the Dun and collect its revenues. 82

Labouring under these disadvantages, Mawby felt inclined to do nothing until the arrival of his heavy guns from Delhi. But Headquarters was not sympathetic, and let it be known that some show of activity was expected. In consequence, on November 15th, a rather feeble attempt was made to occupy the Buddhraj mountain, an eminence in the range which bounded the north of Dehra Dun, to the west of modern Mussoorie. A post of four companies was maintained there for a few days, but it experienced difficulty in obtaining provisions, and Mawby, alarmed by a couple of daring night raids which the Nepalis had made on his convoys, had the detachment recalled on the 2 lst. 83 Despite a certain boredom, spirits in camp remained high. No-one seriously doubted that the campaign in the Dun would be brought to a swift and unequivocal conclusion once the battering guns had arrived, and meanwhile the army basked in the lingering warmth of a mild autumn. The salt provisions failed; but this was more a blessing than otherwise, for the slaughter of cattle was authorised, and the Europeans enjoyed the rare luxury of fresh meat. There were besides game, fruit, and nuts in plenty. 84 
On November 24 th the battering train at last arrived - four eighteen-pounders, and two eight-inch mortars, with their details of artillerists. With it came the extra battalion of native infantry which Hastings had promised Gillespie, two more companies of light infantry, and the remainder of Carpenter's battalion (the 1st/17th Native Infantry), which had been left at Meerut for its protection. ${ }^{85}$ Mawby now put into operation his plan for a third assault on the fort of Kalanga.

Early on November 25th he deployed troops around the fort to prevent the escape of the garrison. Ludlow was s ent with a force to the tableland, Major Baldock to the watercourse on his right, Captain Bucke to Lakhaend, and Captain Coultman to Asthal village. ${ }^{86}$ The tents in the camp were left standing in order to confuse the enemy. The guns in the fort fired on Ludlow's detachment as it ascended to the table land, but again, did little damage. ${ }^{87}$ This time, the main column ignored the main road, and pushed round the skirt of the spur, in the direction of the Song river, to mount its south eastern flank. The way was longer and much more difficult than the road, but entirely out of sight of the fort. The column then proceeded along the eastern ridge, and encamped under Kalanga village, about a mile north east of the fort on a level some 500 feet below it. Here its rear was protected by the majestic ravine of the Song. "From the camp", wrote Sherwood, "I the river T seems like a narrow blue line running through a yellow bed. It cannot be less than 600 feet below..." 88 Captain Carmichael Smyth, the engineer sent to replace the wounded Ensign Blane, had, after a careful reconnaissance, wisely decided to abandon the table land as a position for the batteries. By approaching from the north east, the guns could be pushed much nearer the fort, for the natural barrier of the water course was only about 200 yards distant from the eastern walls. If he could but get the guns from the new camp up to the watercourse - a distance of nearly a mile, all uphill - the old difficulty concerning aim and impact would be eliminated. ${ }^{89}$ The main task now, therefore, was to clear the eastern approaches of the fort. This was done with great promptitude by a small advance guard composed of men of the 53rd under Captain Parker. By four 
in the afternoon, they had moved to within 250 yards of the north eastern aspect of the fort, where they established themselves in a few huts. There was a square stockade about 300 yards to their right, which had to be taken, because it commanded the spot selected for the batteries. Parker sent down for a howitzer, and as soon as it arrived, fired a few shells. By good luck, one of them burst directly over the stockade, forcing its occupants to flee. Captain Stone immediately took possession. 90

Throughout the night of the 25th, Carmichael Smyth supervised the construction of batteries about 250 yards from the fort, while working parties coaxed up the ordnance pieces. The heavy howitzers and two twelve pounders were placed in position during the night; and at seven the next morning the four eighteen-pounders loomed impressively into view, like primitive idols drawn in monstrous state by hundreds of human votaries. All the morning was spent manipulating them into position, and at noon they opened fire with pounding explosion, joining a deep bass counterpoint to the crepitation of the lighter pieces. For nineteen hours this awesome chorus continued. Every natural sound was drowned, and the hill enveloped in acrid smoke. Eighteen-pound cannon balls tore one after another into the flank of the fort, and shells and grapeshot were showered into its interior. Even at this range, many shells missed the small enclosure, but sufficient found their target to bring the garrison to the limit of endurance. At about four in the afternoon of the $26 \mathrm{th}$, the Nepalis made an unsuccessful attempt to sally from the fort; and during the night Bal Bahadur Singh offered terms, which Mawby rejected. At seven the next morning, the Gurkha commander sent another message but still he refused to concede to the full limit of Mawby's demands. ${ }^{2}$ So the cannonade continued. By one o'clock that day (the 27th), nearly six tons of eighteen-pound shot alone had been discharged at the small fort, and Captain-Lieutenant Battine, commanding the artillery, and Carmichael Smyth reported to Mawby that the breach was ready. The colonel examined the gap in the defences through his glass. It looked wide, and the slope up to it was gentle. He had no doubt that the moment to storm had come. Major Ingleby of the $53 \mathrm{rd}$ was to command the storming party. The grenadiers of the $53 \mathrm{rd}$ were to lead, followed first by a battalion 
company of the same regiment and then by the grenadier companies of the native battalions. All were instructed to move with muskets unloaded, and to carry the breach with the bayonet. Equal divisions of the light company of the 53 rd were to move up on both sides of the column and slightly in advance, with their pieces loaded. Their task was to cover the advance of the storming party, and pick off defenders in the breach or on the walls. 93

Ingleby did not get far. He was wounded early in the action and forced to withdraw. Captain Parker took his place at the head of the 53rd grandiers. 94 Once they had crossed the water course, the ascent of 200 yards or so up the eastern glacis was easy, and within a few minutes Parker and his men were below the great gash in the fort's stone wall. They clambered over the debris as far as the breach, and then halted in consternation and horror. The breach was cut high in the parapet of the fort's defences, and by scooping out the rampart behind, the enemy had made a drop of about five feet. The surface of the pitted rampart was thickly planted with sharpened stakes. Behind these was another sharp drop, for the body of the fort was sunk like a gravel pit into the rock, where Nepalis crouched with spears and muskets, ready to repel all intruders. It seemed that if anyone leapt down, he was bound first to impale himself, and then be shot or stabbed, while floundering helplessly. In their brief moment of hesitation, all the grenadiers who had mounted the breach were either killed or wounded, and Parker drew back to wam the others. Lieutenant Harrington was just behind him, and, not realising why he faltered, savagely elbowed Parker aside, determined to save the impulse of the charge. Parker caught him by the sash.

"It's useless! We can't get in."

"I must go!" Harrington tugged himself free. But he was too late. The rest of thestorming party, seeing the unexplained disconcertment of the European grenadiers, had slowed their advance, and hung back. The momentum was lost. Harrington, in a defiant effort to re-animate the men, drew his sword and clambered onto the breach. He in his turn stopped short, as he saw what it was that had checked the grenadiers. Turning, he ran along the whole width of the breach looking for a point 
of entry and then, facing the men, was seen to raise his hands in a gesture of hopelessness. A second later he was shot in the back. ${ }^{95}$

Scores of defenders now strafed the glacis with bullets, stones and arrows, but the Europeans kept formation and did not turn. In contravention of their instructions they loaded their muskets and began returning the fire. 96 The sepoys, who dreaded arrows even more than musket balls, which at least could not be seen, readily followed their example. All movement ceased, and the operation degenerated into a sniping contest. There was little cover on the glacis, and casualties were heavy. Dejection and apathy took a hold on all the troops. One eager young subaltern of the $53 \mathrm{rd}$, still not aware of what was causing the stoppage, called out irritably to his men "Go on, my boys, go on!" "Go on yourself, and we will follow you," was the surly rejoinder. The superstitious Huslims ascribed dark significance to a third failure; and one group of native grenadiers, those of the 1st/6th Native Infantry, suffered a deeply afflicting loss. Captain John Campbell, a stalwart of six feet three, the most popular officer in the regiment, the hero of his men and the favourite of Ludlow, his commanding officer, was shot as he stood on the glacis after surviving the storm. An arrow entered deep into his chest, and he collapsed, racked with anguish. Long after, one of his sepoys still remembered how the surgeon gravely shook his head, and said that on account of its broad point the arrow could not be removed; how, in his agony, Campbell wrenched it out himself, so that blood frothed out of the wound; how they carried him down; and how the whole battalion became pervaded by an ineffable sorrow. "I never expected to see my Captain Saheb recover. He was so loved by the men of his own company and in the Regiment was such a great favourite, that his absence was hard to bear. The regiment had lost its champion. [Campbell_T Saheb was sent to England." 98 Campbell in fact died. "How deeply do I deplore his loss", sighed Ludlow. "Ending sure, the poor fellow preserved his wonted goodhumoured smile to the last and uttered fine kind thanks to the friends he was parting from. Alas! Poor Campbell..."

Mawby, not realising that the reluctance of the troops was caused by something more than the determined resistance of the defenders, 
ordered Lieutenant-Colonel Buckland to take the remaining companies of the 53 rd to reinforce the storming party. He gave strict orders that they were to ascend to the breach without firing a shot. ${ }^{100}$ Reeling under a pelting hail of missiles of every description as they neared the fort, only a few of the fresh detachment managed to mount the breach and return; and they too pronounced the descent to be impracticable, having glimpsed what appeared to be a veritable forest of pointed bamboos and spears bristling below them. Just before three o"clock, Buckland sent a message to Mawby to say that if a twelve-pounder and a howitzer could be brought nearer the breach, something might be done. Presumably his intention was to clear the breach of defenders and make it lower, so that the men could get onto the rampart behind. In great haste, two pieces were taken out of the battery and conducted across the water course and up to the glacis by Lieutenant Luxford of the horse artillery. The howitzer was brought to the foot of the breach itself, but before it could even be fired Luxford had been fatally wounded, and eleven of his men either killed or disabled. ${ }^{101}$ By now, the nature of the difficulties had been explained to the colonel, who was mortified to think that he had kept the troops futilely exposed for close on two houns. His immediate concern was to prevent further useless waste of life, and he ordered a retreat, only regretting that he had not done so earlier. He had no complaint to make concerning the conduct of the army. On the contrary, he warmly praised "the great gallantry of men who were exposed till 3 $o^{\prime}$ clock to a most galling fire of musketry and matchlocks...showers of stones, spears, and arrows."

It was now felt that the only resource left was to continue the batteries open until the whole eastern face of the fort had been rased. 700 rounds of eighteen-pound shot had been expended, and only 500 remained. To husband the supply, the bombardment was continued at a slower rhythm. ${ }^{102}$ Meanwhile, the losses were counted. Four officers had been killed, and seven wounded. Of the men and native officers, 36 were dead, and 431 wounded. This made a total of 478 casualties, of which almost half had been sustained by the $53 \mathrm{rd} .^{103}$ Losses for both attacks amounted to nearly 750 , which was appalling, because the total number of enemy did 
not exceed 600 . 13 bodies were retrieved on the morning of November 28th, with Bal Bahadur's permission. They had again been horribly mutilated. Harrington's had both legs tom from the trunk. 104

The guns thumped on, and by nightfall on the 29th had done so much damage to the masonry before them, that there was nothing left for them to aim at. They were therefore silenced at last, preparatory to being moved in front of a fresh target, further to the left. ${ }^{105}$ Work was begun on a new battery; but the night had events in store which were to make its use unnecessary. 106

At about two o'clock in the morning, there was a sudden clatter of musket fire as Captain Bucke, guarding the wells on the southern glacis, was attacked by a party of the garrison which had crept out, apparently desperate for water. They did not reach the wells. Bucke's men returned the fire, and drove them back into the fort. All was silent for about half an hour; then, at about three o'clock, another, larger party streamed out of the breach and made towards the southern glacis. This time they were obviously intent on escaping, under cover of the jungly water course. Ludlow was roused, and went to give support to Bucke's party, forming the left of his own position on the table land; but by the time he had arrived, the affair was almost over. A large number of Nepalis had been killed, wounded, and captured, and only a small group of about 70 had escaped. 107 Major Kelly, commanding in the trenches before the battery, listened for sounds of movement in the fort: but nothing stirred. He ordered forward a force of grenadiers, who advanced cautiously, for it was a known ruse of the Gurkhas to inveigle theirvictims into a position by inducing them to think it abandoned. But an impatient drummer boy ran forward to the breach ahead of all the others. He peered into the dark interior, then turned round crying that the fort was empty (kali: kali!). The men began shouting and cheering, and the drums beat out the grenadiers' march. ${ }^{108}$ Kelly then entered the fort and took possession. It was four $0^{\prime}$ clock on the moming of November 30 th. 109

The inside was still dark, but the sickening stench and the terrible moaning forewarned the victors of the scale of their destruction and the 
price of the garrison's defiance. Lights were brought, and they gazed in horror on a miniature Golgotha. They had to enter carefully, for fear of treading on the dead and dying. Henry Sherwood was one of the first to visit the fort, and he was overcome with

nausea and compassion.

"The fort was very small, and the whole place covered with bodies," he wrote. "On my right in a small redoubt were two small brass guns; one of them in a space not above ten feet long and six feet broad, and there lay seven bodies across each other. In going from one enclosure to another (for the place seemed all small enclosures) the same kind of objects appeared. Within the body of the fort we heard groans and cries of "Pani! Pani!" ("Water! Water!") and on descending, never was anything so shocking. The fort itself was trenched across in every direction, and these tenches were about two feet deep; in them the unhappy people had endeavouredto find shelter. There were 86 dead bodies lying in this small place. The wounded were in a most wretched state. Those who could in any way move had attempted to get out: but others were calling for water, and our officers were assisting, as well as they could, by pouring water out to them. Some of the poor creatures had lain there for three days with their limbs broken. I shall never forget one young woman with a broken leg, lying among the dead. She was partly covered or entangled among dead bodies, and as she could not move, she held her mouth open for water so anxiously that there is no describing it. We could not get near her, but Heathcote poured water at her mouth from a distance, which she received. There was another woman, herself unhurt, but she had a wounded baby at her breast. She seemed dreadfully distressed, but the child was taking its food, and did not seem to mind it. There was a soldier-like looking Gurkha also lying on a bed in the fort. His wound had been in his head, and had taken away his senses. He was making figures in the bloody dust with his fingers. The most affecting sight was two little girls, one about four years old, the other about one. Their father and mother had both been killed. They were both taken care of, but the elder screaming very much, fearing she shoudd be separated from the younger.

When I again visited the fort, it was partially cleared. 97 dead bodies had been burnt, but this was only a part, for all around the fort you might see the marks of imperfect burials. The ground was rocky, and it was difficult to dig into it, so that I could still count 30 bodies lying only half buried, in many cases having a leg or an arm above the ground. is. "II0

This day I saw the horrors of war; and indeed, horrible it 
In Mawby, already worn out and depressed by events of the previous few days, this nightmarish spectacle produced an equally strong reaction, and it was all he could do to pick up his pen to report to Headquarters. ${ }^{111}$ According to Sherwood, Kalanga could never have been captured. "I do not see how it is possible to take such places, if properly defended; for although you knock down the wall, yet the body of the fort being sunk within the rock is not to be destroyed; and of the shells very few entered the fort, although it seems to be the fashion to say otherwise." 112 John Ludlow disagreed.

"Thank God", he wrote, "the place is ours on almost easy terms; for after seeing the interior...I'm persuaded that our army, or rather the eastern part of it, never would have taken it - though I declare to God that I saw no obstacles which ought to have deterred brave men from getting in."ll3

The informant of the Calcutta Monthly Joumal reported that "the physical obstacles at the breach were found on examination to be less formidable than had been supposed." 114 There is no doubt as to which opinion weighed most with Hastings. In his view Kalanga was "a place certainly of no great strength or extent, destitute of a ditch, laid open by a breach up which a carriage might have been driven, and defended by a garrison whose only means of resistance consisted in their personal gallantry."115 The failure of a third assault against the place evoked his wrath and indignation, and the whole weight of it fell on the head of Colonel Mawby and the 53rd.

The Governor General's judgement was inferred from two premises. The first was that the failure of the second attempt was caused not, as thought at first, by the temerity of Gillespie, but by the delinquency of the 53 rd Regiment. In this, it must be admitted, there was a substance of truth. The second premis, was that the breach had been practicable on November 27th; and from the two he deduced that the participation of the 53 rd was the common cause linking both failures. But the second assumption was notsound. It was based on the information of private advisers, of whom Ludlow was undoubtedly one, and it must be remembered that no-one except the officers and men of the $53 \mathrm{rd}$ had been in a position 
to examine the breach at the time of the storm. All subsequent inspections, including Ludlow's, had taken place three days later, under circumstances quite different from those experienced by the assaulting party, and when the breach had been considerably enlarged by a further 500 rounds of eighteen-pound shot. All things considered, it seems reasonable to assume that on November 27th entry into the fort had been as impracticable as those who looked into the breach maintained. But the Governor General was not feeling reasonable. A letter which he wrote to the Prince Regent's Private Secretary in January, 1815, makes it quite clear how his assessment of the $53 \mathrm{rd}$ 's behaviour in the second assault had changed; and how his new knowledge of that event, taking in conjunction with reports concerning the state of the breach on November 27 th, made him oblivious of the probability that the presence of the $53 \mathrm{rd}$ at both failures was no more than circumstantial.

"...part of the troops who had behaved remarkably ill I in the second attempt $\bar{T}$ ", he wrote, "vindicated their shyness by expatiating on the unexampled courage shown by the enemy - as if there were any peculiar degree of valour in the continuing on the top of a high rampart when the assailant has not the possibility of getting at you. This opinion of the enemy became so current, that when the $\Gamma$ third $T$ assault took place, or rather was ordered, there was no getting the soldiers to follow their
officers to a breach up which a coach might have been driven."

No names are mentioned here; but there were no doubts in the Horse Guards concerning the identity of the culprits.

"I am sorry to hear so bad an account of the $53 \mathrm{rd}$ ", wrote Sir Henry Torrens, Private Secretary to the Duke of York, * in a letter to Hastings later the same year. "The Duke was very partial to this corps - and he is convinced that their misconduct is entirely owing to the apathy and worthlessness, as an officer, of Colonel Mawby. It will not be easy to prevent this officer from experiencing the ill-effects of your report, tho' you so kindly endeavour to qualify it."ll7

Hastings prided himself on his chivalry, and his indignation against the 53 rd was so much the greater because he had inadvertently blamed the dead and defenceless Gillespie for the failure of October 3lst.

*ommander in Chief of the British Army. 
To redeem his injustice, he now began to emphasize Gillespie's positive qualities. "Had he survived", he wrote, "he would have prevented his division from duping itself into fear." 118 He announced his intention of erecting a cenotaph in memory of the major-general, ${ }^{119}$ and his attitude towards Raffles, whose charges against Gillespie he had been investigating, became virulently hostile. It was discovered that Raffles, before making his charges against Gillespie, had actually received a report from the Resident at Samarang which apparently cleared the major-general of one of the charges of abduction, at least. This incensed Hastings, who told Raffles: "You appear to have given currency to a gross charge against a meritorious and highly esteemed officer when, as far as appeans, you had the means of refutation in your power." He demanded an explanation. 120

But it was not only from a concern to rectify an unfair traducement that Hastings defended the integrity and propagated the celebrity of the dead major-general. He had reasons of state, too. At the time of his death Gillespie had become a patriotic symbol. In recognition of his exploits in Java he had, in January 1815 , been gazetted Knight commander of the Bath; and when the news of his death reached England it became the occasion of various poetic tributes in the Byronic style; of a vote in Parliament for a monument in St. Paul's; and of a biographical panegyric dedicated to the Prince Regent as "the history of a soldier whose VALOUR could only be surpassed by his LOYALTY, and who closed his career of labour and glory by devoting himself at the moment of perilous extremity as an example to inspirit his troops." 121 Hastings must have been acutely aware that if Gillespie's reputation were posthumously sullied, the Prince Regent would be ridiculed, the Etat Major both in India and at home made an object of derision, and the dignity of the British administration in India compromised.

Raffles was difficult to hold at bay. He refused to withdraw his accusations, pointing out that the report of the Resident at Samarang related only to the first charge of abduction, and was in any case not exhaustive enough to warrant the conclusion that even that charge was unfounded. On the matter of the second charge, he did not more than refer the Governor General to the records of the Bench of Magistrates for 
confirmation of the fact that a slave girl had been forcibly removed from Mr. Shuyster's house and transferred to Gillespie's. Hastings refused to admit that Raffles' explanations were satisfactory; ${ }^{122}$ but as both he and the calcutta council had publicly acknowledged that Gillespie's indictment of Raffles had been totally unjustified, ${ }^{123}$ the latter had no further personal motive for pressing a case against his dead antagonist, and was content to forget the whole sordid affair. If his private character had not exactly been retrieved, Hastings was now sure that Gillespie's professional aptitude, a subject of doubt after the second failure at Kalanga, could be vindicated. Probably it was with the intention of rendering this service, as well as of castigating the 53 rd for their having sabotaged such an important operation, that he took the rash step of announcing that a court of enquiry would be set up to examine the causes of the failures at Kalanga. ${ }^{124}$ Despite the general terms of its commission, it became commonly known that the object of this court was to investigate the conduct of Colonel Mawby and the $53 \mathrm{rd} .{ }^{125}$ No official censure could be pronounced until the court's findings were known; but Hastings disguised his own sentiments so ill, and conducted the whole affair in such a way, that innuendo and gossip had achieved the destruction of the reputation of the $53 \mathrm{rd}$ even before the court had convened. Gillespie, meanwhile, became exalted as a hero. "The gallant Gillespie would, I am sure, have carried everything, had he not been deserted by a set of cowardly wretches", wrote Charles Metcalfe in June, 1815 , expressing a sentiment which had become widespread. ${ }^{126}$

The officers of the regiment, recalling its sacrifices at the seige of Kalinjar in 1812, the vainglorious selfishness of the man its reputation was being sacrificed to vindicate, and the heavy losses and adverse circumstances attending the third assault on Kalanga; and experiencing the undissembled hostility of a Governor General who was flagrantly prejudging an issue he had avowedly instituted a court to investigate, not unnaturally became embittered and resentful. Knowing that however well they might acquit themselves in subsequent operations they would still in the end be subjected to a degrading scrutiny, their 
mood of enthusiasm for the present service gave place to one of apathy and inhibition. For the debâcle which followed from this collapse of morale, Hastings had only his own persecution of the regiment to blame. For some days previous to the evacuation of Kalanga, a body of about 300 Nepalis had been seen moving about the hills on the other side of the Song river, and were assumed to be a reinforcement sent to the fort from Nahan. Mawby's concern after the flight of Bal Bahadur was to prevent his junction with this party. On the afternoon of November 30 th, intelligence was received that the 70-odd fugitives from Kalanga were on a hill to the rear of the fort, some five or six miles distant, near the source of the Nalapani water course. Two parties were immediately despatched, one from the camp and one from the table land, to converge on them. The columns met as planned, but found no sign of Bal Bahadur's party. After a fruitless search, they returned to camp on the following morning.

Mawby then suggested to Ludlow that he continue the search. He forbore to order him to do so, because he appreciated that he must be worn out after the exertions of the previous few days. But Ludlow, one of the most energetic and enterprising officers in the Company's service, readily agreed to go. At half past two that same afternoon (December lst), he set off with a party of about 450 light infantry sepoys, striking northwards up the ridge. They arrived back in camp at nine o'clock the next morning, dusty, tired, and with lacerated feet; but triumphant. They carried two captured stands of colours - a trophy with which Mawby was "mightily pleased". After crossing the gorge of the Baldi river, and clambering up a shrunken track with deep void on either side, thry had descried the enemy camp fires by night, when the land was surrealistic in moonlight. A short sharp raid with bayonets, by a courageous vanguard of three officers and $100 \mathrm{men}$, had been sufficient to disperse the unsuspecting Nepalis, and Ludlow estimated that about 60 must have been killed. His own casualties were no more than four seriously wounded. 127

This little victory, the work of the native troops and their officers alone, coming so soon after the humiliating setbacks at 
Kalanga, served to strengthen Hastings' conviction that the King's troops had so far set a harmful rather than a salutary example to the sepoys. To underline the point, the Adjutant General was commanded to remark that it was "particularly gratifying to the commander in Chief to observe that in this affair, the first which / had_T taken place between our sepoys and the Gurkhas since the defence of Kalanga by the latter, our native infantry, animated by the example and under the guidance of the European officers, I had T maintained their accustomed superiority in close combat [with_ $\bar{T}$ an enemy of determined courage." Mawby was instructed to offer the Commander in Chief's thanks to the officers concerned, and to make a gratuity of 100 rupees to Guru Singh, Ludlow's intrepid spy. ${ }^{128}$

Although considerably weakened, the Nepali band was still at large in the hills north east of Dehra Dun, and the zemindars in contact with Fraser soon made it known that it had retreated through Saklayana district, plundering as it went, and taken post in the strong fort of Chamur, situated on the west bank of the Baghirati river. Here it was joined by another group, this time from Srinagar, which swelled its number to 400 . Fraser urged that if the inhabitants of interior Garhwal were to be encouraged to assist the British, this enemy eyrie would have to be captured, for it overawed all the eastern section of the province. Hastings, however, was anxious for the main force to push westwards into Sirmur, to reduce Nahan, now that the essential part of its work in Dehra Dun had been accomplished. The occupation of Kalanga had been followed by the enemy's evacuation of Birat, the strong fort just to the north of Carpenter's position at Kalsi. According to Fraser, the decisive influence in this surrender had been the defection of the principal zemindars and the resistance of the local populace; according to Major Kelly, who had arrived there from Kalanga with a howitzer and two mortars just before the place was abandoned, it had been the sight of the British ordnance; but whatever the reason, its relinquishment by the enemy had completed the British domination of the central section of the line of communication between the eastern and western sections of the Gurkha 
empire, ${ }^{130}$ and letters subsequently intercepted at Birat revealed that the operation had been completed none too soon. Ranjor Singh Thapa, commanding at Nahan, was expecting a reinforcement of two or three hundred men from the east by way of Srinagar, which was an important magazine for the manufacture and deposit of military stores. ${ }^{131}$ The garrison of Birat had, unfortunately, also escaped into the hills, and it was expected that it too would make its way to Chamur. But Hastings felt that the reduction of this place could safely be left to Carpenter, appointed to command the Dun occupationary force. He was to be assisted by all the irregulars that Fraser could spare; and the Political Agent was authorised to increase the levy of these auxiliaries as far as he thought expedient. ${ }^{132}$ Mawby was now ordered to take the main army to Nahan - but not by way of the Kayarda Valley. It was thought that this route would prove too obstructed, and he was directed to use the road along the foot of the hills instead, One of his last tasks in the Dun was to supervise the destruction of Kalanga fort. ${ }^{133}$ True to his instructions, Mawby had every vestige of the place erased; but with all his gunpowder he had no power to destroy the baneful influence which that inauspicious fortress was yet to exercise over his career.

The army, which had moved back to its old camping ground near Dehra on December 3rd, now began to make preparations for a move. On the 6 th, the heavy guns and field artillery left camp; but before the rest of the force could follow, the dry autumnal warmth gave place to cold persistent rain, which fell as snow on the nearest range of hills. For two days Mawby delayed his departure, hoping for better conditions; but by the 9 th there was still no sign of an improvement, and instructions from Headquarters being so peremptory, he decided he could wait no longer. The troops marched at seven that morning, up to their knees in mud as they passed through Dehra. Labouring under the weight of sodden tents, the camels slipped and slid uncontrollably. Progress towards the Timli Pass was slow and uncomfortable. The route lay westwards, through the northern sector of the valley to Sahanspur on the Asan river. Here the army turned south, and on December 10th crossed the Asan, which by now had about a foot and a half of water in its bed. Thereafter the road began 
to climb, and on the evening of the 10th camp was pitched on high ground near the defile in the grass - "a jungle about five feet high and very wet". The whole of the next day was occupied in manoeuvring the pass itself, which was thirteen miles long. Happily, the road had been repaired for the preceding artillery, and by one o'clock the main part of the force had at last quitted the territory of Garhwal and arrived in Company territory once more, at Fyzabad, on the plains.

Here junction was made with the artillery train, and the whole force (save the horse artillery and two of the eighteen-pounders, sent back to Delhi) trailed ponderously down the eastern bank of the Jumna, hoping to ford it at Nanauli, 12 miles farther south. But the recent heavy rain had so swollen the river, that it was after all impossible to cross it at this point. The march was resumed, in the hope that a crossing could be made farther south. On December 13th, after another march of 14 miles, a ferrying place was discovered, about 4 miles above Chilkana. But there were only six boats, and to bring the whole army and ordnance across in these took four days. The weather had again become dark, cold, and wet; and to add to its discomfort the 53rd found itself encamped in a low boggy turnip field for two days, waiting to embark. Crossing the commissariat and bazaar was a labour of Hercules. The camels were terrified of the boats and violently refused to enter them, hooting, grunting, and shedding their loads into the river. In the turmoil, many were either killed or lamed. Later, a place shallow enough to ford was found a few miles up river, and the majority were taken across there. Once the Jumna had been cleared, the army commenced its march along the skirt of the foothills, through the lush, well-cultivated country of the protected Sikhs. On the moming of December 17th, when the weather was suddenly bright and clear, officers caught their breath as they had their first glimpse of their next objective - Nahan, the capital of Sirmur. It was a cluster of miniature white cupolas, towers, and minarets, shining among the clouds on the grey hills to the north like something from an arabian romance. 134

On December 18th, after the arrival of Major Kelly's battalion from 
Dehra Dun, the army struck northward from the town of Sedaura, and after about ten miles began to ascend the hills into Sirmur.
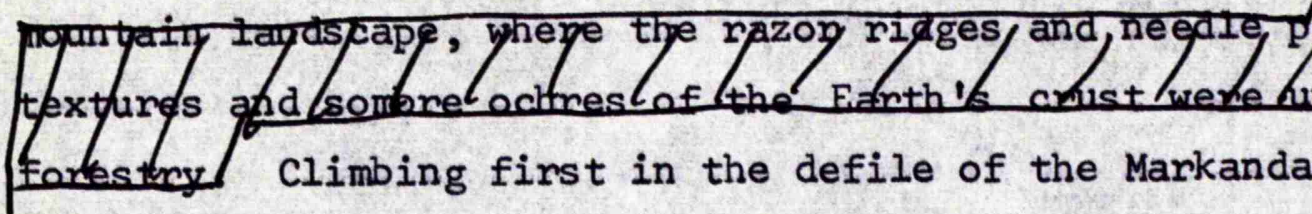

Climbing first in the defile of the Markanda river, and then branching to the right up the course of a subsidiary nulla the force came to the village called Mojamand, which was about six miles south from Nahan. The riverbed made a bad road: / very stony, and littered with nightfall on the 19th before all the guns been brought up to the camp. At seven o'clock that same evening a guard of honour was drawn up to greet Major-General Gabriel Martindell, appointed successor to Robert Gillespie. ${ }^{135}$ 


\section{Stagnation in Sirmur}

Martindell's was a very different character from Gillespie's. He was courteous, mild-mannered, unaffected, and so withdrawn in his social habits that he seldom visited or entertained. Professionally, he had not been without capability. In his younger days he had shown vigour and perseverance, if not much imagination; and the battalion of native infantry which he had raised and commanded as a major had been generally recognised as one of the best in the service. Appointed to command in Bandelkhand in 1804, when that province was in turmoil from the feuds of the various Bundela chiefs and the depredations of the Pindari freebooter, Amir Khan, Martindell had done useful work of pacification. He had driven out Amir Khan, defeated and dispersed the forces of the pusillanimous Raja Ram Singh, and taken the strong fortress of Jaitpur. In 1809 he had invested and compelled the surrender of the stronghold of Ajaigarh, earning thereby the "approbation and applause" of the Governor General. 1

But by 1815 , the effects of 40 years in the Indian climate, of which the last four or five had been soured by failure and the loss of the confidence of his superiors, had begun to show. His energies had become vitiated; his self-assurance sapped. The siege of Kalinjar of 1812, although counted a success, had nevertheless involved the repulse of the storming party with severe loss; and it seems that from this time the ageing officer had begun to lose all taste for responsibility, and to become a prey to vacillation and excessive caution. In 1813, he had been ordered to advance with a force of over 6,000 men into Rewa, a principality in east Bandelkhand whose Raja was refusing to honour the terms of his alliance with the Calcutta government. The Political Agent in Bandelkhand having sent an ultimatum to the Raja, Martindell had been instructed not to delay his march and his operations against the fortress for anything less than the arrival of the Raja or his deputies in his camp, for the season was advanced, and the rains imminent. Martindell had reached Panna, his rendez-vous, on April 8th; but instead of advancing forthwith, as ordered, had dithered there in a state of nervous 
consternation because his spies had brought word that Amir Khan was intending to create a diversion by invading the company's territory in another quarter. "He appeared so fully impressed with a conviction of the truth of these reports as to give no credit to the correct and authentic intelligence of the movements of Amir Khan and the Pindaris obtained by [ the Political Agent_ ... which showed Amir Khan to have been 200 miles from where he had been reported." ${ }^{2}$ He had then been sent the "most urgent and positive orders of the Commander in Chief to proceed....without any reference to external circumstances which were... beyond the sphere of his cognizance." Yet still he had dallied, now waiting for an artillery train from Ajaigarh - "although he was in possession of the commander in Chief's unqualified opinion that his march ought not to be delayed on that account." On April 23rd, he had moved at last, "having...remained inactive at Panna during the period of a fortnight at the most critical season of the year, and when the delay of a single day might have hazarded the success of the expedition". 3 To crown this display of ineptitude, Martindell had waited in advance of the fortress of Rewa for the arrival of the Raja or his agents, and the junction of reinforcements from Mirzapur, ignoring strict instructions to chastise some of the Raja's particularly contumacious zemindars in any case; and had then negotiated and concluded, entirely without authority, a treaty with the Raja, on the basis of a draft submitted by the Political Agent, but unsanctioned by the government. This had caused considerable embarrassment. The whole business of negotiation had had to be reopened, and the military operations against the zemindars held over until the following season. Official approval and thanks had been publicly withheld from Martindell on this occasion, and he had been permitted to relinquish the Rewa force. 4

In March, 1814, he had resigned his command in Bandelkhand and withdrawn to Cawnpore. 5

The reasons which Hastings gave for withdrawing Martindell from his semi-retirement to command the army in Sirmur were hardly flattering. 
"The selection of Major-General Martindell for the command", he wrote, "was founded on the general character which he had acquired in a long course of service; the hope that the occurrences attending his command at Rewa in the year 1813 would have stimulated him to exert himself in regaining the ground he had lost in the public estimation on that occasion; and, more than all, the difficulty of finding any other unemployed officer of rank sufficient to exercise so large a command." 6

But there was little reason to hope that Martindell would prove able to seize this opportunity to repair his dilapidated reputation. The effect of his disgrace had been to make him self-doubting to the point where he was content to abdicate real leadership and rely almost servilely on the advice of stronger-minded officers. Instead of giving a standard and direction to an army, he had reached the stage where he was more liable to take his own standard and direction from it. This being the case, his command in Sirmur was doomed to failure. It could only have succeeded had he been surrounded by purposeful and energetic coadjutors. Instead of that, the officers of H.M. $53 \mathrm{rd}$, whom he knew well, and to whom he was $t$ herefore most inclined to turn for inspiration, were discouraged and diffident. As a result of their double repulse at Kalanga and the Governor General's censure, they instinctively shrank from all projects which seemed to involve even the slightest risk of another failure. Company officers like John Ludlow, on the other hand, quickly grew impatient of policies which they considered to be the result of supineness and timidity. They fretted for a more dynamic leadership. Subjection to two contradictory influences and sets of advice made Martindell hopelessly uncertain and bewildered. He lapsed into a state of perpetual perplexity, and found it more and more difficult to make decisions.

Having commanded in Bandelkhand for a considerable time, the major-general was as accustomed to mountain warfare as any officer in India; but the scene of his present operations surpassed in difficulty anything even in his experience. Nahan nestled compactly on a plateau, which rose some 3,000 feet above the level of the plains, and which was shielded to the north by a massive, crudely serrated, ridge of hills. 
monesterient views of the lowlands, and of the river Markanda, which curved round its northern and western skirts and cleft a sinuous passage through the foothills to the plains. There were oceasional groves of pine, shish am, and wild fruit trees on the surnouning slopes, but the vegetation was mostly scrub and flowering thorn, spread sparsely, so that the light ochres and lunar texture of the ground showed through. The eastem part of Nchan, around the citadel, was walled, and looked immensely strong. Mojamand, the camp site of the British army, was six or seven miles to the south, and separated fromthctown by the valley of a tributary of the Markanda. The road ascending from this nulla to the town was about five miles long. It was a mere track scratched onto the surface of the rock, all sharp angles and hairpin bends, and so narrow and steep that it seemed impassable for any animal. It was, furthermore, defended at almost every turn by a stone redoubt in the shape of a star. Hastings, appreciating that the army must be dispirited after the repulses at Kalanga, had advised Martindell to blockade the place, rather than risk an assault; ${ }^{7}$ but such a recommendation, in view of the inaccessibility of Nahan, seemed superfluous. A storm must have been suicide.

If he was overwhelmed by the immensity of the task which he had inherited, Martindell did not at first show it. He made up his mind to move the camp to a spur farther to the north east, which was only about four miles from Nahan ridge, and ordered Ludlow to occupy the position with two battalions of infantry and a couple of field pieces. Soon after Ludlow had left, intelligence was received which it was feared must be too good to be true. It was rumoured that Ranjor Singh Thapa had abandoned the town and retired to the fort of Jaithak in its rear. Ludlow was immediately instructed to probe his way forward to test the truth of the report. 8 The spectators at Mojamand held their breath as they watched his column turn to ascend the Nahan road. Some camels missed their footing, fell, and were dashed to pieces; and the men had to use their hands to steady themselves as they moved up inch by inch. But save a few tree trunks laid across the path, they met no contrived obstacles. Not a shot was fired in resistance. The journey was an exhausting half-day's work; but at the end of their arduous climb, the troops walked unmolested into the neat and narrow streets of Nahan. The 
town was indeed abandoned. By one o'clock, the British flag was flying over the citadel. 9

Henry Sherwood marvelled that the enemy had ever allowed the advance to reach the town, which seemed as though it might have been defended forever. "The Gurkhas at one moment defend themselves well, not only with bravery but with judgement; and at another, neglect the commonest means of defence", he wrote. 10 But then, he had not yet seen Jaithak.

Artillery might conceivably have been brought to bear on Nahan; but to bring it to bear on Jaithak, whither Ranjor Singh had now retired on the advice of his father, Amar Singh Thapa, was apparently a physical impossibility. The fort itself was rectangular, with bastions at each corner, and tiny. It measured only about twelve yards by eight. But its position, on a towering pinnacle, seemed to make it immune from bombardment. The guns would first have to be brought up to Nahan - which seemed hardly practicable, for a start - then somehow directed at a target which was not only three miles distant as the crow flies, but some 1,600 feet higher again. Sherwood was filled with despair and anger as he contemplated the fort which the army was expected to conquer.

"It stands altogether detached", he wrote, and is of so great a declivity that we have no idea how we are to proceed... It is doubtful whether, with all our exertions, we shall ever be able to make a road for the guns and mortars even to Nahan....Even if this is done, can they proceed farther? And even if they do, can they find a spot to throw shells from (for a mortar cannot throw at above 45 degrees elevation)?....As for the great guns, they appear out of the question."

He thought that the only hope lay in a scheme of protracted investment, for the fort was reputedly short of water. "However," he added, "take it ever so easy, even without the loss of a man, I think it one of the most ill-judged, ill-conducted enterprises ever heard of."ll such feelings of disgust and pessimism were shared by all the other officers of the $53 \mathrm{rd}$.

If he had decided to act in the spirit of their assessment, and put into operation a plan for starving Jaithak into surrender, Martindell would have been acting in full harmony with Hastings' instructions. But as he studied the position of the fort, military instinct and professional 
judgement - attributes which, though impaired and weakened, he still retained in small measure - told him that in the case of Jaithak thetics of blockade would be the less practicable. "Your force is too small; your maps demonstrably too inaccurate, and the approaches to the fort obviously too many and too dispersed", said the faint but still distinct voice of experience within him. "On the other hand," continued the voice, "it appears that the fort might possibly be assaulted with success. Jaithak perches at the angle of two rising mountainous spurs, which converge to form an arrow head pointing towards Nahan. It cannot easily be bombarded from Nahan; but it could conceivably be bombarded from one or both of these spurs." True, the guns would have to be brought to the spurs; but after his experiences at Kalinjar, Martindell was no novice in the art of moving heavy ordnance to seemingly impossible places, and dogged perseverance was one of his old qualities which he still had not lost. So, mustering his last reserves of faith in himself, he declined to defer to the misgivings of Mawby and the officers of the $53 \mathrm{rd}$, and resolved on a plan of bombardment. Hastings was quite happy to accept his as the better scheme, and allowed him credit for the enterprise necessary to implement it. ${ }^{12}$ It was first necessary to bring the guns to Nahan; and with this object, the pioneers and fatigue parties were set working to widen the road which led from the artillery park, at the foot of Nahan hill, to the town itself. ${ }^{13}$ knowing this would be a protracted operation, Martindell decided to establish a position on each of the two spurs in the meantime.

During the night of December 26th, two columns were formed for this purpose, the intention being to seize the two spurs simultaneously, each force causing a diversion in favour of the other. Ludlow, with about 800 men, was to take the left, and Major William Richards,* with about 500 , the right spur. Acting in concert, these forces would, it was reckoned, outnumber the Nepalis, whom intelligence reports represented to be about 1,000 strong. $^{14}$ Both columns had a couple of six-pounders and two small howitzers, carried on elephants; and it was estimated that both 
should reach their positions before daylight. ${ }^{15}$ Richards, having farther to go, set off at about 10.45 that night. Ludlow moved at one o'clock the next morning, and engaged the enemy first.

The enemy's main water supplies were derived from wells on these spurs, so they were heavily guarded. They lent themselves well to defence, for they swept back from the dominating pinnacle of Jaithak rather like the wash from the prow of a ship, descending as they receded. Their crests were, furthermore, jaged, almost every peak along them was crowned with a picket or stockade.

Ludlow's destination was a peak about a mile from the fort on the left spur. The distance from Nahan was some six miles "but equal to twenty from the ruggedness of the road". He had first to descend from the Nahan ridge into the Markanda valley; then proceed northwestwards along the skirt of the spur, before mounting its flank diagonally. It was a very fatiguing march, and took much longer than had been expected. Dawn was already breaking when he began to climb the flank; and the column, hampered by the slow and ponderous elephants, had become widely scattered. When about two miles from the point at which they were aiming, the front half of the column, which comprised the grenadiers of the 53rd and some companies of native light infantry, passed under the enemy's finst position on the crest, which was a stockade. They had now lost the cover of darkness, and were within range. Suddenly there was a crackling of musketry, as the Nepalis in the stockade opened fire. Ludlow ordered the advance guard to load, but to reserve their fire - unless warmly engaged until they reached the crest. The force passed under two more posts, each of which opened fire, but the men, well-covered by the uneven ground, pressed obediently on and did not turn to retaliate.

By eight o'clock, the advance was within 200 yards of the summit. The fourth and principal enemy post was just ahead - strong, and generously garrisoned. Ludlow was still under good cover, and he called a halt to enable the colum to consolidate. While he was still waiting for his own battalion, the 1st/6th Native Infantry, who were toiling far behind, a guide brought word that considerable enemy reinforcements were on their way down from the fort. Ludlow now had about 400 men at hand and 
after a rapid assessment of the alternatives open to him, he decided to try to gain the unreinforced post with the men he had, instead of waiting to attack it with his whole force, which would give the enemy reinforcement time to come up. He gave the order, and the European grenadiers and native light infantry charged with fixed bayonets up the remaining section of the ascent, scattering the enemy from the post by the sheer elan of their advance. John Ludlow was an audacious and impulsive officer, ever prepared to exploit his opportunities with energy, but not always with self-mastery. In taking this position on the crest, he had done what he had been ordered to do; but his men were eager, the Nepalis in disarray, and in such a situation it would have taken more than the letter of his instructions to restrain him. Seeing the confused retreat of the enemy, he excitedly urged his men to give chase, so that once they had reached the crest they did not stop but turned sharply right to push their adversaries back up the spur. Down from the peak they had won they went, then up to the one in front. This was topped by the ruined village of Jampta, where the enemy had their third post. The grenadiers of the 53 rd reached it first, and again surged up with such fierce resolve that the Nepalis, still unformed and unsteadied, fell back to their second position to make their stand. Down went the grenadiers again, and up to the second post, a picket. Here the struggle was savage. The Nepalis were desperate, and determined not to yield; but the shock of the impact of the grenadiers and sepoys had left them so winded and dazed, that they were still unable to resist. They were forced to retreat yet again, to seek shelter in their first post, which was the stockade. Behind that lay the cantonments of the fort itself. It was now about half-past eight. Faces gleaming with sweat, gasping with effort and excitement, buoyant with triumph, tendons trembling and tensed for exertion, the grenadiers turned eagerly to Ludlow for the word to charge the stockade. This time, the commander hesitated. His better judgement warned him that it was strong and already reinforced; that his own force was small; and, his rear being so far behind, that he was without support. But prudence was only one of several influences vying to command his actions. Gratitude, inspired by the heroism in faces which 
on that fatal day before Kalanga had registered only surly refusal, urged him to allow his men the reward of victory; animal instinct, quick to be roused in this virile soldier by any display of martial ardour, impelled him to enjoy the exultant sensation of battle, the intoxicating aroma of blood. He could not be resolute and stern, as the troops surrounded him, clamouring, beseeching, reproaching. "Why, sir, there ain't more than eight or ten men in the stockade, and bye and bye there'll be as many hundred!" Half-laughing with the pleasure of that mystic companionship formed between members of a group by the common and simultaneous experience of a single emotion, Ludlow had not the power to summon a tone which did not contrast with his intention to sound severe. Instead of positively ordering his men to halt, as he later admitted he should/s he could only implore them to spare themselves. "You have already done more than I expected. Why not take breath awhile, and wait for the others and the guns? Let them come up, and then we'll see what can be done."

But they sensed that there was no conviction behind his words. Even as he was speaking, two or three of the grenadiers roared out huzza! and part of the light infantry leapt forward. Had he had sufficient determination, Ludlow $x$ could still have stopped them. But he had the gambler's weakness, which is a secret hope that recklessness somehow lessen unfavourable probability. He consented to the charge - though in deference to the misgivings which, if they would have no value in the event of success must, in the event of failure, be the insurers of his reputation and self-esteem, he sounded as reluctant as he could.

It was a lapse for which he afterwards bitterly reproached himself. The men rushed ahead. The Nepalis, strengthened by reinforcements from the fort and having had a few minutes' respite in which to collect their senses and plan their retaliation, allowed them to come close. Then, with a swift and well-concerted movement, they sallied out on either side of the stockade; and as the attackers neared the defences they opened fire on them from both sides and from the front simultaneously. Ludlow's party gasped and reeled, utterly confounded. They backed away - not down the crest of the ridge the way they had come, but sideways, over the flank of the spur. The Nepalis followed, brandishing khukuris and 
yelling war cries, hard pressing the European grenadiens and sepoys, who stumbled, slipped and slid down the $h$ mountainside. Ludlow managed to rally them for a few minutes farther down; but ammunition was low and it was impossible to keep up a consistent fire. The enemy, increasing in numbers all the time, poured over the crest of the ridge as irresistibly as spilt liquid, and Ludlow had no option but to retreat again.

In this, his moment of greatest need, Ludlow was forsaken by his own corps, the 1st/6th Native Infantry, which formed the rearguard of his column. When the vanguard was repulsed, the sepoys of the 1st/6th had come as far as Jampta; but then, instead of moving forward to provide desperately wanted assistance to the grenadiers and light companies, which their having their communications entire they were well enabled to do, they became so terrified by the sight of events in front that they refused to form and began to back away. The sepoys' hormor of the Nepali khukuris became almost hysterical when they saw even the European grenadiers humbled beneath them. Officers shouted and swore, struggling to make themselves heard above a rising babble of fear: but all their efforts to impose order were made vain by the crucial defect in the military system which this crisis exposed. Casualties at Kalanga had so depleted the battalion's small complement of European officers that only three were on duty, and they were simply too few to allay the trepidation of 400 men. The military machine could not accommodate the human error which had caused Ludlow to allow the column to become too extended. The men of the 1 st/6th, instead of advancing to succour comrades who were fighting for their lives, took to their heels and fled.

Ludlow, on the side of the spur, worked desperately to hold a position, hoping that sooner or later the rear would close up in support. Twice more he rallied the men; but twice he had to yield his ground. On the latteroccasion, the fire from his musketry finally spluttered into silence. All the cartridges were spent, and, still receiving no help from the 1st/6th, he had no choice but to admit defeat and order an uncovered retreat. It became a rout. Breaking formation entirely, the men partly ran, partly fell, and partly jumped down the rocky slopes, 
crashing through the scrub and wildly clutching at branches to control their descent. So precipitate was their flight, that the remains of the detachment were back in camp by ten o'clock. The casualties amounted to 151, of whom about a dozen, including one officer, were killed. Ludlow himself reached Nahan unhurt, save for a sprained ankle, but he burned with shame. "I should have thought it a friendly ball that had brought me to the ground", he wrote to his wife. ${ }^{16}$ To have been so near triumph! He blamed his own unmastered greed for victory for the repulse at the final stockade; but for the fiasco into which it had needlessly developed he blamed the lack of European officers and the reluctance of his own sepoys to meet khukuri with bayonet. He told his wife a short time after: "I'm exerting my utmost with the raggamuffin set of a corps of mine to impress on them the necessity for using their bayonets, assuring them that the Gurkhas will always attack them sword in hand, and $\Gamma$ that $T$ if they do not make use of the best offensive weapon in the world...they must be cut down to a man."17

Hastings was disappointed and disturbed at such grave misconduct on the part of the 1st/6th Native Infantry, the more especially as he had been in the habit of indirectly reprehending the King's troops by paying the sepoys marked compliments and praises. Nevertheless, his inclination was still to treat this behaviour as altogether exceptional - "a circumstance almost unheard of in the Bengal army"18 - and, while admitting his severe displeasure, he forbore, inview of "the peculiar circumstances of the public service... and of IMartindell's T detachment in particular", to inflict condign punishment. All he ordered was that the European officers who had been commanding the corps should report any instances of cowardice on the part of the native officers which they had noticed, and that all so accused should be immediately dismissed. ${ }^{19}$ Hastings feared the effect which stronger chastisement might have had on the morale of native troops already subjected to the unusual stresses of mountain war and not without reason. Even this tempered expression of disapproval, and the few courts martial which followed, seriously undermined the confidence of the 1st/6th, and in subsegefunt weeks the corps lost over 100 men by desertion. ${ }^{20}$ Hastings, as commander in Chief, could not avoid 
officially expressing his regret that the column had not moved more slowly, and that Ludlow had not been able to restrain the men in advance; ${ }^{21}$ but George Fagan, the Adjutant-General, privately assured Ludlow that his personal reputation had not suffered:

"I read extracts and parts of your letter where descriptive of the scene and of your own feelings to Lord $/$ Hastings $T$, who has been pleased to allow me to tell you privately 'that it has not in the slightest degree impaired his good opinion of you; and that the misbehaviour of troops, whether proceeding in one case from blind and precipitate rashness, or in the other from backwardness, often ruins the best conceived hopes of success and renders every effort of their leader vain.' Do not then suffer yourself to be depressed, my dear friend; you have already established sufficient claims to public favour and approbation and to the confidence of your superiors, and you will continue to increase them."22

Poor 53rd! Nothing that the men of the regiment could do was right in the eyes of the Governor General. While before he had chided their shirking, now he ignored the bravery and vigour they had displayed in the early part of the action on the ridge, and by implication blamed their "blind and precipitate rashness" for the failure which marked its final stages. This judgement provoked deep resentment among officers of the $53 \mathrm{rd}$, and it long remained an issue of acrimonious controversy in Indian military circles. Critics of the native army attributed it to a blind prejudice in favour of the sepoys and their officers which prevailed among servants of the East India Company; ${ }^{23}$ but this was not its real cause. Ludlow was partly responsible, because he admitted his own error with the sort of manly frankness which was especially calculated to cajole Hastings into forgiving it; and at the same time he implied that he had risked his own reputation in order to spare that of the men:

"This much I do blame myself for, and am liable to reprehension for it", he told his wife, "viz: that I did not at all risks peremptorily resist the importunities of both officers and troops to attack the stockade; my efforts of persuasion were fruitless where positive commands might have been more effectual - but I never gave my assent to advance until I saw part of my little band actually on the move. I stated this candidly in my public report; and though I think I should have failed in any case to restrain the eagerness of the troops, still, as I gave my consent (though Heaven knows a reluctant one) I preferred in faimess to say so rather than entail on the troops a stigma for absolute 
disobedience of my orders." He then concluded, a trifle smugly: "It is this candour which has, no doubt, drawn on me the reflection of his Lordship." 24

But there is no doubt that, more than by anything else, Hastings' attitude was influenced by the deep grudge he had borne the 53 rd ever since he had decided that it had sabotaged the siege of Kalanga.

While Ludlow directed his efforts against the left, William Richards descended the eastern end of the Nahan plateau and proceeded north east towards the right hand spur. When he left Nahan, at a quarter to eleven on the night of December 26 th, there was not sufficient ammunition in camp for his column to be supplied with spare cartridges, so the men had to march with only those they had in pouch. A serjeant's party was left to bring on the extra rounds when they had arrived from the park. This party followed with the spare cartridges in the early hours of the morning, but by some deplorable negligence was not provided with a guide. In the darkness it not unnaturally lost its way. Appreciating that it would be foolish to proceed further, the serjeant left the ammunition with the coolies in a convenient village, and probed his way back to Nahan, where he arrived at four o'clock. After hearing his story, Martindell quickly mustered a company of native infantry to retrieve the ammunition and take it on to Richards. So few men remained unoccupied in camp at this hour, that he had to contribute his own bodyguard to make a force of sufficient strength. This party hastened to the village under the serjeant's direction, only to find that they were too late. Nepali prowlers had discovered and bagged the ammunition. 60,000 cartridges had been lost. ${ }^{25}$

Richards' march was sixteen miles, and was more dangerous and exhausting even than Ludlow's. The stony pathway plunged and mounted crazily, and was never more than wide enough for single files. He was always having to call a halt, to enable the rear and the ordnance elephants to come up. The last two and a half miles were unremitting steep ascent, and it was not until eight o'clock in the moming of the 27 th that the advance guard reached the crest of the ridge. Fortunately, the point where it ascended, a peak about two and a half miles from the 
fort, was not defended. As there was water close by, Richards halted for two hours, to allow the stragglers to come up and to take some rest. Then, at ten 'clock, he advanced along a narrow footpath on the northern side of the ridge, until within about a mile of the fort. Here his advance neared a picket of the enemy, which accosted it with a salvo of musketry, but retreated as it still determinedly advanced. Richards took possession of successive peaks along the ridge, and soon reached a pinnacle which was only about 1,000 yards from Jaithak. He was greeted by musket and gun fire from the fort; but this did little damage, and by noon he was firmly established in this position, which was called Peacock Hill.

Near one o'clock, the Gurkha drums beat to arms, and a considerable force assembled and paraded under the walls of the fort. From their number, which he estimated at about 1,500, and from the silence in the direction where Ludlow was supposed to have ascended, it was obvious to Richards that something had happened to upset the plan for concerted action. He thought that Ludlow, encountering unforseen obstacles, must have been recalled - which meant that his own 500 had the undivided enemy host to confront. Soon after, the Nepalis moved down from the fort, and began an attack, with guns and musketry. Their fire was directed against Richards' advanced post, which was on the slope before the summit he occupied; but its position was so well-protected that casualties were trifling.

Towards four o'clock, however, when the spare ammunition still had not arrived, and when there was still no sign of activity on Ludlow's ridge, Richards' anxiety began to mount. He wrote a note for Martindell, describing his situation, and had two sepoys disguise themselves and take it to Nahan. Meanwhile, finding that the British fire was slackening, the Nepalis became bolder, and made several attempts to storm points in his position. Deciding he must concentrate his resources, Richards called up a party which he had posted to guard the well in a hollow some 300 yards below his left, and to husband the remaining ammunition, gave strict orders that all fire be reserved until the last possible minute. It was a notorious weakness of the sepoys that they could seldom be made 
to do this. Their habit was always to fire too soon, before they could have accurate aim, with the consequence that their cartridges were wasted, and the enemy given time to assault while they were fumbling to re-load. But on this occasion, the instruction was scrupulously obeyed, and the men eked out their precious cartridges with stones.

Soon the light began to fail, and the enemy edged nearer and nearer. Again and again bands of them tore up to the breastwork which the pioneers had built in front of the advanced post, and tried to force their way in; but each time they were repulsed. The European officers spared no effort to inspirit the men by encouragement and personal example. Even the surgeon, Darby, took a musket, slung a cartridge box over his shoulder, and made good use of both whenever he could snatch a few minutes from medical duties. ${ }^{26}$ Thomas Thackeray, lieutenant commanding the light company of the $2 / 26$ th Native Infantry, made Richards promise to allow him to deal with the enemy if they charged again. He was an uncle of the future novelist, William Makepeace, who was at that time a small pale boy of four years living in Calcutta. Soldiering was a vocation which claimed his passionate and exclusive devotion, and his ambition to realize its best ideals in his own conduct burned with brilliant and destructive intensity. He was only twenty-five, but had already spent ten years campaigning fervently all over north India, fighting the Marathas and the rebellious rajas of Bandelkhand. At the second assault of Kalanga, he had been seriously wounded in the right arm, and still had not regained full use of it; but he scomed the idea of pleading this as an excuse for inactivity. ${ }^{27}$ His men revered him as a paragon, and all immediately volunteered to repel the next attack. When the Nepalis charged again, for the eighth or ninth time, Thackeray and his company careered lustily at them, and fairly swept them back down the hill.

By half past seven, it was quite dark, and the enemy muskets spurted luminous tongues. Ammunition was now almost spent, but Richards remained confident. His situation was strong, his losses amounted to no more than about twenty killed and wounded, and he reasoned that by now a reinforcement must surely be at hand. Then, almost simultaneously, he received 
two messages from Martindell. They were both to the same effect, and he could hardly believe that he had read them aright. The general had sent no ammunition, and no reinforcement: only curt and peremptory orders that he was to return to camp at once. ${ }^{28}$

At half past nine that moming, when he received news of Ludlow's defeat, Martindell immediately wrote to Richards, ordering him to return to camp. Now that it would not have the benefit of a diversion on the left spur, he feared that if it were allowed to continue, Richards' column would only meet destruction. By another oversight, the guide and intelligence staff had failed to make arrangements for messengers to be posted along the route of the column, and these instructions never arrived. This was soon apparent to all the officers in camp, because Peacock hill was fully visible from Nahan, and Richards' movements could be closely followed through telescopes. There was no way of signalling, because, by yet another oversight, no code of flags had been arranged. Martindell therefore sent another, very urgent note.

Then soon after noon, two things happened, which completely changed the whole tactical situation. First news arrived that Richards' spare ammunition had been lost; and then the engagement on Peacock hill began. As the spectators watched, their initial sense of helplessness and horror changed to excitement. They realized that Richards was holding his position. There was perhaps still time to send fresh ammunition from camp. Soon it was obvious not only that he could be saved, but that he could be given the means of securing a decisive victory. Eagerly, a young subaltem called Robert Stevenson volunteered to take a couple of companies with spare cartridges to Peacock hill. But events had moved too fast for the general. Incredibly, he refused, and merely continued to send Richards orders to retreat.

Martindell's reflexes were so paralyzed, and his imagination was so impoverished, that he was completely incapable of grasping the significance of the developments on Peacock hill. Having begun with the assumption that Richards could succeed/if Ludlow succeeded, his mind remained prisoner of that idea, and simply refused to register the visible evidence, which plainly indicated that Richards could succeed in spite 
of Ludlow's failure, provided he was sent reinforcements and ammunition without delay. "Had Major Ludlow been able to make good his position... there would then have been a diversion of the enemy's force in favour of Major Richards, which would have enabled him to maintain his ground and supplies of all kinds could have been sent to his detachment", Martindell later lamely explained, still propounding the terms of his original assumption long after it had been confuted by the event. It never occurred to him that the failure of the operation on the left spur only made it the more essential to exploit the success on the right, and that by continuing to send orders to retreat instead of men and cartridges he would not only ruin a splendid opportunity, but probably turn it into a disaster. With egregious stupidity, he took no heed of the likelihood of one of his missives arriving after dark, and compelling a party of exhausted men, without ammunition, to retreat blindly, by hair's breadth mountain pathways, with an enemy three times their number in pursuit. It was precisely this dreadful possibility which materialised, and the consequences were tragic.

When Richards read the messages which ordered him to withdraw, he clenched his $h$ ands in anger and utter exasperation.

"Situated as I was", he wrote as dispassionately as he could, in his official report, "with but little ammunition left and the enemy pressing in one me from all sides in numbers three times my force, it was a most difficult task that devolved on me to conduct a retreat when the distance I had to return is considered and the difficulties I had to contend with are known."

It is axiomatic that in all tactical withdrawals the most dangerous role is that of the covering party. For these men, success in a gamble against overpowering odds is only the prelude to even greater jeopardy, because their acutest peril comes only after they have held the enemy at bay for the benefit of the main party, when they have to withdraw themselves. It was now Richards' invidious task to select a corps to fulfil this suicidal function. One consideration determined his choice. Thackeray's company still had most of its ammunition unused, the major having kept it in reserve for any accident. He turned to Thackeray, and 
asked him to cover the retreat as well as he could. Thackeray received the opportunity as if it were a gift from destiny. Some of his men urged him to make his way back to camp, and leave them to do the job; but the idea was abhorrent to him. He had a friend, Wilson, an ensign of the lst/13th Native Infantry, to whom he was devoted, and who loved him. They had made wills in favour of each other to symbolize their att zchmgnt.

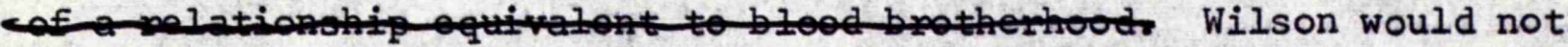
leave Thackeray, and all of his company insisted on staying too. They were joined by Tumer, ensign of the 1st/27th Native Infantry, who was supported by about half of his company. All told, there were scarcely 200 men to resist 1,500 . Thackeray formed squares on two heights commanding the escape route. He and Wilson remained with the one in advance, while Turner commanded the one to the rear. Their men fixed their bayonets, and performed prodigies of valour in an effort to stem the engulfing enemy tide until the main column was clear. Behind them, there was a frenzied stampede. When the signal to retreat was given, the rush was so great that the narrow pathway down from Peacock hill was soon choked with men, all shoving and trampling each other. Mercifully, the night was fine, and a fragile disc of moon enabled them to find the way.

The covering party managed to keep the Nepalis at bay for half an hour; but the pressure of their advance was inexorable. Thackeray's group was forced to retreat, and kept retreating in a desperate bid to escape encirclement. The fire it had to sustain was terrible. Men were falling all the time, and soon half his own company were dead or dying. At last they were surrounded. As they made a furious dash, in an effort to cut their way free, Thackeray was hit in the chest by a bullet and brought to the ground. All that he had time to say to Wilson was that he must take command, because he thought he himself was dying. Wilson groped his way to Turner's post, blinded by tears, almost suffocated by muscular contraction in his chest, and hardly conscious that his thigh had just been shot to pieces. The Nepalis swarmed everywhere. Men not dead were captured, and only seven of Thackeray's company escaped. Tumer knew that it would be futile to stay any longer, and shouted hoarsely to his men to disperse. They fled in every direction, running to the limit 
of their strength into the night.

The first men of the main column limped into Nahan at one o'clock the next morning, giddy from hunger and fatigue; but the remnants of the covering party straggled in for days afterwards. One group had fled northwards, to the Giri Ganga river, where they were found by friendly villagers, who fed them and guided them back to camp. Another 40 were taken prisoner. Despite $/$ threat of death, they refused to enter the enemy service and were finally released on parole the following day - save a little drummer boy, who was kept "to teach the Gurkhas." Ranjor Singh sent in the wounded, a courtesy unknown in India; but many of the bodies recovered had been atrociously mutilated. Wilson had been helped away by Turner, but after a while, weak from loss of blood, had been unable to go farther. Tumer had gone on alone to find help. He had soon been accosted by a small party of Nepalis, and threw himself down a precipice and crawled into a cave to escape capture. Thereafter he had wandered lost and starving in the jungle for two days. At last he was found by an old peasant woman, who fed him, and had her son lead him back to Nahan. Turner never forgot her kindness, and had a pension settled on her for life. He gave some indication concerning Wilson's whereabouts, but the ensign was never found alive. Thackeray's body was not recovered for several days. All the officers of the camp, including the major-general, were at his funeral, and none could hide his emotion. The surviving sepoys of his company, $h$ defyed the strictest rules of caste $l$ not only carried his biert the grave but buried him. 29 Moved as he had seldom been in all his long military career and experience of war, Hastings issued a special order in honour of Thackeray,

"whose heroic spirit and personal example animated his little band to as daring an effort of zeal and courage as ever distinguished any portion of the Bengal Native Infantry, and, His

Excellency may say, any description of troops whatever." 30

The total of Richards' casualties was 306 - well over half its number. Of these, 81, including three officers, were killed. ${ }^{31}$ Hastings was completely at a loss to understand Martindell's behaviour. "The Commander in Chief concludes", ran a sarcastic despatch from the Adjutant 
General, "that some insuperable objection must have intervened to prevent your supporting either column, or taking measures to cover its retreat, after you were appraised of the failure of Major Ludlow's attack."32 It was later learnt that had Richards persevered in his operation, the enemy would have abandoned Jaithak early the next morning. 33

This double calamity was all the more vexing because it made a strengthening of the Sirmur division essential. By virtually denuding the stations of Hansi and Rewari, and by detaching a battalion from his own escort, Hastings was able to muster a reinforcement of 21 companies of infantry, or nearly 2,000 men. 34 But casualties, desertions, sickness, and the detachment of troops for the occupation of Dehra Dun had reduced the original strength of the force by over a half, and even after the arrival of eleven companies of his reinforcement Martindell had only 2,700 effective men at his disposal. ${ }^{35}$ True, he also had Fraser's irregulars, but he placed little faith in them. Nervous and discouraged after the disaster of December 27 th, he complained that his force was too small for its assignment. Jaithak was, he knew, expecting reinforcements, for Bal Bahadur Singh had left Chamur and edged his way westward to a new stronghold at Jauntgarh, on the east bank of the Jumna behind Dehra Dun, whence Major Baldock, with a party of troops from Dehra, had failed to dislodge him. It could only be a matter of time before he reached Jaithak.

Despatches in this querulous vein elicited no sympathy from Headquarters.

"Hitherto", observed the Adjutant General acidly, "it has not been the habit of Company's officers to calculate whether they have a numerical superiority to the enemy. The introduction of a principle so novel and so infallibly destructive to our Empire can never be admitted by the Commander in Chief. But his Lordship directs me to say, that were this species of computation allowed, he apprehends it could not apply in your case, as he believes your numbers to be considerably beyond those of Ranjor and Bal Bahadur Singh united. When you represent the advantages of Ranjor Singh's position, His Lordship thinks it escapes you that a situation which presents peculiar difficulties of approach must be one to which the means of egress and communication are equally embarrassing when the skill of an antagonist is deployed in availing itself of these obstacles.

I am instructed to say that it is the province of the Commander in chief to weigh the possibility of the enemy's receiving reinforcements. To you, His Lordship looks for the vigorous employment of 
such force as the ability of the state affords the means of furnishing to you. Did you feel the nature of your command too embarrassing to you, which His Lordship would be deeply loath to imagine, it would be incumbent on you to express it; for in holding it...you are pledged to your country to aim with your utmost energy at the fulfilment of its objects." 37

If he expected this sort of language to galvanise Martindell, Hastings had misunderstood the deeply sensitive nature of the major-general. The rebuke harrowed his dignity and deprived him of his little remaining self-confidence. Contrite and despairing, he offered his resignation. ${ }^{38}$ The offer reached Headquarters within a fortnight; ${ }^{39}$ but no reply was sent for another two weeks, and it was not until the end of March that Martindell knew of the Commander in Chief's decision regarding it. 40 The sense of uncertainty under which he worked in the meantime hardly helped to make his leadership more assured.

In the first weeks of the New Year the weather turned very cold, and there were some violent nights of storm and wind. The army's misery was worsened by a state of inertia, because all activity now ceased, pending the arrival of reinforcements and the transportation of the heavy guns to Nahan. The road from the park to the plateau was pronounced ready on December 31 st, but experience proved otherwise. ${ }^{41}$ After prolonged efforts to get the guns up this pathway the attempt had to be abandoned as hopeless, because there were too many turnings to givescope for even pull. A new straighter road had to be started on another part of the rock, which was not expected to be ready until the end of February. 42 Meanwhile the Nepalis strengthened their defences by constructing another stockade on the left spur.

John Ludlow occupied the interval between operations by repairing the broken spirit of his disgraced battalion. The letter he wrote to his wife on the subject offers an interesting insight into the way a sepoy battalion was administered:

"You will recollect, my Love," runs his letter of January 22nd, "that I was much annoyed at no distant date back at the great desertion which was taking place in my corps. I spoke to the native officers collectively on the parade and reproached them for this aggravating of this past ill-conduct of the corps. I expressed that 
from the period of the promulgation of the General's sentiments of censure on the corps, that their first wish and desire should be to redeem their good name by future meritorious conduct. They all replied they felt this sentiment themselves, but there was some latent cause which made the men unsteady and leave the corps. I requested they would make a point of finding it out whatever it might be, and to inform me of it, as well as of any grievance they might have to complain of. This they promised to report faithfully in the morning. At the time agreed on, all the native officers waited on me, and with much gravity told me that the only cause which they could discern for the ill-success, bad name, and bad conduct which had befallen the corps was, that - don't laugh - an unhappy accident had happened to one of the new colours on their march from Kamal, a hackery wheel having gone over the staff of the King's colour and broken it off; that from this period nothing but courts martial, desertion and every other mischief had attended the corps. They therefore solicited me as a great favour and a sure remedy to receive their lost character etc., to allow them to replace this staff with an old colour staff under which they had formerly fought with success. I immediately assented to their superstitious request; had the new staff removed and the old one put in its place. By this acquiescence to their prejudices I have once again got them in good humour. They have consecrated the colours even afresh in their way, and promise to do wonders when next employed." 43

This shows plainly how little direct contact a commanding officer had with his sepoys; how unreliable the native officers were as a medium of communication (for it is surely obvious that in this case their explanations were designed rather to appeal to the known preconceptions of their commander than to represent the truth); and how readily even an officer of Ludlow's capability accepted that the loyalty and affections of the sepoys were to be commanded by nothing more than outward deference to their "prejudices". The officers of the East India Company always made much fun of the naivete of the native troops, and never realised that in accepting the most convenient and superficial explanations of their behaviour they were even more naive themselves.

While Martindell awaited his reinforcements and his guns, he had all the approaches to Jaithak reconnoitred, only to find them apparently impassable for artillery. ${ }^{44}$ This confirmed him in his resolution to suspend all operations until the heavy guns had arrived at Nahan - though quite how he expected this to alter his predicament it is difficult to understand, if all roads from there to the heights were reckoned 
impracticable. He can hardly have contemplated bombardment from Nahan, over a distance of four miles, when at Kalanga it had failed over 800 yards. As Ludlow saw it, he had become so obsessed with silly fears concerning the safety of his guns that he was incapable of thinking of anything else until he had them in the town, and all his attentions had become engrossed by the progress of the road. ${ }^{45}$ Probably he found a welcome means of escape from the real problems of command, without, however, abandoning all : semblance of involvement, by busying himself with preparations for the removal of the artillery park. Ludlow confessed he had no idea what the major-general's ultimate plans were, and "positively had the fijgits" as he waited for evidence of some tactical purpose to emerge from his dithering.

"There is but one road now by which we can get up decently," he told his wife on January 30 th, "and from this we may be cut off, or, what is worse, perhaps obliged to attempt it with great loss, if we give the enemy more time to defend it...I know you must have been in expectation of something decisive having taken place 'ere this, whereas we are lessprepared to set about it than we were on the 29 th of last month, the day on which I would have followed up the first attempt before any additional defences were made. In my humble opinion, these great delays are the causes of all our failures; they not only betray the poverty of our resources, and give the enemy time to strengthen theirs; but they moreover damp the spirit of our troops from the very inaction incident to them." 46

William Fraser, the politicalagent, was even more exasperated by Martindell's procrastination, and he soon became a painful thom in the general's flesh. There was little in the temperament of either man to endear him to the other. Fraser, thirty years old, was / a company civil servant only through deference to ambition, for his nature and interests drew him strongly towards the army. An intimate friend of James Skinner, fconsidered himself a ripened military expert, and modelled himself on the old-style "Hindu" officers, more common in the days of Clive than now, who wore whiskers in imitation of their sepoys, abjured pork and beef, and hunted big-game on foot. Irresistibly attracted to any affray, he had accompanied Gillespie to the assault of Kalanga on October 31st, and received a serious arrow wound in the neck. ${ }^{7}$ Fraser was garmlous and opinionated, $/$ Metcalfe, whose assistant he was at the Delhi Residency, could 
not abide him, and complained that he was "over speculative, and too much disposed to put his own theories into practice." 48 However, the younger and more zestful Company officers, Ludlow and Frederick Young especially, readily accepted $\mathrm{him}$, for there was much in what he said that showed discernment. His imagination and vitality would have operated as healthy antidotes to Martindell's diffidence had not the general been unresponsive to all advice save that of the officers of the $53 \mathrm{rd}$, and had Fraser himself not been so much less persuzsive than outrageous. 49

Finding the inhabitants of northern Sirmur (of the provicnes of Jubbal and Jaunsar especially) to be more spirited and seditious than those of Garhwal, Fraser planned a partisan army for the interior, with himself as commandant. Krishna Singh, now in camp, whom he found "a remarkable character for activity and bravery" he proposed should be his assistant. 50 But after the disasters of December 27 th Headquarters cancelled this project. The detachment of regular troops into the interior was also now out of the question; but Martindell was instructed to provide whatever irregulars he could spare to support the rebels, and to encourage them to harass foraging parties from Jaithak. 51

The irregular force, the brainchild of Fraser, and commanded by his close friend, Lieutenant Frederick Young, was by now over 4,000 strong. But less than half were paharis, or hill men. Krishna Singh had worked assiduously and raised a corps of about 900 , of whom roughly a half were highland troops of the Bilaspur Raja - a chieftain whom he had persuaded to support the British effort. The only other highlanders were 1,000 men from Jubbal and the Jaunsar district of Sirmur, and about 300 locals raised by two officers of the Sirmur royal family. This response from the hill people was disappointing, and in Fraser's opinion a clear indication that the British had done more harm than good to their cause by advertising their policy of restoration. As far as he could see, the presence of the son of the dispossessed Raja of Sirmur in the British camp, with several of the royal family's civil officers, was, far from encouraging local resistance to the Gurkhas, tending to confirm the people in their present allegiance. This was especially so in the case of the inhabitants of Jubbal, among whom enthusiasm for the Company's war was tempered by the 
fear that in the event of victory they would be made subjects of the Sirmur house - a prospect which they dreaded even more than domination by the Gurkhas. Furthermore, it was becoming increasingly clear that even in Sirmur proper Ranjor Singh Thapa was far more popular than the old royal family, who had exercised a tyranny far more oppressive than his own. 52 The upshot was that recourse had had to be made to lowlanders of various descriptions - Sikhs, Pathans and Mewatis mostly - to swell the numbers of the imegular contingent. 53 It was therefore a tatterdemalion band, hastily raised, hardly trained, racially and religiously heterogeneous, and, what is more, issued with ancient flintlocks which used shot and powder (popularly called "matchlocks" at this time), instead of more modern cartridge-firing "muskets". 54 Martindell can hardly be blamed for having had little confidence in them.

Nevertheless, it was a band of these irregulars which broke the long tedium of inactivity and set the army in motion again, by means of aminor but notable success against the enemy. Some 375 were posted on an eminence called Boneta, about nine miles west of Nahan, to help intercept Nepali foraging parties. At daybreak on January 3lst, they were attacked by about 250 of Ranjor Singh's choice warriors. They acquitted themselves splendidly, not only repulsing the enemy, but killing 23 and wounding many more. 55 Ludlow waited restlessly for Martindell to react to this opportumity.

"This little gallant affair may produce a very beneficial result
wrote
to his wife the following day. "It assures us that the irregulars may be relied on, $I$ and $T$ it will give them increased confidence in themselves and proportionately depress that of the enemy. It is also stated that many of the Gurkhas who were beaten have deserted, through fear of returning. Had we been on the hill, no doubt these runaways would have taken refuge with us, for we always treat them well. They knew if they went to the irregulars their heads might have been cut off to swell their victory. I should hope, tho' I see no symptom of it at present, that this little triumph... will be a spur to our exertions. If it is not taken advantage of, we may rue the lost opportunity. If I commanded (for ambition has no bounds), I would have gone up there last night and indeed long, very long, before that. The appearance of affairs just now would wear a very bright aspect indeed in this quarter were we but on the hill. The enemy certainly in number do not exceed 1,500 men; we can well take 2,000 regulars up and as many irregulars; and if this is not enough ? - We shall in vain attempt to prosecute 
this war to success. I think the enemy will get reinforced 600 men in a day or two. This increase, were we once up, would be a disadvantage to them as their provisions would naturally fall shorter. On the contrary if Bal Bahadur with his 600 should join before we get up, they will then be strong enough to thrash the irregulars and will by so doing obtain what supplies they like." 56

Martindell hesitated, while he tried to decide whether he should venture another attempt on the left spur, and it seemed that the opportunity must be lost before any resolution was made. Then, during February ist, the irregulars actually moved forward to the western end of the spur, and occupied, unaided, a prominent height called Nauni, which was about three miles from the fort. Considerably reassured by such an unexpected performance, Martindell finally made up his mind to support the irregulars, and at eight o'clock the same night he sent Lieutenant-Colonel Kelly to Nauni with 1,200 men. Two small mountain guns, transported by bearers, were sent after him - but no field ordnance, because the road was reckoned impracticable for elephants. It was a gruelling march: only between eight and ten miles in length, but of full 16 hours' duration. At about eleven o'clock on the following moming all the troops remaining in camp were turned out and paraded under arms on the north eastern point of the Nahan plateau, in order to draw the enemy's attentions from Kelly. The feint was successful, for the Nepalis hurriedly made a stockade in the supposed path of this force, and Kelly joined the irregulars on Nauni unopposed. 57 "This move I heartily rejoice at, for I was afraid our general was asleep and would have given time to the enemy to prevent our getting up at all" Ludlow told his wife with a sigh of relief; "I think, my dear girl, there is every chance of our getting possession of Jaithak within ten days." $" 58$

But then, as if fate maliciously contrived to goad Martindell into action only that she might relish the confutation of his initiative and enjoy his relapse into perplexity and despondency even deeper than those from which he had momentarily been roused, the wind rose, the skies darkened, the temperature dropped, and it began to rain. It rained continuously for three days andnights. It was heavy, glacial rain, driven by raging winds. Soon every tree was stained to ebony, and every rock to gleaming porphyry. 
Tents were dragged down; note paper became so damp that the ink would not dry; the light was so bad that at three $0^{\prime}$ clock in the afternoon it was impossible to write or read without a candle; and all the time, everywhere, was the sound of running water.

On bleak Nauni hill the sufferings of the sepoys were pitiful. Kelly had marched in haste, without tents or spare provisions, and it proved impossible to send these up to him while the vile weather lasted. His men huddled abjectly under makeshift shelters, which they formed by throwing $/$ blankets over bars supported by crossed sticks at either end, like roasting spits; but the kammals were made of coarse wool, and absorbed the wet like blotting paper. There was little fuel for cooking, and even the few scraps of timber that were found proved too damp to ignite. By the third day 20 sepoys and 12 bearers had died of exposure, and scores more were seriously ill. 59

Martindell, grieved by the sufferings of the troops, would probably have abandoned the position altogether had he not received a note from Major Baldock on February 5 th, which said that Bal Bahadur, whom Baldock had been trailing, had eluded him altogether and crossed the Tons river the last major obstacle in his progress to Jaithak. This meant that a reinforcement of between five and six hundred men was about to reach the fort. The weather cleared for a few hours on the same day, and Martindell resolved to use the occasion not to withdraw from Nauni, but to replace Kelly's force with one better equipped. John Ludlow, with his own battalion, a six-pounder and two mountain guns, was sent to relieve it; and during the night the remainder of Kelly's drenched and shivering detachment arrived back in camp, with 30 of the men on stretchers. 60

At about eight that night, after Ludlow had reached his destination, the rain began pouring down again. 61

"... I have not got your daily despatch to me", he wrote to his wife on February 7th, "nor could I well expect it in such weather as we have had, it never having ceased for a moment to rain ever since we have been up here. It has been very trying for the troops, especially those who have been exposed to it without any covering at all / probably the irregulars 7 . Thank God today we have had a few hours of dry weather, and as the sun is peeping out I trust it will favour us with its genial influence, 
for never did poor fellows want it more. Many of the servants as well as sepoys have fallen sacrifice to the inclemency of the weather, and I had just now a report of one of my poor bearers, a Bangywalla, having died coming up. With regard to myself, I never was better, although I have been without a bed and have not changed my clothes these three days. This is not weather that severely injures the constitution of Europeans, but natives cannot stand such cold. I'm told that it snowed here for an hour last night, but as it lay not on the ground 'till morning I did not witness it.

I feel much more contented up here than I was below... I have the honour to maintain a post here with 400 men which has been previously held by 1,200 . It is a very strong one indeed, and provided the elements do but favor us would be impregnable to any force the Gurkhas would send against us. We have, besides my own force, 1,100 irregulars which will prove of merit and I? illegible $T$ in case of attack. But the enemy know the strength of our position too well and have too much dread of our guns to make any such attempt. They are withal full 3 miles distant from us with a large dale between us and them." 62

On the 8 th, the rain turned first to hail, and then to snow, which soon lay three inches thick on the tents, and in drifts of three feet on the ground. At Nahan, the Europeans were in their element, pelting each other with snowballs; but the natives, for whom this was their first contact with the white matter which covered the Himalayan peaks, were flabbergasted and miserable. Nor were the lowland sheep and cattle of the commissariat any happier. "The cattle are dying and lying in all directions" wrote Sherwood; "800 sheep are reported dead belonging to our regiment." 63 On Nauni hill the snow was even deeper, and Ludlow's force became completely cut off. Supplies and reinforcements could not be sent to it for five days. "Since $40^{\prime}$ clock yesterday", he told his wife on the 9 th, "we have had neither snow nor rain, but an exceeding hard frost; and the snow is now on the trodden roads so many cakes of solid ice. The stupendous hills around all covered with snow present to Europeans a grand and congenial sight - but not so to the natives. Fuel as you may suppose is exceedingly scarce, and it is here so especially, there being no other tree but the fir, which is not particularly numerous... There is this advantage in fir, that it burns readily green, from the quantity of turpentine which 
is in it. I am greatly in hopes from the clear appearance of the weather, and I it I being withal new moon today, that all bad weather is at an end. Most sincerely do I trust so on account of the troops, who have suffered every privation, and I must say with unexampled constancy."64

Finally, the sun came, like a chord of music. The spectral light changed to one of dazzling brilliance, and the sound of trickling water was heard again. On February 10th the road was considered passable, and a reinforcement of 450 sepoys, with another three six-pounders, was sent to Ludlow under Captain Watson. The paths, however, were still very slushy, and two elephants slipped over precipices and were killed. "The road is difficult beyond measure; everyone $I$ is $T$ wishing that Lord I Hastings_T would look at it" wrote Sherwood feelingly. After the junction of the reinforcement the spirits of the troops at Nauni were high, and his men told Ludlow that if he would lead them into Jaithak, they would follow. 65

But there was little likelihood of him doing that. Martindell had no intention of giving Ludlow an opportunity to repeat his previous error and upset plans afresh by impetuosity. Now that he had, almost in spite of himself, pushed artillery onto one of the spurs, the bombardment of Jaithak again seemed feasible, and his original decision to reduce the fort by this means appeared justified after all. From now on, Martindell clung to the notion of bombardment with a desperate faith and refused to be distracted by any incidental opportunities for other forms of tactics. He simply ignored the fact that, to be successful, bombardment needed to be combined with a policy of blockade; that unless the enemy were pinned to their present position the guns might merely drive them to another hill in their rear, where it would perhaps be impossible to attack them.

The Nepali defences on the left spur were now increased to two stockades, and as a preliminary to moving his artillery along the ridge to within range of the fort itself, the major-general intended to obliterate these with shot and shell. On February 12th, all the light infantry companies were sent up to Nauni with two heavy mortars, and Ludlow was instructed to move forward about 1,100 yards to an eminence 
called Black Hill, which, it was judged, would be a good position for a battery. Irregulars under Frederick Young were left to guard Nauni. 66 But before the bombardment of the stockades could begin, two things happened. Bal Bahadur finally entered Jaithak; and Ranjor Singh's men occupied Peacock Hill, the important position on the right spur which Richards had been ordered to abandon on December 28 th.

Bal Bahadur reached the fort that same evening, February 12th. "He ought to have been prevented long ago", grumbled Ludlow, who witnessed the entry from Black Hill. 67 Estimates of the strength of this reinforcement varied. Pessimists of the 53rd, like Sherwood, reckoned that the force was $700 ;{ }^{68}$ while Fraser, less alarmist, realised that the number could not exceed 400 at the most. ${ }^{69}$ Martindell, engrossed by the immediate problem of moving his artillery, did not even think to mention the event in his despatches to Headquarters; and when asked to explain why Bal Bahadur had not been intercepted, indicated that that question would be more appropriately addressed to Major Baldock.

"With regard to any force being sent from hence to intercept Bal Bahadur Singh, I have candidly to state that if I had been possessed of the means, I should not have been able to do so with any effect, for want of correct intelligence respecting the enemy's movements; and in such inclement weather and in so difficult a country I have more than a doubt of my superiors approving such a detachment so distant from any reinforcement and so exposed... between the fort and the advancing chief."70

It is a fact that Martindell derived little collateral cooperation from the force in Dehra Dun. As far back as December, Lieutenant-Colonel Carpenter, left in charge there, had been told to give priority to an attack on Chamur, where Bal Bahadur was then lodged. But Carpenter's force was so small - only just over 200 strong - that he had felt compelled to wait for reinforcements before beginning operations. In the meantime Bal Bahadur had moved west to Jauntgarh and here, in early January, had successfully resisted the efforts of 400 regulars and 600 irregulars under Major Baldock to dislodge him. Soon after he had moved on again, still westwards, towards Jaithak. He had been harassed by some local partisans of Jaunsar district on his way to the Tons river; but Baldock's force, 
hampered by deep snow and the ruggedness of the country, had been too far behind to afford any support, and the elusive Gurkha had crossed the river with little trouble. Troops from the Dun did not attack Jauntgarh again until March 1lth, when the remaining garrison of about 300 withdrew eastwards across the Baghirati river. Chamur was not attacked by a British force until March 20th, when its occupants too retreated across the Baghirati. Both the expelled groups made their way to Srinagar in east Garhwal, now become the new enemy rallying point. 71

Now that the fort had had its garrison increased, mastery of Peacock hill, which commanded the wells on the right spur, was of crucial importance to Ranjor Singh Thapa, and he sent men to fortify the peak. "It ought to have been taken possession of by us long ago", wrote Ludlow; "I wish in Heaven the General would show a little more activity and not give the enemy time to add to his defences." He wanted to open his mortars to distract the Nepalis' attention from their stockade-building, to which proposal Martindell reacted by announcing that he was coming up to Black Hill to examine the position for himself. 72

His visit was made on February 14 th, when, in consultation with Mawby, now become his alter ego, he fixed on a spot at the foot of Black Hill, about 300 feet below Ludlow's present position and some thousand yards distant from the nearest Nepali stockade, as the site for the batteries. 73 The emplacements were duly constructed that night, but Ludlow received no orders to put the guns in. 74 The major-general had been suddenly distracted by a report that 500 Nepalis from Amar Singh Thapa were on their way towards Jaithak. Trembling for the safety of his artillery park he suspended all operations on the left spur, and even recalled a reinforcement which had just been sent there. Ludlow described news of this recall as "the most discouraging information based on the strangest reasoning The T ever heard of", 75 because the route of the Nepalis was supposed to lead them directly by his own position, while the major-general had a force at least four times their estimated number in Nahan. No confirmation being received of the report, two six-pounders were carried down to the batteries on the 16th. But fire was not opened until the 18th, when the 
two mortars were also in position.

"We have fired three or four shot", Ludlow told his wife in a letter written later the same day, "which, altho' they do not appear to have killed any of the enemy, still have had the effect of driving them from their work, and all have scrambled away under cover of the stockade - where, of course, I shall leave them unmolested until I receive orders from below to advance inwards, which it does not appear to be the General's disposition to do. Indeed, I hear it is now deemed advisable to bring up the battering guns all the way to this place."76

He had heard correctly. Advised by Mawby and Captain Battine, the artillery officer, Martindell haddecided that the distance of the batteries from the stockades was too great for light ordnance to have any effect, and that the eighteen-pounders would have to be brought up. 7

At this stage, the battering guns were not even as far as Nahan, and it was only on the 19th that the road on which the pioneers had been labouring for three weeks was pronounced ready. A fatigue party of 200 men of the 53 rd went down to the park to drag the first gun up the four and a quarter mile ascent to Nahan. The road was more perpendicular, and in appearance far more difficult, than that which was used by the army and the provision convoys; but it had fewer turnings and gave scope for even pull by the men on the drag ropes. It took two days to get both guns up; and the operation, an object of general wonder and interest, was not completed until the evening of February 20 th. 78 Work on continuing the road to Black Hill had been started on the 18 th, and the plan was to utilise the water course of the Markanda river where it lay along the northern skirt of Nahan hill, before curving away southwards to the plains.

Meanwhile, the reinforcement from Amar Singh Thapa was again reported to be approaching, and Frederick Young, with Krishna Singh and 1,400 irregulars, was sent from Nauni to intercept it. ${ }^{79}$ Martindells lack of confidence in his own judgement was now such that he would switch from one opinion to its opposite at the slightest provocation; and the little victory achieved by the irregulars at the beginning of the month had transformed his mistrust of these troops into an unquestioning acquiescence in the sanguine confidence of Fraser and Ludlow. As it happened, on this occasion his old prejudice would have served him better. 
During the march, Krishna Singh told Young that it was already too late to intercept the Nepali force, because his spies had brought word that it was already in the fort. A cursory reconnaissance revealed nothing to suggest that the report was unfounded, and Young returned to camp.

But then further, and more positive intelligence indicated that the force was in fact still at large; and Young left Nauni again on the morning of February 19th, this time with over 2,000 irregulars. He struck due north, making for the Sain range of mountains, stretching horizontally behind Jaithak, where he expected to encounter the enemy party. After a march of 48 hours, he finally came up with his prey at nightfall on the 20 th, at a place called Chanalgarh, 15 miles from Jaithak and overhanging a deep chasm through which the Jelal river tumbled in noisy cataracts. He scribbled a hasty note to Ludlow:

"I am at length up with the enemy, but he has got such a post I really know not what to do. His force does not consist at present of more than 500 fighting men and a number of followers. We have upwards of 2,000 . Is it not a shame? But I fear if I was to order an assault the men would not go on - at least so Krishna Singh says. I am really so tired I cannot keep my eyes open, so excuse this short epistle. We had the Devil's own march..."80

Krishna Singh had in fact lost his nerve, and far from being of assistance to Young was nearly the cause of his destruction. The irregulars held the enemy party in check during the night, but on the morning of the 2lst the Nepalis made a sudden effort to break the blockade. They fired a few volleys, and then drew their khukuris, resolved to try to cut their way free. Suddenly the rumour flew around the ranks of Young's force that a reinforcement of 2,000 enemy troops from Jaithak was at hand. The notion was absurd: Jaithak was fully 15 miles away, and there were not that many troops in the place; but it wrought panic among the irregul ars, who threw down their arms and fled. They were hotly pursued. Many fell to their death over precipices; others were either slaughtered or horribly mutilated by the Nepali knives. 180 were killed, 273 wounded, and nearly 1,500 deserted either there and then or subsequently. Krishna Singh attempted to extenuate the flight by claiming that the enemy had numbered between twelve and 
fourteen hundred; and there was little reason to doubt that he had been the author of the pernicious rumour concerning reinforcements. ${ }^{81}$

This unfortunate affair widened beyond repair the rift between Fraser and Martindell. Fraser refused to abandon, and arrogantly reaffirmed his faith in the irregulars. He laid most of the blame for the catastrophe on Krishna Singh, "who", he claimed, "from incorrect information or personal apprehension fabricated and used a mischievous falsehood." 82 Young said that such a heterogeneous and inadequately trained band should never have been employed without a seasoning of regulars to inspire and support them, but Fraser disagreed. He even disputed the superiority of the Nepalis' muskets over the irregulars' old matchlocks. ${ }^{83}$ Martindell, on the other hand, was angry and mortified to think that he had ever changed his original estimation of the irregulars. "I can no longer place any dependence on the few troops of this description who remain" he wrote firmly, refusing to listen to Fraser and discriminate in favour of the mountain soldiers, at least. ${ }^{84}$ The Political Agent took it upon himself to conduct a detailed enquiry into this affair. He submitted a questionnaire to Young, which, lavishly glossed with his own lengthy and emphatic comments, he afterwards forwarded to Headquarters through his own department, without reference to the major-general. This was a tasteless breach of etiquette. Although Fraser had been granted charge of the organisation of the irregular force, Martindell should, as a matter of propriety, have been made a party to a correspondence so patently military in character. ${ }^{85}$

At the end of February Fraser heard that the elders of Jubbal province were at last stirring, and needed arms and men. He suggested that a force of irregulars be sent, proposing to accompany them himself; and Martindell, glad to be rid of him and his corps for a while, agreed. Departure was delayed for some time by the demoralised and refractory state of the irregulars. New levies were no sooner added than droves more deserted, reducing the mean strength of the corps to about 1,400, and detachments showed themselves timid and unsteady in face of even the most trivial hazards. It was March 15 th before Fraser finally left camp, 
taking 450 men with him. 86

Meanwhile Hastings grew increasingly disturbed at the fecklessness of Martindell's command. The major-general began to be bombarded with trenchant missives, each betraying more asperity than the last.

"The Commander in Chief... Texpresses $T$...his anxiety that Colonel ochterlony should derive the aid of a more active cooperation from the force under your command, and His Excellency trusts you will speedily endeavour to afford it to him after the Iast Battalion, the 15th Native Infantry shall have arrived", the Adjutant-General informed him on February 1lth.87

On February 25th he wrote:

"His Excellency cannot but view with increasing anxiety the appearance of continued inactivity in your proceedings. The reinforcements which have been sent to your division at such an inconvenience to the public service, and the large addition which has been made through the zeal and activity of Mr. Fraser to the irregular force... amounting, His Excellency understands, to about 3,684 men, have authorised the expectation of results commesurate to so great a preponderance of strength." 88

And on March lst:

"The Commander in Chief observes that your last is dated from Nahan, and not being aware of any advantages which that place affords as a headquarters while operations are going on...requests to be informed of the reasons which induce your remaining so long at that place. As a position it appears to His Excellency to engross an undue share of solicitude, as well as a much larger portion of your force than circumstances seem to warrant or require.

The advanced state of the season; the little expectation your despatches hold out of any speedy commencement of active operations, notwithstanding the large force at your disposal, cannot but fill the mind of the Commander in Chief with unusual, anxiety for the public interests so deeply involved in the success of the army under your command. In the absence, therefore, of all positive and specific information as to your present plans and intentions, I am directed by the Commander in Chief to request you will state fully and explicitly what you propose to do towards the accomplishment of the service which has been specially entrusted to your direction." 89

Wearily, Martindell strove to impress on his unfeeling superiors the nature of the difficulties and deficiencies with which he was having to contend. Poor, even useless intelligence; terrain difficult beyond the conception of those who did not actually see it; and, worst of all, 
lack of men. He insisted that he must guard Nahan, because it was his magazine, depot, treasury and link with the plains, and he claimed that he had no troops to spare for the occupation of the heights north east of Jaithak, which was essential if the place was to be blockaded until it could be bombarded. 90 The badness of his intelligence and the obstructions of the ground cannot be disputed; but it was absurd to plead insufficiency of troops. By this time he had at his disposal some 6,000 regulars alone; and Ranjor, with all his reinforcements, could not have had more than 2,000 men of all descriptions. ${ }^{91}$ The principle behind his operations was, he reiterated, bombardment:

"It is my intention, as soon as the eighteen-pounders are got up, to use them in driving the enemy from their stockades, and then moving the guns forward along the ridge to establish them within battering distance from the fort." 92

But Martindell was so nervous that as the hour. of trial of even his most carefully and confidently prepared designs approached he became incapable of coping with the simplest arithmetic of assessing probabilities. Calculations of success changed into prefigurations of failure, and he became flustered and inhibited by false premonitions. His faith in his plan to take Jaithak by bombardment and assault dissipated as its testing time drew near.

"The ground along the whole ridge is very unfavcurable, being so narrow as not to admit a company to form ab reast he observed in his despatch of March lst, "and the point in which Jaithak is built is of such steep ascent that in the event of a breach being effected the result of an assault will be very doubtful." 93

It was his misfortune that he was surrounded by King's officers who, instead of providing opinions against which he could measure his own and find them false, shared his lack of confidence and so gave a semblance of corrobonation to misgivings which were in fact quite unjustified. On March 6 th he again asked to be allowed to resign his command if the explanations he had provided proved unsatisfactory. ${ }^{94}$ Hastings made it plain that they did prove so; but he forbore to dismiss Martindell "because", the Adjutant general explained to him, "there would be no explaining the procedure so that it should not carry with it, to the 
conception of the public, an unqualified condemnation of your conduct." Dissatisfied as the Commander in Chief was, he intended his admonitions more as a private stimulant than as a formal verdict. But the plain truth was that Hastings had no option but to bear with Martindell, because there was no available officer of sufficient rank to succeed him. ${ }^{96}$

The progress of the road from Nahan to Black Hill was bedevilled by vacillation. It was begun along a route designed to utilise part of the course of the Markanda river, but on February $23 \mathrm{rd}$ some bearers and camp followers were cut off and plundered in the ravine between Nahan and Jaithak, by a part of Nepalis using the water course as shelter. This mishap persuaded Martindell that the road was too hazardous, and it was abandoned for another, more to the west. ${ }^{97}$ After two days this was found to be even more exposed to enemy raids. ${ }^{98}$ Work was therefore resumed on the first road, much to Ludlow's exasperation. "I like not this chopping and changing in a commander. It bespeaks so much indecision - a quality which I expected not to find in General M, tho' I now perceive he has it in an impardonable degree. In truth his whole command has been a comedy of errors throughout - or perhaps a tragicomedy you may term it." 99 The next day, the 27 th, two engineers went down to examine the road, and were promptly fired on by a lurking party of Nepali snipers. They consequently reported the road to be far too dangerous, and yet another was begun, this time about mid-way between the two abandoned ones. 100 For some days work continued uninterrupted, but the officers of the 53rd were still uneasy, maintaining that the road passed too closely under the enemy stockades on the crest of the spur for comfort. "I was sorry to hear that they reported the old road impracticable", Charles Chepmell, Mawbys' Major of Brigade, noted in his journal, "as the one they intend bringing the guns up by will be greatly exposed to the enemy's fire." 101 As always, the major-general finally came round to their way of thinking, and on March 2nd he ordered the engineers to turn the road to the left "to save the troops being unnecessarily exposed."102 So the pioneers and fatigue parties laboured on, always expecting some fresh capricious change of plan, and sweltering in warm weather. Life in the hills was delightful 
enough now. The wild pear and apple trees were encrusted with 6lossom, and alive with furry bees, muxlin-winged insects, and butterflies as big as a child's fist. Occasionally a cuckoo's voice sounded from some unidentified distance: tiny, ethereal, and evanescent, like the last reverberation of an echo; and aromatic Greezes, faintly chilled, drew the signs of spring had too ominous a portent to be fully enjoyed. They

were wamings that the season was waning fast: advanced harbingers of the

monsoon,/whech all operations would have to be abandoned.

While the road for the eighteen-pounders was being made, the Nepalis

constructed yet a third stockade on the left spur, in advance of the

second and just their side of the ruined village of Jampta. ${ }^{103}$ The

distance was still too great for the British ordnance to hinder them, and the arrival of the battering guns was awaited on Black Hill with/impatience. John Ludlow found an escape from the boredom of inactivity by continuing to unburden himself in letters to his beloved and devoted wife, at Meerut, to whom he described how the road finally approached completion.

Camp, Black Hill, 7th March.

.... am happy to say that the General is now working most seriously and with effect on the road for the 18 pounders. They have not as yet got to the next rocky part, but hopes are entertained that if it cannot be cut through... the road may be so brought over the summit of the hill that an 18 pounder may eventually be got over it. If this even can be managed, a month instead of two would then finish the work - nay, if he increases the working party with Europeans, which he yesterday did, it may be got through perhaps quicker... But under any circumstance, the delays are most impolitic, I as $T$ evidenced by the enemy throwing up their today's stockade. It will cost more lives to drive them from this than we could have lost in bringing up the guns by a road more direct. 104

Camp, Black Hili, 8th March, 1815

... I am happy to say, my Love, that a hint from Head Qurs has made our General exert himself a little, and he has further 3 days past put upwards of 500 men as a working party on his favorite road. By dint of exploring and perseverence they will manage I hope to get the guns over the pinnacle of a rocky hill which it would have been in vain for them I to attempt $T$ by the regular footpath. There may be some danger in bringing the guns over after the road is made, owing to the narrowness of the ridge; but of the practicability of this I shall be better able to tell you tomorrow, as Smith, the Chief Engineer, is gone down to look at it, and I shall have his report tonight about it. Stevenson seems to think it may be finished in ten days... That will be quite a relief to us, for when these fine guns are up matters will go on famously - provided only that our commander takes advantage of circumstances and does not permit the enemy to retreat to other ranges of hills further back, which they have already contemplated and will do if not hindered. 105 
Camp, Black Hill, March 1lth.

...The road is very nearly finished: but there are yet two places in it so steep and rugged that the artillery officer, Captain Battine, thinks the guns cannot be brought over them without some alteration. This possibly may occasion a few additional days' delay. I suspect the General will be wishing bye and bye that he had commenced on the road more direct, for that would have been finished many days ago, and the guns, by reason of $i$ ts gradual ascent, very easily got up. But the working party getting through the road I as I they have done, have performed wonders.106

Camp, Black Hill, Sunday, March 1lth.

... Our road for the guns is again subject to some alterations, and it will depend on the General whether this alteration shall take a fortnight or two days' additional work. The General, without seeing the road, has ordered it to be turned - i.e., taken round the rugged part; whereas the engineers have recommended it to be scalped - i.e., the pinnacle to be taken off. The latter will require two days to execute, so that in 6 days altogether it might possibly be finished.107

The road was in fact pronounced ready on March 13 th. It was five miles long, with many high humps and low dips after it quitted the Markanda valley and zigzagged across the craggy skirt of the left spur. Many parts were little more than spaces cleared of vegetation and loose stones, where hollows in the $g$ round had been filled up and smoothed; elsewhere it was a footpath widened by cutting back the bank and artificially raising the outer edge. Its ascent up the flank of the spur, following the straightest of possible routes, appeared from a distance almost perpendicular, and dizzily precipitous. In one place it followed the narrow ridge of a rocky projection which jutted from the spur like a natural flying buttress, with an immense abyss on either side. 108 "It may reasonably be doubted", wrote James Baillie Fraser, brother of the Political Agent, who arrived in camp on March 14 th, "if ever till this period it had been contemplated to drag guns of such heavy metal up precipices so high and rugged, and over so many of them."109

The eighteen-pounders were moved from Nahan at daybreak on March 14 th, two hundred soldiers of the 53rd and a party of gun lascars allotted to each gun. Martindell was in agonies of apprehension for their safety. The whole army was put under arms and Colonel Kelly was sent with a 
battalion of sepoys and two six-pounders to cover the road - "and for what? Because, forsooth, our General was fearful the Gurkhas would come and run away with them!". Ludlow's patience was exhausted, and his disdain beyond dissimulation. 110 In truth, the general need not have imposed such an additional strain on the army. The Nepalis were far too engrossed by the spectacle to interrupt it. Hundreds came out of the fort and watched the operation, as if mesmerised into a state of horrified fascination. First the guns were let down the northern face of Nahan Hill, each held"back by its team of Europeans, and guided by lascars with levers on either side. They were then moved along the course of the Markanda, the easiest stretch of the route, and brought to the road proper which branched away towards the spur. Progress was painfully slow, and the guns were brought only half way on the first day. During the 15 th the army was again kept under arms while the operation was completed. James Baillie Fraser watched from a distance as the first gun moved up to the crest of the spur:

"Main strength was necessary to drag it up the straight road which, viewed at a distance, seemed perpendicular; and the men in detail, with the ropes and guns attached, appeared right up and down on its face. On the edge of steep precipices, again, more caution was necessary; for then, had the huge engine swerved the least to one side, it must have tumbled down to the gulf below, whence it could never have been recovered, and probably many lives must have been lost with it. Several times I trembled as I saw it verge towards the edge and the ground crumble beneath it; but it moved on majestically, following the mass of men that drew it....and on the moming of the next day the two heavy guns were placed in battery." ll1

They opened fire on the moming of March 17th, and for two days belched flame and iron in the direction of the nearest enemy stockade. Several humdred rounds of shot were discharged, and the wind tugged away billow after billow of dense sulphurous smoke. Yet on the evening of the 18th the stockade was still standing and a deserter reported that the total of the enemy's casualties did not exceed half a dozen. 112 The operation of bombardment was again being beset by the problem of aim. The stockade emerged only some five feet above the ground, and any hits on so small a target at 800 yards were due more to luck than science. 113 
But the artillerists doggedly persevered, and by the next evening some effect was at last visible. The stockade itself appeared to be in ruins, and his more vigorous officers advised Martindell to assault. The major-general refused, insisting that the trenches, which extended from each side of the stockade over the flanks of the spur, were still too strongly defended. 114 Instead, he ordered the construction of another battery for the eighteen-pounders at a point about 350 yards from the nearest stockade and to the right of Jampta village. A special path had to be cleared along the ridge for this purpose, and the first gun could not be moved up until daylight on the 20th. Within an hour of hurling its first ball into the defences of the stockade, it was on the way to demolishing all trace of them. Still not satisfied, Martindell had the second gun moved to a point nearer Jampta, where it bore on the left of the stockade. The combined fire of the two guns was so destructive that by the evening no sign was left of the stockade save a pile of smoking debris. 115 There were still Nepalis in the trenches however, and the advancement of the batteries had brought the gun parties within the range of their musket fire. 22 casualties had already been sustained, and the Company officers urged Martindell to waste no more time and storm the position immediately. Again he refused. Instead, he ceased all fire for the night in order to make a road for yet another battery - this time for the six-pounders, in advance and to the left of Jampta, at a point which was only 200 yards from the remains of the stockade. In the moming he was quite surprised to discover that the enemy had repaired their defences during the lull in the bombardment. They had re-erected a breastwork at the back of the demolished stockade, and dug a new trench behind that - thereby tuming their old rear into a new front. Ludlow had warned Martindell of the likelihood of their doing precisely this, and was sick with despair and exasperation to find his prediction fulfilled.

"I have more and more reason to be disappointed at the faults and blunders caused by insupportable procrastination ... I suppose the General will not allow another night to pass without molesting them. If he does there is no saying what may be the consequence, for nothing is so dispiriting to troops as to let a favourable moment pass by without taking advantage of it." 116 
But that night, March 2lst, there was still no attack, and the soldiers became filled with disgust and resentment as they continued to be subjected to the galling fire of Nepali snipers without being allowed to make reprisal. The positions at the advanced batteries were so exposed that with all their shot and shell the British were unable to inflict more casualties than they suffered. 117

The next afternoon, a few irregulars who had been sent to act as sharpshooters took advantage of a slackening in the enemy fire to creep up the glacis of the stockade almost to one of the flanking trenches. Spontaneously aided by a few sepoys who were at hand, they plunged in among the enemy, and soon seemed on the point of gaining the trench and turning the position. James Baillie Fraser was convinced that they could even have captured the stockade. But when their action was pointed out to the major-general, he was shocked by their rashness and immediately had them called down. 118

Martindell's disastrous circumspection was less an expression of pressonal timidty than a result of the counsel of officers of the $53 \mathrm{rd}$, who persistently eschewed assault as too risky. Mawby was Martindell's éminence grise: always at his elbow and completely dominating his meek and submissive personality. "Unluckily," wrote Ludlow, whose own advice was constantly ignored, "there are advisors at our fountainhead who ruin everything in the way of enterprise and who, I firmly think, expect the enemy will surrender at discretion without our attacking them."119 We have only to note that Captain Chepmell, Mawby's Major of Brigade, described the eagerness of the sharpshooters as "foolish" to confirm the identity of these advisors. 120 Prevented, by influences of this nature, from escaping from the trammels of self-doubt; humbled by successive bastinados from Headquarters; and bemused by the problems of warfare in such inaccessible country, the unhappy major-general lapsed into a state of complete mental subservience to the King's officers. Four days later, after three precious months and untold quantities of stores and ammunition had been spent in preparation for the exercise, he made the extraordinary decision that he would not, after all, attempt to take Jaithak by assault. Finally, after three months spent reconnoitring and studying it, he reached 
the conclusion that "the hill on which the fort I was 7 situated I was $T$ not to be carried by assault if defended." The weak and exhausted commander had surrendered at last - though to a more powerful and insidious enemy than the one he was supposed to be fighting. "I did not deem it necessary" he told the Adjutant-General, "to call for the opinions of the senior engineer and artillery officers...especially when I adverted to their periods of service compared with my own and those of other officers under my command." 121 The allusion speaks for itself. He now announced that he had decided to reduce the fort by blockade, and evoked Ochterlony's example in a pathetic attempt to reconcile the Governor General to his change of plan. 122 Hastings was incredulous, and utterly at a loss to understand why the grounds for this decision had not been obvious from the start. Angrily, he accused the major-general of having squandered months of time and labour as well as huge quantities of valuable stores and ammunition. 123

Martindell's first move in his new scheme of operations was to send William Richards back to the right hand spur, whence he had been so prematurely withdrawn on December 27th. With 1,100 sepoys, about 600 irregulars under Frederick Young and Krishna Singh, and two small mortars, he left camp on the moming of March 3lst. The distance from Black Hill was of course even greater than that from Nahan, and the march occupied one and a half days. It was not until late on April ist that he reached the crest of the right hand spur, at a point about three and a half miles north east of the fort, and here he rested to bring up his guns and supplies. At half past three the next moming he began to creep along the ridge, aiming at Panjal peak, which was slightly to the south of Peacock Hill. In the lead were three light companies under Young, followed by the 1st/13th Native Infantry. This body was to attack a detail of the enemy which was known to be lurking somewhere before Panjal. The lst/15th Native Infantry were left to bring up the mortars, ammunition and provisions; and the rear guard comprised the irregulars under Krishna Singh.

The advance had proceeded about two miles, when a large body of troops was seen on an eminence in advance - immobile, silent, and 
indistinct in the still imperfect light. Richards was puzzled, and finally decided that they must be a party of his own irregulars who had moved round to the front. He continued to approach, more confident as the troops still made no movement and opened no fire. He was only within forty yards of them when their muskets suddenly spat and flashed a vicious tirade. Young immediately formed his light infantry, and they returned the fire with perfect composure. The exchange las ted about ten minutes, during which the sepoys gradually inched forward up the slope to the enemy position. Then the 1st/13th came up, and the Nepalis who were 1,000 strong promptly fled. The sepoys took up the chase, and remained so close behind that their adversaries ran from height to height without having sufficient time to turn and re-form until they reached Panjal peak itself.

Richards halted the advance guard and the lst/l3th in a dell below the peak, about a quarter of a mile from the enemy position. He wanted to let the rear guard come up, and allow the men to get their breath back. To lessen the fatigue of the ascent to the peak, he ordered the troops to take off theirknapsacks. He then formed them into two columns, and instructed them to charge up full pelt to take the position. They responded splendidly. The swiftness, determination, and organised precision of their assault completely unnerved the Nepalis, who did not stay to resist. They fled again, leaving both their post and their leader, Acham Bir Pant, for the sepoys to capture. Richards' casualties were relatively light -8 killed and 51 wounded; and the whole operation was a clear vindication of the worth of the native troops, even in mountain warfare, when properly handled. 124

"It is indeed a success which ought to inspire you with a just confidence in the officers and in the troops under your command", the Adjutant General was instructed to inform Martindell. "The Commander in Chief trusts you will have availed yourself of the obvious advantage afforded to you by this defeat and discomfiture of so large a part of the force opposed to you. The consequent division of the remainder of it will have presented to you a most favorable opportunity for restricting the enemy's movements and really establishing that close blockade on which you have placed your dependence 
for the reduction of the fortress. His Excellency will await with considerable impatience the accounts of your further proceedings, as your views must undoubtedly have become more distinct and defined through the important success of that division, on which you would not have calculated when you intimated the outline of your plan...

His Excellency will also hope to hear that you have seen cause before this to reduce the force you have hitherto kept in inactivity at Nahan. In the position of the division of your command relatively to that of the enemy, His Excellency conceives no apprehensions could be entertained for the security of the town of Nahan were it left to the protection of a corps far short of that which is now allotted to its defence."125

Hastings should by now have accumulated enough experience of Martindell's foibles to be so unsceptical. Having switched his attentions to the tactics of blockade, Martindell pursued them with somnambulistic inflexibility, and with absolutely no heed for contingent advantages if they seemed to require tactics of assault. The evening of April 2nd was the ideal time for an attack on the stockades of the left spur, since it was known that the pick of the Nepali troops had been withdrawn to support the force attacked by Richards; but no move was made - neither then, nor in the days and weeks succeeding. "If the Genl. would take the stockades to the west, I could then close in on this side, and we might do something," cried Richards, in despair, to Ludlow. "We must have patience, I see; but even that is almost exhausted. I know mine is, although I believe I have as great a stock as most people." 126 The major-general ceased to react in any professional sense to the events going on around him. He moved through each day in a semi-comatose state, making a few motions of command, but in reality avoiding all decisions and doing nothing more than mechanically forbidding any measure which involved the slightest risk. John Ludlow made himself very unpopular by repeatedly advocating more assertive measures, and Martindell always tried to edge away when he went to make reports.

"I went to him only two days ago", wrote Ludlow to his wife on April 12th, "and told him I observed 50 to 60 men with a chief descending from the most southem stockade to interrupt some working parties of ours halfway between this and Nahan, who came shooting up and destroying the company. I asked him if I should 
detach a company or two from my post, which was nearest, to endeavour to cut them off from the fort, which might easily have been done, as the Gurkhas had got quite down into the nella and were much nearer this than the fort is. The old gentleman began to shy about, asking continually where they were, and I as frequently pointed out several of them. He at last told me there would be no use in sending after them, and he should direct Kelly $I$ in charge at Nahan $T$ in future not to risk his working parties so near. Fraser also reported the same evening that a party of 150 Gurkhas had gone out to the north west to forage and that they would not return until the following night: but this was by him taken as little notice of as my report. Major Ingleby of the $53 \mathrm{rd}$ I hear last night proposed to reconnoitre the trenches of the stockade as he believed there were few men in them. The General thanked him for his zeal, but would not risk valuable lives. I hope he gets many of these hints, if only to convince him of the general sentiment which prevails in this army. I confess my military ardour is beginning very much to evaporate; and whose could not when matters are so ill-conducted? If we do stay out the rains, which please God we may not yet, all of us so doomed will have no-one to thank for it but the man who commands us."127

The army on Black Hill groaned under the oppressive tedium of an unbroken routine of trench duty at the batteries interspersed by listless periods of relief in camp. The guns continued a desultory cannonade against the paltry stockade, and by the end of the second week in April over 3,000 round of ammunition of one kind or another had been expended. Reliable sources represented the enemy force as 200 at the most in the nearest defences, and 300 in the post behind. These 500 were the only troops they had on the southern side of the fort. Martindell had, with his irregulars, upwards of 9,000 men lying idle before it. One day a Nepali deserter came into Ludlow's post at the batteries, bringing with him as a propitiatory offering five British six-pound cannon balls. He explained the Ranjor Singh Thapa now had an immense store of them. ${ }^{128}$ The atmosphere in camp grew very strained. William Fraser, recalled from Jubbal only a few days after he had arrived there by the resumption of operations against Jaithak, was no longer on speaking terms with the major-general, and treated him with undisguised contempt. On April 4 th, (false) reports circulating that Bal Bahadur Singh had been severely wounded in Richards' action, he sent a note into Jaithak under a white 
flag, offering medical aid. Ludlow, who was then commanding in the trenches, saw that the messenger, whom he thought sent by the majorgeneral, had been received by the enemy and that they had stopped firing. He therefore ordered the British guns to cease, until the exchange had been completed. Martindell, whom Fraser had not troubled to consult or even inform of the measure he had taken, was surprised when the batteries were suddenly silenced without his orders, and he asked for an explanation. Yet such was the man's torpidity, and so complete his loss of selfrespect, that he didnot even complain of what was, after all, an inexcusable impertinence on the part of the Political Agent. ${ }^{130}$ Only one section of the officers professed to believe in some inscrutable wisdom behind the commander's behaviour, and that was the group which surrounded Mawby. "If we are to go by ppearances we are not one step nearer taking the fort than we were a month ago," wrote Henry Sherwood to his wife at the end of April, "but I believe the General knows what he is about."131 The entry in his journal for April 25 th reads thus:

"We are building small redoubts on the top of Black Hill and Nauni as protection to air rear. The younger men laugh at the precaution and give them ridiculous names; however, it is but prudent to be secure, for the enemy may have 6,000 men while we have not 2,000 in any one I section of the T army."132

Such an estimate of the enemy's force was demonstrably fatuous. Even at its greatest extent the garrison of Jaithak could not have exceeded 2,000 fighting men, and how many of those could have been trained soldiers is a matter for conjecture. After the beginning of April, Ranjor's force was furthermore dwinding all the time, because deserters came into the British camp every day. Yet wildly exaggerated conceptions of the enemys strength, and a corresponding sense of inadequacy on the part of the British officers who entertained them, continued to cripple enterprise not only before Jaithak, but in Dehra Dun as well. On April lst the major-general received a despatch from Lieutenant-Colonel Carpenter, who complained that there were not enough troops in Garhwal to garrison the four main captured fortresses (Kalsi, Birat, Chamur, and Jauntgarh) as well as to guard all the ghats on the 
Ganges and Baghirati rivers. Lieutenant Menteith, commanding at Chamur, had reported that a force of 600 Nepalis from Srinagar was prowling on the eastern bank of the Baghirati waiting for an opportunity to cross, representing that it was quite impossible for his 250 irregulars to guard all the ghats over a 30 mile stretch of river. ${ }^{132}$ Martindell immediately wanted to send extra irregulars to Carpenter, and he requested Fraser to increase the levy. ${ }^{133}$ For Fraser, this was the last straw. He diagnosed the request as a symptom of the appalling credulity, ineptitude and lack of imagination which had bedevilled the campaign from its inception; and against these all his instincts had been too long in revolt for him to hold his peace now. He gave full vent to his feelings in a vehement public letter to Martindell:

"If the unarmed miserable inhabitants of conquered districts, pressed at the point of the sword and bayonet to show themselves as scarecrows; if a long retinue of camp followers and ammunition carriers; if feeble women, described old age and unfledged youth be drawn up in formidable array and counted and reported as hostile phalanxes to be opposed to British troops, to force them to retreat, I am at a loss to discover how long the campaign will be protracted, how often we may be driven disgracefully back, and to what extent our troops may not be dispirited and browbeaten. What numbers were constantly reported to be under the command of Bal Bahadur Singh and Rewant Kaji where Major Baldock's party retreated before them; what causes existed for this retrograde movement,.... I am totally unacquainted [with_/, but rumour mentions that the enemy were represented to amount to $1,000,1,200$, and 1,500; and I have understood from private information that the party was certainly rated 800 fighting men. From whence this number started up I am quite at a loss to discover; and although I have since taken every opportunity to endeavour to arrive at the truth, the result which is entirely satisfactory to my mind shows that Bal Bahadur never had more than 300 muskets, probably not so many, out of which 60 were left at Jauntgarh. The same array of pressed inhabitants, rusticks, ploughmen carriers, camp followers, women, boys, and old men were mustered (and not without their effect) as a stratagem..."

Menteith's supposed 600 from Srinagar Fraser disdainfully demonstrated must be more like 215 , or 300 at the most; and with indisputable cogency argued that had that officer but thought, or been allowed, to organise his force as a single mobile unit, instead of dispersing it into small fixed parties, it could have moved swiftly to any place where the Nepalis threatened to cross the river, and would 
have been more than adequate to frustrate their design. He attacked the supine tendency to attribute physical, as well as numerical superiority to the enemy:

"On the point Iof $T$...the physical and moral superiority the Gurkhas are said to possess over our troops I shall say little, and I could wish that the general impression in their favour was less prevalent. But supposing that it does exist, is superiority in equipment, in discipline, in members to be quite overlooked? Will no species of superiority be admitted in our favour? Will not the boldness of the enemy increase in proportion as we fail in confidence, enterprise and success, and their assurance and energy grow up as diffidence and indecision mark the steps of our troops?"134

Hastings was entirely on Fraser's side, and considered his views "just and luminous"; but he nevertheless felt that in deference to the declared opinion of the commander of the division, the levy of irregulars should be increased. ${ }^{135}$ Martindell wanted 7,000, but Fraser subsequently reported that it was proving difficult to bring the levy, which stood at just over 6,000 , to this amount. To make good the defiercy, he wanted to $\mathrm{arm}$ and embody the Nepali deserters, of whom there were now nearly 500 in camp, derived partly from Jaithak and partly from Chaupal, the garrison in Jubbal which had been forced to surrender. They had provided willing and invaluable instruction to the engineers in the art of making stockades. "I am of opinion that they will be found trustworthy and faithful, and always a hardworking and serviceable body" wrote Fraser. Martindell opposed the idea; but Headquarters supported Fraser, and one of the British Gurkha Regiments was born. ${ }^{136}$

Soon after, Fraser and his brother quitted the camp and went to Jubbal again, taking another motley body of irregulars to reinforce those already there. The main object of the expedition was to incite the inhabitants to attack the various Nepali garrisons scattered between Jaithak and the scene of Ochterlony's operations; but as it happened, the timely defection of the Basahar Raja, which led to the defeat and dispersal of the enemy army of the interior under Kirti Rana, made its services unnecessary. The Frasers were nevertheless not disposed to return to camp. Leaving a part of their force to occupy Chaupal they 
embarked on a tour of the cis-Sutlaj Himalayan states, which was quite a voyage of discovery. James Baillie described the journey in a book which earned him the admiration of Sir Walter Scott. His brother's conduct in the campaign was later rewarded, at his own request, by the grant of the brevet rank of Major in the cavalry corps of his friend, James Skinner. 138

Meanwhile Martindell made cautious and feeble efforts to straiten Jaithak. On April 12 th he sent Captain Wilson and a battalion of sepoys to occupy a peak about a mile to the left of Black Hill, and almost immediately behind the fort. ${ }^{139}$ From here, a clear view was had of the rear of the nearest stockade, which had been built into the back of the one destroyed.

"They have erected strong sheds made of large timbers to keep them from the shells", wrote Ludlow after a visit to Wilson's post, "and have others lower again, nigh the stockade, which look more like dog kennels than anything else. In $/$ the $T$ rear of and about their trenches each man seems to have a hole or cave, like bears' and wild beasts' to retire into from the effects of the shells. Their number, however, is truly contemptible, and very few of them are real Guarkhas.* Indeed, the deserters say there that there are not more than 20 Gurkhas in the first stockade and trenches." 140

A few days later, Wils on moved round still farther, and another force was sent to occupy the hill he vacated, so that Jaithak was completely surrounded. 142 But by now Ranjor Singh had the measure of the man against whom he was pitted and had little difficulty in breaking his blockade whenever he wished. If he wanted to send out a party to forage for grain, he would circulate a report through the British spies in his camp that he intended to attack one of the British positions. Alarmed, Martindell would then immediately put all his men under arms and order them to the defence of their posts, thus leaving the Nepali party free

$\bar{*}$

The men whom the British knew as "real Gurkhas" are described by J.B. Fraser as having "broad Chinese or Tartar-like physiognamy... small eyes, flat nose, and meagre whiskers...stout square make, and sturdy limbs" - from which it is obvious that they were not Gurkhas at all, but mongolian hillmen - Magars and Gurungs. Real Gurkhas were similar in appearance to the native Khas of Sirmur, with whom Fraser mistakenly contrasted them. 
to roam abroad undisturbed. ${ }^{142}$ The only retort to this stratagem which he could devise was the destruction of all the grain, now fully ripened, within a ten to fifteen mile radius of Jaithak - a cruel and odious measure, which can hardly have contributed to popularise the British cause among the local farmers and peasants. 143 It was clear from the large number of deserters who came into the British camp each day after the last weeks of April that the measures taken to starve the garrison were beginning to have some effect; but at Headquarters they despaired of ever seeing the fort completely succumb under the major-general's palsied grip. 144 He was sent another reprimand, and with it a solemn warning:

"It appears to the Commander in Chief that the posts you have established are at much too great a distance from the place you mean to invest, as well as too few in number; and that you do not detach parties sufficiently often to endeavour to intercept the supplies which it must be obvious the enemy has it in his power to receive from the country - particularly by night. The very advanced state of the season; the glorious successes which have attended the British arms under Major-General Ochterlony in Hindur and under Colonel Nicolls in Kumaun, contrasted with the little apparent advancement of public interests in your quarter render the state of our operations before Jaithak highly detrimental to the interests of the state, a source of continued anxiety to the Commander in Chief, and, His excellency fears, of discredit to our military character...

You spontaneous ly...took upon yourself the formidable responsibility of abstaining from attack upon the positions which you instructions directed you to attempt reducing. By that act you pledge $I d T$ yourself to effect the surrender of Jaithak through starving the garrison. You ought to be apprised that should Ranjor Singh now come to a convention for the evacuation of the fort and country (a measure not attributable to your operations but to our conquest of Kumaun) a rigid enquiry will not the less be made into the measures taken by you for the prosecution of that plan which you had engaged should prove effectual; and were it to appear that those steps which could alone make a blockade successful had been omitted, the consequences would be very distressing."145

Barely a week after, in a despatch dated May 17th, came the dismissal which was now to late to be a coup de grace. Ochterlony's operations to the west being almost at an end, he was instructed to proceed, as soon as Amar Singh Thapa capitulated, to assume the command 
at Nahan. Martindell was informed that he might proceed to Saharanpur, Moradabad or Bareli, as best might suit himself, to await further instructions. 146 As fate would have it, he was in fact spared the ignominy of actual supersession. Before the arrangement could become operative, the war in Sirmur had come to an end. On May 2lst, when violent winds and hail announced the advent of the rainy season, Ranjor Singh Thapa, deserted by all his best soldiers and convinced, after receiving news of the Gurkha collapse both to the west and to the east, of the futility offurther resistance, formally surrendered. 147 The campaign had lasted slightly longer than five months.

Henry Sherwood went to examine the enemy defences, and was "astonished at the weakness of the works". He nevertheless added that the natural strength of the position was "very great...almost insurmountable." 148 The Field Engineer, Captain Carmichael Smyth, whose opinion regarding the practicability of bombardment and assault Martindell had declined to seek, had other views. In accordance with the wishes of the Commander in Chief, he made an inspection of the fort and the defences before it, and gave it as his judgement that the very confined terreplain of the fort "precluded the possibility of protracted defence after our guns were once placed in a situation to bear upon the walls." The only obstacles totheir gaining such a position had been the stockades on the left spur, "which had they been attempted, must unquestionably have been in our possession in the course of twelve hours." In his view, therefore, "no difficulty or obstacle whatever existed to the possession of the whole of the enemy's position which might not have been very readily and easily surmounted." Such was the conclusion dictated by technical data. In fact, the fort could never have resisted at all. It was full of loose amunition and gunpowder, and a single shell would have blown it sky high. 149

The subsequent fate of Gabriel Martindell forms a most eloquent indictment of the military system of which he was a product. Despite the mental exhaustion and the complete absence of self-confidence demonstrated by his abysmal conduct of the Sirmur campaign, he was neither induced to retire, nor even removed to the invalid establishment. on the contrary, he continued to hold posts of high responsibility - 
the charge of a column in the Pindari war in 1818, and the command of the First Division, Bengal Field Army from 1820. He died a lieutenantgeneral, still on the active list, in 1831, aged 76 . The inquiry into his conduct of the seige of Jaithak which Hastings had threatened does not seem to have taken place. The reason for this may lay in the fact that the major-general was in 1815 included among those company officers who were made Knight Commanders of the Bath.* Hastings was probably apprehensive lest publicly disgracing Sir Gabriel should compromise the dignity of the Prince Regent. ${ }^{150}$ Perhaps he realized too that the delinquency of a single senior officer could only be, in the final analysis, but a symptom of far more fundamental defects which were sapping the whole military system of the East India Company, and which even he must despair of rectifying by superficial measures of chastisement. The misconduct of a King's officer, however, was a different matter; and Sebright Mawby was not spared the deserts of his regiment's malefaction. The $53 \mathrm{rd}$ left Nahan early in June, and proceeded to Fort William in Calcutta, where it was joined by some officers from its second battalion. The new arrivals, who had been on service in Spain, jeered their comrades for their failure to take the paltry hill fort of Kalanga, spoke in terms of mockery and derision of "Indian" and troops and old soldiers. The atmosphere of the mess became highly charged, and its peace shattered by bitter quarrels and violent arguments. Two duels even took place. ${ }^{151}$ Untold damage was done merely by the prospect of the court of enquiry - despite the fact that such courts did not conduct any legalistic form of trial. Their object was merely to gather the information necessary to determine whether or not prosecution under the terms of military law were justified in a particular case. They passed no judgement; and did not even given an opinion, unless expressly ordered to. 152

The Order of the Bath, hitherto consisting of one class only, was now divided into Grand Crosses, Knight Commanders and Companions. Several Company officers, including Ludlow, were made companions in 1815 . 
The one appointed to examine the circumstances of the failures before Kalanga remains, alas, almost wholly mysterious. The meagre scraps of information concerning it which have so far come to light indicate that the court initially convened in January, 1815, but was then adjourned on some point of legal procedure. ${ }^{153}$ It assembled again at Meerut, the following year, under the presidency of Jasper Nicolls, then Quartermaster of the King's Troops in India. The indications are that Hastings had had second thoughts concerning $i t s$ expediency in the meantime. In October 1815, Sherwood had noted in his journal that "Lord Hastings I was_T aware now of his injustice, and appear [ed_T to wish to forget it", 154 and his contention is supported by the fact that the Governor General had become especially anxious that the court should be held in secret. When Mawby agreed to secrecy, Has tings wrote in a tone of relief to Nicolls :

"You will find that your closing the doors of the court of Enquiry was approved. The preference given to the contrary procedure was through apprehension that Colonel Mawby might have misrepresented a secret investigation. When he wishes it, that fear is removed." 155

The court, which began its sittings on January 24 th, 1816, was therefore closed from the outset. ${ }^{156}$ Its proceedings have never come to light, and its opinion, which was asked for, is not known. The court's minutes must have been voluminous, for it was not until July that Hastings received them and "determined to read them throughout", ${ }^{157}$ and with them is undoubtedly lost much valuable information concerning the strange history of Gillespie's last hours and the third failure to take Kalanga. All that is presently known about the court is contained in the few sparse jottings made by Captain Chepmell in his diary. From these it appears that the enquiry began unfavourably for the colonel and the regiment; but that there was a general sense of relief when Nicolls was replaced as President by Lieutenant-Colonel Need, another King's officer, in February. "I feel glad of that circumstance, as I consider Nicolls a prejudiced man."158 But it is possible to make a reasonably confident conjecture concerning the nature of the court's findings. It is known that Mawby did not suffer as a result of the inquisition. 
There is no record of a court martial; he was promoted major-general in 1819; and he died a lieutenant-general in 1851.159 It is therefore almost certain that the court exculpated him. Did it do more? Did it uncover unpleasant truths concerning Gillespie's/conduct? Or had Hastings in that year's interval uncover such truths himself, which made him regret his rash promise to scrutinise the behaviour of Mawby and the $53 \mathrm{rd}$, and anxious that the whole business should be brought to a conclusion as quietly and inconspicuously as possible? It is an interesting and possibly relevant fact that from about October 1815 , Hastings' attitude towards Stamford Raffles began to change. In that month he recorded an official minute recognising that Gillespie had been totally unjustified in traducing Raffles' moral character; and later his manner towands Gillespie's old adversary became almost gracious. 160 


\section{Chapter Eight \\ The Collapse of the Eastern Offensives.}

Major Bradshaw remained in possession of the 22 disputed villages on the frontier of Saran throughout the rains, when the rivers swirled down from the mountains clouded by millions of tons of silt, and the rice fields of the Tarai, covered by the wan waters of the flood, became the resort of ${ }^{\prime}$ whistling teal and nacreous aquatic fowl. He had with him three companies of sepoys, a detachment of the Champaran Light Infantry (a new local battalion), and about 150 troopers of Gardner's Horse, commanded by his young brother-in-law, Comet John Hearsey. This small force was distributed about the village of Ghorasahan, where he had set up headquarters. Although fully twenty miles from the edge of the Tarai jungle, the site was very unhealthy; and during the steamy autumn warmth which followed the monsoon, the men became feverish and sickly. ${ }^{1}$ As soon as the waters had subsided, and the familiar reticulation of streams, creeks and rivulets was again apparent, Bradshaw planned an attack on the enemy post at Barharwa, some dozen miles to the east, where Parsa Ram Thapa was encamped with $300 \mathrm{men}$. His object was to clear the approaches to the hills in preparation for the advance of the main army under Major-General Bennet Marley. Marley's force, assembling at Dinapur, was not expected to cross the Ganges until November 15th; and aware that a premature offensive would be risky, Bradshaw waited until the 17 th before requesting the reinforcement which would enable him to put his plan into operation. ${ }^{2}$ Marley then sent forward two detachments. One, consisting of local infantry and pioneers, was despatched under Major Roughsedge to occupy the frontier of the department of Tirhut, which adjoined Saran on the east; the other, comprising five companies of regular sepoys, went to join Bradshaw. But he warned Bradshaw not to advance too far, because the main army was not yet ready to march to his support. ${ }^{3}$ 
Hastings planned that a chain of military posts should be installed in front of the passes into the hills. They would protect the occupied lowlands, and preserve the army's communications with the plains. He intended that they should be established after the army had entered the mountains and claimed the main attention of the Gurkha commanders; ${ }^{4}$ but Bradshaw, now that his force was to be increased to battalion strength, became over-ambitious, and determined to occupy the proposed sites at the same time that he attacked Barharwa. Instead of moving his force to the frontier along a single line, he decided to advance along three, which diverged and described an arc some 40 miles wide at their northem extremities. While the right hand detachment moved to Barharwa under Captain Sibley, the centre column under Captain Hay was to attack Baragarhi, a mud fort about twenty miles to the west; and the left hand force, under Lieutenant Smith, was to march on Parsa, a ruined stronghold some twenty miles to the west again..$^{5}$ This project was put into operation on the night of November $24 \mathrm{th}$, after the junction of the reinforcement from Dinapur.

Sibley left camp for Barharwa at midnight, with 270 sepoys and Hearsey's risala of irregular horse. They marched silently, and neared their destination, which was on the west bank of the Baghmati river, before daylight. A clammy counterpane of river fog lingered on the country: not high enough to cover the summit of the mango trees, but obscuring the surface of the ground. Sibley formed his detachment into three columns and attacked the Nepali encampment, taking the enemy completely unawares. They had no time to form, and fired blindly through the matting of their huts. Parsa Ram Thapa emerged, and engaged in personal combat with Lieutenant Boileau, wounding him by a sabre thrust in the thigh; but a quick-thinking sepoy, Rama Sahai Singh, immediately swiped at the Gurkha subba from behind. When Parsa Ram turned to deal with this new opponent, Boileau brought down his sword and cleft the Gurkha's skull. All the principal Nepali officers were wounded, and, deprived of leadership, the enemy troops scrambled back towards the Baghmati, hoping to escape by crossing it. But while the infantry had been attacking from the west, Hearsey and his horsemen had dashed round 
their northern flank, got between the encampment and the river, and sunk all their boats - a daring and dangerous move, which exposed them to the fire of the British infantry. The Nepalis, foiled in their intention of crossing, gathered in great consternation inside the river bank, and then surged forward in a disorganised mass, making for the jungle and the hills to the north. Again they were checked. Hearsey's men, now dismounted and with pistols loaded and sabres drawn, had moved north into a ravine which debouched into the channel of the Baghmati. As the enemy approached, they rushed out across their path, discharging volley after volley of shot. The writhing mass faltered, halted, spat one or two shots in return, and then retreated southwards again, making for the small fort of Kararhana, three miles below Barharwa. Hearsey's men pursued, while the infantry moved down on the fort along the river bank, so that instead of finding refuge at the place, the fugitives merely had their number swelled by its small garrison, expelled in its turn. All was lost. Some threw down their arms and begged for quarter; others plunged into the deep icy river and were shot or drowned in a desperate effort to swim to safety. It was estimated that about 50 Nepalis lost their lives in this way alone. The total killed was reckoned at 78 , and 23 were taken prisoner. 6

Among the latter was the vakil Chandra Sekhar Upadhyaya, who was captured early in the action. All the property in his possession, including the presents destined for the Govemor General, was siezed as plunder and shared among the troops of the detachment; and Bradshaw, thinking that he might prove a useful diplomatic pawn, decided to retain Chandra Sekhar himself in his camp. The valkil eamestly assured him that neither he nor his masters had ever seriously anticipated a British invasion, and he begged to be allowed to write to the Raja, to inform him of the gravity of his situation. Permission was granted; and under Bradshaw's invigilation he penned a forlorn despatch, describing the calamity at Barharwa and counselling the Raja to open negotiations immediately.

But the durbar at Kathmandu, apprised of British reverses in Dehra 
Dun, was in a less woeful mood. Bhim Sen Thapa's reaction to the news of the attack on Barharwa was not to sue for peace, but to affect an attitude of high indignation. He shrilly resented Bradshaw's seizure of the vakil and his property, claiming that it constituted a scandalous violation of the basic ethics of diplomacy. 8 Hastings dismissed these protestations as entirely unjustified. Chandra Sekhur had been informed of the nature of the relations between the two countries; apparently possessed no authority to treat for peace; and had been given ample time to withdraw to Kathmandu. By remaining on the frontier he had forfeited all right to diplomatic immunity.

Baragarhi, the objective of the centre detachment under Captain Hay, was about twelve miles in advance of Bradshaw's headquarters. It was a large rectangular mud fort, of some importance since it was the winter residence of the subbas of Makwanpur. Although it was known to be garrisoned by only 50 or 60 men, it was appreciated that its high ramparts and deep ditch would be formidable obstacles, and a field gum was placed at Hay's disposal. 10 The route, though short, was intersected by numerous nullas, and it was not until eight in the morning that Hay reached the place. Its occupants were on the ramparts, apparently intending to offer stiff resistance, so operations were postponed until the six-pounder arrived. Meanwhile Hay parleyed with the foujdar, or castellan, and while their leader was thus engaged all the Nepalis in the fort absconded by scaling the back wall. The gun was not necessary after all. ${ }^{11}$

Lieutenant Smith, who mariked to occupy Parsa, twenty miles to Hay's left, did not even see the enemy. When he arrived at the mud fort, after a march of twelve hours, he found its dilapidated works ghostly and abandoned - though spies soon brought word that there was a Nepali force lurking in the forest a couple of miles in front. ${ }^{12}$ With the capture of this post Bradshaw's plan was all but accomplished, and it only remained to tidy his row of advanced posts by moving forward two companies of sepoys from Barharwa, which was on a latitude somewhat behind that of the other two positions, to the village of Samanpur, which was more nearly aligned with them. This done, Bradshaw declared the Tarai of Saran to be occupied, and called on the inhabitants to submit 
peaceably to the authority of the Company's government. 13

Despite its immediate success, the wisdom of Bradshaw's tripartite advance was very dubious. His three advanced posts - Parsa, Baragarhi and Samanpur - were widely separated; they had no support, because the main army had been delayed and had not yet even crossed the Ganges; and they were in continuous danger of attack from enemy bands prowling in the jungle. By setting up these positions at this stage in the campaign, he had exceeded the letter of his instructions and had, furthermore, infringed a regulation of 1806, which decreed that field guns should always be detached in pairs. There was a single six-pounder with each of the detachments in advance. ${ }^{14}$ Nevertheless, he received neither reprimand nor caution from Headquarters. On the contrary, he and the officers under his command were publicly congratulated by the Commander in Chief on their success. 15

It was not long before the serious dangers of Bradshaw's arrangement became apparent. Early in December, Lieutenant Smith, in charge of the western post at Parsa, became positive that he was about to be attacked by a superior enemy force, and he hurriedly withdrew to join Hay. His arrival was timely, because on December 7 th the pickets in front of Baragarhi were involved in a skirmish with the enemy, and three sepoys were killed. But as the main army was by then at last approaching the frontier, Bradshaw decided not to relinquish any of the positions he had gained. He made a march along the frontier, re-deploying his force so that Captain Blackney was left in charge at Samanpur, Captain Hay at Baragarhi, and the post at Parsa re-established with a stronger force under Captain Sibley. Then he formally surrendered his military command to Marley, and turmed southwards to meet the major-general. 16

Major Bradshaw in Saran and Major Roughsedge in Tirhut having already deprived him of some 1,750 men, Marley's army was less than 5,000 strong when he finally left Dinapur. ${ }^{17}$ of these approximately 900 were Europeans, comprising artillerists, and the King's 24 th Regiment of Foot. To this army was assigned the most important role in the Governor General's grand strategic scheme. It was to seize the enemy capital and impose those terms of submission which the Calcutta government 
had judged as essential for its own security. The route of its advance was left to Marley's discretion; but it would be an important object in his operations to secure the three forts in the first range of hills which commanded the principal passes to the plains - Hethaura, Hariharpur, and Makwanpur.

"The service now entrusted to you", wrote the Adjutant General, "is of a peculiarly important nature. We are about to engage in hostilities with a new power, whose insolence and aggression have defied us to arms. The maintenance of the established renown of our country in Asia, the future security of a vast proportion of our dominions, and the prevention of future wars of a similar character will greatly depend on a speedy and successful issue to the approaching contest. Of all the operations now in progress against Nepal, none can more effectively contribute towards bringing about such an issue than the accomplishment of the important and họnable part assigned to you in the general plan."l8

At first it was considered both impracticable and unnecessary to send heavy battering ordnance with Marley's column; but further information representing the road to Makwanpur to be less difficult than had been supposed, and a prudent lesson being drawn, no doubt, from events in the west, a siege train was ordered from Cawnpore to Betiya. Marley was to use this if the need became apparent after he had entered the hills. ${ }^{19}$

The supreme importance of his mission naturally caused Hastings to follow Marley's progress with special attention; but this was not the only reason for his scrutiny. While it is true that his choice of generals had been very limited, there nevertheless remained in Calcutta a very eligible officer, whom Hastings' personally preferred to Marley, but whom he had felt bound to pass over because he was Marley's junior and not on the general staff. This was Major-General George Wood, known after 43 years' prominent service in the ast as "the Royal Bengal Tiger". His part in the capture of Java had been less conspicuous only than Gillespie's, and had eamed him a gold medal and the praise of the Prince Regent. ${ }^{20}$ Such a reputation, and such a token of royal favour had been more than enough to ensure him the effusive partiality of Hastings. "Let me assure you that your character is too well known to me for it to be possible that I should not have you in contemplation 
when I look forward to staff appointments", he wrote to him in November, 1814. 21 It seems sure that the principal command in Nepal would have been given to Wood had the Governor General not been concerned to avoid an invidious supersession.

But if Hastings was not the man to allow personal predilections to outweight the preference due to seniority, neither was he one of those men whose concern to act with scrupulous faimess makes them distrust even their own judgement, where the object of their prejudice is concerned. On the contrary, his sympathy for George Wood made him eager to discover lapses in Marley's conduct which might justify his yielding to his predilections and replacing Marley with his favourite.

It so happened that Marley's army was detained at Dinapur for two weeks beyond the date fixed for its departure, because its supply of treasure, which the commander reckoned he ought not to march without, was late in arriving at the rendez-vous. ${ }^{22}$ Hastings chafed at the delay, complaining of Marley's dawdling ,,$^{23}$ and he asked George Wood to hold himself in readiness for immediate service. "Wherever you may be placed, I can assure you of my full dependence on you." ${ }^{24}$ He obviously did not expect that it would be long before an opportunity to dismiss Marley presented itself.

Marley finally left Dinapur and crossed the Ganges at the end of November, aiming to move to Baragarhi, the central point in Bradshaw's advanced line of defences. To save time, the field guns, stores, and engineering equipment were sent directly to the western end of this line, by way of Betiya, because it was Marley's intention to enter the hills with his main force through the Bichakori pass, which was just in front of Parsa. The army arrived at the southern bank of the Great Gandak on December 6th. Because the rains had been so late, the river was still about 100 yards wider than normal, and it was unfordable even by the elephants. As there were only seven or eight boats at the ghat, getting the army across might have taken many days had it not been for the ingenuity of the Field Engineer, Captain Tickell, and the cooperation of a local indigo planter, Mr. Moran. With the help of large coils of 
rope, cast iron weights, large slabs of rock from the indigo factory vat, and plenty of manpower - all provided by $\mathrm{Mr}$. Moran - a long pier head was constructed to join a bridge laid over the boats, and the whole force with all its baggage and camp followers brought across the river in one and a half days. ${ }^{25}$ By December 19 th it was encamped at Lautan, two miles from the forest and slightly west of Baragarhi. ${ }^{26}$

Marley was very preoccupied as he approached the frontier. News of the harassment of the advance posts convinced him that he must enter the hills quickly; but at the same time he was very reluctant to quit the plains without the battering train, which would not arrive at Betiya for over a week. The root of his predicament was Bradshaw's premature establishment of the line of frontier posts. Marley felt that he had insufficient troops to reinforce them, and he would rather have protected the Tarai by advancing into the hills with his whole force and monopolising the enemys attentions. ${ }^{27}$ Bradshaw, however, having issued a proclamation to the border inhabitants which pledged them British protection, was now unwilling to have the posts withdrawn; ${ }^{28}$ and the major-general was not resolute enough to contradict an officer whom he had been specially instructed to consult. He therefore silenced his misgivings, hoping that the confident reports ${ }^{29}$ of the officers in advance were not unfounded, and allowed the posts to remain as they were until the battering train joined the army. They were then to serve as bases for his projected three columns of invasion. But after he had entered the hills they were to be garrisoned not by regulars, but by a special levy of matchlockmen. ${ }^{30}$ On December 30th, when the heavy ordnance had at length joined the field train at Betiya, and the whole of the artillery was preparing to move forward to Parsa, news was received from Captain Sibley, in charge of that post. He wrote that the enemy were gathered in some force in his front, and seemed to be meditating an attack. The tone of Sibley's note was almost casual, and apparently he did not even request a reinforcement; but the major-general's suppressed apprehensions at once revived, and he immediately sent four companies of sepoys to strengthen him. Under the command of Major Greenstreet, they left camp at three 
$0^{\prime}$ clock in the moming of December 3lst. ${ }^{31}$

Henry Sibley was a brave officer, but he was also a very cocksure one. He was so confident of his ability to drub the Nepalis that when he received a note from Greenstreet on December 3lst, informing him of the approach of the reinforcement, he did not even bother to send a reply. Greenstreet, who was as obtuse as Sibley was confident, consequently saw no reason to hurry, and halted on the road for the night. ${ }^{33}$

Sibley's force consisted of about 360 men, including 50 of Gardner's horse. Besides the six-pounder, he had a small one and a half pounder mountain gun. Finding the mud fort of Parsa too small to accommodate all his men, he had neglected altogether to use this, and taken up a position farther north. His camp was spread along the western bank of a deep nulla. Serried sal forest enclosed it to the front and left. No situation could have been more obviously perilous: yet Sibley had remained there for two weeks without taking any measures to make it more defensible. No trenches had been dug; no forest had been cleared. He had not even adopted the obvious expedient of posting look-out men in the trees. The enemy had excellent cover to well within gun shot of the camp both on its northern and western approaches: the advanced pickets, in fact, were merely a few yards from the forest. The only precaution he had taken on the night of December 3lst, when Lieutenant Smith wamed him of an imminent enemy attack, was to put all his men under arms. He was too intent on celebrating the advent of the New Year to do more.

The Nepalis emerged from the jungle half an hour before daybreak on January 1st. When Sibley saw, in the indistinct light, what appeared to be myriads of adversaries - officers later swore that they had counted five battalions of regulars alone - with numerous elephants mounted with jinjals (deadly large matchlocks on pivots, throwing a two-pound ball), his heart sank, and he realised that he almost surely faced destruction. The enemy tactics were well conceived and executed. Their main body swept round the left flank and attacked the British rearguard, which contained the officers' tents, the magazine and the bazaar, but which was protected only by the 50 irregular horsemen. These were soon overpowered, and the enemy rushed among the tents and grabbed the stores and ammunition. 
Simultaneously, other parties attacked the advance guard and inserted themselves between the right flank and the nulla. Smith was commanding the pickets in front, which were pelted with anobliterating fire. He urgently requested Sibley to send forward the small gun, which was done; but the thing was of experimental design and the cartridge shells proved too large for the barrel. Only a few rounds had been discharged before the gun was overturned and crippled by a jinjal shot. Sibley, who had come forward to assess the situation, now turned to hurry back to the main camp, which was being attacked from both flanks as well as from the rear, but he was wounded twice during his journey: first in the leg, and then much more seriously in the chest. He remained conscious, but incapable, and a sepoy ran forward to tell smith that the command had devolved on him. Smith thereupon galloped back to the main camp, where he found Lieutenant Matheson, the artillery officer, trying to clearthe ground at the rear with the six-pounder. But the Nepalis remained inaccessible in the forest, and the shot merely ripped bark from the trees. The artillerists had no cover from their sniping fire, and were falling at an alarming rate. Seeing that the sepoys refused to advance and reoccupy the ground of the rearguard, and that the pickets in front had been overpowered and were falling back on the main body, Smith decided that his only resource was to make a circle, and in this formation the force defended itself for another hour. The European artillerists and native lascars sweated at the gun, courageously exposing themselves to the lethal snipers' bullets. Four Europeans of the detail were killed, and nine wounded. Matross William Levey was wounded twice, in the arm and leg; but he grimly persevered until the priming pouch was blown from his side and he was forced to sit down, cramped with pain and weak from loss of blood. Matheson then seized the ramrod and the spongestaff and worked the $g$ un himself, stoically assisted by a native lascar called Salari, whose hand and foot were lecerated. But after an hour all ammunition was spent, and with it all hope. Smith and Matheson, dishevelled, and grimy with gunpowder, held a hurried discussion, and agreed that they must attempt a withdrawal to the old mud fort. Gun, 
baggage, and stores were all abandoned. The Nepalis could have massacred the fugitives; but they were more intent on plunder, and the fort was reached with few additional casualties. Sibley, who was still alive, had to be carried on the shoulders of four grenadiers. But here was no respite. The place was full of Nepalis; and as a last resort, Smith ordered his men to retreat across the eastern water course. As the river was high, glacial, and unfordable, few of the enemy attempted to pursue, and those of the British force who managed to swim to the easterm bank escaped. Smith himself could not swim, but two strong sepoys managed to bring him across. Sibley, like the rest of the helpless wounded, was abandoned. If his agonies were intense, they cannot have been long, because the enemy gave no quarter.

Early that morning, Major Greenstreet, ambling easily along the route to Parsa,was startled to hear the sound of heavy firing. He speeded his advance; but when within about three miles of the scene of action the sight of a horde of drenched and bedraggled survivors coming to meet him told him only too plainly that it would do little good to hurry now. officers who came up warned him that his small force could do nothing against such a multitude; so he halted to receive the survivors and gave up the idea of marching to Parsa. Casualties were reckoned at 121 killed, 134 wounded, and three missing. ${ }^{34}$

When he received Greenstreet's report, Marleywas shocked and alarmed. His depot and artillery trains were actually on their way from Betiya to Parsa, and unless swiftly intercepted might be attacked by the enemy or even led straight into the captured post by their unsuspecting officens. He wasted no time. Within a couple of hours the whole of the main army was on its way eastwards. Before he left Lautan the major-general sent orders to Blackney, commanding the western post at Samanpur, and to Major Roughsedge, coming from Tirhut, to withdraw at once to Baragarhi. 35 But his ordered were too late to save Blackney. Two hours after leaving camp a messenger arrived with a despatch from Lieutenant Strettel, Blackney's second in command. Marley was filled with dismay as he deciphered the hu rried scribble. The detachment at Samanpur had been 
ferociously attacked and dispersed at five o'clock that morning. Strettel reckoned that the enemy strength had been 2,000 men and twenty guns:

"Captain Blackney and all the officers of the wing did their utmost endeavours to bring our sepoys to the charge, which failed in every attempt from the very destructive fire which opposed them. It is with the utmost sorrow I am to mention, that after the action had continued about ten minutes with equal ardour on each side, we were deprived of the assistance and directions of Captain Blackney and Lieutenant Duncan (who, I fear, are both killed, having been very severely wounded and disabled). On the fall of these two gallant officers, the sepoys became quite dispirited, and began to retire with some confusion upon which the enemy advanced upon and destroyed our tents by fire. The village of ISamanpur 7 , in which was the commissariat depot, was burnt in the commencement of the action by the enemy. Finding that the detachment had suffered most severely, added to the great numbers and strength of the enemy, it was judged most prudent to retire; and as the enemy had taken possession of the road to Baragarhi, we directed our course to I Ghorasahan T, at which we have just arrived. I am unable to state the exact loss of the detachments, as the stragglers are coming in every minute." 36

Apart from the two officers, no men were listed as dead; but of the 70 returned as missing, it seems few escaped alive, for when John Shipp visited the sight of the engagement over a year later the ground was strewn with skulls, bones, and even whole skeletons. 37

The major-general was profoundly shaken to find Gurkha tactics much more sophisticated, and the Gurkha army far more numerous, than he had been led to expect. Assuming that the enemy had kept in reserve a force at least equal to each of those which had been detached to attack the outposts, he, Bradshaw, and Lieutenant William Pickersgill, the surveyor, agreed that the number of Nepali troops between the British and Kathmandu must be something near 13,000; and there were in addition reports of reinforcements on their way from Tirhut and from the west. ${ }^{38}$ Wondering how he could possibly overcome such a force with the means at his disposal, Marley continued towards the high road linking Betiya to Parsa, and encamped between the two places to await the guns. On January $3 r d$ he sent his light infantry and pioneers north to Paraa, to bury the dead and bring away any wounded who were still alive. The remains of Sibley, of the European gunners, and of the native Christian 
drummers were recovered and brought back to the camp, where they were buried with military honours. ${ }^{39}$ on the 4 th reports were received from Major Mason, conducting the artillery train from Betiya, that enemy parties were hovering around him, and Marley quickly moved his force southwards to escort him for the rest of his journey. Much to his relief, he met the artillery without incident later the same day. On the 6 th, the completed army moved forward again, and encamped about one and a half miles south of Parsa. 40

Hastings blamed no-one but Marley for the calamities at Parsa and Samanpur.

"While he was delaying at Dinapur", he wrote to Colonel McMahon, "the country in his front was cleared for him by a successful attempt of Major Bradshaw's. Instead of profiting by the event and making rapid movement forward, he sends in advance two weak detachments. He stations them at forty miles as under; and he leaves them without any support within twenty five miles of either. He remains utterly inactive in his retired camp for three weeks, during which term these two posts continued under the enemy's nose in the skirt of a forest without a work of any kind to cover them. At length the enemy appeared to have been shamed into the resolution of attacking these sacrificed parties." 41

This was most uncharitable. Hastings knew full well that the advanced detachments had been stationed not by Marley but by Bradshaw, during the time of his independent command; and he omitted to state that the measure had received official approval. He told McMahon that the affair was "very vexatious, though nothing more", 42 but the language in which he had Marley castigated for it was quite out of harmony with such a judgement.

"Your reports... are in every point of view unsatisfactory", the Adjutant General was instructed to tell the major-general. "I They bear the appearance $T$ of your not estimating these occurrences as they really affect the state and yourself. It seems at present as if you were not aware of the heavy responsibility attaching upon you for the loss incurred; nor do you intimate any sense of the mischievous consequences of this triumph given to the enemy, so...that a hope may be entertained of your striving instantly to counterbalance them by energetic effort...

Of the imprudence of making these detachments at all (unless suitably protected) no doubt exists in His Excellency's mind; but the danger and I dis_Tadvantage of extending and advancing them 
was greatly increased by your remaining inactive in a position so remote and from which no timely support could be given in the event of information that the enemy meditated an attack...

It was never the Commander in Chief's intention, nor agreeable to any of his instructions, that your force should be divided and dispersed over the Tarai. The corps under your orders had a specific destination... A reserve follows you for the purpose of establishing posts, covering your rear, and protecting communications. There is therefore no call for deductions from your active strength by detachments. To an injudicious distribution His Excellency primarily attributes the disasters which have befallen these two detachments." 43

Scornful of the startling figures which had begun to appear in Marley's despatches, Hastings warned him against over-estimating the enemy's strength. The main army of the Gurkhas was known to be fully engaged in the west, and they had had neither the time nor the means to increase the force before Kathmandu. But this sort of computation carried little conviction in the field, where responsible officers swore they had seen the enemy in numbers far exceeding the calculations of theorizers at Headquarters. To make matters worse, there was a considerable number of desertions from the corps which had been thrashed at Parsa and Samanpur, and also from the body of camp servants. 44 Before long, the panic had spread to the barkandaj, or native militia, raised for Marley's use by the Raja of Betiya, and all thousand of them had to be dismissed for unreliability in the face of the enemy. 45 The other zemindar of the Company in the area, the Raja of Ramnagarh, showed no disposition at all to help the cause, now that he had seen the Company's troops trounced; in fact, his manner became so evasive that he was for some time suspected of conniving with the enemy. 46 To the east, in Tirhut, the Magistrate had been instructed to raise 1,000 barkandaj in order to relieve the regular army of the duties of internal protection; but in the second week in January he sorrowfully reported that he had so far enlisted precisely seven men. 4 47

The discouragements seemed unending, and Marley's sense of quandary became acute. It was clearly impossible for him both to protect the Tarai and to advance to Kathmandu while his force remained so small. On Bradshaw's advice he put the issue squarely to his two brigadiers, and 
called for their opinion. They both expressed the view that his army was inadequate for the calls on its strength which an advance as far as Kathmandu would entail. To protect the Tarai of Saran and Tirhut; to guard the grand depot at Betiya; to form smaller ones at Hethaura, Hariharpur and Makwanpur; and to furnish convoys for lines of communication would, they conceived, require all the 4,000 effective troops at his command even before provision was made for an advance from Makwanpur to the enemy capital. His own convictions thus fortified by their concurrence, Marley abandoned all intention of advancing beyond Makwanpur during the present cold season. He then withdrew his camp to Binjara Pokhra, fifteen miles south of Ghorparsa, so as to be nearer his depot until reinforcements arrived. 48 To lighten the artillery and commissariat departments considerable quantities of shot and engineering materials were sent to be lodged at Betiya; and as a measure of economy all the coolies of the engineering department, whose services would only have been required in the hills beyond Makwanpur, were dismised and replaced by bullocks. ${ }^{49}$

The major-general's change of plan cost him much misgiving, despite the support which the opinion of his brigadiers afforded; but events of the subsequent weeks, before Hastings' response was known, must have satisfied him that his decision had been well-founded. After Major Roughsedge had joined the main army in Saran, when there was not a single sepoy of the line in the whole of Tirhut, the Magistrate received a report from his frontier police that four Nepali regiments had arrived at Janakpur - the post in the Tarai which Roughsedge had evacuated. Mr. Sealy was a very nervous man, and he entreated Marley and Colonel Gregory, who was at Dinapur gathering reinforcements for the main army, to send troops into his district. ${ }^{50}$ Marley replied that he could not spare a man; ${ }^{51}$ but Gregory immediately made plans to divert the whole of the corps assembling under his command into Tirhut. ${ }^{52}$ The major-general, however, was not prepared to sacrifice the whole of his reinforcement; and he ordered Gregory to take only one infantry battalion and two six-pounders into Tirhut. The rest of his force was to be sent to the Saran army. 53 Gregory's departure was delayed by a lack of bearers, and those impressed 
by the Magistrate of Patna ran away and left the public stores on the road as soon as his back was turned. ${ }^{54}$ Then the country, towards the frontier, became very difficult - "no regular roads and nothing but rice fields" ${ }^{155}$ - so the 40 mile journey to Muzafferpur, the civil station of Tirhut, took almost ten days. Meanwhile, Sealy's agitation became hysterical. Every day brought fresh reports of villages being pillaged and terrorised; and his tandars reported the strength of the Gurkha border force first at eight, then ten thousand. 56 No account was too exaggerated, no computation too preposterous to impress the credulous and excitable magistrate. 57 When Gregory arrived on the frontier, he quickly realized that Sealy's despatches were mischievously extravagant. There was indeed a Nepali force at Janakpur, which he estimated at five or six thousand men; but the frontier disturbances were traceable to the activities of bands of five or six people, who burnt villages and stole cattle. Even these incidents Gregory was inclined to attribute to the zemindars themselves, whom he knew were not averse to destroying their own villages in time of war in order to get their rent assessments reduced. ${ }^{58}$ Sealy disputed this; but there is no doubt that the alarms derived more from instances of banditry in one form or another than from acts of war. The Tarai jungles were infested with fugitives from justice who took advantage of the general disruption to rustle and plunder. Even in the district of Saran, where the main British army was encamped, the Magistrate received daily accounts from his tanadars of villages being fired and cattle driven off, ${ }^{59}$ and here the problem was complicated by a moral obligation towards the inhabitants, who had been promised the protection of the company's government. The criminals and vagrants in its lowland territories were thus proving a valuable additional resource to the Gurkha government. Their activities were a harassing distraction to the main British army, and they confused the attempts of British commanders to estimate the strength of their enemy. "It is confidently asserted, and may readily be believed", Bradshaw told Headquarters, "that many of the inhabitants of the lowlands joined in the attack on our troops at Parsa." 60 It was undoubtedly the presence of these uncounted supernumeraries which created the impression of such 
a swollen enemy force on this and other occasions. It should not be overlooked that the collapse of law and order on the frontier was hastened by the Company's own subjects and servants, who made private reprisals against depredators from across the border. Cases were reported of tanadars having applied to indigo planters for armed men in order to repulse marauders and conduct retaliatory excursions in to the enemy's territory. ${ }^{61}$

Marley, still hoping that he would be able to march as far as Makwanpur that season, worked hard to raise a corps of 2,000 matchlockmen, so that his regular troops might be relieved of the police duties which were at present detaining them at Betiya and on the frontier. He did not have much success; for by the end of the third week in January not a single recruit had enlisted. He was therefore glad to take up the offer of Mr. McEntee, a local indigo planter, to raise 1,000 irregular infantrymen, and advanced him money for the purpose. ${ }^{62}$ The offer of Mr. Cracroft, an attorney of Ghazipur, to furnish a body of horse and foot was also accepted; and the Resident at Liknow, the Agent at Benares, and William Moorcroft were all asked to recruit men. ${ }^{63}$ But these expedients were also frustrated. Mr. Elliot, the Magistrate of Saran, strongly objected to Marley's unorthodox measures, and reported them to the government. "The characters and pursuits of the persons employed in recruiting and the high inducement held out to all seem to indicate a degree of alarm and precipitation, and are consequently calculated to create distrust and a disinclination on the part of the people to come forward", he complained, with somewhat inscrutable logic. ${ }^{64}$ Calcutta agreed, and Marley was censured for employing such unsuitable agents as indigo planters. The troops supplied by private individuals were ordered to be dismissed forthwith, and the collector of Bihar was instructed not to honour, for the time being, drafts on his treasury issued by Mr. Moorcroft. ${ }^{65}$

But these were matters for the attention of Bennet Marley's successor. When Hastings heard of the major-general's conference with his brigadiers, and of his resolution not to advance to Kathmandu, his patience was exhausted, and he reckoned that he had more than sufficient justification for replacing him by George Wood. Angrily, he told 
McMahon that Marley had countenanced "every childish rumour about myriads of regular troops opposed to him" and "terrified his officers (who supposed him to have correct information) by the exhibition of his own alarms."66 Marley was directed to surrender his charge to George Wood, and then proceed to Berhampur, to assume the command at that station and of such troops as it might be deemed advisable to assemble there in reserve for future objects. George Wood was at the same time appointed to the staff of the Bengal army. ${ }^{67}$ Elaborating the reasons for his dismissal, Hastings accused Marley of disobeying his instructions. It had never been intended that his force should protect the Tarai. The risk of enemy incursions had been appreciated and advisedly incurred, in the hope that the advance to Kathmandu would distract the Gurkhas from such enterprise. For any consequences resulting from the insufficiency of his force Marley himself would not have been held responsible. The present commotion and paralysis derived from his initial blunder of distributing his force in weak and unsupported detachments. As for delaying to await the junction of the heavy artillery, this had never been authorised. His army had been furnished with special portable light artillery with the express purpose of expediting its march to Kathmandu. The battering train had been provided only as a reserve to be called on in case of proven need. ${ }^{68}$ Subsequent investigation revealed a further lapse of Marley's. It transpired that during the period between his assumption of the command and the repulses at Parsa and Samanpur, the major-general had never once inspected his division, or seen any corps of it under arms. ${ }^{69}$

Marley was numbed by the news of his disgrace, and made absolutely no attempt to defend himself. Appalled by the prospect of public humiliation, his only wish was to go away and hide. He told nobody about his dismissal; but/began to circulate the camp, and soon the wretched officer could hardly bring himself to show his face. On the moming of February 10th, his second in Command, Lieutenant-Colonel Dick, was supremely astonished to learn that the major-general was not to be found and had left no indication why or whither he had gone. He had 
issued only the briefest moming order, directing that all reports of the camp were to be made to Dick until further notice, and the colonel could only suppose that he had absconded, in a moment of mental abstraction. What had in fact happened was that Marley's sense of ignominy had finally become too much for him. Hearing of the approach of George Wood he had, in a fit of moral cowardice, slipped secretly out of camp with the intention of meeting his successor at Betiya and surrendering his command as surreptitiously as possible. Hastings was flabbergasted, and very nettled, by the news of Marley's extraordinary behaviour. He was not persuaded that the major-general was insane; but he had no doubt that he was inexcusably insubordinate and criminally irresponsible.

"The Commander in Chief's instructions to Major-General Marley... directed that officer to make over to Major-General George Wood 'on his arrival his (Major-General Marley's) instructions together with care of his Division'. Independent of the pointed disobedience of orders which Major-General Marley's conduct involves, the perilous situation in which he placed his Division, at the time almost in face of the enemy; and the risks to which he exposed the public interests committed to his charge by the manner in which he quitted his post, appear to the Commander in Chief to be offences of such a serious nature as to call for the prompt and exemplary notice of Government..."

He was removed from the general staff in Bengal, where Ochterlony was appointed in his place; and at the same time, the station of Berhampur, whither he had been banished and which, being so near to Calcutta, was in the nature of a sinecure, was annexed to the Presidency command and declared to be no longer the headquarters of a general staff officer. By these two measures Hastings intended to "apprize all officers who may hereafter hope to attain I general_- rank and the honorable distinction of the Staff, that it [ was_T not altogether a reward for length of service to be enjoyed in ease and inactivity."

"The liberal policy of the Court of Directors has not overlooked the claims of unemployed officers who are no longer capable of fulfilling the active functions of command. But the General Staff has high and arduous duties annexed to it, which must be faithfully and zealously discharged ... The Commander in Chief will proceed to take into his earliest consideration the further course of military procedure which it may be 
necessary to pursue in the case of Major-General Marley." 70

No further measures were in fact taken. Marley's mansuetude prevented his ever attempting to exonerate himself publicly; but he wrote privately to Hastings, eamestly assuring him that his behaviour had been dictated not by contempt of authority, but only by a sense of acute embarrassment. Hastings, while he had perhaps been indecorously eager to publicise the justification of his own conduct towards Marley, was not by nature vindictive; and as it implicitly admitted that justificiation, he professed himself satisfied with the explanation and decided that the major-general had already suffered punishment enough. ${ }^{71}$ Marley was never again employed either on active service or on the general staff; but he remained on the army active list as commandant first at Berhampur, and then at Allahabad. Assured of a comfortable obscurity by the tender mercies of the seniority system, he was promoted lieutenant-general in 1821, and full general in 1838. He was then eighty-five years old. ${ }^{7 / 2}$

Marley's was not the only head to roll. Shortly after his dismissal the timorous $\mathrm{Mr}$. Sealy fell a victim to the Governor General's displeasure, and was relieved of his post.

"Theevident incorrectness, the extravagant nature, and the injurious tenor of the reports which have for some time past been regularly transmitted to Government by Mr. Sealy regarding the numbers of the enemy and the extent of the danger menacing the frontier of $\bar{T}$ his $\bar{T}$ district, have attracted the serious attention of the Government General; and combined with the conduct of Mr Sealy on the occasion have established in His Excellency's mind a conviction of Mr Sealy's unfitness for the charge of a frontier district in time of war."13

$* * * * * * * * * * *$

Major-General John Sulivan Wood* had been directed to advance through the district of Gorakhpur, along a route about 80 miles west of

No relation to George Wood. 
Marley's. He was to quit Gorakhpur town, his rendez-vous, as soon as possible after November 15 th, and re-establish the Company's authority in the disputed frontier departments of Siuraj and Butwal. He was then to attempt to force or turn the Butwal pass and, should he succeed in entering the hills, to march to Tansing, the military station in Palpa province which had served as General Amar Thapa's headquarters. A fullscale invasion of the provinces of Palpa and Gurkha was not expected of him, because his resources (he had some 3,700 men and a few pieces of light artillery) were recognized to be inadequate for the penetration of such formidably obstructive country. His main object was to create a diversion in favour of the army bound for Kathmandu, and to help constrict the Gurkhas' channel of communication with their armies in the west. 74

John Wood had great difficulty in finding porters. He was delayed at Benares until the middle of November while the commissariat searched for coolies for the public stores, and company commanders, whose responsibility it still was at this time, struggled to collect sufficient bearers for the doolies, or hospital stretchers. 75 Meanwhile the Nepalis took the initiative, and made menacing movements along the frontier of Gorakhpur, causing great commotion among the population. 76 To stay the alarm, the major-general ordered Captain Heathcote, who with five companies of sepoys had gone on to Gorakhpur in advance of the main force, to proceed northwards to Lotan, a village in the Tarai south of the Butwal pass. He found the going very heavy. While Saran, across the Gandak river to the east, was one of the most intensely cultivated and prosperous districts in the Company's dominions, Gorakhpur was assuredly one of the most wild and desolate. The whole area north of the district capital was a malarial wasteland of swamp and jungle. The frontier was lost in a wilderness of elephant grass and forest, which extended from the foot of the first range of hills to within 300 yards of the sepoy cantonments of Gorakhpur town itself. At this time of the year, wide expanses of the country were waterlogged, and Heathcote had to make long detours. 77 
Wood, with that part of his force which had been stationed at Benares, arrived at Gorakhpur on November 15 th. Here he was joined by the King's 17th Regiment of Foot, from Ghazipur, and a troop of the 8 th Native Cavalry, from Partabgarh. A certain delay was inevitable, because the stores and ammunition had to be transported from Benares by cattle, owing to the lack of human bearers; ${ }^{78}$ but John Wood was fanatically meticulous, and his insistence on having all his arrangements completed to the most intricate detail before moving increased the length of his stay at Gorakhpur from the expected week to a whole month. The inadequacies of his commissariat stimulated no talent for improvisation. Never was there a more helpless victim of the military system of supply, whose slow and ponderous machinery required weeks of precious time to complete the preparations which he regarded as the sine qua non of any military enterprise. He dallied for the porters which the Magistrate and Collector were working to enlist, despite the fact that he already had a thous and in hand by the end of November, and notwithstanding the Magistrate's assurance that a further 2,000 would be available once he had occupied the Tarai. In any case, porters would not be required until the army had actually entered the hills. By the end of the first week in December he had collected nearly 2,000; the medical authorities were satisfied that the climate of the Tarai was now safe; and eighteen score carts had arrived from Allahabad; but even then he did not move. He decided he must wait for the 50 elephants and five companies of infantry promised by the Nawab of Oudh, and was still dissatisfied with the state of his consignment of warm clothing. Only 2,300 woollen waistcoats and pairs of pantaloons had arrived, and as he disliked the idea of partial distribution, he set his commissariat to work to make good the deficiency. These, again, would be of no use at all until the troops had entered the hills. He assured the Adjutant-General that he was making the utmost exertion to advance as quickly as possible, but explained that if he did not ensure that his arrangements were complete before leaving Gorakhpur, he would only have to wait at the foot of the hills, consuming supplies which could not easily be replaced. ${ }^{79}$ It was 
typical of his thinking that the possibility of a problem concerning supplies outweighed the certainty of military advantage. By December 14 th the native infantry from Oudh had at last joined; but the major-general would have delayed even then, for the elephants, for more porters, and for his chief surgeon, 80 had he not received an urgent despatch from Captain Heathcote.

This informed him that a force of Nepalis, es timated at 8,000 , had come down in advance of Lotan and were preparing an attack for the night of December 16th. It left the major-general no choice: he was compelled to act. A reinforcement was sent to Heathcote, and the rest of the army followed on the 15th. As it happened, there was no attack; so instead of resuming his march, Wood waited at Lotan, which was still 30 miles from Butwal, for the bullocks with the commissariat and stores. They arrived on the fourth day, when Wood announced that he would move forward again - but slowly, so that the pace of the bullocks would be accommodated and the elephants on their way from Lucknow not be left too far behind. 81 The commissariat and stores moved with excruciating slowness. Nullas had to be forded, trees chopped down, thom bushes and undergrowth cleared; then wheels came off,drivers decided to bathe, cattle fell sick, and guides missed the way. Flustered by all these difficulties, Wood dithered and worried, and managed to cover no more than three miles a day. It took the army ten days to reach Siura, a village a few miles south of Butwal. As he marched, he pondered his plan of campaign. He too had intended to establish three posts to protect the Tarai: Palli, in Butwal department, to his right; Lotan to his front; and Mynari, in Siuraj department, to his left. But these positions too were far-flung, covering a 50 mile extent of frontier; and for this reason he had decided not to occupy them until his main force was menacing the foothill passes and engrossing the enemy's attention. ${ }^{82}$ When he left Lotan, he had sent Lieutenant Anderson to the west, with a force of about 700 , to seize the ruined fort of Mynari; ${ }^{83}$ but on reflection it had seemed that his remaining force - 26 companies and a few guns - was insufficient to enable him to garrison Palli as well. Instead of sending a detachment to the east, he had therefore written to Bradshaw, asking him to send 
a force across the Gandak for that purpose..$^{84}$ This now left all his remaining resources available for a concentrated attack on the Butwal pass.

The old and derelict town of Butwal was situated on the west bank of the Tenevi river, whose defile formed a passage for the main route to Palpa from the plains. The pass itself was protected by the fort of Niakot, which overlooked it from the heights a few miles north west of the town. Originally, Wood had planned to beseige the fort by ascending the hills to its left, and moving along successive peaks to attack from the west; but now he revised his tactics on the advice of his principal informant, a brahmin called Kanaka Nidhi Tewari. This man was a member of the family who had served as counsellons to the old rajas of Palpa, and he had been recommended to Wood by Francis Hamilton, whom he had assisted in the researches for his book on Nepal. ${ }^{85}$ Kanaka Nidhi said that the country to the west of Niakot was too inaceessible to make the major-general's plan practicable, and that in any case there was no water outsidethe fort within a radius of three miles. He suggested that the force should instead turn the Butwal pass by advancing in to the hills by a less known route to the east, occupy Palpa, and then attack Niakot from the rear. Like most people without imagination, John Wood was easily impressed by ingenuity in others. Struck by the neatness and attractiveness of this idea, he determined to adopt it, and submitted trustingly to the guidance of the brahmin. Kanaka Nidhi then pointed out that there was a Nepali post at a place called Jitgarh, which was at the southern foot of Niakot hill. It might perhaps be more advisable to reconnoitre and attack this place from the plains before moving round to take the main fort from behind. He assured the major-general that it was only a redoubt, and would give little difficulty, being in an exposed position at the far end of a clearing in the forest which was some 700 yards in extent.

Wood acquiesced without hesitation, and on January 3rd moved northwards with the greater part of his army, leaving only five companies and a gun to protect the camp at Siura. For a few miles the march was 
along the eastem bank of the Tenavi. Just below Butwal the army crossed the river and struck westwards through thickets and jungle grasses on a route parallel to the skirt of the hills. About two miles from the river a party under Major Comyn turned right, climbed over the tumbled folds of the lower foothills, and made to turn the left flank of the post at Jitgarh. Wood and the rest of the force continued westwards for another three miles, and then turned into the glaucous recesses of the sal forest, which grew thick where the foothills curved away to form an extensive bay. Kanaka Nidhi directed the way forward for about two miles. The march was very poorly organized. No light infantry flanking or preceding parties were detached, with the consequence that the general and the three companies of the advance guard were startled to find themselves suddenly in a narrow glade, at the far end of which, only 50 paces ahead, was a kind of wall, made of large loose stones and almost concealed by grasses and creeper. Wood was nonplussed. Immediately behind the structure the hills rose up, crowned by the fort of Niakot, so it was impossible to proceed farther: but the nature and location of the edifice ahead gave it no resemblance to the one which had been described to him. He summoned Kanaka Nidhi, to ask him if this was indeed the Jitgarh redoubt; but the brahmin, foolishly left unguarded, had vanished, and was no where to be found. There was no sign of life ahead; but the disappearance of his guide made the commander uneasy. He sent forward Ensign Stephens of the engineers with a small party to reconnoitre. They advanced cautiously; but there was still no sound or movement ahead, save the twittering and rustling of birds among the foliage. Stephens was convinced the place must be empty, and was on the point of ordering his men to enter when, suddenly, there was the familiar sound as of green wood split by burning. One or two men fell, but most of Stephens' party scrambled back to the body of the advance guard unhurt, because the enemy were aiming too high. John Wood showed great coolness and personal courage. He marshalled the vanguard into formation, and ordered them to return the fire until the rest of the column and the guns should arrive. They fought at a great disadvantage. They were fully exposed, while the Nepalis were concealed 
by the jungle. Only occasional glimpses could be had of them as they sidled round the flanks of the detachment. Bullets, fortunately badly aimed, sped in every direction. Wood himself was bruised on the chest by a ricocheting ball.

When the head of the main body came up, led by H.M. 17th, they approached the redoubt boldly, while the grenadier and two battalion companies of the 17 th struck out to the right of it, herding enemy snipers before them up the steep flanking slopes of the bay. Captain Croker, who headed this group, killed Suraj Thapa, a Gurkha chief, in personal combat. His men successfully established themselves on the slopes in a position commanding the redoubt, which was meanwhile flushed of its inmates by exuberant Europeans and sepoys. All the officers and men realised that the Nepalis had lost their initial advantage, and they were confident of victory. But Wood was not happy. He could conceive success only in the terms of his own preconception, which was an engagement on a wide plain. The sharp contrast between the Nepali post as he had envisaged it and as it really was, added to the unexplained elopment of Kanaka Nidhi, had disconcerted him and disposed him to expect failure; for victory in his philosophy was the fruit of carefully laid plans and the reward of accurately anticipating eventualities. He had no notion of improvised success. He turned helplessly to colonel Hardyman, and asked him what was to be done; and when Hardyman replied "Support Captain Croker, or withdraw him" he took the line of least resistance and ordered a general retreat, convinced that this was the only way to avoid a "fruitless waste of lives". He insisted that the difficulties were too great for success to be possible. Enemy snipers were still firing from all directions, many from treetops; the hill behind the redoubt was covered with Nepali and strongly protected by the fort of Niakot; and the enemy strength he calculated must be about 4,000, which was twice the size of his own force. But all this was merely rationalization of his own dismal lack of versatility. In fact the position could have been held and even advanced - perhaps as far as Niakot itself, which Major Comyn had successfully approached by the eastem flank. As itwas, the retreat caused considerable confusion. 
of the porters threw down their loads and fled, and the ammunition boxes had to be brought away by the soldiers. Even so the British casualties were only 119, of whom 19 were killed; while it was calculated that the enemy had lost at least 500 killed and wounded. But the major-general's inopportune withdrawal gave the Nepalis the semblance and feelings of vanquishors. When Vazir Singh, the Gurkha commander, was later applied to for the dead and wounded, he replied in the insolent tone of a conqueror:

"I have issued orders to the troops of this victorious state not to molest your wounded men ... any attempt to commit unjust aggression on this powerful state will be severely punished by its gallant army..."

Despite his assurance, many of the corpses brought into camp had been shockingly mutilated. The fate of Kanaka Nidhi remained unknown. "If he is with the enemy, I can have no doubt of his treachery," wrote Wood, with exquisite inanity. ${ }^{86}$

Hastings wascompletelymystified by such a precipitate retreat from a promising confrontation.

"Why, in an attack on the Butwal pass he retired without having suffered anything like a repulse, I have never yet been able to make out - unless it were that he had really found the enemy at a place where he had been apprized that he would meet them", he wrote to McMahon. "As far as his troops were engaged at all they were successful, and had driven the enemy before them. He judged it expedient to sound a retreat, and retired without the enemy's making the smallest attempt to harass him. The difficulty of deciding against the judgement of an officer to whose discretion the management of troops is confided; the persuasion that this could not be regarded as a check; and that he would instantly make an attempt elsewhere; above all, disinclination to be censorious where there was a hope that the contrary procedure might stimulate exertion, made me suppress all criticism. I cheered him under the disappointment $\Gamma$ by_T assuring him I did not regard the event as in any way discreditable; and I endeavoured to animate him with expressions of confidence..." 87

John Wood retreated first to Surajpur, a few miles south of Jitgarh; and then, when the water there had become contaminated, marched east, back to Lotan, where he arrived on January 20 th. $^{88}$ He was now firmly convinced that the Butwal pass was too strongly guarded to be penetrated 
by the troops at his disposal. Some reports represented the enemy force protecting it to be 16,000 strong; and as nature had omitted to compensate him for lack of imagination by endowing him with extra phlegm, he was credulous enough to allow such estimates to discourage him. Expectations of assistance from the exiled pretender to the throne of Palpa had, furthermore, ended in disappointment. It had become plain that he and his entourage had been too long from the hills, and had too little notion of the precise sort of information required by military officers, to be of any use; while the royal family's erstwhile subjects were too awed by fear of Gurkha vengeance to rebel spontaneously. ${ }^{89}$ His original intentions completely upset by these frustrations, Wood tried to think of something else to do. He heard that the passes further to his left especially those west of Tulsipur, which debouched into the dominions of the Nawab of Oudh - were less carefully protected by the Gurkhas. He therefore decided to march to Tulsipur, by way of the department of Siuraj. Such a move might involve more than a search for negotiable passes into the hills. The inhabitants of the western frontier of Gorakhpur were unsettled and affrighted, because Lieutenant Anderson's party had been recalled from Mynari following reports that 3,000 Nepalis were about to attack it, and the reappearance of a British force in the area would restore calm. It would also be possible to prevent the cultivation of the Tarai in that quarter, thus depriving the enemy of resources for a second campaign. The Tharus could be removed from the frontier and resettled in the waste areas of the Company's territory in Gorakhpur. Depopulation would hinder cultivation and would besides arrest the illicit trade in arms and military stores which was known to be conducted between northern Oudh and Nepal. 90 These suggestions were approved at Headquarters, and orders were issued that the restof the 8 th Native Cavalry should be sent from Partabgarh to Wood's camp, to assist the implementation; ${ }^{91}$ but despairing, from the snail's pace atwhich all his operations seemed to be conducted, and from his gullibility where reports of the enemy's strength were concerned, of ever seeing him accomplish that urgent punch into the enemy's flank which had been his assignment, Hastings had already resolved that the major-general must be removed as 
soon as an opportunity arose - under the pretence of entrusting him with another command, if possible. 92

As John Wood prepared for his march to the west with his usual time-consuming fastidiousness, taking a week to complete arrangements for having his wounded sent to Gorakhpur, it began to dawn on him that he was being surrounded. No longer held in check by his presence before Butwal, the enemy had begun to move down on both his flanks. On his right, they were intruding from the north east comer of Gorakhpur. There were no troops to hinder them, because Marley, his division already over-worked, had been unable to spare men to garrison Palli. 93 By the end of the first week in January reports had arrived from the police at Palli of Nepali incursions and looting; 94 and before long similar despatches were coming in from Nichlaul, further south. Martin, the Magistrate of Gorakhpur, told Wood that if he moved westwards as planned, the enemy might well march in from the east and attack Gorakhpur town itself. 95 of them, with two guns, were said to have arrived at Nichlaul. This was only 40 miles north east of the districtcapital, where there were but 435 sepoys and 3 European officers. 96

Simultaneously, came alarming reports of Nepali intrusions on his left. Colonel Baillie, Residentat Lucknow, sentword that the enemy had occupied the passes in front of Tulsipur, and were threatening to overrun the plains. The Raja of Tulsipur, who was a tenant of the Nawab of Oudh, had asked that reinforcements be sent to his frontier immediately. Baillie had accordingly had a force moved up to Balrampur; and its commander, Captain Robertson, reported thatan apparently immense Nepali force $(12,000$ men and 25 elephants mounted with guns) was collected on the frontier before him. 97 There was an additional cause of apprehension in this quarter, because the allegiance of the Tulsipur Raja himself seemed uncertain. He had from the start shown little enthusiasm for the Company's cause; and even the promise thathe would be restored to his old hill possession of Dang if he contributed to its success had failed to dissipate his scepticism. In his opinion the strength of European armies lay in their artillery and cavalry, and these arms he predicted it would be impossible to convey across the "thick jungles, deep ravines 
and stupendous torrents" of Nepal. 98 He had so far failed to respond to Wood's repeated appeals for a diversion in his quarter, and had not even bothered to reply when Lieutenant Anderson, before quitting Mynari, had asked him for assistance. 99 The Nawab of Oudh was induced to send his vassal a sharp admonition; 100 but meanwhile the Nepalis set about destroying the frontier posts in Siuraj and menaced the whole area north west of the British army with invasion. 101

Threatened from the front and from both flanks, John Wood's first concern was for the safety of Gorakhpur town, and he sent 1,200 men to reinforce the garrison there. But he could not decide what he should do next. His feeble intellect was paralysed by the predicament with which it was having to cope. To move westwards would expose the district capital to attack; to stay at Lotan and allow the enemy to plunder with impunity seemed equally ill-advised. Completely nonplussed, he appealed to Headquarters for fresh instructions to match his "new and embarrassing situation". Meanwhile, he resolved to make one of his favourite creeping marchs towards Bansi, 25 miles west, in the hope thathe would receive the Commander in Chief's directions on the way. The only comment which he could offer concerning his present situation was hardly a constructive one: "With the force now atmy disposal I could not even much expect to promote indirectly the success of the war by occasioning a diversion of the enemy's resources; for these are so numerous that no quarter need be left uncovered, while his frontier is so strong that the march of an inconsiderable enemy towards it is likely to be beholden with little alarm."102

Hastings' annoyance and disappointment atWood's fecklessness and defeatism were acute. In a very frosty despatch, he made it clear that when the government entrusted an officer with a distant command, it did not expect to have to spell out instructions for every move, but counted on that officer's own resourcefulness. In his view, all present embarrassments sprang from the major-general's having allowed himself to be delayed for trivial reasons at the outset. He had thereby lost the initiative on which the whole success of the general strategic plan depended:

"The enemy have now gained the move of you; and instead of their being so occupied in their own defence as to be under an 
inability to assail our possessions, they are at perfect liberty to distract you.... and to lay waste those parts of our territory which must unavoidably be without protection. This is the known and certain evil of defensive war. When an army has information of your fixed position, he can apply his force to objects which yourposition does not cover."

Wood was told that his primary concern now must be the safety of Gorakhpur town. If he remained at Lotan, he was to organise the force in the capital into a mobile column able to strike at the enempy marauding parties - for although the Nepalis may well have had an appreciable force in his front, the demonstrations on his flanks were assuredly the work of small detachments intent on propagating an exaggerated idea of their own strength. If he advanced to the hills, he was to leave a strong force for the protection of Gorakhpur. But as Hastings had no real hope that the latter was the alternative which the major-general would adopt, he instructed him to send the King's 17 th Regiment into Saran, forthwith, where George Wood would have better use for it. ${ }^{103}$

John Wood left Lotan on January 28th, and arrived at Bansi, 25 miles to the west, on February 3rd - having covered, on an average, between three and four miles a day. While he was at Bansi further troubling reports arrived from the east, where the town and tana of Nichlaul had been sacked by Nepalis. 104 Then a torrential rain set in. It continued for several days, and so swelled the nullas and flooded the country that Wood declared that it would be impossible for him to move again until several days after it had ceased. Thus conveniently absolved from the responsibility for his/inertia, the major-general ruminated at leisure, and finally formulated the resolution which had long been hovering latent in his mind. To advance any farther west would be futile. Information suggested that the enemy would make a strong stand in Siuraj, and in any case the more he learned of the Nepali frontier the less he was disposed to think that he could pass beyond it. He would therefore, for the rest of the present season, concentrate on wasting the enemy's resources on the lowlands. He defended himself against Hastings' strictures in a tone of mild injury: 
"If I have become exposed to some of the disadvantages attendant on defensive war, it has not been from any want of anxiety to avoid such a system, but from the force of circumstances: from the impracticable nature of the hills, the close intersected face of the lowlands, and the wary active character of an enemy unencumbered with baggage."105

The weather cleared; but now that he had been deprived of the King's 17th Regiment, Wood considered that he had insufficient troops even to march northwards into Siuraj, and more time passed while he waited for the 8 th Native Cavalry, moving up from Partabgarh, and for reinforcements called from Lotan and Gorakhpur. It was not until February 17 th that he finally struck camp. 106 The old fort of Mynari was only 25 miles to the north, but it took Wood no less than twelve days to arrive there. Once in Siuraj, he began to devastate the country, destroying the crops on the ground and inciting the camp followers to pillage the hamlets, which had been evacuated on his advance. Within twelve days he had razed some two hundred villages and bumt immense stores of grain. 107 Meanwhile measures were taken to re-settle, in the more southerly areas of Gorakhpur, the wretched Tharus who were deprived of their lands and homes by this odious but essential operation. 108

In the second week of March, it became known that Vazir Singh, the local Gurkha commander, had, on account of ill health among his men, been compelled to retire from Niakot with six companies of his force and station them in the higher and cooler regions of Palpa. The news, surprisingly enough, inspired Wood to contemplate another attempt on the Butwal pass. There were of course long delays before the thought was translated into action. He dallied first for Captain Robertson's force from Balrampur, and then for the contingent of Gardner's Horse which had been put at his disposal in place of the 8 th Native Cavalry (now also sent into Saran). 109 He found that he could not quit Siuraj until Gardner's horse had arrived there, because, having inflicted havoc on the Gurkha territories in the area, it was necessary to leave cavaldry to protect the Company's subjects from enemy reprisals. Unforseen circumstances delayed the departure of Gardner's Horse from Cawnpore (their commander complained that when he joined them they were in a 
state of virtual mutiny) and they did not arrive on the frontier until April 4th. Even then they proved totally unsuited for their duties, be because instead of allaying local panic they inflamed it, by ransacking and looting themselves. 110

Wood did not arrive back at Lotan until April 6th. By then the healthy season was waning fast, and the weather had become dangerously sultry. Yet still no sense of urgency spurred the ambling general's progress. He dithered at Lotan for three days and then, with 24 companies of infantry and 200 irregular horsemen, trudged north up the east bank of the Tenavi river. Now hindered by heavy artillery - he had two eighteen-pounders, sent from Gorakhpur, as well as fŏh light pieces he managed to cover only four miles a day. On the morning of April 17th, having suffered no molestation, despite the thickly wooded country, he arrived at a position on the river bank directly opposite Butwal town. He set his ordnance to smite its defences, while skirmishers from the irregular horse held atbay an enemy party from Jitgarh which was badgering his left flank. There was a sporadic retaliation from one or two guns in Butwal, but these were soon silenced, and it appeared that the town had been abandoned. Some carcasses were thrown, but these failing to set the town on fire Wood ordered a party of light infantry to cross the Tenavi and enter the place. The river bed was stony, and the water waist deep. The party were barely half way across when renewed musketry fire from the town's defences wounded a few men and forced the others to withdraw. Wood's big guns gave short shrift to the Nepali sharpshooters, while his men still held their fire in reserve; but closer inspection had revived and confirmed rather than diminished the major-general's conviction that the pass was impregnable. He therefore decided that his object had not, after all, been to force an entry to the hills, but merely to make a demonstration. Having thus conveniently modified his ambition to match his accomplishment, he called off the troops, limbered the guns, and marched back to Siura, congratulating himself upon a success. 111

He lingered on the frontier for a few more weeks, but passed the time planning the distribution of his army for the monsoon, and made 
no further offensive measures. Hastings contained his displeasure, because he appreciated that by making Wood's instructions so imprecise he had disarmed himself in advance for the eventuality of the majorgeneral's incompetence. If Wood had abused the spirit of his orders, he could nevertheless claim that he had created that diversion which had been prescribed as the guiding principle of his operations. Hastings had been reluctant to shackle any of his generals with fussy directions, only to discover to his cost that to allow latitude for initative is to risk that it will, with impunity, be used for ineptitude. Wood combined a mania for method with such a lack of imagination that after having spent weeks perfecting arrangements which could only have been of use

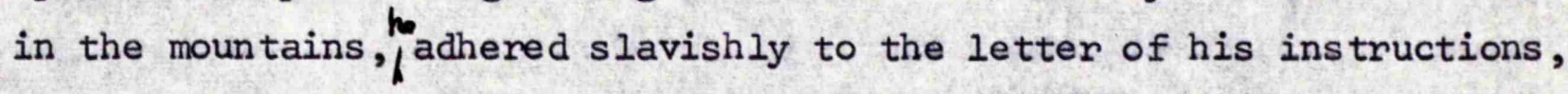
and never really made a serious effort to leave the plains. Such a mentality was totally inadmissible. in the holder of a military rank as high as his; but the East India Company's was not the only army in which inadequacy was rewarded with high command. Wood was not again employed on active service, but this was probably no more than the inevitable consequence of his returning to Europe soon after the Nepal campaign, where the British army fought no wars in the remainder of his lifetime. There is no evidence that he had forfeited the confidence of the Horse Guards. He was promoted lieutenant-general in 1819, and full general in 1836. When he died in 1851 he was Governor of the Tower of London. 112

$* * * * * * * * * *$

While John Wood crawled aimlessly up and down the frontier of Gorakhpur, to his right, across the river Gandak in Saran, the main division of the army lay waiting for its new commander, Major-General George Wood, to arrive. Colonel Dick kept the men active. The whole force at Binjara Pokhra was divided into three watches, which remained under arms by turns during the night. The line was turned out regularly an hour before daybreak, and the troops exercised in brigade until about eight $0^{\prime}$ clock. ${ }^{113}$ The area around the camp was by now a scene of absolute desolation. Independently of the depredations of the enemy, the presence 
of the British army of $5,000,114$ and the attendant public servants and camp followers who swelled the total to nearly four times that number, 115 had been sufficient to lay waste the surrounding country over a considerable area. All the local inhabitants had fled at the army's approach, and the deserted villages had been torn down and used for firewood. 116

Early on the moming of February 20th, Lieutenant William Pickersgill left camp with twenty horsemen and twenty light infantry sepoys to reconnoitre the borders of the forest, which was about a dozen miles to the north. At half past nine, when about seven miles from the camp, the cavalry, in advance, came to the village of Pirari, which appeared to be still inhabited. They kept a wary distance at first; but then, assured by some peasants that there were no armed men in the village, they advanced again, more confidently. A salvo of musketry was suddenly discharged from among the huts. The horses shied, and backed away. Pickersgill hurried forward with the footmen, and joined the cavalry near one of the 'tanks' which are characteristic of rural north India. It was in effect a pond enclosed by high mud walls to prevent cattle and wild animals drinking the water, situated on the left bank of a nulla about 1,000 yards west of the village. He withdrew his party into the shelter of its walls, hoping to inveigle the enemy into coming from among the huts and revealing their number. The ruse was successful, for the Nepalis did emerge, and assembling on the bank of the nulla farther to the north, showed themselves to be between five and six hundred strong.

When Dick, back at B (xinjara Pokhra, heard firing, he immediately asked Bradshaw for the use of the remaining part of his escort of Gardner's Horse; and this being granted they were soon mounted and off to the rescue, headed by (and dashing cornet John Hearsey. Ensigns Wilson and Patton of the Infantry followed, leading the infantry pickets. The officers in camp were so excited by the prospect of a spell of action that most of them dropped everything and rode out to take part, in some cases armed with nothing more than riding whips. The western embankment of the tank had been washed away by the adjacent stream, which had flowed high and fast in the previous rainy season, so 
Hearsey was able to lead his men into the enclosure and await his opportunity unseen. Pickersgill's men continued to expose themselves on the sides of the tank in view of the Nepalis, and then contrived to draw them down by setting fire to some of the huts in the village. The enemy party thereupon advanced menacingly, and Pickersgillenticed them by retreating southwards towards the infantry reinforcement which he knew to be approaching in his rear. When they were between the tank and the village, Hearsey and his horsemen charged out from behind the tank, formed line, and advanced to take them in flank. The Nepalis were startled, and their advance wavered as they turned to deal with this unexpected thrust on their right. But unknown to Hearsey, the ground between the tank and the village was spongy. His horses were soon floundering in a morass, and the Nepalis directed an angry fire at them. Hearsey was forced to back out of the mire, and the enemy, fancying that he was retreating, resumed their advance. The cavalry, however, merely skirted the swamp, and took them in flank again farther south. This time the Nepalis halted, and withdrew in confusion to the burning huts. Hearsey, Patton, and the cavalry galloped in pursuit, and were soon fighting hand to hand in the enclosed spaces of the hamlet. One adversary lunged at Patton from the roof of a hut, cut clean through the peak of his cap and gashed his forehead, Peering over his shoulder Hearsey could see, through the smoke, the gleam of the bayonets of the infantry pickets, and he decided to withdraw his men from the village and assemble them on the plain to the north, so as to hinder the enemy's retreat to the jungle. He galloped away from the huts, sounding the kettledrums as a signal for his corps to follow. By then, however, Dick and several staff officers had reached the village, and under the impression that the horsemen were absconding, ordered them back to the huts to face their enemy. Consequently, Hearsey had only had 30 or 40 of his men with him on the plain when, as he had expected, the Nepalis attempted to flee in that direction. Confident that the infantry would emerge from the village on their tail and give him support, he dashed down to meet the advancing rabble. But his men, instead of following directly, swerved to the side and went to attack their flank; and 
Hearsey and his native standard bearer, Dilowar Khan, found themselves alone in the enemy's midst. They pushed forward against the flow of the surging throng, flaying about them with sabres. Hearsey was parrying a khukuri thrust, when the rivet in his sword gave way and the blade fell useless to the ground; but he checked his antagonist by hurling the handle with all his might. Another enemy let fly an arrow; but by a merciful stroke of fortune, the missile pierced the wooden knob of Hearsey's sash - splitting it in two, but not penetrating beyond. Then a musket nozzle was pressed to his ribs; but the powder in the pan was damp, and flared, causing his horse to shy. The Nepali's aim was lost, and the discharge did no more than set alight the young comet's sash. Miraculously, both Hearsey and Dilowar Khan cut their way free without suffering serious harm.

Meanwhile the rest of the cavalry and the infantry harried the enemy from the flank and rear, chasing them northwards towards the jungle. The Nepalis fled across a deep and difficult nulla, which Dick judged it inexpedient to cross without more men and artillery. When eight companies of sepoys and two six-pounders had arrived, he advanced again. But the progress of the guns was slow. There were no pioneers and only four bildars to clear a road; and eventually Dick decided to proceed without them. When he reached the edge of the forest there was no sign of the fleeing enemy, and as the light was failing he forbore to hunt them in the jungle. The villages on the forest fringe were deserted, but stuffed with grain. Before returning to camp, Dick ordered them to be burnt in retaliation for the treachery of the local Tharus, who had coaxed Pickersgill's force into a trap.

It had been an auspicious and stimulating affair. Almost 100 of the enemy had been killed and wounded, at the cost of only 18 British casualties. 117 The new commander arrived at Binjara Pokhra the following day, and found the troops keyed up/avid for more action.

George Wood was a bilious old officer, known as "the Tiger" as much because of his growling and swearing as because of his courage. He hoarded and secretly enjoyed his reputation as a miser does his gold. Professional service had acquired the nature of an investment. He weighed 
the risks involved in any enterprise; computed the returns in terms of increased prestige; and chanced a move only when the prospect of gain seemed sure. When he scrutinised his present instructions, he was immediately seized by that suspicion which jealousy makes instinctive in the commercial speculator, because it seemed that the Governor General was requiring him not only to undertake an assignment which was more than usually dangerous, but to bear the blame for any failure. Hastings had made it quite clear, in one way and another, that Wood had been appointed in order to resume active operations; but the official instructions with which he was furnished were very vague, and did not enjoin a specific course of action. Pointing put that the malarial season was expected to begin in the first weeks of April, the Adjutant General merely suggested that an advance as far as Makwanpur might still be attempted. The final form of his operations was left to be defined by Wood's own discretion. 118 To the major-general, this seemed to imply that if he did advance and his army was in consequence decimated by disease, his judgement would be pronounced faulty and himself be held responsible. Imputing his own cunning in matters concerning reputation to the Government General, he concluded that Hastings had advisedly made the instructions imprecise in order to insure himself against culpability in the event of failure. The wily Tiger was immediately on his guard. So convinced did he become that his instructions were designed as a trap, that he dropped all idea of taking his army into Nepal. He told the Adjutant General that he could not advance. His discretion wamed him that it was too late in the season to do so without endangering the health of his army.

"I am of opinion that an advance through the forests at this late period...to seize and occupy any of the passes leading to the valley of Nepal may eventually be attended with much risk to the general welfare and preservation of this division.

I have therefore determined not to hazard the risk of attempting the valley of Nepal this time, as a measure of too serious a responsibility and involving the danger of incapacitating the army for the early service of the ensuing season."

Instead, he said, he would devote his attention to expelling the enemy from their advanced positions on the plain. ${ }^{119}$ 
Mingled astonishment and anger surged through Hastings when he arbitrary and preposterous

received news of this fdecision. Was this the measure of the Bengal Tiger's capacity? Was this the value of his gratitude for the partiality and patronage with which he had been favoured? Even Marley had not given up hope of going as far as Makwanpur; but Wood refused even to consider leaving the plains! The reply which he dictated to the Adjutant General was trenchant with disgust and reproach:

"The embarrassment and the discredit of our present circumstance.... arise from the fallacious supposition that a long extent of frontier can be defended by posts; or that the audacity of an encouraged enemy can be repressed but by offensive exertions vigorously pursued. The Commander in Chief desires me to observe that had the adoption of such a manly policy not been his expectation or not been demanded by the most obvious exigencies of the state, the Division might have been still left to the charge of Major General Marley...

As you appear to have thought it a matter of indifference whether the service should be prosecuted this season or not, His Lordship (superfluous as he should otherwise have imagined it), instructs me to point out the serious disadvantages entailed by your determination on the public interest.

It has escaped you that the leisure given to the enemy ensures a more efficacious preparation for resistance to us in your front when operations shall be resumed, while it enables the enemy to detach reinforcements towards such points as have already been penetrated.

It has escaped you that the subjecting the Honorable Company to the expense of the Division in the Field for six months of inaction, after which a new campaign is to be commenced, can with difficulty be extenuated by an officer who has the apparent means of inducing the enemy to submission in a month.

It has escaped you that under the $\overline{\text { ? }}$ unfortunate $T$ disgrace which the British arms have sustained, there is no making peace with the Gurkhas, because they must not be left with the show and sentiment of having baffled us; whereas any brilliant success over the enemy's army, though far short of reaching the capital, might have enabled Government to accept with honour and security those atonements which the Raja of Nepal seems inclined to offer.

The Commander in Chief directs me to say that when you reflect upon these mischiefs attendant on your unfortunate and extraordinary decision; and when you remark that you were placed at the head of the Division avowedly on account of the inertness of its former general, you cannot think he has applied too rigorous a construction to your I procedure $7 . " 120$

George Wood was left in no doubt that he would not be commanding the division in the campaign of the following season. 121 
The major-general, still secure in his belief that Hastings had wanted the benefits of but not the responsibility for an advance into the hills, was incensed by the hypocrisy which he fancied he discemed in this missive. Hot with rage, he retorted by openly stating his conviction that invasion had not been specifically enjoined because it was desired that all the blame for a failure would accrue only to himself. ${ }^{12}$ He was in effect accusing the Govemor General of moral cowardice and deceit, and even Wood, when his passion had subsided, realized that this was going too far. Hastily, he wrote a private letter of apology to Hastings, asking that his indiscretions be forgiven and forgotten. But this letter which, far from evincing contrition, invoked the Governor General's 'undeserved imputations' as the cause of his illtemper, instead of mollifying Hastings, made him furious. He disdained to be offended by insults whose vulgarity was apparent even to their author in his moment of reflection; but he fulminated against the contention that the imputations which had provoked them had been undeserved. In his reply, he vigorously reiterated his arraignment of Wood, and accused him of having grossly abused the good faith for which it should have been obvious he had been accredited:

"I had with great pain to myself been constrained to subject Major-General Marley to the disgrace of a removal from the command of the Saran Division ... That fact alone was sufficient to point out to his successor that energy was expected and required of him. You were the person selected by me for the command; and when you were substituted for Major-General Marley professedly that you might repair the mischief entailed by his inactivity, I should have thought it an unworthy impeachment of your character had I by any special orders for exertion insinuated that you might not feel the necessity of it.

You assumed your command at a moment when the spirits of the enemy had been remarkably affected by the brilliant success of our irregular cavalry against a detachment of their infantry; you further found yourself strengthened, beyond any hope that had been held out to you, by the addition of the King's Seventeenth Regiment to your army. Every circumstance concurred to urge your attempting that impression stated in the letter of February 2nd as so important for the public interests.

Had you, in this situation, informed me that you deliberately weighed my representation of the benefits to be gained by inflicting a severe blow on the enemy, but that you thought they would I be I purchased too dearly by exposing the troops to a 
pestilential malady on penetrating through the forest, and that you would therefore limit your enterprises to ... attacking the enemy in their several fortified positions on the plain, I should have had no impalatable remark to make. I should have lamented that you saw cause to forgo what appeared a most advantageous opportunity; but I should have given you credit for acting from an upright conviction of expediency, and I should have applauded you for the vigor with which you projected the expulsion of the enemy from the advanced stockades. Nothing of this sort is even the most remotely intimated by you. ... Do not deceive yourself. Your neglecting to give me, your Commander in Chief, whose other plans were to be modelled accordingly, satisfaction on that point, was no venial oversight. It was substantially culpable... My selection of you for the command manifested my opinion of your character and my personal disposition towards you. I must not, however, suffer my partialities to betray me into a parley with insubordination. I desire you as a soldier to say conscientiously how I, your General, ought to act in the case which I have detailed to you." 123

Hastings' anger was all the more intense because his information indicated that had Wood taken the trouble to seek professional medical advice on the issue, he would have found that enough time still remained to penetrate as far as Makwanpur at least. If necessary a force could have been maintained there during the ensuing hot and rainy seasons; but the Governor General's own persuasion was that this measure, in conjunction with Ochterlony's successes in the west, would have been sufficient to cause the Kathmandu government to sue for peace. 124 Furthermore, the lower provinces of the Bengal Presidency had been mulcted of troops in order to reinforce Wood's division; and by the beginning of March an additional ten companies of infantry, a specially constituted eight-company battalion of sepoy grenadiers, and two King's regiments (the 14th and 17th Foot) had either joined or were about to join his force. These made a total of some 3,000 men, and brought the strength of his army to about 8,000. This moreover was exclusive of an extra battalion of native infantry which was sent to join Colonel Gregory in Tirhut. After all these detachments had been made only 2,500 troops of the line remained in Calcutta for the duties of the Presidency and the lower provinces, and two battalions of the Madras Army had to be moved up into Cuttack to relieve them of the pressure of duties on the southern frontier. ${ }^{125}$ The 8 th Native Cavalry 
had also been sent from Gorakhpur to reinforce the Saran army; but on leaming of Wood's supine disposition Hastings countermanded the order, deciding that the services of cavalry were too precious to be wantonly squandered. 126

Despatches travelled slowly in India, even when impelled by choler; and by the time Wood's quarrel with the Governor General had reached its climax, the plan which he had devised was already in operation and the season was too far advanced for alterations to be ordered. Having waited about two weeks for his force to assemble, Wood then proceeded to divide it. Roughly a half was left for the protection of the camp and of the depot at Betiya, while the rest, with six guns, was led on a hundred mile march along the borders of Saran and Tirhut to clear the jungle approaches of enemy stockades and pickets - a measure which was, as far as the disgusted Governor General could see, no less hazardous to the health of the troops than a penetration of the hills would have been. ${ }^{127}$

The detachment, headed by George Wood himself, left Binjara Pokhra on March 3rd. He planned first to oust the Nepalis from their post in the forest north of Baragarhi; but they heard of his approach, and withdrew into the hills before he arrived. The defences of their position were then destroyed by Roughsedge, commanding at Baragarhi. ${ }^{128}$ Wood continued eastwards, past Samanpur. There was no road, and the pioneers had to make one for the carts and artillery as the army went along. High jungle grasses had to be cut away; and innumerable channels of water courses filled with branches and bundles of grass to prevent the gun carriages $/$ sinking into the mud and sand. On one day's march, no less than nine nullas had to be crossed in this way. Each operation drew torrents of swearing from the general. At night, he pitched a very small tent in front of the whole army, so as to be first into the fray if the enemy attacked. ${ }^{129}$ As there were no other mounted troops with the force, the small band of Gardner's Horse had to control the baggage train the whole length of the way.

"I scarce had a night's rest the whole way", grumbled Hearsey. "I did not know what it was to take off my clothes, long boots, or sash at night, or to take any sleep. I was obliged to be on horse back at eleven p.m., guarding with my men the 
only road to prevent its being blocked by baggage. When the force moved I had to precede the column on its march, and to prevent the elephants, camels, bullocks and camp followers from obstructing it... I seldom got any food, except what I carried in my haversack, until $50^{\prime}$ clock in the aftemoon, and very frequently not then... I had all the arduous duties of baggage master to perform, and this disagreeable and incapable old general would not even enter my name in orders as 'Baggage Master' to increase my Comet's allowance of pay."130

The army reached the Baghmati on March 9 th, having ascertained that no Nepalis remained in the Tarai of Saran. Across the river in Tirhut, the situation was the same as far as the neighbourhood of Janakpur. Rupithgarhi, three miles south of that place, was known to be occupied by an enemy garrison, reported by local inhabitants to be 12,000 strong. Hearsey wanted to gallop ahead and beleaguer the place until the rest of the army could move up to the attack; but Wood would not consent, and the enemy, hearing of his approach, made good their escape. Hearsey chafed that such a good opportunity had been lost. The Nepalis were known to be still at large in the neighbourhood, but instead of staying to seek them out, the major-general, after only three days at Janakpur, tumed about and marched all the way back to Saran, taking a route slightly south of that by which he had come. Colonel Gregory was left to deal with the enemy still remaining in the north east comer of Tinhut. "I swept the whole of the eastern Gurkha territory, destroying several stockades" Wood later boasted. True, he fired the odd deserted enemy outpost; but he never saw a single Nepali, and his main achievement was to exhaust his army and swell its number of sick. Once back at Betiya, he busied himself with arrangements for the dispersal of his force during the rains. The native part of the army and the King's 24 th were posted in selected positions at suitable retired distances from the forest, while the rest of the Europaans were remanded to cantonments. This accomplished, he hurried away to Dinapur, pleading ill health, but probably not without the intention of avoiding the indignity of being superseded at the start of the next campaign. 132 Paris Bradshaw quitted the army on April 14th, and retired to thevillage of Segauli, where he built himself a bungalow for the monsoon. 133 
Gregory, joined by his reinforcement from Calcutta, under Joseph o'Halloran, flushed the Tarai in Tirhut of the remaining pockets of enemy troops before settling his men at Nathpur, on the west bank of the Kosi, for the rains. 134

So ended the first campaign of the grand army. The Tarai of Saran and Tirhut had been cleared of the enemy, and the occasion taken to declare $i$ ts annexation to the dominions of the East India Company; ${ }^{135}$ but such a timidintrusion into the Nepalese lowlands fell far short of the spectacular climax so confidently envisaged by Hastings. The army was hardly nearer Kathmandu than it had been five months earlier. All its time, though hardly all its energies, had been consumed in retrieving the consequences of an initial blunder. Hastings must himself bear a large share of the blame for the débâcle. He had switched commanders half way through the campaign more in deference to arbitrary partiality than to military judgement, and had thereby replaced an indifferent commander by one much worse. Marley had fumbled and hesitated, it is true; but it must be remembered that at the very outset of his command he had been upset by a double calamity for which he was not principally to blame, and that throughout he had been assisted by second rate subalterns and misinformed advisers. His own tactical ideas had been perfectly sound, and it is quite possible that had he been given an opportunity to collect his wits he would have attempted that advance on Makwanpur, which, had it been successful, would, as Hastings himself admitted, probably have brought the Gurkhas to their knees. Whether it would have been successful is another matter. The main pass, the Bichakori, was in fact impregnable and it was only by extraordinary good luck that a vastly better general with a much larger army managed to turn it and reach Makwanpur the following year. Perhaps, in refusing to advance, Wood had done the right thing. But the fact remains that he had done it forentirelywrong reasons.

His fondly treasured reputation did not suffer. Together with Gillespie and Martindell he was gazetted K.C.B. in April, 1815, and in 1821 he was promoted lieutenant-general. But during the remaining half dozen yeass of his service life in India, Hastings never again gave 
him a field command. ${ }^{136}$

$* * * * * * * * * * *$

The only commander employed in the eastern theatre whose performance was a cause of congratulation was Captain Barre Latter, who was entrusted with the defence of the frontier beyond the Kosi river. The Gurkhas having a major military station at Vijaypur, in the eastern hills, a certain apprehension was felt for the safety of the district of Parnia, which stretched for some seventy miles between the Kosi and Tista rivers. Beyond the Tista, there was thought to be little danger, because the Company's territories there bordered those of the Raja of Bhutan, who was not expected to ally with Nepal. The Sikkim Raja, of counse, had no lowland possessions at this time, but was confined to a small sliver of territory wedged between the Nepalese and Bhutan frontiers in the mountains.

This stretch was perhaps the most moumful and pestilent in all the length of the northern frontier. The sandstone foothills, which broke the monotony of the lowlands farther west, here swept back to join the main bulk of the mountains, exposing the extensive and perpetually swamped marshland known as the Morang. From Latter's headquarters at Titaliya, a village near the east bank of the Tista river, you looked north to the Nepalese mountains of the left, and those of Bhutan on the right, over an intervening fen of reeds, brushwood, and moist jaundiced grasses.

It seemed at first that Latter would be hard put to discharge even his duties of defence efficiently. His only troops were the Rangpur Battalion - a new local corps of untried recruits - four companies of regular infantry, and a few light field guns with their details: about 1,200 men in all. ${ }^{138}$ In order to deploy his force most advantageously he needed the close cooperation of the civil authorities, who controlled the police; but this cooperation he never had. Magistrates were wont to adopt the language and manner of independent despots, and none more so than Mr. C. R. Martin, the Magistrate of Parnia. When Latter restrained Martin's police officers from crossing the enemy's border in pursuit of some criminals, the Magistrate lost his temper and sent the young military 
commander an insulting letter. "You have nothing whatsoever to do with my police officers", he wrote imperiously. "I must strictly enjoin you never again so far to presume as to prevent the execution of any directions I may in my official capacity deem proper to give." The police on the frontier then actually began claiming authority over the parties of sepoys which Latter had stationed, thereby endangering them, and Martin made Latter's position intolerable by refusing to concede him a controlling authority along the frontier he had been appointed to defend. Instead, he grew almost pathologically enraged at Latter's claims, and his language became so savage that Edmonstone* confessed that he "would not have conceived it possible that a person invested with the high office of judge and magistrate should have employed such terms." Martin was removed, and sent to Gorakhpur; ${ }^{140}$ but his successor, Mr. Halhed, was as timorous as he had been abusive, and proved no better qualified to help Latter.

Even before the double repulse suffered by the Saran army it had been clear that the Gurkhas were moving considerable reinforcements into their eastern provinces, and consequently four extra companies of regular infantry had been sent to Latter; ${ }^{141}$ but when Marley's retrogressive movement released even more Nepali troops for service in the east, it was appreciated that Latter might need yet another reinforcement, and he was given the authority to call to his aid, if the urgency of his situation seemed to warrant it, a detachment of five companies of native infantry which was proceeding under Captain Cock across lower Parnia on $i$ ts way from Berhampur to the army in Saran. This would bring the total of his force to $2,700 .^{142}$ Circumstances in fact compelled Latter to requisition Cock's detachment before he had received permission to do so. On February 2 nd, his frontier post at Madhuvani, which was about half way between the Kosi and Titalia, was attacked by an enemy force from Koilia, in the Morang. ${ }^{143}$ Lieutenants Foord and Thomas had just over $200 \mathrm{men}$; and they were set upon, at three in the morning, by a

Vice-President in Council, now that Nugent had returmed to Europe. 
number estimated at 1,000 , besides an attendant rabble of plunderers. One section of the attackers drew the British force to the north, while the other fell on the lines to the south, burning the tents and stables. But the 200 reacted bravely and energetically and drove off the enemy, killing about 60 and wounding at least 100. Foord's casualties were only five killed and sixteen wounded. There was another British post a dozen miles to the west, at Sissugatchi, where there was a guard and extra ammunition. Foord should have called these to him, and held his post until his wounded had been removed; instead of which he made preparations to withdraw with his wounded to Sissugatchi. It was while he was doing this that he saw another large enemy party bearing down on him. Its motive was probably nothing other than to retrieve the Nepali wounded, who lay all over the ground; but the British coolies, thinking it was an attack, ran off, and Foord, infected by the panic, made a hasty and devious withdrawal to Sissugatchi. 144

Anxious to strengthen the post at Sissugatchi before Foord's error and their own self-confidence should induce the enemy to renew their offensive, Latter ordered Captain Cock, by last accounts at Parnia town, to proceed no farther westwards, but to turn north and join Foord without delay. ${ }^{145}$ But communications along this frontien were particularly slow and unreliable, and much to Latter's vexation cock had actually arrived on the west bank of the Kosi, at Lieutenant Yates' post at Nathpur, before he received these instructions. ${ }^{146}$ It was not until February 14 th that he recrossed the Kosi and marched briskly eastwards to beat up the enemy station at Koilia and join Foord at Sissugatchi. ${ }^{147}$ Unfortunately, he had not gone far before he was met by a highly agitated $\mathrm{Mr}$. Halhed. Alarmed by outrageously over-dramatised reports from the civil police, concerning frontier attacks by teeming cohorts of Nepalis, the new Magistrate had become flustered and frightened; and instead of working to allay panic had increased it by chasing up and down the frontier with two local indigo planters and their armed henchmen, and by sending peasants across the border to recover property which they claimed had been seized by the enemy. One party of peasants had crossed the border on the night of February 13th, had snatched cattle which they 
claimed to be their own, and then set fire to two villages for good measure. The Nepalis had thereupon retaliated by looting and burning a village called Kursa Kanta, which was a few miles west of Sissugatchi. Halhed trembled for fear of fresh reprisals, convinced that the enemy force at Koilia was 3,500 men. ${ }^{148}$ Cock now arriving opportunely in the neighbourhood, Halhed entreated him to stay at Kursa Kanta, instead of proceeding to Sissugatchi. The enemy were still lurking in advance of the burnt village, so Cock enlisted the services of Mr. Bames' (one of the indigo planters) horsemen and chased them back across the border. A similar excursion was made the following day, much to Latter's disapproval, who saw the inadmissability of men not subject to military law taking part in excursions against the enemy. 149 Yielding to Halhed's importuning, Cock then declared he would stay where he was, and not proceed to Sissugatchi. Exasperated, Latter brusquely reminded Cock that he was subject to his, Latter's orders, and not to Mr. Halhed's, and censured him for keeping the detachment divided and remaining stationary. 150 He was understandably annoyed by Halhed's irresponsible propagation of false intelligence. The number of Nepalis at Koilia was more like 400 than 3,500. "I need not remark", he wrote to the authorities at Calcutta, "upon the dangerous consequences which may ensue from persons in official situation giving countenance to such reports. That it has acted on the minds of the European officers I have undoubted proof: and it may soon extend to the sepoys."151

Even when he knew of Latter's displeasure, Cock still did not proceed directly to Sissugatchi, but turned and marched in the opposite direction in consequence of a report concerning enemy forays from the tanadar of Matiari; 152 and it was not until seven o'clock on the morning of February 27 th that he finally arrived before the enemy post at Koilia. Besides his $400 \mathrm{men}$, he had with him a six-pounder which Latter had sent to Foord and which he had then requisitioned from Sissugatchi. He found the Nepalis drawn up on the plainbetween their stockade and a nulla which ran about 700 yards to the east, apparently with the intention of resisting the attack; but when he moved boldly forward, they scurried back to within their defences. The stockade was built on a bank, and was 
about a hundred yards square by seven feet high. To its west, the jungle grew close; but its three open sides were each mounted with light guns. Cock led his men across the nulla, and advanced to within 350 yards of the eastem face of the stockade, where there was a gateway. The sixpounder was unlimbered, loaded, and fired. Enemy guns replied - but so inaccurately that no damage was done. Cock nevertheless soon abandoned his battering, because it was obvious that the single field piece could never make a breach. He turned his efforts instead against the garrison town, and crippled the cutchery, or court house, before falling back to encamp on the Company's territory. Two days later intelligence was received that the discharges of the six-pounder had caused so much consternation that the enemy were abandoning the stockade, whereupon Cock quickly marched forward again. He arrived just in time to see the Nepalis retreating over the plain towards the forest, retarded by the last of their guns, which they were dragging with them. He sent a party to occupy the stockade, and set off in pursuit with the rest of his men. The enemy appeared to be about 1,000 strong, armed with muskets and matchlocks; but they made little effort to save their gun from capture by the British sepoys, who were barely a quarter of this number. They fled into the forest, surrendering the only trophy which the armies of the eastem theatre acquired in the whole of the first campaign. ${ }^{153}$

Cock then resumed his progress eastwards to Sissugatchi, occupying another deserted enemy stockade on the way, at Harchandgarhi. 154 Meanwhile, east of Sissugatchi Lieutenant Chalmers, in charge at the frontier post of Karwamani, had made a raid into the enemy's territory and sacked the town of Jhapa - a large straggling settlement of mud villages, notorious as the most thickly infested lair of bandits in the Morang. His men dispersed the enemy guard, and burnt down the cutchery, the lines, and the residences of the principal brigand chiefs. ${ }^{155}$ These several energetic thrusts into their own barderlands pushed most of the enemy troops across the Mechi river into the extreme east of the Morang, where they concentrated at the post of Bansgaon. ${ }^{156}$ This, and its supporting outwork at Nizamtara, were but a few miles north of Latter's own headquarters. Their defences were clearly visible from Titalia, 
and with the aid of a spyglass Latter was able to assess the strength of the accumulated enemy forces as something near $4,000.157$ On March 6 th he took a detachment to reconnoitre the ground to the north of Bansgaon, and in passing fired a few shots at the Nizamtara stockade. Its occupants promptly decamped, and Latter set fire to the works. He still did not feel confident enough to attack the post of Banslgaon itself, which was very advantageously positioned, and decided that he would have to call in all his detachments and concentrate his force for that purpose. ${ }^{158}$ But as it happened, such a measure proved unnecessary. Soon after noon on March 8th, all the Nepali troops at Bans $\$$ gaon withdrew into the forest, apparently having decided that they were not strong enough to resist a British attack. On hearing the news the native subadar commanding Latter's outpost hurried to the spot, expelled the few remaining stragglers, and burnt down the stockades. Almost the whole of the Morang was now controlled by the Company's troops. 159

The operations in Latter's quarter were all the more gratifying to Headquarters because their effect was not confined to the lowlands. It was in the eastern hills that there at last occurred a stirring among the mountaineers in support of the British effort. Not that this cooperation came whence it had most confidently been anticipated. The heirs of the quondam Makwanpur empire had proved as ineffectual as all the other exiled hill chiefs, and the rather naive expectation of Hastings who was imbued with the legitimist ideas fashionable in contemporary Europe - that the Kiratas would flock to the standard of their ancient princes, had proved sadly lacking in foundation. Bradshaw had sent the brother of the surviving pretender to Latter's camp, but his efforts to raise a force of Kiratas had proved as futile as Latter had predicted, and he had been sent crestfallen back to Betiya. ${ }^{160}$ The hill chief who rose to the occasion was the young Raja of Sikkim who, with his old Lepcha general, Lepcha chagzod (minister), and band of loyal retainers was still flouting the Gurkhas from Gangtok. Quite spontaneously, the minister wrote to Latter, enclosing a letter from his master to the Governor General, suggesting that if the British occupied themselves with conquering the lowlands, their men would attack the Gurkhas in the hills. The only 
help they asked was gunpowder and musket flints. ${ }^{161}$ Latter eagerly responded. He sent ten seers (about $20 \mathrm{lb}$.) of gunpowder and 200 flints, and advised the Sikkimese leaders to direct their efforts against the fort of Nagri. ${ }^{162}$ This was a stronghold in the hills about 25 miles north of Titalia, in a position of great strength, and traditionally the residence of the headman of the Lecha tribe. Yuk Namchu, the brother of the Raja's minister, having died, this office was now filled by the minister's young son who was kept as a virtual prisoner at Nagri by his Gurkha coadjutor, Gentri Khatri. The Raja's emmissaries had been confident that if Nagri were taken, all the Lepchas with Gentri Khatri would desert. 164

At first, Latter had been keen to make plans for concerted action with the Sikkimese, undertaking to attack Nizamtara while they dealt with Nagri; but news of the reverses suffered by Marley's army caused him to abandon the idea, and he warned the Raja's agents that their people should only assault Nagri if they felt strong enough to succeed alone. 165 Notwithstanding this caution, the Raja's minister contrived to insinuate himself into Nagri in the place of his son, who was spirited away to Gangtok, and then worked to undermine the Gurkha position from within while the Raja's troops awaited their opportunity at a short distance outside, under the command of the loyal Lepcha general, who was the minister's uncle. ${ }^{166}$ After his own successful advance on Nizamtara and Bansgaon Latter wrote to the Raja and encouraged him to exploit this diversion to press home his attack; but then, just at its moment of greatest promise, it seemed that the Sikkimese enterprise was to be wrecked, and all the fruits of Latter's efforts lost. An irate despatch arrived from Headquarters accusing Latter of having detained Cock's detachment without sufficient cause, and thereby withholding reinforcements urgently required by George Wood. He was instructed to send cock and his men into Saran without delay. ${ }^{167}$ Latter was in despair. He feared that to withdraw so large a force from the Morang would free the Nepalis to wreak bloody vengeance on the plucky hill chief, who would reproach the Company for having beguiled him with empty promises. "I... shall to the last moment of my existence lament the share I have had 
in urging the Sikkim Raja to those exertions which will now most probably end in his destruction", he wrote bitterly to the Adjutant General. 168 But then he defiantly determined not to abandon his spirited ally until he should have made further reference to the authorities at Calcutta. "There are common principles of Justice, Candour, and Humanity which are applicable to all transactions, which it can never be the intention of the British Government to deviate from" he wrote to the Political Secretary, in vindication of his resolve. 169

Latter's initiative and strong sense of honour were probably the means of averting an unnecessary last minute tragedy. The order from Headquarters had been issued in the belief that affairs in the extreme east were quite different from what they were in fact. Latter, because of the crushing amount of clerical work with which he was having to cope - without the assistance of a staff - had omitted to send duplicates of his despatches to Headquarters, desiring that this should be done from Calcutta. But in the Deputy Adjutant General's office his wishes had been misconstrued, and no duplicates had been sent. The Commander in Chief had consequently received no official notice of Foord's retreat from Madhuvani, which had been the cause of Latter's need for Cock's detachment. When the situation was made clear to Hastings, he unreservedly withdrew the aspersions he had made on Latter's conduct, and endorsed his detention of the five companies in question. ${ }^{170}$ Latter's proposal to send extra supplies of gunpowder to the Sikkim Raja, and to present him with the gun captured at Koilia was furthermore heartily approved. ${ }^{171}$

Meanwhile the Sikkimese army had commenced its assault on Nagri, only to find itself outnumbered, for the garrison had been reinforced by troops fleeing from Bansgaon. There was a contest which lasted three days, but little impression could be made with bows and arrows against Nepali firearms, and a request for assistance was sent to Titalia. At the beginning of May, Latter decided to make a personal inspection of the scene of operations; but his strength was already undermined by months of overwork, and now that the hot weather had arrived he swiftly fell a victim to some jungle fever or infection. He was forced to go to Rangpur to recuperate, making over his command not to Captain Cock, who 
was ailing under the effects of a similar distemper, but to Captain Ward, David Scott, the Magistrate of Rangpur, assumed charge of the correspondence with the Sikkimese, and in July sent a consignment of muskets to the force before Nagri. He had heard that the Raja's army was now blockading the place, with the help of 200 soldiers from Tibet. Soon after, however, the rains set in; and the messenger sent with the muskets found that the beseigers had been forced to withdraw into the mountains. 172

So here too, operations fizzled to an inconclusive termination; but enough had been achieved to compensate in some measure for the puny efforts of the generals in command of the two principal columns. Latter's small force of 2,700 , of whom only half were regulars, had had the undivided eastern field army of the Gurkhas to contend with - an army which, according to the information of a knowledgeable brahmin prisoner, consisted of 7,000 musketeers and an extra 5,000 auxiliaries armed with bows and arrows. ${ }^{173}$ Its success in not only holding in check, but actually repulsing considerable segments of this force, was a convincing indication that the judgement of officers farther west had been corrupted by irrational fears and faulty information. It had been demonstrated that even the Gurkhas' regulars, on the plains at least, were far from formidable antagonists when confronted with well-armed troops incisively led and shrewdly disposed; and as for the swarming cohorts which had so agitated officers with the 2 main columns in the eastern theatre, they had been shown to be nothing more than mobs of wretched scavengers, scarcely clothed, let alone armed, who fled at the briefest glimpse of a red coat. Thus fortified in his belief that his own strategy and the estimates on which it had been based were incontrovertible, Hastings felt he had incurred a debt of gratitude towards Barré Latter. In a despatch to London, he drew the attention of the Secret Committee of the Court of Directors to the "vigorous and well-concerted measures" with which that officer had "not only foiled the attempts of the enemy to make a serious impression on our territory in that quarter, but... driven him from all his posts on the frontier and wrested from him a considerable portion of the province of Morang." 174 


\section{Chapter Nine}

The Triumph of Ochterlony

The more westerly of the two 'divisions' formed to act in the western theatre of the war was commanded by major-general David Ochterlony. Acting on the remotest periphery not only of the East India Company's possessions, but of known south Asia itself, its purpose was to attack the Gurkha field army under Amar Singh Thapa. This lay in the hill station of Arki, deep within the fastnesses of the freshly conquered Gurkha colonies between the Jumna and Sutlaj rivers. Hastings determined that the army must be destroyed, dispersed, or compelled to surrender before it could move eastwards to assist the resistance to the main onslaught of the British advance. Assuming that his tactics would be more those of pursuit than of siege, the Governor General did not anticipate that Ochterlony would need heavy ordnance; but he was allowed to equip himself with this arm according to his own discretion. ${ }^{l}$

If Ochterlony had little esteem for Hastings, the latter in his turn did not have any special regard for ochterlony. There was no reason why he should. Ochterlony's promising youth was long past, and he had had no dazzling career in Java to signal him as an object of popular notice and renewed patronage and favour. He was not on the Bengal general staff, andhad for five years been absent from the main centres of military life, exercising a rather obscure political function at the very extremity of the Bengal Presidency. The task which Hastings now entrusted to him was therefore modest. It involved no more than occupying the attentions of Amar Singh Thapa for a few weeks, until the second western division could join his force. He was then to surrender his command to major-general Gillespie. His army contained no European troops; and as the scene of his operations was reckoned to present "comparatively fewer difficulties" than that of the divisions farther east, he was told that he would not be furnished with "the same description and extensive scale of equipment". ${ }^{2}$ It is not clear what Ochterlony's privations were; but it is perhaps significant that there is no record of his men having been supplied with specially prepared warm clothing. This, it is sure, the Governor General did not regard as the flower of his army. 
Ochterlony was consequently compelled to pin all his hopes on the unaided merits of his sepoys, and to rely on whatever extraordinary resources he could improvise himself. His force consisted of four and a half battalions of native infantry, two troops of native cavalry, two companies of pioneers, and a company of foot artillery - making a total of between five and a half and six thousand men, including gun lascars and ordnance drivers, of whom only the commissioned officers and 62 artillerists were Europeans. ${ }^{3}$ He had in addition some auxiliaries provided by Ram Saran, the exiled Raja of Hindur (in whose old hill territories he was to operate), and by the lowland Sikh rajas under the Company's protection, among whom the Raja of Patiala was the most unstinting contributor. These amounted to about 4,000 men. ${ }^{4}$ His aggregate force therefore outnumbered that of his adversary, the total of whose army he estimated as 7,000 men, ${ }^{5}$ but which in fact was probably more like 5,000. The Sikhs were most impressive. With their tall athletic physiques, long glossy beards, multicoloured turbans, broad scimitars and proverbial matchlocks, they looked ready to eat the Devil. But it was doubtful that they would prove reliable in mountain warfare. Their traditional mode of combat was as free cavaliers, and they had no experience of fighting as disciplined infantry. 6

In addition to the troops there were about 3,000 public servants and 6,000 camp followers, so the concourse which assembled at the town of Rupar, on the eastem bank of the Sutlaj below the foothills, finally comprised something in the region of 18,000 people. ${ }^{7}$ The number of servants was small in relation to the size of the fighting force, and reflected the difficulties experienced in trying to amass sufficient bearens. The client Sikh rajas made strenuous efforts to recruit porters from among their subjects; but the lowlanders half dreaded and half reverd the hills as the abode of the gods, and those impressed as coolies risked being punished as deserters rather than violate their sanctity. Anxious to avoid initial delays, ochterlony made up his mind to use bullocks for transportation at the outset of his campaign, and his commissariat department collected 5,000 of these. He counted on being able to recruit porters, who would be essential when the difficult country of theinterior was reached, after 
he had entered the hills. 8 Perspicaciously, he declined to proceed without heavy ordnance. Hastings had suggested that he leave operations against the subsidiary forts of Hindur, Nalagarh and Ramgarh, until Arki itself had been reduced; but, learning that these strongholds commanded the most practicable route from the lowlands to Amar Singh Thapa's headquarters, Ochterlony chose instead to commence with their reduction. Moreover, it had already become plain that the Gurkha kaji was preparing to make much more than a mere token defence of the territories he had conquered; and Ochterlony had begun to question the premis which underlay the Governor General's strategic thinking. Hastings, assuming that Amar Singh Thapa's first concern would be to rush his force to the defence of Kathmandu, had inferred that Ochterlony's operations would take the form of pursuit and interception; but Ochterlony himself was becoming increasingly convinced that his tasks would in fact be siege and dislodgement. "It may be concluded", he wrote as early as August, 1814, "that either at the entrance of the Nalagarh pass, or in some chosen strong position on the way to Arki, I Amar Singh Thapa T will make his first and principal stand with every man he can collect and with every defensive art of stockade etc., which they have in use." Making use of the latitude which the Governor General had accorded him, he therefore decided to equip himself not (as had been recommended) for the pursuit of a mobile enemy, but for confrontation with a stationary one who would have to be expelled from hilly fortresses by shot and shell. Two eighteen-pounders, ten six-pounders, two heavy howitzers and two heavy mortars were summoned from the magazines at Kamal and Agra.

The army left Rupar shortly before the end of October. Its march lay north eastwards, and the mountains of Hindur stretched transversally across its path in successive massive ridges, heaving progressively higher towards the farthest ranges of peaks, which glistened like/alabaster. Each ridge was buttressed by hefty spurs, which thrust at irregular intervals and haphazard angles into the interjacent valleys. Well within this immense and multiple barricade lurked the old Gurkha general: resolute, defiant, and at his ease. His defences at Arki were strong; the route thither well guarded; and his communications with his client 
state of Bilaspur, lying across the Sutlaj to the north west, well secured. Its puppet Raja, Maha Chand, acting under the vigilant eye of Shirva Dat Rai, the kaji's personal agent, had so far proved a complaisant ally. He was keeping the Gurkha army well supplied, and had obediently complied with Amar Singh's request for 1,000 soldiers. 10 Ochterlony arrived at Plasia, the lowland capital of the Hindur Raja, on October 3lst, and halted a day to enable the troops to be paid and relieved of much of their superfluous baggage. On November 2 nd he resumed his march, striking due east along the route to Arki, through thickly tufted forest. Occasional glimpses could be had of the first range of hills, and, on a high forward-jutting buff before it, the fort of Nalagarh.

This was known as the key to Hindur. It was of irregular shape, matching the contours of the ground, and seemed like an excrescence of the rock itself. Its bastions and walls were high, parapeted, and punctured all over with loopholes; but it did not, on inspection, give an impression of great strength. The approaches, however, presented formidable difficulties. The only access was by a mere pathway, etched across towering acclivities and intercepted by numerous water courses which, although dry, were littered with boulders and obstructed by rocky projections. The whole ground was covered with a matted jungle of spiky shrubs and spindly bamboos with arthritic joints. It was impossible to pitch camp any nearer than three miles from the fort, but Lieutenant Peter Lawtie, the Field Engineer, immediately took a small party, by a widely circuitous route, to reconnoitre the adjacent heights. He found a site suitable for a battery near the ruins of the abandoned town of Nalagarh, and only 225 yards from the walls of the fort, and this position was occupied the same night (November 2 nd) by seven companies of sepoys under Lieutenant-Colonel Thompson. The Nepalis in the fort kept up a brisk fire from muskets and jinjals while the detachment prepared the ground, wounding a few men and killing a serjeant of pioneers. The following morning, while the battery was being constructed, the two eighteen-pounders and two six-pounders were moved from the camp by fatigue parties of sepoys. There had been no time to make more than 
a perfunctory clearance of the road, and it would have been impossible to drag up the heavy guns had it not been for the elephants. Ochterlony had been warned by native informants that the mountain paths were impassable for all four-footed animals save the hill pony; but when he heard that an elephant had once been sent as a present from Nahan, in Garhwal, to Basahar, he had reasoned that these beasts must be capable of manoeuvring the ground if carefully handled. ${ }^{11}$ The performance of the elephants on this occasion amply vindicated his judgement. The eighteenpounder barrels, made of iron and weighing well over a ton, were too heavy for even these powerful animals to carry on their backs; but wherever there was room two elephants followed each mounted gun, and at a mysterious command from the mahouts perched precariously on their necks, bent their massive foreheads to the backs of the carriages and thrust the machines bodily up the slope, while the men at the drag ropes guided them along. When a wheel lodged in a rut or cavity, an elephant would either mould his trunk to the outer rim or entwine it around a spoke, and lift the whole engine free of the obstruction with an impressive combination of finesse and strength. They showed little hesitation, so long as low overhanging branches were cut away. Yard by yard the ascent was covered; and by dusk the ordnance pieces were at the summit. They were in battery by eight o'clock the next morning, November 4 th.

Shortly after the hills reverberated as the notes of the different guns and their echoes mingled in a thunderous dissonant fugue. To begin with, the six-pounders wrought great havoc. The Nepalis had piled stones on their ramparts, ready to assail a storming party, and a few welldirected shot sent the whole lot showering into the fort, lethal as grapeshot. But the walls themselves proved more resilient than had been expected. Although the eighteen-pounders were at reasonably close range, it took them 24 hours to hammer down sufficient fabric to make a breach. At about nine o'clock on the morning of the 5 th, when preparations were at last being made for an assault, two brahmins appeared in the breach and intimated that the garrison wished to surrender. The condition they demanded was freedom to march to join Amar Singh Thapa, with all their arms. Ochterlony declared that such terms were inadmissible, 
and prepared to complete the siege. But the inmates of the fort did not renew their resistance, Before operations could be resumed they surrendered as prisoners of war and relinquished their arms. A small outpost to the northwest capitulated at the same time, bringing the total of prisoners to 95. These were sent to Ludhiana, escorted by one of the troops of native cavalry. So the first of Amar Singh's fortresses fell to Ochterlony - at the cost of much labour and patience, but with few casualties. Apart from the serjeant of Pioneers, none of the British force was killed, and only about half a dozen wounded. 12

The road to Arki meandered over the shoulder of the Nalagarh spur to a village called Goela, where it crested the first ridge of hills. From Goela, the road plunged 1,000 feet into the valley of the Chikni river, and thence climbed up the western flank of the second hilly range. This second ridge maintained a general altitude of between four and five thousand feet above sea level, save opposite Goela, where there was a wide gash, 800 feet deep. Through this, like a very fine strand lost in the eye of a huge needle, threaded the Arki road. Guarding the gorge from its northern side, sprawling confidently astride the crest of the ridge, was the fort of Ramgarh.

On the night of November 4th, Ochterlony had received intelligence to the effect that the main body of Amar Singh Thapa's army had left Arki and its subsidiary post of Subathu and advanced to Ramgarh with the intention of operating from there to dislodge the British from their newly acquired perch on the Nalagarh spur. Anxious to forestall any such attempt, Ochterlony directed his reserve, commanded by Thompson, to move on immediately to secure the road in advance of Nalagarh. Speed. was essential, because the kaji's intention was said to be a night attack; so Thompson marched without artillery. By the morning of November 5 th he had reached Bariyan, en route for Goela, without having encountered the enemy. ${ }^{13}$ Meanwhile Ochterlony lightened his column as much as possible, in preparation for his own advance. He transferred all spare ammunition and stores into Nalagarh, which he intended to use as a depot; sent part of his treasure back to Ludhiana in the care of his remaining troop of cavalry; and remanded six six-pounders to Plasia. 
His heavy ordnance, however, he retained, now persuaded that his forecast concerning the nature of the warfare in which he would be engaged had been confirmed. "It would seem that the character and operations of the war should be changed", he told the Adjutant General; "and instead of being composed of small detachments with light artillery, our force should be concentrated on certain points; and however tardy their progress ... Inone T should move without a gun or guns sufficient to throw open these barriers ... It is not my intention to relinquish the battering guns if any strength, labour or exertion can get them forward."14 He resigned himself to a slow but sure advance. "Manual labour, strength and perseverance seem our principal dependencies in these alpine regions. Our progress will be slow, but I trust it will be certain; and I hope His Excellency will approve a determination I have formed not to be hurried into any attempt that will occasion more eventual delay than the very tedious advance I now anticipate." 15

Hastings had many faults as a Commander in Chief, but he was not dictatorial. Not being on the scene of action himself, he did not presume to question the decisions of deputies who were, provided always that those decisions were cogently argued and genuinely influenced by local circumstances. Secretly, he was dismayed by the loss of speed which Ochterlony's proposals would entail; but having allowed the commander. to use his own discretion and formulate his own tactics, he did not now hesitate to honour the spirit of that permission. Publicly, he fully endorsed his argument. "The Commander in Chief entirely concurs in the general view which you have taken of the character the war has now assumed" ran the Adjutant-General's answer. ${ }^{16}$

So the pioneers set to work to prepare the road for the heavy artillery - two eighteen-pounders, four six-pounders, and a couple each of heavy howitzers and mortars. They were diligently assisted by artisans and labourers supplied by the Raja of Hindur. Trees had to be felled, and rocks blasted, to clear the way. Labyrinthine pathways had to be widened, borders scarped, pot holes filled, declivities banked, and parapets raised to prevent the heavy engines from toppling over the brinks of precipices. By dint of unremitting labour the ordnance was 
got forward to Thompson's position at Bariyan by November 10th, and Ochterlony then prepared to follow with the line. Thompson again moved ahead of the main force, and arrived at Goela at sunset on the 1lth which was none too early, because he disturbed a party of Nepalis who had already begun to stockade the position. ${ }^{17}$ He was now on the crest of the first ridge of hills. From Goela he could look across the valley of the Chikni to Ramgarh fort on the second ridge. Here lay Amar Singh Thapa, with the flower of his army - nearly 3,000 men, besides his Bilaspur auxiliaries. His dextrous soldiers had already been busy, stockading the spurs below and the heights adjacent to the fort, so that his position now straddled the gorge through which the road to Arki passed. Ramgarh guarded the passage from the north; while just over a mile south of it a peak called Kot, which was 200 feet higher again than Ramgarh, had also been occupied and fortified. Between these two posts were five stockades: four on the crest of the ridge, and one in the gorge astride the Arki road itself. ${ }^{18}$

The major-general arrived at Goela with the rest of the army on November 12 th. It needed only a glance through his telescope to convince Ochterlony that the Gurkha's position was unassailable from the front and north; but it did seem that Kot stockade could be attacked by a force moving up the crest of the ridge from the south. The next day, therefore, he augmented the reserve of two battalions by three companies, and directed Thompson to lead it across the valley and up the flank of the ridge to a settlement called Kahanani. Kahanani was on the crest of the ridge about two miles south of Kot, and was situated on ground broad enough to give sufficient camping space. After reaching the position Thompson was to turn left up the crest, attack the Kot stockade, and push as far northward as circumstances permitted. ${ }^{19}$

He arrived at Kahanani without mishap; but Ochterlony was already having second thoughts about the feasibility of his own instructions. He was fully impressed with the great significance of this first encounter with the main Gurkha army. He appreciated that its outcome would influence "not only the future conduct of the Gurkha troops, but that of all the peasantry of the hills"; ${ }^{20}$ and although anxious to avoid 
delay, realised that the necessity for speed was insufficient justification for risking such a crucial enterprise with no greater knowledge of the ground than that provided by a telescope at two miles' distance. Hastily, he summoned Ram Saran, the Hindur Raja, and asked his opinion of the ground between Kahanani and Kot. As the Raja remembered it, the ground was very unfavourable; and he supported his assertion with such a convincing description of the difficulties involved that ochterlony immediately countermanded the orders he had issued to Thompson, and told him to postpone his attack on the stockade until a more adequate reconnaissance had been made. Field Engineer Lawtie, who had accompanied the reserve, then embarked on an intricate inspection of the vicinity of the Gurkha position. Every night for a week he roamed into the rugged and uncharted crevices of the Ramgarh ridge, producing invaluable maps and sketches of country hitherto untrodden by Europeans. The front and southern flanks of Amar Singh Thapa's position he confirmed were inaccessible; but in the valley to the Gurkha's rear, on the other side of the ridge, he discovered the settlement called Nori. This was on an extensive plain, and Lawtie reckoned that an attack could belaunched against Ramgarh from here. Ochterlony readily accepted his assessment, and resolved that the fort must be assaulted from behind. ${ }^{21}$

Peter Lawtie was only 24 , and there cannot have been many Bengal officers who would have consented to be guided by so young an officer. In an army where responsibility was almost exclusively the perquisite of mere seniority, an exaggerated deference had come to be paid to age and lengthy service alone; and most commanders would have felt consultation with a subaltern less than half their own age to be intolerably undignified and liable to foster upstart pretensions in the juniors. Martindell's attitude towards his Field Engineer was typical. But no such prejudice hindered the application of Lawtie's considerable talent and indefatigable energy to the task now in hand. Ochterlony worked closely with his Field Engineer from the start, made him an A.D.C., and on many occasions warmly acknowledged his debt towards him. This cooperation was based on a close personal relationship. Although Ochterlony recognised professional aptitude when he saw it, and was without prejudice in favour of age and length of service for their own sakes, he did allow himself to be 
influenced by private feelings. He would willingly tolerate no man who could not win his affection as well as command his respect. It was Lawtie's decisive merit that he combined ability with that utterly disarming charm of men who are so fundamentally good-natured that they begruige sympathy to no-one, and with a modesty which ensuredthat he never falled to appear complimented whenever the major-general sought or accepted his advice. Before long Ochterlony's esteem haddeepened into tender fondness, and he came to rely heavily both on his professional services and on his friendship.

When he transferred his base to Nori Ochterlony would, of course, considerably extend his line of communication and supply; but he did not reckon that this need significantly increase the danger of its being attacked. He had already learned from the Nepalis themselves how effective the stockade was as a mode of defensive war, and he shrewdly calculated that the enemy would hesitate to attack his detachments if these were defended after their own manner. He was the only officer in the war to discover this fundamental tactical truth. Inevitably, more detachments would entail a dispersal of his army, and reduce the number of men he could bring against Ramgarh; but he acted with the hope that the advantages of ground on the eastern side of the ridge would be sufficient to compensate this diminution by enabling him to bring his artillery into play, and so making his remaining force strong enough to take the fort. Even failing this, there was always the advantage in the move that it would place the British army between Amar Singh Thapa and Arki, his main base, and thereby enable it to harass the enemy supply lines more effectively.

As a ruse designed to mask his main manoeuvre from the enemy, he decided for the time being, howld leave his two eighteen-pounders and a couple of pieces of light artillery in the Chikni valley, below the western approaches to Ramgarh, under the charge of a battalion of native infantry. A convenient position once established on the heights by an assault from the east, these could then either be brought through the Ramgarh gorge or taken to the crest over the western flank of the ridge. The most daunting obstacle to the main movement was the appalling difficulty of the road. It was as well that Ochterlony had prepared his men for the expenditure of "manual labour, strength and perseverance", 
because the campaign could never have proceeded had the army drawn on its fund of these qualities grudgingly. The pioneers had already been busy clearing the descent from Goela, and all the artillery was moved down to the Chikni valley by the evening of November $17 \mathrm{th}$; but the route thence over the hump of the ridge into the valley beyond was still impassáble for carriage cattle. Determined to economize every hour at his disposal, Ochterlony had each of the field guns selected to accompany the principal force taken from its carriage and lashed to the back of an elephant. 7,000 coolies were put to work to drag the empty carriages and carry the ammunition. In this fashion the force and its ordnance were got as far as Thompson's position at Kahanani, on the crest, by nightfall on November 19th; and simultaneously the battering train, with a battalion of sepoys under Lieutenant-Colonel Adams, had made its way north up the Chikni valley to a site below the western face of Ramgarh. All the baggage and the bazaars were left temporarily at Goela, under the protection of a party of Patiala Sikhs, pending the completion of a practicable road to Kahanani. Fortunately, as the army had moved into the interior, certain of his quondam zemindars had joined the Hindur Raja, and these were now induced, by promises of handsome reward, to set their people working on this task. They laboured strenuously, and by the evening of the 20th the stores and baggage had begun to arrive at Kahanani. The position here was meanwhile defended by an elaborate Gurkhastyle stockade. But before the army could descend the eastern flank of the ridge and move to its new ground at Nori, the route thither had also to be cleared. This required three days' more ant-like industry on the part of the pioneers, the hill men, and the various fatigue parties of sepoys, so it was not until the 23 rd that the movement was resumed, and not until the 24 th that camp was finally pitched in the valley at the rear of Ramgarh. 22

The new position of the British army was a level plateau in the majestic valley of the Gambar river, about one and a half miles north, and some 500 feet below the gorge of the Ramgarh pass. The valley was well watered, and generousiy wooded with shrubsthild cherry, apple and pear abounded, now luminous with autumnal amber. As soon as he had understood 
Ochterlony's intentions, Amar Singh Thapa had set his men to defend the eastern approaches to his position, and the spurs jutting into the Gambar valley were already pimpled with stockades and stone redoubts. Ochterlony had a battery for his field guns constructed in front of the foremost enemy stockade by November 26 th, and early that morning an attempt was made to bombard the structure. It soon became apparent that the guns were too far from and below their target. At about half past nine, the major-general asked Major Mcleod to stop firing and to send Lawtie to reconnoitre the ground farther forward. The Field Engineer left the battery about an hour later, and as it was impossible for him to make his exploration unobserved, Mcleod reckoned that he should be accompanied by a party of sufficient strength to deter enemy harassments. Ensign Symes was therefore desired to escort him with 100 sepoys. The detachment proceeded towards a hill which had been designated as a possible site for a new battery. To arrive at this ground it was necessary to pass through a small ravine, and before this had been cleared enemy marksmen opened a fierce fire from the heights on both flanks. Lawtie thought quickly. The hill he was aiming for was not far ahead, and although it was crowned by an occupied stone breastwork, he judged that a rapid advance to assault it would involve no greater hazard than a retreat through the defile; while if the hill were gained, it would be a secure position in which to await a reinforcement. He therefore divided his force, and sent 50 men forward immediately to the attack. They responded splendidly to Symes's brave example. Ignoring the bullets hissing about their ears they charged up the hill to the breastwork and sent its few occupants scrambling back to the main stockade, which was about 300 yards behind. Greatly excited, they kept firing at the fugitives until their mouths were black with gunpowder frombiting off the ends of cartridges. They wanted to charge the stockade as well, and only consented to take cover under the breastwork after repeated urging from their officer. Meanwhile Lawtie came up with the remainder of the force, whom he deployed to the right and the left of the position to ward off the snipers still on its flanks. After about ten minutes a crowd of Nepalis emerged from the stockade, drums 
beating, colours flying, and trumpets braying. Resolutely, they stalked down to the small party at the breastworks.

When Ochterlony heard the sound of firing, he immediately ordered forward a reinforcement under lieutenant Williams, which advanced bravely through the defile. But, because of a cruel contretemps, their assistance came too late. Before the main body of the reinforcement could reach their position, Lawtie's men were without ammunition, and alreadyin retreat. Cartridges were supplied in wooden boxes, which were fashioned after the manner of cigar cases joined end to end at their bases, designed to fit in an upright position into the sepoys' leather ammunition pouches. The cartridges were pulled lengthwise from their tubular cavities by small tags. When all the cartridges in the one section of the box had been used, it had to be lifted from the pouch, reversed, and re-inserted so that those in the lower tier were uppermost. But on this occasion the sepoys at the breastwork found to their consternation that when their upper rows of cartridges had been expended, it was impossible to lift the boxes from the pouches and get at those below. Variations in the climate had shrunk the leather or swollen the wood, or both. As one sepoy after another exhausted the first half of his ammunition he found himself fumbling helplessly, trying to reverse this cartridge box. Emboldened by the slackening of their fire, the Nepalis came on faster. Even so, it was only when the accessible supply of cartridges failed altogether, and when the enemy were hardly twenty paces away, that the party consented to retreat. With fire coming from both flanks and the rear, to which there was no means of replying, the withdrawal threatened to become a massacre; and only the timely arrival of the bulk of the reinforcing party enabled Lawtie's men to complete their retreat in reasonably good order. Williams lost his life while supervising the covering operation in the defile. 41 sepoys were also killed, and 33 injured.

Lawtie was full of praise for the courage of his men. "The bravery of the sepoys was most conspicuous indeed", he affirmed, and he insisted that any blame for the reverse must attach to his own 
misjudgement. But Ochterlony reproached only himself, for having entrusted the operation to a weak reconnaissance party instead of making it a regular and concerted attack. 23

The repulse, slight though it had been in itself, carried implications grave enough to destroy all the hopes which he had entertained of his complicated and arduous move to Nori. The mortifying fact was that while certain advantages of ground had indeed accrued from the manoeuvre, the detachments from his main force which it had entailed had after all made it impossible for him to exploit them. "These detachments have greatly lessened my numbers, and incapacitated me from doing what with a greater force might have been practicable", he wrote gloomily. 24 Furthermore, as the weeks slipped by it became increasingly apparent that the manoeuvre would produce only slow and uncertain effect by way of straitening Ramgarh. Amar Singh was now beleaguered on three sides, it was true; but his communications with the north were still secure, and he continued to draw supplies from Maha Chand and Shiva Dat Rai in Bilaspur, Ochterlony had hoped that Raja Sansar Chand of Kotoch, the Gurkha's erstwhile rival contender for Kangra fort, would attack Bilaspur from west of the Sutlaj, and his failure to do so was the cause of fresh and unexpected disappointment. Sansar Chand's military commander was, it will be recalled, an Irish deserter from the 8 th Dragoons, calling himself O'Brien, who had professed to be willing to use his influence to help the British cause. At the beginning of November he had written to Ochterlony to assure him that Sansar Chand had placed all his troops in readiness to enter the war, whereupon Ochterlony had requested him to attack Bilaspur. But instead of allowing his army to march, Sansar Chand had sent his excuses, affirming that he dare not move it for fear lest Ranjit Singh (to whom he now professed allegiance) should attack his territories in its absence. 25 Convinced that the Raja was merely prevaricating, Ochterlony had sent a letter to Ranjit Singh making it perfectly clear that his suzerainty over Kotoch was not questioned, and renewed his efforts to persuade O'Brien to cooperate. He had extended to him the promise of a free pardon, and the prospect of even further 
reward. But subsequent developments gave no cause for fresh optimism. Ochterlony's letter found O'Brien flat on his back in an alcoholic stupor. When, after a few days, he was sufficiently sober to raise the matter again with the Raja, the latter flew into a rage and acoused his lieutenant of unauthorised correspondence with the British - an attitude which, despite Ochterlony's scepticism, must have been influenced by the presence at his court of an emissary from Ranjit Singh. 26 The quarrel between the two men became very violent, and by the end of December O'Brien seemed to have resolved to desert with all his army. He sent messengers to Headquarters with an exquisitely semi-literate communication for the Governor General, offering to bring over 1,500 men and 8 pieces of ordnance in return for a free pardon for himelf and "a Nother European" called Charles Macdonald, and a similar proposal was addressed to Lieutenant Lawtie in Ochterlony's camp. Ochterlony asked for a clearer indication of his intentions; but a month went by without a reply, and in the meantime a despatch from Headquarters made it plain that while Hastings was unwilling to prevent the major-general from using $O^{\prime} B r i e n$ as a free agent in the last resort, he was reluctant to employ him otherwise than as an officer of Sansar Chand. Even then, while Ochterlony was left free to resume attempts to influence the Raja through the medium of O'Brien, it was stressed that the Raja's cooperation would not be worth the ill-will of Ranjit Singh. Thus discouraged on the one hand by hedging and hesitation in Kotoch, and inhibited on the other by doubts and second thoughts at Headquarters, Ochterlony finally concluded that it would be idle to hope for assistance from Sansar Chand's army, and resigned himself to the necessity of fighting the war alone. 27

This was not the only source of disheartenment. Ochterlony was finding himself increasingly hamstrung by his lack of information. He knew almost nothing of the country in which he was operating, and local guides had absolutely no notion of accurate information. They reckoned distances, for example, in terms of the "coss", which could mean anything between three quarters of a mile and two miles; and they were incapable of descriptions of terrain which had any meaning in military terms. He was therefore entirely without the means of ascertaining what natural 
strategic advances his position afforded. The exact location of Arki was unknown, and the number of forts and the nature of the routes between that place and Ramgarh only guessed at. He was circumscribed by uncharted territory, and could not plan beyond the range of his telescope - which was not very long in country composed of toiling mountains and deep intervening glens, of which twice as much was always concealed as was surveyed from any single vantage point. Then again, the proclamation inviting the cooperation of the hill chiefs and their people had evoked only a very limited response, and not enough porters could be found even for the most essential purposes. Finally, there was the deeply disturbing knowledge that three attempts to take the contemptible hill fort of Kalanga had failed. News of the last repulse arrived on December 2nd, just as Ochterlony was contemplating another attempt to gain an advanced position for his field battery, and the information made him throw up the idea in despair.

"The intelligence, I must confess, has had its full effect on my mind", he told the Adjutant-General. "Situated as The enemy $\bar{T}$ are, I do not find myself at liberty to say that $\bar{I}$ could attack them with any certainty of success even with a greater force; but without reinforcements I feel myself precluded even from making an attempt... In fact, as I their 7 front was declared unassailable by the Engineers, so I must consider their rear, on a careful consideration of their positions as compared with our means."28

During the month of December the campaign remained in a state of impasse. It now seemed most unlikely that theprojected junction of the othe western division would ever take place; but in his pessimism Ochterlony expressed the view that he would in any case be unable to do more than embark on the long and wearisome expedient of starving the Nepalis into submission. ${ }^{29}$ Despondency pervaded the British camp in these dull dank days about the winter solstice, when mists brooded in the valley and the landscape's imposing distances were no more than grisaille washes on a flat sky. The sepoys began to fall ill, and by the middle of the month almost 600 out of 4,600 infantry were listed as sick. ${ }^{30}$ The nights were frosty, and many of the invalids were probably suffering from the effects of the cold, against which they can have had little protection if, as 
seems likely, they had not been supplied with specially made warm clothing. But primitive sanitation must also have played its part in causing the general debility. When in the field Indian armies, like medieval monarchs and their suites, were compelled to keep moving in order to escape the diseases engendered by their own garbage; and now that the troops and all the attendants and followers of the army had been using them for a month, the various camp sites around Ramgarh must have been like open latrines. Seeing the sickness and dejection of his men, Ochterlony wasopressed by qualms and dark presentiment. He began to think that the Bengal sepoys were physically incapable of withstanding the duressef of mountain warfare, and he doubted that success was even possible. 31

A reinforcement of a battalion of sepoys (the $2 / 7 \mathrm{th}$, "one of the finest in the service and nearly complete") had been promised Ochterlony soon after the outset of the war, and would have reached him early in the campaign had its progress from Lucknow not been delayed by civil disturbances in Moradabad. It was not until the third week in December that the corps, commanded by Lieutenant-Colonel Lyons, finally arrived in the Chikni valley. Here it relieved Adams of the eighteen-pounders and escorted them over the ridge, arriving in the main camp at Nori on December 27th. At about the same time two field howtizers andfour light mortars, all with collapsible carriages of the type which Hastings had personally designed, arrived from Cawnpore. ${ }^{3} 2$

Ochterlony's effective regular infantry force now stood at about 5,000 , of whom just over 3,000 were in the main camp at Nori, the remainder being distributed between the Chikni valley and Kahanani on the ridge. His resources thus far augmented, he felt strong enough to try to close the northern gap in his encirclement of Amar Singh Thapa's position.

On the crest of the ridge, about four miles north of Ramgarh, was a fort called Mangu, ${ }^{33}$ possession of which would, Ochterlony reckoned, serve his purpose well. It was approached by a two mile-long spur, which jutted from the ridge into the Gambar valley, and which was defended by a stone redoubt called Tibu at its eastem end. Soon after dusk on 
December 27th, Thomps on left Nori with 14 companies of sepoys, 1,000 auxiliaries, two six-pounders, and two howitzers to occupy this spur and attack Mangu.

The night was fine, and the distance not great; but the ground was so broken andinhospitable that it was eight o'clock the next morning before Thomps on began to ascend the flank of the spur. He reached the crest with his advance about 700 yards in front of Tibu, and was at once assailed by musket fire from a party of the enemy who had emerged from the redoubt and advanced to an eminence near the end of the spur. He immediately ordered his advance guard to turn left and repel this party, which they did, driving the Nepalis back along the crest of the spur and into the redoubt. The post itself he decided was too strong to attack without artillery, so he waited for the gun-bearing elephants to arrive before recommencing operations. At about four in the afternoon the two six-pounders opened fire at 500 yards, but made little impression. Thompson decided that the battery must be pushed nearer, and he asked the pioneers to make extra fascines and gabions.

By now, however, Amar Singh Thapa had fathomed Ochterlony's intentions, and he determined to bring every man he could spare into an effort to dislodge Thompson. During the night he withdrew all his troops from the stockades south of Ramgarh, and moved them into fresh positions on the crest of the ridge to the north. He transferred his own headquarters to Mangu. About a quarter of an hour before sunrise on December 29th the largest force of Nepalis so far seen, estimated at between 2,000 and 2,500 men, streamed out of Mangu and came in full career towards the peak on which the British camp was perched, at the eastern extremity of the spur.

There followed a ferocious and confused engagement, which lasted for nearly three hours. The enemy, sword in hand, assailed Thompson's position with fiendish intrepidity, by every practicable and even more impracticable approaches. It seems, indeed, that it was to the general inaccessibility of their ground, and the command it gave them over the various assailing detachments, that Thompson's party owed their deliverance. The sepoys displayed their customary horror of the khukuris, 
and refused to parry them with bayonets. Several fled in terror, and were ripped to shreds by flashing enemy sickles. But because almost all the directions of their assault could be enfiladed by musketry, few Nepalis actually reached the camp and great numbers were killed and wounded in the attempt. The main party grimly persisted in their effort to scale an escarpment raked by fire from above, but were finally forced to retreat, which they did slowly and with the snarling reluctance of wounded and baffled animals. Sprayed with scorching grapeshot, they backed sullenly away, bearing many wounded and leaving 60 dead. It was estimated that the total of their casualties must have reached 250 wounded and 150 killed. Thompson had 9 men killed and 44 wounded. $^{34}$ As soon as it got dark the Nepalis in the intermediate redoubt at Tibu abandoned their post and retired to Mangu. It was immediately occupied by Thompson's light infantry pickets, who discovered that it had been so deeply excavated as to be virtually impregnable by artillery. Amar Singh Thapa had suffered a repulse, but he had nevertheless successfully forestalled Ochterlony's attempt to turn his northern flank. By abandoning his posts to the south of Ramgarh and establishing new ones to the north, he had in effect shifted his position farther up the ridge, so that it still outreached Ochterlony's in the direction of the Sutlaj and the crucially important area of Bilaspur. He might thwart further attempts to outflank him simply by repeating the manoeuvre. The contest would then develop into a race to the north, in which Ochterlony could have no hope of overtaking his adversary, because every step forward would manifoldly increase his difficulties of communication and supply. The road even to Tibu was impracticable for bullocks, and although only three miles long it took three and a half hours to cover even under the most favourable conditions. The troops there had no tents, and the officers only small canvas shelters open at both ends. ${ }^{36}$ ochterlony could now have bombarded Ramgarh from the south, since all its outlying positions on that side had been evacuated and he already had a post at Kahanani on the crest - but this would have done nogood. The effect would still only have been to drive the elusive Gurkha farther up the ridge towards the impenetrable wildemess of Bilaspur, 
and a decisive issue to the campaign would have been as far off as ever.

It seemed that there was deadlock. Assault was futile; blockade impracticable. The contest threatened to become a war of attrition in which time was on the side of the enemy. There is no need to explain what would have been the reaction of a Martindell or a John Wood under circumstances such as these. Ochterlony had as much, perhaps even more, tendency to succumb to despair as his fellow generals; but the difference was that with him it was no reflection of helplessness and incapacity. It was only a plea for sympathy. Ochterlony had rich reserves of talent which were released by adversity and stimulated by the solicitous attention of an audience; and now that his difficulties were most complex, and the despondent concern of his Commander-in-Chief most gratifying, he revealed his full brilliance as a strategist.

All the while he remained in his present situation, Amar Singh Thapa was immune from assault and straitenment. The only way to destroy his immunity was therefore to draw him into another position, where he would be deprived of his a priori advantage of unrestricted access to the north. Behind Ochterlony's camp at Nori, parallel to but yet higher than the Ramgarh ridge, lay a third range of hills, dominated by the fortress of Malaun. That, Ochterlony decided, was where he wanted the Gurkha. Lawtie set to work, and after a month of crippling exertion, had collected enough information concerning the topography of the Malaun ridge to enable his commander to devise a bold and ingenious plan. Ochterlony's basic idea was to seal the eastern, southern and northern approaches to the ridge; inveigle Amar-Singh Thapa into quitting the Ramgarh range and concentrating his army in Malaun; and then attack the cornered Nepalis as opportunity might best dictate. The crucial assumption in the plan was that Amar Singh could be induced to move to Malaun, and at first glance it seems that Ochterlony was so sanguine as to expect his adversary to walk into what would obviously be an ambush. But in fact the plan's mechanism would be less apparent than that. The move to block the northem end of the Malaun ridge would not take place until the kaji had actually entered Malaun fort. In its 
first stages Ochterlony's manoeuvre would bear the appearance simply of a preparation to attack Malaun from the east, which it was hoped would cause the kaji to move all his men to defend the fort. Here Ochterlony was gambling on Amar Singh's concern for his treasure and his youngest son and kinswomen, all of which he was known, from intercepted letters, to have left in Malaun. ${ }^{37}$ However, there was the possibility that he would discern Ochterlony's ultimate intentions, dissembled though they were, and march immediately to Bilaspur to protect the source of his supplies and conserve his access to the north. The plan was therefore designed to accommodate this eventuality. While the main force and the auxiliaries moved, under Ochterlony's own command, round the southern end of the Malaun ridge and up into the Gamrola river valley on its eastern side, Colonel Arnold was to be left with the force at Tibu to see how the Gurkha reacted. If he moved across the Gambar and entered Malaun, Arnold was first to expel any remaining detachments from the Ramgarh range, then move up the Gambar valley to the town of Bilaspur in the plain beyond its northern end, overawe the Raja, and secure a position on the northern extremity of the Malaun ridge. If, on the other hand, Amar Singh marched north to Bilaspur, Arnold was to follow. Ochterlony planned to have a force moving northwards up the Gamrola valley simultaneously, so that when the Nepali army arrived at Bilaspur it would be pincered between a pursuing column and one emerging from the eastern side of the ridge. They would be forced into an engagement on a plain, where all their best-tried tactics would be useless.

The operation was set in motion on January 16 th, and in one swift movement Ochterlony successfully accomplished his own maneouvre. He crossed the Gambar river south from Nori, continued down the easterm skirt and round the southern end of the Malaun ridge, tumed north into the Gamrola valley, and finally halted near the village of Barog, ${ }^{38}$ which was on a latitude slightly south of that of Malaun fort itself. Lieutenant Ross, with 2,000 Hindur auxiliaries, then continued up the bank of the Gamrola for Bilaspur. The Hindur troops, used to this sort of ground, covered the distance in no time, relishing the opportunity to 
deal a blow at the Bilaspurians, who were their mortal enemies. They occupied the Bandela heights, which overlooked the town of Bilaspur, and then moved on grimly to attack a force assembled under Shiva Dat Rai himself, and triumphantly dispersed it. Trembling for his life, the indolent and profligate Raja Maha Chand scuttled across the Sutlaj, convinced that his capital was about to be sacked by the Hindur troops, who were baying for blood. But Ross had strict orders to restrain his men from inflicting this final indignity. In Ochterlony's view, consigning the town to destruction would have been both repugnant to humanity and contrary to policy. He was relying on its granaries to replenish Arnold's stock of provisions, which was sufficient only for a week; and he was besides anxious to coax Maha Chand into actively supporting the British, which might be done if they showed themselves to be forbearing deliverers, but not if they descended on him as bloodthirsty plunderers.

Meanwhile, back in the Gambar valley, Arnold had awaited the reaction of Amar Singh Thapa, to Ochterlony's movement. As had been anticipated and hoped, the kaji's only immediate concern was for the safety of his treasure and family. As soon as he perceived the direction of the major-general's march, he reduced the garrisons in Ramgarh and three other main positions along the ridge to a company each, gathered his men about him, quitted Mangu, and hurried across the valley to Malaun. It now only remained for Amold to complete the British ambush of that place by joining Ross at Bilaspur. On January 18th he sent men to occupy the deserted fort at Mangu; then, leaving Lieutenant-Colonel Cooper with the heavy guns and a force of sepoys to reduce Ramgarh and the remaining occupied posts on the ridge, prepared to march north up the Gambar valley.

It was at this stage that the whole plan was menaced by disaster. That brisk advance on Bilaspur which Ochterlony had prescribed for Arnold's force became in effect an agonizing crawl. First the march was delayed by desertions among the coolies and porters; and then the route up the left bank of the Gambar river, over the spreading feet of the spurs which buttressed the western face of the Malaun ridge, 
was found to be atrocious beyond anything that local information had represented. Finally, to fill the cup of frustration and disappointment, the weather turned viciously cold and violent. A heavy fall of snow obstructed the march for two days and made the road to Bilaspur even more inhospitable; and when the column at last moved on, it trudged through lashing sleet and freezing slush. The sepoys were bewildered and supremely miserable. The vicious cold split their lips, numbed their fingers and toes, and dappled their faces with blue and orange blotches. Gurkha snipers still prowling on the Ramgarh ridge added to their tribulations. Ochterlony, tired and trembling for the success of his plan, began to show signs of strain. He became edgy and peevish, and carped at Arnold for petty things - such as the style of his reports. But he did not blame him for the slow progress of his advance. After detailing the hindrances which had occurred in a letter to Headquarters, he concluded:

"I state all this not to blame Colonel Amold, but only to prove that I guarded as far as possible against every contingency that was likely to occur. Colonel Arnold has met with difficulties greater than I had supposed to exist, and I can only lament what I have so often regretted - the defective state of our information. The state of the weather, which has partly occasioned delay, would not be prevented." 39

Obviously, while Arnold's force remained in the Gambar valley, derived ko arvantage achterlony / from the completed part of his manoeuvre. In fact, there could be no more eloquent testimony to the maxim that great advantages are only bought at the expense of great dangers than the nature of his position at this time. In order to put his adversary into a potentially dangerous situation Ochterlony had been compelled to afford him advantages which he hoped would only be temporary but which nonetheless were formidable. His own army was now in an extremely hazardous situation. It was in two sections, each without ready contact with the other, and divided by a ridge commanded by the enemy. Had Amar Singh decided to make an attack, the disposition of the British force would have lengthened the odds overwhelmingly in his favour. No doubt the risk was one which Ochterlony had felt justified in incurring by 
virtue of the reluctance he had observed on the part of the Gurkha to adopt offensive tactics; ${ }^{40}$ but he could not be certain that this tendency had not merely been the result of what his antagonist considered to be inadequate opportunity. Amar Singh Thapa might well be stimulated into action now - not only by the propitious nature of his ground but also by the realization (for the purpose of Arnold's movement must have been obvious) that unless he interrupted the British operations their completion would swing the balance of advantage heavily from his own to Ochterlony's favour. This was the hour of Amar Singh Thapa's supreme opportunity, in which he was conceded the power to postpone or even forestall that distribution of British troops which was the essential condition of Ochterlony's victory. But the old kaji had either insufficient discernment to perceive or insufficient confidence to use his momentary ability to determine the issue of the campaign. He did not attack; and Arnold marched on without molestation, save that offered by sporadic discharges of musketry from the Ramgarh ridge. He reached the northern end of the Malaun range by the second week in February, and established himself in a position within three miles of Bilaspur. ${ }^{41}$ His men were exhausted and wretched, but the turning point in the campaign had been passed.

Ochterlony decided that now that Amold's force was in the vicinity of Bilaspur, only a few of Ross's auxiliaries need remain on the Bandela heights. He therefore withdrew the greater part of the Hindur troops; and on February 11th they were despatched under Lawtie and Ensign Murray, together with all the Pioneers and 200 sepoys, to the Gambar valley, where Cooper still occupied the old camp at Nori. Cooper then made preparations to eject the troops which Amar Singh Thapa had left behind to hold the main forts on the Ramgarh ridge. ${ }^{42}$

There were still Nepali garrisons in Ramgarh fort itself, and in the less elaborate stone sangars at Jorjoru, Taragarh and Chamba, which were widely spaced along the crest of the ridge farther north. Ramgarh contained about 100 men; Jorjoru about 160; and the others about 100 each. Cooper first concentrated on getting a position on the crest between Ramgarh and Jorjoru. Lawtie and 600 auxiliaries left camp to climb the ridge in the small hours of February 12th. The ground was 
dauntingly rough, steep; and hard with frost; but this was the Hindur soldiers' own country, and they had reached the crest by daylight, unseen by the enemy. They took up a position about 750 yards north of Ramgarh. Soon members of the garrison were seen scurrying among the clutter of huts and ramshackle outworks under the walls of the fort, intent on protecting their three guns, which were in a stone emplacement in front of the northward-facing main gateway. A party advanced, khukuris unsheathed, as if to give battle; but the intrepid Hindurians immediately riposted with a menacing movement forward, striking up their own martial tune. The Nepalis thereupon halted, and taking cover behind rocks and bushes, resorted to sniping. The guns in front of the gateway were also occasionally discharged; but their shot, of which the heaviest was only 3 or $4 \mathrm{Hb}$., invariably went wide. By four in the aftemoon Lawtie had coaxed up an elephant with a six-pounder strapped to $i$ ts back, and he set up the gun to give cover to the pioneers who were now on the crest, labouring at the construction of two batteries - one for mortars at 300 yards, and one for the eighteen-pounders at between 500 and 750. Meanwhile parties of auxiliaries took possession of all the pinnacles between Ramgarh and Jorjoru. All had been stockaded by the Nepalis who, on evacuating them, had left the defences conveniently intact. A party of 100 Rohillas, who occupied the stockade nearest Jorjoru, were threatened by a large group of the enemy, who made a sortie from that fort. They not only prevented them from seizing the stockade, but hounded them, swords drawn, back to the walls whence they had emerged. Several reinforcements were sent from Nori, and by nightfall 1,200 auxiliaries were posted along the heights.

The batteries were ready by ten o'clock the next morning, and work was begun on preparing a road for the eighteen-pounders from Nori to the crest of the ridge. The Pioneers dug, blasted, felled trees and built parapets all through the day and night, while the six-pounder and two small mortars already aloft maintained a slow and regular fire to prevent the enemy from removing their guns from the emplacement. The eighteen-pounders were trundled from the park at Nori at noon on February 14 th, with three complete companies - 270 men - assigned as a 
working party to each. Yard by yard they were hauled up the 1,200 foot ascent, the teams at the drag ropes straining in rhythm at the bark of command. Only a third of the distance was covered that day; and not until ten $0^{\prime}$ clock on the morning of the 15 th was the first piece in battery. It was aimed at the Nepali gun emplacement. An hour later the earth shuddered as it discharged its first ball with an explosion which was heard 40 miles away, in Nahan. 50 rounds had been expended by one o'clock, and two of the enemy guns buried under a pile of rubble. One embrasure was still intact; but the Nepali artillerists were so encumbered by masonry and continuing fire, that they could make no use of the cannon within it. The second eighteen-pounder arrived in battery at three in the afternoon. Both guns were then aimed at the wall of the fort itself, but before they opened the garrison was given a chance to surrender. Liberal terms were offered, for Ochterlony, evincing that versatility of mind which enabled him to treat each opportunity empirically, and thereby extract from it advantages which mechanical conformity to prescribed usage would have left unexploited, had issued instructions which radically departed from the handbook formula for the conduct of sieges. Instead of enjoining that the enemy's capacity to resist be destroyed, he had ordered that they be merely dispossessed, or ejected. In order not only to spare the lives of his own men, but also to increase the difficulties of supply in Malaun, he had instructed that the garrison of each fort was to be allowed to join Amar Singh Thapa with all its arms and property. The Ramgarh garris on nevertheless rejected these terms, and prepared to resist a storm. Stones were gathered and piled in heaps on the bastions, ready to be rolled down on an assaulting party. Lawtie therefore ordered the bombardment to recommence. After only a dozen rounds it was too dark for the operation to continue, and the guns were silenced for the night, save for the six-pounder, which was fired at long intervals to prevent the enemy repairing the damage or removing their guns.

At dawn on the 16th the same terms were again offered and were again rejected. Consequently, at eight o'clock, the heavy guns resumed their pounding. 200 rounds were discharged before any effect was 
noticeable. Then the walls began to split; loose stones began to tumble; and crumbled mortar began to cascade. Still the solid iron balls thumped into the flank of the fort - fifty, a hundred, a hundred and fifty more. Suddenly, at three in the afternoon, with a loud roar and a rushing sound the whole curtain opposite the battery collapsed in a single heap. At last there was a breach; but it was not wide enough to storm. The shot flew on, now fragmenting the ragged fringes of the gap and shaking down great masses of masonry both outside and inside the fort. To intensify the destruction shrapnel shells were occasionally fired from the sixpounder. These exploded over the fort into showers of incandescent metal.

Great commotion in Ramgarh was now visible. Soon a messenger appeared in the breach, and was allowed to come forward. He said that the garrison wanted to treat, to which Lawtie replied that a white flag hoisted over the fort would be regarded as a signal of surrender. Until it appeared the battering would continue. At four o'clock another messenger appeared, this time waving a white flag. He was admitted to the battery, and the guns were silenced while he discussed terms with Lawtie. Finally, at sunset, after a long conference, a treaty was signed. By its terms, the garrison of Ramgarh was permitted to march to Malaun with all its arms, colours, musical instruments, and public and private property, including cannon; and it was agreed that all belongings which could not conveniently be carried away at once should be preserved until they could be sent for. In return, the subadar commanding consented to try to persuade the garris on of Jorjoru to surrender on the same terms. He was as good as his word, and that fort capitulated at noon the following day.

Thus two formidable strongholds were captured without the loss of a single life - virtually, in fact, without a single casualty, because the only wounded man in Lawtie's force was a Sikh auxiliary who injured himself while attempting to plunder some caves. The Field Engineer had managed the whole operation with tact, judgement, and unflagging endurance. After the treaty was signed he quitted the battery for the first time in 72 hours. 
At Headquarters, everyone was relieved to hear of the fall of Ramgarh, and in his capacity as Commander-in-Chief Hastings paid handsome tribute to Ochterlony's enterprise and to the "cheerful patience" with which his sepoys were sustaining conditions of climate and combat for which their training was so inapposite and their dispositions so unsuited. ${ }^{44}$ But the success did not dispel his misgivings. He remained convinced that the rains must set in before the war in this quarter had reached a conclusive issue. ${ }^{45}$ On the scene of operations the way of thinking of one person at least was in harmony with the Governor General's - and that was Amar Singh Thapa's. Never for a moment did he relax his posture of self-assurance or relinquish his belief that he retained the ability to win the contest, or at least the option of ending it on his own terms. The attitude of his own government, supine and disposed to sue for peace after the loss of Kalanga, exasperated him beyond measure and made him even more intransigent and defiant. Seeing that the administration in Kathmandu, having committed the initial error of provoking the war, was now contemplating adding to it the even more appalling blunder of seeking a premature and disastrous peace, he envisaged himself as the sole remaining cantilever of the Gurkha empire: its isolated guardian, appointed by divine agency to fight not only a strong enemy without, but weak and foolish ministers within, and preserve it inviolate. On December 23rd the Raja had sent Ranjor Singh, Amar Singh Thapa's son, who was, it will be remembered, defending Jaithak, a letter enjoining him to treat for peace. He was authorised to surrender all the disputed lowlands. If that was insufficient to buy peace, he was to offer as well the whole of the Tarai and Dehra Dun; and if this still was not enough, he might cede in addition all the mountainous country from Dehra Dun to the Sutlaj. ${ }^{46}$ Ranjor sent a copy of this missive to his father, who agreed to negotiate on the basis of the surrender of the disputed lowlands, but flatly refused to offer more. This was tantamount to saying that he would fight on regardless of instructions from Kathmandu, because, having already tried to propitiate the British with them and failed, he knew full well that his terms would never end the war. ${ }^{47}$ The further concessions he emphatically deprecated since in 
his view they were as extensive as the worst sacrifices that defeat could entail, which it would be shameful to offer before defeat was even a reality. On March 2 nd he sent the Raja a reply (but which, being intercepted by the British, never arrived in Kathmandu). It was a mixture of cantankerous reproach, grim warning and urgent reassurance. He upbraided him for his folly in instigating a war for trifles; warned that appeasing the British by such large concessions would merely inflame their cupidity (he advised the Raja to ponder the fate of Tipu Sultan of Mysore); and bade him take heart, for the East India Company was not invincible - as was clearly proved by its failures at Bharatpur - and the Sikhs and Marathas were but waiting for a Gurkha victory as the signal for joining a grand coalition against it. ${ }^{48}$ He counselled conciliation of the brahmins as a means of mollifying the gods, and suggested that the Raja, acting in his capacity of loyal vassal of the Emperor, invoke the aid of China by representing the British intention to be the conquest of Tibet.

It was a stirring exhortation: the war speech of a consummate and informed rhetorician, rich with that speciousness which a dextrous manipulation of historical references and a cunning presentation of enticing possibilities can give. Amar Singh had in fact received no indication that the Sikhs were prepared to join the Gurkhas. Ranjit Singh had made it clear that he would not ally himself with them while his relations with the British remained friendly; ${ }^{49}$ but the kaji, himself an opportunist par excellence, obviously believed, and perhaps with reason, that if the British were brought to the point of submission an entirely new political situation would arise which such opportunist powers as the Sikhs, the Marathas, and even the dynasty of oudh would be unable to resist exploiting to the detriment of the Company.

Thus impressed with the momentous implications of his prevailing over Ochterlony, not only as an event essential to preserve the Gurkha empire, but also as a means of creating a situation which would favour its expansion, he refused to allow himself even to contemplate failure, and stifled symptoms of defeatism in his camp with the tyranny of a religious bigot whose creed is assailed. The unfortunate members of the 
Ramgarh garrison had their ears and noses cut off as a punishment for unjustified surrender, and the castellan was shackled withirons. The subadar in charge of the force would have been summarily executed had not Bhakti Thapa, the kaji's more humane principal lieutenant, intereded on his behalf. ${ }^{50}$ It would be a mistake to imagine that Amar Singh Thapa was wilfully deceiving himself. He had been informed of the despatch of a large reinforcement from Kathmandu, said to amount to 27 companies of 100 men each. This was known to have almost reached Kaumaun, and he confidently expected that it would join him in Malaun within a few weeks. When it arrived, he judged he would have sufficient men to launch a decisive counterattack against ochterlony. ${ }^{51}$ Meanwhile he made a determined effort to redeem the worst consequences of the capitulation of Ramgarh by reinforcing the troops still remaining in Taragarh and Chamba.

When he received news of the arrival of these extra men, Cooper, hitherto occupied in strengthening the defences of Ramgarh, which now replaced Nalagarh as the principal British depot, made preparations for besieging the two remaining forts. A force was sent forwards up the crest of the ridge to a position south of Taragarh, and a battery was erected at about 900 yards' distance. It took two days to move up the eighteen-pounders, because Ramgarh was four miles behind and the crest a succession of abrupt dips and rises. The guns opened fire late in the afternoon of March 9th. No impression was made on the walls during the short remaining period of daylight, but no time was lost in recommencing the bombardment next morning. The resilience of the stonework amazed everyone. A lange section of masonry was brought down during the day, but nothing like a practicable breach was made. On March 1lth the guns opened at nine $o^{\prime}$ clock and disgorged without interruption throughout the day; yet at dusk the main part of the wall before them was still standing and showing no sign of collapse. At daybreak on the 12 th it was discovered that the fort had been evacuated during the night. When Cooper's men occupied it, they found that the wall facing the battery had been lined, so that the total thickness was twelve feet at the bastions and sixteen feet at the curtain.

It now only remained to reduce Chamba, six miles still farther 
north. Tirelessly, the auxiliaries under Lawtie pushed forward to take up a position about 350 yards before the fort, and the pioneers set to work yet once more to make a road. The Bengal Pioneers or Sappers were not without their critics; and they were said to have been useless in Java, and to have refused to bury the dead. ${ }^{52}$ But there is no indication that indolence or caste-consciousness ever affected their performance in any of the Nepal campaigns. Indeed, they were a mainstay of Ochterlony's effort. By March 16th an eighteen-pounder had been set up before Chamba, and it opened fire at half past eleven. This time the effects were swift. After only an hour one complete bastion had been reduced to rubble and the garrison signified its desire to surrender. There were only 50 men in the fort, the rest having already absconded. So greatly did they dread the wrath of their commander, that they begged for quarter as prisoners of war, which was granted. Seeing that they remained very apprehensive lest in his vindictiveness the kaji should make their families atone for the capitulation, Cooper agreed to continue firing blank cartridges, so that Amar Singh should not guess what had occurred, while two of their number went to Malaun to bring away the prisoners' women and children.

So were the enemy dislodged from their last footholds on the Ramgarh ridge. Only small detachments of auxiliaries were needed to man the captured fortresses, and the 1,100 regulars under cooper were made free to assist Ochterlony's measures against the main Gurkha army in Malaun. 53

When Amar Singh Thapa realized that Chamba had surrendered and its garrison defected, he was enraged. To give vent to his vexation, and to re-animate his troops, whose morale was flagging under the frustrations and inertia imposed by Ochterlony's blockade, he at last resolved to take the offensive. But he planned only a token attack, devised more because it was likely to succeed than because it had significant tactical purpose. He selected as his prey not one of the detachments of regular troops in the Gamrola valley, but a party of Sikh auxiliaries who had taken post on the western flank of the Malaun ridge, above the Gambar 
river. Late on March 19th, he sent a party of 400 men from Malaun. They crept towards the unsuspecting Sikhs in the half-light of the evening, and then lay quiet until the moon had gone down. 300 Sikhs were in an outwork, and some 900 below, in the main stockade. The Nepalis assaulted in three groups, screaming their chilling war cry as they charged. There was a noise like that of ripping tarpaulin as the first body discharged a volley; then the second and third attacked the outpost and stockade simultaneously. The Sikhs, completely unprepared and aghast, made only feeble efforts to defend themselves. Those in the outpost were hacked mercilessly, and only 60 survived. In the stockade there was pandemonium, and the occupants fled to a man without waiting to resist. ${ }^{54}$

But this cheap triumph can have caused only transitory exultation among the troops in Malaun, because it had no important long-term consequences, and was not dazzling enough to disguise the grave portent of other events to the north, south and east. Slowly, a cordon was tightening around them.

Maha Chand of Bilaspur, at last convinced that the grand Gurkha vessel was doomed, had lowered himself hurriedly into the modest lifeboat proffered by the British. For a fortnight he had resisted Ochterlony's summons to change his allegiance, hoping to barter his support against a recognition of his claim to the Twelve Lordships; but at the end of February, perceiving the advance of Arnold's force towards his capital and aware of the new posture of affairs, he had attached himself "heart and soul to the British Government" in return for a sanad which confirmed to him only the territories which he then possessed on the eastern bank of the Sutlaj. By its terms, he became a protégé of the East India Company, but was excused liability for tribute. ${ }^{55}$ When he received news of the Raja's tergiversation, Shiva Dat Rai fled across the Sutlaj into the territories of Ranjit Singh, and Amar Singh Thapa's remaining influence in Bilaspur was thus destroyed. ${ }^{56}$ He lost the services of his 1,000 Bilaspur auxiliaries, while Amold's force was furnished with plentiful supplies and given access to the stronghold of Ratanpur, which was on the Malaun range and barely two miles north 
of Malaun fort itself. The kaji's passage to the north was at last well and truly stopped, and the cooperation of O'Brien, who still had not sent Ochterlony a final reply, was made a matter of little consequence. This was just as well, because it seems that that extraordinary character had composed his quarrel with Sansar Chand and relinquished his intention to desert. Probably, in one of his few moments of sober reflection he had realized that he would have made a poor bargain in exchanging the princely powers, the unlimited liquor, and the copious harem which he enjoyed in Kotoch for the dubious adyantages of a free pardon from the Governor General. 57 On April list, Amar Singhthapa'saccess to the south wasaloo Glocked. the Ramgarh ridge, occupied a hill on the southern end of the Maulaun range. In its new position his force was only a mile or two below Surjagarh, the fort south of Malaun which was occupied by Amar Singh's best officer, Bhakti Thapa. 58 Meanwhile, in addition to his accumulating advantages of ground, Ochterlony had begun to derive great benefit from his own corps of Nepalis. This was composed of deserters and prisoners of war. At the beginning of April there were 324 of these in the British camp, and they had quite won over the major-general by their sunny nature, their industry, and their eagerness to gratify. He resolved to form them into a separate battalion of three companies.

"I shall with the sanction and approbation of His Excellency call it the 'Nasiri* Paltan' and consider myself their commandant and patron. These trifles have great weight; and I must confess myself sanguine in my hopes of their not discrediting my favour."

Hastings readily approved, and suggested that the garrison of Nalagarh, sent as prisoners to Ludhiana, be invited to join the corps. 59 It was this body which formed the nucleus of the regiment later called the lst Gurkha Rifles.

The steady trickle of deserters from Amar Singh Thapa's camp was a sure indication that the policy of blockade was beginning to have an effect. Time, however, was running short. By early March the pear trees in the Gamrola valley were already resplendent, each one a galaxy

Nasiri $=$ friendly. 
The Himalayan

of blossom. $/$ spring, in the ungency of its parturience, had pushed winter violently aside; and within a couple of months it too would be unceremoniously displaced by the sombre season of the rains, when all military operations would be impracticable. Determined to deprive his adversary of the advantages of such respite, Ochterlony devised a complex and daring manoeuvre which, if successful, would give him a position on the Malaun ridge whence he might hammer the fort into submission. As soon as he had finished his work in the vicinity of Ramgarh, Peter Lawtie began making an intricate reconnaissance of the hills around Malaun; and the major-general afterwards acknowledged that it was entirely to his "intelligent mind, diligent inquiry, and personal observation" that he owed the information essential for the construction of his plan. 60

The Malaun ridge rose four and a half thousand feet above the level of the sea, and two thousand above the Gamrola stream, which flowed in a deeply ploughed channel along its eastern base. The crest of the ridge was narrow and jagged, with a succession of variously shaped pinnacles. The ground fell steeply from thesumit, in places precipitously, to swell out into broad spurs, on whose level ledges stood little hamlets. Scraggy vegetation sprouted here and there; but generally the slopes were arid, gaunt, and brutally scarred by water-worn furrows. On a commanding height towards the northern extremity was the stone fort of Malaun: long, with square bastions, and deprived of visible height by the massive proportions of the rock on which it sprawled. The eye being unable to embrace it and the immobile features of the valley simultaneously, it seemed deprived of anchorage, and ever about to move off into the clouds. The military cantonments were outside the fort - a clutter of huts huddling under its eastern walls, protected by a semi-circular stockade. Bhakti Thapa's headquarters were about four miles farther south, in the fort of Surjagarh. The Nepali forces were concentrated in and about these two centres. Stockades and redoubts, scattered over the different levels of the ridge, hovered around them like electrons around nuclei. But the two configurations did not meet. Between their outer orbits on the crest there was a vacant space, called Raila Peak by the British. 
Equipped with a thorough knowledge of the ground, Ochterlony completed his plan. Although it involved several simultaneous movements, it was basically very simple. His aim was to establish two positions on the crest of the ridge: one at Raila, to hold Bhakti Thapa at bay; and one on a vacant site within the system of defences around Malaun, south of the fort and separated from it by two intervening stockades. For convenience of identification this site was named Dionthal. ${ }^{61}$

Starting from different positions in the Gamrola valley, three columns were to advance up the eastern flank of the ridge on converging lines, finally to meet at Raila Peak. At the same time two columns were to leave the valley from points farther north and converge on Dionthal. Such were the main movements of the plan. But in addition, in order to distract Amar Singh Thapa's attention from the columns advancing to Dionthal, a feint attack on the Malaun cantonments was organised. One party was to advance on them from the Gamrola valley, while another approached from the north, so that the two lines of attack were at a right angle. The northencolumn was to come from Colonel Annold's position at Ratanpur, and would have to cross the thousand feet deep ravine which separated that fort from Malaun.

All these movements were to begin on the morning of April 15th, at the appearance of a pre-arranged signal. This was to be given by the centre column of the Raila operation, when it had reached its destination. 62

The Raila operation was accomplished without a hitch. The three columns designed to converge on Raila can be labelled the left (southernmost), the central, and the right.

The central column moved first. Led by Lieutenant Fleming, it quitted the village of Patta in the valley late on the night of April 14 th. It consisted of $1,100 \mathrm{men}$, and included 300 of the Nasiri Battalion under Lawtie. This was the first occasion when "Gurkha" troops went into action as British mercenaries, and they immediately impressed their officer by the closeness of their files and their perfect silence, both maintained even over the most difficult ground. The column reached Raila Peak at one o'clock in the moming of April 15th, having encountered 
no opposition, and discharged the signal flare. This was answered from a hill in the rear of Ochterlony's camp, and the other columns immediately put themselves into motion. On the right, Major Innes with the Grenadier Battalion and two six-pounders moved from headquarters, and ascended to Raila "in admirable order". The left hand column, led by Lieutenant Hamilton, moved from a small village called Jainagar on the lower slopes of the ridge below Surjagarh. It was composed of troops from Cooper's post at Lag Hill, at the extreme south of the ridge, who had moved to their starting position during the night. The column was fired on from an enemy stockade as it marched up the flank of the ridge; but the men pressed on in perfect composure and reached the summit without mishap. Meanwhile Raila Peak had been stockaded by a group of pioneers, enthusiastically assisted by the Nasiris, who seemed oblivious of the musket fire from the fort. 63

The Dionthal operation was the focus of Ochterlony's plan. Two columns marched up to the site: Major Laurie's on the right ( 400 auxiliaries), and Colonel Thompson's on the left (1,3000 regulars, 300 auxiliaries, and two six-pounders). The heads of the columns arrived at Dionthal almost at the same time, but the guns still lagged a long way behind. A patter of firing to the north telling him that the diverting columns had begun their work, Thomps on mustered his three companies of light infantry and, leaving the rest of the combined columns under Laurie to wait at Dionthal for the guns, marched boldly northwards up the crest of the ridge to seize a position for a battery nearer Malaun. Enemy musketeers, sniping from behind rocks and bushes, tried unsuccessfully to check him. But as he approached the nearer of the two stockades which commanded his path to the fort, a party of Nepalis threw themselves from it with khukuris drawn and charged madly at his men. The sepoys, steadfast enough under the invisible onslaught of musket balls, quailed before that terribly conspicuous coruscating steel. They greatly outnumbered their antagonists; but their officers cursed and cajoled in vain. They would not use their bayonets. Breaking formation they fell over themselves in their anxiety to get back to Dionthal, where 
Laurie and his men were luckily prepared to cover their retreat. The Nepalis did not attempt to assault the Dionthal position, but sheathed their weapons, took cover, and began sniping. The pioneers worked feverishly to raise a breastwork; but enemy marksmen were ubiquitous and because of the infuriating ruggedness of the ground had cover to within twenty yards of the position. Soon the sepoys were visibly flagging, ammunition and water were getting low, the six-pounders still did not arrive, and pioneers were being picked off at an alarming rate. Crichton, the Surgeon, could not cope with all the wounded, and made an urgent request for medical assistance. Thompson feared that he would be unable to strengthen his post sufficiently to withstand the attack which he was sure must come during the night. Ochterlony was in agonies of anxiety, and implored him to retain his ground at all costs. If it were lost, the whole plan would be wrecked. During the afternoon the major-general withdrew two companies of infantry from Raila and transferred them to Dionthal; and Ram Saran, the Raja of Hindur, provided men to replenish the depleted ranks of Thompson's pioneers. Nevertheless, for the rest of the day it remained touch and go whether the force at Dionthal would be able to hold its position. The elephants carrying the six-pounders arrived on the crest late in the afternoon, but there were only eight European matrosses to serve the guns, and before long one of these had been wounded. Meanwhile, the enemy, shooting from behind rocks and trees, remained secure from the effects of grape. At dusk Thompson was still in possession of his ground; but the hours of darkness were a time of almost unbearable suspense. All the troops knew that their severest trial was yet to come, for it was inconceivable that the Nepalis would not make a full-scale attempt to dislodge them. More than once there was a sudden shout, a rush, and a cocking of musket hammers. But each alarm proved false. There was no attack; only the cramp, the thirst, the fatigue and the tension of creeping hours of vigil. 64

The diversion had long averted from Thomps on's detachment the brunt of the Nepali resistance.

Captain Charles Showers, who led the column from Ratanpur, was 
an earnest young officer who combined magnificent courage and a vivid sense of chivalry with an evangelical sobriety. He had sworn that he would never accept a challenge to a duel, and always said that he trusted to his profession to provide him with a more appropriate claim to the title of soldier. His avidity for that title was about to destroy him. At the head of the battalion (the lst/19th Native Infantry) of which he had assumed the command at the outset of the war, he marched from Ratanpur early on the moming of April 15th. He had first to negotiate the slopes which plunged into the ravine between Ratanpur and Malaun, and then cover the long and difficult ascent to the Nepali cantonments. Its climb took his column by an enemy stockade, which was on a ledge to its left, about 100 feet below Malaun fort. This was passed without incident; but at about half past ten, when the force was half way between the stockade and its objective, a party of the enemy issued from the cantonments and came down to the attack. Showers, seeing that they were numerically considerably inferior to his own column, and eager for an opportunity to exhibits his prowess, commanded his men not to load, but to disperse the pack withtheir bayonets. The first part of his order they obeyed. The second part they did not. Intewt in personal glory, Showers had forgotten what had been demonstrated time and time again: that the Bengal sepoy's musket was his fetish. His men hung back, chilled fith fear. All urging was in vain; they would shuffle forward a few yards then jostle back again, as the squat, slant-eyed enemy advanced. Striving to enspirit them by his own example, Showers ran forward alone, outstripping even his orderlies. A Gurkha officer came towards him; and for a moment the Nepalis' advance slackened as they instinctively yielded space and attention to their leader's encounter with his opponent. Exultantly, Showers coaxed him forward, with taunting gestures. The young Briton was an adroit swordsman, and he soon had his man on a desperate defensive. Then, with a sudden vigorous lunge, he killed the Gurkha. But his triumph was brief. As he struggled to pull out his sabre, he swayed under the weight of the corpse, which was on higher ground. Seeing him encumbered, the Nepalis sprang forward and savagely stabbed him to death. Horrified, his sepoys receded. The enmy took up the pursuit, yelping and gaining 
confidence as the momentum of their descent increased. Some sepoys tumed about and ran; and as others followed their example the retreat became a general flight down the crumbling contouns of the gorge. Not until they reached the plateau of a small village 1,500 feet below did Lieutenant Rutledge, on whom the command had devolved, manage to halt and rally the men. Once they had had time to load their muskets they became more amenable, and responded obediently when Rutledge ordered them to chase the enemy back up the hill. Colonel Arnold had been watching operations from Ratanpur, and when he saw Showers killed and his men routed, he immediately ordered forward a third column of diversion. In a stockade called Tipnu, on the eastern side of the ridge below Ratanpur, there was a party of Sikh auxiliaries and a subadar's party of regulars. Amold directed these troops to advance on that enemy stockade below the cantonments which Showers had passed on his ascent. This they did with exemplary enthusiasm. The subadar was killed; but the leader of the Sikhs, Ghoshi Ram, led the party right up to the stockade, and would probably have entered it had not some of his men wavered at the last minute. Rutledge's fresh advance to their right now afforded this party support and cover for its retreat.

Meanwhile, farther south, Captain Bowyer, leading the second diverting column from the valley floor, had reached Malaun village, which was about 1,000 feet below the fort. Here he sent out his partyof Sikhs to grab a height slightly to his left; but, being immediately accosted by a party of Nepalis from a stockade in their front, they uttered screams of terror and fled in confusion back to the valley. Fortunately the effect of their repulse was soon made good by the arrival of a fresh party of auxiliaries under Lieutenant Dunbar, which had been instructed to hover in the rear and support either diverting column as circumstances required. The enemy collected in considerable numbers in front of Bowyer's position, and made several attempts to oust him; but he parried every thrust energetically, anxious to draw as much as possible of the Nepali effort from Showers' column, operating to his right.

At about eleven o'clock came news of Showers' death and the 
overpowering of his column. Bowyer persisted at his post for another hour and then, deciding that action against the Malaun cantonments with his limited resources alone was bound to be abortive, he ordered a withdrawal to the Tipnu stockade. The retreat was performed with field day precision: one half of the detachment retiring to a rear position, and the remainder then following under cover of its fire. It was during their retreat that the sepoys of this detachment finally derived support from the other diverting column, Amold having ordered Rutledge to incline to his left to help cover Bowyer's movement. The detachment finally reached the Tipnu stockade with no more than 14 casualties. Despite their failure to penetrate the enemy cantonments, the diverting columns had accomplished their main purpose. For several crucial hours during the morning they had almost monopolised Amar Singh Thapa's attention, and thereby greatly lessened the opposition with which the Dionthal columns had had to contend. But their achievement had been costly. In an army where their importance was so exceptional and their numbers so inadequate, the loss of any European officer was no light matter; but when the officer was "most zealous, brave, and excellent", which is how Ochterlony described Showers, the loss was especially grave. However, Showers had proved his merit as a soldier, even in the estimation of his enemy. In the East, it is a gesture of respect for a brave foe to cover his remains with fine cloth. When the bearers went up the next day to retrieve Showers' body, they found it lain on a bed of leaves at the top of a steep, wrapped in a shroud of silk. ${ }^{65}$

Thus ended the grand concerted manoeuvre of April 15th. When night fell Amar Singh Thapa was brooding within the walls of Malaun, conscious that he had reached the most criticat emergency of his career. If the British were not expelled from the post they had gained at Dionthal, Malaun must either be strangled or bombarded into submission. Early in the night, Bhakti Thapa decided that his own post, Surjagarh, must be sacrificed in an attempt to preserve his chief's headquarters. Prevented from attacking Thompson from the south by the intervening British post at Raila, his force was no more use to Amar Singh than a severed limb. He therefore mustered his men and, proceeding stealthily 
below the crest on the western flank of the ridge, made for Malaun. He hoped to bypass Innes' and Thompson's posts unobserved, or at least unimpeded. But his design had been anticipated and Lieutenant Murray, in charge of the Hindur auxiliaries at Raila, had placed himself and his men in a position commanding the Gurkha's route. Falling pitilessly on their inveterate enemies, the Hindurians turned Bhakti's progress to Malaun into an ungainly tumble. 66

Bhakti Thapa was the bravest officer in the Gurkha army, and the most popular. When he arrived in Malaun, Amar Singh appointed him to lead a dawn attack against Thompson's position. He assigned to his command the élite of his army: 2,000 warriors, all uniformed in scarlet broadcloth. It is said that Bhakti delivered his son into the kaji's care, and solemnly swore that he would return victorious or remain dead on the field. Shortly after four $0^{\prime}$ clock on the morning of April 16th, having adjured his two wives to be prepared to sacrifice themselves on his funeral pyre, he led his men from the fort. Silently, they took up positions on the narrow ledges around Dionthal, clustering thick as bristles on a hairbrush.

Thompson's force by now mustered between 2,000 and 2,500 men, of whom about 1,000 were auxiliaries. He had two six-pounders, but only seven artillerists to serve them. Ochterlony had realized that the attack this force would have to encounter would be the most fierce and desperate of the whole campaign, and he had sent a note to Lawtie, still at Raila with the Nasiris, asking him to suggest to his men that they go to Dionthal to strengthen Thompson's force. Only extreme need could have induced him to make such a request, because he was a man of sensitivity who appreciated that the Nasiris might feel abhorrence at the prospect of fighting their own erstwhile comrades-in-arms. But his scruples were unnecessary. The Nasiris were not authentic Gurkhas, but men from the western hills of Nepal and Kumaun, who had never considered themselves as anything other than mercenaries in Gurkha pay. Their attachment to the government of Kathmandu had been essentially contractual. There had never been any transcendental tie, any sense of patriotic loyalty. Now that the contract with their original masters had been broken, and they 
had made a fresh one by "eating the salt" of the British, their only concern was to discharge their new obligation with as much honour and honesty as they had discharged the old. There was therefore no hesitation; on the contrary, they eagerly consented to follow Lawtie to the fray, and were verydisappointed to arrive at Dionthal too late to take part in the engagement.

India is 2 land of nocturnal beauty, and it was now the hour of perfect night. Myriad glittering st ars were sus pended in the black sky, like fountain spray immobilized Invisible flowers exuded perfume, like objects belong ing tolegend, and not reality. It was the hour when man's compulsion is to be at peace, and wor ship. At a guarter past four, the Nepalis attacked; and never could the din of their war cries and harsh trumpets kave sounded move jaming, mone sataric. Musketeers opened fire from do. range on the northern front and both flanks of the post at Dionthal, but their main offensive was directed against the guns. Bhakti knew that if he could but silence these, the proven superionity of his men in close combat would bring victory within his grasp. The two six-pounders had been placed in embrasures commanding the smooth ground on the western side of the position, which was the only approach free of natural impediments. Naked khukuris in the right hand, loaded muskets in the left, the Nepali assaulting party surged out of the darkness with frenetic resolution, straight towards the nozzles of the cannon. There was a vivid flash, a crash, and red-hot blasts of grapeshot punctured the advancing scarlet mass. So many Nepalis were killed and wounded that their charge could not be completed, and Bhakti was forced to withdraw the party to replenish the losses. The British gunners worked with fanatical haste to recharge the pieces, but the encircling enemy snipers were inflicting vicious execution, and the little band was quickly being extinguished, man by man. Again the Nepalis charged; and again the hill top shuddered and flared briefly into brilliance as they were blown away from the very mouths of the guns. Their defiance of $h$ artefacts, whom bravery could never intimidate, and whom steel and muscle could never humble, had an ecstatic nobility. Still once more the Gurkha chief rallied and reformed his men. Behind him, on a hill within musket range of Dionthal, was Amar Singh Thapa himself. He stood conspicuously by a stand of colours, strenuously urging on his troops. Once again Bhakti Thapa ordered his men to charge the guns, and again they obeyed magnificently: not a whit less ferocious, not a degree less heroic for all the punishment they had 
suffered. Their perseverance was inspired by the decreasing futility of their enterprise. In the British battery Lieutenant Cartwright of the Artillery now had only one gunner undisabled, and with him was loading one of the guns himself. The other was being served by Lieutenant Armstrong of the pioneers and Lieutenant Hutchison of the engineers, with the help of two pioneer serjeants. Before the next discharge could be made, one of the serjeants spun away, shot through the head. It seemed, for a second or two, that at last the enemy would take the battery. But then, when the Nepalis were only yards away, the pieces again were convulsed and again disgorged, and the assaulters were swept flat like reeds before a hurricane. Bhakti Thapa was compelled to relinquish his design. Choking with despair, but with courage still unimpaired, he collected the remnants of his storming column and marched them over the crest to the eastem flank of the ridge, with the intention of assailing the British position from that direction. Here Major Laurie and the Hindur Raja's auxiliaries were posted with a body of sepoys in a small outwork. Thompson decided that this was the moment to counterattack, and he ordered Laurie's detachment to make a sortie and accost the enemy with swords and bayonets. If the sepoys had misgivings, the Hindur troops had none. Ever ready for a chance to come to grips with the Nepalis, they needed no second bidding. They rushed in among Bhakti's band, flaying about them with barbaric relish. The sepoys, incited by their example, plunged with gus to into the imbroglio of conflict. At first the Nepalis disputed every yard of ground. The battle raged fierce and savage, and the earth became saturated with blood. Then suddenly, it was as if aninvincibleweariness quelled the enemy. Their resolution changed almost into apathy. They ceased to retaliate to the blows, the thrusts, and the lunges of their exultant antagonists, and with a fatalistic quiescence began abjectly to retire. The Hindur troops pressed onwards, merciless in their revenge, and turned the retreat into a mass acre.

The battle of Malaun was over; and the day was Ochterlony's. It was seven o'clock. Pink antennae of light began to probe the grey smoke, slowly revealing all the grisly debris of war. The windswept 
crest was littered with stiffening corpses, which were caked with gore, and melted and welded again by heat. There were severed limbs; steaming entrails; broken weapons; trampled colours. Here and there was a feeble movement; a spasmodic groan; heavy breathing - hideously inappropriate signs of life in a world of death and carnage. In the distance a dark form stumbled away, as if to hide its shameful mutilation; and over the eastem mountains the sun, swollen and heavy, hung low. Among the bodies was found one in an officer's full dress uniform. It was brought into the camp at Dionthal for identification, and the Nasiris sorrowfully confirmed that it was that of Bhakti Thapa. The reason for the Nepalis sudden surrender to despair in the middle of the battle was now apparent. Ochterlony ordered that the body be treated with the utmost deference and sent with an escort to Malaun. When it arrived at the fort, the Nepali army must have been gratified to see that the British general had had it covered with costly shawls. That night, as Charles Showers was being buried with military honours in the valley, there was a bright glow on the heights before Malaun. It was Bhakti Thapa's funeral pyre, into the flames of which, in full sight of the British army on the ridge, the Gurkha hero's distraught widows flung themselves.

When the muster roll was called, it was found that Thompson's force had suffered 253 casualties - but of these only 30 were deaths. Amar Singh's losses were much greater, 150 dead were left on the field alone, and it was reckoned that his total casualties must have reached at least 500.67

But the Gurkha kaji had lost more than his best officer and a quarter of his army. He had never commanded the affections of his men; but from this time he was deprived even of their loyalty. Large numbers deserted daily, despite his brutal measures to prevent them. ${ }^{68}$ To add to his troubles the expected reinforcement from the east had been detained in Kumaun by Brahma Shah, and did not now seem likely ever to arrive in Malaun. Then another of his subject allies, the Vizir of Basahar, defected to the British. This minister, who had formed a part of Amar Singh's retinue since the subjugation of cis-Sutlaj Bdsahar in 1811, had come into Ochterlony's camp to proffer his allegiance even before the 
battle of Malaun, and on April 13th had left to promote rebellion in his own country. Within a few weeks news arrived from William Fraser that the Nepali occupationary force in Basahar, led by Kirti Rana, had been attacked and dispersed "by a piece of deep treachery ... the Commander of Basahar, who had hitherto kept the Gurkha force supplied with grain ... decoyed them at last to a spot where water and provisions were easily cut off." Fraser added: "The event is fortunate, particularly as the British character has not been implicated in the act." Kirti Rana, his officer, and 400 men, were now prisoners in Basahar. ${ }^{69}$ Meanwhile, Ochterlony's cordon round Malaun had continued to tighten. Surjagarh and all the stockades south of Dionthal, having been evacuated by the enemy after the final battle, were seized by British detachments; 70 later two more positions were occupied on the western flank of the ridge, completing the blockade on that side; and at the beginning of May Lieutenant Ross, with the Nasiris, moved to a site north of Thompson's advanced posts whence the nearest outwork of the Malaun defences could be reached with artillery. 71 On May 3rd Ross took possession of the outwork itself, the garrison making no resistance and accepting an offer of service. The troops in a redoubt to its right also accepted an invitation to pass to the rear with their women and children, and this post too was occupied. Possession of all the defences south of Malaun was finally completed when a third stockade on a peak to the left surrendered. 72 Work now began on clearing a way for heavy ordnance, and on May 7 th two brass twelve-pounders, strapped to elephants, arrived on the crest.

As the situation outside Malaun became so ominous as to leave no room for hope, the spirit of mutiny increased within, $/$ the kaji's control over his officers and men. When they saw the arrival of the twelve-pounders, all his principal sirdars, or lieutenants, presented Amar Singh Thapa with an ultimatum. They demanded either food for their men, or some decisive line of conduct. But Amar Singh, powerless to attack again, yet withheld by stubbornness and pride from opening negotiations for surrender, refused to stir from a state of taciturn inactivity - the last refuge where those who have not strength to assume the burden of defeat may for a moment dally with their illusions. 
Peevishly he ordered his officers to await events; but they had no patience for futile temporizing. They gathered their men, amounting to nearly $1,600,73$ left the fort, and pledged their allegiance to the British. To Amar Singh's army, reduced already to half its original 4,000 by casualties and desertions, this was the death blow. The old man in Malaun now had about him but 250 fighting men. At last he sent an ungracious note to Ochterlony, demanding to know his wishes; but the major-general replied that according to usage all proposals must come from him. ${ }^{74}$ Thereupon the kaji relapsed again into sullen silence, struggling with his pride and - who knows? - perhaps still clutching at the hope of a last-minute intervention by Ranjit Singh. It appears that he made another application to the Sikh about this time; ${ }^{75}$ but Ranjit, while confessing himself surprised at the swiftness of his defeat, had too many of his own problems to help redeem it. ${ }^{76}$

By May 9 th emplacements for the twelve-pounders and mountain bowitzers had been constructed within battering distance of the southern aspect of the fort, and on the following moming, at seven o'clock, the pieces opened fire. The bombardment continued all day, save for a few intervals during which notes were exchanged. The effect of the twelve pounders was perceptible, but slow; and the mountain howitzers, because of the flimsiness of Hastings' collapsible carriages, tumbled over like toy cannon every fourth round or so. ${ }^{77}$ Ochterlony therefore decided that he must bring up the eighteen-pounders; and it was the sight of fatigue parties labouring up the flank of the ridge with these instruments of sure destruction that finally wrung from Amar Singh Thapa a surly concession of defeat.

His youngest son, Ram Das, came to tell the British that his father was willing to negotiate on the basis of the surrender of the fort; and in reply Ochterlony offered liberal terms. Malaun and all the forts west of the Jumna, including Jaithak, were to be evacuated, and such members of their garrisons who did not choose to take service with the British would be allowed to march unmolested back into the eastern provinces of Nepal, with all their private property. In addition, Amar Singh Thapa and his kinsmen would be permitted to march with all their arms and 
accoutrements. 78 Ochterlony's forebearance is all the more apparent when it is recalled that he and his army, according to the usages of war, were entitled to the contents of Malaun (which included the kaji's reputedly immense store of treasure) and of all the other captured forts as prize money. His motive in thus conciliating the Gurkha was to induce him to use those powers to negotiate for a general peace treaty which he was known to possess, but which he had not so far exercised. 79 His hopes in this direction, however, were thwarted by Hastings, who had other plans. Brahma Shah, governor of Kumaun, and a known opponent of the Thapa administration in Kathmandu, had signified his desire to the Gurkha negotiator. The Governor General reckoned that he would be both more amenable and more sincere as an agent than Amar Singh Thapa, and fancied that if the Thapas were denied the prestige attaching to the conclusion of a satisfactory peace treaty, their ruin, already half-assured by the disastrous issue of the war, would be completed, and the way prepared for a return to power of the pro-British Panre party. Ochterlony was therefore informed that the settlement with Amar Singh should embrace no more than the conditions of his own immediate surrender. 80

Suarting with Chagrin andhumiliationAmar Singh resigned himself to the necessity of relinquishing for ever all the territories which he had spent ten years of his life acquiring. He was not noble in defeat. At the last minute, he avidly seized an opportunity to disclaim responsibility for his own surrender. A letter arrived from Brahma Shah, who was ignorant of the latest developments in the west, announcing his own capitulation and advising Amar Singh to follow suit. The kaji thereupon insisted that a clause be inserted into Octherlony's convention, which stated that he agreed to its terms only at the behest of the Governor of Kumaun; and when informing the Raja of his capitulation, he expressly stated that he had agreed to it on the authority of Brahma Shah's letter. 81 It was a shabby stratagem, dictated equally by vanity and malice. It was calculated not only to remove the obloquy attaching to his own defeat from himself, but to transfer it to his hated political enemy.

So he left Malaun, his body ailing and his mind poisoned by wormwood, and made his way slowly back to Kathmandu. The empire which he had 
laboured to build had collapsed about his ears, and the army which he had so proudly and domineeringly led had rejected him to serve his enemy. No fewer than two thousand Nepali soldiers had elected to stay with the British. 82

As for David Ochterlony, he had snatched celebrity while on the very brink of obscure old age. From being one of the least known he had become one of the most famous of Bengal officers, and an acknowledged favourite of the Governor General. Hastings' tribute to him was effusive:

"So complete a fulfilment of his instructions, under difficulties known beforehand to be of no common amount, would alone have been sufficient to establish a high rate for Major-general Ochterlony's reputation as a commander; but there are details in the arduous service so ably conducted by him which must meet from the mind of everyone a more particular attention. The unremitting zeal, the sagacious foresight, and the admirable decision which he has had the opportunity of displaying should make him feel himself indebted to the embarrassments he has had to encounter. They have only served to mark in brighter colours the extent of his claim to applause." 83

It had been intended that he should return to his old command at Allahabad at the conclusion of the campaign; instead it was Marley who was banished to that obscure backwater, vacating a place on the general staff which Octherlony was appointed to fill. 84

In a flattering despatch from Headquarters, he was asked to proceed to Nahan and assume command of the division under Martindell:

"The Commander-in-Chief is well aware of the irksome nature of the duty he is now about to impose on you, and nothing but the extreme importance of the object to the public interests, His Excellency's despair of seeing it effected by the officer to whom it is now committed, and his firm reliance on your confirmed character for zeal, public spirit, and military talents, could induce him to assign to you this new labour at the present advanced season and after the successful close of your long and arduous campaign." 85

But it so happened, as we have seen, that Jaithak surrendered before this appointment became operative.

Ochterlony had, together with Gillespie, Martindell, and George Wood, been gazetted K.C.B. early in 1815, before news of his success reached England; and when the Court of Directors of the East India Company heard of the resounding victory that he had achieved, they supplemented the 
the award with a pension of $£ 1,000$ a year, "to enable him to live in a style commensurate with the dignity bestowed on him by the Prince Regent." 86 Ochterlony's satisfaction was great; but it was not complete.

When his triumph was almost full-blown there had come to blight it, like a summer frost, a sharp tincture of tragedy. Weak after his unceasing exertions during the campaign, Peter Lawtie had succumbed to a typhus infection, and died a few days before the surrender of Malaun. In the ageing major -g eneral, his loss inflicted a wound which never completely hezled. Uttterly disconsolate, hequested all the officers of his division to wear mourning for a month - a gesture unprecedented for one so young. A subscription was opened for a marble monument in his memory, and this can still be seen in the Cathedral Church of St. John, Calcutta. ${ }^{87}$

It was by the division of which at least had been expected that most had been gained. Hastings was right to attribute the victory above all else to Ochterlony's brilliant quality as a commander - but in what, particularly, did that quality consist? A list of his merits would include all those of a good general - ingenuity; opportunism; courage; audacity. But more than in any of these, his quality consisted in that perspicacity which had enabled him to foresee the necessity for guns, and in that calm patience and dogged determination which had enabled him to eschew flashy exhibition of prowess and concentrate with absolute seriousness on making use of them. Without the use of artillery he could not have won the contest. Of that there is no doubt.

His infantry had been poor. The Bengal sepoys had made a show that compared most unfavourably with that made by their Nepalese antagonists. There had been, as ever, instances of bravery and heroism; but time and time again they had demonstrated that in the particular art of close combat which mountain warfare demanded they were quite unable to match the courage and skill of the men against whom they were pitted. An anonymous civilian who accompanied the expedition was appalled the lack of confidence, the trepidtionand the apathy which he had observed on their part. It caused him to draw some alarming conclusions conceming the worth of the Bengal trmy:

"They turned", he wrote, "almost uniformly from the contest before a blow had been struck, under the influence of a moral impulse which deterred them from proving the badness of the ground and the inferiority of the bayonet." 88 
And again:

"The physical mass of the army bent or broke like a useless weapon whenever a blow was to be struck." 89

These are severe strictures, and perhaps in his desire to shock the authorities at home from their complacency, he exaggerated somewhat. It is a fact that his accounts of engagements tend to differ from those contained in official despatches, in that they present a much less flattering picture of the behaviour of the sepoys. ${ }^{90}$ This could be partly tendentious denigration; but, on the other hand, it could be because his view, as a civilian, was less clouded than that of the army officers, whose partiality and complaisance were the subject of more than one commentator's criticism. But the essential truth of his complaint is indisputable. It is attested by Ochterlony's own views, and by his consistent avoidance of full-scale infantry engagements. Infantry had never formed the spearhead of his offensives. There had been no escalades, and the footsoldiers had played a secondary role in the capture of every fort. The most important attribute throughout had been his artillery. But it was not only the particular and local circumstance of the poomess of his infantry which had induced Ochterlony to rely most heavily on his guns. He had discovered principles which enjoined their use in mountain warfare in general.

The first of these principles was that in mountain warfare it was muchless important for an invader to equip himself to pursue, than to equip himself to dislodge his enemy. It had been assumed by many, including the Governor General, that the Nepalis' main advantage would be their mobility. The premis which underlay Hastings' planning was that his divisions would have to deal with an elusive antagonist. He had expected Amar Singh Thapa to try to move either eastwards, or northwards, across the Sutlaj; he had envisaged the likelihood of the main Kathmandu army escaping to the west. For this reason, despite his reluctance to deprive his commanders of artillery if experience should prove its desirability, he had urged that they make lightness and mobility their primary attributes. But Ochterlony had doubted, from the outset, that this was accurate reasoning. He had therefore equipped himself to 
fight a static, fortified enemy; and his experience, like that of the other commanders, had completely vindicated his decision. In practice it had transpired that the Gurkhas treated as their main asset not their elusiveness, but their inaccessibility. They had shewn themselves very unwilling to budge from positions they had occupied, and only moved from them as a last resort. Hastings had ignored a tactical truism - namely that the principle behind defensive war is the preservation of territory at the expense of men. By postulating mobility as a prime resource, he had assumed that its purpose was to preserve men at the expense of territory. It was the Nepalis' reluctance to move, their stolid defence of every yard of ground, which had rendered artillery indispensible. Even with the best army in the world, it seems unlikely that Ochterlony could have taken their hill forts without it.

The second principle which Ochterlony had discovered and illustrated was that in mountain warfare the delays which artillery causes need not increase the invader's likelihood of being attacked. It was commonly believed then, and later, that they must. 25 years after the Nepal War Sir Jasper Nicolls sent a body of infantry to force the Khyber pass without guns on the ground that they must have delayed the column and increased its exposure to fire. ${ }^{91}$ Yet if there was one precept for which military theorists were beholden to Ochterlony it was that in mountain war such delay was no liability, because the invader can partake of his adversary's principal advantage - inaccessibility. By adopting the mode of defending advantageous ground with stockades - an expedient entirely novel in the Bengal army - he had virtually eliminated the risk of counterattack. Only twice during the whole campaign had detachments of his army had to sustain a major offensive while waiting to bring guns into play at Tibu and at Dionthal - and on both occasions they had been saved by a combination of natural and artificial defences. ${ }^{92}$

On the occasion of the Gurkhas' defeat, a prominent native is reported to have remarked to a Bengal staff officer:

"Of what use is it to fight with the English? Beaten or successful, they are always conquerors!"193 
It is easy to see what he meant. It had not been granted to any of the British divisions to deserve success; but they had nevertheless won, because it had been in the power of Ochterlony's guns to command it. 


\section{Chapter Ten \\ The Conquest of Kumaun}

Hastings' original strategy included an attack on Kumaun. He appreciated that its position on the west bank of the Kali river would make this province a foothold and base for any reinforcements which Kathmandu might send to the western theatre of the war; and the incentive to invade it was the more especially strong as it promised to succumb very easily. The number of troops in Almora, the capital, was estimated by reliable informants as between three and six hundred only; ${ }^{1}$ and the disaffection of Brahma Shah, the Gurkha governor, was well known at Headquarters. Francis Hamilton, Hyder Hearsey, and William Fraser were all of the opinion that he would forswear his allegiance to the Thapa government in Kathmandu if sufficient inducement were offered. ${ }^{2}$ It was therefore determined that while Hyder Hearsey was busy raising the corps of irregulars which was to help effect military occupation of the province, overtures should be made with a view to encouraging the Gurkha to apostatize. He was to be offered a jagir, or estate, under the protection of the Company - possibly in the Gurkha province of Doti, on the eastem bank of the Kali, of which his brother, Hasti Dal, was at present governor. ${ }^{3}$

Thomas Rutherfurd, the merchant Surgeon of Moradabad, had a high opinion of his own qualifications and art as a secret agent, and he took it upon himself to communicate with Brahma Shah before the government's intentions were known. One of his servants intercepted Brahma Shah's mail, and the Surgeon used this as an excuse to depute an agent to the Governor, ostensibly to apologize, but in reality to invite him to attach himself to the British cause. Rutherfurd's efforts were not appreciated at Headquarters. Much to his disappointment, he was scolded for meddling, and told that it was not the Governor General's intention to appoint him Political Agent for the affairs of Kuman. 4 Hastings, deeming it "advisable that the conduct of this important branch of our measures should be vested in an individual of more approved talents, judgement, and politicalexperience", ${ }^{5}$ selected the Honorable Edward Gardner for the post. Gardner was William Fraser's fellow Assistant at 
the Delhi Residency. Like his colleague, he permitted himself eccentricities. In common with Hindu and Muslim society, he wore immense whiskers, and abjured pork and beef; but his equable temperamentyand courtly manners made him better suited to diplomacy than Fraser. ${ }^{6}$ He had a flair for oriental languages, and had qualified with distinction in Persian and Hindustani at the College of Fort William in $1802 .^{7}$ Reaching Moradabad in the middle of November, Edward Gardner made his own soundings, and discovered fewer encouraging signs than he had been led to expect. Brahma Shah's enigmatic reception of Rutherfurd's agent had, it was true, evinced a certiin indecision; but other intelligence represented the Governor to be raising troops and making preparations for resistance. Garnder was personally inclined to discredit reports of the Gurkha's infirm loyalty, but he suggested that it was possible that the presence of Amar Singh Thapa's officers was preventing him from divulging his true disposition. He recommended that some form of military demonstration be made at once against Kumaun, as a means of provoking Brahma Shah into disclosing his true sympathies.

"I should readily conceive that a battalion, aided by the corps of irregular troops now organizing by Captain Hearsey, would be of sufficient strength ... to warrant immediate invasion of the province, and I should be very sanguine that it might, with the assistance of the inhabitants, prove equal to obtaining complete posession of it. 18

But the calamities in Garhwal meant that all available regular troops were now occupied, ${ }^{9}$ and Hastings did not at this stage even moot the idea of sending irregulars alone into Kumaun. Early in December, however, his tour of the Upper Provinces brought him to Moradabad, and Gardner, who was very keen to satisfy the expectations of military assistance which had been aroused among the recalcitrant inhabitants of Kumain, was able to exert direct persuasion on members of the Govemor General's suite - especially on John Adam, the Political Secretary, who was a personal friend. Perhaps even more decisive was the presence at Moradabad of Lieutenant-Colonel William Gardner, Edward's cousin. This was a remarkable character. Beginning his military career in the King's service, he had served under Hastings (then the Earl of Moira) at Quiberon, in 1795. Some time after he had quitted the King's army in 
order to try his fortune as a freelance in India. He had entered the service of Holkar, the Maratha prince of Indore, and when on a mission to Cambay had sought and obtained the hand of the 13 year-old Begam of that state, thereby becoming brother-in-law to Hyder Hearsey. After a quarrel with Holkar, in which he made to cut the Maratha down, he had fled from Indore and taken service with Amrit Rao, father of the Peshwa of Poona, Gardner made a spectacular escape from the clutches of this prince in 1804, when he clambered down a 50 foot precipice, swam a river in full flood, and disguised himself as a grass-cutter in order to join Lord Lake. He had been in the Company's employ ever since, latterly as the commander of the corps of irregular honse which bore his name, though he was only a pensioner, and his rank was purely nominal, or local. 10

William Gardner was in very easy circumstances in 1814, enjoying, by special dispensation, possession of the considerable estate near Agra which had been bestowed on his wife by the Emperor of Delhi; and he had nothing material to hope from the command of an expedition into Kumaun. But he was still only in his early forties, was lithe and healthy, and had far from expended his prodigious reserves of energy and enterprise. Hastings, for his part, had an admiration for the experience and expertise of the 80 or so ex-Maratha officers now on Company pensions, as well as a respect for the patriotic motives which had induced them for forsake positions of great power and remuneration and join the British in 1804. He was always pleased to indulge them compensation for the advantages they had sacrificed. It was no doubt this disposition, together with characteristic feelings of generosity towards an old fellow campaigner, which caused him to change his mind and consent to a "hazardous" military expedition, which was cast more in the old Maratha than the modern Company mould. Gardner, assisted by such of the ex-Maratha officers as appeared eligible, was permitted to raise a corps of 3,000 irregular infantry from Rohilkhand. This, together with Hearsey's corps, was to commence the invasion of Kumaun, pending the availability of a supporting force of regulars. Gardner was to be fumished with a couple of six-pounder field 
guns, a few elephants, and Mr Rutherfurd as chief medical officer, commissary, post master, chief of intelligence and general factotum. ${ }^{11}$ Hastings was right to describe it as a "hazardous effort". The martial populace of Rohilkhand consisted of Afghan immigrants, mostly of Pathan extraction, who, although individually intrepid, were instinctively cavalry rather than infantry soldiers; who were not susceptible to discipline; and who, unlike Hindus, were not renowned for loyalty to their salt. ${ }^{12}$ The fact that he was prepared to allow Gardner to form a corps of such men and lead it into active service barely a month after, speaks much for Hastings' audacity and imagination as a commander in chief, as well as for his confidence in Gardrier's ability.

There was no shortage of volunteers. Both Gardner and Hearsey recruited in the neighbourhood of Rampur, the estate of a semi-independent Muslim nawab, whose capital was the resort of the thousands of Pathans who came down from Afghanistan every year in quest of employment as mercenaries. ${ }^{13}$ By the béginning of January, 1815, Gardner had collected 1,600 men. ${ }^{14}$ Soon after he was joined by the body of Pathans who had taken service with the Gurkhas at the outbreak of the war, and these swelled his corps to a numberin excess of its permitted limit. The 500 surplus troops were put at the disposal of the exiled Raja of Doti, who, it was decided, should be encouraged to make a diversion fnto his old territories. This would prevent Hasti Dal from crossing the Kali and going to the assistance of his brother in Kumaun. As an extra insurance against this eventuality, it was arranged that Hearsey's force should move up the westem bank of the Kali and secure the ghats. ${ }^{15}$ Harak Deva Joshi arrived at Gardner's headquarters at Kasipur early in January. At the invitation of Edward Gardner, who was struck by his intelligence, and persuaded that his local knowledge and influence could be turned to good account, he agreed to accompany the expedition. ${ }^{16}$

The main trade route to Almora from the plains followed the course of the Kosila river. ${ }^{17}$ Entering the Kumaun hills south-west of the capital, this struck north for about fifteen miles, then meandered across the province in an easterly direction for some 35 miles before bending to the 
north once more and skirting the western aspect of the hilly ridge on which Almora was built. This was the road which Gardner decided to take, with the main part of his force. But there was another route, less frequented, which entered the hills farther east, and struck almost due north to Almora. It was guarded by two Gurkha outposts, Barakheri and Chikata, in the neighbourhood of Bhim Tal. A detachment of 500 men, under the charge of a native officer, was sent to force this passage, and then join the main army before the capital. Leaving Kasipur early in February, this force succeeded in occupying Barakheri by the beginning of March. But it was then detained before the fort of Chikata, and never in fact arrived before Almora to take part in the main operations of the campaign. 18

Gardner, with his main force of 2,500 men, was delayed at Kasipur for over a week, first by a lack of porters, and then by tempestuous weather. He finally marched on 1lth February, and went north for about twelve miles up the western bank of the river bed, which was now virtually dry. The Tarai in this quarter had little forest, and was mostly a tangle of reeds and grasses. The army entered the hills just above Chilkia, which was little more than a huddle of wretched huts, despite its importance as a market town. In the hills, the shingle of the Kosila's bed was washed by a quick stream, which gradually widened into a black and rapid river. As the march progressed, the limestone cliffs on either bank grew higher and more fractured, and the occasional eagle alighted. Dhikuli, where there was a Gurkha post, was reached on February 15th. The enemy defences were abandoned, save for three dozen Kumauni horsemen, who promptly took service with Gardner. Thereafter the path traversed the endless anfractuosities of the river, and it became impossible to cover more than eight or ten miles a day.

On the 18th, camp was pitched at Chakangal, in the elbow formed by the Kosila's turn to the east, and a two-day halt was made to enable the porters who attended the advance to return and bring up the rest of the baggage and supplies. Across the river, about six miles to the north, was the fort of Kathkinau, flying the Gurkha flag and housing a Nepali garrison. It was perched on a rock, very abrupt and difficult 
to climb, which reared some 3,000 feet above the river. Gardner was chary of risking an attack against such a daunting obstacle with his untried troops, but the place threatened his line of communication with the plains, and he had no choice. Early on the 19th, in spite of a torrential rain which had started the day before, a party of 500 men was sent to beleaguer the garrison, and even dislodge it if circumstances seemed propitious. As it happened, the enemy abandoned Kathkinau at the mere sight of the detachment advancing towards them, and by the next morning it was the British flagwich was above the fortress. Meanwhile, the rest of the army had advanced about seven miles more. The route still followed the course of the Kosila, which now pointed eastwards; and on the evening of February 19th, the army arrived at Ukhaldanga. This was a little hamlet of about ten families, of which an advance party had taken possession the night before. 19

The tropical jungle wilderness with its confusion of undergrowth, high grasses, and thick sal trees, had now been left behind. The ground was clearer at this altitude, where the characteristic timbers were pine, oak, and birch, grouped into elegant groves, and draped with gauze-like fern. The roadside was lined with rhododendron, wild raspberry, nettles, thistles, and blackthorn; and the river, after the recent rain, was deep, clear, and full of gliding trout. Progress became tiring. When, on 2 lst February, the advanced moved on again to the village of Sethi, five or six miles ahead, they found the ground along the river bank so strewed with rocks and stones as to be like a sea beach. The stream had to be forded about a dozen times, and the water was often waist-high. ${ }^{20}$ During the march, intelligence was received that the Nepalis expelled from Kathkinau and various outposts on the southern bank of the Kosila had gathered in, and strongly defended, a very important position about fifteen miles upstream. This was Bhujan, which commanded the river route to Almora from heights on the Kosila's northern bank. Gardner, whose policy was to avoid direct confrontation with the enemy as much as possible, decided that instead of attacking the Nepalis while they were in such a formidable position, he would try to out-manoeuvre them. He was fortunate in that he was accompanied by men who knew the country well. Harak Deva Joshi 
had a store of knowledge and advice which was at the commander's disposal, and the local inhabitants were showing great willingness to respond to his appeals and furnish information and guides. Bhujan was at the southern extremity of a long/|mountain ridge, which stretched like a natural barrier before the western approaches to Almora. Learning that there was a subsidiary path cutting across country to Ranikhet, where it surmounted the northern end of this ridge, and then curving towards Almora from the north west, Gardner resolved to follow this and confound the enemy, who were expecting him to take the main river route. On February 22nd, he advanced a few miles to Panth Pipul, named from the pipul tree where the two roads to Almora met, and then turned right up the subsidiary path. Difficulties accumulated with every mile traversed. The way to Ranikhet lay initially up the channel of a tributary of the Kosila, which although dry was littered with huge granite blocks, and then over a considerable mountain, called Chaumukhia, which rose to well over 6,000 feet above the sea. The ascent to its crest was gradual, but nearly seven miles long. It took Gardner's vanguard of 300 men first through a gloomy dell, where startled white monkeys bounded away, and then throughtall forests of tapering pine, cedar and cypress. reached the summit, where there was, at least, no water problem, because the ground was covered with snow. The rest of the advance arrived the next morning; but it was February 28 th before the whole army and $i$ ts guns and baggage were on the mountain top. The local inhabitants continued friendly, and there was no shortage of supplies.

The Nepalis at Bhujan had guessed Gardner's design too late to forestall his occupation ofChaumukhia; but they had now deployed themselves farther up the ridge with a view to preventing his turning their northern flank. In addition, some $1,500 \mathrm{men}$, almost the whole of the force remaining with Brahma Shah, had been sent from Almora to defend Ranikhet. This was a small temple, situated where the subsidiary path to Almora crossed the ridge at $i$ ts northern end. It was about 6,000 feet above sea level. A glass levelled at the spot from the British camp at Chaumukhia disclosed a series of stockades of sturdy construction, in positions almost inaccessible, and swarming with defenders. As soon as 
his force was complete, Gardner left Chaumukhia for a hill in front called Kapina Kidana, which was separated from the enemy positions by the Tarkhet valley. He hoped that he might be able to commence operations from here. ${ }^{2 l}$ But closer examination did not dispel his misgivings; and he declined to send his men into an engagement which would have involved their advancing up escarpments two miles long, steep, and fully exposed to fire. He therefore devised a plan for turning the two most southern of the positions on the ridge. He resolved to attack these posts, and push a detachment across the central part of the ridge to a hill called Sihayi Devi, lying between it and Almora. This was a prominent landmark, 7,000 feet high, and Gardner shrewdly reckoned that possession of such a position in their rear would cause consternation among the Gurkha commanders on the ridge, and induce them to hurry back to the capital. Arrangements were made for a force of 600 to move on the night of 7 th March; but information concerning the difficulties of the road subsequently caused the colonel to postpone the move until it could be more minutely planned, and until he should be joined by the corps of irregulars which Captain Hunter had been raising in Hapur. Gardneralways refused to be hurried into any operation whose chances of success he knew could be improved by the passage of time. He never forgot that a force such as that at his disposal would not be able to withstand the shock of a defeat, and his constant concern was to prune away unnecessary risks by the most patient planning. Such restraint was all the more remarkable in a man whose career bore the hallmarks of audacity and bravado. Perhaps even more praiseworthy were his resistance of the temptation to exploit the chances which his situation offered for personal glory, and his dedication to the success of the enterprise as a whole. Realizing that he was occupying virtually the whole of Brahma Shah's army on the Ranikhet ridge, and that Almora could have no more than a handful of defenders in it, he constantly urged Hearsey to attack from the east while the opportunity was so favourable, and showed no signs of coveting that final triumph for himself. He was genuinely disappointed to hear that Hearsey had run into difficulties which prevented his marching on Almora; and when, in the middle of March, he learned that a detachment 
of regular troops was on its way to join his own force, his only feelings were ones of "much satisfaction", even though he knew that its officer must supersede him in the over-all command. ${ }^{22}$

On 17th March there was prolonged skirmishing, in which the Pathan irregulars showed unexpected worth. Early in the morning, Angat Sirdar, the Gurkha commander on the ridge, concentrated the major part of his force at his principal stockade, near Ranikhet, and then sent forward towards the British camp an advance of about 100 men. Information about the affair is scanty; but it appears that Gardner aimed at coaxing them into a general action on ground favourable to himself. He led a small party forward to engage the enemy advance. An exchange of musket fire began, and lasted all day. Both sides were progressively reinforced, until the Gurkha had between six and seven hundred men engaged, and Gardner about eight hundred. By sunset the Nepalis had been driven from their forward positions, and they concentrated in front of Gardner's foremost party, preparatory to a charge. The 300 Pathans were very cool. They waited until the enemy were but sixty paces away, then drew their swords and rushed to the assault. Their antagonists did not persevere in the face of such resolution. They turned and ran for the shelter of their stockades, leaving a few of their number dead. The Pathans sustained only three casualties. ${ }^{23}$

On 22nd March Captain Hunter's corps of 830 irregulars at last arrived, and Gardner was well pleased with them - "good, and better armed than any irregulars I ever saw". The plan to turn the southern end of the enemy's position on the ridge was put into operation without further delay. The same night 1,325 men were sent ahead to secure the road and advance as far as Siyahi Devi. They were commanded by Mohan Singh, a risaldar from Gardner's Horse. He was an exceptionally able officer, and a favourite of his commander. He probed his way down the skirt of the ridge, and in order to give the enemy posts on its crest as wide a berth as possible, continued as far as Bhujan at its southern end. It was a journey of fifteen miles, over country cruel to the calf and back muscles of men accustomed only to horseback travel on wide flat plains. Nevertheless, by daylight on the 23 rd he had turned the southern end 
of the ridge; and then, leaving 500 men to guard the heights of Bhujan, he struck north east across country to the hill called Suri, just in advance of Siyahi Devi. Here he constructed a breastwork, and posted 200 men to cover the final phase of his operation. But his ascent to the summit of Siyahi Devi was not interrupted. Gardner mounted a demonstration against the principal enemy stockades at Ranikhet on the morning of the 23rd, and when, at noon, the Nepalis had attention to spare for events in their rear, Mohan Singh was already in possession of the summit of Siyahi Devi. The ridge had been turned, and the river route to Almora was open again.

The next morning, the main part of Gardner's force, with all its baggage, elephants, and the guns carried by hill porters, prepared to follow Mohan Singh by the southern route. But as soon as the enemy on the ridge understood Gardner's intention, they hastily evacuated all their stockades, setting fire to some of them, and made an undignified tumble back to Almora, in order to avoid being cut off from the capital. The 300 or so Kumauni provincials with them took this opportunity to desert and enlist with Gardner, thereby bringing the total of effective troops at his command to about 4,000. When he saw that the ridge had been abandoned, Gardner decided to continue in his original intention of taking the northern road to Almora. There was little difference in length between the two, but he was advised that the one to the north, via Ranikhet, was more practicable for elephants, and that progress by it would therefore be quicker. This was now an important consideration, because he was anxious to take advantage of the enemy's disarray and trepidation. 24 on the 25 th, the force consequently retraced its steps to Tarkhet, and continued from there up the flank of the ridge. A severely steep and difficult pathway led to the crest at Ranikhet, and the troops found the going heavy, especially in the afternoon, when the strong spring sun was on their backs. Despite the assurances of the guides, the route proved impassable for the elephants. Gardner had to send them back and have the guns brought on by manual labour. The troops reached Ryuni, about eight miles north west, and within sight, of Almora, on 26th March; but it was not until the following day that the six-pounders 
reached the spot, lumbering reluctantly behind the straining teams of hillmen from Rutherfurd's commissariat establishment.

The Kosila, lost in the deep creases of the crumpled landscape, here ran down from the north, separating the British army from Almora. Gardner's concern was to secure a good base for operations on the eastern bank of the river. The obvious position was a hill called Katarmal, which lay on a latitutde slightly south of that of the capital. It was at present occupied by an enemy detachment, which Gardner planned to dislodge by an assault from the west. On the morning of $28 \mathrm{th}$, March Mohan Singh, recalled from Siyahi Devi, marched with about 750 irregulars and 200 of the Kumauni provincials to occupy an eminence some 1,000 yards west of Katarmal. The rest of the force, delayed by the guns, did not join him there until sunset. It was then too late to make an attack, but preparations were completed to wrest Katarmal from the Nepalis early the next morning. They proved superfluous. Katarmal was abandoned during the night, and the British troops took it without opposition. 25

Gardner, having secured a position whence he could effectively impede all Brahma Shah's contacts with the west, was content to beleaguer Almora pending Nicolls' arrival.

"From the certainty of your speedyarrival ... at this place", he wrote to Nicolls on 5th April, "I have deemed it my duty not to risk any of the advantages already gained by any precipitate attack on enemy posts, and have confined my efforts to prevent $[$ ing $T$ as much as possible provisions reaching the fort." 26

His magnanimity was appreciated at Headquarters, and Hastings commended him for "so generously spurning the temptation of assaulting the city before Colonel Nicolls should come up, and availing himself (though at the hazard of the public interest) of what might have proved a brilliant opportunity for himself." 27 Before long there was evidence to show that his blockade, in which the local landholders and peasants enthusiastically cooperated, was very effective. Spies, deserters, and intercepted correspondence all told the same story. The Nepali troops were without pay and so straitened for provisions that they were having to plunder the adjacent villages. Most of its civilian inhabitants had abandoned the town - in response to Brahma Shah's orders, according 
to one report. Letters written by Brahma Shah to his brother, Rudra Bir, and intercepted by the British, had a tone of world-weariness and despair:

"My authority no longer exists", ran one. "The call for funds is urgent, and expenses have been furnished by means of loans... The bankers will no longer advance money. In reply to my applications to the government for men and money, I have been told that I have sufficient force for the defence of Almora and that whatever reinforcements arrive here must be forwarded to the frontier... The reinforcements which have arrived for the frontier are without arms. How can I dispatch this force thither when the enemy in this quarter is in possession of the hill Siyahi Devi? Our troops in the gurries of Kumpur / Ranikhet $T$ opposed and stopped the advances of the enemy; but instead of attacking us they took another road and got thither. It was the intention of Captain Angat to have made a night attack upon them, but his people were ill-armed and therefore it was not done.

The enemy are strong in men and resources. They are not to be driven back by one defeat. No provision has been made for the levies that have been raised from the country, and what service can be expected from them if they have no means of subsistence? For these six months I have managed by disposing of my private property. The reinforcements which have been sent from the eastward, for the armies on the western frontier, are also destitute of everything, and are much distressed, I have lately, by the sale of jewels, raised 800 or 1,000 rupees, which I have expended on their account. The arrangements which have been made in this quarter are not in conformity with the orders received from the durbar. Without supplies of money, what can be done?" 28

That his men were ill-equipped was fully attested by the age and disrepair of the muskets in the possession of deserters. It was abvious, too, that they were very much hindered by the inferior quality of their flints. Gardner himself several times saw the enemy having recourse to matches in order to discharge their weapons. ${ }^{29}$ The main source of disquiet at the British headquarters was the various rumours to the effect that Brahma Shah's second brother, Hasti Dal Shah, had crossed the Kali and was on his way to Almora with a large additional neinforcement. At first there was little fear that he would be able in any event to reach the capital, because Hearsey was known to be operating in eastem or Kali Kumaun with the express purpose of preventing such a juncture; ${ }^{30}$ but on the night of (5th April a feu de joie was fired from a fort on the Almora ridge, which informants said was in celebration of a victory gained 
by Hasti Dal over Hearsey on April 2nd. 31 Worst fears were confirmed the next day, when Edward Gardner received the following note from Brahma Shah:

"You will have been informed that my brother Hasti Dal, being on his march hither from Doti, met me on the road after crossing the Kali, with Mr Hyder Hearsey who, having opposed and engaged him, was wounded and made prisoner. My brother has sent for surgeons to attend him; and Mr Hearsey having observed that his own medicines were best suited for the cure of his wounds, my brother has sent for his private servants and his own medicines, and has kept him comfortably accommodated near himself." 32

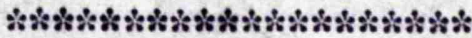

Hyder Hearsey's background and experience were similar to Gardner's, but he had nothing like the same ability and modesty as a commander. Among other functions, he had fulfilled that of lieutenant to George Thomas, the Irish adventurer who was for some years at the end of the eighteenth century the ruler of his own private empire in Sirhind. It had been largely owing to Hearsey's bad judgement that Thomas's army, of which he was in effective command while Thomas himself was prostrate from the effects of alcohol, was defeated by the forces of his rival Perron at Georgegarh in 1801. 33 He was very flamboyant, and struck people as boorish. "Very ingenious, but uneducated" was Lady Nugent's opinion. He made no secret of the contempt in which he held the Gurkha army. ${ }^{34}$ Hearsey had had three months in which to raise and train his corps, as opposed to Gardner's one; but even with this advantage, he was unable to draw from his men a performance that bore comparison that given by the force under his brother in law.

He was instructed to force the Timla pass, which led into eastern Kumaun from just north of Pilibhit, and then secure possession of the ghats on the Kali, so as to prevent Hasti Dal's crossing the river from Doti. 35 But from motives of vanity, of revenge against the Gurkhas for the rough treatment he had suffered with Moorcroft in Garhwal in 1812, and, no doubt, of inspiring in government a gratitude which would cause it to favour his claim to Dehra Dun, Hearsey privately made up his mind to widen his operations and win greater éclat. Instead of devoting 
his resources to guarding the river ghats, the function for which they were intended, he undertook the siege of forts in the interior as well, thereby dispersing his troops and making them insufficient for both purposes. Embarking on such risky enterprises was all the more reprehensible because by his own admission the border country in his rear was in a particularly defenceless state. Bareilly district was completely devoid of troops, and public order menaced by the presence of lange numbers of convicts who had escaped from the jail in Bareilly town early in February $1815 .^{36}$

After crossing the Tarai from Pilibhit, Hearsey arrived at the market town of Bilhari, at the foot of the Timla pass, on 13th February. Here he tarried for almost a week, endeavouring to collect a sufficient number of hill porters and carriage cattle. But trying to persuade the lowlanders to enlist for service in the hills was futile, and the troops were finally obliged to march carrying their own baggage, a week's provisions, and as much spare ammunition as they could manage. On the 18th, a small advance was sent forward up the pass to seize the small forts guarding its summit. These were taken without opposition, their garrisons fleeing north to Champawat, the old capital of the province. Hearsey despatched a reinforcement of $500 \mathrm{men}$, and ordered the combined advance to pursue the fugitives, and take possession of Champawat itself. The garrison there made no more resistance than those at the head of the pass. The 300 local troops took service with the British, while their companions took refuge in the fort of Katalgarh, five or six miles to the north west. These successes, and the favourable disposition of the local inhabitants, which caused him to boast of a "levée en masse", added greatly to Hearsey's self-assurance and led him to believe that anything was possible. As soon as the baggage cattle had returned to the foot of the pass, he had them loaded with all his spare provisions and supplies, and strode up to the summit with the principal part of his force. He paid no heed to Gardner's anxious despatches, which stressed that the securing of the Kali ghats was his essential object, and turned his main attentions to besieging Katalgarh. ${ }^{37}$ It was a senseless undertaking. Katalgarh was the strongest fortress in Kumaun. 
Its position gave it immense natural strength, and precluded the possibility of its being completely surrounded, while Hearsey had few men and not a single gun. 38

At the beginning of March, the greater part of Hearsey's force was distributed between Brahmadeo, at the foot of the Timla pass; the forts at the top of the pass; Champawat; and Katalgarh. He spared only the remainder, amounting to hardly 300 men, to guard the river ghats. 39 Until this time there had been perhaps, some semblance of an excuse for Hearsey's neglect of his main assignment. He had acted on the assumption that Prithvi Pat Shah, the exiled Raja of Doti, would be sent with a corps of irregulars into his old territories to detain Hasti Dal on the eastern side of the Kali. 40 After March 3rd, however, he had no cause to cling to that assumption. On that day the detachment intended for the Doti expedition, which was for the moment guarding the post at Brahmadeo, was attacked by Hasti Dal, who tried to cross the Kali at this point. Mainly because of the timely arrival of Hearsey's munshi, with a small reinforcement, from Bilhari, the attempt was foiled; but the force at Brhamadeo was severely mauled and Prithvi Pat Shah completely incapacitated by a very bad wound in the right hand. The native leader of the detachment retreated to Bilhari without orders, and his men thereafter became increasingly refractory. This event alone should have been sufficient to cause Hearsey to revise his plan of operations; but there were also the admonitions from Gardner, reminding him that securing the ghats was his urgent priority.

"I am very sorry to find the enemy can cross from Doti into Kumaun, as I was in hopes Captain Hearsey would have succeeded in the primary object of his employment in that quarter" the colonel wrote to the Adjutant General. "I shall again draw his attention to this important point." 41

But instead of abandoning his abortive blockade of Katalgarh, Hearsey actually increased to 700 the party engaged in the siege. Ignoring all directions to divert his own troops for the purpose, he asked government to organize a separate incursion into Doti in onder to contain Hasti Dal. 42

On (3lst) March", intelligence was received by Hearsey, then at 
Champawat, that 500 of the enemy had crossed the Kali about 14 miles upstream and, harassed by a body of local troops, was attempting to make a stockade on the westem bank. His guide, knowing that this part of the country was the stronghold of the Phartiyal faction, propitiated by Brahma Shah and implacably opposed to Harak Deva Joshi, warned the captain that this was probably a feint and advised him not to engage the force. But Hearsey fancied he knew better, and in a fit of irritation, sent the guide to Katalgarh in order to be rid of him. He marched that night with 270 men, and reached the scene of action the next morning. Judging that the enemy could not be driven back without a reinforcement, he sent to Katalgarh for 400 extra troops. That evening the scomed guide's waming was only too well vindicated. It was learnt that at three $0^{\prime}$ clock in the afternoon Hasti Dal had taken advantage of Hearsey's preoccupation to cross the river below the scene of the engagement with a force reported to be 1,500 strong. Hearsey at once marched his force south again, in a desperate bid to intercept the wily Gurkha. Hot with haste, tired, and thirsty, and with no ammunition save that which they had in pouch, they finally accosted the enemy early on April 2nd at Khilpati, about five miles north east of Champawat. The battle was fierce, and Hearsey's men had soon expended all their cartridges. The captain was severely wounded in the thigh, and his fall was the occasion of the flight of all his soldiers. Most were hacked to pieces by pursuing Nepalis. It is a tradition in the Hearsey family that Hyder would have been decapitated as he lay on the field, had it not been for the timely intervention of Hasti Dal. The two men were not strangers. Hearsey had met Hasti Dal when on an official expedition, whose purpose was to survey the upper reaches of the Ganges, in 1808. According to the family story, that encounter had been the occasion of his saving the Gurkha from being killed by a wild bear. Hasti Dal now recognised his deliverer, and repaid his debt of gratitude.

Hearsey's adjutant was William Martindell, son of Sir Gabriel by a native woman, and holder of the titular rank of lieutenant. He had been conducting the siege of Katalgarh, and was now left before the fort with only 300 men. He was in a very tight spot. The enemy were soon badgering 
him from every side, and his troops, increasingly frightened and unsure of themselves, were deserting in large groups. On the evening of 3rd April, he was attacked by a detachment of Nepalis whom he reckoned to be 1,200 strong. His men returned their fire for about an hour, but then began to give way. "In a few minutes" runs his own account," their rout became general. The Gurkhas fell on their rear with their sabres and cut them up without the least resistance. Some of my men behaved very gallantly; but most of them in a very cowardly manner." Tents, provisions, and muskets were all abandoned in the pandemonium. Martindell wandered lost in the mountains all night, and quite by chance found himself on the road to Timla the next morning. At the head of the pass he found the garrison of Champawat, which had retreated on hearing of Hearsey's débâcle, and the bedraggled and mutinous remnants of the various other detachments. He attempted to reimpose some order, but men continued to desert in droves. He ordered up the detachment at Brahmadeo, but its commander was dilatory, and by 5 th April still had not brought his men to Timla. Martindell decided he could hold the pass no longer, and withdrew to the plains. He met the Brahmadeo detachment on the way, but its commander refused to obey when ordered to continue to the top of the pass. He insisted that his men would refuse to follow him. The combined detachments, comprising only about 400 of the original 1,500, thereupon retreated to Bilhari, and remained there in such a state of trepidation and indiscipline that all plans for a renewed offensive had to be abandoned. 43

$* * * * * * * * * *$

In view of Hearsey's failure, it was lucky that a reinforcement of regular troops was already on its way to join Gardner. Hastings reasoned that the collapse of the British offensive in the eastern theatre had made the possession of Kumaun indispensable. Once the Gurkhas had been relieved of the threat of an attack on Kathmandu, it was essential to prevent their diverting their unexpectedly available reserves of manpower to bolster the defensive in the west. ${ }^{44}$ Acting on this conviction, he had, early in March, requested Lieutenant-Colonel Jasper Nicolls, a King's officer of the 14th Foot, to prepare for active service. The force which 
could be put at his disposal was very modest. It consisted of two battalions of native infantry, a detachment consisting of flank* companies from Dehra Dun, four six-pounders, two small mortars, and a few pieces of heavy artillery. ${ }^{45}$ According to paper estimates, the strength of the infantry was 2,035 men; but these took no account of men sick and 'on command', *** and the number who actually took the field with Nicolls did not exceed about 1,300. 46 of these, only the 30 artillerists were European. 47

Concerned above all else with the need for speed, Nicolls wasted no time at Moradabad, his rendez-vous. His force was barely half-assembled by the end of March, and no word had been received from Captain Leys, commanding the detachment from Dehra Dun. Nevertheless, the colonel marched on the 29th with two six-pounders and a vanguard of three companies, leaving the remaining segments of his column, with the rest of the ordnance and the elephants, to make their own way into the hills. There had been no time to acquire and distribute greatcoats, long pantaloons or tents, and the men were going to have to improvise protection against the cold with their kamals (blankets). It had been impossible to collect an adequate number of hill porters, and the arrangement had to be made whereby all spare provisions and supplies were left in a depot at Dhikuli, just within the foothills. It was hoped that porters sufficient for moving these forward would be enlisted subsequently. Meanwhile the sepoys would have to carry their own equipment and five days' provisions - loads which weighed little less than 80 pounds. ${ }^{48}$ Nicolls had had to choose between two evils - delay and a deficient commissariat; and although he had decided that the former was the greater, he never lost sight of the insufficiencies he had had to march without having remedied. Although spring was well advanced, the weather remained capricious in the hills, and there were periods of heavy rain. Anxious to provide against the worst discomforts of these and

\footnotetext{
*.e. grenadier and light. ***

i.e. detached on extra-regimental duties.
} 
of the monsoon season proper, which was expected in a few weeks, the colonel asked for graatcoats and pantaloons for the men, which the Adjutant-General promised should be provided. News of the defeat of Hearsey's detachment made Nicholls fear that the local populace might cease to provide victuals should his own column suffer any mishap, and he made an urgent request to the Magistrate of Moradabad for 1,000 bearers, to bring up supplies from the depot:

"A timely reinforcement of 1,000 men of the classes suited to the transport of grain on their heads or backs may save this army from a retreat in search of subsistence perhaps when near the accomplishment of the service for which it has been directed to enter the province."

The Magistrate, Mr Oldham, was compelled to impress men for the service, paying them an advance of one rupee in return for a promise not to run away for 25 days. Needless to say, most of them pocketed their rupees and absconded even before they had reached Dhikuli. The lack of means of bringing forward his provisions remained a major problem for Nicolls throughout the campaign. 48

He reached the camp before Almora with the advance on April 9th, and the other sections of his force, including the artillery, arrived at various intervals over the next ten days. ${ }^{49}$ The new arrivals, who, with camp followers, numbered more than 3,000 souls, had soon consumed available stores of grain, and poor Rutherfurd was at his wits' end to feed the army. 50 Some time about the 15 th or 16 th April, Captain Butterfield was detached with 500 imegulars to the north west, to a place called Eri Deo in the despatches, in order to encourage the Bhotias, a group who had so far proved diffident about supplying provisions. 51 This measure succeeded in opening up a new source of supply, and crisis was averted; but the threat of severe dearth stalked Nicolls throughout his campaign. One observer wrote that "not unfrequently the men, after toiling all day over the hills, had no better eveningfare awaiting them than a few ears of wheat, which happened to be ripe, gathered in the fields, I and T roasted over a fire."

Jasper Nicolls, who was only thirty seven, was an officer who had partaken to the full of the opportunities for military experience available 
in Europe and beyond during the years of the Revolutionary and Napoleonic Wars. He had served with distinction in the West Indies, in the Peninsular, in Hanover, and at Buenos Aires; and had returned for a second spell in India in 1813, when he assumed the staff appointment of Quarter Master General to the King's Troops. 53 Lean, dark-eyed, and prematurely balding, he was, unless roused, a man of tact and delicacy of feeling. Sensible of the embarrassment to Gardner which his arrival on the scene of action involved, he did his utmost to mitigate it by displaying an unfailing courtesy in all his dealings with him. But he had no sympathy for the self-blandishing Hearsey. "I have never approved of Captain Hearsey's grand views, and great extension of his force", he grumbled to the Adjutant-General on receiving news of the calamity in eastern Kumaun; "but I arrived too late to confine his exertions." 54 He did not estimate the consequences of the defeat lightly. "We may fairly suppose that the enemy's defence of the capital will / now T be greatly prolonged", he told the Magistrate of Moradabad; 55 and he wrote to the Adjutant-General: "The effects of our defeat by Hasti Dal have in every quarter been most deeply injurious to our reputation and cause." 56 For his own part, Hearsey detested $\mathrm{Nicolls}$ until the end of his life, and ever afterwards insisted on disparaging his achievement in Kumaun. 57

On the evening of April 12th, guns were fired from Almora in salute. There was no doubt in the British camp that this signalled the arrival of the triumphant Hasti Dal with his prisoner. 58 Intelligence reports represented his force to be no greater than three to four hundred, of whom only between 125 and 175 had matchlocks. 59 This suggests either that Hasti Dal had left the greater part of his men in Kali Kumaun, which seems unlikely, or that estimates in Hearsey's camp had been wildly exaggerated. Informants from the fort assured Gardner that the total force at Brahma Shah's disposal did not exceed 2,000 men, and that they were all "distressed for want of provisions and rather down in the mouth, the few remaining I civilian T inhabitants running off for want of food."60

On April 22nd, when his column, including the two iron twelvepounders and the two eight-inch mortars by which he set great store, was at last complete, and when he was waiting only to improve his stock of 
provisions, Nicolls received a note of intelligence from Rutherfurd which stated that Hasti Dal had quitted his position on the ridge before Almora with two or three hundred men, and was making for Gananath. This was a mountain about fifteen miles north of Almora, situated between the valleys of the Kosila and Kali. The colonel, knowing that Rutherfurd's intelligence was not always reliable, doubted that the Gurkha could in fact have made such a rash move. "What an opportunity!" he scribbled on the back of the paper. "I fear it cannot be true."6l But subsequent information confirmed the news, and Nicolls could only assume that Hasti Dal's march had been occasioned by the expected arrival of ammuntion and treasure from the west. In fact, as was afterwards learnt, the only reas on for the move to Gananath was the Gurkha commanders' concern to maintain possession of the northern perganas of Kumaun, as a means of safeguarding communications between Kathmandu and the western theatre of the war. 62

Nicolls acted swiftly. At midnight, Major Patton was despatched with ten companies of native infantry, a company of irregulars, a sixpounder, a small mortar, and a day's supply of victuals. His instructions were to pursue Hasti Dal, and attack him before he could stockade himself in his new position. 63 The elephant carrying the field gun hampered progress, and at dawn Patton decided to send it back to camp. He then pushed forward to the north east, crossing the Kosila above Almora. The sun rose higher, and the dark conifer-clad / became tremulous in vaporous heat. The mountain river beds were generally dry, and by the time they neared their objective, the men wereparched/thirst, as well as fatigued. When the vanguard reached the crest of a thickly wooded ridge in the vicinity of Gananath, the column was widely strung out, and men in the rear were drooping, and lagging far behind. A scout presently brought word that the main party of the enemy was on a peak about a mile and a half farther along the ridge. Between their post and the ground occupied by the British advance was a steep eminence, which parties of Nepalis could be seen creeping towards, through the trees, with the obvious object of seizing and stockading. As this was only about 600 yards in front of his present position, Patton resolved to try to thwart their 
intention. Three flank companies, one light and two grenadier, were ordered to advance under Lieutenant Blair. A party of the enemy was already in possession when they reached the peak; but a few shots dispersed them, and Blair moved up with little opposition. At this time only about 300 men had joined Patton, and Blair assumed that he would not attack the main enemy position at Gananath until the straggling tail of the column had come up. He therefore allowed some men to go in search of water, so that the party could slake its raging thinst. But Patton judged that the momentum of his advance must not be allowed to slacken, and he sent forward his remaining available company of light infantry under Lieutenant Webster, with orders for Blair to place himself under Webster and "push on and attack". Blair put his men under arms again at once, and moved to join Webster. The sepoys were in agonies of thirst, and their cries were pitiful. Many collapsed. The two light companies, which together numbered only $100 \mathrm{men}$, were ordered to assault the Gananath stockade while the grenadiers, under Lieutenant Browne, formed a reserve.

The Nepali position was an exact crescent, and its occupants were so well covered that only their heads were visible. The two light companies, moving up in a directly frontal advance, suddenly found themselves in the focus of a scathing fire. Numbers of men were bowled over, and the remainder spontaneous ly edged to one side and sought cover behind the trees. Advancing upwards in this fashion, they came within 50 yards of the enemy stockade. Then, however, it became apparent that they had not understood the function of the grenadiers. Disconcerted by their failure to advance, they became restive, and would not go farther. Blair was struck in the groin by a musket ball while he wrestled vainly with his Urdu, trying to explain and encourage them, but he gave no sign of pain and no-one knew, for the moment, that he had been wounded. Taking advantage of the faltering in the British advance, the Nepalis rushed out of their stockade with khukuris drawn. Sexpietily unnerved, the light infantry backed towards the grenadiers, who were still hovering in the rear. But once they had the support of their companions, the light companies took courage, and Blair and Webster were able to rally them. 
When the Nepalis were 40 yards away, they were halted by a well-directed salvo of musketry. Then they in their turn were forced to recede, chased up to the summit of Gananath and then, having had no time to re-form, down the steep slope on the other side. They scrambled away, nimble as forest game, and had soon vanished into the wooded depths below. The British casualties were 2 killed and 26 wounded. Blair, it was discovered, had had a narrow escape. Because his cash-keeper was sick, he had taken custody of 60 rupees belonging to an absent sepoy. These, quilted in a handkerchief and tied at his waist, had tumed the musket ball into the flesh at the right hip and away from the groin, where it would probably have proved fatal. When extracted, the bullet was seen to bear the imprint of a rupee.

The enemy killed were about 80 , and Hasti Dal was among them. He had been shot through the temple, and died on his way back to Almora. 64

Although his provisions were still dangerously inadequate, Nicolls decided that he must take advantage of the dejection and despair which Hasti Dal's death was bound to have caused in the enemy camp, and attack Almora forthwith.

It was a small town by European standards, but ranked as considerable in these hills. It stretched for about three quarters of a mile along the crest of a mountain ridge, in a north west - south east direction. There was one main street, naturally paved with slatey rock and lined with houses. These had open ground floors of whitewashed stone, fitted as shops, and wooden upper storeys. To Bishop Heber, who visited the place ten years later, they were redolent of buildings in Chester. There were two citadels in the town. One, Fort Almora, was in the centre of the ridge. The other, then called Lal Mandi, and later re-named Fort Moira in honour the Governor General (whose title was Earl of Moira until after the war) was at its southern extremity. They were not impressive, being little more than glorified circular sangars constructed of unhewn stones embedded in clay. Their walls were not above about eight feet in height, but the scarped knolls on which they stood increased their elevation considerably. A narrow col ran to the west, connecting the Almora ridge with a parallel range, which rose from the eastern bank of 
the Kosila. This range formed a natural bulwark against attack from west of the river, and was sprinkled with stone breastworks. The most considerable of these was at the northern extremity, on the pinnacle called Sitoli. It formed Brahma Shah's principal outpost, and seemed almost immune to attack. The ground fell steeply from its walls, and a mountain slightly to the north, called Kalimath, overlooked the position and commanded the approaches to it. The main British camp, on the west bank of the river, was at Katarmal, a mountain slightly to the south of Almora. In general aspect, the landscape was rather bleak. The highest reaches of the mountains were devoid of trees, and their stony sides were cut into terraces, to make more room for cultivation. 65

The five flank companies under Captain Leys returned from Gananath at nine $0^{\prime}$ clock on the moming of April 25th, and four hours later Nicolls launched an attack against the enemy outposts on the Sitoli range. He marched in person at the head of the flank companies and the 1st/4th Native Infantry, with the aim of establishing a position on the northern end of the range and expelling the Nepalis with mortar fire. Gardner advanced with the irregulars on a parallel line to his right, directing his effort against the defences on the southern part of the range. Those who remained in camp at Katarmal watched the columns march down together, and found it a stirring spectacle.

But the road was rough and narrow, and made it impossible for the columns to remain compact. As soon as he had crossed the Kosila, here a small mountain stream with deep pools and fordable shallows, and reached a small level spot on its eastern bank, Nicolls halted for about half an hour to allow the men to collect and to reform his column. He asked his two artillery officers to give the enemy a few shells. A howitzer was unloaded and mounted within five minutes; but appearances were deceptive, and the enemy breastworks were found to be much too distant for the shells to have any effect. Then came the order "move on!", and the long climb up the flank of the Sitoli range began. It took two hours to reach the crest. As Nicolls' troops got nearer, a gun opened on them from the breastwork most immediately above, but the hill was too steep for it to bear with any accuracy. By comparing 
their height with that of some enemy soldiers who had earlier been standing outside them, Nicolls had been able to ascertain that the breastworks rose no more than between four and five feet above the ground. This fact, and the eagemess of his men, determined him not to wait for the mortars, but to take the positions by coups de main. Appreciating that the flank companies must be tired after their recent exertions, he put the 1st/4th Native Infantry in front. Led by Lieutenant Wight, one group of four subalterns and some sepoys with fixed bayonets dashed at the first breastwork. It was about four feet wide, with an embrasure in the centre, cut to within about two feet of the ground. As the barrel of the enemy gun obstructed this, only one person could enter at a time. Wight was first in. He was immediately cut down, and lay dangerously wounded; but another officer, clambering after, saved him by felling his adversary with a swingeing blow. The Nepalis were overpowered within three minutes. Abandoning the gun, they left their position by the rear, which was open, and fled down the opposite side of the ridge.

The two breastworks to the left were carried almost simultaneously. His bravery in one of these encounters earned a sepoy named Dokal Singh special mention in Detachment Orders as "a hero, who, though wounded in five places, refused, when lying disabled on the ground, to surrender his musket to several of the enemy, who would have wrested it from his hands." The flank companies, under Leys, now reaching the crest of the ridge, Nicolls directed them to take up the pursuit of the ejected enemy. They promptly divided, and hounded them by five different routes down the eastern side of the range, into the valley below Almora. Meanwhile the 1st/4th easily ousted the occupants from the four or five breastworks to the north, including that on Sitoli mount itself. The enemy post on Kalimath was thus completely cut off from Almora. Gardner's men seized the three breastworks on the southern end of the crest at about the same time.

This was the first time that Nicolls had commanded native troops in action, and their bravery had made the occasion unforgettable for him. "I congratulate His Excellency the Commander in Chief", he wrote to Headquarters, "on the glorious result of the noble exertions of the troops, 
whom it will be a source of pride to me, to the end of my life, to have commanded." These, it should be remembered, were the sentiments of an officer who had no reason to be biased in favour of the native army, and who, after commanding soldiers of the crown in the campaigns which made them legendary, could not but judge by the highest standards. More than anything else, the behaviour of the sepoys on this occasion demonstrated the decisive influence of the presence of an adequate number of European officers. Because the column had been disorganized by the badness of the road, almostall the officers were in front when the engagement began, and there were five subalterns with the party which attacked the first breastwork alone. 66

The Sitoli range once secured, an advance party was pushed across the connecting col onto the northem end of Almora ridge. Headquarters was established in a quadrangular fort, about sixty yards square, which had been abandoned by the enemy.* About 250 men of the 1st/4th and flank companies were then sent southwards into the town itself. They occupied a pagoda, called Dip Chand temple, and set up two howitzers on its terrace. The first shells were fired at about six o'clock. They were aimed at Fort Almora, which was 300 yards farther south, beyond the Raja's palace. 67

Meanwhile, all was quiet on the Sitoli range. Then, at about eleven o'clock, the Nepalis still at Kalimath made a desperate attack on Lieutenant Costley and the 80 sepoys who occupied Sitoli mount. A local story is that they covered their advance with a drove of cattle carrying firebrands on their horns. ${ }^{68}$ Nicolls immediately sent a reinforcement of about 150 sepoys under Lieutenants Browne and Whinfield to aid the overwhelmed party. Garnder, who was with Nicolls at headquarters, volunteered to go with them, taking Mohan Singh and a company of irregulars. The reinforcement met costley and his men at the foot of Sitoli mount, fleeing before the Nepali onslaught. Browne, Whinfield and Gardner immediately directed all their efforts at driving the enemy 
at bayonet point back up the hill. So ferocious was their offensive, in which they did not fire a shot, that Sitoli had been retaken in ten minutes. But the Nepalis would not concede defeat, and contested the post stubbornly throughout thenight, hurling themselves against it three times more. The British officers and their native troops, with equal pertinacity, refused to yield, and each charge was repulsed. The valour of Browne and Mohan Singh was especially conspicuous. In honour of the former, the hill was later named Mount Browne; and the latter was presented with the sword which Hastings had entrusted to Nicolls with the instruction that it was to be given to the sirdar of Gardner's levy who proved himself most worthy. "He headed three successive and successful charges of the Pathan levies", ran his citation, "and taught the Gurkha chiefs that at night, their favourite hour of conflict, and with the sword, their favourite weapon, they were unequal to face our gallant troops with any hope of success." 69

The noise of battle from Sitoli acted as a summons to the enemy in Fort Almora, who attempted to dislodge the advanced post and battery at Dip Chand temple. They made a sortie, and sprinted up the main street of the town. The wall of the temple enclosure was only five or six feet high. This they lobbed stones over, with leather slings, and tried to vault. Several were shot or bayonetted on the wall, and one was killed actually inside the enclosure. The rest were beaten off. Work meanwhile continued on the placing of eight inch mortars, and these opened on the fort about midnight.

The night was murky, and it was impossible to distinguish objects even at ten yards' distance. Throughout, the repetitious crepitation and orange flashing of musketry continued, and there was incessant skirmishing, which added considerably to the casualties on both sides. It was reckoned that many of Nicolls' losses were caused by his own men, firing blindly. Early in the morning of April 26th, Lieutenant Tapley, at Dip Chand temple, lost his life. Each time an enemy party had been repulsed, he insisted on going outside the wall of the enclosure "to watch when they were coming again". Lieutenant Field, commanding the post, repeatedly urged him not to expose himself so needlessly; but his wamings were 
ignored, and about two o'clock Tapley was shot by a musketeer in one of the houses which overlooked the temple.

Mental strain and hunger made the night seem interminable. Nicolls was restless with worry; but when at last the hills were streaked with the first long shadows of the dawn, all his positions were still secure, and the Nepalis slunk back into their lairs. The British commander's first concern now was for the comfort of his men. Remembering that they had not eaten for twenty four hours, he mustered a group of his own servants and some coolies, and personally visited each post with bread and butter and bottles of warm tea for the officers, and gram and sweetmeats for the sepoys. As he spoke little Hindustani, he asked Lieutenant Hay to tell the men how pleased he was with them. Needless to say, Jasper Nicolls was ever afterwards a favourite of the Bengal army. Near half past eight, when extra cartridges had arrived from Katarmal, operations were resumed. Field was directed to take his party from the temple down the main street of the town and seize the palace, which intervened between his present position and Fort Almora. It was a spacious, square, upper-storeyed building, surrounded by an eight foot stone wall. The Nepalis in the place peppered his men with bullets as they advanced; but they vaulted the wall, entered the building, and ran up the main staircase. Eight or ten of the enemy were shot or bayonetted; the rest fled down a back staircase and escaped to the fort. Field waved his cap as a signal, and Bell and Wilson of the artillery brought down a couple of six-pounders. They knocked embrasures in the rear wall of the palace compound, which was only about 70 yards from the fort, and set up a battery.

Meanwhile, the mortars at Dip Chand temple had continued to fire, and despite the great distance, several shells landed in the fort. Soon large numbers of the enemy were seen leaving the place by a door in the eastern wall, and making for Lal Mandi for'tbehind. Nicolls ordered Lieutenants Field and McGregor to try to enter while the enemy were coming out. The two officers took a small party of sepoys and ran up the side street which led to the entrance; but on reaching it/found that the enemy had been leaving through a wicket, which was slammed shut as they approached. 
They could not force it open, and, being showered with stones and shot from the walls of the fort, were compelled to withdraw. ${ }^{70}$

The contest, however, was all but over. Brahma Shah had neither enthusiasm nor energy for further defiance. He had never understood the expediency of the war; and now that his troops were hungry, unpaid, and increasingly disgruntled, he saw no merit in prolonging it by futile self-immolation. Having made as honorable a resistance as his means permitted, he resolved, inconsultation with his chief officers, that it was his duty to end the contest on the most favourable terms which he could induce the British to concede. ${ }^{71}$ At the end of March, Edward Gardner had offered him and his men a safe conduct to the eastern bank of the Kali in return for the surrender of the capital. ${ }^{72}$ At nine o'clock on April 26th, he sent a note to the Political Agent, under a flag of truce, requesting a suspension of hostilities on the same terms. Nicolls and Edward Gardner had no inclination to flaunt their victory by demanding stiffer terms, and William Gardner was sent to meet Brahma Shah and negotiate the surrender. There was some delay before a convention was signed, owing to the Gurkha's insistence that the troops originally intended for Amar Singh Thapa's army in the west should be allowed to continue thither; but finally, on April 27th, realizing that the colonel was adamant in his refusal, he relinquished the demand and agreed to release Hearsey and withdraw with all his men to the eastern bank of the Kali within ten days. On the 28th, Nicolls and Edward Gardner paid Brahma Shah a visit, and the reasons behind his concession became clear. He wanted to retain control of negotiations for a/general peace, and had "projects of inducing the British Government to assist the Raja's party in regaining their power and overturning that of the Thapas." Gardner felt bound to decline discussing such issues at this stage; but he found it impossible not to feel considerable sympathy for this tall, stout, affable Gurkha, whose looks did not betray his seventy years, whose hervous speech impediment somehow removed all doubts concerning his sincerity, and whose competent Hindustani made it possible to address him with reasonable ease and informality.

On the night of April 3lst, Brahma Shah quitted Almora, taking with 
him such part of his army as had remained loyal. ${ }^{74}$ This must have included the great majority of his regular troops, for only the irregular Kumauni soldiers had taken service with the British - and even they did not number more than about 300.75

As the news of the surrender of the capital spread through Kumaun, the other Gurkha garrisons scattered throughout the province spontaneously capitulated. ${ }^{76}$ British military occupation being thereby completed, Edward Gardner declared the territory annexed to the dominions of the East India Company, and assumed the functions of civil administrator. ${ }^{77}$ The cost of the acquisition had not been great. British casualties during the operations of April 25th and 26 th did not exceed 50 killed and 161 wounded; 78 and the total of casualties for the whole campaign was not greatly in excess of those figures.

Nicolls attributed his success to "the daily miracle of feeding the troops in such a poor country", and "the efficient service of our eight-inch mortars", which "considerably hastened" the fall of Almora. ${ }^{79}$ The latter conviction confirmed Ochterlony's experience of the necessity for heavy artillery in mountain warfare, and makes it all the more surprising that Nicolls, when Commander-in-Chief, sent a column to the Khyber Pass without guns. The response of the sepoys under his command appears to have been far more impressive than that of those under the other commanders of the war, Ochterlony included; but it must be remembered that the Kumaun detachment had been in the hills for barely a month when its first and only major engagement took place - a month, moreover, in which the weather had been at its kindest. The other two divisions in the western theatre had had to endure all the rigours of a mountain winter.

Considering their notoriety, and the circumstances under which they had been raised, the performance of Gardner's corps of Pathans had been nothing less than remarkable. More than anything else, this had been a testimony to the talent and personality of the man who commanded them. By means of that occult power which is the attribute only of born leaders, he had transformed untamed brigands into disciplined, tractable and steadfast soldiers. No-one else could handle them. No sooner had 
Gardner returned to the plains, after the cessation of hostilities, than the Pathans, left in the hills to garrison the various acquired strongholds, again reverted to unruly rabble. They deserted in droves, helping themselves to Rutherfurd's stores of grain, and terrorizing local villages. ${ }^{80}$ Nicolls fully appreciated the measure of Gardner's contribution to the success of the campaign. With characteristic generosity, he made his acknow ledgement the subject of a separate despatch to Headquarters; and on his recommendation Gardner's monthly pension was raised from 300 to 1,000 rupees. ${ }^{81}$

Hastings was naturally delighted with the result of this risky and virtually makeshift expedition. By coaxing victory from such unfavourable circumstances, Nicolls and Gardner had confounded those foolish generals who had declared their own means inadequate and their difficulties insuperable, and left them entirely without the basis for self-justification. For the edification of Martindell, John and George Wood, and Marley, as well as for the glorification of Nicolls and William Gardner, the Governor General drew a trenchant moral from the conquest of Kumaun.

"Warfare in a mountainous region", he wrote in a General Order, "offers embarrassments which when viewed from a distance appear insurmountable, but which dwindle into insignificance under the grasp of vigour and genius. It is only in unnatural situations, demanding readiness of resource and animated efforts, that the difference between officer and officer can be displayed; and it ought always to be present in the mind of every military man that he who in circumstances of perplexity tries and fails, has to plead those chances from which no operation in war can be secured, his pretensions to the character of zeal and energy being in the meantime maintained; while he who contents himself with urging difficulties as an excuse for doing nothing, voluntarily registers his own inefficiency." 82 


\section{Chapter Eleven}

Interlude

During the hot and monsoon seasons of 1815, the troops acting in the eastem theatre had the unenviable task of defending the frontiers of Bihar and Bengal against possible enemy encroachments. Time hung heavy on their hands, because the Nepalis knew better than to enter the region at this deathly period of the year; but casualties in these divisions were nevertheless greater than they had been during the whole period of active operations. The prevalent symptoms - violent fever and delirium ${ }^{1}$ indicate that the principal malady was malaria; but its effects were complicated by all the various disorders caused by primitive sanitation, contaminated drinking water, and the well-intended by horrifyingly unscientific antics of contemporary surgeons. John Wood's division was distributed between three posts on the border of Gorakhpur. By the middle of May more than 1,200 men were sick, and had had to be withdrawn. There being no hospital in Gorakhpur town, they were lodged in the bullock sheds, ${ }^{2}$ which can hardly have hastened their recovery. H.M. 24 th Foot was the only European regiment on the frontier, the others having been remanded to cantonments. They were posted at Amowa, just south of Segauli. 135 men out of 751 were seriously ill in June, and between the end of March and the beginning of September 60 died. ${ }^{3}$ At Nathpur, farther east, Colonel Gregory was in charge of some 2,500 native infantry. In the middle of August his force was in "a dreadful sickly state". "In less than a month", he wrote, "I lost four European officers; nearly 300 men are absent on sick certificate, and an equal number are now in the hospital; and the men who have recovered from the Tarai fever have not yet regained their strength, and are perfectly useless ... added to which I have only one medical man in charge of the sick of two and a half battalions." ${ }^{4}$ This last fact may have been less a liability than he thought. While the troops suffered, the political agents talked. Serious negotiations began at the end of May, and were protracted for seven weary months. During the latter half of his tour of the upper provinces, and in the first months after his return to Calcutta in October, hardly a week 
passed without the Govemor General's receiving a formidably bulky despatch conceming peace discussions, and without his dictating an equally elaborate on in reply.

A few days after Brahma Shah had crossed the Kali and entered Doti, he was joined by his surviving brother, Rudra Vir, who was govemor of Sallyana province, beyond Doti to the east. ${ }^{5}$ William Gandner, who had escorted the garrison of Almora to the river, met Rudra Vir, and had a long informal conversation with him. During the course of this, it became clear that great political significance attached to the selection of a Nepalese negotiator. The Gurkha assured Gardner that "whoever was charged with arranging a treaty with the British government would hereafter have the greatest weight in the Nepal councils." 6

There were three contenders for the commission. They were Brahma Shah; Gajraj Misr, the erstwhile guru of the royal family, who had approached the Governor General with an offer to mediate; and Amar Singh Thapa. Hastings, having no wish to increase the political influence of the last, did not contemplate negotiatingthrough him; but he was prepared to conclude a treaty with whichever of the two other parties offered the indemnification he demanded. He reasoned that if either of them was deputed to treat, it must be with powers to grant all the territorial sacrifices he required, because the durbar at Kathmandu was not ignorant of their scope. Bradhsaw, in his exchanges with Chandra Sekhar, the captured vakil, and with Gajraj Misr, had made it known that the Company would insist on retaining all the lands it had conquered, and would demand a treaty which guaranteed it compensation for the cost of the war and security from fresh aggression. ${ }^{7}$ If either of the two contenders, therefore, offered less than the decided price, it could only be in order to increase his own prestige and influence. It followed that acceptance of a reduced offer would be tantamount to abetting the ambitions of a particular individual or political party, and such behaviour was, in Hastings' view, beneath the dignity of the Company's government. ${ }^{8}$ But neither of the Nepalese agents understood that this was the British attitude. As they saw it, the prime purpose of the Company must be not territorial indemnification, but the establishment of an influence in 
Kathmandu. This was why Gajraj Misr emphasized that it was his especial desire to recover the office of royal guru, and exercise it under the protection of a British residency; ${ }^{9}$ and why Rudra Vir Shah urgently stressed to Gardner that their securing the peace negotiation would enable his brother and himself to overthrow the low caste usurping Thapas, whom he contemptuously referred to as "Khasias", and re-establish the power of their own party, which had always been the most favourably inclined towards a connection with the British. ${ }^{10}$ Neither seems to have taken the British demand for indemnification in territory seriously at first, and the two governments negotiated at cross purposes for many months.

Because he was the first to secure the appropriate authority, negotiations were begun with Gajraj Misr. Since the palace revolution of 1803, this brahmin had been constrained to live in exile at Benares, on the proceeds of a jagir provided by the Company. Motivated partly by a desire to re-ingratiate himself with the durbar and recover his lost position, and partly by a genuine concern to open the Raja's eyes to the peril of his situation and save his kingdom from destruction, he had offered his services as a mediator. Both governments had welcomed the tender. Hastings had recalled his previous adherence to the pro-British party in Kathmandu, and the valuable influence he had exerted to promote the success of the Kirkpatrick and Knox missions; and the durbar was anxious to employ an agent who was in favour with the British and able to inform it of the true nature of the Governor General's conditions of peace. In response to an invitation from the Raja, he had left for Kathmandu early in May, accompanied by Chandra Sekhar Upadhyaya, whom Bradshaw had re-possessed of his private property in order to foster an auspicious atmosphere. ${ }^{11}$

Both men returned to Bradshaw's headquarters at Segauli on May 18th. Gajraj Misr produced an authorisation under the Raja's red seal, and declared that he was empowered to accept whatever terms the victors in their mercy might require. But, confident in his assumption that what the Company really sought was the institution of himself as guru in Kathmandu, Gajraj had given the durbar to understand that the price in 
territory would not, when it came to the point, be as high as had been threatened; so when Bradshaw informed him that the Gurkhas were required to relinquish all colonies west of the Kali and the whole of the Tarai and Morang, he was aghast and incredulous. He was forced to confess that he had no mandate to accede to such stringent demands, and asked to be allowed to make further reference to Kathmandu. Hastings, on the other hand, was disposed to think that he must have received plenary powers with his commission, and that he was bargaining well within their limit with a view to improving his personal standing. He therefore retaliated by ordering a suspension of negotiations in this quarter, and informed Edward Gardner that he might begin discussions with Brahma Shah. ${ }^{12}$

The Shah brothers were desperately eager to be acknowledged as negotiators by the British. Brahma had been edgy and nervous ever since his capitulation, because he dreaded the effects which the misrepresentations of Amar Singh Thapa might have at Kathmandu. It had taken all the kindly expostulation of William Gardner to induce him to cross the $\mathrm{Kali}$ and enter Nepalese territory once more. On Edward Gardner's advice, he had applied to Kathmandu for authority to treat, and while waiting to know the result of his solicitation had been in such a state of agitation (earnestly affirming that if he failed to be appointed negotiator he had nothing but death to expect from the despised "Khasias") that William Gardner had been moved to compassion. He had suggested that Brahma and his brother be afforded the option of seizing the Gurkha province of Doti and ruling it as Company protégés. Headquarters had approved the proposal; but when it was put to the brothers, they had showed compunction, and prevaricated. On being pressed, they had finally declined the invitation, Brahma's reason being that he could not endanger his many relatives still within the reach of the Thapas. He had announced that if he failed to secure control of the peace negotiations, he would withdraw as a religious recluse to India. ${ }^{13}$

On July 4th, Brahma Shah informed Edward Gardner that he had received a favourable answer from Kathmandu; and the following day Edward Gardner's own instructions to open negotiations arrived. Brahma being ill, it was Rudra Vir Shah who crossed the Kali to confabulate. He was more aggressive 
and stronger-willed than his brother, and when he heard Gardner's demand for the whole of the Tarai he flatly refused to entertain such a sacrifice. With great energy he told Gardner that he was authorised to cede no more than the western hill provinces, and that the Tarai was the most vital source of the wealth of his state. Take away the lowlands, he insisted, and national penury would ensue. Unconditional powers to treat subsequently arrived, but Rudra Vir refused to change his attitudes. He had several more interviews with Gardner, some of them in company with his brother, and at all of them he reiterated the same arguments in a tone increasingly acrimonious. At the last he became almost violent. He informed the Political Agent "that others might negotiate on these grounds; but that for himself he would not accept of a commission for that purpose... That it was what would never be consented to at Nepal, and was a subject, in fact, he had received no orders or authority to treat of... That if this point were insisted upon, it would occasion a popular war in which every subject of Nepal would personally engage; that hitherto many of the chief people had kept aloof through party feelings and disapprobation of the contest the Thapa faction had involved them in; but no sooner should it be known that we insisted on the dismemberment of the whole Tarai, then all party faction would be forgotten in the general cause, and everyone unite in the general defence." Even the normally mild and timid Brahma Shah was infected by his brother's vehemence, and met all Gardner's remonstrances with steady pertinacity. 14

Such a reaction was not, in fact, unreasonable. The Tarai estates were the main source of income for the Gurkha government and nobles, all other land being assigned to the army in lieu of payment. ${ }^{15}$ But Gardner knew nothing of this, and was convinced that all these protestations were subterfuge; that the Shah brothers were holding in reserve concessions which they had been authorised to make, in the hope of securing a cheap peace. This would not only enhance their political prestige; it would also, in the case of Rudra Vir, at least, who possessed extensive estates in the Tarai, preserve personal interests. ${ }^{16}$ Hastings was of the same opinion, and he agreed that Rudra Vir probably greatly exaggerated the importance of the lowlands in the national economy. Nevertheless, if 
the Gurkha's demurring had failed to persuade him that a relaxation of his demands concerning the Tarai was necessary in order to secure a settlement, it had convinced him that such a relaxation would make the settlement, once concluded, more permanent. Above all else, he was anxious to avoid extorting from the Gurkhas a treaty which they would dishonour as soon as his back was turned. Events during the early period of the Bengal army's preoccupation in the mountains had, to his mind, presented a striking portent of the situation which might arise if the British challenged the Maratha powers of central India before the Gurkha threat had been exorcised. There had been simultaneous and ominous stirrings among all the Company's potential antagonists. Ranjit Singh, had, in November, 1814, marched his army to precisely that point whence he had intended to cross the Sutlaj in 1808, while the whole British force on the east bank of the river consisted only of the two squadrons of native cavalry at Ludhiana; Sindhia, the Maratha Raja of Gwalior, had taken the first step towards a revival of the Maratha confederacy, by concluding an alliance with Berar in contravention of the treaties of 1805; Amir Khan, the leader of the Pathan mercenaries of central India, had collected an army said to be 30,000 strong on the bonders of Jaipur, in Rajputana, at a position only 12 marches from Delhi, while Sir William Kier Grant, commanding the remainder of the 2nd (Meerut) Division of the Field Army, had little more than a single battalion of native infantry with which he could oppose a hostile move; disquieting reports had arrived from the north east to the effect that Gurkha vakils had been received in Bhutan, and that Bhutanese troops were accumulating in the passes of the Bhutan-Nepal boundary; and finally, the long-truculent King of Burma had been known to be watching events in India with interest, and to have made secret communication with Nepal. ${ }^{18}$ "The cloud which overhangs us is imposing", the Governor General had noted in his Journal; ${ }^{19}$ and Metcalfe, surveying the scene from the Delhi Residency, had been convinced that the end was at hand. "I, who have always thought our power in India precarious, cannot help thinking that our downfall has already commenced." 20 So pressing had been the emergency, that urgent requests for European troops had been despatched to Ceylon, the Cape of Good Hope, Mauritius, and even to England. ${ }^{21}$ 
During the ensuing months the immediate crisis, it was true, had passed. Ranjit Singh had been distracted by a recrudescence of his quarrel with the King of Kabul; Sindhia's generals had fallen to fighting amongst themselves; Berar had been effectively over-awed by the despatch of an army of observation, 10,000 strong, from Madras to the northern border of the dominions of the Nizam of the Deccan; and apprehension concerning the bellicose intentions of the Deb Raja of Bhutan had been dissipated. Relations with this last monarch had, in fact, become so promising that the British authorities were disposed to think, for the moment, that they had found a new ally rather than a new enemy. He had most convincingly disavowed inimical intentions, and had agreed to an exchange of vakils, whose purpose was both to settle the boundary disputes between the Company and Bhutan, and to afford a passage for British explanations concerning the war to the Chinese authorities in Lhasa. ${ }^{22}$

But however transitory, these menaces had buttressed the Governor General's conviction that there existed an incipient danger of collaboration among the native states which must be nipped in the bud by the establishment of an effective British hegemony; and his main concern throughout the negotiations with Nepal was to secure a peace which would indispose the Gurkhas to re-enter the conflict when British energies were absorbed in central India. To make this object sure, he now realized that he would have to make concessions; but he equally realized that the concessions must be granted from a position of strength - that is to say, after the Gurkhas had eaten humble pie and agreed to the terms originally proposed. To grant concessions before they had avowed submission would, by giving an impression of weakness, merely whet their appetite for revenge.

"If relaxation ... be granted", wrote the Political Secretary to Edward Gardner, "it must be as a boon from the British Government, after unqualified submission of the court of Kathmandu to the terms imposed: because, in that case, there might be a sense of liberality of our procedure; whereas, in the other, there would be ground for an erroneous supposition, on the part of the Gurkhas, that a respect for their strength had narrowed our pretension, and they might thence draw an encouragement to renewed aggression."23

As a reward, therefore, for submission, Gardner was to indicate the Governor General's willingness to assign to Gurkha nobles nominated 
by the durbar either jagirs in the Tarai, or pensions. Either form of grant was not to exceed a total of two lakhs $(200,000)$ of rupees in value, and was to endure only for the lifetime of the recipients. ${ }^{24}$ Hastings asserted that he had no serious apprehensions that the Gurkhas would reject his terms of pacification.

"I am still not disposed to think that they will stand the hazard of another campaign", he wrote to the court of Directors in August, "and though they may delay to make peace during the present season of inaction, in which they know we cannot increase their difficulties, I have little doubt that, as soon as the season for active operations approaches, they will become more sensible of the impending danger, and will resort to the only means of averting it." 25

Nevertheless, he took the precaution of ordering preparations to be made in every department for a renewal of the war. ${ }^{26}$

It soon seemed that his optimism was justified. No sooner had they learned of the collapse of negotiations in Brahma Shah's quarter, than Bhim Sen Thapa and the Raja hastened to re-open the communication through Gajraj Misr. Wrote Bhim Sen to the guru: "All our hopes rest on you. This state will agree to whatever you may do, and I charge myself with the ratification of it... Bring the subject to a conclusion by whatever means it can be effected, consistently with the public interest and your own reputation." 26 Towards the end of August, Chandra Sekhar, who had

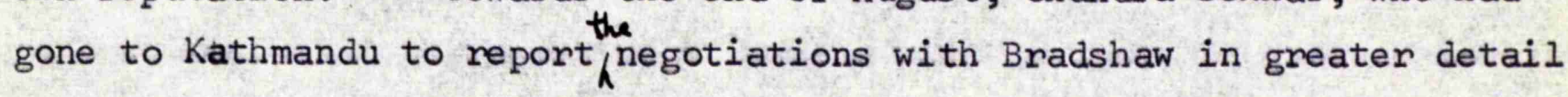
to the durbar, returned with more letters for Gajraj Misr. Their tone was in harmony with that of the previous one. Wrote the Raja: "The country towards Kumaun in the west, and the Tarai, have lately been conquered by the British Government. With regard to those conquests, whatever may be the result of your negotiation will be approved by me." Wrote Bhim Sen: The sentiments of the bharadars [chiefs] to the west are these: 'If, for the sake of peace, you will give up to the British Government our territory hill and plain, east of the Sutlaj to Kumaun, we will not beparties to such a policy. Rather than with our hands and voice surrender that territory, we consent to sacrifice our lives in it.' But the sentiments in this quarter are, that with regard to our territory west of Kumaun and the Tarai, which have lately fallen into the hands of 
the British Government, whatever you shall do or say, we will advocate the same before the Raja, and obtain a confirmation of it." ${ }^{28}$ Gajraj Misr showed these letters to Bradshaw, whom they satisfied that the last impediment to peace had been removed. ${ }^{29}$ The Governor General was of the same persuasion. He forthwith ordered the discharge of the extra troops who had been enlisted for the war emergency, ${ }^{30}$ and shortly after commissariat preparations for renewed hostilities were countermanded.

The tone of the letters from Kathmandu was a source of great relief to Hastings. In his view it was sufficiently humble to constitute that submission which he had required as the precondition of concessions, and he now felt able to demonstrate his generosity, conciliate the Gurkhas, and bring the whole business to a close. In government circles, uneasiness at the prospect of another campaign was growing. Edmonstone and the Council, in Calcutta, had become so hostile to the idea that they had publicly dissociated themselves from the Governor General's conditions of peace and counselled "a relaxation of our demands to the extent solicited by the Court of Nepal." Hastings was furious because, after a previous unbroken silence which he could not but interpret as assent, they had chosen to register disagreement in an official despatch, thereby evading responsibility for meas ures which had not even been the subject of discussion between them and himself; ${ }^{32}$ but although he took exception to the mode of their dissent, there is no doubt that he felt the force of $i$ ts content, and was becoming aware that by insisting on indemnification he was perhaps prejudicing the success of the main purpose of the Gurkha war. Consequently, now that he was offered the opportunity to modify his original terms without a blatant sacrifice of dignity, he did not hesitate to grasp it. Bradshaw was instructed to alter the draft of the treaty so that it provided for the retention by Nepal of all the lowlands as far west as the Gandak river which were at present inoccupied by the British; the grant of pensions for two lives to selected nobles; and the relinquishment of the demand for the surrender of the Gurkha official responsible for the atrocities in Butwal in 1814. Thus revised, the treaty* was not thereafter altered; but Bradshaw was given latitude to 
modify it still further. Should he judge that such concessions would be the means of averting its rejection, he was to commute the pensions for jagirs, tenable for one life, in the Tarai east of the Rapti river, and to delete the article stipulating an exchange of residents. 33

The new draft was submitted to Gajraj Misr. Despite the apparent plenitude of his mandate, he refused to sign it until he had made further reference to Kathmandu. His reluctance was probably not completely unexpected at Headquarters. Edward Gardner had been having more conference with Brahma Shah, who was informed of events at Kathmandu, and he had reported that according to the Gurkha there was no real authority behind the guru's powers. 34 still, it seems, British demands for territorial compensation were not taken seriously at the durbar. The Gurkhas were gambling on the expectation that indication of a willingness to incur the demanded sacrifices would prevent their actual extortion, and the guru was understandably chary of actually using an authority which he was only meant to flourish. His fresh application to Kathmandu elicited an answer which he refused to show Bradshaw, and which manifestly perturbed him. After some days of prevarication, he offered to sign the treaty provided the stipulated temporary pensions were exchanged for a permanent restitution of lands of equivalent value in the Tarai east of the Gandak. Bradshaw refused, and Gajraj pleaded for time to consult the durbar once more. But the British agent was adamant, and told him (presumably having judged that the further concessions he was authorized to offer would not alter the guru's attitude) that he was at liberty either to sign the treaty as it was, or terminate negotiations and withdraw to Kathmandu. Gajraj Misr chose the second alternative, and left Segauli, with Chandra Sekhar, on November 3rd. On departing, he assured Bradshaw that he would return within 12 days with the Raja's acceptance of the peace terms, or not at all. 35

This was a grave setback, and Hastings ordered a resumption of the commissariat preparations which he had suspended in September. The Assistant Commissary General at Dinapur, base of the main eastem division of the invading army, was instructed to see to the hiring of porters and carriage cattle; the purchase of depot supplies, shoes, and blankets; 
and the grinding of atta for 12,000 men. ${ }^{36}$ Sir David Ochterlony was requested to assume command of the division as soon as Sir George Wood had absented himself on sick leave; ${ }^{37}$ Jasper Nicolls was asked to hold himself in readiness to proceed to sitapur and lead a column into the hill provinces west of Kathmandu; and a corps of observation was ordered to be assembled at Lautan, on the frontier of Butwal, under Major-General John Wood. 38

It was Hastings' professed belief that this show of determination would induce the durbar to sanction the treaty. In the event of his belief proving unfounded, Bradshaw was authorised to make yet another concession, if it appeared that it would tip the balance in favour of peace. As the final extremity, short of war, the Company would agree, to the furthest extent compatible with the assurances of protection given to the inhabitants of the Tarai, to accede to the guru's request for permanently restored estates in the lowland tract between the Kosi and the Gandak instead of pensions. 39

The twelve days stipulated by Gajraj Misr elapsed without his returning; but on November 23 rd Bradshaw received a note to the effect that he had been delayed by illness, and would return to Segauli within a week. Sure enough, at the end of the month both he and Chandra Sekhar arrived again at Bradshaw's headquarters, bearing letters for the Political Agent and for the Governor General from Bhim Sen Thapa and the Raja. These contained no concrete proposals, but their tone seemed not to admit a doubt concerning the durbar's final resolution to accept whatever terms the British would impose. Gujraj Misr was importunate. "I He T besought my good offices with His Lordship for effecting some arrangement to mitigate the severity of the conditions of peace", wrote Bradshaw; but as he did not again mention the commutation of pensions, Bradshaw did not raise the subject and confined his assurances to general promises to use his limited influence in favour of the Raja's hopes and expectations. Gajraj Misr then agreed to sign the treaty. The ceremony took place on December 2nd. Two copies were signed. One was then sent to Calcutta, for ratification by the Governor General in Council, and the other to Kathmandu, for ratification by the Raja of Nepal. 40 
Hastings breathed again. Once more the commissariat officers were instructed to "discharge all establishments and discontinue all expenses" connected with preparations for renewed hostilities. 41 A special Council was summoned for the purpose of ratification, and the signed treaty was hurriedly sent back to Bradshaw. But the months of hesitation, protest, and indignation on the part of the Gurkhas had not been without their effect on the Governor General. He realized that the treaty had been wrung from an unwilling and unconsoled foe, and appreciated that it was therefore liable to be disavowed at the first provocation. Motivated by this fear, and also by the consideration, prominent after the recent sufferings of the troops, that its climate would make the Tarai more a liability than an asset, he now framed more concessions. These were to be offered as "a gratuitous and liberal relaxation from conditions already acceded to", after the ratified copies of the treaty had been exchanged. As a substitute for pensions, Bradshaw was to grant permanent estates from the Tarai as far west as the Rapti river. This would involve retroceding to the Gurkhas "a portion, or even the whole, of the lands of Butwal and Siuraj which they occupied previously to the war". As these were lands to which the Company had initially laid claim, their formal surrender had been "indispensable to the honour and satisfaction of the British govermment". But, explained the Political Secretary to Bradshaw, "what the Government would not yield as a stipulation in favour of a party negotiating on equal terms, it may with safety and with dignity relinquish as a gratuitous boon to an enemy which has submitted to prescribed terms of pacification." 41 By this characteristically magnificent display of condescension, Hastings hoped to efface any grudge which the Gurkhas retained, and disincline them to recommence their old trespasses. He probably would have gone even further, and offered estates in the Tarai west of the Rapti, had he not already earmarked that territory for a special purpose. The Nawab of oudh, who lived in terror of the tyrannical Major Baillie, British Resident at his court, had been persuaded to "volunteer" to lend the company two crore $(20,000,000)$ of rupees - equivalent to two and a half millions sterling. This had formed Hastings' war fund. He now planned to liquidate half the loan by 
granting the Tarai on the Oudh border to the Nawab. Even the prospect of mollifying the Gurkhas could not deter the Governor General from this project, which, for personal reasons, he contemplated with great satisfaction. Edmonstone had been sending to London what Hastings considered to be mischievous ly unfounded complaints conceming the expense of the war, and discharging half the oudh loan in this manner would enable him to claim that the war had no, in fact, cost the Company a single shilling. ${ }^{43}$ The ratified Nepalese copy of the treaty was confidently awaited; but time slipped by and it was not brought. Then, only a few days before the interval fixed for its receipt had expired, events took a dramatic turn. Hot with haste, the son of Chandra Sekhar arrived from Kathmandu, with a message for Gajraj Misr. It was from Bhim Sen Thapa, who warned the guru that a hitch had occurred to delay ratification. Amar Singh Thapa, summoned to endorse the treaty, had arrived in Kathmandu with his judgement, it seems, still perverted by acerbity, and was striving to incite the chiefs of state to reject the British terms. He had lavished odium upon the clause relating to pensions, and stigmatized those willing to receive them as potential puppets of a foreign power. In order to allay the scruples he had aroused, Bhim Sen needed a firm assurance that after the treaty had been ratified, the pensions would be exchanged for territory. Considering that this was a situation which called for the revelation of the special concession which he held in reserve, Bradshaw promised the messenger, the guru, and Chandra Sekhar, that such a modification would subsequently be 'sanctioned. Chandra Sekhar's son then returned to Kathmandu, followed on December 28th, by Gajraj Misr and Chandra Sekhar, who went to receive the ratified instrument. ${ }^{44}$

"His Lordship does not renounce the hope that the treaty will be ultimately ratified by the Government of Nepal", wrote the Political Secretary to Bradshaw, early in January, 1816: "to provide for the opposite event, however, His Lordship in Council has judged it proper to direct the commencement of operations against that power if the ratification be not received by the 20 th instant." The same despatch continued: 
the field, Sir David Ochterlony shall unite in his person both political and military authority... You will be pleased, therefore, to transfer to Sir David Ochterlony, on receiving an application from him to that effect, all documents and correspondence in your possession relative to the past and pending negotiation with the Nepalese... and you will refer to $\operatorname{Sir}$ David Ochterlony all the communications connected with that branch of public affairs which may be thenceforth received by you. $" 145$

At the same time, Hastings privately determined that Bradshaw should be removed from his post of Head Assistant at the Lucknow Residency as soon as a favourable occasion arose. 46

Paris Bradshaw's fall from grace had long been pending. His behaviour as administrator of the occupied Tarai had demonstrated that the hapless Marley had probably not been the author of the crimes for which he had ostensibly been removed - a revelation for which the Governor General was obviously not grateful. In May, George Wood had warned Headquarters that it would be unwise to allow Bradshaw to requisition troops from the frontier posts for civil purposes. "It is still fresh in recollection", he had written, "that the parties at Parsa and Samanpur were stationed by Colonel Bradshaw"; 47 and before long it had become obvious that the caution was not unwarranted. Bradshaw had persisted in requiring soldiers to make excursions into the Tarai to preserve the crops from possible enemy raids, despite strong deprecation from officens commanding on the frontier, who sensed the profound unwisdom of detaching small unsupported bodies of troops. He had consequently had to be reprimanded for flouting military advice and assuming a military function to which he was not entitled. 48 In addition, his manner of negotiating had latterly been very unsatisfactory. In September, although possessing instructions to waive unconditional surrender of the whole Tarai and offer modified terms, he had continued to browbeat Gajraj Misr for an acknowledgement of unqualified submission. Hastings had then sharply admonished him for "entire inattention to the principles laid down for $\bar{I}$ his $T$ guidance" and "a demeanour and a language, if not absolutely repulsive, at least calculated to check any confidential advances on the part of the Gurkha negotiator." 49 The occasion of his dismissal 
was a quarrel with Ochterlony, which developed only a few days after the major-general had assumed command of the Dinapur division. Bradshaw complained that Ochterlony was supercilious, and Ochterlony accused Bradshaw of being obstructive. There was a measure of justice in both charges; but Bradshaw's stock was by now too far fallen, and Ochterlony's was too high, for there to be any doubt concerning whom the Governor General would support. 50 Bradshaw received the news of his supersession with a very bad grace. He adhered to an absolutely literal interpretation of his instructions, and thereby kept Ochterlony in the dark concerning the state of negotiations, and delayed his acquisition of the relevant papers, until the last possible minute. 51 It is unlikely that Bradshaw's shortcomings had caused any serious damage to the negotiation; but it is indisputable that his replacement by Ochterlony, who, with his insight into the oriental character, and his grasp of asiatic idioms, was an incomparably better diplomat, was a salutary change.

On January 23 d, Gajraj Misr returned crestfallen from Nepal and told Bradshaw that he had not got the ratified treaty. In his absence adverse councils had prevailed, and the durbar now demanded that the whole of the Tarai between the Gandak and the Kosi be substituted for the proposed pensions. 52 He was referred to Ochterlony, who informed him that he might return either to Kathmandu or to Benares, as best his fancy dictated. 53

There is no reason to question the essential truth of the reason given by Chandra Sekhar's son for the treaty's failure to gain acceptance in the durbar. Information obtained by Edward Gardner confirmed that Amar Singh Thapa had been summoned to Kathmandu on business of state; 54 and Chandra Sekhar, on his return from Nepal in August, had told Bradshaw that the kaji, bitterly opposed to the terms of peace, had been recalled to count. 55 Amar Singh Thapa's counsel must have been the weightier because, by a freak of circumstance similar to that which had obtained on the eve of the war, his avowed political enemies, the Shah brothers, were in fundamental agreement with it. The "Bharadars to the west" mentioned by Bhim Sen Thapa probably included Brahma and Rudra Vir Shah, as well as Amar Singh Thapa. So much would seem to be indicated, at least, 
by the tenor of their representations to Gardner, and by the fact that neither again evinced any hesitation concerning their allegiance to the durbar. 55 Bhim Sen Thapa himself appears to have been an unstable and ineffectual figure at this crucial juncture of his country's history. The instructions sent to Ranjor Singh Thapa after the fall of Kalanga, enjoining an attempt to secure peace by extensive sacrifice, show that he was still far from defiant and resilient in the face of defeat, and his professed desire for an acceptance of the treaty had therefore probably been sincere. But he was very impressionable. Thus while the moderating influence of Gajraj Misr prevailed, he had been disposed to throw himself on the mercy of the conquerors; but after the return of his uncle, now the elder statesman of Nepal and the symbol of her resistance, he had neither the self-possession nor the prestige to prevail against his fiery exhortations.

Amar Singh's belief in miracles had been fortified by adversity. He clung to the idea that China might be induced to help, despite the fact that repeated applications to the Imperial authorities in Lhasa had failed to evoke any sympathy. It is known that an application for aid had been sent to Lhasa, for the purpose of being forwarded to Peking, by the Nepal Raja early in 1815. It had been couched in the form of an accusation against the British, whose gravamen was that they were seeking to force a passage to Tibet. ${ }^{57}$ Accounts differ concerning the fate of the petition. When the two Chinese amban in Lhas a wrote to the Rangpur Magistrate later in 1816, they haughtily scorned the idea that they should ever have sent such a contemptible missive into the august presence. "What has befallen us that we should communicate the unsuitable petitions of the Gurkha Raja, or of anyone else to the Emperor, or to trouble His Majesty with such misrepresentations?"; 58 and in a letter later intercepted by the British Resident, the Nepal Raja complained that no attention had been paid to his petition, which had been returned from Lhasa. ${ }^{59}$ But other sources and subsequent events show that this apparent indifference was mere dissimulation. The amban had, in fact, secretly forwarded copies of the application to the Emperor, together with the Rangpur Magistrate's explanation of British procedure. The result had been a refusal to aid 
the Gurkhas; but the Emperor had nevertheless felt the need to investigate the whole situation in the Himalayas a little more thoroughly, and he had ordered an agent, called Shee Chan Choon in the English records, to advance from Peking to the southern frontier of Tibet with an army said to number thousands. ${ }^{60}$ Nothing was known of this in Nepal at the time of the rejection of the treaty, however. The Emperor had enjoined the Lhasa authorities not to divulge their communication with himself ${ }^{61}$ probably because he did not want to encourage the Gurkhas in their conflict with the British.

It appears from the report of Kishen Kant, the Company's vakil in Bhutan, that Nepalese attempts to acquire the support of the Deb Raja had been no more successful. A Gurkha ambassador resided at the court of Bhutan, and special messengers had, in addition, been sent there from Kathmandu late in 1814. But Kishen Kant found no evidence to suggest that there was any formal alliance between the two governments. His suggestion was that the Deb Raja was detaining the Gurkha agents only in order to make the British more tractable in the matter of his border disputes with Company zemindars. ${ }^{62}$ There was a Gurkha embassy sent to Burma, either late in 1814 or early the following year, ${ }^{63}$ which must have seemed more promising, because Anglo-Burmese relations had been disturbed ever since 1785, when the King of Burma had conquered Arakan and made his territories contiguous to those of the Company; but there is no doubt that, insofar as Amar Singh Thapa and the Gurkha durbar were induced to reject the treaty by promises of cooperation, it was the machinations of Sindhia, the Maratha Raja of Gwalior, which were their main source of encouragement. Information obtained by the British in the latter half of 1815 showed that Amar Singh Thapa's expectations of assistance from the Marathas were not entirely fanciful. The British newswriter at the court of Ranjit Singh reported that Sindhia had sent vakils to try to persuade the Sikh leader to help the Gurkhas, and thus contribute to the success of a grand plan for the conquest of Hindustan; 64 and in September, 1815, British informants in Benares reported the passage through the city of a messenger from the Gurkha vakil at Gwalior. He was carrying a letter, from Sindhia to the Nepal Raja, which information 
represented as "of a nature inimical to the negotiations now pending between the British and the Nepal states, urging the latter to spin out time by negotiation and not to make peace, in which case they would be assisted by the Marathas." 65

True, there had been such promises before, which had not been kept; so perhaps the Gurkha nobles did not really have much faith in Sindhia. But even if they did, the receipt of such assurances was probably less the cause than the occasion of the rejection of the treaty. It seems unlikely that a majority in the durbar was reconciled to it. Rudra Vir Shah's attitude had been unequivocal, and no doubt typical. "He acknowledged", Gardner had written, "that if the war were prosecuted it might terminate in their ruins; but that the result was in the hands of Providence and that they would stand the hazard of the issue." 66

Hastings had therefore accomplished only half of his aim of leaving a substantial and conciliated Gurkha state. By merely disfiguring, instead of crippling Nepal, he had incensed her leaders without making them incapable of retaliation. It had become clear that a greater demonstration of his strength was necessary if the Gurkhas were to appreciate the measure of his leniency. But he had reason to be grateful, at least, that the incompleteness of his policy had been made apparent while the occasion was yet propitious for further measures. The Gurkhas could have lulled him into a false sense of security by ratifying the treaty and then rejecting it a a later opportunity more favourable to themselves, on the ground that it had been extorted under pressure - an expedient at which nations professedly more civilised and sophisticated have not baulked. Pride, fortunately, has many aspects. Stubbornness, ungraciousness, and intolerance are some; but honesty is another. "Lands transferred under a written agreement cannot again be resumed" Amar Singh Thapa had written in his intercepted letter to the Raja of March, 1815. ${ }^{67}$ If negotiations for peace collapsed because of his adherence to this principle, at least that collapse contained a promise that peace, once attained, would not be destroyed by guile. 


\section{Chapter Twelve}

The Final Campaign

Hastings saw no reason to change the strategy he had devised for the main invading division. Captain Casement, who had been in charge of the guide and intelligence department of the main force during the first campaign, had assured him that Marley's instructions, had they been carried out, would have produced success. No new information had come to light which suggested that any of the recommended passes across the foothills was impracticable. His only new idea, adopted at Casements suggestion, was that one of the columns of the main division should advance from Ramnagarh into the Rapti valley, considerably to the west of Kathmandu, which was reckoned to be "the interior Tarai of Nepal". Otherwise Ochterlony's instructions were the same as Marley's: to penetrate the foothills below Kathmandu; occupy the three forts of Hethaura, Makwanpur, and Hariharpur within the finst range of hills; and then, if submission was still delayed, to advance into the Nepal Valley and attack the Gurkha capital itself. ${ }^{1}$

It was already very late in the cold season, and only two clear months remained for military operations. In 1814, Francis Hamilton had written to the Political Secretary: "It cannot be too earnestly recommended that the troops should reach the approaches to Kathmandu by the lst of December, so that they may have time before the return of the unhealthy season, which often begins by the lst of April, and usually by mid-May." ${ }^{2}$ If Ochterlony was to remain true to the lessons of his first campaign, he would have to ensure that he always had heavy artillery at hand to dislodge the Nepalis from roosts on ridges and pinnacles. But whereas, in the previous year, he had had six months at his disposal, he now had only slightly more than that number of weeks. His well-tried tactics of slow but sure advance would now be inapplicable. Somehow, he was going to have to combine the use of heavy ordnance with exceptional mobility. It was almost an absurd task that he had been set, because the two requirements were mutually preclusive.

Hastings compensated for Ochterlony's lack of time by increasing his 
division to four brigades - a total of almost 20,000 men - and no less than 83 pieces of ordnance. ${ }^{3}$ The nucleus of the force was composed of men who had served in the eastern divisions during the first campaign; but the additions were drawn, wisely, not from corps which were tired from serving in the western theatre, but from those which had either remained in the interior during the previous year, or recently arrived from Mauritius. No troops had been sent from England in response to the Governor General's request. Some had been on the point of embarking, but had then been retained because of minatory events in Europe. Hastings had himself rescinded his requisition for troops from the Cape and Mauritius as far back as May, when the situation in India had become less disquieting; but the order had arrived too late to have effect in Mauritius, and troops from the island had disembarked at Calcutta in August, $1815 .^{4}$ Among them was H.M. 87 th, the Prince of Wales' Own Irish Regiment of Foot, ${ }^{5}$ which was now ordered to the frontier to join Ochterlony's division. Sir David had besides two other King's regiments: the 24 th Foot, which had formed part of themain eastern division the previous year, and the 66th Foot, fresh from garrison duty at Fort William.

But even this force, which was almost equal in number to the original four divisions in combination, did not satisfy Hastings. Determined that prolonged resistance by the Gurkhas must be precluded, he prepared to overwhelm them with a human avalanche. On Ochterlony's left, John Wood, reprieved from threatened supersession by present urgent necessity, remained in charge of the division he had commanded the previous year. Now 5,000 strong, with a small artillery train, this was to complete the occupation of the Tarai north of Gorakhpur, thereby creating a diversion in favour of the principal operations, and, if circumstances permitted, to advance to Palpa, Tansing, and the provinces immediately west from the Nepal Valley. On Wood's left, Jasper Nicolls was to march into. Doti, now the most western Gurkha province, with six and a half thousand men and 20 pieces of ordnance. "The penetration of the hills, the raising of the country against the Gurkhas, and the eventual movement eastward to facilitate the operations of Major-General Sir David 
Ochterlony by distracting the attention of the enemy remain the abjects of your enterprise", Hastings told him. Edward Gardner was to accompany him, and make another attempt to buy the allegiance of the Shah brothers with promises of the independent sovereignty of the territories they administered. Nicolls' advance was to be supplemented by a thrust from Kumaun, organized by Lieutenant-Colonel Adams, onto the flank of the enemy positions in the west. Finally, at the other extremity of the line of operations, Barré Latter, now recovered, was to resume command at Titalia. His function, as before, was to be essentially defensive; but he planned to encourage the Sikkimese to renew their siege of Nagri. Altogether, some 35,000 men of the regular army and more than 100 pieces of ordnance would take the field for the second campaign.

It is a worider that the main division was ever mobilised in time. The commissariat officer at Dinapur, after having received four sets of instructions in six months, ordering and countermanding the resumption of preparations in alternation, can hardly have known whether he was coming or going. In response to orders of December llth, all extra field establishments of coolies, bullocks, and carriage cattle had just been discharged again; ${ }^{8}$ and now yet a fifth set of instructions enjoined the immediate recruitment of carriers and cattle sufficient for an army of 20,000 men and 80 guns. Fortunately, followers had been so recently dismissed that large numbers of them were still at Dinapur, and by dint of great energy on his own part, and of unstinting cooperation on that of the Dinapur commissariat and the Magistrate and Collector of neighbouring Patna, Ochterlony was able to send the artillery train across the Ganges on January 13th. He followed them north, with H.M. 24th, the following day. Because the expense would have been so enormous, and because peace had, until very lately, seemed likely, no pantaloons had been prepared for the sepoys this season, and only the Europeans were provided with tents. 9 Arrangements for the comfort of the native troops being so inadequate, it was in one sense lucky that the worst of the winter was past.

The rendez-vous for Ochterlony's division was near Balwi, a hamlet on the frontier of Saran, about six miles from the border of the Tarai 
forest. Troops had been accumulating there since the end of November, and the normally desolate area had become transformed into a sprawling, teeming shanty town, clamorous with all the noise and bustle of an Indian military encampment. Both officers and men were in good spirits. Sickness had declined with the hot weather, and provisions were plentiful. "As one proof of the goodness of our fare", wrote Walter Henry, Surgeon to H.M. 66th, "I may mention that at the mess we had green peas in abundance, that had been carried in baskets on men's shoulders, all the way from Dinapur." The troops were regularly turned out an hour before dawn, and kept under arms until it was light; but the enemy made no attack, and the days were free to be devoted to the amusements of the camp - the bazaar, the nautch girls, the jugglers, the musicians, and the edifying spectacle of sadhus locked in expiatory contortion. The European officers would take their fow ling pieces, and ride out to shoot mallard, teal, widgeon and snipe. 10

Ochterlony planned to divide his force and cross the foothills (here called the Churia range) at three points. The central column, under his own direction, would comprise the third and fourth brigades, consisting of H.M. 87th and seven and a half battalions of native infantry - about nine and a half thousand men, including the gun lascars and ordnance drivers. This would force the Bichakori pass, which was known to be defended, and advance to take Hethaura and Makwanpur. 30 miles to the west, Lieutenant-Colonel $\mathrm{Nicol}$, of H.M.66th, was to lead the second brigade, consisting of his own corps and four native battalions, and totalling about 5,000 of all ranks, into the Rapti valley by way of Mahajogi, and then march east to join Ochterlony. Brigadier Kelly, in charge of the first brigade, would operate with H.M. 24th Foot and 4,000 natives on a line some 35 miles to Ochterlonys right. He was to march up the ravine of the Lakanda nulla, an eastern tributary of the Baghmati, and deal with the fort of Hariharpur. Half the light and mountain ordnance, amounting to 30 pieces, was divided equally between the two subsidiary columns. Two heavy artillery depots were to be established: one at Bhagwanpur, on the west bank of the Baghmati, for the use of Kelly in the case of need; and the other at a convenient point on the borders 
of the Tarai forest on Ochterlony's own line of march, which would serve both the main and Nicol's columns. ${ }^{11}$

On February 3rd, Ochterlony led the third and fourth brigades forward some six miles to Simra Basa, on the edge of the jungle. Here he had a strong stockade constructed, designed as the second heavy artillery depot. At seven o'clock on the morning of the 9 th, the column began to move from Simra Basa with four six-pounders and four three-pound mountain guns. Striking north, the advance guard led the way through the matutinal mists into the primeval forest of the Tarai.

It seemed obvious that they must meet resistance. No territory lent itself better to defence. The utter stillness, and the monotony in the aspect of innumerable massive sal and sissu trees, stretching in endless repetition, gave the claustrophobic impression of being enclosed by mirrors exchanging reflections in infinity. For nine miles the army marched up the western bank of a dry river channel, encumbered by undergrowth and grasses. The pioneers often had to clear a passage by chopping and firing, and then the screaming of startled parakeets broke the silence; but there was neither sight nor sound of enemy soldiers. The march was twelve miles long, and it was not until late in the afternoon, when the splendid noonday columns of sunlight lay collapsed and fragmented across the ground, that the vanguard reached Bichakori, a hamlet of about a dozen huts in a clearing under the foothills. Camp was pitched in the dry bed of a nulla, whose channel farther up formed the Bichakori pass. Ochterlony was astonished that he had been allowed to come so far unmolested. ${ }^{12}$

He remained at Bichakori for five days, gathering information about the enemy defences in the pass, and seeing to the fortification of a large, square, brick building, which was apparently a caravansary. This he had decided to use as a depot and hospital. On the fifth day, February 14 th, he was paid a visit by Chandra Sekhar Upadhyaya, accompanied by Gajraj Misr, who had declined to quit the frontier before he had been vouchsafed an interview with $\operatorname{Sir}$ David. They were very humble and apologetic. The guru said he could not justify the behaviour of the durbar, but explained that it was only the result of its anxiety to have 
a clause commuting pensions for lands incorporated into the treaty. It seems that the durbar placed no trust in Bradshaw's promises of a supplementary clause, because the guru now asked Ochterlony if the pensions could be paid to the Raja, instead of to selected nobles. Jocularly, and with a view to making it clear that the offer of pensions had not been inspired by a wish to have dependents at the durbar, Ochterlony replied that he was sure that the Governor General did not care whether the money was paid to the Raja or thrown into the Ganges. But as they had not brought the ratified treaty, he begged that they would stay no longer. ${ }^{13}$ They then separated, the guru returning to Segauli, and Chandra Sekhar to Kathmandu.

The information of scouts and spies concerning the obstacles in the Bichakori pass allowed only one conclusion: it was impregnable. Enemy preparations had turned it into a death trap. ${ }^{14}$ But William Pickersgill, now acting Quarter Master, told Sir David that there was an altemative route across the Churia range slightly to the west, which was "unguarded and practicable, though difficult". ${ }^{15}$ It was a passage well-known by smugglers, and seems to have lain about half way between the Bichakori pass and the modern road from Amlekhganj. Satisfied that Pickersgill must know what he was talking about, after spending months surveying the border country, Ochterlony decided to try to penetrate by this passage with the third brigade and then, by attacking the Gurkha defences in the Bichakori pass from the rear, open the main route for the fourth brigade and the heavy guns. He commanded the operation in person, and moved from camp when the moon rose, at nine $0^{\prime}$ clock at night on February 14 th. He had two six-pounders, carried by elephants, and 3,000 men. Tents at Bichakori were left standing, and immediately occupied by men of the fourth brigade, in order to conceal the movement.

Ochterlony's detachment followed the dry channel of the Bali river. Where this began climbing into the hills, its banks were steep and rugged, thick with overhanging trees, and hirsute with trailing wild ginger. John Shipp, ensign of H.M. 87th, recalled that, in the deep chiaroscuro of the night, it seemed like the entrance to a deep cavern. The men moved in files, with the silence of a funeral procession. 
The only sounds were the thudding of axes, as the pioneers moved trees grown or fallen across the path, and the crashing of a distant cataract. As they climbed higher, hefty/rocks glimmered above them, transformed by moonlight into mythological phosphorescent sculpture. After five or six miles, the path branched off into the ravine of an even narrower water course, whose bed was hard and flinty. White baboons occasionally peered from the foliage, and pelted the intruders with nuts; but there was no sign of any Nepalis. When dawn broke, the men were aching and parched with thirst; but they felt the invigorating air of the mountains, and knew that their march must be almost completed.

Almost: but not entirely, and the part which remained contained difficulties ten times worse than anything they had yet experienced. To Ochterlony's horror, the channel of the watercourse suddenly became the face of a waterfall, soaring almost sheer before him, to a height of some 300 feet. For the moment, Ochterlony was sure that he could not continue. He turned to Pickersgill, and spoke in a voice trembling with despair and reproach.

"Sir, you have deceived me!"

Pickersgill remonstrated, and told him that if he thought so, he should go back; but he urged that if the passage were cleared the enemy were bound to evacuate their positions in the Bichakori pass, to escape being attacked from behind. Ochterlony said nothing, as he struggled to reach a decision. At last, quietly, he gave the order:

"Move on!"

The scree was so steep that the men had to haul themselves up by means of bushes and branches. The major-general, who despite his near sixty years had walked every yard of the way, encouraging his troops, had to claim the assistance of the artillerists in order to climb it. They tied their sashes together to form a life-line, and he scrambled up with the aid of this. While the main body of the brigade was negotiating this final stretch of the pass, the advance moved on in search of water, and eventually bivouacked in a small wooded valley with a running stream, about five miles further north. The last of the rearguard did not join them until nine o'clock that night - a full 24 hours after leaving Bichakori. 
By now the men were a sorry sight. Their clothes had been torn to tatters, and their toes protruded from lacerated shoes. But nothing could dampen the spirits of the $87 \mathrm{th}$, who were up in the trees and lopping off branches almost as soon as they had arrived. Then they set to work building huts for their officers, themselves, and "Sir David Maloney". The bivouack was on a small hill, protected by an arc of outlying pickets. The majorgeneral and the men remained without tents for four days, until the baggage had been brought throughthe pass. They were even without food until the morning of the 16th, when the first supplies of liquor and biscuit arrived. Outwardly, Ochterlony remained buoyant and good-humoured; but inwardly he was still numbed by dreadful uncertainty, because even all his previous experience of hauling artillery over mountains could not persuade him that it was possible to bring the elephants and the guns over that last 300 foot acclivity.

As had so often been the case in his first campaign, it was to the ingenuity and the sweat of his pioneers that he owed the accomplishment of the seemingly impossible. Commanded by Captain Baines, they laboured from late on February 15th until early on the 17th, and turned the ascent into a rough flight of steps. First, the hill was cut away and made less steep; then trees were felled, and laid transversally up its whole length. His mahout coaxed the first elephant to try the ascent with a six-pounder strapped to his back; but it was too steep to enable him to balance with this extra weight. There was a moment of panic as he swayed, trumpeted, and almost toppled over; and there was nothing for it but to remove the gun. Both animals then ascended - slowly, and never taking a step before testing the strength of the tree trunk or projection in front. The guns had to be dragged up by hand, mounted on their carriages. The hill was made, as far as possible, a succession of direct ascents. Next, fox wedges were driven into the bank on either side, and down the centre of the road. Pulleys were attached to the side fixtures, and ropes from each side of the gun carriage passed through them. Working parties then descended, pulling the ropes, and the gun moved upwards for a few yards. As soon as it had reached the level of the pulleys, the machine was made fast by its preventer rope's being tied to one of the 
central wedges, and preparations were made to repeat the process higher up. A subaltern of artillery sat astride the gun to direct the operation, and fifes and drums played a working tune. In this way both the sixpounders were taken up the slope, followed on subsequent days by the bullocks and tumbrils with ammunition and stores. 16

Describing his manoeuvre in a despatch to Headquarters, Ochterlony wrote that the assurance he had received of the practicability of the pass had been "founded on an erroneous estimate of our resources, powers and means". He added: "that the movement has been effected is to be ascribed to great good fortune, as well as to the most persevering labour, the greatest exertion, and most persevering fortitude."17

It is true of many daring enterprises that they are undertaken in innocence, and it is probable that ochterlony would never have attempted this manoeuvre had he been aware of its difficulties. But the moral and physical courage which he had shown was nevertheless very great. He may not have known of the technical problems which the movement was to involve; but he could have had no doubt concerning the consequences which would have followed had the enemy opposed it. Movement between adjacent heights in hostile country is the classic invitation to catastrophe. Had but a handful of Nepalis been posted to defend the pass, they could, with impunity, have inflicted a historic massacre. A man who is responsible and shrewd needs nerves of steel to court such a catastrophe. The measure itself was frankly a gamble, depending more on chance than on skill for success, and ipso facto not liable to be assessed in terms of text book criteria. One cannot judge the action in such cases; one can only judge the circumstances and the man. Circumstances made a gamble of this nature unavidable. The Churia range had to be crossed somewhere, because the season was already too far advanced for the campaign to be halted and rethought, while to postpone it for another year would have involved crippling expense and imponderable political consequences, and any pass would have presented the same risk. As a judgement on the man, it is enough to say that of all the generals who ever needed good luck, few have deserved it better.

Lieutenant-Colonel Burnet, in charge of the fourth brigade, had 
meanwhile probed his way into the main Bichakori pass. He struck camp at daylight on February 15th, and continued north up the bed of the nulla for about seven miles. The ascent was regular, but not steep, the pass proper beginning only beyond the hamlet of Simalbasa, where the pathway left the nulla and turned right into a narrow defile. Three enemy stockades barred this passage. Burnet bivouacked at Simalbasa for the night, and early the next morning he sent a detachment forward under Captain Tickell, the Field Engineer, to reconnoitre the first stockade. It was deserted, and promptly occupied by a British party. As soon as he had been reinforced, Tickell pushed on to the second enemy position. This was a palisaded barrier astride the path, with a sunken central gateway commanded by guns in flanking embrasures. It was occupied when Tickell sighted it, but the inmates fled as he advanced. The third stockade was at the summit of the pass, and was made virtually unassailable by its situation. It was on a high bluff, which lay across the end of the deep ravine through which the approaching pathway meandered. Tickell, having received another reinforcement, stationed a party in the second stockade, and proceeded with his reconnaissance. When he was in the ravine, a shattering fire of musketry was opened on his party by the enemy in the stockade in front and above. Damage was not so bad as it might have been, because the fire was ill-directed; but even so one man was killed and seven wounded. Tickell hurriedly withdrew to the second stockade, and all further measures were abandoned until the next day. It was now that the full benefit of Sir David's daring manoeuvre was felt. During the night, the enemy in the Bichakori pass were astounded and thoroughly unnerved to learn that he had turned their position and got between them and Makwanpur. Fearful of being pincered by simultaneous attacks from the front and the rear, they hastily abandoned their third stockade and moved back to join the main Nepali force. News of the evacuation was brought to Burnet early on the morning of February 17th, and he immediately ordered forward a party under Major Campbell, which seized the post and secured the top of the pass.

It soon became obvious that the enemy had placed their greatest faith in the impregnability of this passage. As well as constructing 
three stockades, each immensely strong, they had heaped rocks and stones on surrounding eminences, ready to be rolled down on the invaders; and had even poisoned the mountain pools, by infusing them with some plant like belladonna. Five elephants of Burnet's detachment bellowed and shrieked in the most dreadful agony after drinking, and had to be destroyed lest they should become maddened and uncontrollable. ${ }^{18}$ Ochterlony's breathtaking movement, by nullifying all these elaborate precautions, threw the Gurkhas off balance. It was an eventuality for which they were psychologically completely unprepared, and they never recovered the equilibrium which would have enabled them to make the most of the advantages they still retained. At first, it seems incomprehensible that they should have omitted to fortify the pass by which ochterlony had ascended, because, far from being unknown, it was even marked on some maps. But, in fact, there were good grounds for their assumption that it could be safely disregarded. In the first place, its difficulties were so prohibitive that no general could be expected to tackle them advisedly. Secondly, it must be remembered that the Gurkha commanders in the east had so far encountered only incompetent and unimaginative British generals, and this had lulled them into a sense of security. Daring and incisive leadership such as Ochterlony's was something with which their experience had not taught them to reckon. Thus by a fine irony, the very British ineptitude which had brought the Gurkhas near to victory in the first campaign had a significant responsibility for their defeat in the second.

Burnet was now delayed for nearly a week, engrossed by the formidable task of bringing the artillery, including two eighteen-pounders from the depot at Simra Basa, through the Bichakori ghat. Ochterlony did not wait for the fourth brigade to join him, but resumed his march to Hethaura as soon as he had learnt, on February 15 th, that the main pass had been secured.

His route lay north eastwards, over open, gently rolling country, intersected by watercourses and powdered with early spring flowers. The march could not be hastened, because the path was narrow, and much prickly brushwood had to be cleared away. Slightly to the south of Hethaura the Karara river, a branch of the Rapti, flowing from the east, 
crossed the route. The buildings of Hethaura could be seen on its northern bank. They consisted of two converted and fortified caravansaries, rather like the one at Bichakori, but larger and stronger. The river was forded without difficulty, and the light company of the 87 th pushed on to beleaguer the enemy posts. There were soldiers in the buildings, but they offered no resistance, and fled into the forest at the rear on the approach of the British force. Ochterlony remained encamped at Hethaura for over a week, while one of the caravansaries was converted into a dépôt, and it was here that Burnet's brigade and the battering train finally caught up with him. 19

On February 25 th, Sir David received another visit from Chandra Sekhar Uadhyaya. He was earnestly assured by the vakil that the treaty had been ratified, and was now at Makwanpur, in the possession of Bhaktawar Singh, brother of Bhim Sen Thapa. Bhaktawar was ready to surrender it, and was only waiting for the arrival of Gajraj Misr, whom the Raja had summoned from Segauli. Ochterlony sternly declined to allow his advance to be delayed by these pledges, and said that he must have the treaty in his own hands before he could deign to enter into discussions and grant any form of armistice. Secretly, he wished that he was able to believe Chandra Sekhar, because the moment seemed propitious for a lenient peace, and he viewed the prospect of a prolonged campaign with weariness and misgiving. "Protracted war", he told Headquarters, "can only produce enormous expense, which the most successful results cannot indemnify, but may, as in our western provinces, burden us with territory without revenue, and with troops without resources to maintain them." But he dared not trust the Gurkhas until he had irrefragable evidence of their sincerity. It could well be that they were temporizing, with a view tohalting his operations until the hot weather would compel him to withdraw on their own terms. When he left, the vakil said that he would do everything in his power to bring Bhaktawar Singh into the British camp that same day; "but", remarked the major-general. "it seem [ed_ impossible to place any dependenceeven on assurances which seem/ed_ dictated by self-interest." 20

Nothing more had been heard by the moming of February 27 th, when 
Ochterlony's arrangements at Hethaura were complete, so he ordered camp to be struck. Seven companies of native infantry were posted to guard the dépôt, and at seven o'clock the rest of the combined third and fourth brigades moved eastwards for Makwanpur. The third brigade under Ochterlony led the way, while the fourth, with the heavy ordnance, followed. The distance was only about six miles; but there were extensive tracts of woodland to be crossed, in which Ochterlony insisted on probing his way with the utmost circumspection, so it was three o'clock in the afternoon before the first troops arrived before the fort of Makwanpur. They found themselves in an exquisite valley, which was bisected by the Karara. On the southern bank of the river, there were broad green pastures, inclining gradually to the stream. To the north, the ground rose more sharply, and culminated in a hefty ridge of sandy hills, some 1,500 feet high. It was a universe apart from the Tarai. Foliage had lost its waxy patina; trees and grasses moved and breathed; partridges and woodcocks flickered through the sunlight; and the water was transparent.

The army encamped in a long line of deserted huts on the northem strand of the river, which were apparently enemy summer quarters. All the Gurkha forces were now concentrated in and about Makwanpur, a fortress in itself unimpressive, but situated in a position of great strength. It was on a high and steep hill beyond the eastern extremity of the northern ridge of cliffs. The main enemy outpost was a small village of about twenty huts, called Sikhar Khatri, which was at the western endo of the ridge, slightly below the crest. It was connected to Makwanpur by a road, which ran eastwards along the crest of the ridge, dropped to cross a considerable indentation, and then, at a point about one and a half miles from the village, turned sharply to the north. A large stockade straddled the road about a mile beyond the turning, and the eminence carrying the fort of Makwanpur rose just behind it. West of the hollow, the ridge was bare; but its eastem half was covered with luxuriant deciduous forest. 21

When day broke the next morning, there was no sign of the enemy colours and troops which had thronged Sikhar Khatri the afternoon before. 
Ochterlony had not yet formed his plan of action, and he had reckoned on waiting for the arrival of Colonel $\mathrm{Nicol}$ and the second brigade, whom latest despatches reported to have successfully penetrated to the Rapti valley and to be only two or three days' marching from Makwanpur, before starting operations. But his instinct prompted him to grab the abandoned site. He reckoned that he might be able to turn it to good account subsequently, and thought that in any case it would afford a good view of the enemy's defences. Three companies of sepoys and 40 men of the 87 th were instantly sent up the ridge to seize the village. 22

Once they were ensconced among the abandoned hats, Tickell and Pickersgill took a small escort and went out to reconnoitre the road along the crest. The party had occupied two more breastworks to the east of the village, and had crossed the hollow and entered the forest beyond, when, at about half past twelve, a substantial enemy force emerged from the woods below, and began to ascend the northern side of the ridge. Their intention was obviously to cut off the reconnoitring party from Sikhar Khatri. Seeing that it was already too late to regain the village, Tickell, Pickersgill and their party made their escape by clambering down the southern flank of the ridge and making for the main camp. Before they had got far, the enemy were swarming on the crest, and eight sepoys were killed and one wounded in a spray of musket shot. The Nepalis then turned their attention to the British in front of the village. They made khukuri charges against the two advanced positions, overwhelming them and forcing their inmates back to Sikhar Khatri. Here the troops were rallied by Lieutenant Tirrell, the adjutant of the Company's Marine Battalion*, who, intent on gaining experience of active service, had obtained leave from his corps and arrived in camp only a few days before. The enemy, now seen to be a good thousand strong, surged up to the hamlet from four different directions successively, but each ons laught was repulsed by what one observer called the "astonishing intrepidity" of the young lieutenant and his men. Ochterlony, who was watching the engagement from the main camp below, ordered a reinforcement, consisting of a full

The lst Battalion, 20th Regiment of Native Infantry. 
battalion of native infantry and the light company of the 87 th, to speed to Timell's assistance; but the path to the village was half a mile long, and very steep and strangled. The men could advance only slowly, and in single file. Tirrell was dead before they could reach him. But the troops of the reinforcement compensated for their tardiness with their fortitude. Imitating the enemy's style of combat, they covered the last stretch of the ascent not in formation, but in an extended line, so that they could take advantage of the irregularities of the ground. Resolutely, they inched their way up to the village, nudging the Nepalis forward almost at point-blank range. But then trumpets sounded in the main stockade, and 2,000 more of the enemy, with several small guns,poured along the crest of the ridge to bolster the resistance of their comrades. Realizing that the Gurkha commanders were, for some reason, making a major issue of re-taking a post which they had recently spontaneously relinquished, Ochterlony threw a further battalion of sepoys, four more companies of the $87 \mathrm{th}$, and two six-pounders on elephants into the conflict. As this second reinforcement was moving up to the village, under Lieutenant-Colonel Miller, Ochterlony turned out his line and commanded the artillery to play on the enemy troops as they advanced along the crest of the ridge. Their commander immediately retaliated by turning his own guns on the British camp. Ochterlony's tent was pitched well within their range, and his flag, and the red and white plumes of his and his staff officers' cocked hats, were conspicuous targets. The major-general only narrowly escaped death when a shell exploded near him, killing the servant who was holding his inkpot.

The action was now a full-scale battle, raging more and more ferocious. Miller determined to try to rout the Nepalis from the village with a bayonet charge. The Europeans of the 87 th led, and among them was Ensign John Shipp, an irrepressible Englishman who was one of that rare breed of officers who had won their commissions from the ranks. Soon he was engaged "hammer and tongs" with Krishna Bahadur Rana, the Gurkha subba who had been responsible for the attacks of Parsa and Samanpur the previous season. "He was a strong, powerful man", wrote Shipp, "protected by two shields, one tied round his waist and hanging over his thighs as 
low as his knees, and the other on the left arm, much larger than the one round his waist... He cut as many capers as a French dancing master, 'till I was quite out of patience with his folly. I did not like to quit my man, so I tried his other extremities; but he would not stand still, all I could do. At length I made a feint at his toes, to cut them; down went his shield from his face, to save his legs; up went the edge of my sword smack under his chin, in endeavouring to get away from which he threw his head back, which nearly tumbled off, and down he fell." The enemy flinched under the impact of the assault, and recoiled beyond the hollow. Miller's men streamed into the village, and formed a convex line round its eastem approaches; but the enemy rallied once they had crossed the hollow, and formed a corresponding line on its opposite brink, which outflanked the British on either side, Thus deployed, they maintained a stubborn, scorching musket fire, and even brought up a gun to the edge of the hollow. Miller thereupon called for his own sixpounders, but an accident had delayed one of the elephants, and only one gun was at hand.

It was now late in the afternoon, and Ochterlony realized that Miller must have yet more men if he was to finish the action before sunset. The Nepalis were astonishingly resilient; but they had been fighting without respite for the whole afternoon, and when the $2 \mathrm{nd} / 8$ th Native Infantry, fresh and unscarred, joined the conflict, the scale was turned decisively against them. Under Major Nation, the 2nd/8th made a bayonet charge along the crest of the ridge, across the hollow, and up its eastern slope. Their assault was furious and irresistible, and the enemy defensive finally collapsed beneath it. Milling in confusion, the Nepalis blew up their ammunition and threw their advanced gun into the hollow. Then they retreated eastwards along the ridge, to the shelter of their main stockade. They left hundreds behind, strewn all over the ground. In the hollow, their dead and wounded lay in masses, and John Shipp's last impression, before the light failed, was of hacked and bloody bodies in a pit, some squirming, some jerking, and some attempting to rise, and falling back again. It was like an allegorical hell.

The British casualties were 45 killed, 175 wounded, and two missing. 
The enemy were reckoned to have lost $800 \mathrm{killed}$ and wounded. The gum they had abandoned was later recovered from the bushes in the hollow, and was found to be "of beautiful construction, and equal to our mountain ordnance, being in every point exactly similar." ${ }^{23}$

The Gurkha effective force now amounted to just over 2,000 men, all of whom were jaded and dejected. Taking account of the detachments made to guard the depots along his line of communication, Ochterlony had some 6,000 fighting men at his disposal, of whom about two and a half thousand were still untried. His artillery, the arm which had proved decisive in his first campaign, had hardly yet been used; and a couple of days later, on March 2nd, Nicol arrived from the west with the second brigade and thirteen pieces of ordnance, consisting of twelve-pounders, six-pounders, mortars, howitzers, and light mountain guns. ${ }^{24}$ But for all this, he knew that the odds were not so overwhelmingly against the Gurkhas as appearances suggested. They still held the eastern and strongest part of the ridge, where their main defences were intact; and a powerful and insidious agent was working in their favour among the British ranks dysentry. It was spreading with alacrity, and every day Ochterlony became more anxious to end the war and quit the hills. ${ }^{25}$

Spurred on by his commiseration; by that vague distaste which, for all the personal prestige he had gained from it, the war against Nepal seems never to have ceased to inspire in him; and by the knowledge that time was running short, the major-general intensified his efforts to bring the confrontation swiftly to a conclusive issue. On March 3rd, H.M. 66th Foot, which had arrived with Nicol the day before, a battalion of sepoy grenadiers and four elephants with two field guns, were sent to the captured village. From there they advanced along the crest of the ridge, crossed the hollow, and pushed forward to a point only about 800 yands from the principal enemy stockade, while all the troops remaining below made a parallel movement along the valley, so as to be able to provide support in the event of an attack. A temporary redoubt was built for the guns, pending the construction of a battery, and a road begun from the camp for the eighteen-pounders. 26

The same day, Ochterlony received a letter from Bakhtawar Singh. 
It explained, in the urbane understatements of a practised diplomat, that he had intended to send the ratified treaty on February 28 th, but that "owing to the unexpected occurrence of your troops having ascended the hills, and the conflict that ensued.... delay of two or three days was occasioned." He now requested permission to send Chandra Sekhar to the British camp with the treaty. 27

The Gurkhas had at last decided to submit - but not solely as a result of thein repulse from Sikhar Khatri. The final straw had been news from the east, as yet unknown to Ochterlony, that Kelly, leading the first brigade, had reached Hariharpur, attacked it from the west, and compelled the Gurkha garrison of 1,000 men, under Ranjor Singh Thapa, the hero of Jaithak, to flee. ${ }^{28}$

ochterlony now found himself in a dilemma. He was in possession of instructions from the Governor General which enjoined him to alter the treaty and insist on the unconditional surrender of the whole of the Tarai "in the event of a renewal of hostilities unaccompanied by the early submission of the enemy." ${ }^{29}$ Obviously, surrender after a fullscale engagement could not be qualified as "early". On the other hand, his own strong wish was for an acceptance of the treaty as it stood. He wanted to forgo the tiresome process of renewed negotiation, which would not only retain his ailing army in the hills, but might, in the event of a fresh collapse, compel it to reduce Makwanpur and even march against Kathmandu. He resolved the problem, with a typically imaginative compromise. He received Chandra Sekhar the following afternoon, but at first declined to accept the treaty, and roundly harangued him for the "duplicity, folly, and perfidy" which had marked every stage of the durbar's conduct. The unfortunate vakil wilted before this tirade, and made no attempt to defend his government. Almost cringing with contrition, he pleaded the youth and inexperience of the Raja, and humbly begged Sir David to be merciful, as became the powerful. Ochterlony, still feigning reluctance, said that he feared the displeasure of the Governor General, who was determined to inflict condign punishment, and agreed to accept the treaty only if it was accompanied by a written declaration, signed by Chandra Sekhar and Bhaktawar Singh, which 
registered unconditional acceptance of the stipulated terms, and disclaimed all hope of subsequent modification. Eagerly, the vakil promised that this should be provided, and hurried away. Work on the road still continued, and Tickell selected a sight for a breaching battery only 500 yards from the principal stockade. Chandra Sekhar returned at about half past two the next morning, March 5 th, when the eighteen-pounders were actually in position before the stockade, and laid the required declaration before the major-general. Satisfied that after such an overt signal of humility, the British govemment might grant the original terms of pacification without losing face, and secretly deeply thankful for that satisfaction, Ochterlony received the copy of the Treaty of Segauli which had been signed by the Raja, and surrendered that ratified by the Governor General in Council. ${ }^{30}$

So the war with Nepal came to an end. That it had not led to the extirpation of the Gurkha dynasty was due in the final analysis to Ochterlony's integrity and humanity. Had avidity for the fabled treasure of Kathmandu outweighed his desire for a politically expedient peace and his solicitude for the health of his troops, he might, both in perfect consonance with his instructions and with confidence in his own superior strength, have demanded terms so severe that the enemy would almost certainly have rejected them and enabled him to carry his offensive against their capital. Hastings was out of patience with the Gurkhas, and had made it plain that his own preference was the subversion of their government; ${ }^{31}$ while the major-general, following the successes of Nicol and Kelly, had at his command between twelve and fourteen thousand effective men and a formidable array of artillery. In the army, hopes of prize money had been high, and the troops were disgruntled that an early peace had thwarted their expectations; ${ }^{32}$ but the temptation of private fortune seems never to have influenced the calculations of their leader.

When Ochterlony told Chandra Sekhar Upadhyaya that he feared the displeasure of the Governor General, he had not been bluffing because he was still not sure that his compromise would satisfy Hastings. "I am 
in a terrible fright lest Lord [Hastings_T should be angry", he wrote to Metcalfe a few days after the conclusion of peace, "but new negotiations, with the necessary cessation of hostility, were in my mind worse than the acceptance of the old, ready cut and dry." ${ }^{33}$ However, he need not have worried. The Governor General was grateful that his initiative had made extreme lengths of chastisement unnecessary, and in his relief he even indulged a little humour at the expense of George Wood, then recuperating from jungle fever (awl):

"Ochterlony has done admirably", he wrote to Jasper Nicolls. "I fear Sir George Wood will die of the owl when he hears to what profit less time than he had at his disposal has been turned!"34

So swift and incisive had been Ochterlony's advance, that the separate divisions under John Wood, Jasper Nicolls, and Colonel Adams had hardly begun to move at the time of the Gurkhas' capitulation. ${ }^{35}$ Only in the extreme east had there been time for any collateral operations, where the Raja of Sikkim and his generals had again acted as enterprising and plucky allies. They had even sent troops beyond the Mechi river, and occupied the Gurkha posts at Ilam and Phae-Phae, Latter had invited the Gurkha subba of Nagri, Genti Khatri, to desert to the British. Peace had been made before his answer was received; but it was an answer which made it clear that he would never have contemplated such a step. 36

Ochterlony emerged from the war in a blaze of glory. He was fêted and toasted all over India. In December, 1816, he joined the very few Company officers who had been created baronets, and became the first among them to receive the Grand Cross of the Order of the Bath. When bestowing these decorations, Hastings told him that Company officers had now at last come into their own:

"You have obliterated a distinction painful for the officers of the Honorable Company, and you have opened the door for your brother officens in arms to a reward which their recent display of exalted spirit and invincible intrepidity proves could not be more deservedly extended to the officers of any army on earth."137

This proved an accurate prognosis, because Company officers were 
thereafter decorated by the crown with fair frequency. But their merits, however outstanding, never became sufficient to secure them the reward of promotion. When he died, nine years later, Ochterlony was still only a major-general.

Nevertheless, he had become a legend in the Bengal army, and for years afterwards hill chiefs and sepoys alike spoke in wonder of "Loney Ackty" and his eighteen-pounders. His name is still a household word in Nepal, and he is well remembered in India, for the Ochterlony Column in Calcutta has become the same sort of focal point as Nelson's Column is in London. In his last years, he discharged the combined functions of Resident in Delhi, Malwa, and Rajputana, and many tales were told of his wealth, his princely hospitality, his harem, and his vast entourage. He became a last lingering example of the old "nabobs" of the East India Company, whose mode of existence was a happy compromise between oriental and western styles, and who exercised an almost viceregal authority. Before his death, opinion was already running strongly against such licence, and Amherst, who became Governor General in 1823, was not so prepared as Hastings had been to let Ochterlony have his own way, The old major-general quarrelled bitterly with the new authorities in Calcutta, and soon resigned with his pride imeparably injured. He died in 1825 - of a broken heart, according to his friends.

These last nine years were perhaps Ochterlony's most conspicuous, but it is doubtful that they were his best. If he has joined men like Malcolm, Tod, Elphinstone, and Cunningham in the pantheon of the heroes of his age, it is less because of his achievements in peacetime than because of his leadership in war. As an administrator, he lacked the breadth of vision and the penetration which an emotional or scholastic commitment to India could have given. He moved among the Sikhs and the Rajputs for many years, but no embryo of mysticism was ever disturbed; no intellectual curiosity awakened. In spirit, he remained a conscientious and upright European civil servant, seeking only the applause of his seniors in Calcutta as the final authentification of the worthiness of his opinions and actions. He was unable, as Tod and Cunningham were, to draw sustenance from deep personal convictions, and brave the storm of official 
castigation in a determination to earm the approbation of a more ulterior tribunal. Ochterlony came to despise Tod, who was his assistant in Rajputana, precisely because of the / emotional involvement with the Rajput past and his apparent indifference to the esteem of his superiors. ${ }^{38}$

Cunningham, in his History of the Sikhs, indirectly criticised Ochterlony for his shortcomings as a provincial governor, but he also acknowledged his merits as a soldier. "Sir David Ochterlony", he wrote, "will long live in the memory of the people of northern India as one of the greatest of the conquering English chiefs; and he was among the very last of the British leaders who endeared himself both to the army which followed him and to the princes who bowed before the colossal power of his race." 39

That is a good, and not too-generous, epitaph. 
PART 111 


\section{Epilogue}

For a few anxious months it seemed that the victory over Nepal was going to cost a serious confrontation with China. Late in May, Shee Chan Choon, the Emperor's special envoy, arrived in Lhasa with his army. He sent a letter, by way of Sikkim, to Captain Latter, explaining that he had come to investigate the situation in the Himalayas, and would shortly arrive at Tingri, a pass on the Nepal-Tibet border. The agent of the Sikkim Raja told Latter that his army was commanded by five generals, and amounted to between twelve and sixteen thousand men. "You can safely assure His Lordship", wrote Latter to the Political Secretary, "that the Chinese vizir is an officer of high rank, and that the army which is under him has actually come from China." I At about the same time, the envoy informed Bhim Sen Thapa of his arrival, and required a deputation of senior Gurkha officials to wait on him. The prime minister replied that the Gurkhas had been forced to submit to the English, who had deprived them of all their old provinces, and that an agent was being sent to explain at greater length. "Pacify and talk smoothly to the Raja Lama*, the Shee Chan Choon, and the ambans", he instructed his agent, "to draw down their compassion and favour on us, and return with suitable answers." ${ }^{2}$

Such was the situation when Edward Gardner arrived in Kathmandu as the first British Resident, at the end of June. He soon learned how matters stood, both from his spies and from Chandra Sekhar and Gajraj Misr, who acted as go-betweens for himself and the durbar. From these last two, he received news of the death of Amar Singh Thapa at Nilkanth, a shrine five days' journey north of the capital, where, they hinted, he had been engaged in negotiations with the Chinese. Gardner did not doubt the substance of their intelligence, but suspected, probably with reason, that they were exaggerating the Chinese menace in order to alarm the British and induce them to relax the terms of the treaty. ${ }^{3}$

But then affairs suddenly began to look critical. The durbar received a note from its agent at Tingri, stating that the Chinese envoy had left

*i.e. the Dalai Lama? 
Lhasa and marched south to Digarché, and advising that vakils and presents be sent to him at once. ${ }^{4}$ Shaken to find that Chinese displeasure was apparently sincere, the Gurkhas abandoned all rusing. Gajraj Misr and Chandra Sekhar, dropping their usual prolix and devious style of address, implored Gardner to advise them, and begged to know what the attitude of the British government would be in the event of hostilities. The Resident, realizing that their apprehension was real, himself became very uneasy. 5

Early in December, the durbar received further news that some Imperial troops had advanced to the Kirong pass, by which the Chinese had invaded Nepal in 1792. Shee Chan Choon had remained at Digarché at the instance of the Lama and officers of Tibet, but would not hesitate to move forward if the expected deputies did not quickly arrive. In desperation, the Gurkhas sent three senior bharadars to the envoy, with instructions to reiterate Nepal's allegiance to the Emperor, and to inculpate the British as aggressors. 6

The Calcutta government was determined to avoid a rupture with China at all costs. A detailed explanation of British policy was sent to Lhasa through Sikkim, ${ }^{7}$ and Gardner was instructed to adopt an attitude of strict neutrality. He was to withdraw to India immediately if hostilities ensued. The view in Calcutta was that the Residency was not worth the resentment of China, and that even the extension of Imperial hegemony over Nepal, while regrettable, would not be sufficient tojustify a quarrel with Peking. 8

Fortunately, the cloud passed. The Chinese envoy received the Governor General's explanations shortly before the arrival of the Gurkha deputation, and he professed himself completely satisfied. His mind at rest, he would, he replied, duly forgive the Nepalese Raja for his transgressions. ${ }^{9}$ The Gurkha deputation was received at Digarché, and treated with great indignity. But that was as far as the envoy's chastisement went. The bharadars returned to Kathmandu humiliated, but unscathed and much relieved. ${ }^{10}$

On receiving the Governor General's assurances, Shee Chan Choon remanded his troops to China; ${ }^{11}$ but the matter did not quite end there. The Gurkha representations, and the establishment of the British Residency in Kathmandu, had combined to engender a lingering mustrust in the envoy's 
mind, and he politely requested that the Residency be withdrawn. Calcutta expostulated, pointing out that some restraining influence over the Gurkhas was necessary, and agreed to recall its own agent only if the Chinese sent a replacement. The reply was that it was not the custom of the Imperial court to depute ambassadors, and with that the incident was closed. ${ }^{12}$ The Chinese had maintained a temperate, if haughty, tone throughout; but their sensitivity concerning their interests in Tibet had been sufficiently obvious to cause the British to make their own presence in the Himalayas as inconspicuous as possible, for the time being.

The business of implementing the Treaty of Segauli was impeded by evasion and chicanery on the part of the Gurkhas. Gajraj Misr, still secretly convinced that the British would be prepared to sacrifice important acquisitions in return for an influence in the Kathmandu durbar, had assured the prime minister that if he were reinstated as Raj Guru, he would be able to secure retrocession of the Tarai and abolition of the Residency. Shim Sen thereupon reinvested him with his old office, and had the Raja inform Lieutenant Boileau, Acting Resident pending Gardner's arrival, that the durbar now confidently awaited the indulgences promised by colonel Bradshaw. ${ }^{13}$ The truth was, of course, that Gajraj Misr's was now a correct calculation of the ulterior concern of the Governor General who, although he was not willing to forgo the Residency, still intended to exchange the stipulated pensions for extensive tracts of the Tarai in order to ensure the goodwill of the durbar. Gardner was obliged, as a matter of principle, to secure strict adherence to the letter of the treaty before he broached the subject of clemency; but he was enjoined to proceed with "the utmost conciliatory and temperate...tone of conduct... and the greatest care to avoid everything capable of being misinterpreted to the disadvantage of the British Government or I hazarding $T$ the interruption of the growth of that confidence which it is the hope of the Governor General in Council will arise between the two governments after the imitations arising from past events shall be allayed."14 Pleading various pretences, the Gurkhas delayed evacuation of the lowlands for some weeks; but finally, seeing that Gardner was adamant, and also, it seems, receiving a warning from their vakil at Gwalior to the effect that no help could now be expected from Sindhia, they ordered their troops to be 
withdrawn, and negotiations concerning the demarcation of a permanent frontier began. 15

By December, a settlement had been made. The British government surrendered, in commutation of the pensions, the whole of the occupied Tarai between the Kosi in the east and the Rapti in the west, with the exception only of areas which had been the subjects of dispute before the war. 16 The Tarai west of the Rapti was retained, to be made over to the Nawab of Oudh in extinction of half his loan. The new boundary was then surveyed, and marked with pillars of masonry.

The Treaty of Segauli set Nepal firmly apart from the native states of whom the British demanded tribute and feudal obligations, and abstention from foreign relationships, in return for protection. The only permanent liability with which Nepal was encumbered, apart from amity with the British and the acceptance of their Resident, was forebearance to employ Europeans. The British, for their part, undertook to protect the Gurkha dynasty neither from external nor from intemal aggression. This meant that the position of the Resident in Kathmandu was fundamentally different from that of Residents elsewhere, whose obligations to uphold native governments drew them increasingly into the sort of political interference which they were, paradoxically, required to eschew. He was, in fact, an ambassador ${ }^{17}$ - a foreign agent whose taciturnity concerning internal affairs was not bound to be interpreted as official British sanction. Thus was Nepal defined as a sovereign state outside India a status which she still retains.

It did not always seem that that status would survive. Hastings' hope for a cordial relationship with Nepal was not immediately realized. The death of Guru Gajraj Misr, while on $\stackrel{a}{\phi}$ embassy to the Governor General in $1817,{ }^{18}$ removed a salutary influence from the durbar, and for many years thereafter intrigues in Kathmandu remained a cause of constant concern at Calcutta. While Nepal escaped the anomalies which caused the collapse of the subsidiary system and the annexation of Indian states, it was not spared the sort of scrutiny which fears inspired by Russian ambitions caused British statesmen to bestow on states beyond the Indus; and for some time in the $1830^{\prime}$ 's and $40^{\prime}$ s it seemed that Nepal must fall a 
victim to the same policy which led to the expedition to Afghanistan and the annexation of Sind and the Panjab. It was not until the two rival parties, the Panres and the Thapas, had finally destroyed each other in a gory political struggle, which lasted for a decade from the fall of Bhim Sen Thapa in 1837, that a firm tradition of Anglo-Nepalese alliance was established. Only then did a minister emerge, called Jung Bahadur Rana, who abandoned imperial ambitions and made amity with the British the comerstone of his policy.

Although Hastings forsook the style of treaty dear to Wellesley when dealing with the truncated state of Nepal, his settlement of the hill states from which the Gurkhas had been expelled bore the clear imprint of Wellesley's influence. The Govenor General's policy was "to restore the ancient chiefs in all cases in which special reasons did not exist against it", and then afford them protection in return for feudatory obligations such as submission to the Company's arbitration of disputes, the furnishing of troops when requisitioned, and the provision of a free passage for merchants. ${ }^{19}$ These principles were applied to Sikkim, whose Raja was restored to all his old hill territories east of the Mechi river, ${ }^{20}$ and to all the hill states west of the Kali river except Kumaun, which remained annexed to the Bengal Presidency. Hastings' extreme reluctance to burden the Company with direct responsibility for remote hill territories made him unwilling to disqualify any chieftain, and in the event not even the Thakurs of Bhagat and Kinthal, two of the Twelve Lords who had refused to renounce their allegiance to Amar Singh Thapa, were completely excluded from the benefits of his scheme, $/$ the greater part of their patrimonies was sold to the lowland Sikh Raja of Patiala. ${ }^{21}$ In cases of escheat, it was planned to transfer the lapsed estates to neighbouringchieftains. ${ }^{22}$ Some reinstated sovereigns were required to cede small portions of territory, which the British wished to retain either for strategic reasons or as payment for subsidiary forces. Thus Malaun, in Hindur, and Sabathu, in Kionthal, were both kept as British fortresses. ${ }^{23}$ The restored Raja of Sirmur, infant son of Karman Prakash, was compelled to cede Kayarda Dun, and accommodate British garrisons in Jaithak and Nahan; ${ }^{24}$ and the Raja of Garhwal was deprived of Dehra Dun and all lands east of the Alaknanda 
river. ${ }^{25}$ Hyder Hearsey was naturally vexed on discovering the government's intention to annex Dehra Dun. Flourishing his title deeds, he pushed himself forward as zemindar and proprietor, and proposed that he farm the revenues. He based his claim on the principle that "a king or raja expelled by force loses no rights or pretensions", which was absurd, and which the government justifiably rejected. "The Governor General perceives no ground for recognising your claim to the proprietory right to that part of country founded on a transaction which avowedly took place after the absolute extinction of the Rajas of Garhwal by the Gurkha Govermment." In other words, the Garhwal heir had sold to Hearsey something which he no longer possessed. ${ }^{26}$

It was intended that political relations with Bhutan should ceased after the war, and the native agent sent by the Magistrate of Rangpur was recalled. ${ }^{27}$ But demarcation squabbles and border raids kept the two governments in dissonant contact for many years, until in 1865 a war was undertaken against Bhutan in circumstances similar to those which had led to the invasion of Nepal half a century before.

The annexations in the western Himalayas were justified by Hastings on strategic and economic grounds; but their greatest significance in the history of British India was to pertain to neither of these considerations. In a letter to Jasper Nicolls, dated Almora, April, 1816, Captain Raper wrote: "I think in the course of a year or two...this place will become a fashionable resort in the hot weather." ${ }^{28}$ He thereby prophesied a phenomenon which ultimately transformed the whole of the social life of the British in India. Recognising the value of the place as a sanatorium, the government had before long built special hospital bungalows in the vicinity of Almora, and the hill station was thus born. ${ }^{29}$ Obscure mountain hamlets near the battlefields of the Nepal war became, within the space of a quarter of a century, as well known as Calcutta, Delhi, Bombay and Madras. Such were the village of Mussoorie, only a few miles $h^{\text {west }}$ of the spot where Gillespie fell in 1814; the spa called Naini Tal in Kumaun; and the hamlet of Simla, in the mountains just north of the scene of Ochterlony's final combat with Amar Singh Thapa in 1815. When Lord Amherst 
moved to Simla for the hot weather of 1827, he began a custom that soon transformed it into the elegant summer capital which Kipling immortalised in Plain Tales from the Hills. The contribution which the hill stations made to the consolidation of British rule in India must have been considerable. By providing such a respite from the devastating climate of the plains as had hitherto been obtainable only from a voyage home, they made India more accessible to Europeans than it had ever been before, and helped make European family life possible. ${ }^{30}$

The hill stations were a legacy of the Nepal war which the British retained until they left India, 130 years later. Another legacy of that war they did not relinquish even then, and have still. This is the 2nd, King Edward VII's Own, Gurkha Rifles - a regiment raised in 1815 as the Sirmur Battalion.

By the time the war in the west ended, in 1815, about 4,650 soldiers of the Gurkha army had deserted and sought service with the Company, in response to the invitations of the British commanders. Of these, roughly 1,000 were in Kumaun, 1,860 at Nahan in Sirmur, and 1,890 in the Nasiri Battalion organized by Ochterlony. ${ }^{31}$ It was the Governor General's intention to group these men into provincial battalions: some for the occupation of the acquired hill territories, and some for the use of the restored mountain chiefs. ${ }^{32}$ The number of deserters in Kumaun had not greatly exceeded 300; and some difficulty was experienced in enlisting the hillmen required to bring the number to the 1,000 of Hastings' proposed Kumaun Provincial Battalion ${ }^{33}$ - though this was not for any lack of ingenuity on Rutherfurd's part, as the following letter to Jasper Nicolls shows:

"As you are determined on enlisting provincials, I shall commence recruiting officer immediately. In the meantime I have hoisted a red turban surmounting a blue petticoat, as insignia of love and war; and by means of a merry band of pataris (filles de joie) dancing round the pole, and the aid of sack and tobacco, some stout recruits have already presented themselves. Without tipping them with the Company's money, however, I shall not be able to get on, as all the new hands want two or 3 rupees to get themselves up with smart clothes, arms, etc. They are besides generally introduced by some old hands, whobesides complaining of impecuniosity themselves, always derive a perquisite out of the first advances to a recruit. It will be necessary, therefore, to 
authorize Major Agnew, who is zealous in the business, or 34 myself, to give them an advance on their being enrolled."

But then Ochterlony came to the rescue, by sending some 700 Kumauni soldiers who had been serving in Hindur, and the Company was spared the agony of loosening its purse-strings. ${ }^{35}$ The available soldiers in Nahan and Hindur, on the other hand, greatly exceeded the estimated need; ${ }^{36}$ and as Hastings was anxious to honour the pledge of employment which all the deserters had been given, he was compelled to reject Ochterlony's plan for a single regiment of two battalions, and order the embodiment of three battalions, each consisting of eight companies of 120 privates. They were denominated the 1 st and 2nd Nasiri Battalions, and the Sirmur Battalion. They were organized on the same pattern as the Kumaun Battalion. To each was attached a European commandant and-Adjutant, and the monthly pay of each private was five/ rupees (about elevenshillings), less offreckonings. ${ }^{37}$ The uniform of the four corps was to be "clove green jacket without facings, red cuffs, collar, and trimmings". 38 The value of these new battalions was quickly made apparent. The regular sepoys detested the climate of the hills, and it was not long before sickness and desertion were seriously depleting the ranks of those in Kumaun. ${ }^{39}$ At first, the Governor General was not disposed to humour this dislike, because in his view, "it would not...be wise or politic...to unaccustom the native troops altogether to hill service. ${ }^{40}$ But by the middle of 1816 , he had relaxed this attitude, and found it expedient to replace a part of the regular infantry stationed in Kumaun by the 2nd Nasfiri Battalion. 41

The "Gurkhas" have become legendary by virtue of their service with the British, but it was in fact a long time before the British exploited this new acquisition to their fighting strength. Successive commanders in chief in Indiarecognized the potential worth of the hill corps, but fear of offending the high-caste sepoys of Bengal and Bihar, as well as parsimony, long operated to prevent their being brought into the regular army; while distaste for the idea of employing mercenaries precluded their being replenished or supplemented with bodies of recruits from Nepal proper. The Sikhs were far more enterprising than the Company in this regard. Ranjit Singh had followed the progress of the war with 
close interest, and the resistance offered by the Gurkha army to the British convinced him of the importance of skilled infantry. ${ }^{42}$ Almost as soon as hostilities were over he had Siva Dat Rai (Amar Singh Thapa's old mentor - now a refugee in Sikh territories) send an agent across the Sutlaj, who was to try to entice the men of the 2nd Nasiri Battalion to forsake the Company's service for his own. ${ }^{43}$ This particular design was unsuccessful, despite his offer of high pay; but Nepali mercenaries did enter his army in increasing numbers as time went on. They even included Bal Bahadur Singh, the hero of Kalanga. 44 To this day, the Gurkhali word for mercenary is lahure - ore who goes to Lahore. Most hillmen in the Company's service had to make do with inferior status and the same miserable pay for 50 years. ${ }^{45}$ It was only in 1861 , after they had shown superb steadfastness during the Mutiny of 1857, that the hill corps (save the Nasiri Battalion, made regular in 1850) were finally brought into the line and the prejudice against mercenaries from among the tribes of Nepal abandoned. Now called Gurkha regiments, the original number had been increased to ten by 1947, of whom four, including the Sirmur Battalion, under its modern title, remained with the British Army. The others became part of the Army of the Republic of India.

Hastings did not receive many thanks for his victory over the Gurkhas, because he had influential detractors in the court of Directors. The Court was required by the Board of Control to approve his dealings with Nepal in principle, ${ }^{46}$ but its Chairman, Charles Grant, a venerable figure with immense experience of Indian affairs, was too implacable an opponent of Hastings' martial pretensions to neglect to find some way of deploring the scale of the war. Under his guidance, the court resumed its favourite theme and complained of the enormous expense involved, which it attributed to the Governor General's elaborate strategy. The objects of the war might, it insisted, "have been secured by the employment of one strong concentrated body of troops".

"We therefore regret that you should have deemed it necessary to pursue a course of hostilities upon an extended plan in a country so extremely difficult of access, both from situation and climate, as Nepal... We are inclined to the opinion, from the nature of the resistance opposed by the enemy, that if, instead of dividing our force into so many detachments for the purpose of 
offensive operations, a concentrated attack had been made, it might possibly have been the means of bringing the war to a successful conclusion without looking to the issue of another campaign." 47

This was a common criticism, 48 and it almost certainly originated with Nugent, who had arrived back in England full of rancour, ready to support Edmonstone's lamentations concerning expense with on the spot recrimination. ${ }^{49}$ Hastings had no difficulty whatever in undermining the Court's rebuke, because the war had, in fact, been conducted with remarkable economy. The expenditure incurred during the first campaigns had been scarcely more than a third of the original estimate, considerably less than the charges involved in either of the campaigns of 1803-04 and 1804-05, and less than a third of the expense of any former war in India for a corresponding length of time. In any case, the cost of the war, which was roughly estimated at a million Sterling, was more than covered by the half of the oudh loan which was to be liquidated with acquired territory. 50

These revelations took the wind out of the Court's sails, and it was obliged to modify its attitude. It conceded that the arrangements for the final campaign had been "very judicious, both in a military and in a political point of view", 51 and expressed its satisfaction at the economies which the commissariat had realized. ${ }^{52}$ But no real gratitude lay behind its formal phrases. Besides the intense distaste of men like Grant for all acquisitive enterprises, there was a general apprehension in London lest Hastings' policy should embroil the Company with China - if not directly, then in the long run, by making the British territories contiguous to those of China in an area where the frontier was almost bound to be a cause of altercation. ${ }^{53}$

While the Directors were eager to expatiate on the ruinous expenses created by the war, they were by no means ready to adopt those measures which it had plainly indicated would lead to long-term economies. Still paralyzed by a petty cash mentality, they remained incapable of balancing immediate sacrifices against the prospect of ultimate gain. Hence, although they recognized that the commissariat had saved considerable expense, they refused to allow that department to profit by its recent experiences and perfect $i$ ts organization. Hastings warned that "satisfactory 
as the duties were fulfilled, the machine was evidently too feeble." He continued: "the individuals whom I temporarily lent to the commissariat, though deserving of applause for zeal and activity, were avowedly ignorant of details, and might have been found deficient had the enemy been skilful enough to comprehend the consequence of intercepting convoys." He therefore proposed increasing the permanent staff of the commissariat by five officers, making a total of 24.54 The Directors refused to sanction the increase, and complained that they saw no reason why it had ever been necessary to add to the original staff of eight. Fearful that such augmentations would lead to understaffing in the regiments, they commanded that "the utmost attention be paid to confining the number of officers employed on the commissariat both in peace and war, within the narrowest practicable limits." 55 At the same time, they ordered meas ures designed to stifle the department's independence. Normally; all applications for government funds in Bengal had to be screened by the Military Board. This was a committee of the seven senior staff officers of the Bengal army, to whose "unbiassed pinions"the Court professed itself "accustomed to look with confidence in all cases of military expense", but which, in the opinion of a later Governor General, Dalhousie, "managed everything and marred everything". 56 It had been intended, in Calcutta, that the Commissary General's operations should be speeded and facilitated by his being allowed to submit his applications for money through the Military Auditor General; and it had been reckoned that, as his own department would therefore not be liable to the scrutiny of the Board, he might, in recognition of the importance of his office, be given a seat on that body. But the Directors peremptorily objected. They made it plain that they did not understand the commissariat to be independent of the Board at all. Not only did they take exception to his having a seat on that body; they furthermore instructed that he was to have no official status whatever. 57 In 1817, they directed first that the Military Board make an annual report on the commissariat's accounts; 58 and then that the Commissary General be made directly subordinate to the Board, through which he was thenceforth to submit all his applications for funds. 59 The consequence of all this jealous restriction was that the commissariat never became 
capable of fulfilling its functions. In 1824, Sir Edward Paget, the new Commander in Chief, complained, very much as Horsford had done ten years before, that "the efficiency of the army would be destroyed were the troops taught to depend on the commissariat for the carriage of their private baggage." 60

The branch of the army which had emerged from the war with is reputation in ruins was the guides and intelligence department. Instances of its inefficiency were manifold, and almost every calamity of the war was caused in some measure by its failings. Treacherous guides had taken Gillespie's columns astray at Kalanga, and led John Wood into a trap. No guide had been provided for the party with Richards' spare ammunition on December 26th, 1814, and no messengers had been posted along his route. Inaccurate intelligence had upset Martindell, confused Marley, terrified the frontier magistrates, caused Hastings to pronounce negotiable a pass that was in fact a death trap, and led Ochterlony into a defile from which he had emerged only by miraculous good luck. Again, the basic mischief was stinginess. An army gets only the intelligence it pays for. The King's army/recognized this and set up a special fund called secret service money, and general officers were allowed to account for its disbursement on oath, without divulging the names of informants. In India, there was no separate intelligence organization. Securing information and guides was a function of the Quarter Master General's department, which was allowed so little money for the purpose that no useful spy could be induced to sell his services. During the war in the Carnatic, in 1780, when a man, at the risk of his life, brought Sir Hector Munro information concerning the position of Colonel Baillie's detachment, Sir Hector gave him sixteen shillings. The situation was still much the same 66 years' later, when one Bengal officer complained:

"In India, you can...easily get intelligence if you pay well; but no man will risk his life for 16 shillings... It is probable that for every rupee we save by low payments, we lose hundreds or thousands of rupees and many valuable lives."6l With regard to the size of the army, even the Directors were compelled to admit that an increase was necessary; but, concerned above all else with immediate economy, they allowed only "the establishment of 
provincial corps to a certain limited extent", and the formation of "some local corps in the hilly districts lately acquired from Nepal." They sanctioned the augmentation proposed by Hastings for the corps of irregular horse only on the condition that no additions were made to the regular cavalry. His three extra regiments of regular infantry they regarded merely as temporary expedients for the emergency of the Nepal war. "We therefore trust that no impediment will arise to their being disbanded at an early period." ${ }^{62}$ Their wish was never acted on, because war with the Marathas and their Pindari henchmen had broken out before the despatch reached India, and the enormous increase in British territorial responsibility with which that struggle ended would have made such a reduction quite unrealistic; but from then on the use of ad hoc local and provincial bodies of troops as cut-price altematives to new regular battalions became well established. The army grew mainly by means of them, and within a decade there were something like 30 battalions of irregular infantry and eight regiments of irregular cavalry in Bengal. ${ }^{63}$

This method of augmenting the military establishment had one grave disadvantage: it made the shortage of European officers even more acute, because each irregular corps required between two and eight officers of the line. The experience of the Nepal war, combined with the effects of this new drain on the army's contingent of regimental officers, led critics to press for an increase in their number, ${ }^{64}$ and in 1825 the Calcutta government made a formal request to that effect. But the court had no intention of nullifying the economies realized in one sector by increasing expenditure in another. It insisted that any deficiency in the number of regimental officers was caused only by the indiscriminate allotment of military men to political functions, and it stubbornly refused, until the very end of its existence, to authorize any significant increase. 65

War is bound to expose weaknesses in any military organization; but the dismissal, for professional ineptitude, of three out of the four Company major-generals employed in the invasion of Nepal indicated nothing less than the fatal deficiency of the company's method of promotion. Yet no 
attempt was ever subsequently made to remedy even the worst abuses of the seniority system by making retirement compulsory or financially enticing, or both, at a suitable age. Until the Mutiny of 1857 there remained "brigadiers of seventy, colonels of sixty, and captains of fifty" 66 -to say nothing of generals of eighty-five, like Marley. Lord Roberts wrote in his memoirs:

"It is curious to note how nearly every military officer who held a command or a high position on the staff in Bengal when the Mutiny broke out, disappeared from the scene within the first few weeks, and was never heard of officially again. Some were killed, some died of disease, but the great majority failed completely to fulfil the duties of the positions they held, and were consequently considered unfit for further employment. Two Generals of divisions were removed from their commands, seven Brigadiers were found wanting in the hour of need, and out of the seventy-three regiments of Regular Cavalry and Infantry which mutinied, only four commanding officers were given other commands, younger officers being selected to raise and command the new regiments." 67

Curious it may have been to young Roberts; but to anyone who remembered Nepal, the situation must have been only too terribly familiar. It was not only that seniority promotion made responsible officers old and tired; it also completely divorced rank from merit, and made the whole military hierarchy ridiculous. By the time he died, Ochterlony had been superseded in rank, and was therefore liable to be commanded, by both/officers (Martindell and George Wood) whom he had been appointed to replace in the war of 1814-16.

Other lessons of the war were disregarded because of a callous concern to preserve vested interests. Perturbed to hear of the part which the sepoys' cartridge boxes had played in the defeat of Lawtie's detachment on November 26th, 1814, Hastings and the Military Board turned their attention to improving the design of this article, and requested the Court to send no more from England. The Directors made no reply to this communication, but, eighteen months later, informed the calcutta government that they had been disturbed by a private report concerning an engagement in the late war, in which "a party of infantry were cut off under a Captain Williams... owing to the cartridges sticking in the pouch boxes." 
They had, they explained solicitously, "deemed the rumour to be of sufficient importance to enquire whether any such incident did occur and, if so, the grounds from which it appeared to proceed." Would it be preferable, they wondered, tosend tin cartridge boxes in future? "This article of military store has at different times led to much discussion and egrossed much more of the time of our survey department than any other." In reply, Calcutta patiently reiterated its wish that all such consignments from England be stopped. "This article of military equipment... can at all times be prepared here at trifling expense, of a quality equal to those sent from Europe... We understand that a cartridge box on an improved plan, particularly calculated for the service and climate of India, has been prepared by the commissariat and approved by His Excellency the Cormander in Chief." But the Court had no intention of transferring any of its contracts for military stores from England to India and, Calcutta having intimated that the substitution of wood by tin would not solve the problem, it simply continued to send boxes of the old type. They were still in use twenty years later, when a writer in a military journal complained: "The 'office men' by whom these things have been regulated continue to issue these worse than useless, because dangerous equipments." He stated that they had become so disreputable, that the sepoys in action at the final siege of Bharatpur in 1826 had carried their cartridges loose in their pouches. All the boxes had been left in a pile under the protection of a sentry, to be replaced when the flghting was over. 68

Circumstances made it easy for the court to be remiss towards its armies. It was very difficult for the Directors to share the sense of urgency which caused men on the scene to place such importance on efficiency in their military arrangements. Most had never been to India, and they formed their policies in the remote calm of East India House, with its heavy furniture and imperturabable clocks, from the evidence only of calligraphic despatches and complacent newspapers detailing events four, five, or even six months old. In such an atmosphere private ideals, mania for economy, and fear of strengthening the hands of the Company's critics by infractions of the spirit of Pitt's Regulation Act, were bound 
to weigh heavier than the local realities of Indian politics. Even the memory of the American experience was insufficient to awaken the Directors to the possibility of their Indian possessions being lost. It is noteworthy that even Hastings, a soldier who had been directly involved in the struggle to retain the American colonies, had, earlier in his career, been as ready as anyone to condemn the military pretensions of Indian statesmen. It was only when he arrived in India that his views changed, and he became the most martial of them all. But news of the worst calamities of the Nepal war still failed to trouble the Court's equanimity. "The only objects which, in our situation of pre-eminent power maintained by most expensive establishments, could render a war proper with the poor and mountainous country of Nepal, were the preservation of our honour and the integrity of our territories", it pronounced with unshakable self-assurance, at the end of 1815. ${ }^{69}$ Yet it was, in fact, precisely the lack of pre-eminent power which that war had by then served to demonstrate. Although members of the government in India argued whether pre-eminence was necessary, none of them seems ever to have pretended that it actually existed. They were too close to the evidence too delude themselves so far. The Bengal army had proved itself so inadequate, in one way and another, for the type of war it was fighting, that other frontiers had had to be denuded in order to reinforce it, and urgent recourse had to other colonies for extra British troops. When success was finally achieved, every nerve was strained, and every resource exploited. There was no power in reserve, because Europe was again in ferment, and no troops could be spared from home. Had the Sikhs and the Marathas, or either, joined their strength to that of the Gurkhas, it is hardly debatable that the British dominions in north India at least would have been destroyed.

The reality was not, then, a pre-eminence of power; and insofar as there was a balance of power, it was a fortuitous one, maintained by political events outside British control. The British victory against Nepal was not the ineluctable, pre-determined consequence of British might. It was not achieved by the crude appurtenances of power - by numbers, wealth, weapons, and superion military organization - alone; but by these plus good luck, and the extraordinary ingenuity, dynamism, and courage of 
a handful of European officers. An anonymous civilian who accompanied Ochterlony on both his campaigns reckoned that the officers had been the saviours of the army:

"The general owed the execution of his designs entirely to the unyielding resolution and ability of the officers, qualities which were auspiciously manifested when they had to keep their ground or throw up fortifications in the face of a victorious enemy."

He ascribed the unsteadiness of the sepoys to fundamental defects in the native character. They had no notion of disinterested honour, and were deficient in mental energy. He drew the inference that more European officers were essential, as the only source whence they could imbibe such qualities. 70 This is, of course, an unsound diagnosis. It was afterwards estimated, by a reliable judge, ${ }^{71}$ that in addition to sustaining some 3,000 battle casualties, the Bengal army/lost about 2,000 men as a result of sickness and desertion during the Nepal War. This indicates that lack of training for such a novel type of warfare, and the demoralizing influence of inadequate clothing, sanitation, equipment and shelter, and of what Hastings himself called the "constant, harrassing, and unmilitary duties imposed on them even in times of peace", 72 were the real causes of their infirmity. The presence of British officers was not, therefore, a panacea for the army's ills; but there is no doubt that the example of the best of them was still of immense importance as a palliative.

To modern eyes, these officers seem half unreal, archaic figures. This is bound to be so, because the circumstances which moulded them have no modern equivalent. Wars are no longer fought without maps, scientific medicine, knowledge of hygiene, specially adapted clothing and food, organized intelligence, $h$ radio and aircraft, on peripheries of the known world. Theirs is a lost experience; and it fostered mutations which make them strange. In some, no doubt, the normal human properties were destroyed. Instances of suicide and pathological deviation there must have been, even though they are not recorded. But in the best, they were heightened by vivid compensatory qualities. These officers became sublimelbrave, and capable of the alchemy which transforms men into heroes. The Nepal War marks the beginning of the final stage in the history 
of the Bengal army. It was a stage marked on the one hand by the struggle to rationalize the army's internal structure, and on the other by its increasing involvement in difficult and far distant operatious. The Nepal War, which was an initial exercise for the inchoate military organization of Bengal, and a foretaste of the sort of service which the sepoys would increasingly have to undergo, served to demonstrate the sort of leader which the army now needed. But it also served to demonstrate that such was not the sort of leader which it provided. The most successful commanders of the War - Ochterlony, Nicolls, and William Gardner - were not products of the Bengal system of promotion. Ochterlony was a junior general officer and would hever have had an independent command had it not been for the accident of Gillespie's death; Nicolls was a King's officer; and Gardner was a freelance. It was the least successful commanders who had owed their advancement to the system.

The Bengal army never resolved its new problems. Each step in the process of rationalization was more painful, and everyone knows what happened when greased cartridges were introduced. Journeys to distant theatres of war became causes of unrest and rebellion. These ills could not be controlled and contained because as the need for it increased, so the palliative of good leadership grew weaker. At regimental level officers continued to get fewer, less able, and, because of changing social conditions in India, increasingly out of touch with the men. The holders of high commands continued to be enfeebled by age and mental exhaustion. The causes of the destruction of the Bengal army in 1857 are no doubt manifold and complex; but its essential precondition was the destruction of that army's best asset: the European officers who were qualified by ability for their repousibilities. 


\section{Appendix}

TREATY of PEACE between the HONOURABLE EAST INDIA COMPANY and MAHA RAJAH BIKRAM SAH, Rajah of Nipal, settled between LIEUTENANTCOLONEL BRADSHAW on the part of the HONOURABLE COMPANY, in virtue of the full powers vested in him by HIS EXCELLENCY the RIGHT HONOURABLE FRANCIS, EARL Of MOIRA, KNIGHT of the MOST NOBLE ORDER of the GARTER, one of HIS MAJESTY'S MOST HONOURABLE PRIVY COUNCIL, appointed by the Court of Directors of the said Honourable Company to direct and control all the affairs in the East Indies, and by SREE GOOROO GUJRAJ MISSER and CHUNDER SEEKUR OPEDEEA on the part Of MAHA RAJAH GIRMAUN JODE BIKRAM SAH BAHAUDER, SHUMSHEER JUNG, in virtue of the powers to that effect vested in them by the said Rajah of Nipal, - 2nd December 1815.

Whereas war has arisen between the Honourable East India Company and the Rajah of Nipal, and whereas the parties are mutually disposed to restore the relations of peace and amity which, previously to the occurrence of the late differences, had long subsisted between the two States, the following terms of peace have been agreed upon:-

\section{ARTICLE IST.}

There shall be perpetual peace and friendship between the Honourable East India Company and the Rajah of Nipal.

\section{ARTICLE 2ND.}

The Rajah of Nipal renounces all claim to the lands which were the subject of discussion between the two States before the war; and acknowledges the right of the Honourable Company to the sovereignty of those lands.

\section{ARTICLE 3RD.}

The Rajah of Nipal hereby cedes to the Honourable the East India Company in perpetuity all the undermentioned territories, viz.-

First. - The whole of the low lands between the Rivers Kali and Rapti. Secondly. - The whole of the low lands (with the exception of Bootwul Khass) lying between the Rapti and the Gunduck. 
Thirdly. - The whole of the low lands between the Gunduck and coosah, in which the authority of the British Government has been introduced, or is in actual course of introduction. Fourthly. ; All the low lands between the Rivers Mitchee and the Teestah.

Fifthly. - All the territories within the hills eastward of the River Mitchee including the fort and lands of Nagree and the Pass of Nagarcote leading from Morung into the hills, together with the territory lying between that Pass and Nagree. The aforesaid territory shall be evacuated by the Gurkha troops within forty days from this date.

\section{ARTICLE 4 TH.}

With a view to indemnify the Chiefs and Barahdars of the State of Nipal, whose interests will suffer by the alienation of the lands ceded by the foregoing Article, the British Govemment agrees to settle pensions to the aggregate amount of two lakhs of rupees per annum on such chiefs as may be selected by the Rajah of Nipal, and in the proportions which the Rajah may fix. As soon as the selection is made, Sunnuds shall be granted under the seal and signature of the Governor-General for the pensions respectively.

\section{ARTICLE $5 \mathrm{TH}$.}

The Rajah of Nipal renounces for himself, his heirs, and successors, all claim to or connexion with the countries lying to the west of the River Kali and engages never to have any concern with those countries or the inhabitants thereof.

\section{ARTICLE 6TH.}

The Rajah of Nipal engages never to molest or disturb the Rajah of Sikkim in the possession of his territories; but agrees, if any differences shall arise between the State of Nipal and the Rajah of Sikkim, or the subjects of either, that such differences shall be referred to the arbitration of the British Government by which award the Rajah of Nipal engages to abide. 
ARTICLE 7TH.

The Rajah of Nipal hereby engages never to take or retain in his service any British subject, nor the subject of any European or American State, without the consent of the British Government.

\title{
ARTICLE 8TH.
}

In order to secure and improve the relations of amity and peace hereby established between the two States, it is agreed that accredited Ministers from each shall reside at the court of the other.

ARTICLE 9TH.

This treaty, consisting of nine Article, shall be ratified by the Rajah of Nipal within fifteen days from this date, and the ratification shall be delivered to Lieutenant-Colonel Bradshaw, who engages to obtain and deliver to the Rajah the ratification of the Governor-General within twenty days, or sooner, if practicable.

Done at Segowlee, on the 2nd day of December 1815.

$$
\text { PARIS BRADSHAW, Lt.-COl., P.A. }
$$

Received this treaty from Chunder Seekur Opedeea, Agent on the part of the Rajah of Nipal, in the valley of Muckwaunpoor, at half-past two o'clock p.m. on the 4th of March 1816, and delivered to him the Counterpart Treaty on behalf of the British Government.

\author{
DD. OCHTERLONY, \\ Agent, Govermor-general.
}


REFERENCE NOTES. 


\section{Notes to Chapter One}

1. B. H. Hodgson, "On the Aborigines of the Sub-Himalayas", S.R.G.B., vol. xxvii: 1857, p. 134 .

2. Sylvain Levi, Le Nepal, vol. i, pp. 220-38, vol. ii, passim; B. H. Hodgson, "A Description of the route from Kathmandu...to Darjeeling in Sikim", loc.cit., p. 144; Edwin T. Atkinson, The Himalayan Districts of the North West Provinces of India, vol. ii, pp. 355, $362,460,466$; Luciano Petech, Medieval History of Nepal, -p. 1, $6-7,29,179 ;$ A. L. Basham, The Wonder That Was India, pp. 40, 63, 70, 96; Daniel Wright (ed.), History of Nepal, p. 77; Stanley Maron, Leo E. Rose, et al., A Survey of Nepal Society, Chapter VI, passim.

3. Petech, op. cit., passim; Levi, op. cit., vol. i, pp. 15, 226, et seq.

4. Caste is a Portugese word, denoting the jat of Hindu society--a group which is endogamous and commensal. The system of caste organisation probably had economic origins, and it grew up independently of the classical brahministic division of society into four varna (literally, colour), though the attempt was made to harmonize the two systems by classifying the castes as brahmana (priestly) ksatriya (warrior), vaisya (peasant), and sudra (serf): see Basham, op.cit., pp. 35, 148. The chetris are in effect an endogamous group. The only subdivisions are thar (clans), which are generally exogamous, and gotra, which are strictly so. There are about three dozen thar, scattered widely through the Nepal hills to Kashmir. Gotra are subdivisions of the thar. All members of a gotra, claim descent from the same ancestor. Most traces of the endogamous tribal castes which originally made up the Chetri group seem to have disappeared.

5. Sukhet, Mandi, Kionthal and Kashtawar, for example: see J. Hutchis on and J. Ph. Vogel, History of the Panjab Hill States, vol.i, p. 341 .

6. D. N. Majundar, "Some Aspects of the Cultural Life of the Khasa of the Cis-Himalayan Region", J.R.A.S.B. (Letters), vol. vi: Nov., 1944, pp. 1-44.

7. Atkinson, op.cit., vol. ii, p. 282.

8. Ibid., p. 283.

9. Majumdar, op. cit., passim; Atkinson, op. cit., vol. ii, p. 440.

10. G. Tucci, Preliminary Report, pp. 109 et seq.

11. Petech, op. cit., pp. 102, 105, 113. 
12. Ibid., p. 123.

13. T. W. Clark, Introduction to Nepali, p. vii.

14. For example: The Raja of Basahar (J. B. Fraser, Journal of a Tour, p. 269); The Raja of Palpa (Levi, op. cit., vol. i, p. 262); and the Raja of Gurkha (Francis Hamilton, An Account of the Kingdom of Nepal, p. 26). In fact, the Muslim invasions probably only speeded up a process which had been going on for centuries. The hills were the natural asylum of political exiles and adventurers in times of crisis and upheaval. There were also the generations of brahmins who found their way to the shrines in the mountains as genuine pilgrims.

15. Older theories concerning the origin of the Chetris were based on the assumption that the term had no significance except as a vernacular distortion of Ksatriya. Levi, thought that the mongolian Magar tribesmen were the earliest inhabitants of the western hills, and thatthey were the first to come into contact with the exiles from Rajasthan. Basing his conclusions on the pioneer investigations of Hodgs on, he took the present Khas to be the product of miscegenation between the Rajput and brahmin exiles and native Magar women. The illegitimateprogeny of these unions, while keeping the names of their fathers, formed a new caste called Khas. Since its inclusion in the Laws of Manu, the designation Khas had lost any identification with a specific tribal society, and was used as a general pejorative for the barbarous hill peoples of the north. The brahmins now revived the old name as a label for the new caste, which was allowed ksatriya status. Membership of the new group was increased by the admission of Magar proselytes, and so became a hybrid caste including brahmin, Rajput and Magar clan names. Ultimately, the authentic Rajputs merged with the new ksatriyas or Chetris, and all became members of a single tribal caste called Khas. This theory, which recognizes no distinction between Khas and Chetri, and sees the Khas as a new creation, was founded on the erroneous assumption that Nepali, the language of the Khas and Chetris of the Nepal Valley, was in itself a recent language - a mere patois or dialect of Hindi. Levi considered its existence to be an important indication of the recent infiltration of Hindi speakers into the hills. It was professor R. L. Turner who first contended that Nepali had its closest affinity with the much earlier Indo-Aryan dialects of the north west Panjab - especially Kumauni with which it has experienced important sound changes not shared by dialects of the plains. He reckoned that, at the most, southerm languages such as Hindi lent words to Nepali, thus giving it a superficial similarity to themselves. When Tumer published these views, he had no knowledge of any written Nepali more than a century old, and his conclusions were based entirely on his examination of sound changes. Recently, Tucci's Report on his scientific expeditions to west Nepal revealed the existence of a 
royal donation dated 1376 and written partly in a dialect which sufficiently resembles the modem language of Nepal to be alled "old Nepali". This confirms Turner's theory that Nepali is related to dialects which were in use in the western hills long before the first major incursion of Hindi speakers; in fact it confirms that it was closely related to the language of the group of Khas whose corporate and cultural existence it was the main achievement of Tucci's expeditions to reveal.

Nepali is but one dialect among a number of related tongues known generically as Khas kura (Khas speech) or Parbatiya (relating to the hills). Modem Nepali is often referred to as either of these names, but this in effect involves using generic terms for an individual dialect. A much more satisfying label for the language is Gurkhali, because this refers the dialect to the Khas of a specific area.

See: Levi, op. cit., vol. i, pp. 253-61; B. H. Hodgson, "On the Origin and Classification of the Military Tribes of Nepal", loc. cit., pp. 141-44; R. L. Tumer, Comparative and Etymological Dictionary of the Nepali Language, pp. xxx, xiii-xvi; Tucci, op. cit., p. 113 .

16. This became apparent in Brahma Shah's conferences with Edward Gardner during the war. Vide infra, Chapter Eleven.

17. Hamilton, op. cit., section iv, passim; W. Kirkpatrick, An Account of the Kingdom of Nepal, chapter viii; Hutchison and Vogel, op. cit., vol. i, pp. 75-77.

18. Hodgson, in "On the Law and Legal Practice of Nepal", loc. cit., pp. 231-33, remarks on this, but ascribes it to a conscious desire, on the part of refugees from Muslim bigotry, to preserve the traditions of Hinduism undefiled. This would appear to be far too sophisticated an attitude to attribute to the unidealistic and untutored Gurkhas, who were quite ready to waive the prescriptions of ritual when policy demanded. Kirkpatrick recounts that the Nepalese army was authorised to consume chauri bullocks during its expedition into Tibet (1788-92) on the ground that these animals were not distinguished by the long dewlaps which were the generic mark of the sacred bull. (Op. cit., p. 120). Furthermore, the Hinduism practised by Prithvi Narayan Shah and the Gurkhas seems to have been far from undefiled. It was a primitive, sacrificial religion, characterised by worship of the most baneful forms of the female aspect of the deity Shiva, and betraying the persisting influence of pagan fertility rites and Tantrism.

19. Hamilton, op cit., p.110; Kirkpatrick, op. cit., p. 124; Henry Ambrose Oldfield, Sketches from Nepal, vol. i, p. 172. 
20. Hamilton, op. cit., p. 210; Kirkpatrick, op. cit., p. 186.

21. Hamilton, op. cit., pp. 141-44; K. C. Chaudhuri, Anglo-Nepalese Relations, pp. 49-54.

22. MS History of Sikkim, ff.70, 89-93; F. Buchanan Hamilton's* report on Sikkim: P.R.N.W., p. 267.

23. Such is essentially the version given by Hamilton, op. cit., pp. $120-33$, and $P \cdot R \cdot N \cdot W \cdot$, P. 268. His Yu Kang Ta seems to tally with the Yug Namcha of the MS History, but without a knowledge of both Tibetan and Bengali, no further collation of names can be risked. The MS makes no reference to the arrangement at Nagri. Mention of Yu Kang Ta's brother is given in Captain Latter's version of the story, Mil. Cons., 23rd. Dec., 1814, no. 61. According to Latter's information, the arrangement at Nagri was the result of the old Raja's brother having defected to the Gurkhas and come to private terms with them. One of his sons (Yu Kang Ta or Yuk Namcha) continued in the civil government there under the Gurkhas; but theother remained with the raja as his minister. The MS History confirms that Yu Kang Ta and the chagzod were brothers. Latter's names appear to be wildly phonetic renderings of Bengali versions, which have been made even more confusing by the mistranscriptions of Calcutta clerks. Thus Yu Kang Ta becomes Under Gaboor - recognisable because Hamilton, op. cit., p. 123, mentions that Yuk Namchu was called Angriya Gabur by the Bengalis - and Chogyal Namgyal becomes alternatively Chadoo Nangie (!) and Jan Kiram (Bengali). He gives the name of the defecting brother as Jam Karowan.

24. Hodgson, "Route from Kathmandu...etc.", loc. cit., p. 118; Evidence of Kumar Swami, erstwhile guru of the Vijaypur raja in E.S.D.B., vol. ix, no. 394 .

25. Hamilton, op.cit., pp. 173-76.

26. Atkinson, op. cit., vol. ii, pp. 467-571, 580-611, 617; Letter from Captain H. Hearsey to Government: P.R.N.W., P. 47; Memorandum by William Fraser: P.R.N.W.Pp. 244-45.

27. G. W. Traill, "Statistical Sketch of Kumaun", A.R., vol. xvi: 1828, pp. 189-90; W. Moorcroft, "A Jourmey to Lake Manasarova in Undes, a Province of Little Tibet", A.R., vol.xii: 1816, p. 514 .

28. In 1806, for example, a body of about 1,200 came down into Rohilkhand to escape oppression. See Home Misc., vol. 515, f. 468.

*At this time he was using the single name of Buchanan, I include his later name for the sake of clarity. 
29. G. W. Traill, "Statistical Report on the Bhotia Mehals of Kumaun", A.R., vol. xvii: 1832, pp. 30-3l; Traill, A.R., xvi, p. 190; Atkinson, op. cit., vol. ii, p. 616.

30. Memoir by Captain Raper: P.R.N.W., PP. 145; 147; Letter from Capt. H. Hearsey to Govt: P.R.N.W., p. 49; Memorandum by W. Fraser: P.R.N.W., p.245; Atkinson, op. cit., vol. ii, p. 624.

31. Traill, A.R., xvi, p. 190; Atkinson, op. cit., vol. ii, p. 625.

32. Chaudhuri, op. cit., pp. 102-04, 142-44; Hamilton, op. cit., pp. 248-6l; Oldfield; op. cit., vol. i, pp. 284-96; J. Talboys Wheeler, A Short History of India and the Frontier States of Afghanistan, Nipal and Burma, part 3 , chapter $x l$, passim; Hearsey to Government: P.R.N.W., p. 47. The text of the last source states that Amar Singh Thapa in the west was 'nephew' to Bhim Sen Thapa. This should undoubtedly read 'uncle'. In one letter in the English records (addressed to Ochterlony: Sec. Coms., 27th Sept., 1815, no. 43) Amar Singh Thapa in the west refers to Bhim Sen as his 'son'. But this is probably a translator's error, arising from the fact that in Nepali distinction is not always made between 'son' and 'brother's son'. Neither Hamilton, nor Atkinson, nor Chaudhuri realised that there were two officers with this name. Chaudhuri contends ( $p .42)$ that the senior queen's return was not intended as a prelude to her husband's reinstatement. I remain unconvinced - especially if, as Wheeler affirms, she and Bhim Sen were lovers.

33. J. B. Fraser, op. cit., p. 7.

34. Acting Resident at Kathmandu to Govermment, 18th April, 1816: Sec. Cons., 4th. May, 1816, no. 54 .

35. Hamilton, op. cit., p. 26l; Capt. F. V. Raper, "Narrative of a Survey for the Purpose of Discovering the Source of the River Ganges", A.R., vol. xi: 1810, p. 560 .

36. Atkinson, op. cit., vol. ii. pp. 575-79; G. R. C. Williams, Historical and Statistical Memoir of Dehra Doon, pp. 97-105.

37. Atkinson, op. cit., vol. ii, pp. 615-16; Williams, op. cit., pp. 105-112; J. B. Fraser, op. cit., pp. 383-84; Report by W. Fraser: P.R.NW., Pp. 240-4l; Lt. R. Ross, "Memoir on the Hill States between the Tonse and Sutleje": Sec. Cons., 27th. Sept., 1815 , no. 41.

38. H.H. Wils on (ed.), Moorcroft and Trebeck, xi, pp. 463, 494; Capt. H. Hearsey to Govt.: P.R.N.W., P. 48; Memoir by Capt. F. Raper: P.R.N.W., p. 147; J. B. Fraser, op. cit., p. 218.

39. Atkinson, op. cit., vol. ii, p. 619, indicates that a donation of land was made to Kaji Amar Singh Thapa in Garhwal in 1804. 
39... Surya Vikram Jnavali, in Amar Sinha Thapa, p. 49, states that Amar Singh was not raised from the rank of sarda to that of kaji until 1810; but no authority is cited.

40. J. D. Cunningham, History of the Sikhs, 1955, p. 133, fn.

41. Ross, "Memoir".

42. The names of the Bara Thakuri as given by Ross and adopted in Walter Hamilton's Gazetteer, vol. ii, p. 612, are:

Kionthal, Baghat, Baghal, Kothar, Kumaharasin, Bhajji, Mailog, Dhami, Kiari, Kunhiar, Mangal, Koti.

the other fourteen Ross lists as:

Jubbal, Kotgarh, Balsan, Kanatu, Karankulu, Detailu, Thioka, Pandur, Kiund, Utraj, Sarani, Sangri, Barauli, Darkoti.

Both J. B. Fraser (p. 52) and Hutchison and Vogel (vol. ii, p.497) give different lists. Fraser lists 18 instead of 14 additional states, and his names have in many cases been distorted beyond recognition by the misreadings of his compositor.

Hutchis on and Vogel list the Twelve as:

Kionthal, Baghat, Baghal, Kothar, Beja, Bajji, Mailog, Dhami, Jubbal, Kunhiar, Mangal, Balsan.

43. J. B. Fraser, op. cit., p. 271.

44. The observer was G. Fonster. His description is quoted in Hutchison and Vogel, op. cit., vol. i, p. 178.

45. Ross, "Memoir"; Ross to Metcalfe, 17th April 1816: Sec. Cons., 25 th May, 1816, no. 2 .

46. Hutchis on and Vogel, op. cit., vol. i, pp. 79-80, 108, 179-81.

47. Ross, "Memoir". A slightly different account is given in the Nepalese vamsavali, as recounted by jNavali, op. cit., pp. 35, 37-38. According to these sources, Bhim Sen Thapa's brother, Nayan Singh Thapa, marched from Nepal with reinforcements for the Kangra expedition, and had a skirmish in Hindur on his way tojoin Amar Singh. Amar Singh, already at Kangra, sent a detachment to aid him, and the combined Gurkha forces defeated the Hindur troops at Ramsahar. Nayan Singh Thapa then joined the main amy before Kangra, but was killed in an attempt to take the citadel by a coup de main. If reinforcements were sent for the purpose from Nepal, it might perhaps add weight to the rumour that Amar Singh was forced by orders from Kathmandu, but against his own better judgement, to advance against Kangra. Ross mentions this but discounts it on the ground that the kaji mentioned no such compulsion in his later correspondence on 
47... the subject with Ochterlony. Moorcroft's informant mentioned that cannon were sent from Nepal for the siege of Kangra (P.R.N.W., p. 84); but this could have been in response to requests following the failure of attempts to take the place by storm.

48. jNavali, op. cit., p. 39 .

49. Ross, "Memoir".

50. Hutchis on and Vogel, op. cit., vol. i, p. 185.

51. Ross, "Memoir"; Raper, A.R. xi, pp. 502-03.

52. Hutchis on and Vogel, op. cit., vol. i, pp. 185-186; Cunningham, op. cit., pp. 12l, 132-33; jNavali, op. cit., pp. 40-44; Ochterlony to Govt., 20th Dec., 1813: Ludhiana Records, p. 360.

53. Ross, "Memoir".

54. See J. B. Fraser's observations on the state of Basahar, op. cit., pp. 271; 489-91.

55. Hamilton, op. cit., p. 26; B. H. Hodgson, "Memorandum Relating to the Gurkha Army": Sec. Cons., 4th. March, 1825, no. 16, para 13.

56. Hodgson, "On the Origin and Classification of the Military Tribes of Bengal": loc. cit., pp. 232, fn; 146.

57. Hodgs on, "Memorandum", paras $8 ; 9$.

58. Kirkpatrick, op. cit., pp. 214-15; information derived from a spy during the war: Home Misc., vol. 654, ff. 92-94; Henry T. Prinsep, Political and Military Transactions, vol. i, p. 86, fn. Prinsep's note is worth quoting:

"The use of English terms for their grades of command was general in the Gurkha army, but the powers of the different ranks did not correspond with those of our system. The title of general was assumed by Bhim Sen, as commander in chief and enjoyed by him alone;* of colonels there were three or four only - all principal officers of the court, commanding more than one battalion. The title of major was held by the adjutant of a battalion or independent company; and captain was the next grade to colonel, implying the command of a corps. Luftan, or lieutenant, was the style of officers commanding companies under the captain, then followed the subaltern ranks of subadar, jemadar, and havildar, without any ensigns."

"This presumably refers to the situation obtaining after the death of General Amar Thapa. 
59. Hodgson, "Memorandum", para. 6.

60. John Shipp, Memoins, p. 211; correspondence from the Acting Resident in Kathmandu: Sec. Cons., 4th May, 1816, nos. 55, 56, 57. Shipp refers to Brown and Bell; the Acting Resident to Bymes and Bell. Shipp obtained his information from a Gurkha officer, and obviously misunderstood his pronunciation. Shipp's informant said that both men had been dismissed at the start of the war, but this was contradicted by information obtained subsequently by the Resident and by his attempts to have them extradited. Moorcroft, in Pol. Cons., 18th Dec., 1812, no. 30, refers to a 'lleserter from the British army ... now entertained by the Gurkhas in the Dun with an increase of rank and allowance for the purpose of disciplining their troops according to the British system."

61. A.J., vol. ii: 1816, p. 324 .

62. When Hamilton visited Kathmandu (1802-03), uniforms were a standard red. He recalled that Kirkpatrick, ten years earlier, had remarked that they were then in a variety of colours - op. cit., p. 112 .

63. Shipp, op. cit., p. 198; after the war, the Acting Resident wrote (Sec. Cons., 4th May, 1816, no. 54):

"The troops were badly dressed in red clothing faced with blue, and were badly armed. Their officers were clad in the most fantastic and ludicrous manner in attempts to copy our several dresses..."

64. Hamilton, op. cit., p. 246 .

65. Moorcroft to Govt: P.R.N.W., Pp. $80-81,86$.

66. Ibid; Chaudhuri, op. cit., p. 93; Moorcroft to Govt., Nov. 24th, 1812: Pol. Cons., 18th. Dec., 1812, no. 30.

67. A.J., vol. ii: 1816, p. 324 .

68. C. R. Markham (ed.), Bogle and Manning, p. Ixxvii.

69. "Extract of a Letter dated Srinagar", C.M.J., vol. xxvii: October, $1815, \mathrm{p} \cdot 366$.

70. Evidence of Kumar Swami, E.S.D.B., vol. ix, no. 394; Hodgson, Memorandum, final section on artillery; J. B. Fraser, op. cit., p. 101; Hamilton, op. cit., pp. 112, 246.

71. Hamilton, op. cit., p. 78; Hodgson, "Route from Kathmandu...etc.": loc.cit., p. 117. A little saltpetre was produced in the Nepalese lowlands, but only sufficient to supply half the needs of the state - Bradshaw to Govt., 8th. April, 1814: Pol. Cons., 22nd. 
April, 1814, no. 43. Apparently the rich saltpetre deposits which Oldfield mentions (op. cit., vol. $i, p .25$ ) as existing in Sallyana, just east of Doti, had not yet been discovered.

72. Hodgson, Memorandum, paras $8,9, \&$ table entitled "Particulars of Effective Troops"; Report on the Hill Districts by Ochterlony: Ludhiana Records, p. 400.

73. Hodgs on, Memorandum, para 15; Memoir by Capt. Raper: P.R.N.W., pp. 145-46; Report on Hill Districts by Ochterlony: 1oc. cit., pp. 399-400, 407; Information supplied by Capt. Hearsey to Capt. Richards: Pol, Cons., 23 rd. July, 1813, no. 34; Moorcroft, A.R. xii, p. 513. Both Moorcroft and Hearsey were in agreement in estimating the proportion as $1 / 3$ regulars, $2 / 3$ locals. Ochterlony reversed the proportion. Hearsey estimated the whole army beyond the Kali at 6,000; Ochterlony estimated that beyond the Jumna alone at 7,000. Subsequent experience showed that Ochterlony's was an over-estimation - vide infra. Chapter Nine. A rough collation of available sources indicates that the strength and distribution of the regular army on the eve of the conflict was as follows:

War Strength of army - about 14,000. Distributed between Kathmandu and Palpa $(7,000)$, provinces east of the Kali $(3,500)$; and provinces west of the Kali $(3,500)$. Irregulars of equal strength west of the Kali would bring the total of troops there to 7,000.

74. Evidence of Kumar Swami: loc. cit.

75. Information supplied by Hearsey to Richards: loc. cit.

76. Information of Captain Richards: Pol. Cons., Aug. 20th., 1813, no. 34; Ochterlony's Report on Hill Districts: loc. cit., p. 399. Hyder Hearsey saw four guns lying on the ground outside

75. the entrance to Almora fort in Kumaun - P.R.N.W., p. 49.

秐7\%. Rutherfurd to Govt: P.R.N.W., p. 27; Memorandum by Hearsey: P.R.N.W., P. 55 .

78. Traill, A.R., xvi, p. 142 . 


\section{Notes to Chapter Two}

1. G. R. Gleig, Warren Hastings, vol. i, p.279. See also pp.296, 306.

2. F. B. Hamilton, An Account of the Kingdom of Nepal, p. 65;

W. H. Sleeman, A Joumey through the Kingdom of Oude in 1849-50, vol. ii, pp. 102-03.

3. George Campbell, Modern India, p. 305.

4. Sec. Cons., 27th April, 1816, no. 9, para. 13.

5. Sec. Cons., 27th October, 1815, no. 49; R. B. Pemberton, "Report on Bhutan", in Political Missions to Bootan, p. 12.

6. Sec. Cons., 27th April, 1816, no. 9, paras 38-57.

7. See, for example, the remarks of the Magistrate of Tirhut on claims submitted by one Raja 'Gurchur Narain', in Sec. Cons., 3rd Feb., 1816, no. 22; Henry T. Prinsep, Political and Military Transactions, p. 64; Walter Hamilton, Gazetteer of Hindustan and the Adjacent Countries, vol. i, p. 592 .

8. K. C. Chaudhuri, Anglo-Nepalese Relations, p. 86. Prithvi Narayan Shah had already displayed a conciliatory attitude by agreeing to pay rents for certain areas of the Tarai which rajas ejected by the Gurkhas had held as tenants of the Company - ibid., pp. 44,52 .

9. P.R.N.W., p. 678. G.W. Traill, "Statistical Account of Kumaun", A.R., vol. xvi: 1828, p. 199.

10. W. Hamilton, op. cit., vol. ii, pp. 245-46.

11. R. Heber, Narrative of a Joumey, vol. ii, p. 255.

12. W. Hamilton, op. cit., vol. ii, p. 487.

13. F. J. Harvey Darton (ed.), The Life and Times of Mrs. Sherwood, p. 402 .

14. W. Hamilton, op. cit., vol. ii, p. 247.

15. Edwin T. Atkins on, The Himalayan Districts of the North West Provinces of India, vol. ii, p. 601 .

16. W. Hamilton, op. cit., vol. ii, p. 110. 
17. Political Letter to Bengal, 18th Feb., 1814: Political Letters to Bengal, vol. ii, f. 204.

18. Ibid., p. 205.

19. Ludhiana Records, pp. 197-99, 202-06.

20. Ibid., pp. 175, 195.

21. Ibid., pp. $219-20$.

22. Ibid., p. 222 .

23. Pol. Cons., 20th Aug., 1813 , no. 34 , enclosure (Letter from Amar Singha Thapa, dated 29 th June).

24. Col. Hugh Pearse, The Hearseys, pp. 38-60; Hearsey to Pol. Sec., 24th Aug., 1814: P.R.N.W., P. 47; Notes supplied by Hearsey included in a letter from Capt. W. Richards to Ochterlony: Pol. Cons., 20th Aug., 1813, no. 34 .

25. Ludhiana Records, p. 339.

26. Ibid., p. 341.

27. Ibid., pp. 343-44.

28. Pol. Cons., 22nd Oct., 1813, nos. 31, 32, 39.

29. Pol. Cons., 12th Nov., 1813, no. 32.

30. Pol. Cons., 19th Nov., 1813, no. 36 .

31. Ludhiana Records, p. 351. Only the arable land attached to the villages was on the plain.

32. Ibid., pp. 360-61, 371.

33. Chaudhuri, op. cit., p. 149.

34. F. B. Hamilton, op. cit., p. 177; Prinsep, op. cit., vol. i, pp. $68-69$.

35. P.R.N.W., p. 682; Prinsep, op. cit., vol. i, pp. 69-70.

36. The main agents were Raganath Pandit, Guru to the Raja; his brother, Krishna Raj Pandit, for several years past Gurkha vakil at Calcutta, and deputed to the frontier at the special request of the Raja; and Dil Bhanjan Panre - one of the Panre clan who 
$36 .$. appears to have retained his influence after the 1803 revolution. Such were the commissioners listed by Amar Singh Thapa, P.R.N.W., p. 19, and the Governor General, ibid., pp. 683-84. Chaudhuri (op. cit., p. 154) also lists Kaji Rundip Singh and Parsaram Thapa as commissioners.

37. Proclamation issued by the Governor General, dated November Ist, 1814. C.M.J., vol. xxv: Dec., 1814, pp. 371-72; P.R.N.W., pp. 689-89; Home Misc., vol. 652, ff. 542-43; vol. 654 , ff. $442-48$; Sec. Cons., 26th July, 1815, no. 11.

38. Biographical details of Bradshaw are given in Pearse, op. cit., pp. 150, 217-20; but he was First Assistant at Lucknow, not Resident, as stated there. The note about the abolition of pigtails and hair-powder is taken from W. H. Carey, The Good Old Days of Honorable John Company, vol. i, p. 268.

39. P.R.N.W., P. 686 .

40. B. H. Hodgson, "Memorandum Relating to the Gorkha Army": Sec. Cons., 4th March, 1825, no. 16, para. 22.

41. P.R.N.W., pp. $686-87$.

42. His disgrace is mentioned by Amar Singh Thapa, P.R.N.W., p. 19 .

43. The Gurkhas claimed that the twenty-two villages were included in the tappa or sub-department of Rautahat, part of the Mackwanpur estates which had been restored to the Nepalese in 1783 by Warren Hastings, after having been occupied by Captain Kinloch (vide infra, Chapter Three). Bir Krishna Singh, Raja of Betiya, insisted that the villages were in fact in the tappa of Nanur, which had continued to form part of his own territories after the adjustments of 1783. Summing up the findings of Mr. Young's enquiry, the Magistrate of Saran later wrote: "The whole of the evidence taken on both sides seems evidently to conclude in favour of 1 the Raja of Betiya $\bar{T}$ as some of the witnesses on the side of the Nepalese allow that he hashad possession since $1765 \pi$, whilst his own witnesses unanimously give evidence to his uninterrupted possession of upwards of forty years." (Sec. Cons., 3rd Feb., 1816, no.21).

44. P.R.N.W., Pp. 691-92; C.M.J., vol. Xxv, p. 3, p. 373 .

45. P.R.N.W., p. 692 .

46. Ibid., p. 687 .

47. Ibid., p. 692 .

48. Home Misc., vol. 652 , f. 543 ; P.R.N.W., pp. 383-84, 694 . 
49. Pol. Cons., 22nd April, 1814, no. 43.

50. Ibid.

51. Ibid., para. 10.

52. The original account of this war debate is in Sec. Cons., 20th October, 1815 , no. 54 . It has been printed in several places, including Prinsep, op. cit., vol. i, pp. 458-60.

53. C.M.J., vol. xxv, pp. 374-75; P.R.N.W., Pp. 696; 993-94.

54. A. Aspinall (ed.), The Letters of King George IV, vol. i, pp. 179-83.

55. See his letters to Col. Mcmahon; ibid., vol. i, pp. $316,326$.

56. Maria, Lady Nugent, Journal, vol. ii, 225; Nugent to the Earl of Buckingham, Nov. Ist, 1813: Nugent Correspondence, f. 180.

57. Bute, Marchioness of (ed.), The Private Journal of the Marquis of Hastings, vol. $i$, pp. $6,54,323$, et passim.

58. Ibid., vol. i, pp. 44-45. Vide infra, Chapter Four, for further discussion of this point.

59. Bute, op. cit., vol. i, p. 44 .

60. P.R.N.W., P. 699; letter to McMahon, 22nd Jan., 1815: Aspinall, op. cit., vol. ii, pp. 16-17.

61. P.R.N.W., P. 699 .

62. Ibid., p. 994.

83. Letter to the Earl of Buckingham, Nov. 1st, 1813: Nugent Correspondence, f. 181 - written when a war with Nepal was a distinct possibility. Lady Nugent's Joumal contains no indication that her husband ever doubted the inevitability of war; and Moira (P.R.N.W., P. 994) claimed that he registered not simply concurrence, but strong conviction as to its necessity.

64. Political Letter to Bengal, 18th Feb., 1814: Pol. Letters to Bengal, vol. 3, ff. 202-03.

65. P.R.N.W., p. 701 ; C.M.J., vol. $x \times v$, p.375.

66. Marquis of Hastings, "Operations in India, with their Results, from the 30th April, 1814 to the 1st January, 1823", Appendix II to the Report of the Select Committee of the House of Commons on the Affairs of the East India Company, 1832, p. 138; letter to Prince Regent, March 10th, 1819: Aspinall, op. cit., vol. ii, p. 270 . 
67. P.R.N.W., P. 554 .

68. Ibid., pp. $340 ; 554 ; 598$.

69. Resident at Gwalion to Govt., May 26th, 1816: Sec. Cons., 11th June, 1816, no. 29.

70. $\quad$ P.R.N.W., pp. 18-19.

71. Ibid., pp.730-32.

72. Vide infra, Chapter Three.

73. Evidence of Kumar Swami: E.S.D.B, vol. ix, no. 394. Kumar Swami was of the family of gurus who ministered to the Vijaypur royal family. On the Gurkhas' assumption of the Vijaypur possessions, their grants of rent-free land were confirmed, and as fakirs or holy men they enjoyed considerable esteem and confidence at Kathmandu. Kumar Swami was captured by the British during skirmishes in the Morang early in 1815.

74. P.R.N.W., Pp. $45,85-86,91-92,251$.

75. Ibid., p. 170.

76. Ibid., pp. $382-86$.

77. Ibid., p. 371 .

78. Ibid., pp. 94, 360-61.

79. Ibid., pp. 343-44, 373 .

80. Hodgs on, "Memorandum": 1oc. cit., para. 8.

81. Pol. Cons. 22nd April, 1814, no. 43, para. 10.

82. Prinsep,op. cit., vol. i, p. 59. 
Notes to Chapter Three

1. Bute, Marchioness of (ed.), The Private Journal of the Marquis of Hastings, vol. i, p. 246 .

2. K. C. Chaudhuri, Anglo-Nepalese Relations, p. 15.

3. C. J. Hamilton, The Trade Relations between England and India, p. 138.

4. Chaudhuri, op. cit., p. 27.

5. S. C. Sarkar, "Some Notes on the Intercourse of Bengal with the Northern Countries in the Second Half of the Eighteenth Century", P.I.H.R.C., vol. xiii: Dec., 1930, p. 101.

6. B. H. Hodgs on, "Letter to the political Secretary to Government, 1831", S.R.G.B., vol. xxvii: 1857, p. 12.

7. C. R. Markham (ed.), Bogle and Manning, p. 184, et passim.

8. G. R. Gleig, Warren Hastings, vol. iii, p. 261, et seq.

9. Markham, op. cit., pp. 188, 133.

10. Gleig, op. cit., vol. i, p. 413.

11. Markham, op. cit., p. 57. There is a plan for the invasion of Nepal among the Warren Hastings Papers in the British Museum.

12. Vide supra, Chapter Two.

13. Markham, op. cit., p. 1, fn.

14. Correctly Bhutant, meaning the end of Tibet, Bhot is the Sanskrit name for Tibet.

15. R. B. Pemberton, "Report on Bootan"; Political Missions to Bootan, p. 89 .

16. Samuel Tumer, An Account of an Embassy to the Court of the Teshoo Lama in Tibet, pp. xii, xiii.

17. Sylvain Levi, Le Nepal, vol. i, p. 93. (Quoting Tavernier).

18. Sarkar, loc.cit., p. 101.

19. Levi, op. cit., vol. i, p. 92. 
20. Such was the expedition, in 1763, of Mir Qasim, Nawab of Bengal, See W. Kirkpatrick, An Account of the Kingdom of Nepaul, p. 174; Chaudhuri, op. cit., p. 10 .

21. Markham, op. cit., pp. 133, 142 .

22. F. B. Hamilton, An Account of the Kingdom of Nepal, p. 195;

F. Buchanan (Hamilton) to Political Secretary, 14th Aug., 1814: P.R.N.W., P. 40.

23. G. W. Traill, "Statistical Sketch of Kumaon", A.R., vol. xvi: 1928 , p. 141.

24. Levi, op. cit., vol. i, p. 94; F. B. Hamilton, op. cit., p. 195; Markham, op. cit., p. 124 .

25. Levi, op. cit., vol. i, pp. 95-97.

26. Markham, op. cit., p. 125; Turner, op. cit., pp. 382-83.

27. G. W. Traill, "Statistical Report on the Bhotia Mehals of Kumaon", A.R., vol. xvii: 1832 , p. 35 .

28. William Moorcroft, "A Journey to Lake Manasarova in Undes, a Province of Little Tibet", A.R., vol. xii: 1816, p. 394; Traill, A.R., xvi, p. 193.

29. Moorcroft to Pol. Sec., 7th Sept., 1812: Pol. Cons., 18th Dec., 1812 , no. 29, paras. 5-14; Moorcroft, A.R., vol. xii, p. 476.

30. Ibid., pp. 447, 45l: F.B. Hamilton, op. cit., pp. 93-94; H. H. Wilson (ed.), Moorcroft and Trebeck, vol. i, p. 336.

31. Some Notices Respecting Tibet: Sec. Cons., 16th March, 1816, no. 48 .

32. H. A. Oldfield, Sketches from Nipal, vol. i,p. 11; F. B. Hamilton, op. cit., p. 212 .

33. Chaudhuri, op. cit., p. 6 .

34. J. B. Fraser, Journal of a Tour, p. 490.

35. J. Hutchis on and J. Ph. Vogel, History of the Panjab Hill States, vol. ii, p. 448; Fraser, op. cit.,p. 256; Moorcroft, A.R., vol. xii, p. 443.

36. Fraser, op. cit., pp. 264, 489.

37. Traill, A.R., vol. xvii, p. 32 . 
38. Wison, op. cit., vol. i, p. 347.

39. Levi, op. cit., vol. i, p. 94.

40. William Fraser to Pol. Sec., 20th Oct., 1814: P.R.N.W., P. 242 .

41. F. B. Hamilton, op. cit., p. 195; Memorandum by Moorcroft: P.R.N.W., P. 85 .

42. B. H. Hodgson, "Memorandum Relating to the Gurkha Army": Sec. Cons., 4th March, 1825, no. 16, paras. 19-27.

43. Kirkpatric\%, op. cit., pp. 211-12.

44. Ibid., p. 217.

45. The emb lem of the Gurkhas. By 1816 the number stood between two and three thousand - See Notices Respecting Tibet: Sec. Cons., 16th March, 1816, no. 48; E. Huc, Souvenirs d'un Voyage, vol. $i$, p. 262. Huc alls them Peboun - which, presumably, is the Tibetan designation for the Nepalese.

46. Levi, op. cit., vol. i, p. 128; B. H. Hodgson, "The Trade of Nepal", S.R.G.B., vol. xxvii: 1857, p. 42.

47. Notices Respecting Tibet: 1oc. cit.

48. Levi, op. cit., vol. i, p. 128.

49. Markham, op. cit., p. 157.

50. Kirkpatrick,op. cit., pp. 204-05.

51. Markham, op. cit., p. 183; Turner, op. cit., p. 369.

52. Kirkpatrick, op. cit., p. 204; F. B. Hamilton, op. cit., p. 104. The Gurkha authorities in Kumaun showed great willingness to assist the promotion of the local trade in timber with Rohilkhand - Chaudhuri, op. cit., pp. 15l-52.

53. Levi, op. cit., vol. i, pp. 111-12.

54. Markham, op. cit., p. 1xix.

55. P.R.N.W., P. 340 .

56. Traill, A.R., vol. xvii, p. 35.

57. Tieh-Tseng Li, Tibet Today and Yesterday, pp. 20-2l; Markham, op. cit., pp. $1 \overline{3-18}$. 
58. Li, op. cit., p. 12 .

59. Ibid., pp. 23-34.

60. Ibid., pp. 36-50.

61. Levi, op. cit., vol. i, p. 110.

62. Li, op. cit., p. 28; Hodgson, "The Trade of Nepal", loc. cit., p. 43.

63. R. Montgomery Martin, China: Political, Commercial, and Social, vol. ii, p. 118; Markham, op. cit., p. 125 .

64. Turner, op. cit., pp. $373,381$.

65. C. H. Desgodins, Le Thibet, pp. 334-38; Markham, op. cit., p. 125; Turner, op. cit., p. 369 . Huc, op.cit., vol. ii, p. 267, gives a different picture; but his testimony is too often distorted either by derision or by a relish for the sensational to be accepted in preference to the mutually corroborative evidence of other authorities.

66. Markham, op. cit., p. 143; see also Turner, op. cit., pp. 253-54.

67. Ibid., p. 374 .

68. Pemberton, op. cit., p. 74.

69. Turner, op. cit., pp. 272-73.

70. Schuyler Cammann, Trade through the Himalayas, p. 77.

71. Nepalese and Chinese sources agree on this interpretation - cf. Kirkpatrick, op. cit., pp. 339-40, with Li, op. cit., p. 244, n. 154. According to Bogle's information, and to that of the native informant of Moorcroft, it was the Nepalese coinage which had been debased see Markham, op. cit., Pp. 128-29; P.R.N.W., p. 91.

72. Camille Imbault-Huart, "Histoire de la Conquete du Nepal par les Chinois, 1792; Traduit du Chinois ... ", J.A., 7e. serie, vol. xil: 1878, p. 360 .

83. Li, op. cit., p. 54 .

74. In Imbault-Huart's text the date is 1790. Li demonstrates that the true date was probably 1788 - op. cit.,p. 243, n. 7.

75. Imbault-Huart, loc. cit., pp. 360-69; Markham, op. cit., p. Ixxvii. 
76. Cammann, op. cit., p. 126 .

77. Li, op. cit., pp. 55-56. The rigorous control exercised over foreign trade on the Kumaun frontier is described by Traill, A.R., vol. xvii, pp. 34-37.

78. P.R.N.W., P. 91. (Moorcroft's Memorandum).

79. Markham, op. cit., p. 213.

80. H. Y. Hearsey to Pol. Sec., 24th Aug., 1814; P.R.N.W., p. 48.

81. H. B. Morse, The Chronicles of the East India Company Trading to China, vol.ii, p.373.

82. Martin, op. cit., vol. i,p. 348.

83. Li, op. cit., vol. i, p. 348 .

84. Ibid., p. 370.

85. "At about this time 1793 the Chinese Amban, named Changjun Pthuluzai See-ton, sent three or four letters to the Sikkim Darbar. One said that although a Tibetan force had always been stationed at Phari Ia military post on the Bhutan/Tibet border 7 since a long time Isic T it was now thought ... that it was desirable to depute Kao-tsong-yer hitherto at Gyantse, to Phari, and to place troops in both these places, with no other innovations or alterations in view but that of the convenience of making inquiries into the movements of the Ferangs, and that the Sikkim Darbar need not entertain any fears on this score." - MS History of Sikkim, ff. 106-07.

86. Report from Capt. Webbe: Sec. Cons., 14th Sept., 1816, no. 36.

87. Kirkpatrick, op. cit., p. vi.

88. Mins. of Ev., 1813, Pp.169, 171-72; Walter Hamilton, Gazetteer

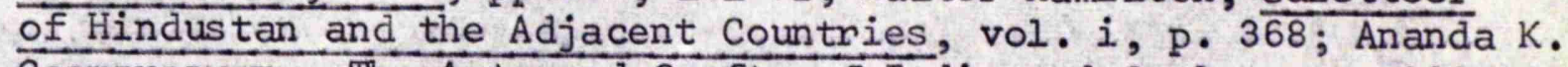
Coomaraswamy, The Arts and Crafts of India and Ceylon, pp. 193, 250.

89. Turner, op. cit., p. 356.

90. "Memorandum Relating to the Sources Whence Horses were Formerly Procured for the Cavalry on this Establishment": Nugent Correspondence, ff. 72-75.

91. Moorcroft to Metcalfe, 8th April, 1812: Moorcroft MSS, f. 1.

92. Moorcroft to Metcalfe, 17th Nov., Ist Dec, 1812: ibid., ff. 7, 9. 
93. Moorcroft, A.R., vol. xii, p. 456.

94. Ibid., p. 449 .

95. J. B. Fraser, op. cit., pp. 257, 276; Moorcroft, A.R., vol. xii, p. 444 .

96. Wilson, op. cit., vol. i, p. 110.

97. D. Rouire, La Rivalite Anglo-Russe au XIXe Siecle en Asie, p. 86.

98. Moorcroft to Pol. Sec., 7th Sept, 1812: Pol. Cons., 18th Dec., 1812 , no. 29. paras. 30-32. In this letter Moorcroft expressed his conviction that France was using Russia's ambitions in Central Asia as a means of promoting her own plans to invade India; and that the oppressed and ineffectively defended Gurkha provinces in the western Himalayas would be the natural corridor for a Franco-Russian incursion.

99. Political Letter to Bengal, 6th Jan., 1815, para. 75.

100. Quoted by Alistair Lamb, "Tibet in Anglo-Chinese Relations, 1767-1842, Part I", J.R.A.S., parts 3 \& 4: 1957, Pp. 165-66.

101. Mins. of Ev., 1813, p. 483.

102. Ibid., p. 484 .

103. c. J. Hamilton, op. cit., pp. 175-77.

104. Mins. of Ev., 1813, p. 492.

105. Ibid,, p. 487.

106. Ibid., p. 492.

107. Ibid., p. 485. It was impossible to define with certainty the nature of the loss. In conformity to its mercantilist ethos the Company made up its accounts as a balance of resources between England and India, maintaining no separation between its trading and its political operations. Hence, the figures could only show. with certainty that the balance of payments was in favour of India (ibid., pp. 485; 505). In order to decide whether trade was subsidizing territorial administration, as the Company claimed, or territorial revenues trade, as its critics maintained, it would have been necessary to regard Britain and British India as a single field of economic operation and recast accounts as a balance between 
107.. trade and territorial administration. This is precisely what Parliament ondered the Company to do in 1813; and when the affairs of the Company were re-examined in 1832 the new method in its books made it clear that the profits of commerce not only covered the payments of dividends, but supplied up to $25 \%$ of a territorial deficit ( 1832 Report, pp. 51-53,60). But the enormous commercial profits derived entirely from the China trade, not the Indian (ibid., p. 73).

108. c. J. Hamilton, op. cit., p. 138.

109. Michael Greenberg, British Trade and the Opening of China, 1800$1842, \mathrm{p} .9$. The importation of opium into China gave so much alarm to the Chinese Government, that a further Imperial Decree banning the drug was published in 1800. The Company had long since prohibited the traffic in its own ships (Morse, op. cit., vol. ii, p. 327), but the volume imported from India by pirates did not abate (Greenberg, op. cit., p. 221), and this illegal traffic was all to the advantage of the Company. Most of the opium was paid for with bullion, and much of this found its way back to India and into the Calcutta Government's treasuries, since the Company retained the monopoly of the internal trade in opium from its own territories, and derived enormous revenue from the excise thereon (Mins. of Ev., 1832, Sec. 2, pp. 35, 45).

110. Ibid., Sec. 2, p. 45 .

11l. Bute, op. cit., vol. i, p. 40.

112. 1832 Report, pp. 51-53.

113. C. J. Hamilton, op. cit., p. 227.

114. Ibid., p. 160.

115. Mins. of Ev., 1813, p. 492.

116. For Moorcroft's description of this change of attitude see Wilson, op. cit., vol. i, p. xxxiii.

117. Mins. of Ev., 1813, pp. $88-90,263,280,296,313,370,377,380$, 384 .

118. See Appendix 5 to llind Report, 1811 (this shows the invoice value of goods and stores imported); and Appendix 35 to 1 Vth Report, 1812 (invoice value of stores alone). By subtracting the latter figures from the former, the invoice value of goods alone is obtained. The prime cost, as given in the text, is obtained by dividing the result by 110 and then multiplying by 100 . 
119. Reckoned as $2 / 3$ of the whole, as given in Appendix 2 to 1llnd Report, 1811 (where the prime cost is presumably stated). Goods and stores from Europe were not accounted for separately from those purchased in India. The estimate of $2 / 3$ of the one to $1 / 3$ of the other was that used by the Company's own accountants.

120. Like the Nizam of Hyderabad: see Mins. of Ev., 1813, p. 320. Clothing for the Company's and the King's troops in India was classified not as goods, but as stores.

121. Ibid., p. 392 .

122. Mins. of Ev., 1832, pp. 106-07.

123. Ibid., p. 110. See also Extract from General Letter to Canton, 3lst Jan., 1811: Appendix 13 to 1Vth Report, 1812.

124. Appendix 13 to 1Vth Report, 1812, passim.

125. Goods exported in $1791-92 \ldots £ 621,890$.$) ) invoice values.$
in $1808-09 \ldots £ 1,092,967$. Sources: Appendix 5 to 1lind Report, 1811; Appendix 35 to 1Vth Report, 1812 .

126. Appendix 14 to 1Vth Report, 1812.

127. Mins. of Ev., 1813, pp. 508-09; Appendix 2 to 1Vth Report, 1812.

128. Mins. of Ev., 1813, p. 487.

129. 1Vth Report, 1812, pp. 418-19.

130. Morse, op. cit., vol. ii, p. 160; Martin, op. cit., vol. ii, p. 17.

131. The British never actually requested that the sale of opium be legalised until 1840; but the unspoken aspiration was always there as part of the general concern to open China to all the products of India, without discrimination. At the time of the projected Cathcart Embassy to China in 1787, the official view was that "the property of our territorial possessions in India ... would be promoted by securing a secure vent for their produce and manufactures in the extensive Empire of China." (Cited in Morse, op. cit., vol. ii, p. 160).

132. Mins. of Ev., 1813, p. 439.

133. Supracargoes to Governor General, 5 th Oct., 1815: P.R.N.W. p. 272. 134. Pol. Sec. to Major Bradshaw, 26th Nov., 1814: ibid., p. 261. 
135. Gov. Gen. to Chairman of the Court, 6th Aug., 1816: ibid., p. 996.

136. Pol. Sec. to Hon. Edward Gardner, 14th Sept., 1816: Sec. Cons., 14th Sept., 1816, no. 43.

137. Morse, op. cit., vol. iii, p. 282.

138. Supracargoes to Gov. Gen., 5th Oct., 1815: P.R.N.W., p. 273.

139. C. J. Hamilton, op. cit., p. 171.

140. Ibid., pp. 175-77.

141. 1Vth Report, 1812, p. 445 .

142. Mins. of Ev., 1832, Sec. 2, pp. 40, 124.

143. Ibid., p. 126. Saltpetre was also imported, in conformity to the requirement of Parliament. Indian raw cotton, because of its coarseness, was not favoured in Britain (ibid., pp. 276-77).

144. Alistair Lamb, "Tibet in Anglo-Chinese Relations . . Part 2", J.R.A.S., Parts 1 \& 2: 1958, p. 38 .

145. Mins. of Ev., 1832, Sec. 2, p. 38 .

146. Ibid., p. 110; C. J. Hamilton, op. cit., p. 208.

147. Mins. of Ev., 1832 , Sec. 2, pp. 38, 40 .

148. Cammann, op. cit., p. 127.

149. Kirkpatrick, op. cit., p. 350.

150. Aitchison, Treaties, vol. xiv, pp. 56-57.

151. Chaudhuri, op. cit., p. 95.

152. Ibid., p. 107.

153. Ibid., pp. 108-16.

154. Ibid., p. 107.

155. Ibid., p. 116.

156. Ibid., pp. 119-23.

157. Ibid., p. 125 .

158. Ibid., pp. 134-40. 
159. Latter to Acting Chief Secretary, 3rd May, 1815: Home Misc., vol. 654 , ff. 375-76.

160. This was in 1811. See Markham, op. cit., pp. dvii-dviii.

161. Ochterlony to Pol. Sec., 18th May, 1810: Ludhiana Records, p. 220. Vide supra, Chapter Two.

162. Moorcroft, A.R., vol. xii, pp. 515-33.

163. Nepal Raja to Gov. Gen., received 28th July, 1813: Pol. Cons., 24 th Sept., 1813, no. 36.

164. Pol. Sec. to Moorcroft, 18th Dec., 1812: Pol. Cons., 18th Dec., 1812 , no. 31.

165. P.R.N.W., P. 13 .

166. Ibid., pp. 50-51.

167. Pol. Sec. to Ochterlony, 30th Sept., 1814: ibid., p. 65.

168. P.R.N.W., pp. $236-42$.

169. Pol. Sec. to Delhi Resident, 23rd October, 1814: P.R.N.W., p. 139. Captain Raper's Memorandum, dated Oct. 20th (ibid., p. 145), probably had a decisive influence in the formation of this resolution.

170. Pol. Sec. to W. Fraser, 24th Nov., 1814: ibid., p. 248.

171. Pol. Sec. to Adj. Gen., 22nd Oct., 1814: ibid., pp. 135-36.

172. Gov. Gen. to Secret Committee, 2nd Aug., 1815: ibid., p. 699.

173. Ibid., p. 762 .

174. Gov. Gen. to Secret Committee, 11th May, 1815: ibid., pp. 550.

175. Political Letter to Bengal, 13th Feb., 1817: ibid., p. 991.

176. Draft of treaty: ibid., p. 263.

177. Latter to Pol. Sec., 30th Dec., 1815, 19th Jan., 1816: ibid., pp. 926,929 .

178. Pol. Sec., to Latter, 13th Jan., 1816: ibid., p. 928.

179. Gov. Gen. to Supracargoes, 15th June, 1816: Sec. Cons., 15th June, 1816, no. 17. 
180. Moorcroft to Pol. Sec., 19th Sept., 1815: Sec. Cons., 13th Jan., 1816 , no. 90.

181. Chaudhuri, op. cit., Chapter 4, passim.

182. Correspondence between Pol. Sec. and Moorcroft: Sec. Cons., 13th Jan., 1816, no. 92; 5th Oct., 1816, nos. 15, 16.

183. Gov. Gen. to Supracargoes, 15th June, 1816: 10c. cit.

184. Pol. Sec. to Moorcroft, 13th Jan., 1816: Sec. Cons., 13th Jan., 1816 , no. 92 .

185. Pol. Sec. to Capt. Webbe, 14th Sept., 1816: Sec. Cons., 14th Sept., 1816, no. 37.

186. Ross to Delhi Resident, 29th Feb., 1816: Sec. Cons., 30th March, 1816 , no. 8 .

187. Pol. Sec. to Delhi Resident, 30th March, 1816: ibid., no. 9.

188. Moorcroft to Metcalfe, 27th Dec., 1819: Wilson, op. cit., vol. $i$, pp. xxxil-iv.

189. Ibid., vol. i, pp. xxiv-vi.

190. Major Hearsey, "Mr. Moorcroft's Journey to Balkh and Bokhara", A.J., New Series, vol. xviii, Part 1: 1835, p. 107.

191. N. K. Sinha and A. K. Dasgupta (eds.), Selections from the Ochterlony Papers in the National Archives of India, pp. 185-86; Wilson, op. cit., vol. i, p. 421 .

192. Huc, op. cit., vol. ii, pp. 348-49.

193. Letter to Metcalfe, 27th Dec., 1819: Wilson, op. cit., vol. i, p. xxxiv. 


\section{Notes to Chapter Four}

1. Information concerning soldiering in Bengal in the early 19th century is given in the following sources: John Shipp, Memoirs, pp. 101, 103, 246; Sita Ram, From Sepoy to Subadar, p. 25; F. G. Cardew, A Sketch of the Services of the Bengal Native Army, pp. $53,113-15 ;$ F. J. Harvey Darton (ed.), The Life and Times of Mrs Sherwood, p. 33l; W. H. Carey, The Good Old Days of Honorable John Company, vol. i, pp. 442-45; R. Heber, Narrative of a Journey, vol. $\mathrm{ii}, \mathrm{pp} .18,163$; B. H. Hodgson, "On the Origin and Classification of the Military Tribes of Bengal", S.R.G.B., vol. xxvii: 1857, pp. 145-46; Walter Badenach, An Inquiry into the State of the Indian Army, Pp. 111, 143; Maria, Lady Nugent, A Journal from the Year 1811 to the year 1815, vol. i, pp. 241, 278-79, 402-03; Amiya Barat, The Bengal Native Infantry, pp. 173-74; Walter Henry, Events of a Military Life, vol. i, p. 234; Mins. of Ev., 1813, p. 242; Smet MS, entries for October and November, 1815; Sir George Nugent, Report on the Bengal Army dated 20th June, 1813: Sec. Cons., 6th Aug., 1813, no. 4, paras. 61-63; Commissary General to Military Sec. to Govt: Mil. Cons., 16th April, 1811, no. 36 .

Details of the arrangements made specially for the Nepal War are in correspondence from the Commissary General to Mil. Sec.: Mil. Cons., 17th Sept., 1814, no. 84; 14th Oct., 1814, no. 126.

2. Cardew, op. cit., p. 30.

3. Ibid., p. 53; Charles Ross (ed.), The Correspondence of Charles, lst Marquis Cornwallis, vol. i, p. 230 .

4. Gov. Gen. to Vice Pres., 9th Feb., 1815: Sec. Cons., 2lst March, 1815, no. 1, para. 88 .

5. They were actually numbered as 36 in 1786 , but each battalion was smaller and the total was almost equivalent to that of the 24 numbered in 1796 - Cardew, op. cit., pp. 53, 66.

6. Gov. Gen. to Vice Pres., 9th Feb., 1815: 1oc. cit., para. 88; Cardew, op. cit., p. 53.

7. In 1814 the composition of the Bengal army was as follows : 
$7 \ldots$

Corps

( Engineers

( Horse Artillery

( 3 battalions of

European

( Foot Artillery

( 1 regiment of

( Company European Infantry

Total European contingent

( 1 battalion of Native

(Foot Artillery (Golandaz)

( 45 Companies of Gun Lascars

( 8 regiments of Native

( Cavalry

Native ( 27 Regiments of Native

( Infantry (including the Marine

(Regiment)

( Pioneers )

( Miners

( Ordnance Drivers

Total native army

Grand Total
Total all ranks

312

1,761

1,103

3,207

2,975

4,512

$52,880 *$

728

131

$\underline{2,860 *}$

64,038

67,245

The figures are those given in Gov. Gen. to Vice Pres., 9th Feb., 1815, loc.cit., para. 88, except those marked*, which are taken from the General Abstract Return of H.M. and the Hon. Company's European and Native Troops Serving under the Presidency of Fort William, 13th Jan., 1812: Nugent MSS, ff. 108-109. These figures have been used where Hastings' estimate takes account of increases made for the purpose of the Nepal War. The above therefore represents the peace establishment of the regular army in 1814 . For irregular corps vide infra, note 37. The Pioneers and Miners were in fact a single corps, having been designated since 1808 as the Corps of Pioneers or Sappers - Cardew, op. cit., p. 114. Supplementary bodies, counted as part of the Bengal military establishment but not liable for general service, were the Governor General's Bodyguard and the Residency escorts at Hyderabad, Poona, Berar and Gwalior.

8. R. Montgomery Martin (ed.), The Despatches, Minutes and Correspondence of the Marquess Wellesley, vol. iv, p. 225.

9. Ross, op. cit., vol. i, p. 230 , vol. ii, p. 18.

10. Ross, op. cit., vol. i, p. 350; Sir Courtenay Ilbert, The Government of India, p. 68 . One of the 4 battalions of foot artillery in 1814 was in fact composed of native artillerymen, or golandaz, who had come over from the Marathas (see note 7); but the Court of 
10.. Directors, arguing that "the natives of India ought on no account to be instructed in the service and practice of artillery so long as we have the means of furnishing you with an adequate supply of European recruits for that service", issued orders in that year, repeated in 1817, that the corps be allowed to dissolve, by not replacing casualties and by drafting its members into infantry and cavalry corps (Military Letter to Bengal, 7th Jan., 1817, paras. 50-51). This policy was never in fact implemented, and native artillery remained a part of the Bengal army until 1857 (Cardew, op. cit., p. 455).

11. Ross, op. cit., vol. i, p. 354; Ilbert, op. cit., p. 68.

12. Ross, op. cit., vol. i, p. 329; Return of the Troops in India, 26 th June, 1811: Nugent MSS, f. 25.

13. FLt. Wallace $T$, Fifteen Years in India, or Sketches of a Soldier's Life, p. 31 .

14. Mins.of Ev., 1813, p. 74; Mil. Cons., 23rd Sept., 1813, no. 87.

15. Mins. of Ev., 1832, Sec. 5, pp. 91, 129.

16. Sir J. Ranald Martin, The Sanitary History of the British Army in India, Past and Present, p. 10 .

17. Harvey Darton, op. cit., p. 406.

18. Ranald Martin, op. cit., p. 14. In 1815, of 1,116 corporals and private in the Company's European Regiment, 922 , or $83 \%$ had served less than 7 years. In the foot artillery the proportion was $63 \%$, and in the horse artillery, 47\% - Bengal Annual Military statement, 1814-15, ff. 19, 22, 235, 236, 239 .

19. See Lee Warner, Life of Dalhousie, vol. ii, p. 260 for a table of comparative costs. This applies to a later time, but the ratio of expense between the upkeep of King's and Company's Europeans cannot have altered significantly over the intervening period.

20. Gov. Gen. to Vice Pres., 9th Feb., 1815: loc. cit., para. 88.

21. a) In 1786 the total (to nearest half-thousand) of the Company's regular troops in Bengal and Madras was

The total of King's troops in same was

(Source: Ross, op. cit., vol. i, p. 329) Ratio: 13 to 1 .

70,000

5,500 
b) In 1811-14 the total of regular troops in Madras was (Source: Mins. of Ev., 1832, 77,500 Sec. 5, p. 194). The total of King's forces in same was

(Source: Nugent MSS, f. 25) 12,000 Therefore total Company troops in same was Total Company regular troops in Bengal (vide note 7 ) Therefore, total Company regular troops in Bengal and Madras was Total King's troops in same (Source: Nugent MSS, f. 25).

$$
\begin{array}{cc}
\overline{65,000} \quad 65,000 \\
67,000 \\
132,000) \text { ratio } 8: 1 \\
17,000)^{\text {rat }}
\end{array}
$$

22. Mins. of Ev., 1813, p. 129 .

23. D. G. Crawford, A History of the Indian Medical Service, vol. ii, p. 210; Kaye, Lives of Indian Officers, vol. i, pp. 275-76.

24. Mins. of Ev., 1813, p. 173 .

25. See, for example, the view of Dundas in Ross, op. cit., vol. i, p. 330, and of Lt. Col. Wats on in Mins. of Ev., 1832, Sec. 5, p. 93.

26. Such was the view of Cornwallis - Ross, op. cit., vol. i, p. 247.

27. Peter Auber, Analysis of the Constitution of the East India Company, pp. 83,98 .

28. Cardew, op. cit., pp. 49-53.

29. Ibid., p. 102 .

30. Hastings' Summary, p. 130; Cardew, op. cit., p. 102.

31. Mins. of Ev., 1832, Sec. 5, p. 82 .

32. Gov. Gen, to Vice Pres., 9th Feb., 1815: loc. cit., para. 44. 33. Mins. of Ev., 1832 , Sec. 5 , p. 81.

34. Nugent's Report of 20th June, 1813: loc. cit., paras. 71, 84-85, 87.

35. Letter to Chas. Grant, 7th June, 1812: Nugent MSS, f. 162. 
36. Nugent to Torrens, 26th Sept., 1813: Nugent MSS, f. 174; Mins. of Ev., 1832, Sec. 5, p. 219; Bute, op. cit., vol. i, pp. 41-42, 290-91; Cardew, op. cit.,pp. 113, 139.

The irregular corps were as follows:

Ramgarh Local Battalion

Hill Rangers

Skinner's Horse

Gardner's Horse

Delhi Najibs

Calcutta Native Militia

6 Provincial Battalions

European Invalids

Native Invalids

Total

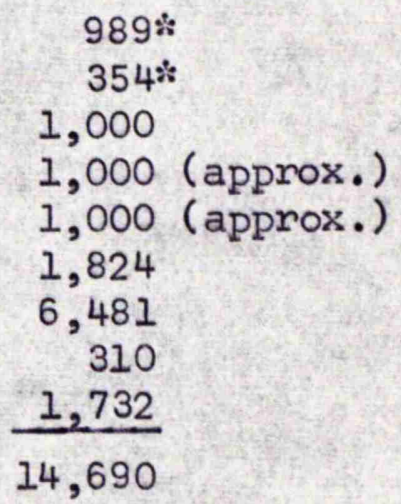

Figures are taken from Gov. Gen. to Vice Pres., 9th Feb., 1815: 1oc. cit., para. 88, except those marked* which are taken from Nugent's Retum, Nugent MSS, ff. 108-09 (in the case of corps increased by Hastings for the Nepal War) and that for Gardner's Horse, which is unaccountably omitted in Hastings' list.

37. Patna Magistrate to Judicial Sec., 24th April, 1814: Mil. Cons., 3rd Dec., 1814, no.

38. Lady Nugent, op. cit., vol. ii, pp. 23-25, gives a colourful account of Skinner's Horse in action.

39. Gardner to Adj. Gen., 7th Feb., 1815: E.S.D.B., vol. 6, no. 24.

40. Vide infra, Chapter Eight.

41. Gov. Gen., to Vice Pres., 9th Feb., 1815: 10c. cit., paras.21, 44, 88; Extract from the Secret Department, 4th Oct., 1814:

Mil. Cons., 7th Oct., 1814, no. 92 .

42. P.R.N.W., PP. 70, 185 .

43. Gov. Gen. to Vice Pres., 9th Feb., 1815: 1oc. cit., paras. 21, 44; to Vice Pres., 15th June, 1815: Sec. Cons., 4th July, 1815, no. 1. The Local corps were raised at Saran (the Champaran Light Infantry), Mirzapur, and Rangpur. All were modelled on that already existing at Ramgarh.

44. Minute, 30th Aug., 1815: Sec. Cons., 30th Aug., 1815, no. 36.

45. Vice Pres. to Gov. Gen., 2lst March, 1815: Sec.Cons., 2lst March, 1815, no. 17 , para. 14.

46. Such is the premis behind the reasoning in his letter to the Vice President, 9th Feb., 1815: 1oc. cit. 
47. Metcalfe's views on the subject are to be found in $\mathrm{J}$. W. Kaye, Life of Metcalfe, vol. i, pp. 400-05, 445-46; \& J. W. Kaye (ed.), Selections from the Papers of Lord Metcalfe, pp. 78-79, 146. Their influence on Hastings own outlook is abvious. Metcalfe was Resident at Delhi at this time. John Adam was Secretary to Government in the Political and Political and Secret Depts.

48. The view of Edmonstone is in his letter to the Govemor General, dated 2 lst March, 1815: loc. cit.

49. Minute by Gov. Gen.: Sec. Cons., 30th March 1816, no. 1 .

50. Vide infra., Epilogue.

51. Nugent's Report of 20th June, 1813: loc. cit., para. 23; Sir John Horsford, MS Memoir on Artillery.

52. Minute by the Commander in Chief: Mil. Cons., 16th April, 1811, no. 37 .

53. Commissary General to Mil. Sec., 9th April 1811: Mil. Cons., 16th April, 1811, no. 36; Military Letter from Bengal, 3lst Oct., 1810: L/Mil/3/5, f. 708 .

54. Military Letter from Bengal, 16th April, 181l: L/Mil/3/5, ff. 1045-46.

55. Comm. Gen. to Mil. Sec., 9th April, 1811: 1oc. cit.

56. Nugent's Report of 20th June, 1813: 1oc. cit., paras. 23-28; Secret Letter from Bengal, 30th June, 1813: Secret Letters from Bengal, vol.xxiv, f. 433 .

57. Minute by the Governor General: Mil. Cons., 22nd Dec., 1815, no. 1.

58. Ibid.; Extract from the Proceedings of the Military Board, 8th Nov., 1814: Mil. Cons., 25th Nov., 1814, nos. 72-73.

59. Sir John Horsford's complaint - see his minute in the Extract mentioned in the previous note.

60. Mins. of Ev., 1832, Sec. 5, p. 26 .

61. Ibid., p. 40.

62. Camaticus, "A General View of our Indian Army", A.J., vol. xi, no. 65: May, 1821, p. 433. 
63. John Ludlow to his wife, 25th Oct., 1814: Ludlow MSS, $A D / 7450 / 1$, no. 2. A further letter (23rd Nov., 1814, $A D / 7450 / 1$, no. 10) runs:

"I dined last night at the mess of the 8 th Light Dgns... I will not acknowledge that I drank too much, for I drank nothing but port, and that I took medicinally. The water T? - illegible $T$ deems is not good, perhaps some mineral in it from the hills. I have lately adopted the precaution of boiling it, which I think likely to make it more salubrious."

64. Agent, 2nd Division Army Clothing to Gov. Gen., Ist Jan., 1817: Mil. Cons., 7th Feb., 1817, no. 174; Military Letter from Bengal, 13th Jan., 1810: L/Mil/3/5, f.400.

65. C. R. Markham, Bogle and Manning, p. 229, fn.

66. G.0., 29th March, 1816: C.M.J., vol. xxviii: 1816, pp. 402-03.

67. Mins. of Ev., 1832, Sec. 5, pp. 93-94, 176, 235.

68. Military Letter to Bengal, 15th March, 1816, para. 18.

69. Horsford to Adj. Gen., 30th Nov., 1809: Mil. Cons., 12th Dec., 1809, no. 38 .

70. See, for example, Mil. Cons., 13th Nov., 1806, no. 85.

71. Mil. Cons., 12th Dec., 1809, nos. 37, 40.

72. Mil. Cons., 23rd July, 1811, no. 68.

73. Mins. of Ev., 1832, Sec. 5, p. 243.

74. Ibid., p. 211.

75. Ibid., pp. 13, 31 .

76. Kaye, Life of Metcalfe, vol. i, p. 389.

77. Cunningham, History of the Sikhs, P. 155; Sir. H. M. Lawrence, Essays Military and Political, p. 429.

78. Nugent's Report of 20th June, 1813: 1oc. cit., para. 23.

79. F. W. Stubbs, A History of the Bengal Artillery, vol. ii, p. 42 .

80. Young, Arsenals and Manufactories, p. 181; Mins. of Ev., 1832, Sec. 5, p. 127. The weight of the gun itself was about 6 cwt C.R., vol. xii: 1849 , p. 343 . 
81. Nugent's Report of 20th June, 1813: loc. cit., para. 8.

82. Mins. of Ev., 1832, Sec. 5, p. 77 .

83. Hastings' Summary, p.135.

84. Letter to Secret Committee, 29th Oct., 1813: Secret Letters from Bengal, vol. xiv, f. 713. Cf. note 7 .

85. G.0., Nov., 1814: P.R.N.W., pp. 195-98. In 1815 the corps of Engineers consisted of 1 colone 1 commanding, 2 lieutenant-colonels, 2 majors, 9 captains, 8 lieutenants, 8 ensigns, and 2 cadets Bengal Annual Military Statement $1814-15$, f. 155 .

86. Bute, op. cit., vol. i, p. 151.

87. Cardew, op. cit., pp. 97-99; Stubbs, op. cit., vol. i, pp. 265-90.

88. Shipp, op. cit., p. 245. Details of the siege are in Stubbs, op. cit., vol. i, pp. 322-24; Sophia Kelly, The Life of Mrs Sherwood, p. 437; Richard Cannon, Historical Record of the $53 \mathrm{rd}$ or Shropshire Regiment of Foot, p. 16; Cardew, op. cit., p. 112; and transcripts of official comrespondence in the Stubbs MSS, ff. 60 , et seq. The date was 2nd Feb., 1812.

89. Carey, op. cit., vol. i, p. 432; Cardew, op. cit., p. 24; Sir John Malcolm, Political History of India, vol. ii, pp. 227-29.

90. Carey, op. cit., vol. i, p. 432; Major V. C.P. Hodson, A List of the Officers of the Bengal Army, Part 1, p. xxi.

91. Ross, op. cit., vol. ii, p. 567; Cardew, op. cit., pp. 66-70; Malcolm, op. cit., vol. ii, p. 202; Barat, op. cit., pp. 60-68, 72.

92. Mins. of Ev., 1832, Sec. 5, pp. 16-17.

93. Ibid., p. 86 .

94. Badenach, op. cit., p. 65 ; Barat, op. cit., pp. 96-97.

95. Nugent's Report of 20th June, 1813: loc. cit., para. 5.

96. Mins. of Ev., 1832, Sec. 5, p. 71.

97. Barat, op. cit., p. 103.

98. Badenach, op. cit., p. 46.

99. Nugent's Report of 20th June, 1813: loc. cit., para. 73. 
100. Hodson, op. cit., p. $x x x v$; Young, op. cit., p. 39.

101. G.0., 5th April, 1816: C.M.J., vol. xxviii: 1816, pp. 372-73.

102. Hods on, op. cit., p. xxxv.

103. Lawrence, op. cit., p. 54.

104. Badenach, op. cit., p. 37; Mins. of Ev., 1832, Sec. 5, p. 49; E.I.U.S.J., vol. viii: $1836, \mathrm{pp} \cdot 112-13$.

105. Lady Nugent, op. cit., vol. ii, p. 9.

106. Sketches of India, Written by an Officer for Fireside Travellers at Home, 225. Stuart is not named, but there is no doubt that he is the officer referred to - cf his entry in Hodson, op. cit., part 4. Kincaid, in British Social Life in India, p. 118 , notes that during Welles ley's incumbency "it was no longer fashionable in Government House circles to profess an interest in Persian poetry or Hindu metaphysics."

107. It may be mentioned that Hastings, more charitably disposed towards half-castes than most of his contemporaries, was compelled to fight a prolonged battle with his colleague on the Bengal. Council in order to have a restricted temporary rank conferred on James Skinner, who was the son of a Yorkshireman and a Rajput woman, in recognition of the services of his troops or imregular horse. Officers in the irregular cavalry corps had no independent rank, and were liable to be commanded by the youngest and most inexperienced comet of the line. Hastings proposed that in one on two special cases they should be eligible for the restricted ranks of major and lieutenantcolonel, though with no seniority as field officers. This would give them the right to commandall captains of the line, but make them junior to the youngest major. The Vice President objected, principally on the ground that Skinner was dhalf-caste, pointing out that "it had long been an established rule with the court of Directors to decline admitting the illegitimate offspring of Europeans by native women, or as they are ordinarily termed, half castes, into their military service". Hastings insisted that there was no question of abrogating the principle of exclusion, and that he was merely urging a more empirical application of it. The matter was referred to the Court of Directors, who reluctantly agreed that restricted temporary rank should be available in specially approved cases, but desired it to be explained to the recipients that "this indulgence I was T not to give them any claim to pay or allowances of any kind, now or hereafter, beyond those which they at present possess." The ruling affected Skinner and William Gardner (who was not a half caste) who were both made temporary and restricted lieutenant-colonels (Gardner having held that rank hitherto in titular form only). Hyder Hearsey was made a major, under the same conditions. Skinner was eventually granted 
107.. a King's commission in his rank, and awarded the Order of the Bath; but this was truly exceptional, and no half caste would normally anticipate such recognition. See: Bute, op. cit., vol. i, p. 392; J. B. Fraser, Military Memoir of Lt. Col. James Skinner, vol. ii, p. 198; Gov. Gen. to Vice Pres., 2nd April, 1815: Sec.Cons., 2nd May, 1815, no. 1; Vice-Pres. to Gov. Gen. to Vice Pres., 24th May, 1815: Sec. Cons., 28th June, 1815, no. 1; Military Letter to Bengal, 26 th Aug., 1818, para. 225.

108. E.I.U.S.J., vol. iii: 1834, "Selections", p. 46; Badenach, op. cit., p. 132 .

109. Barat, op.cit., p. 88.

110. These were the saddle contract, contract for the repair of arms, and the allowance for hirracahs, or guides - ibid., p. 84 .

111. Ibid., p. 92; Mins. of Ev., 1832, Sec. 5, p. 218.

112. Ross, op. cit., vol. ii, p. 314, et seq.; Barat, op. cit., pp. $66-68$.

113. Military Letter from Bengal, 12th Feb., 1811, para. 807.

114. Letter from Hewitt to Nugent, 8th Dec., 1811: Nugent MSS, f. 36 .

115. Mins. of Ev., 1832, Sec. 5, p. 218 .

116. H. H. Wilson, The History of British India, vol. i, pp. 264-84.

117. Barat, op. cit., pp. 86-92. By a regulation of 1828 , the rank of colonel was conferred regimentally.

118. Lady Nugent, op. cit., vol. ii, p. 329.

119. Quoted by Mr. Hume during the debate at East India House, Jan., 1816: A.J., vol. i: 1816, p. 70. O'Halloran is not named; but according to the East India Register for 1814, 2nd edition, p. 28,0 'Halloran was 20 th in the line of succession for regimental lieutenant-colonelcies, although he had held the brevetrank from June, 1814. He further fits the description given by Hume in that he joined the service in 1781, and had therefore completed 34 years' service by 1814 .

120. Carey, op. cit., vol. i, pp. 476-77, Sir John Hearsey, in his Autobiography, gives a convincing picture of the way in which petty altercations were inflated to dominate the lives of junior 
120.. regimental officers. See Col. Hugh Pearse, The Hearseys, pp. 161-76.

121. Badenach, op. cit., p. 14; Mins. of Ev., 1832, Sec. 5, pp. 88-89.

122. Nugent, to Torrens, Sept. 26th, 1813: Nugent MSS, f. 172.

123. Nugent to Chas. Grant, 7th June, 1812: Nugent MSS, f. 161.

124. Nugent's Report of 20th June, 1813: loc.cit., para. 74; Badenach, op. cit., pp. 9-10; Nugent to Torrens, 26th Sept., 1813: Nugent MSS, f. 174. An essential defect in the system was that officers absent on leave or extra-regimental appointments remained on the paper strength of their regiments.

125. Military Sketches of the Goorkha War, p. xi.

126. Wallace, op. cit., p. 38 , describes how at one end of an officers' dining table "might be heard an animated discussion respecting the spirit of Miltiades or a difference of opinion between Caesar and Pompey; while at another there was a description given of the Persians pouring 'wollies' into the Russians; and to the question 'Pray, what fish is that before you?' this answer was returned: 'Really, I do not know; I am not botanist enough for that.'"

127. Mins. of Ev., 1832, Sec. 5,pp. 16, 215, 231. The language was Urdu.

128. Sita Ram, op. cit., pp. 13, 54.

129. Nugent's Report of 20th June, 1813: loc. cit., para. 99.

130. Mins. of Ev., 1813, p. 54; Henry, op. cit., pp. 293-94.

131. In one of the new infantry battalions, raised at Benares in 1814, there were 329 brahmins, 304 Rajputs (of ksatriya status), 92 Muslims, and 110 low-caste Hindus (Badenach, op. cit., p. 74).

132. Badenach (ibid., p. 74) estimates the proportion of Mus lims to Hindus in infantry regiments as 1 to 10.

133. J. T. Pryme and A. Bayne, Memorials of the Thackeray Family, p. 488. Cf. Mins. of Ev., 1832 , Sec. 5, p. 23 .

134. Nugent's Report of 20th June, 1813: loc.cit., paras. 88-91.

135. Barat, op. cit., p. 304 .

136. Mins. of Ev., 1832 , Sec. 5, p. 178. The sepoy's 7 rupees, which included full allowance and from which a deduction was made for the off-reckoning fund, was higher than the wage received by the 
$136 .$. peasantry, but lower than that received by many natives employed as servants by Europeans - ibid., p.41.

137. Quoted by Barat, op. cit., p. 217. Dr. Barat also makes the significant abservation that when 6 more regiments mutinied, the colonel commanding was in no case present with his corps.

138. Capt. S. Parlby, The British Indian Military Repository, vol. ii, pp. 147-49, 159. The majority of cadets "educated themselves" and then applied for certificates of proficiency from professors at the Woolwich Academy. The educational expenses of successful candidates only were reimbursed by the court.

139. Carey, op. cit., vol. i, pp. 240-41; Mins. of Ev., 1832, Sec. 5 , p. 174 .

140. Mins. of Ev., 1813, pp. 64, 321.

141. J. W. Kaye, A History of the Sepoy War in India, vol. i, p. 216.

142. Sita Ram, op. cit., p. 52.

143. Badenach, op. cit., p. 143.

144. Heber, op. cit., vol. iii, pp. 337-39.

145. Dr. Barat discusses this point, op. cit., pp. 292-94.

146. Mins. of Ev., 1832, Sec. 5, pp. 222-23.

147. Wilson, op. cit., vol. i, p. 126.

148. Mins. of Ev., 1813 , p. 82; Mins. of Ev., 1832, Sec. 5 , p. 223; Wilson, op. cit., vol. i, pp. 125, 127, 139-40.

149. Lawrence, op. cit., pp. 415-28.

150. Heber,op. cit., vol. ii, p. 280.

151. Camaticus, 10c. cit., p. 433.

152. Military Sketches of the Goorkha War, p. 53.

153. Mins. of Ev., 1832, Sec. 5, p. 216.

154. Lawrence, op. cit., p. 396. 


\section{Notes to Chapter Five}

1. E. Noel, "The Marquess of Hastings and the Nipal War of 1814 16", U.S.M.: March, 1913, p. 656.

2. A point stressed by Hyder Hearsey. See P.R.N.W., p. 52 .

3. For Hastings' explanation of the principles behind his strategy see P.R.N.W., Pp. 995-96; and his letter of August 17th, 1814 to the Prince Regent in A. Aspinall (ed.), The Letters of King George IV, vol. i, p. 480. A lucid enunciation of these principles is also given in a "Letter from an Officer on the Staff of the Bengal Army", A.J., vol. i: May, 1816, p. 427.

4. Noel, loc. cit., p. 656 .

5. Hastings' own summary of his plan is in P.R.N.W., pp. 702-03. Regarding the original strength of each division, no two estimates agree, but a careful collation of a vailable assessments gives these approximate figures. A comparis on of the figures given by Hastings in P.R.N.W., Pp. 703, 708, 712, and 715 with the details concerning the composition of each force given in ibid., pp. 195, $433,196,197$, and 433 , shows that his figures are rough ly correct only for Ochterlony's column. In the case of Gillespie's force the figure 2,343 for native infantry must be a misprint for 3,243 , and no allowance is made for the regiment of native cavalry and the detachment of King's cavalry. The assessment on p. 715 for Marley's force $(7,989)$ is too high. The Return for 23 rd Dec., 1814 gives the total combatant force as 6,686 (pp. 518-19). The figure for Wood's column on p. 212 is an over-estimation. The Calcutta Monthly Journal, vol. xxv, Dec., 1814, p. 381, computes the force at 3,700. This seems much more likely.

6. Circular Letter to Ochterlony, Gillespie, Wood and Marley, P.R.N.W., P. 164. Marley's force was finally organised as two brigades and a reserve, ibid., p. 197.

7. P.R.N.W., Pp. 702, 996.

8. Report from Rutherfurd, P.R.N.W., p. 96; Report from Magistrate of Moradabad, ibid., p. 131; Political Secretary to Adjutant General, ibid., p. 142.

9. P.R.N.W., p. 13 .

10. P.R.N.W., P. 47 .

11. P.R.N.W., Pp. 187-92.

12. P.R.N.W., Pp. 185, 703 . 
13. P.R.N.W., P. 994.

14. P.R.N.W., p. 996; letter to McMahon: Aspinall, op. cit., vol.

15. P.R.N.W., P. 784 .

16. W. Hamilton, Gazetteer of Hindustan and the Adjacent Countries,
vol. ii, pp. $\frac{549 ; 612 \text {. }}{}$

17. Bute, Marchioness of (ed.), The Private Journal of the Marquis of Hastings, vol. i, p.170.

18. C.M.J., vol. xxv: Nov. 1814, p. 267; F. W. Stubbs, History of the Bengal Artillery, vol. ii, p. 40.

19. Mil. Cons., 30th September 1814, no. 92.

20. Mil. Cons., 14th Oct., 1814, no. 74 .

21. Mil. Cons., 23rd Dec., 1814, no. 29.

22. Mil. Cons., 30th Sept., 1814, no. 92.

23. Mil. Cons., 19th Nov., 1814, no. 166.

24. D. G. Crawford, A History of the Indian Medical Service, vol. ii,

25. H. A. Young, The East India Company's Arsenals and Manufactories, p. 182 .

26. Crawford, op. cit., vol. i, pp. 310, 312. All medical officers in the Company's service held a military commission, but assistant surgeons were allowed to opt for civil employ.

27. Mil. Cons., 30th Sept., 1814, no. 120; P.R.N.W., p. 30.

28. P.R.N.W., P. 28.

29. This is apparent from a sketch in the Ludlow MSS: AD $7450 / 2$, no. 65 .

30. P.R.N.W., PP. 22, 28-29, 99, 100, 107.

31. P.R.N.W., P. 28 .

32. P.R.N.W., p. 977.

33. Military Letter to Bengal, 26th August, 1818, paras. 195-98.

34. Mil. Cons., Dec. 22nd, 1815, no. 1. 
35. Rutherfurd, Bradshaw and Hearsey all urged that no reliance should be placed on foraging: P.R.N.W., Pp. 9, $29,56$.

36. Mil. Cons., Dec. 22nd, 1815, no. 1.

37. Mil. Cons., 22nd Dec., 1815, no. 1.

38. P.R.N.W., P. 552; Mil. Cons., 14th Dct., 1814, no. 126. Normally, when on foreign service the sepoy was provided with his rations, for which a fixed nominal sum was charged. In P.R.N.W., p. 977, it is mentioned that 15 days' supplies were carried. But Mil. Cons., 14th Oct., 1814, no. 126 makes provision for one month's supplies with Marley's column. It may be that Marley's supplies were reduced at the last minute because of the difficulty of obtaining carriage.

39. C.M.J., vol. 25: Nov., 1814, p. 267.

40. $\quad$ P.R.N.W., pp. $722 ; 723$.

41. See, for example, the information submitted by Rutherfurd, Buchanan, Hearsey and Fraser - P.R.N.W., pp. 33, 44, 59, $238-43$.

42. P.R.N.W., p. 703 .

43. $\quad$ P.R.N.W., Pp. 63-64.

44. See instructions to Ochterlony and Bradshaw: P.R.N.W., Pp. 62, 260.

45. Pol. Sec. to Ochterlony, 30th Sept., 1814: P.R.N.W., p. 64 .

46. Instructions to Bradshaw, 26th Nov., 1814: P.R.N.W., pp. 254, 260.

47. P.R.N.W., pp. 47-48.

48. Instructions to Metcalfe, 30th Sept., 1814: P.R.N.W., p. 69.

49. Edwin T. Atkins on, The Himalayan Districts of the North West Provinces of India, vol. ii, p. 647 .

50. Gandner to Govt., 22nd Nov., 1814: P.R.N.W., P. 299; R. Heber, Narrative of a Journey, vol. ii, pp. 163-64.

51. Instructions to Fraser, 24th Nov., 1814: P.R.N.W., P. 248; Proclamation to be issued to the Inhabitants of Garhwal: P.R.N.W.,
pp. $134-35$.

52. The notes of Hearsey which were submitted by Moorcroft to Government (P.R.N.W., Pp. 52-59) are almost identical to those by him submitted by Captain William Richards to Ochterlony in 1813 (see Pol. Cons., 20th August, 1813, no. 34). 
53. Ludhiana Records, p. 405 .

54. P.R.N.W., pp. 73, 705 .

55. P.R.N.W., Pp. 65-66.

56. P.R.N.W., P. 16 .

57. Instructions to Ochterlony and Metcalfe: P.R.N.W., pp. 65, 120.

58. P.R.N.W., P. 134 .

59. P.R.N.W., pp. 153-54.

60. P.R.N.W., p. 257 .

61. Instructions to Bradshaw: P.R.N.W., p. 256 .

62. P.R.N.W., p. 269 .

63. P.R.N.W., P. 266 .

64. P.R.N.W., pp.258, 260.

65. P.R.N.W., pp. 257-58, 721 .

66. C.M.J., vol. 25 : Nov., 1814, p. 268 .

67. Letter to Resident at Lucknow: P.R.N.W., P. 134 .

68. Letter to McMahon, 22nd Jan., 1815: Aspinall, op. cit., vol. ii, p. 14.

69. P.R.N.W., P. 715 .

70. East India Register: 1814, (Second Edition), p. 25.

71. Sec. Cons., 6th August, 1813, no. 4, para. 73. "It was with great difficulty, I can assure your lordship in Council", he wrote to the Governor General, "that I could find two or three lieutenant colonels, in a pretty numerous list, in this quarter, from whom to select one for the command of the Rewa force after Colonal Martindell had been permitted to relinquish it."

72. V. C. P. Hodson, A List of the Officers of the Bengal Army, part 2; Personal Records, vol. 18, f. 171 .

73. It was Lady Temple who later recommended Octherlony to the notice of Lady Nugent. See Maria, Lady Nugent, Journal, vol. ii, p. 31. 
74. F. G. Cardew, "Major General Sir David Ochterlony, Bart., G.C.B., 1758-1825", J.S.A.H.R., vol. 10: 1931, pp. 40-63; Walter Kendall Watkins, The Scotch Ancestry of Major General Sir David Ochter Iony, Bart.; J.W. Kaye, Life of Metcalfe, vol. i, pp. 204, 213-14; The East India Military Calendar, vol. $i$, pp. 379-383. Shipp mentions his missing eye in op. cit., p. 207; but it is obvious from his portrait.

75. Cardew, op. cit., p. 49.

76. Ludhiana Records, pp. 392-93.

77. Kaye, op. cit., vol. i, p. 386, fn.

78. Ludhiana Records, p. 402.

79. Sec. Cons., 25th Oct., 1814, no. 4.

80. Sec.Cons., 18th Nov., 1814, no. 22.

81. Ludhiana Records, p. 402.

82. Home Misc., vol. 738 , f. 647.

83. R. H. Murray, History of the King's Royal Irish Hussars, vol. ii, p. 348; Royal Military Calendar, third edition, vol. iii, p. 14.

84. Letter to McMahon, 22nd Jan., 1815: Aspinall, op. cit., vol. ii, p. 14.

85. C. R. Low, Life and Correspondence of Field Marshal Sir George Pollock, p. 97.

86. See, for example, the opinion of Captain Taylor, quoted in C. E. Wurtzburg, Raffles of the Eastern Isles, p. 212; and of Col. James Welsh in his Military Reminiscences, vol. i, pp. 322-23.

87. Details of Gillespie's career are given in Eric Wakeham, The Bravest Soldier: Sir Rollo Gillespie, 1766-1814, passim; Memoir of Sir R. R. Gillespie, passim.

88. Wurtzburg, op. cit., pp. 166-67.

89. Wakeham, op. cit., p. 179.

90. Wurtzburg, op. cit., pp. 199, 216-17.

91. Ibid., pp. 182-86, 222 .

92. Nugent to Tomens, Sept. 26th, 1813: Nugent Correspondence, f. 172.

93. Wurtzburg, op. cit., p. 280. 
94. Ibid., Pp. $295 ; 299,301,303$. 95. John Bastin (ed.), The Journal of Thomas Otho Travers, 1813-1820,
p. 43, fn.

96. Demetrius Charles Boulger, The Life of Sir Stamford Raffles, p. 237.

97. Ibid., pp. 223-35.

98. Wurtzburg, op. cit., p. 212.

99. Lady Nugent, op. cit., vol. ii, p. 333.

100. F. J. Harvey Darton (ed.), The Life and Times of Mrs Sherwood,
p. 408 .

101. Wurtzbung, op. cit., p. 372.

102. Boulger, op. cit., p. 237.

103. Wakeham, op. cit., pp. 237-38.

104. Raffles Collection, f. 189. 


\section{Notes to Chapter Six}

1. Adjutant General to Gillespie, 13th Sept., 1814, 25th Sept., 1814: P.R.N.W., Pp. $123-24,160$.

2. F. J. Harvey Darton (ed.), The Life and Times of Mrs Sherwood; p. 497; Gillespie to Adj. Gen., 13th Oct., 1814: Mil. Cons. 19th Nov., 1814, no. 61 .

3. Sherwood MS; Harvey Darton, op. cit., p. 497.

4. Adj. Gen. to Gillespie, 6th Oct., 1814: P.R.N.W., p. 163.

5. Harvey Darton, op. cit., p. 498.

6. Adj. Gen. to Gillespie, 13th Sept., 1814: P.R.N.W., pp. 123-25.

7. Return of European and Native Soldiers, Public Establishments, and Camp Followers...: : P.R.N.W., P. 980. The figures in the 2nd and 3rd columns of this table have been confused and should be interchanged - cf. P.R.N.W., p. 558.

8. Ludlow MSS: AD $7450 / 1$ no. 2 .

9. Adj. Gen, to Gillespie, 24th Oct.,1814: P.R.N.W., p. 181.

10. Memoir of $\operatorname{sir}$ R. R. Gillespie, p. 214.

11. Chepmell MS; Statement of Arrears of Pay...: Mil. Cons., 3rd Dec., 1814, no. 101. Carpenter's battalion was the lst/17th Native Infantry.

12. Sherwood MS; Chepmell MS.

13. Adj. Gen. to Gillespie, 13th Sept., 1814; P.R.N.W., p. 123;

Chepmell MS.

14. Memoir of Gillespie, p. 215; Harvey Darton, op. cit., p. 499.

15. John Wells Fast to J. Mackilliop, 10th March, 1828: India Office Library Special Military Collections: L/Mil/5/391, f. 203.

16. Chepmell MS; Sherwood MS.

17. See article on 'Deyhra Dun' in Walter Hamilton, Gazetteer of Hindustan and the Adjacent Countries.

18. Chepme11 MS. 
19. James Baillie Fraser, Journal of a Tour, p. 14.

20. Chepmell MS.

21. Adj. Gen. to Political Secretary, 3rd Nov., 1814: P.R.N.W., p. 435. The date given in this letter is the 28 th, but this is probably a misprint for $23 \mathrm{rd}$, for Chepmell mentions that Carpenter's force, the 1/17th N.I., formed part of the attacking party on the morning of October 24 th.

22. Memoirs of Gillespie, p. 219.

23. The Regimental Journal of the King's Shropshire Light Infantry, Vol. 10, no. 55: Feb., 1935, pp. 19-20, gives a useful description and map of the topography of the place. See also the plan sketched by Ludlow: Ludiow MSS. AD $7450 / 2$ no. 73 . The outer stockade is mentioned by Mawby in a letter to the Adj. Gen., lst Nov., 1814: P.R.N.W., P. 439; and by Rutherfund, in a letter to Political Secretary, Oct. 15th, 1814: P.R.N.W., p. 105. All traces of Kalanga fort have now disappeared, and the site is overgrown with trees; but the features of the hill, as mentioned in the contemporary sources are still distinctly traceable.

24. J. B. Fraser, op. cit., p. 14; Henry T. Prinsep, Military and Political Transactions, vol. i, p. 87.

25. Chepmell MSS.

26. Ibid.

27. Adj. Gen. to Gillespie, lst Oct., 1814: P.R.N.W., P. 161.

28. Memoir of Gillespie, p. 218.

29. Memoir of Gillespie, pp. 215-17.

30. Chepmell MS.

31. Sherwood MS; Harvey Darton, op. cit., pp. 499-501; Sophia Kelly (ed.), The Life of Mrs Sherwood, pp. 463-64.

32. Memoir of Gillespie, p. 219. Also printed in R. Cannon, Historical Record of the 8th or King's Royal Irish Regiment of Hussars, p.129.

33. Memoir of Gillespie, p. 227; Mawby to Adj. Gen., Ist Nov., 1814: P.R.N.W., pp. 438,440 .

34. Chepmell MS; Memoir of Gillespie, p. 226; Ludlow MSS. AD 7450/2 no. 54 . 
35. Memoir of Gillespie, p. 227.

36. Mawby to Adj. Gen., lst Nov., 1814: P.R.N.W., p. 438.

37. Chepmell MS.

38. Memoir of Gillespie, p. 227; Mawby to Adj. Gen., lst Nov., 1814: P.R.N.W. , p. 439; Prinsep, op. cit., vol. i, p. 88.

39. Memoir of Gillespie, $\mathrm{pp} \cdot 222-24$.

40. Harvey Darton, op. cit., p. 501; Mawby to Adj. Gen., lst Nov., 1814: P.R.N.W., p. 439; Memoir of Gillespie, p. 228. The Memoir says seven $0^{\prime}$ clock, but this agrees with no other account. It is obviously calculated from the time of the assault, and based on the assumption that Gillespie made no error.

41. Sherwood MS. Prinsep, op. cit., vol. i, p. 88, says an hour early. J. B. Fraser, op. cit., p. 16, says "some hours" early. Mawby, in his letter to the Adj.Gen., (P.R.N.W., p. 439), says that the other officers did not hear the signal; but it seems unlikely that he meant that the guns were inaudible to them. The sound of ordnance travelled so well in the hills that at a later stage, when this division was before Nahan, the guns of Ochterlony's column, some twenty miles away, were audible to it. The Memoir says that Kelly and Fast did not hear - but this hardly explains Campbell's failure to come up.

42. Memoir of Gillespie, p. 228; F. W. Stubbs, History of the Bengal Artillery, vol. ii, p. 5 , fn.

43. Memoir of Gillespie, p. 230 .

44. Capt. Byers to John Wells Fast, 2nd Nov., 1814: I.0.L. Special Military Collections, L/Mil/5/319, f. 205.

45. Sherwood MS; Mawby to Adj. Gen., lst Nov. 1814: P.R.N.W., p. 439.

46. Sherwood MS; Chepmell MS (entry for lst Feb., 1816).

47. Ludlow MSS, AD $7450 / 2$ no. 54 .

48. Stubbs, op. cit., vol. ii, p. 6; Sherwood MS; Letter signed "Parry" in E.I.U.S.J., vol. viii: April, 1836, pp. 274-76.

49. Stubbs, op. cit., vol. ii, p. 6; Fraser, op. cit., p. 16.

50. Mawby to Adj. Gen., Ist Nov., 1814: P.R.N.W., p. 439; Sherwood MS; Cannon, Historical Record of the 53rd Regiment of Foot, p. 19. 
51. There is some uncertainty concerning Carpenter's part. An unsigned account in the Ludlow MSS, AD $7450 / 2$ no. 55 , tallying with Ludlow's personal account in other details, relates that Carpenter was soon obliged to retire, but that Ludlow's column entered the stockade and maintained it. Ludlow, in AD $7450 / 2$ no. 54 , does not name Carpenter, but says "we got and retained possession of a stockaded village". Chepmell, who was on the table land throughout, makes no mention of the return of Carpenter.

52. Chepmell MS.

53. Sherwood MS.

54. Ibid.

55. Memoir of Gillespie, p. 231.

56. Ibid., p. 232 .

57. Stubbs, op. cit., vol. ii, p. 6 .

58. Ludlow MSS, AD $7450 / 2$ no. 55 .

59. Stubbs, op. cit., vol. ii, p. 7; C.M.J., vol. xxv: Nov., 1814, p. 281 .

60. Stubbs, op. cit., vol. ii, p. 7.

61. Ludlow MSS. AD $7450 / 2$ nos. 54,55 ; J. B. Fraser, op. cit., p. 14; Ludlow to his wife, 30th [sic.T Oct., 1814: Ludlow MSS, AD 4750/1, no. 3 .

62. Stubbs, op. cit., vol. ii, p. 7.

63. Ludlow MSS. AD $7450 / 2$, nos. $54,55,56$; W. H. Sleeman, Rambles and Recollections, vol. ii, pp. 432-33; G. R. C. Williams, Historical and Statistical Memoir of Dehra Dun, p. 131; Harvey Darton, op. cit., p. 500; Sherwood MS. Sleeman makes the comparison between the 53 rd and the army of Appius. He does not name Gillespie, but there is no doubt that the major-general was the martinet to whom he refers. Williams again mentions no names, but recounts that the men hated their commanding officer. It is most unlikely that this was Mawby, for reasons mentioned in the text. All contemporary writers on Gillespie, even the anonymous and eulogising author of the Memoir, mention his strictness and passion for discipline.

65. Chepmell MS.

65. Sherwood MS.

66. Stubbs, op. cit., vol. ii, p. 8 . 
67. Chepmell MS.

68. Mawby to Adj. Gen., Ist Nov., 1814: P.R.N.W., p. 441.

69. Harvey Darton, op. cit., p. 500; Sherwood MS.

70. Harvey Darton, op. cit., p. 408.

71. Bute, Marchioness of (ed.), The Private Journal of the Marquis of Hastings, vol. i, pp. 223-24.

72. Quoted in Robert H. Murray, History of the 8 th King's Royal Irish Hussars, vol. i, p. 371 .

73. Mawby to Adj. Gen., Ist Nov., 1814: P.R.N.W., P. 439; Ludlow MSS, AD $7450 / 1$, no. 8 .

74. C.M.J., vol. xxv: Nov., 1814, p. 282 .

75. Ludlow MSS, AD 7450/2, no. 8; The "Memorandum", AD 7450/2, no. 54, is probably the draft of such a letter. Ludlow's views were certainly made public - see Memoir of Gillespie, p. 235.

76. Royal Military Calendar, 3rd Edition, vol. iv, pp. 2-4; Harvey Darton, op. cit., p.227, et passim.

77. Cannon, History of the 53rd, p. 16 .

78. Ibid., p. 16 .

79. Mawby to Adj. Gen., 2nd Nov., 1814: P.R.N.W.; p. 460; Chepmell MS.

80. Mawby to Adj. Gen., 3rd Nov., 1814: P.R.N.W., p. 461.

81. Ludlow MSS, AD $7450 / 1$. no. 4 .

82. Fraser to Pol. Sec., 30th Oct., and 25th Nov., 1814: P.R.N.W., pp. 247-48, 274-78; Pol. Sec. to Fraser, 30th Nov., 1814: P.R.N.W., p. 278 .

83. Chepmel1 MS; Ludlow MSS, AD $7450 / 1$ nos. $5,10$.

84. Ludlow MSS, $\operatorname{AD} 7450 / 1$ nos. 5, 6, 7, 8; Fraser to Pol. Sec., 25 th Nov., 1814: P.R.N.W., p. 276 .

85. Chepmell MS.

86. Field Onders, 24th Nov., 1814: P.R.N.W., p. 467. 
87. Harvey Darton, op. cit., p. 502; Chepmell MS; Ludlow MSS, AD $7450 / 1$ no. 11 .

88. Sherwood MS.

89. Ibid.; Chepmell MS; Ludlow MSS, AD 7450/2, no. 73.

90. Chepmell MS; Sherwood MS.

91. Sherwood MS; Harvey Darton, op. cit., p. 503.

92. Chepme11 MS.

93. Mawby to Adj. Gen., 27th Nov., 1814: P.R.N.W., pp. 465-66.

94. Cannon, History of the 53rd, p. 20.

95. Sherwood MS: Harvey Darton, op. cit., p. 503; The Englishman, 29 th Sept., 1846.

96. J. B. Fraser, op. cit., p. 28 .

97. The Englishman, 24th Sept., 1846.

98. Sita Ram, From Sepoy to Subadar, pp. 19-20. In this text the name of the Captain is printed as Burrumpeel. This is undoubtedly a compositor's mistake for Kurrumpeel - a phonetic rendering of Campbell. Sita Ram's corps can thus be identified as the Grenadier Company of the lst/6th Native Infantry. This battalion became the 3rd Native Infantry in 1824.

99. Ludlow MSS, AD 7450/1, no. 11.

100. Cannon, History of the 53rd, p. 20; Mawby to Adj. Gen.,28th Nov., 1814: P.R.N.W., P. 467 .

101. Stubbs, op. cit., vol. i, p. 9; C.M.J., vol. xxv: Dec., 1814, p. 379. 102. Mawby to Adj. Gen., 27th Nov., 1814: P.R.N.W., Pp. 465-67; Chepmell MS.

103. Return of Killed, Wounded and Missing...: P.R.N.W., p. 471.

104. Chepmell MS.

105. C.M.J., vol. xxvi: Jan., 1815, p. 43.

106. Stubbs, op. cit., vol. ii, plate $x \times x$.

107. Sherwood MS; Mawby to Adj. Gen., 30th Nov., 1814: P.R.N.W., pp. 492-93; Ludlow MSS, AD $7450 / 1$, no. 12 ; AD $7450 / 2$, no. 73 . 
108. Sherwood MS.

109. Mawby to Adj. Gen., Nov. 30th, 1814: P.R.N.W., P. 492.

110. An amalgam of the account in the MS joumal and that contained in a letter to his wife,printed in Kelly, op.cit., pp. 465-67.

111. Mawby to Adj. Gen., 30th Nov., 1814: P.R.N.W., p. 493.

112. Sherwood MS.

113. Ludlow MSS, AD $7450 / 1$, no. 12 .

114. C.M.J., vol. xxv: Dec., 1814, p. 378.

115. Letter to Secret Committee, 2nd August, 1815: P.R.N.W., p. 734.

116. A. Aspinall (ed.), The Letters of King George IV, vol. ii, p. 14.

117. Torrens to Hastings, 30th Nov., 1815: Public Records Office MSS, W.0. $3 / 610$, f. 285 .

118. Aspinall, op. cit., vol. ii, p. 14.

119. Memoir of Gillespie, p. 240.

120. Eric Wakeham, The Bravest Soldier, pp. 239-40.

121. Dedication of Memoir of Gillespie.

122. Wakeham, op. cit., pp. 242-43.

123. Demetrius Boulger, The Life of Sir Stamford Raffles, pp. 239-42.

124. C.M.J., vol. xxvi: Jan., 1815, p. 7; Sherwood MS.

125. Captain William Hough, The Practice of Courts Martial and other Military Courts, p. 135, fn; Chepmell MS - entry for Sept. 4th, 1815 .

126. Metcalfe to Richard Jenkins, rec'd 6th June, 1815, printed in John Kaye, Life of Metcalfe, vol. i, p. 409.

127. Mawby to Adj. Gen., 3rd Dec., 1814: P.R.N.W., Pp. 493-97; Ludlow MSS, AD 7450/1, no. 13; Chepmell, MS.

128. Adj. Gen. to Mawby, 11th Dec., 1814: P.R.N.W., p. 306.

129. Fraser to Pol. Sec., 8th Dec., 1814: P.R.N.W., Pp. 293-94. 
130. Carpenter to Major of Brigade, 5th Dec., 1814: P.R.N.W., pp. 498-99; Fraser to Pol. Sec., 6th Dec., 1814: ibid., p. 288; Ludlow MSS AD $7450 / 1$, no. 20 .

131. P.R.N.W., p. 337 .

132. Pol. Sec. to Fraser, 13th Dec., 1814: P.R.N.W., Pp. 296-97; Adj. Gen. to Officer Commanding in the Dun, 13th Dec., 1814: ibid., pp. 310-11.

133. Adj. Gen. to Pol. Sec., 10th Dec., 1814: P.R.N.W., pp. $491-92$.

134. Sherwood MSS; Chepmell MS; Harvey Darton, op. cit., pp. 503-04; Ludlow MSS AD 7450/1, nos. 14-20.

135. Chepmell MS. 


\section{Notes to Chapter Seven}

1. The East India Military Calendar, vol. i, pp. 406-07; F. G. Cardew, A Sketch of the Services of the Bengal Native Army, pp. 71, $89-90,107$; Ludlow MSS AD 7450/1, no. 45; R. Heber, Narrative of a Journey, vol. i, p. 403.

2. Secret Letter from Bengal, 30th June, 1813: I.0.L. Records, Secret Letters from Bengal, vol. 14, f. 436.

3. Ibid., f. 437 .

4. Ibid., ff. $438,444-64$.

5. East India Military Calendar, vol. ii, p. 563.

6. Letter to Secret Committee, Aug. 2nd, 1815: P.R.N.W., p. 737.

7. Adj.Gen. to Martinde11, 18th Dec., 1814: P.R.N.W., P. 312.

8. Martindell to Adj. Gen., 20th Dec., 1814: P.R.N.W., p. 324.

9. Ibid., p. 324; Harvey Darton, op. cit., p. 504.

10. Sherwood MS.

11. Harvey Darton, op. cit., pp. 504-05. Details of Jaithak are in an extract from the Joumal of Sir William Richards, quoted in The Englishman, 29th Sept., 1846. The ruined foundations of the fort still exist, and are used as a temple by the villagers of the hamlet of Jaithak.

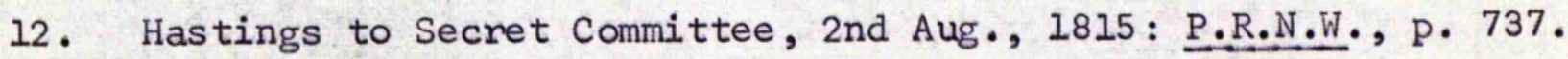

13. Harvey Darton, op. cit, p. 505.

14. Martindell to Adj. Gen., 30th Dec., 1814: Home Misc., vol. 649, ff. 19-20.

15. Ibid., f. 14; Martindell to Adj. Gen., 27th Dec., 1814: P.R.N.W., p. 503; Ludlow MSS AD $7450 / 1$, no. 23 .

16. Ludlow MSS $\operatorname{AD} 7450 / 1$, nos. $23,28,49,49 a$; Ludlow to Major Edwards, 28th Dec., 1814: Home Misc., vol. 649, ff. 24-31; Martindell to Adj. Gen., 30th Dec., 1814: Home Misc., vol. 649, ff. 14-23; Harvey Darton, op. cit., p. 505; Chepmell MS; Prinsep, op. cit., vol. i, pp. 97-99.

17. Ludlow MSS AD $7450 / 1$, no. 27. 
18. Letter to Secret Committee, 2nd Aug., 1815: P.R.N.W., P. 736.

19. Adj. Gen. to Martindel1, 3rd Jan., 1815: Home Misc., vol. 649, ff. $57-63$.

20. Ludlow MSS AD $7450 / 1$ nos. 32, 33; The Englishman, 29th Sept., 1846. Richards noted in his Journal that as they were "chiefly of low caste, no measures $I$ were $T$ adopted to put a stop to their going or to apprehend any of the $\bar{m}$.

21. Adj. Gen. to Martinde1l, Jan. 3rd., 1815: Home Misc., vol. 649, ff. 57-63.

22. Ludlow MSS AD $7450 / 2$, no. 5 .

23. A.J., vol. xi: London, May, 1821, p. 432.

24. Ludlow MSS AD $7450 / 1$, no. 28 .

25. Martindell to Adj. Gen., 30th Dec., 1814: Home Misc., vol. 649, f. 15; Sherwood MS; Harvey Darton, op. cit., P. 505; J. B. Fraser, op. cit., p. 33; Prinsep, op. cit., vol. i, p. 100; C.M.J., vol. xxvi: Calcutta, Jan., 1815, p. 65.

26. Richards to Major of Brigade, Dec., 28th, 1814: Home Misc., vol. 649, f. 43; Ludlow MSS, AD $7450 / 1$, no. 24; Prinsep, op.cit., vol. i, Pp. 99-101; The Englishman, 25 th and 26 th September, 1846.

27. Jane Townley Pryme and Alicia Bayne, Memorials of the Thackeray Family, Pp. 487-88; V. C. P. Hodson, A List of the Officens of the Bengal Army.

28. Richards to Major of Brigade, Dec. 28th, 1814: Home Misc., vol. 649, ff. 43-44; The Englishman, 25th and 26th Sept., 1846.

29. Richards to Major of Brigade, Dec. 28th., 1814: Home Misc., vol. 649, ff. 43-44; Ludlow MSS AD 7450/1, nos. 24, 26; Harvey Darton, op. cit., p. 506; C.M.J., vol. xxvi: Jan. 1815, pp. 86-87; Prinsep, op. cit., vol. i, pp. I01-03; Pryme and Bayme, op. cit., p. 490; The Englishman, 25th and 26th Sept., 1846.

30. C.M.J., vol. xxvi: Feb., 1815, p. 130.

31. Prinsep., op. cit., vol. i, p. 102.

32. Adj. Gen. to Martindell, Jan. 3rd, 1815: Home Misc., vol. 649, f. 57 .

33. The Englishman, September 26 th, 1846. 
34. Adj. Gen. to Martindell, 3lst Dec. 1814: P.R.N.W., p. 506;

Adj. Gen. to Pol. Sec., 2nd Jan. 1815: E.S.D.B., vol. 5,

no. 15 ; C.M.J., vol. xxvi: Calcutta, Jan. 1815, p. 65.

35. Adj, Gen. to Martinde11, Ist Feb., 1815: Home Misc., vol. 652,

f. 603 .

36. J. B. Fraser, op. cit., p. 35; Ludlow MSS AD 7450/1, no. 36 .

37. Adj. Gen. to Martinde11, lst Feb., 1815: Home Misc., vol. 652, ff. 604-05.

38. Martindell to Adj. Gen., 10th Feb., 1815: Home Misc., vol. 652, f. 656 .

39. The Adj. Gen. acknowledged its receipt on Feb. 25 th - see E.S.D.B., vol. 6 , no. 33 .

40. See Adj. Gen. to Martinde11, 14th March, 1815: Home Misc., vol. 652, f. 660 .

41. Ludlow MSS AD $7450 / 1$, no. 26 .

42. Ibid., no. 34 ; J. B. Fraser, op. cit., pp. 58-59.

43. Ludlow MSS AD $7450 / 1$, no. 33 .

44. Ibid., no. 36 .

45. Ibid., no. 49 .

46. Ibid., no. 36 .

47. Mawby to Adj. Gen., lst Nov., 1814: P.R.N.W., P. 450.

48. Kaye, op. cit., vol. ii, p. 138.

49. J. B. Fraser, Military Memoir of Colonel James Skinner, vol. ii, p. 166; Dictionary of National Biography; L. Hadow Jenkins, General Frederick Young, p. 45.

50. Fraser to Pol. Sec., 25th Dec., 1814: Home Misc., vol. 651, ff. $49-66$.

51. Adj. Gen, to Pol. Sec., 8th Jan., 1815: ibid.

52. Fraser to Pol. Sec., 16th Feb., 1815: Home Misc., vol. 652, ff. 79-143; J. B. Fraser, Journal of a Tour, p. 77; Ochterlony to Pol. Sec., 9th July, 1814 : P.R.N.W., p. 16. 
53. Fraser to Pol. Sec., 16th Feb., 1815; 3rd March, 1815: Home Misc., vol. 652 , ff. 101-02; 326 .

54. Ibid., ff. $312-13$.

55. Chepme11 MS; Ludlow MSS, AD $7450 / 1$, no. 37 .

56. Ludlow MSS, ibid.

57. Chepmell MS; Ludlow MSS AD $7450 / 1$, no. 38 .

58. Ludlow MSS, ibid.

59. Chepmell MS; Sherwood MS; Ludlow MSS AD $7450 / 1$, no. 40;

Martindell to Adj. Gen., 5th Feb., 1815: E.S.D.B., vol. 6, no. 18.

60. Martinde11 to Adj. Gen., 5th Feb., 6th Feb., 1815: E.S.D.B., vol. 6 , nos. 18,24 .

61. Ludlow MSS AD 7450/1, no. 41; Martindell to Adj. Gen., 6th March, 1815: Home Misc., vol. 652, f. 647.

62. Ludlow MSS, AD $7450 / 1$, no. 42 .

63. Sherwood MS; Chepme11, MS.

64. Ludlow MSS, AD $7450 / 1$, no. 43.

65. Ibid., no. 44; Sherwood MS; Chepmell MS; Martindell to Adj. Gen., 10th Feb., 1815: E.S.D.B., vol. 6, no. 24; Martindell to Adj. Gen., 6th March, 1815: Home Misc., vol. 652, f. 647.

66. Martindell to Adj. Gen., 12th Feb., 1815: E.S.D.B., vol. 6, no. 33; Martindel1 to Adj. Gen., 6th March, 18I5: Home Misc., vol. 652, f. 647 ; Ludlow MSS, $A D 7450 / 1$, no. 44 .

67. Ludlow MSS, AD $7450 / 1$, no. 45 .

68. Sherwood MS.

69. Fraser to Pol. Sec., 16th Feb., 1815: Home Misc., vol. 652, f. 143.

70. Adj. Gen. to Martinde11, 25 th Feb., 1815: E.S.D.B., vol. 6, no. 33; Martindell to Adj. Gen., 6th March, 1815: Home Misc., vol. 652, ff. 651-52.

71. Carpenter to Adj. Gen., 15th March, 22nd March, 1815: E.S.D.B., vol. 7 , nos. 78, 88; J.B. Fraser, Joumal of a Tour, P. 35, 76; C.M.J., vol. xxvi: March 1815, p. 243. 
72. Ludlow MSS, AD $7450 / 1$, no. 46. The date was Feb. 14th.

73. Ibid; C.M.J., vol. 26: March 1815, pp. 224; 242 .

74. Ludlow MSS, AD $7450 / 1$, no. 47.

75. Ibid., no. 48,50 .

76. Ibid., no. 50 .

77. Martindell, to Adj. Gen., 6th March 1815: Home Misc., vol. 652, ff. 647-48; Chepmell MS.

78. Chepmell MS; J. B. Fraser, Journal of a Tour, p. 59.

79. Ludlow MSS AD $7450 / 1$, no. 50; Martindell to Ochterlony, 18th Feb., 1815: E.S.D.B., vol. 6, no. 33.

80. Ludlow MSS AD $7450 / 1$, no. 8 .

81. Martindell to Adj. Gen., 22nd Feb., 1815: E.S.D.B., vol. 6, No. 34; Martindell to Adj. Gen., 27th Feb., 1815: Home Misc., vol. 652, ff. 190-94; Fraser to Pol. Sec., 3rd March, 1815; ibid., ff. 326; Fraser to Martinde1l, 2nd April, 1815; Sec. Cons., May 16th, 1815, no. 12; J. B. Fraser, Journal of a Tour, p. 103; Sherwood MS.

82. Fraser to Martindell, 2nd April, 1815: Sec. Cons., 16th May, 1815, no. 12; Fraser to Pol. Sec., 3rd March, 1815: Home Misc., vol. 652, f. 295 .

83. Ibid., ff. $301,312-13,319$.

84. Martindell to Adj. Gen., Ist March, 1815: Home Misc., vol. 652, f. 196; Fraser to Pol. Sec., 3rd March, 1815: ibid.,ff. 294.

85. Adj. Gen. to Pol. Sec., 18th March, 1815: ibid., f. 294.

86. Fraser to Pol. Sec., 27th Feb., 1815: ibid., ff. 147-63; Lt. Young to Martindell, 28th Feb., 1815: ibid., ff. 199-201; Martindell to Adj. Gen., 3rd April, 1815: E.S.D.B., vol. 7, no. 98; Fraser to Pol. Sec., 18th March, 1815: ibid., no. 79; Ludlow MSS AD 7450/1, no. 53; Chepmell MS; Sherwood MS.

87. Home Misc., vol. 652, ff. 606-07.

88. E.S.D.B., vol. 6, no. 33 .

89. Ibid., no. 35 .

90. Martindell to Adj. Gen., lst and 6th March, 1815: Home Misc., vol. 652 , ff. 195-97, 643-52. 
91. The paper strength of his regular force, in its fully augmented state, was over 9,000 according to Hastings' calculation (letter to Secret Committee, 2nd Aug., 1815: P.R.N.W., p. 708). But this apparently takes no account of the deficiencies caused by desertion, casualties, and the detachment of troops for the occupation of Dehra Dun (1,000 men were required for this latter task alone). Prinsep, op. cit., vol. $i, p .160$, estimates the force before Jaithak as "at least 5,000 of the Company's army", which would mean that with the King's troops the number would be brought nearer 6,000. This would tally with Ludlow's calculation, which was that upwards of 9,000 men including irregulars were engaged under Martindell's command - Ludlow MSS AD $7450 / 1$, no. 71.

92. Martinde11 to Adj. Gen., 7th March, 1815: Home Misc., vol. 652, f. 659 .

93. Martindell to Adj. Gen., Ist March, 1815: ibid., f. 197.

94. Home Misc., vol. 652 , f. 653 .

95. Adj. Gen. to Martinde11, 14th March, 1815: ibid., ff. 660-64.

96. Ludlow MSS AD $7450 / 1$, no. 77 .

97. Sherwood MS; Chepmell MS.

98. Sherwood MS.

99. Ludlow MSS AD $7450 / 1$, no. 53.

100. Chepmell MS; Sherwood MS.

101. Chepme11 MS.

102. Ibid., Martindell to Adj. Gen., 6th March, 1815: Home Misc., vol. 652 , f. 648 .

103. Chepme11 MS - entry for March 7 th.

104. Ludlow MSS, $A D 7450 / 1$, no. 55 .

105. Ibid., no. 56 .

106. Ibid., no. 57 .

107. Ibid., no. 58 .

108. J. B. Fraser, Journal of a Tour, pp. 87-88.

109. Ibid., p. 87 .

110. Ludlow MSS, AD $7450 / 1$, nos. 59, 60 . 
111. J. B. Fraser, Journal of a Tour, p. 88.

112. Sherwood MS.

113. J. B. Fraser, Journal of a Tour, pp. 88-90. He says 900-1,000 yards, but this was prabably an overestimation. The second stockade was calculated to be at this distance from the batteries.

114. Ibid., p. 90; Chepmell MS.

115. Sherwood MS; J. B. Fraser, Journal of a Tour, p. 90; Martindell to Adj. Gen., 20th March, 1815: E.S.D.B., vol. 7, no. 80.

116. Ludlow MSS, AD $7450 / 1$, no. 61 .

117. Chepmell MS.

118. J. B. Fraser, Joumal of a Tour, p. 91.

119. Ludlow MSS, AD $7450 / 1$, no. 67.

120. Chepmell MS.

121. Martindell to Adj. Gen., 7th April, 1815: Sec. Cons., 2nd May, 1815, no. 89. My italics.

122. Prinsep, op. cit., vol. i, p. 161.

123. Letter to Secret Committee, 2nd Aug., 1815: P.R.N.W., p. 738 .

124. Martindell to Adj. Gen., 3rd April, 1815: E.S.D.B., vol. 7, no. 101 ; J. B. Fraser, Journal of a Tour, pp. $93-94$; Ludlow MSS, AD $7450 / 1$, nos. 68,69 .

125. Sec. Cons., May 16 th, 1815 , no. 25.

126. R Iichards_T to Ludlow, 9th April 1815: Ludlow MSS AD 7450/2, no. 66 .

127. Ibid., no. 72 .

128. Ibid., nos. 70,71 .

129. Ibid., no. 69 .

130. Kelly, op. cit., p. 486.

131. Sherwood MS.

132. E.S.D.B., vol. 7, no. 103 . 
133. Martindell to Fraser, 1st April, 1815: Sec. Cons., May 16th 1815 , no. 12 .

134. Fraser to Martindell, 2nd April, 1815: Sec. Cons., May 16th, 1815 , no. 12 .

135. Pol. Sec. to Fraser, 16th April, 1815: ibid., no. 13.

136. Fraser to Pol. Sec., 27th April, 1815: Home Misc., vol. 653, ff. 615-18; Pol. Sec. to Fraser, 8th May, 1815: ibid., ff. 619-22.

137. Fraser to Pol, Sec., 18th May, 1815: Sec. Cons., 9th Aug., 1815, no. 22 .

138. See Pol. Sec. to Fraser, 2nd Sept., 1815: Sec. Clns. 20th Sept., 1815 , no. 85. J. B. Fraser's book was his Joumnal. The reference to Scott's appreciation of him as a writer is in Alexander Mackenzie's The History of the Frasers of Lovat, p. 713.

139. Ludlow MSS AD $4750 / 1$, no. 73 .

140. Ibid., no. 74 .

141. Ibid., no. 76; Chepmell MS.

142. Ludlow MSS AD $7450 / 1$, no. 78 .

143. J. B. Fraser, Jourmal of a Tour, p. 94.

144. On April 12th, Ludlow wrote to his wife:

"You are right in supposing me no favorite at headquarters here, tho' I have given no reason for displeasure, excepting, it might be, in a way which I thought it was my duty to deliver my opinions and to recommend while I held the command on these heights somewhat more activity. In these suggestions I have entirely met the concurrence of the Hd. Qur. folks, which to me is quite sufficient." AD $7450 / 1$, no. 72 .

145. Adj. Gen. to Martindell, 11th May, 1815: Sec. Cons., June 6th, 1815 , no. 50 .

146. Adj. Gen. to Martindell, 17th May, 1815: ibid., no. 51.

147. Martindell to Adj. Gen., 22nd May, 1815: Sec. Cons., 20th June, 1815, no. 35; Sherwood MS.

148. Sherwood MS.

149. Capt. Smyth to Adj. Gen., 14th June, 1815: Sec. Cons., 20th Jan., 1816, no. 30. Extract from Sir William Richards' Jounnal: The Englishman, 29th Sept., 1846. 
150. Hodson, op. cit.; East India Military Calendar, vol. i, pp. 407-08; D.N.B.

151. Sherwood MS.

152. Samuel Parlby (ed.), The British Indian Military Repository, vol. i, pp. 125-28; Hough, op. cit., p. 135 .

153. Sherwood MS.

154. Ibid.

155. Letter dated 16th Feb., 1816: among the papers of Sir Jasper Nicolls in the National Army Museum, Camberley, Surrey.

156. Chepmell MS.

157. Ibid.

158. Ibid.

159. Army Lists; Royal Military Calendar, 3rd edition, vol. 4, p. 3. 160. Boulger, op. cit., pp. 240, 294-95. 


\section{Notes to Chapter Eight}

l. C.M.J., vol. xxv: Nov., 1815, p. 290.

2. Bradshaw to Marley, 17th Nov., 1814: Mil. Cons., 9th Dec., 1814, no. 30 .

3. Marley to Adj. Gen., 25th Nov., 1814: ibid.

4. Adj. Gen, to Bradshaw, 25thoct., 1814: P.R.N.W., p. 351 .

5. Bradshaw to Marley, 17th Nov., 1814: 10c. cit.

6. Bradshaw to Adj. Gen., 25th Nov., 1814: P.R.N.W., pp. 481-82; Sir John Hearsey, Autobiography, in Hugh Pearse, The Hearseys, pp. 196-99; W. B. Shawe, History of the Second Regiment of Bengal Native Light Infantry, p. 5; C.M.J., vol. xxv: Dec., 1814, p. 34I.

7. Bradshaw to Pol. Sec., 12th Dec., 1814: P.R.N.W., P. 371; the vakil's letter is printed in P.R.N.W., p. 344 .

8. Bhim Sen Thapa to Superintendent for Nizamat Affairs, 7th Jan., 1815: Home Misc., vol. 654, f. 451; and 2nd Feb., 1815: Home Misc., vol. 652 , f. 545 .

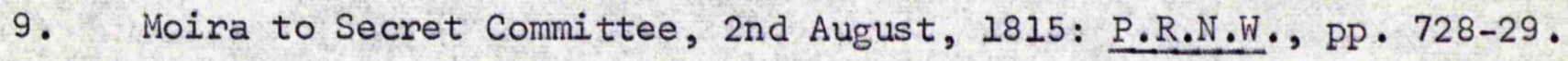

10. Bradshaw to Marley, 17th Nov., 1814: 1oc. cit.; Francis Hamilton, An Account of the Kingdom of Nepal, p. 167.

11. Hay to Bradshaw, 25th Nov., 1814: P.R.N.W., Pp. 307-08; C.M.J., vol. xxv: Dec., 1814, p. 342 .

12. Smith to Hay, 25th Nov., 1814: P.R.N.W., p. 308 .

13. Bradshaw to Adj. Gen., 28th Nov., 1814: P.R.N.W., P.307.

14. Marley to Adj. Gen,, 24th Dec., 1814: P.R.N.W., p. 514; I.0.L. Military Records, Misc. 350 , MR., ff. $51-52$; F. W. Stubbs, History of the Bengal Artillery, vol. ii. p.27.

15. Adj. Gen. to Bradshaw, 11th Dec., 1814: P.R.N.W., P. 310.

16. Bradshaw to Marley, 10th Dec., to Pol. Sec., 12th Dec., 1814 : P.R.N.W., pp. 485, 372; Hearsey, op. cit., p. 201.

17. The total, given in the Return in P.R.N.W., pp. 518-9, includes troops who were already on the frontier. 
18. Adj. Gen, to Marley, 6th Nov., 1814: P.R.N.W., pp. 215-22.

19. Adj. Gen. to Sec. to Gov. Gen., 24th Nov., 1814: P.R.N.W., p. 250; Moira to Sec. Committee, 2nd Aug., 1815: P.R.N.W., p. 717 .

20. Hearsey, op. cit., p. 205; F. G. Cardew, A Sketch of the Services of the Bengal Native Army, p. 110; V. C. P. Hodson, A List of the Officers of the Bengal Army, Part 4; Mrs. F. M. Montague, Memorials of the Family of Wood of Largo, pp. 50-54, 92 .

21. Montague, op. cit., p. 54.

22. Marley to Adj. Gen., 25th Nov., 1814: Mil. Cons., 9th Dec., 1814, no. 30 .

23. Moira to Secret Committee, 2nd August, 1815: P.R.N.W., P. 745; Moira to Col. McMahon, Jan. 22nd, 1815: A. Aspinall (ed.), The Letters of King George IV, vol. ii, p. 15.

24. Montague, op. cit., p. 54. No date is given, merely "November, $1814^{\prime \prime}$.

25. Marley to Adj. Gen., 8th Dec., 1814: Mil. Cons., 23rd Dec., 1814 , no. 31 .

26. C.M.J., vol. xxvi: Jan, 1815, p. 7 .

27. Marley to Adj.Gen., 12th Dec., 1814: P.R.N.W., P. 483.

28. Bradshaw to Pol. Sec., 12th Dec., 1814: P.R.N.W., P. 371; and 17th Feb., 1815: Sec. Cons., March 7th, 1815, no. 75. Hearsey, in op. cit., p. 212 , claims that Bradshaw advised Marley that these posts should either be withdrawn or reinforced - but on this issue his memory was probably distorted by an understandable concern to exonerate his brother in law from the guilt which was always afterwards attributed to him in military circles for his part in the business. Had Bradshaw advised withdrawal Marley would undoubtedly have complied, since he relied heavily on Bradshaw's guidance. In his letter of 8 th Dec., 1814, to the Adj. Gen., (Pol. Cons., 23rd Dec., no. 31) he wrote:

"... I shall do myself the honour of addressing you more fully after a personal conference with Major Bradshaw, from whose extensive and minute information... and from whose high character in the successful discharge of the difficult and delicate duties lately entrusted to him, I am prepared to expect the most valuable cooperation and assistance."

29. Marley to Adj. Gen., 12th Dec., 1814: P.R.N.W., p. 483. 
30. Marley to Adj. Gen., 12th Dec., 1814: Home Misc., vol. 651, f. 26; 24th Dec., 1814: P.R.N.W., Pp. 513-14; H. T. Prinsep, Political and Military Transactions, vol. i, pp. 121-22.

31. Marley to Adj. Gen., 3rd Jan., 1815: P.R.N.W., p. 521.

32. Lt. Smith to Acting Deputy Adj. Gen., 2nd Jan., 1815: P.R.N.W., p. 531; Prinsep, op. cit., vol. i, p. 122.

33. Greenstreet to Marley, lst Jan., 1815: P.R.N.W., p. 523.

34. Smith to Acting Deputy Adj. Gen., 2nd Jan., 1815: P.R.N.W., pp. 530-31; Mathes on to Smith, 6th Jan., 1815: ibid, p. 523; Return of Killed, Wounded and Missing... : ibid., p. 533; C.M.J., vol. xxvi, Jan., 1815, pp. 63; 87-88; Prinsep, op. cit., vol. $i$, pp. 124-26; J. B. Fraser, Journal of a Tour, p. 21; Shawe, op. cit., p. 6; Hough, Political and Military Events, vol. ii, p. 20; The Englishman, 9th Oct., 1846.

35. Marley to Adj. Gen., 2nd Jan., 1815: P.R.N.W., p. 522.

36. P.R.N.W., pp. 521-22.

37. Return...: P.R.N.W., p. 533; John Shipp, Memoirs, p. 214.

38. Marley to Adj. Gen., 14th Jan., 1815: P.R.N.W., pp. 538-40.

39. Marley to Adj. Gen., 4th Jan., 1815: P.R.N.W., p. 526.

40. Ibid., p. 526 .

41. Moira to McMahon, Jan. 22nd, 1815: Aspinall, op. cit., vol. ii, p. 15 .

42. Ibid.

43. Adj. Gen. to Marley, 18th Jan., 1815: Home Misc., vol. 649, ff. $174-80$.

44. Marley to Adj. Gen., llth Jan., 1815: P.R.N.W., P. 528; Bradshaw to Pol. Sec., 8th Jan., 1815: P.R.N.W., p. 387.

45. Marley to Adj. Gen., 23rd Jan., 1815: Home Misc., vol. 649, f. 491 .

46. The Raja's behaviour is discussed in Bradshaw's correspondence with the Pol, Sec., in: P.R.N.W., Pp. 193, 374, 387, 426; Home Misc., vol. 650, f. 56; Sec. Cons., 9th May, 1815, no. 56.

47. Sealy to Acting Chief Sec., 12th Jan., 1815: Home Misc., vol. 649 , f. 728 . 
48. Marley to Adj. Gen., 1lth Jan., 1815: P.R.N.W., Pp. 528-30.

49. Marley to Adj. Gen., 14th Jan., 1815 : P.R.N.W., pp. 537-38.

50. Sealy to Acting Chief Sec., 15th Jan., 1815: Home Misc., vol. 649, ff. 707-12.

51. Marley to Sealy, 16th Jan., 1815: ibid., ff. 719-20.

52. Gregory to Deputy Adj. Gen., 16th Jan., 1815: P.R.N.W., P. 534 .

53. Marley to Adj. Gen., 23rd Jan., 1815: Home Misc., vol. 649, ff. 485-91.

54. Gregory to Deputy Adj. Gen., 16th Jan., 1815: P.R.N.W., p. 536.

55. Gregory to Deputy Adj. Gen., 9th March, 1815: E.S.D.B., vol. 9, no. 349 .

56. Sealy to Marley, 20th Jan., 1815: Home Misc., vol. 649, ff. 717-19; Sealy to Gregory, 25 th Jan., 1815 : ibid., ff. 826-27.

57. See, for example, Sealy's despatches to the Pol. Sec., to Gregory, and to the Judicial Sec., in: Home Misc., vol. 649, ff. 807, 818, $831,879,883-85,905-10$.

58. Gregory to Asst. Adj. Gen. with Marley, 30th Jan., 13th Feb., 1815: E.S.D.B., vol. 9, no. 349 .

59. Saran Magistrate to Acting Pol. Sec., 18th Jan., 1815: Home Misc., vol. 649 , ff. $745-47$.

60. Bradshaw to Pol. Sec., 8th Jan., 1815: P.R.N.W., p. 382 .

61. C.M.J., vol. xxvi: Feb., 1815, p. 184; Judicial Sec. to Sealy, 21st March, 1815: E.S.D.B., vol. 9, no.

62. Marley to Adj. Gen., 23rd Jan., 1815: Home Misc., vol. 649, ff. $492-93$.

63. Moorcroft to Mil. Sec., 3lst Jan., 1815: Home Misc., vol. 649, ff. 643-62; Resident at Lucknow to Pol. Sec., 3rd Feb., 1815: ibid., 322-29; Pol. Sec., to Acting Chief Sec., 23rd March, 1815: Home Misc., vol. 652 , f. 570 . Cracroft is listed as an attorney in the East India Register for 1814, 2nd ed'n, p. 131.

64. Saran Magistrate to Acting Pol. Sec., 30th Jan., 1815: Home Misc., vol. 649 , f. 627 .

65. Pol. Sec., to Saran Magistrate, 23rd March, 1815: Home Misc., vol. 652, f. 590; to Acting Chief Sec., 23rd March, 1815: ibid., f. 567; 
65... Moorcroft to Mil. Sec., 24th Feb., 1815: Home Misc., vol. 654, ff. $461-67$.

66. Moira to McMahon, 22nd Jan., 1815: Aspinall, op. cit., vol. ii, p. 15 .

67. Major Gordon to Sir George Nugent, 22nd Feb., 1815: Nugent Correspondence, f. 210; Adj. Gen. to Marley, 24th Jan., 1815: Sec. Cons., 28th Feb., 1815, no. 97.

68. Adj. Gen, to Marley, 3lst Jan., 1815: Sec. Cons., 28th Feb., 1815, no. 97.

69. Adj. Gen, to Pol. Sec., 23rd Feb., 1815: Sec. Cons., 14th March 1815: no. 28 .

70. Ibid.; General Order by the Vice President in Council, March 17th, 1815: C.M.J., vol. xxvi, April, 1815, p. 273.

71. Moira to Secret Committee, 2nd Aug., 1815, para. 264: the P.R.N.W. version is bowdlerized, and paras. $263-67$ are only to be found in I.O.L. Records, Secret Letters from Bengal, vol. 16, ff.405 et seq.

72. Hodson, op. cit., Part 2. He died in 1842 , in his ninetieth year and still on the active list.

73. Pol. Sec. to Acting Chief Sec., 3rd March, 1815: Sec. Cons., 2lst March, 1815 , no. 90.

74. Adj. Gen, to J. S. Wood, 23 rd Sept., 1814: P.R.N.W., pp. 126-29.

75. J. S. Wood to Dep. Adj. Gen., 4th Nov., 1814: Mil. Cons., 19th Nov., 1814 , no. 76 .

76. Acting Collector of Gorakhpur to Pol. Sec., 11th Nov., 1814: P.R.N.W., P. 177.

77. J. S. Wood to Adj. Gen., 16th Nov., 1814: Mil. Cons., 3rd Dec., 1814, no. 22; and 24th Jan., 1815: Home Misc., vol. 649, f. 214; Walter Hamilton, Gazetteer of Hindustan and the Adjacent Countries, vol. $i, \mathrm{pp}$. $591-92$.

78. J. S. Wood to Adj. Gen., 16th Nov., 1814: Mil. Cons., 3rd Dec., 1814 , no. 22 .

79. J. S. Wood to Adj. Gen., 28th Nov., 1814: Mil. Cons., 9th Dec., 1814, no. 31; and 7th Dec., 1814: Mil. Cons., 23rd Dec., no. 29;

80. J. S. Wood to Pol. Sec., 7th Dec., 1814: P.R.N.W., Pp. 317-18.

80. J. S. Wood to Adj. Gen,, 13th Dec., 1814: P.R.N.W., p. 510.

81. J. S. Wood to Adj. Gen., 20th Dec., 1814: P.R.N.W., Pp. 511-512. 
82. J. S. Wood to Adj. Gen., 28th Nov., 1814: Mil. Cons., 9th Dec., 1814, no. 31; J. S. Wood to Pol. Sec., 7th Dec., 1814: $\underline{\text { P.R.N.W., }}$ p. 317.

83. J. S. Wood to Adj. Gen., 20th Dec., 1814: P.R.N.W., P. 512;

J. S. Wood to Gorakhpur Magistrate, 22nd Dec., 1814: Home Misc., vol. 649 , ff. $674-75$.

84. J. S. Wood to Bradshaw, 4th Dec., 1814: P.R.N.W., P. 318 .

85. F. Hamilton, op. cit., p. 4.

86. J. S. Wood to Adj. Gen., 4th Jan., 1815: Home Misc., vol. 649, ff. 130-45 (also in P.R.N.W., Pp. 524-25); J. S. Wood to Resident at Lucknow, 10th Jan., 1815: ibid., ff. 271-73; J. S. Wood to Pol. Sec., 26th Jan., 1815: ibid., f. 245; C.M.J., vol. xxvi : Jan., 1815, pp. 66-67; J. B. Fraser, op. cit., p. 25; Prinsep, op. cit., vol. i, pp. 116-17; E. H. Webb, A History of the Services of the 17th (the Leicestershire) Regiment, p. 120; The Englishman, 8th 0ct., 1846. It should be remarked that as the official documents concerning this episode passed through their various transcriptions, the usual misreadings of place names accumulated. Hence Siara has become Simra or Simlar; and Niakot Mujkot or Meejakote. There is no doubt conceming the identity of Niakot; and Simra must be the village marked as 'Searah' in a map of the Nepal frontier dated 1830 in the I.O.L. collection.

87. Aspinall, op. cit., vol. ii, p. 14.

88. J. S. Wood to Adj. Gen., 2lst Jan., 1815: Home Misc., vol. 649, f.200; and 1lth Feb., 1815: Sec. Cons., 28th Feb., 1815, no. 39.

89. J. S. Wood to Pol. Sec., 26th Jan., 1815: Home Misc., vol. 649, f. $236-37$.

90. J. S. Wood to Adj. Gen., 15th Jan., 1815: Home Misc., vol. 651, ff. 582-88; and 2lst Jan., 1815: Home Misc., vol. 649, ff. 200-08.

91. Adj. Gen. to J. S. Wood, 27th Jan., 1815: Home Misc., vol. 651, ff. 590-91; Adj. Gen. to Pol. Sec., 9th Feb., 1815: Home Misc., vol. 652 , ff. 480-82; Resident at Lucknow to Pol. Sec., 3lst Jan., 1815: Home Misc., vol. 649, ff.315-17.

92. Letter to McMahon, 22nd Jan., 1815: Aspinall, op. cit., vol. ii, p. 15 .

93. Marley to Gorakhpur Magistrate, 9th Jan., 1815: Home Misc., vol. 651 , ff. $432-33$.

94. Home Misc., vol. 649, ff. $682,684,705$. 
95. Gorakhpur Magistrate to J. S. Wood, 23rd Jan., 1815: Home Misc., vol. 651, f. 620; Gorakhpur Magistrate to Pol. Sec., 23rd Jan., 1815: Home Misc., vol. 649, f. 765 .

96. Lt. Col. Rotten to Dep. Adj. Gen., 15th Jan., 1815: P.R.N.W., p. 535 .

97. J. S. Wood to Adj. Gen., 2lst Jan., 1815: Home Misc., vol. 649, ff. 202-03; Capt. Roberts on to Resident at Lucknow, 3lst Jan., 1815: ibid., ff. $330-32$.

98. Letter from Dan Bahadur Singh to his uncle, n.d.: P.R.N.W., pp. 400-01.

99. J. S. Wood to Adj. Gen., 15th Jan., 1815: Home Misc., vol. 649, ff. 192-93. There were rumours that considerable quantities of warlike stores had found their way into Nepal through his territories - see J. S. Wood to Pol. Sec., 19th April, 1815: Home Misc., vol. 654 , f. 27.

100. Lucknow Resident to J. S. Wood, 18th Jan., 1815: Home Misc., vol. 649 , ff. $298 ; 305-06$.

101. Gorakhpur Magistrate to Pol. Sec., 23rd Jan., 1815: Home Misc., vol. 651 , ff. $625-26$.

102. J. S. Wood to Adj. Gen., 24th Jan., 1815: Home Misc., vol. 649, ff. $213-17$.

103. Adj. Gen. to J. S. Wood, 3lst Jan., 1815; 5th Feb., 1815: E.S.D.B., vol. 5 , no. 15 .

104. Gorakhpur Magistrate to Pol. Sec., 29th Jan., 1815: Home Misc., vol. 649 , ff. $858-59$.

105. J. S. Wood to Adj. Gen., 8th Feb., 1815; 11th Feb., 1815: Sec. Cons., 28th Feb., 1815, nos. 37, 39 .

106. J. S. Wood to Adj. Gen., 16th Feb., 1815: Sec. Cons,, 7th March, 1815 , no. 66 .

107. J. S. Wood to Adj. Gen., Ist, 7th, 10th, and 12th March, 1815: Sec. Cons., 14th March, no. 53; 21st March, no. 135; 28th March, nos. 43,45 .

108. Correspondence on this issue is in Home Misc., vol. 652, ff. 471, 484-87; vol. 653, ff. 508-15. The Court of Directors expressed its distaste for such measures, and enjoined that "every_faculty and assistance should be given. to those [Tharus T who I might I be desirous of returning to their own country; and [ that I care should be taken that such of them as $\overline{-}$ might $\bar{T}$ choose to remain 
108.. within $/$ the Company's T territories 5 might $T$ not be sufferers eventually from the proceeding in question."- Political Letter to Bengal, 18th Feb., 1817: P.R.N.W., p. 989. About 2,000 Tharus in fact settled in southern Gorakhpur, and were advanced sums of money by the government to enable them to procure seed and cattle - W. Hamilton, op. cit., vol. i, p. 593.

109. J. S. Wood to Adj. Gen., 10th March, 1815: Sec. Cons., 28th March, 1815 , no. 43; and 17th March, 1815: Sec. Cons., 4th April, 1815, no. 45 ; J. S. Wood to Lucknow Resident, 16th March, 1815: ibid.,

110. J. S. Wood to Adj. Gen., 27th March, 1815: Sec. Cons., 16th April, 1815, no. 69; and 5th April, 1815: Sec. Cons., April 25th, 1815, no. 52; Capt. Scott to Lt. Baddeley; 4th April, 1815: ibid., no. 53; J. S. Wood to Adj. Gen., 2 ist April, 1815: Home Misc., vol. 654 ,
ff. 38-43. 111. J. S. Wood to Adj. Gen., 12th April, 1815: Home Misc., vol. 654 ,
ff. $2 ; 8-12$.

112. Army Lists.

113. C.M.J., vol. xxvi: Feb., 1815, p. 183.

114. When consulting his Brigadiers, Marley had represented his effective force to be 4,000 firelocks. To this had subsequently been added the reinforcements from Dinapur, and these, with the artillery, would have brought the whole force to near 5,000 . But this would not
include the detachment in Tirhut.

115. See the Return, P.R.N.W., P. 980.

116. Bradshaw to Pol. Sec., 7th March, 1815: Sec. Cons., 28th March,

117. Hearsey, op. cit., pp. 205-09; Lt. Col. Dick to Adj. Gen., 2lst Feb., 1815: E.S.D.B., vol. 8, no. 319; Bradshaw to Pol. Sec., 23 rd Feb., 1815: Sec. Cons., 14th March, 1815, no. 41; The Englishman,
l3th Oct., 1846.

118. Adj. Gen, to Officer Commanding in Saran, 2nd Feb., 1815: Sec. Cons., 28th Feb., 1815, no. 97; Adj. Gen. to George Wood, 25 th Feb., 1815: E.S.D.B., vol. 6, no. 33 .

119. George Wood to Adj. Gen., 23rd Feb., 1815: Home Misc., vol. 652 ,
ff. $48-49$.

120. Adj. Gen. to George Wood, March 3rd, March 4th, 1815: Home Misc.,
vol. 652 , ff. $61-62,68-71$.

121. Ibid., f. 63 . 
122. He wrote two letters in reply to the two which he received. That in reply to the one of March 3 rd is not traceable in the I.0.L. Records, but its import is clear from Moira's reply to it (see next note). That in reply to the letter of March 4 th is dated March 17th, and is enclosure no. 355 in E.S.D.B., vol. 9.

123. Moira to George Wood, 30th March, 1815: Sec. Cons., 23rd May, 1815, no. 14.

124. Moira to Secret Committee, 2nd August, 1815; MS version: 1oc. cit., ff. 410-11.

125. Extract from Proceedings....in the Mil. Dept., 14th Jan., 1815: Home Misc., vol. 649, ff. 342-66; Mil. Sec. to Dep. Adj. Gen., 20 th Jan., 1815; ibid., ff. 382-92; Adj. Gen. to Officer Commanding in Saran, 2nd Feb., 1815: Sec. Cons., 28th Feb., 1815, no. 97; George Wood to Adj. Gen., 25th Feb., 1815: E.S.D.B., vol. 8, no. 323; Bradshaw to Pol. Sec., 7th March, 1815: Sec. Cons., 28 th March, 1815, no. 50.

126. Adj. Gen. to Pol. Sec., 27th Jan., 1815: E.S.D.B., vol. 5, no. 4;

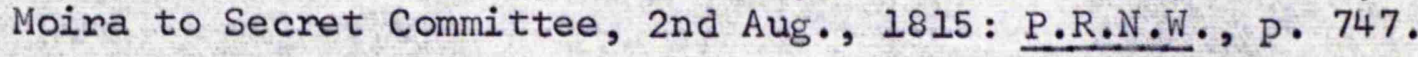

127. Moira to Secret Committee, 2nd Aug., 1815, MS version: loc. cit., f. 411; C.M.J., vol. xxvi.: March, 1815, pp. 224-25.

128. C.M.J., vol. xxvi: March, 1815, p. 245.

129. George Wood to Adj. Gen.,13th March, 1815: E.S.D.B., vol. 9, no. 351; The Englishman, 13 th October, 1846.

130. Hearsey, op. cit., pp. 213-15.

131. George Wood to Adj. Gen., 10th March, 1815: E.S.D.B., vol. 9 , no. 350; George Wood to Bradshaw, 10th March, 1815: ibid., no. 350; George Wood to Adj. Gen., 13th March, 1815: ibid., no. 351; and 2lst March, 1815: ibid., no. 358; Bradshaw to Acting Chief Sec., 14th March, 1815: Sec. Cons., 4th April, 1815, no. 48; Bradshaw to Pol. Sec., 17th March, 1815: ibid., no. 55; Hearsey, op. cit., p. 214; C.M.J., vol. xxvi: April, 1815, p. 290; Montague, op. cit., p. 93 ; C. T. Atkinson, The South Wales Borderers, p. 275.

132. George Wood to Adj. Gen., 2nd April, 1815: E.S.DB., vol. 7, no. 110; and Ist May, 1815: E.S.D.B., vol. 9, no. 381; and 13th May, 1815: ibid., no. 385 .

133. Bradshaw to Pol. Sec., 17th April, 1815: Sec. Cons., 9th May, 1815, no. 56; Hearsey, op. cit., p. 215.

134. Gregory to Dep. Adj. Gen., 16th March, 26th March, and 29 th March, 1815: E.S.D.B., vol. 9, nos. 353, 361, 365; C.M.J., vol. xxvi: April, 1815, p. 324 . 
135. Bradshaw to Acting Chief Sec., 14th March, 1815: Sec. Cons., 4th April, 1815 , no. 48.

136. Hodson, op. cit.; Montague, op. cit., pp. 54, 92 .

137. Adj. Gen. to Latter, 14th Oct., 1814: P.R.N.W., pp. 168-70.

138. Adj. Gen. to Dep. Adj. Gen., 30th Sept., 1814 : P.R.N.W., P. 185;

Dep. Adj. Gen. to Mil. Sec., 13th Oct., 1814: Mil. Cons., 14th Oct., 1814, no. 44.

139. Dep. Adj. Gen. to Mil. Sec., 30th Nov., 1814: Mil. Cons., 3rd Dec., 1814 , no. 61 .

140. Judicial Sec. to Martin, 13th Dec., 1814: Mil. Cons., 16th Dec., 1814, no. 152 .

141. Dep. Adj. Gen. to Mil. Sec., 14th Dec., 1814: ibid., no. 49.

142. Extract of Proceedings ... in the Military Dept., 4th March, 1815 : E.S.D.B., vol. 9, no. 398; Moira to Secret Committee, 2nd Aug., 1815: P.R.N.W., p. 718 .

143. Koilia, or Koileah, is the name featuring in the MS despatches, which corresponds to no name on available maps. It is clear, however, from the various incidental references to its position, that this post was somewhere in the neighbourhood of modern Birathnagar and Rangeli. Kumar Swami, the Vijaypur brahmin captured in the Morang in February, referred to the same enemy poast as being at Dhunpalna (sic., in E.S.D.B., vol. 9, no. 394). It could therefore have been at Dhanpura, marked just north of Birathnagar in Percival Landon's map.

144. Latter to Dep. Adj. Gen., 6th Feb., and 8th Feb., 1815: Home Misc., vol. 649, ff. 561-68, 587-93; C.M.J., vol. xxvi, Feb., 1815, pp. $165-66$.

145. Latter to Foord, 6th Feb., 1815: Home Misc., vol. 649, ff. 576-78; Latter to Dep. Adj. Gen., 5th Feb., 1815: ibid., ff. 530-32; Latter to Foord, 7th Feb., 1815: ibid., ff. 594-97.

146. Latter to Dep. Adj. Gen., 12th Feb., 1815: E.S.D.B., vol. 8, no. 299.

147. Cock to Latter, 15th Feb., 1815: E.S.D.B., vol. 8, no. 308. 148. Halhead to Latter, 16th Feb., 1815: ibid., no. 313.

149. Latter to Dep. Adj. Gen., 19th Feb., 20th Feb, 1815: ibid., nos. 310,311 . 
150. Cock to Latter, 19th Feb., Latter to Cock, 22nd Feb., 1815: ibid., no. 316 .

151. Latter to Dep. Adj. Gen., 2 lst Feb., 1815: ibid., no. 314.

152. Latter to Dep. Adj. Gen., 3rd March, 1815: E.S.D.B., vol. 9, no. 338.

153. Latter to Dep.Adj. Gen., 4th March, 1815 : ibid., no. 331 ; Cock to Latter, Ist March, 1815: ibid., no. 334.

154. Cock to Latter, 4th March, 1815: ibid., no. 343.

155. Chalmers to Latter, 7th March, 1815: ibid., no. 340.

156. This appears in MS despatches as Hansquar or Hansguar.

157. Latter to Dep. Adj. Gen., 9th Feb., 1815: Home Misc., vol. 649, ff. $618-20$; Latter to George Wood, 10th March, 1815: E.S.D.B., vol. 9 , no. 343 .

158. Latter to Dep. Adj. Gen., 7th March, 1815: ibid., no. 335.

159. Latter to Dep. Adj. Gen., 9th March, 1815: ibid., no. 342; Latter to George Wood, 10th March, 1815: ibid., no. 343;

Latter to Adj. Gen., 2 Ist March, 1815: ibid., no. 357.

160. Latter to Adj. Gen., 13th Dec., 1814: Mil. Cons., 23rd Dec., 1814, no. 61; Bradshaw to Latter, 3rd Dec., 1814: P.R.N.W., P. 376; Latter to Bradshaw, 3nd Jan., 1815; ibid., pp. 38-90; Latter to Adj. Gen., 11th Jan., 1815: ibid., p. 408; Latter to Bradshaw, llth Jan., 1815: Home Misc., vol. 650, ff. 28-29.

161. Latter to Pol. Sec., 4th Jan., 1815: P.R.N.W., Pp. 391-92. It had formed a part of the Governor General's original plan to solicit the cooperation of the Sikkim Raja, but this overture came before the Magistrate of Rangpur had had time to put his instructions on this issue into operation: see Pol. Sec. to Latter, 27th Jan., 1815: Home Misc., vol. 65l, ff. 549-51.

162. Latter's reply - P.R.N.W., p. 392.

163. Hamilton's Memoir on Sikkim: P.R.N.W., p. 268; W. Hamilton, op. cit., vol. $i$, p. 275 .

164. Latter to Pol. Sec., Jan. 6th, 1815: P.R.N.W., p. 393; and 15th Feb., 1815: Home Misc., vol. 652, f. 273 . The Gurkhas had tried to induce the minister himself to come to Nagri - Latter to Pol. Sec., 13th Dec., 1814: Mil. Cons., 23rd Dec., 1814, no. 61.

165. Latter to Pol. Sec., 4th Feb., 1815:P.R.N.W., P. 429; and 15th Feb., 1815: Home Misc., vol. 652, ff. 271-75. 
166. Latter to Pol. Sec., 11th March, 1815: Home Misc., vol. $654 \mathrm{ff}$. 294-98.

167. Adj. Gen. to Latter, 14th Feb., 1815: E.S.D.B., vol. 9, no. 398.

168. Latter to Adj. Gen., 18th March,1815: ibid., no. 354.

169. Latter to Pol. Sec., 19th March, 1815: Home Misc., vol. 654, ff. 304-11.

170. Pol. Sec., to Acting Pol. Sec., 6th March, 1815: E.S.DB., vol. 6, no. 37; Adj. Gen., to Mil. Sec., 3rd April, 1815: E.S.D.B., vol. 9, no. 399 .

171. Pol. Sec. to Latter, 16th April, 1815: Sec. Cons., 16th May, 1815, no.10.

172. Scott to Pol. Sec., 14th Aug., 1815: Sec. Cons., 7th Oct., 1815, no. 75 ; Lt. Western to Acting Pol. Sec., 16th May, 1815: E.S.D.B., vol. 9 , no. 384 .

173. Evidence of Kumar Swami: E.S.D.B., vol. 9, no. 394. He described the force as being distributed thus:

Koilia and environs ... 1,800 musketeers, 2,200 archers Nizamtara

Vijaypur

$$
\text { ... 1,200 }
$$$$
2,300 \quad "
$$

of these, only a portion of the musketeers were regulars. At Nijamtara he estimated the proportion of 'old' troops to recruits among themusketeers as 1 to 4 .

174. Moira to Secret Committee, June 1st, 1815: P.R.N.W., p. 560. 
Notes to Chapter Nine

1. Adj. Gen. to Ochterlony, 28th Aug., 1814: P.R.N.W., pp. 117-18.

2. Ibid., p. 119.

3. General Orders: P.R.N.W., Pp. 195-96,433; Moira to Secret Committee, 2nd Aug., 1815: ibid., p. 703; Retumn of Fighting Men, Public Followers, etc.:ibid., p. 980. The Native Cavalry contingent is specified as two troops inOchterlony to Adj. Gen., 10th Nov., 1814: ibid., 230.

4. Ochterlony to Adj. Gen., 3lst Dec., 1814: Home Misc., vol. 649, ff. 111-13.

5. Vide supra, Chapter one, note 73.

6. Ochterlony to Political Secretary, 29th Aug., 1814: Ludhiana Records, p. 404; Bute, Marchioness of (ed.), The. Private Journal of the Marquis of Hastings, vol. i, p. 284 ; J. D. Cunningham, A History of the Sikhs, pp. 154-55; A.J., vol. i: 1816, p. 185; Military Sketches of the Goorkha War, p. 3 . The author of this tract is not known. W. G. Hamilton, in his article "Some Further Notes on Ochterlony's Campaign", J.U.S.I.I., vol. xli, no. 189: Oct., 1912, p. 456, suggests that the author was Captain Edmund Cartwright, Ochterlony's Major of Brigade. This is certainly not so. The author, in his preface, states distinctly that he is a civilian and that he returned to England six years after the war (pp. vii, viii, $i x$ ). Cartwright is disqualified on both counts (see his entry in V.C.P. Hodson's List). It is possible that the author was Ochterlony's own Eurasian son, R. P. Ochterlony. He held an official position as Assistant to his father until July, 1815, so it is more than likely that he accompanied him during the first campaign of the war. He announced his intention of resigning this post in July 1815, but may have accompanied his father ex officio on the second expedition in 1816 - see Ludhiana Records, Pp. 135, 349, 458 for references to this person.

7. Return of Fighting men etc.: P.R.N.W., p. 980. (Cf. infra, Chapter Six, note 7).

8. Ochterlony to Pol. Sec., 3rd Oct., 1814: Sec. Cons., 25th Oct., 1814, no. 4; Ochterlony to Adj. Gen., 2nd Dec., 1814: P.R.N.W., p. 488; Ochterlony to Pol. Sec., 7th Nov., 1814: Sec. Cons., 29 th Nov., 1814, no. 33 .

9. Ochterlony to Pol. Sec., 29th August, 1814: Ludhiana Records, vol. 2, pp. 401-02; Adj. Gen., to Ochterlony, 28th Aug., 25th Sept., 1814: P.R.N.W., Pp. 118, 159; Ochterlony to Pol. Sec., 3rd Oct., 1814: Sec. Cons., 25 th Oct., 1814, no. 4. 
10. Ochterlony to Pol. Sec., 3rd Oct., 1814: loc. cit.; Ochterlony to Adj. Gen., 2nd Dec., 1814: P.R.N.W., p. 489.

11. Ochterlony to Pol. Sec., 29th Aug., 1814: Ludhiana Reconds, vol. 2 , p. 399 .

12. Ochterlony to Adj. Gen., 4th Nov., 1814; 6th Nov., 1814: and 10th Nov., 1814: P.R.N.W., Pp. 230, 449-50, 453, 456, 457; Detachment Onders by Brigadier General Ochterlony, 5 th Nov., 1814: Mil. Cons., 3rd Dec., 1814, no. 46; Sketches, pp. 3-6; Henry T. Prinsep, Military and Political Transactions, vol. i, pp. 104-05.

13. Ochterlony to Adj. Gen., 7th Nov., 1814: P.R.N.W., p. 257; W. G. Hamilton, "Ochterlony's Campaign in the Western Hills", J.U.S.I.I., vol. xli, no. 187: April, 1912, p. 145.

14. Ochterlony to Adj. Gen., Nov. 4th, 1814: P.R.N.W., p. 458. See also his letter to Pol. Sec., 7th Nov., 1814: Sec. Cons., 29th Nov., 1814, no. 33: "That they will not relinquish their conquests without the most strenuous efforts to retain them, I am now more than ever convinced."

15. Ochterlony to Adj. Gen., 7th Nov., 1814: P.R.N.W., p. 457.

16. Adj. Gen. to Ochterlony, 19th Nov., 1814: P.R.N.W., p. 459.

17. Ochterlony to Adj. Gen., 10th Nov., 11th Nov., 17th Nov., 1814: P.R.N.W., pp. 230, 451, 473; Sketches, P. 7. The author of the Sketches claims that this was territory where no wheel had ever rolled before. At the risk of appearing pedantic, it can be pointed out that this is not so. It was known that during his campaign against the Gurkha army the Raja of Hindur had dragged a four-pounder on a wheeled carriage from Nalagarh to Ajmaigarh in the interior. This information was partly responsible for Ochterlony's decision to use the Nalagarh route - see his letter to Pol. Sec., 29th Aug., 1814: Ludhiana Records, p. 401.

18. See the rough sketch, signed H. Watkins, and endorsed "Sketch of Ummer Sing Tharpa's Position at Ramghur 1814", among the Maps and Plans of the Nugent Correspondence.

19. Ochterlony to Thompson, 13th Nov., 1814: P.R.N.W., p. 474; Ochterlony to Adj. Gen., 17th Nov., 1814: ibid., p. 473; Hamilton, 10c. cit., p.146.

20. Ochterlony to Pol. Sec., 29th Aug., 1814: Ludhiana Records, p. 402.

21. Ochterlony to Adj. Gen., 17th Nov., 1814: P.R.N.W., p. 473.

22. Ochterlony to Adj. Gen., 27th Nov., 1814: P.R.N.W., Pp. 478-79; 
22.. Watkins's Sketch; Hamilton, op. cit., pp. 146-47; Sketches, pp. 9, 12; Prinsep, op. cit., vol. i, p.137.

23. Ochterlony to Adj. Gen., 26th Nov., 27th Nov., 1814: P.R.N.W., pp. 476-77; Lawtie to Ochterlony, 26th Nov., 1814: Mil. Cons., 16th Dec., 1814, no. 56; Prinsep, op. cit., vol. i, pp. 107-08.

24. Ochterlony to Adj. Gen., 27th Nov., 1814: P.R.N.W., p. 479 .

25. Ochterlony to Adj. Gen., 10th Nov., 27th Nov., 1814: P.R.N.W., pp. $230 ; 479$.

26. Adj. Gen. to Ochterlony, 2lst Nov., 1814: ibid., p. 231; Punjab News Letter, Punjab Records Book 18 no. 16: printed in Grey and Garrett, European Adventurers of North India, pp. 66-67.

27. Pol. Sec. to Ochterlony, 18th Jan., 1815: Home Misc., vol. 651, ff. 257-73; Substance of a communication from ... a Sowar belonging to J.W. O'Brien; ibid., f. 251 ; Letter from one Heane, Commanding Suzanpur, Coat Congra I Sic T, 25th Dec., 1814: ibid., f. 247; Ochterlony to Pol. Sec., 24 th Jan., 1815: Sec. Cons., March 14th, 1815, no. 37. Heaney was the name under which O'Brien had enlisted - see Ochterlony to Pol. Sec., 9th July, 1814: P.R.N.W., p. 16 .

28. Ochterlony to Adj. Gen., 2nd Dec., 1814: P.R.N.W., pp. 487-88.

29. Ibid.

30. Adj. Gen. to Pol.Sec., 8th Jan., 1815: Home Misc., vol. 649, f. 86 .

31. Prinsep, op. cit., vol. i, p. 108; Cunningham, op. cit., p. 134, fn. 2 .

32. Ochterlony to Adj. Gen., 3lst Dec, 1814: Home Misc., vol. 649, f. 102; Adj. Gen. to Pol. Sec., 8th Jan., 1815: ibid., ff.81-82.

33. Hamilton locates this near the modeh village called Dhar - loc. cit., p. 457 .

34. Ochterlony to Adj. Gen., 29th Dec., 1814: P.R.N.W., p. 507; Ochterlony to Adj. Gen., 3lst Dec., 1814: Home Misc., vol. 649, ff. 102-10; Sketches, pp. 13-15; C.M.J., vol. xxvi: Jan., 1815, p. 85; Prinsep, op. cit., vol. $i, \bar{p}$. III. Thomps on (his report is an enclosure to Ochterlony's despatch of 3lst Dec.), barely mentions this encounter. The author of the sketches describes it in general terms. The C.M.J. account is rather vague, and in one particular at least ("The march of the Gurkhas is said to have been conducted with so much silence that they were close to the stockade before their approach was perceived or suspected") in direct contradication to that given in the Sketches. 
35. Thomps on to Major of Brigade, 3lst Dec., 1814: Home Misc., vol. 649, f. 109; C.M.J., vol. xxvi: Feb., 1815, p. 129.

36. C.M.J., vol. xxvi: Feb., 1815, pp. 128-29.

37. Letters were intercepted in Dehra Dun in December - see P.R.N.W., pp. 339-40. Malaun is therein referred to as Rajgarh, its alternative name.

38. This appears in despatches as Battoh. Its position corresponds with that of the village marked Barog on the Punjab Survey Sheet, no. 289 , reproduced with Hamilton's article: loc. cit.

39. Ochterlony to Adj. Gen., 30th Jan., 1815: Sec. Cons., 28th Feb., 1815, no. 95; Arnold toochterlony, lst Feb., 1815: E.S.D.B., vol. 6 , no. 18; Sketches, pp. 21-22; intercepted letter from Amar Singh Thapa to Bir Singh Thapa and others: enclosure in Ochterlony to Pol. Sec., lst March, 1815: Sec. Cons., 4th April, 1815, no. 43; Prinsep, op. cit., vol. i, pp. 111-12.

40. "The enemy seem generally to confine themselves to the defensive, and to place their entire dependence on the obstinacy and determination of resistance in their stockades, on which they place great confidence" - Ochterlony to Adj. Gen., 27th Nov., 1814: P.R.N.W., p. 479 .

41. Ochterlony to Adj. Gen., 13th Feb., 1815: E.S.D.B., vol. 6, no. 27.

42. Ibid.

43. Ibid.; Ochterlony to Adj. Gen., 18th Feb., 1815: E.S.D.B., vol. 6, no. 35; and 10th March, 1815: E.S.D.B., vol. 7, no. 78; C.M.J., vol. xxvi: March, 1815, pp. 220-21; 243-44; J. Ludlow to his wife, 17th Feb., 1815: Ludlow MSS, AD 7450/1, no. 49. In a circular sent to his subordinate chiefs, Amar Singh claimed that he had recalled the garris on of Jorjoru because he knew it to be inadequate for the defence of the fort. This letter was intercepted, and a translation enclosed in Ochterlony to Pol. Sec., lst March, 1815: Sec. Cons., 4th April, 1815, no. 43.

44. Adj. Gen. to Pol. Sec., lst March, 1815: Home Misc., vol. 652, ff. $5 ; 9$.

45. See extract from a letter written by Lord Hastings to an unspecified addressee (probably the Chairman of the Court of Directors) quoted in the Memorandum on the Nepal War in Home Misc., vol. 515, f. 200.

46. The instructions are summarised in Amar Singh Thapa's reply of 2nd March, 1815, to the Raja. This letter was intercepted and is to be found printed in its entirety in several places, e.g.: P.R.N.W., pp. 553 et seq.; J. B. Fraser, Jourmal of a Tour, Appendix V; 
46.. H. H. Wils on, History of British India, vol. ii, Appendix A; Prinsep, op. cit., vol. i, Appendix B. An MS version is in Home Misc., vol. 653 , ff. 179 , et seq.

47. See Ochterlony to Pol. Sec., lst Jan., 1815: Home Misc., vol. 651, ff. 207-23; Private letter from Ochterlony to Adam, 5 th Jan., 1815; ibid., f. 227; Adam to Ochterlony 14th Jan., 1815: ibid., ff. $235-43$.

48. The expression he used was "the Chiefs of the Dekkan". It is unlikely that he was referring to the state of Hyderabad. Dekkan is probably used in its general sense of "south" here, the reference being to the Marathas.

49. G. T. Garrett (ed.), Events at the Court of Ranjit Singh, 1810-1817, pp. 181-83, 191 .

50. A.J., vol. xi, p. 433 .

51. Translation of a circular letter from Amar Singh Thapa to Bir Singh Thapa and others - see note 43.

52. Ibid.; and intercepted letter to Bhaktawar Singh, Kaji of Garhwal, 2nd March, 1815: Home Misc., vol. 653, f.163.

53. Ochterlony to Adj. Gen., loth March, 1815: E.S.D.B., vol. 7, no. 78 ; C.M.J., vol. xxvi: April, 1815, p. 288.

54. Ochterlony to Adj. Gen., March 20th, 1815: E.S.D.B., vol. 7, no. 88; A.J., vol. i: 1816, p.185.

55. Details of the negotiations are in Ochterlony to Political Sec., 23 rd Feb., 1815: E.S.D.B., vol. 6, no. 42.

56. Lt. Ross to Delhi Resident, 17th April, 1816: Sec. Cons., 25th May, 1816 , no. 2 .

57. Ochterlony to Adj. Gen., 6th April, 1815: Home Misc., vol. 653, f. 138. O'Brien sent another letter to Ochterlony, of which a version is printed in Grey and Garrett, op. cit., p. 65. This purports to be a transcript of a letter in the Panjab Records, vol. 18, no. 11; and the data is given as March 22nd. The text and the date may be correct, but nothing in this book is to be relied upon. A comparison of its transcriptions with versions printed elsewhere shows it to be full of transcriber's errors which shoddy scholarship has allowed to pass unrectified and unnoticed. When William Moorcroft visited Kotoch in 1820, O'Brien was still in the Raja's employ - see H. H. Wilson (ed.), Moorcroft and Trebeck, vol. 1 . p. 125 .

58. Cooper to Major of Brigade, lst April, 1815: E.S.D.B., vol. 7, no. 5. 
59. Ochterlony to Adj. Gen., 6th April, 1815: Home Misc., vol. 653, ff. 133-37; Adj. Gen. to Ochterlony, 20th April, 1815: ibid., f. 147 .

60. Ochterlony to Adj. Gen., 17th April, 1815: P.R.N.W., p. 593.

61. In fact, "second Dionthal"; but as the point named "first Dionthal" played no part in the operations, it avoids confusion to ignore it and omit the ordinal in designating the significant peak. Hamilton, loc. cit., p. 458 , points out that neither Raila nor Dionthal are names actually in use for the positions they indicated, and that Ochterlony and his Field Engineer so labelled them merely for convenience of identification. In the section of the Punjab Survey Sheet, no. 289 , which he reproduces, the peak called Raila in official plans and despatches appears in the vicinity of the village of Sarsa; and that called Dionthal slightly to the north of the village of Luhar Ghat.

62. "Movements to be made by the Different Detachments of the Army on the 14th and 15th of April, 1815"; P.R.N.W., PP. 593-94.

63. Ochterlony to Adj. Gen., 27th April, 1815: ibid., pp. 591-93; Lawtie to Ochterlony, 18th April, 1815: Home Misc., vol. 653, ff. $540-45$.

64. Ochterlony to Adj. Gen., 17th April, 1815: P.R.N.W., pp. 591-93; first two despatches from Thomps on enclosed in Ochterlony to Adj. Gen., 16th April, 1815: Home Misc., vol. 653, ff. 47-55; Sketches, pp. $27-28$.

65. Ochterlony to Adj. Gen., 17th April, 1815: P.R.N.W., pp. 591-93; despatches from Arnold and Dunbar enclosed in Ochterlony to Adj. Gen., 16th April, 1815: Home Misc., vol. 653, ff. 57-65; Lt. Rutledge to Amold, 15th April, 1815: P.R.N.W., p. 594; Capt.Bowyer to Major of Brigade, 16th April, 1815: ibid., p. 595; copy of a letter from an anonymous correspondent in Ochterlony's camp to J.M. Ludlow, 17th April, 1815: Ludlow MSS. AD $7450 / 2$ no. 67 (author possibly Col. Adams, since in a letter to his wife, AD 7450/1, no. 52, Ludlow mentions him as a comespondent with the Hindur army); Prinsep, op. cit., vol. i, p. 169; Fraser, op. cit., pp. 39-40; C.M.J., vol. xxvi; May, 1815, pp. 419-21 (according tothis last authority Showens was killed by a shot in the head); The Englishman, 2nd Oct., 1846.

66. Ochterlony to Adj. Gen., 17th April, 1815: P.R.N.W., p. 593.

67. Ibid.; Ochterlony to Adj. Gen., April 16th, 1815: Home Misc., vol. 653 , f. 45; Lawtie to Ochterlony, 18th April, 1815: ibid., ff. 540-45; anonymous letter to Ludlow, loc. cit.; Returns: P.R.N.W., pp. 596-98; Sketches, pp. 28-30; Prinsep, op. cit., pp. 169-71; Fraser, op. cit., pp. 40-41. 
68. Ochterlony to Adj. Gen., 8th May, 1815: P.R.N.W., p. 602.

69. W. Fraser to Pol. Sec., 18th May, 1815: Sec. Cons., 9th Aug., 1815 , no. 22; Ochterlony to Pol. Sec., 3nd May, 1815: Sec. Cons., 20 th June, 1815 , no. 44.

70. Ochterlony to Adj. Gen., 17th April, 1815: Home Misc., vol. 653, f. 121 .

71. Ochterlony to Adj. Gen., 8th May, 1815: P.R.N.W., p. 602;

Ochterlony to Lt. Ross, 3rd May, 1815: ibid., p. 604.

72. Ross to Ochterlony, 3rd May, 1815: P.R.N.W., pp. 604-05.

73. 324 deserters were already with Ochterlony; the total with him at the end of the war was 1,902 - see Adj. Gen. to Pol. Sec., 25 th July, 1815: Sec. Cons., 30th Aug., 1815, no. 18.

74. Ochterlony to Adj. Gen., 8th May, 1815: P.R.N.W., p. 603;

Ochterlony to Adj. Gen., n.d.: ibid., p. 606 .

75. See Delhi Resident to Pol. Sec., 2lst May, 1815: P.R.N.W., p. 559.

76. Ibid.; Garrett and Chopra, op. cit., pp. 191-94.

77. F. W. Stubbs, History of the Bengal Artillery, vol. ii, p. 4l, fn.

78. Convention dated 15th May, 1815: P.R.N.W., p. 607.

79. Extract from a private letter from Ochterlony to Adam, 13th May, 1815: Sec. Cons., 20th June, 1815, no. 6.

80. Adam to Ochterlony, n.d.: ibid., no. 7.

81. See text of Amar Singh Thapa's letter to Raja, quoted in Raja to Guru Gajraj Misra: Sec. Cons., 18th July,1815: no. 46.

82. See note 73 .

83. G.0. by Gov. Gen., 2 lst May, 1815: P.R.N.W., p. 605.

84. Pol. Sec. to Ochterlony, 28th May, 1815: Sec. Cons., 4th July, 1815 , no. 12 .

85. Adj. Gen. to Ochterlony, 18th May, 1815: Sec. Cons., 6th June, 1815 , no. 51 .

86. The East India Military Calendar, vol. 1. p. 383. 
Notes to Chapter Nine

548

87. Prinsep, op. cit., vol. i, p.173; C.M.J., vol. xxvi: May, 1815, p. 481 ; Gentleman's Magazine, March, 1817, p. 278.

88. Sketches, p.xiv. Cf. note 6 .

89. Ibid., p. 31 .

90. See, for example, his account of the engagement of Nov. 26 th . According to this, complaints concerning the cartridge boxes had merely been an excuse to justify untimely and unnecessary retreat. (p. 10).

91. Stubs, op. cit., vol. ii, p. 35 .

92. The author of the Sketches says that it was afterwards learnt that Amor Singh had frequently intended to surprise the enemy camps, but that his officers had always been deterred from implementing his plans by the complexity of the British defences. (p. 19).

93. A.J., vol. i: May, 1816, p. 428. 


\section{Notes to Chapter Ten}

1. W. Fraser to Pol. Sec., 20th Oct., 1814: P.R.N.W., P. 238;

Rutherfurd to Pol. Sec., 23rd Oct., \& lst Nov., 1814: ibid., pp. 202, 207.

2. F. Buchanan Hamilton to Pol. Sec., 14th Aug., 1814: ibid., p. 45; Hyder Hearsey to Pol. Sec., 24th Aug., 1814: ibid., p. 47; W. Fraser to Pol. Sec, 20th Oct., 1814: ibid., p. 238.

3. Pol. Sec. to Delhi Resident, 23rd Oct., 1814: ibid., pp. 139-40. At first it was intended to offer him the independent rulership of Kumaun, but this plan was modified when Hastings determined to annex that province.

4. Rutherfurd to Pol. Sec., Ist Oct., \& 30th Oct., 1814: ibid., pp. 97-98, 206; Pol. Sec. to Rutherfurd, 20th Oct., 1814: ibid., p. 115 .

5. Gov. Gen. to Secret Committee, 2nd Aug., 1815: ibid., p. 710.

6. He was a brother of Alan, 2nd Baron Gardner - See Lady Nugent, Journal, ii, pp. 6, 9. Lt. Col. William Linnaeus Gardner, of Gardner's Horse, was his cousin, The latter's entry in D.N.B. erroneously describes Edward as a scion of the Gardner family of Co. Wicklow. The mistake probably stems from the fact that in the Gardner family tree given by Fanny Parks in Wanderings of a Pilgrim in Search of the Picturesque, vol. i, p. 420, which was used as a source by the author of the D.N.B.article, Edward Gardner is unaccountably omitted. But there is no doubt concerning his parentage. All references in the MS records are to the Hon. Edward Gardner; and Lady Nugent is specific in her reference to him as "brother of Lord G., who rents our manor house in Buckinghamshire."

7. Personal Records, vol. 16, f. 99.

8. E. Gardner to Pol. Sec., 22nd Nov., 1814: P.R.N.W., p. 299. See also E. Gardner to Pol. Sec., 11th Nov., \& 6th Dec., 1814: ibid., pp. 233,299 .

9. Pol. Sec. to E. Gardner, 22nd Nov., 1814: ibid., p. 234 .

10. Parks, op. cit., vol. i, pp. 185, 408-16; Personal Records, vol. 6, f. 95 ; D.N.B.; Hods on's List, Part 4, Appendix A.

11. Gov. Gen. to Secret Committee, 2nd Aug., 1815: P.R.N.W., p. 750; Pol. Sec. to E. Gardner, 14th \& 2 lst Dec. 1814: P.R.N.W., pp. 301-02, 333; Capt. Butterfield to Commander-in-chief, 26th Dec., 1814: ibid., p. 358; Adj. Gen. to W. Gardner, 2 lst Dec., 1814: ibid., pp. $329-332$. 
12. Recent Indian history offered several examples of their unworthiness. Thomas owed his defeat at the hands of Bourg(iien in 1801 in great measure to the treachery of his Afghan mercenaries - see Herbert Compton, A Particular Account of the European Military Adventurers of Hindustan, p. 198. Sansar Chand was defeated by the Gurkhas in 1805 partly because of the weakness of his new corps of Rohilla Afghans - H. H. Wilson, Moorcroft and Trebeck, vol. i, pp. 128-29. See also Cunningham, History of the Sikhs, P. 154, \& A. T. Atkinson, Himalayan Districts, vol. ii, p. 587 .

13. Bute, Private Joumal of the Marquis of Hastings, vol. ii, p. 113.

14. E. Gardner to Pol. Sec., 2nd Jan., 1815: Home Misc,, vol. 651, ff. $113-20$.

15. E. Gardner to Pol. Sec., 3rd, 12th \& 2lst Jan., 1815: Home Misc., vol. 65I, ff. 139-44, 359-65, 467-84; Pol. Sec. to E. Gardner, 26th Jan., 1815: ibid., f. 487.

16. E. Gardner to Pol. Sec.,2nd Jan., 1815: Home Misc., vol. 651, ff. $113-20$.

17. Rutherfurd to Pol. Sec., 5th Oct., 1814: P.R.N.W., p. 101.

18. E. Gardner to Pol.Sec., 2nd Feb., 1815: E.S.D.B., vol. 5, no. 15; W. Gardner to Adj. Gen., 10th March, 1815: E.S.D.B., vol. 7, no. 78; Nicolls to Adj. Gen., 2nd April, 1815: ibid., no. 105; E. Gardner to Pol. Sec., 17th March, 1815: Home Misc., vol. 652, f. 557;

W. Gardner to Nicolls, 5th April, 1815: Home Misc., vol. 653, f. 288.

19. E. Gardner to Pol. Sec., 14th Feb., 1815: E.S.D.B., vol. 6, no. 24; W. Gardner to Adj. Gen., 14th Feb., 1815: ibid.; E. Gardner to Pol. Sec., 16th Isic; should read 18th 7 Feb., 1815: ibid., no. 26; E. Gardner to Pol. Sec., 20th Feb., 1815; ibid., no. 28; Heber, Narrative, vol. ii, pp.178, 206, 218, 243; Prinsep, Political and Military Transactions, vol. i, p. 145; W. G. Hamilton, "The Campaign in Kumaun", J.U.S.I.I., vol. xxxii, no. 153: Oct., 1903,P. 292; G. W. Traill, "Statistical Sketch of Kumaun", A.R., vol. xvi: 1828, p. 140; W. Hamilton, Gazetteer, vol. ii, p. 100 .

20. This description of the route is borrowed from Heber's, who covered the same ground ten years later - though in a reverse direction. See op. cit., vol. ii, p. 235; \& W. Hamilton, op. cit., vol. ii, pp. 100-01.

21. W. Gardner to Adj. Gen., lst \& 18th March, 1815: E.S.D.B., vol. 7, no. 78; Heber, op. cit., vol. ii, pp. 234-35; Prinsep, op. cit., vol. i, pp. 146-47; Atkinson, op. cit., vol. ii, pp. 649-50.

22. W. Gardner to Adj. Gen., 7th, 10th, \& 18th March, 1815: E.S.D.B., vol. 7 , no. 78 . 
23. W. Gardner to Adj. Gen., 18th March, 1815: ibid.

24. E. Gardner to Pol. Sec., 23rd March, 1815: ibid., no. 81; \& 26th March, 1815; ibid., no. 88; W. Gardner to Adj. Gen., 24th March, 1815: ibid.

25. E. Gardner to Pol. Sec., 26th March, 1815: E.S.D.B., vol. 7, no. 88; W. Gardner to Adj. Gen., 29th March, 1815: ibid., no. 99; Capt. Raper to Nicolls, 30th March, 1815: Nicolls MSS.

26. Home Misc., vol. 653, f. 289.

27. Gov. Gen, to Secret Committee, 2nd Aug., 1815: P.R.N.W., p. 753.

28. Dated 2nd April, and enclosed in E. Gardner to Pol. Sec., 6th April, 1815: ibid., p. 588. See also E. Gardner to Pol. Sec., 5 th April, 1815: E.S.D.B., vol. 7, no. 106; Raper to Nicolls, 3rd April, 1815: Nicolls MSS.

29. W. Gardner to Nicolls, 5th April, 1815: Home Misc., vol. 653, f. 290.

30. E. Gardner to Pol. Sec., 3lst March, 1815: E.S.D.B., vol. 7, no. 106.

31. E. Gardner to Pol. Sec., 6th April, 1815: ibid.

32. E. Gardner to Pol. Sec., 8th April, 1815: Home Misc., vol. 653, f. 22 .

33. Compton, op. cit., pp. 190-96, 362-63.

34. See his letter to Pol. Sec., 24th Aug., 1814: P.R.N.W., P. 48; Lady Nugent, op. cit., vol. ii, p. 70.

35. E. Gardner to Pol. Sec., 2nd Feb., 1815: E.S.D.B., vol. 5, no. 15; W. Gardner to Adj. Gen., 11th March, 1815: E.S.D.B., vol. 7, no. 78.

36. Hearsey to W. Gardner, 15th Feb., 1815: E.S.D.B., vol. 6, no. 41.

37. E. Gardner to Pol. Sec., 16th Feb., 1815: E.S.D.B., vol. 6, no. 26; Hearsey to E. Gardner, 15th \& 19th Feb., 1815: ibid., no. 41; Hearsey to W. Gardner, Ist March, 1815: Home Misc., vol. 652, ff. 426-29. Katalgarh is not marked on modern maps. Its position is described in Nicolls to Lt. Col. Adams, 29th June, 1815: Sec. Cons., 2nd Aug., 1815, no. 42 .

38. Hearsey to Adj. Gen., 23rd March, 1815: E.S.D.B., vol. 7, no. 88; Nicolls to Adj. Gen., 8th May, 1815: Sec. Cons., 20th June, 1815, no. 42 .

39. Hearsey to W. Gardner, 3rd March, 1815: E.S.D.B., vol. 7, no. 78; Major Hearsey (ed.), "The Joumal of Gholaum Hyder Khan", A.J., vol. xviii, part i: 1835, p. 106. 
40. Hearsey to E. Gardner, 3rd March, 1815: E.S.D.B., vol. 7, no. 78; Major Hearsey (ed.), "The Journal of Gholaum Hyder Khan", A.J., vol. xviii, part i: 1815: Home Misc., vol. 652, f. 215.

41. W. Gardner to Adj. Gen., 11th March, 1815: E.S.D.B., vol. 7, no. 78.

42. Hearsey to Adj. Gen., 4th \& 8th March, 1815: Home Misc., vol. 652, ff. 358-59, 454; Hearsey to W. Gardner, 6th March, 1815: E.S.D.B., vol. 7, no. 78; Hearsey to Adj. Gen., 23rd March, 1815: E.S.D.B., vol. 7, no. 88 .

43. Hearsey, "Journal of Gholaum Hyder Khan", loc. cit., p. 106; W. Gardner to Nicolls, 7th April, 1815: Home Misc., vol. 653, ff. 298-301; W. Martindell to W. Gardner, 5 th \& 6th April, 1815: ibid., ff. 316-18, 324-26; W. Martindell to Bareilly Magistrate, 5th April, 1815: E.S.D.B., vol. 7, no. 104; E. Gardner to Pol. Sec., 7th April, 1815: ibid., no. 106; Raper to Nicolls, 15th April, 1815, Nicolls MSS; Atkinson, op. cit., vol. ii, p. 657; Pearse, The Hearseys, pp. 57, 89; See Hodson's List, part 4, Appendix A, for information concerning William Martindell.

44. Gov. Gen. to Secret Committee, 2nd Aug., 1815: P.R.N.W., D. 752.

45. Adj. Gen. to Nicolls, 23rd March, 1815: E.S.D.B., vol. 7, no. 86.

46. Macdoon Sharpshooter (pseud.), "Some Account of the 15th... Bengal Native Infantry", E.I.U.S.J., vol. $\mathrm{i}$ ii: 1834, p. 249 ; Lumsdaine to Nicolls, 30th March, 1815: Nicolls MSS.

47. Return of European and Native Soldiers...: P.R.N.W., P. 980.

48. Raper to Nicolls, 30th March, 1815: Nicolls MSS; Raper to Moradabad Magistrates, 6th April, 1815: ibid.; Moradabad Magistrate to Raper, 19 th April, 1815: ibid.; Pol. Sec. to Lucknow Resident, 3lst March, 1815: E.S.D.B., vol.7, no. 83; Nicolls to Adj. Gen., 27th, 28th March, 2nd April, 1815: ibid., no. 105; Nicolls to Moradabad Magistrate, 8th April, 1815: Sec. Cons., 16th May, 1815, no. 20; Nicolls to Adj. Gen., 6th \& 9 th April, 1815: Home Misc., vol. 653, ff. $293,311-12 ;$ Adj. Gen. to Agent, lst Division Army Clothing, 13th April, 1815: Mil. Cons., 5th May, 1815, no. 100; Macdoon Sharpshooter, loc. cit., p. 249.

49. Nicolls to Adj. Gen., 9th \& 11th April, 1815: Home Misc., vol. 653, ff. 306-09, 319; Nicolls to the Editor of the Asiatic Joumal: A.J., vol., xviii, part 1: 1835, p. 183.

50. Rutherfurd to Nicolls, 20th May, 1815: Nicolls MSS.

51. W. Gardner to Nicolls, 16th April, 1815: Nicolls MSS; E. Gardner to Pol. Sec., 22nd April, 1815: Home Misc., vol. 653, ff. 399-401; Nicolls to Adj. Gen., 23 rd April, 1815: P.R.N.W., p. 572. 
52. Macdoon Sharpshooter, loc.cit., p. 249.

53. For a summary of his career, see D.N.B., \& Mins. of Ev., 1832,

Sec. 5, p. 1 .

54. Nicolls to Adj. Gen., 6th April, 1815: Home Misc., vol. 653, f. 285.

55. Nicolls to Moradabad Magistrate, 8th April, 1815: Sec. Cons., 16th May, 1815, no. 20.

56. Home Misc., vol. 653 , f. 314 .

57. See his remarks in A.J., vol. xviii, part 1: 1835, p. 115, and Nicolls' reply - ibid., p. 183.

58. Nicolls to W. Gardner, 12th April, 1815: Home Misc., vol. 653, f. 330.

59. Note, unsigned but in Rutherfurd's handwriting, dated 13th April, 1815: Nicolls MSS; W. Gardner to Nicolls, 13th April, 1815: ibid.

60. W. Gardner to Nicolls, 14th April, 1815: ibid.

61. Rutherfurd to Nicolls, 22nd April, 1815: ibid.

62. Enclosure in E. Gardner to Pol. Sec., 30th April, 1815: Sec. Cons., 6 th June, 1815 , no. 6 . This letter is also to be found in Atkinson, op. cit., vol. ii, pp. 665-66.

63. Nicolls to Adj. Gen., 23rd April, 1815: P.R.N.W., p. 572.

64. Macdoon Sharpshooter, loc. cit., pp. 246-47; Nicolls to Adj. Gen., 23rd April, 1815: P.R.N.W., P. 572; Major Patton to Acting Major of Brigade, 23rd April, 1815: ibid., p. 573; Nicolls to Adj. Gen., 24th April, 1815: ibid., p. 574.

65. This description is based on the "Sketch of Almorah and the Neighbouring defences Attacked by British Troops on the 25th of April, 1815": Nicolls MSS. Modern maps distribute the names of the various mountains somewhat differently. In W. G. Hamilton, loc. cit., Map 3, for example, the name Katarmal is given to a hill on a latitude north of that of Almora, and Kalimath is positioned to the east of the hill so-called in the "Sketch". See also: W. Gardner to Adj. Gen., 29th March, 1815: E.S.D.B., vol. 7, no. 99; Rutherfurd to Pol. Sec., 5th Oct., 1814: P.R.N.W., p. 104; Heber, op. cit., vol. ii, p. 211.

66. Nicolls to Adj. Gen., 25th April, 1815: P.R.N.W., pp. 575-76; Detachment Orders, 30th April, 1815: ibid., p. 582; caption to "Sketch": Nicolls MSS; Nicolls to Editor of Asiatic Journal: loc. cit., p. 183; Macdoon Sharpshooter, loc. cit., p. 248; The Englishman, 14 th Oct., 1846. 
67. Caption to "Sketch": Nicolls MSS; The Englishman, 14th Oct., 1846.

68. W. G. Hamilton, loc. cit., p. 297.

69. Nicolls to Adj. Gen., lst May, 1815: P.R.N.W., p. 581; Nicolls to Adj. Gen., 26th April, 1815: ibid., p. 576; Macdoon Sharpshooter, loc. cit., p. 248.

70. Nicolls to Adj. Gen., 26th April, 1815: P.R.N.W., P. 576; Macdoon Sharpshooter, loc. cit., p. 248; Caption to "Sketch": Nicolls MSS; The Englishman, 14th Oct., 1846.

71. Intercepted letter, enclosed in Gardner to Pol. Sec., 30th April, 1815: Sec. Cons., 6 th June, 1815 , no. 6.

72. E. Gardner to Pol. Sec., 5th April, 1815: E.S.DB., vol. 7, no. 106.

73. E. Gardner to Pol. Sec., 26th \& 27th April, 1815: P.R.N.W., pp. 567-70; E. Gardner to John Adam, 27th \& 28th April, 1815: Home Misc., vol. 653, ff. 489-92, 583-87. For a description of Brahma Shah, see Capt. F. V. Raper, "Narrative of a Survey for the Purpose of Discovering the Sources of the Ganges", $\underline{A . R}$., vol. xi: 1808, p. 560 .

74. Nicolls to Adj. Gen., lst May, 1815: Sec. Cons., 6th June, 1815, no. 41 .

75. E. Gardner to Pol. Sec., 3rd April, 1815: E.S.D.B., vol. 7, no. 106; Adj. Gen. to Pol. Sec., 25th July, 1815: Sec. Cons., 30th Aug., 1815 , no. 18.

76. E. Gardner to Pol. Sec., 7th May, 1815: Sec. Cons., 6th June, 1815, no. 25; Nicolls to Adj. Gen., 8th May, 1815: Sec. Cons., 20th June, 1815 , no. 42.

77. E. Gardner to Pol. Sec., 10th May, 1815: P.R.N.W., p. 617.

78. Nicolls to Adj. Gen., 26th April, 1815: P.R.N.W., pp. 577-78.

79. Nicolls to Editor of Asiatic Journal; loc. cit., p. 184.

80. Nicolls to Adj. Gen., 6th \& 9th May, 1815: Sec. Cons., 20th June, 1815 , no. 42; Rutherfurd to Nicolls, n.d., but endorsed "7th or 8th May": Nicolls MSS.

81. Nicolls to Adj. Gen., 30th April, 1815: P.R.N.W., p. 579. 82. General Order by the Governor General, 3rd May, 1815: P.R.N.W.,
p. 585 . 


\section{Notes to Chapter Eleven}

1. W. H. Sleeman, A Journey through the Kingdom of Oudh, vol. ii, p. 105.

2. John Wood to Adj. Gen., 14th May, 1815: Home Misc., vol. 654, ff. $172-78$.

3. C. T. Atkinson, Regimental History of the South Wales Borderers, p. 275 .

4. Lt. Col. Gregory to Lt. Boileau, 15th Aug., 1815: Sec. Cons., 7 th Oct., 1815 , no. 33 .

5. E. Gardner to Pol. Sec., 10th July, 1815: P.R.N.W., p. 802 .

6. W. Gardner to E. Gardner, 17th May, 1815: Sec. Cons., 20th June, 1815 , no. 31 .

7. Bradshaw to Pol. Sec., 17th Feb., 1815: Sec. Cons., 7th March, 1815, no. 75; Bradshaw to Pol. Sec., 18th June, 1815: P.R.N.W., p. 799 .

8. Pol. Sec. to E. Gardner, 15th June, 1815: P.R.N.W., p. 795 .

9. Bradshaw to Pol. Sec., 29th June, 1815: Sec. Cons., 18th July, 1815 , no. 44 .

10. W. Gardner to E. Gardner, 17th May, 1815: 1oc. cit.; E. Gardner to Pol. Sec., 28th June, 1815: Sec. Cons., 2nd Aug., 1815, no. 6.

11. Bradshaw to Pol. Sec., 8th \& 22nd Jan., 1815: P.R.N.W., pp. 388, 342; Gov. Gen. to Secret Committee, 5th Aug., 1815: ibid., p. 767; Pol. Sec. to E. Gardner, 19th May, 1815: ibid., p. 614; \& Bradshaw's despatches to Pol. Sec. of 26th Feb., 22nd March, 5th April, 25th April, 28th April, 8th May, 1815: Sec. Cons., 2lst March, no. 137; 1lth April, no. 71; 25th April, nos. 37 \& 38; 16th May, nos. 141 \& 142; 30th May, no. 58 .

12. Bradshaw to Pol. Sec., 28th May \& 18th June, 1815: P.R.N.W., Pp. 781, 799; Pol. Sec. to Bradshaw, 5th \& 27th June, 1815: ibid., pp. 783, 799; Pol. Sec. to E. Gardner, 27th June, 1815: ibid., p. 800.

13. E. Gardner's despatches to Pol. Sec. of 30th April, 17th May, 20th, 23rd, \& 28th June, 1815: Sec. Cons., 6th June, no. 6; 20th June, no. 30; 2nd Aug., nos. 4, 5, \& 6; W. Gardner to Nicolls, 1lth May, 1815: P.R.N.W., Pp. 610-12; Pol. Sec. to E. Gardner, 19th May, 1815: ibid., pp. 612-14; E. Gardner to Pol. Sec., 7th June, 1815: ibid., pp. 791-96. 
14. E. Gardner to Pol. Sec., 4th July, 1815: Home Misc., vol. 655, ff. 97-102; E. Gardner to Pol. Sec., 10th, 11th, 13th, 15th, July, 1815: P.R.N.W., Pp. 802-09.

15. B. H. Hodgson, "Memorandum Relating to the Gurkha Army": Sec. Cons., 4th March, 1825, no. 16, para. 22.

16. E. Gardner to Pol. Sec., 15th July, 1815: P.R.N.W., P. 808 .

17. Pol. Sec. to E. Gardner, 22nd July, 1815: ibid., p. 810; Gov. Gen. to Vice Pres., 3lst Aug., 1815: Home Misc., vol. 655, ff. 238, 245 .

18. Metcalfe to Pol. Sec., 28th Nov., 1814; P.R.N.W., Pp. 404-05; Moira to McMahon, 22nd Jan., 1815: Aspinall, Letters of George IV, vol. ii, P. 16; Pol. Sec. to Metcalfe, 27th Feb., 1815: E.S.DB., vol. 6, no. 31; Capt. Latter to Adj. Gen., 26th Sept., 1814: P.R.N.W., p. 170; Latter to Ass't Adj. Gen., 20th Nov., 1814: Mil. Cons., 3rd Dec., 1814, no. 36; Rangpur Magistrate to Acting Pol. Sec., 28th Nov., 1814: P.R.N.W., p. 410; Latter to Dept. Adj. Gen., 20th Feb., 1815: E.S.D.B., vol. 8, no. 312; Adj. Gen. to Pol. Sec., 3lst March, 1815, \& 10th April, 1815: E.S.DB., vol. 7, nos. 87, 100; Gov. Gen. to Vice Pres., 9th Feb., 1815: Sec. Cons., 2lst March, 1815, no. 1, paras. 32, 80.

19. Bute, Joumal of Hastings, vol. i, p. 298.

20. Letter to Jenkins, Jan., 1815: Kaye, Life of Metcalfe, vol. i, p. 402.

21. Pol. Sec. to Acting Pol. Sec., 17th May, 1815: Sec. Cons., 6th June, 1815, no. 36; Vice Pres. to Gev. Gen., 9th Aug., 1815: Sec. Cons., 9th Aug., 1815, no. 1; Gov. Gen. to Vice Pres., 9th Feb., 1815: loc. cit., paras. 98-101.

22. Bute, op. cit., vol. i, pp. 299-300; C.M.J., vol. xxvi: Feb., 1815, p. 131; Deb Raja to Vice Pres., 5th Jan., 1815: Home Misc., vol. 654, ff. 521-28; Vice Pres. to Deb Raja, 28th Feb., 1815: ibid., ff. 53136; Rangpur Magistrate to Acting Pol. Sec., March 15th \& 20th, 1815, \& May 29th, 1815: E.S.D.B., vol. 8, nos. 292, 293, 295; Acting Pol. Sec. to Rangpur Magistrate, 29th March, 1815: ibid., no. 294; Rangpur Magistrate to Acting Pol. Sec., 17th July, 1815: Sec. Cons., 2nd Aug., 1815, no. 35. The name of the British agent was Kishen Kant Bose.

23. Pol. Sec. to E. Gardner, 22nd July, 1815: P.R.N.W., P. 809 . 24. Ibid.

25. Gov. Gen. to Secret Committee, 5.th Aug., 1815: P.R.N.W., p. 780. 
26. Ibid.; Pol. Sec. to Adj. Gen., 22nd July, 1815: ibid., p. 814.

27. B. P. Saksena (ed.), Historical Papers relating to Kumaun, p. 198.

28. P.R.N.W., PP. 825,826 .

29. Bradshaw to Pol. Sec., 23rd Aug., 1815: ibid., p. 824.

30. Gov. Gen. to Vice Pres., 20th Aug., 1815: Sec. Cons., 27th Sept., 1815 , no. 1 .

31. Adj. Gen. to Pol. Sec., 28th Nov., 1815: P.R.N.W., p. 875. The reference is to an order of 10th Sept., 1815.

32. Correspondence between Gov. Gen. and Vice Pres., 10th Aug. - 11th Sept., 1815: Home Misc., vol. 655, ff. 187-259.

33. Pol. Sec. to Bradshaw, 3rd \& 23rd Sept., 1815: P.R.N.W., pp. 826-29, $833-36$.

34. E. Gardner to Pol. Sec., 4th Sept., 1815: Sec. Cons., 7th Oct., 1815 , no. 23 .

35. Bradshaw to Pol. Sec., 10th, 17th, 26th Oct., \& 3rd Nov., 1815: P.R.N.W., PP. 844-47.

36. Adj. Gen. to Assistant Commissary General at Dinapur, 27th Oct., 1815: Sec. Cons., 2nd Dec., 1815, no. 17.

37. Adj. Gen. to Pol. Sec., 27th Nov., 1815: Sec. Cons., 2nd Dec., 1815 , no. 8 .

38. Adj. Gen. to Pol. Sec., 28th Nov., 1815: P.R.N.W., pp. 875-80; Fagan to Nicolls, Nov. 16th, 1815: Nicolls MSS.

39. Pol. Sec. to Bradshaw, 10th Nov., 1815: P.R.N.W., Pp. 848-49.

40. Bradshaw to Pol. Sec., 24th \& 29th Nov., 2nd Dec., 1815: P.R.N.W., pp. 847-852.

41. Commissary General to Adj. Gen., 30th Dec., 1815: Sec. Cons., 13th Jan., 1816, no. 31 .

42. Pol. Sec. to Bradshaw, 9th Dec-, 1815: ibid., pp. 852-55.

43. Bute, op. cit., vol. i, p. 183, vol. ii, pp. 53-55; Gov. Gen. to Secret Committee,3lst August, 1815: Secret Letters from Bengal, vol. 16, ff. 518-55; N. Chatterji, "Lord Hastings, Colonel Baillie, and the Oudh Loans": J.U.P.H.S., new series, vol. i, part i, pp. 52-62. 
44. Bradshaw to Pol. Sec., 28th Dec., 1815: P.R.N.W., Pp. 857-58; Bradshaw to Ochterlony, 12th Feb., 1816: Sec. Cons., 2nd March, 1816, no. 25.

45. Pol. Sec. to Bradshaw, 5th Jan., 1816: P.R.N.W., P. 859 .

46. A private letter from Richard Strachey to John Adam, dated 16th Dec., 1815, concerning the post of Head Assistant at Lucknow, has this pencil note jotted in the top left hand corner: "to be considered when Bradshaw is removed". See I.O.L. MSS EUR/D/585, f. 161 .

47. George Wood to Adj. Gen., 22nd May, 1815: E.S.D.B., vol. 9, no. 386.

48. Adj. Gen. to Pol. Sec., 6th Sept, 1815: Sec. Cons., 7th Oct., 1815, no. 32; Pol. Sec. to Bradshaw, 30th Sept., 1815: ibid., no. 49.

49. Bradshaw to Pol. Sec., 19th Sept., 1815: P.R.N.W., pp. 830-33; Pol. Sec. to Bradshaw, 23rd Sept, 1815: ibid., p. 833.

50. Ochterlony to Adj. Gen., 16th Dec., 1815, \& Pol. Sec. to Adj. Gen., 30th Dec., 1815: Sec. Cons., 30th Dec., 1815, no. 10; Bradshaw to Pol. Sec., 9th March, 1816: Sec. Cons., 30th March, 1816, no. 24.

51. See correspondence between Bradshaw, Ochterlony, and the Political Secretary: P.R.N.W., pp. 902-916. Bradshaw returned to England on furlough when his dismissal from the Lucknow Residency was announced (probably in 1817) in order to protest before the Court of Directors. His representations were apparently successful, because he returned to India in 1821 to resume his old post. But he never reached Lucknow. He died at Patna the same year. It was rumoured at the time that he had been poisoned with diamond dust at the instigation of the Nawab of Oudh. See Pearse, The Hearseys, pp. 218-20;

Hodson's List, Part 1 .

52. Bradshaw to Pol. Sec., 24th Jan., 1816: P.R.N.W., p. 899.

53. Ochterlony to Gajraj Misr 27th Jan., 1816: P.R.N.W., p. 914 .

54. E. Gardner to Pol. Sec., 2nd Sept., 1815: Sec. Cons., 7th Oct., 1815 , no. 22 .

55. Bradshaw to Pol. Sec., 23rd Aug., 1815: P.R.N.W., p. 824 .

56. It is known, from various casual references, that Brahma Shah remained in the west as governor of Doti province. See, for example, Richard Strachey to John Adam, 19th November 1816: I.O.L. MSS EUR/D/585, f. 212. Rudra Vir's subsequent career is so far unknown. It is probable that he remained governor of Sallyana. 
57. Report of Kishen Kant Bose: Sec. Cons., 25th Nov., 1815, no. 24 ; Commissionerfor Kuch Bihar to Pol. Sec., 14th Feb., 1816: Sec. Cons., 16th March, 1816, no. 51; E. Gardner to Pol. Sec., 6th July, 1816: Sec. Cons., 27th July, 1816, no. 12; letter from the 3 Chinese govemors in Tibet to Capt. Latter: Sec. Cons., 13th July, 1816, no. 17.

N.B. The Chinese residents are sometimes referred to as "tazeen", which appears to be a synonym of "amban". The name "Arzung" also features. This was another designation for Lhasa - see Gardner to Pol. Sec., lst Sept., 1816: Sec. Cons., 28th Sept., 1816, no. 67.

58. Rangpur Magistrate to Pol. Sec., 16th June, 1816: Sec. Cons., 22nd June, 1816, no. 30.

59. E. Gardner to Pol. Sec., 6th July, 1816: loc. cit.

60. Letter from Chinese governors to Latter: loc. cit; Commissioner for Kuch Bihar to Pol. Sec., 14th Feb., 1816: 1oc. cit.; translation of a letter from Bhim Sen Thapa ... to Paniji, vakil to Lhasa: Sec. Cons., 10th Aug., 1816, no. 15. Cf. the slightly different account in R. Montgomery Martin, China: Political Commercial and Social, vol. i, p. 25 .

62. E. H. Parker, "Nepal and China": I.A.Q.R., 3rd series, vol. vii: 1899 , p. 78 .

62. Report of Kishen Kant Bose: loc. cit.

63. Govermment Customs Officer at Cox Bazaar to Govt., 10th Oct., 1816: Sec. Cons., 26th Oct., 1816, no. 15.

64. Metcalfe to Pol. Sec., 9th Nov., 1815: Sec. Cons., 2nd Dec., 1815, no. 21 .

65. John Wood to Pol. Sec., 29th Sept., 1815: Sec. Cons., 13th Oct., 1815, no. 10. There is no reason to doubt the truth of this report. Two years later letters from the Nepalese vakil at Gwalior were intercepted. They urged the Gurkhas to attack the British, and assured Bhim Sen Thapa that the Marathas were preparing to take the field against them: Bute, op. cit., vol. ii, pp. 216-17.

66. E. Gardner to Pol. Sec., 15th July, 1815: P.R.N.W., p. 808 .

67. P.R.N.W., P. 554 . 
Notes to Chapter Twelve

1. Adj. Gen. to Pol. Sec., 2nd Aug., 1815: Sec. Cons., 30th Aug., 1815, no. 25; Adj. Gen. to Ochterlony, 5th Jan., 1816: P.R.N.W., pp. 861-63; Pol. Sec. to Ochterlony, 13th Jan., 1816: ibid., p. 892 .

2. F. B. Hamilton to Pol. Sec., 19th Aug., 1814: ibid., p. 41.

3. Adj. Gen. to Pol. Sec., 28th Nov., 1815: ibid., pp. 875-80; General Return...: Ibid., pp. 882-83.

4. Pol. Sec. to Acting Pol. Sec., 17th May, 1815: Sec. Cons., 6 th June, 1815, no. 36; Vice Pres. to Gov. Gen., 9th Aug., 1815: Sec. Cons., 9th Aug., 1815, no. 1.

5. Shipp, Memoirs, p. 156, fn.

6. F. Lorraine Petre, The Royal Berkshire Regiment, vol. i, p. 181.

7. Adj. Gen. to Pol. Sec., 28th Nov., 1815: P.R.N.W., pp. 875-80; Secret Letter from Bengal,2lst Feb., 1816: ibid., pp. 864-65; Secret Letter from Bengal, 30th March, 1816: ibid., p. 948; Returns of Divisions of the Army under Major-General J.S . Wood, Colonel Jasper Nicolls, and Captain B. Latter: ibid., pp.884-87; Adj. Gen. to Ochterlony, 5th Jan., 1816: ibid., p. 863; Latter to Pol. Sec., 19th Jan., 1816: ibid., p. 929; Moira to Jasper Nicolls, 4th Feb., 1816: Nicolls MSS.

8. Commissary General to Adj. Gen., 30th Dec., 1815: Sec. Cons., 13th Jan., 1816, no. 31.

9. George Fagan to Jasper Nicolls, 16th Nov., 1815: Nicolls MSS; Adj. Gen. to Pol. Sec., 28th Nov., 1815: P.R.N.W., P. 875; Division Orders...10th Jan., 1816: C.M.J., vol. xxviii: Feb., 1816, p. 117; ibid., vol. xxviii: Jan., 1816, p. 90.

10. W. Henry, Events of a Military Life, vol. i, pp. 238-39; C.M.J., vol. xxviii: Jan., 1816, p. 57.

11. Ochterlony to Adj. Gen., 26th Jan., 1816: P.R.N.W., pp. 871-72; Intelligence Report from Capt. Pickersgill,Sec. Cons., 27th Jan., 1816 , no. 21 .

12. Ochterlony to Acting Adj. Gen., 9th Feb., 1816: P.R.N.W., p. 867; F. B. Hamilton to Pol. Sec., 19th Aug., 1814: ibid., p. 39; C.M.J., vol. xxviii: Feb., 1816, p. 175; "India Military Intelligence": A.J., vol. ii, 1816, pp. 401-02; Military Sketches of the Goorkha War, p. 38; Shipp, op. cit., p. 167 .

13. Ochterlony to Pol. Sec., 14th Feb., 1816: P.R.N.W., P. 921. 
14. Sketches, p. 39; Shipp, op. cit., p. 170.

15. The Englishman, 2lst Oct., 1846; Prinsep, Political and Military Transactions, vol. i, p. 194. Ochterlony to Acting Adj. Gen., 19th Feb., 1816: P.R.N.W., P. 933; A.J., vol. ii, p. 402. The contemporary "Map of the Routes by which Major-General Sir David Ochterlony....advanced...towards Mackwanpoor", in the I.O.L. collection, does not show Amlekhganj, but there is a passage from about that location marked "said to be fit for hackeries".

16. Ochterlony to Acting Adj. Gen., 19th Feb., 1816: P.R.N.W., pp. 933-34; Shipp, op. cit., pp. 171-75, 178-79; Sketches, pp. 39-41; A.J., vol. ii, pp. 402-04; Col. George Twemlow, Considerations on Tactics and Strategy, pp. 48-49; Stubbs, Bengal Artillery, vol. ii, pp. 32-33; The Englishman, 2lst Oct., 1846.

17. Ochterlony to Acting Adj. Gen., 19th Feb., 1816: loc. cit.

18. Burnet to Ochterlony's Assistant Adj. Gen., 16th \& 17th Feb., 1816: P.R.N.W., pp. 935-36; Burnet to Acting Adj. Gen., 17th Feb., 1816: ibid., p. 933; A.J., vol. ii, pp. 402-03; Shipp, op. cit., pp. 212; Henry, op. cit., vol. i, p. 259.

19. Ochterlony to Acting Adj. Gen., 19th, 24th \& 28th Feb., 1816: P.R.N.W., pp. 934-36; Shipp, op. cit., pp. 183-85; Sketches, p. 42; F. B. Hamilton to Pol. Sec., 19th Aug., 1814: 1oc. cit.

20. Ochterlony to Pol. Sec., 26th Feb., 1816: P.R.N.W., pp. 941-45.

21. A.J., vol. ii, pp. 404, 407; Sketches, pp. 42-43; Prinsep, op. cit., vol. i, p. 197; Shipp, op. cit., p. 188.

22. Ochterlony to Acting Adj. Gen., 28th Feb., 1816: P.R.N.W., pp. 936-37; A.J., vol. ii, pp. 406-07.

23. Ochterlony to Acting Adj. Gen., 29th Feb., 1816: P.R.N.W., P. 937; Division Orders, 29th Feb., 1816: ibid., p. 938; Return of Casualties, 29th Feb., 1816: ibid., p. 939; Secret Letter from Bengal, 30th March, 1816: ibid., p. 948; A.J., vol. ii, p. 407; Sketches, pp. 43, 45; Shipp, op. cit., pp. 191-95; Prinsep, op. cit., vol. i, pp. 197-200; The Englishman, 23rd Oct., 1846.

24. Henry, op. cit., p. 252; A.J., vol. ii, p. 405; The Englishman, 26 th Oct., 1846. On p. $4 \overline{10}$, the A.J., account states that Nicol arrived on Feb. 29th, and this is the date adopted by Prinsep. Both Henry and Hough (in The Englishman) who were with Nicol's brigade, say March 2nd..

25. C.M.J., vol. xxviii, April, 1816, p. 305; Ochterlony to Bol. Sec.,

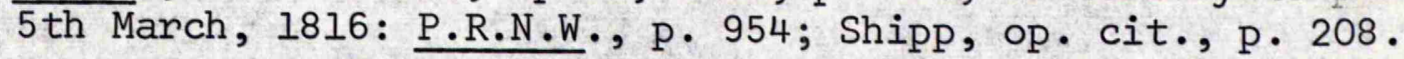


26. Ochterlony to Acting Adj. Gen., 5th March, 1816: P.R.N.W., p. 955; Henry, op. cit., vol. i, pp. 254-55. Shipp, op. cit., pp. 204-05, says that a cannonade was begun. Either his memory deceived him, or he was heightening his narrative, because there is no mention of any guns actually having opened in any contemporary account. Generally speaking, his book is enjoyable, but often exaggerated, and occasionally quite fanciful. Eighteen-pounders become twenty-fours; and when describing the enemy casualties (of whom official reports reckoned 128 to have been killed), he says "eleven hundred were committed to the grave"!

27. P.R.N.W., P. 954.

28. Kelly to Ochterlony, 28th Feb. \& 2nd March, 1816: ibid., pp. 940, 956; A.J., vol. ii, pp. 405, 409; Prinsep, op. cit., vol. i, p. 202 .

29. Pol. Sec. to Ochterlony, 13th Jan., 1816: P.R.N.W., P. 890.

30. 2 letters from Ochterlony to Pol. Sec., dated March 5th, 1816: ibid.,pp. 952-54.

31. Pol. Sec. to Ochterlony, 13th Jan., 1816: ibid., p. 889.

32. Henry, op. cit., vol. i, p. 258.

33. Kaye, Life of Metcalfe, vol. i, p. 421.

34. Moira to Nicolls, 22nd March, 1816: Nicolls MSS.

35. Secret Letter from Bengal, 30th March, 1816: P.R.N.W., PP. 948-49.

36. Latter to Pol. Sec., 16th, 19th, \& 30th Dec., 1815; 16th \& 31st Jan., 18th, 20th \& 25th Feb., 2nd, 14th \& 20th March, 1816: ibid., pp. $922-29,958-64$.

37. East India Military Calendar, vol. i, p. 368; Hodson's List.

38. Sinha \& Dasgupta, Selections from the Ochterlony Papers, passim; Ochterlony's personal correspondence with Metcalfe in Home Misc., vol. 738; Bishop Heber's description of an encounter with Ochterlony in Narrative, vol. ii, pp. 362-63; 391-93.

39. Cunningham, History of the Sikhs, p. 129, fn. 


\section{Notes to Epilogue}

1. Latter to Pol. Sec., 10th June, 1816: Sec. Cons., 13th July, 1816, nos. 15-17; Latter to Pol. Sec., 19th Aug., 1816: Sec. Cons., 7th Sept., 1816, no. 19.

2. E. Gardner to Pol. Sec., 19th July, 1816: Sec. Cons., 10th Aug., 1816 , no. 15 .

3. Gardner to Pol. Sec., 23rd July, 1816: Sec. Cons., 10th Aug., 1816, no. 18; Gardner to Pol. Sec., 2nd Aug., 1816: Sec. Cons., 24 th Aug., 1816, no. 10.

4. Gardner to Pol. Sec., 8th Aug., 1816: Sec. Cons., 3lst Aug., 1816 , no. 13.

5. Gardner to Pol. Sec., 16th Aug., 1816: Sec. Cons., 7th Sept., 1816, no. 18; Gardner's despatches to Pol. Sec., 19th-30th Aug., 1816: Sec. Cons., 14th Sept., 1816, nos. 38-42.

6. Gardner to Pol. Sec., 1st Sept., 1816: Sec. Cons., 28th Sept., 1816, no. 67; Gardner to Pol. Sec., 12th Sept., 1816: Sec. Cons., 12th Oct., 1816, no. 23.

7. Sec. Cons., 30th Aug., 1816, no. 18.

8. Pol. Sec. to Gardner, 14th Sept., 1816: Sec. Cons., 14th Sept., 1816 , no. 43.

9. Latter to Pol. Sec., 29th Oct., 1816: Sec. Cons., 9th Nov., 1816, no. 19 .

10. Gardner to Pol. Sec., 8th Oct., 1816: Sec. Cons., 2nd Nov., 1816, no. 12; Prinsep, Political and Military Transactions, vol. i, pp. 211-12.

11. Latter to Pol. Sec., 13th Dec., 1816: Sec. Cons., 28th Dec., 1816, no. 30 .

12. H. H. Wilson, The History of British India, vol. ii, p. 79, fn.

13. Boileau to Pol. Sec., 1lth April, 1816: Sec. Cons., 27th April, 1816, no. 1; Boileau to Pol. Sec., 18th April, 1816: Sec. Cons., 4th May, 1816, no. 54; Boileau to Adam, and enclosure, April 24th, 1816: Sec. Cons., 11th May, 1816, nos. 30, 31.

14. Pol. Sec., to Gardner, 4th May, 1816: Sec. Cons., 4th May, 1816, no. 70 . 
15. Resident at Gwalior to Pol. Sec., 23rd Nov., 1816: Pol. Cons., 28th Dec., 1816, no. 4; Gardner to Pol. Sec., 14th July, 1816: Sec. Cons., 3rd Aug., 1816, no. 12.

16. Aitchison, Treaties, vol. xiv, pp. 65-66.

17. Sir George Campbell made this observation - Modern India, p. 160. Nepal was not bound to abstain from foreign relationships until 1839.

18. Bute, Joumal of Hastings, vol. ii, p. 209.

19. Pol. Sec. to Ochterlony, 28th May, 1815: Sec. Cons., 4th July, 1815 , no. 11 .

20. Prinsep., op. cit., vol. i, p. 482. Some delay occurred before the conclusion of this treaty, "on account of the difficulty of communicating in a language which I was $T$ not understood by any European or by any inhabitants of the Company's provinces" - Latter to Pol. Sec., 6th April, 1816: Sec. Cons., 15th April, 1816, no. 43.

21. Pol. Sec. to Ochterlony, 28th May, 1815: 1oc. cit: Pol. Sec. to Ochterlony, 17th Aug., 1815: Sec. Cons., 27th Sept., 1815, no. 18; Ochterlony to Pol. Sec., 9th Aug., 1815: ibid., no. 41. The old Mogul institution of suzerainty of stronger hill states over numbers of their weaker neighbours was abandoned on Ochterlony's recommendation.

22. Pol. Sec. to Ochterlony, 2nd Dec., 1815; Sec. Cons., 2nd Dec., 1815, no. 4; Lt. Ross to Delhi Resident, 20th Jan., 1816: Sec. Cons., 2nd March, 1816, no. 6; Correspondence between Ross and Ochterlony: Sec. Cons., 28th Sept., 1816, no. 71. The only territory of any note involved was tha thakuri of Pandur, which was transferred to Kionthal.

23. Pol. Sec. to Ochterlony, 28th May, 1815: Sec. Cons., 4th July, 1815 , no. 11 .

24. Secret Letter from Bengal, 2nd Aug., 1815: P.R.N.W., p. 759.

25. Pol. Sec. to Fraser, 17th Nov., 1815; Sec. Cons., 17th Nov., 1815, no. 31. William Fraser was made Commissioner for the Settlement of Garhwal. His function was the same as that of Residents at native courts on the plains - guidance without excessive interference.

26. Correspondence between Fraser, Hearsey, and Pol. Sec.: Sec. Cons., 7th Oct., 1815, nos. 40, 41; 8th Dec., 1815, nos. 16, 18.

27. Pol. Sec. to Rangpur Magistrate, 5th Oct., 1816: Sec. Cons., 5 th Oct., 1816, no. 13.

28. Raper to Nicolls, 1lth April, 1816: Nicolls MSS. 
29. W. Hamilton, Gazetteer, vol. ii, p. 103; Heber, Narrative, vol. ii, p. 212 .

30. The mortality rate among children born in India of European parentage appears to have been appallingly high until this time see evidence of Lt. Charles Hopkins, Mins. of Ev., 1832, Sec. 5, p. 125, and the experience of the Sherwoods as recounted in Harvey Darton, Life of Mrs Sherwood, passim. It would be interesting to discover what effect the institution of the hill station had on this problem.

31. Pol. Sec., to Adj. Gen., 9th July, 1815: Sec. Cons., 9th Aug., 1815, no. 25; Adj. Gen. to Pol. Sec., 25th July, 1815: Sec. Cons., 30 th Aug., 1815, no. 18 .

32. Secret Letter from Lord Moira, lst June, 1815: P.R.N.W., P. 566 .

33. Nicolls to Adj. Gen., 27th June, 1815: Sec. Cons., 2nd Aug., 1815 , no. 42 .

34. Rutherfurd to Nicolls, 17th May, 1815: Nicolls MSS.

35. Adj. Gen. to Pol. Sec., 28th June, 1815: Sec. Cons., 9th Aug., 1815 , no. 24 .

36. Ibid.

37. Pol. Sec. to Adj. Gen., 9th July, 1815: Sec. Cons., 9th Aug., 1815, no. 25; Adj. Gen. to Pol. Sec., 25th July, 1815: Sec. Cons., 30th Aug., 1815, no. 18; General Order by the vice President in Council, 26th Aug., 1815: C.M.J., vol. xxvii, Sept., 1815, pp. 240-41; Acting Adj. Gen., to Pol. Sec., 26th April, 1816: Sec. Cons., 4th May, 1816 , no. 38 .

N.B. The strength of each battalion was to be allowed to diminish to 100 privates per company, by the effect of retirement and casualties. The 2nd Nasiri Battalion was absorbed into the lst in 1829, and the corps became the 66th Native Infantry in 1850, when the name "Nasiri" was given to another, non-Gurkha, battalion.

It should be noted that these four corps were originally modelled on the pre-war provincial battalions (supra, Chapter Four), but in contemporary correspondence the designations "provincial" and "local" seem to be used interchangeably.

38. Adj. Gen. to Agent, lst Division Army Clothing, 25th July, 1815: Mil. Cons., 12th Aug., 1815, no.76.

39. Major Patton to Lt. Col. Macleod, 6th Dec., 1815: B. P. Saksena (ed.), Historical Papers Relating to Kumaun, pp. 209-10; Patton to Lt. Col. Stuart, 15th Aug., 1815: Stuart MSS. Barat, Bengal Native Infantry, pp. 301-02, suggests that the unrest was due to the fact that when Kumaun became annexed to the Bengal Presidency, the sepoys lost their foreign service allowance. 
40. Adj. Gen. to Pol. Sec., 28th June, 1815: Sec. Cons., 9th Aug., 1815 , no. 24 .

41. Pol. Sec. to Acting Adj. Gen., 17th Aug., 1816: Sec. Cons., 17th Aug., 1816, no. 8; Acting Adj. Gen. to Pol. Sec., 28th Sept., 1816: Sec. Cons., 28th Sept., 1816, no. 72.

42. Cunningham, History of the Sikhs, p. 156.

43. Lt. Ross to Metcalfe, 17th April, 1816: Sec. Cons., 25th May, 1816 , no. 2 .

44. Cited from Prinsep's History of the Punjab, vol. ii, p. 73, by Stubbs, in Bengal Artillery, vol. ii, p. 9. See also Cunningham, op. cit., p. 388 .

45. H. Lawrence, Essays, pp. 29, 344; Landon, Nepal, vol. i, pp. 96-97.

46. Ainslee Embree, Charles Grant and British Rule in India, p. 276.

47. Political Letter to Bengal, 13th Oct., 1815: P.R.N.W., pp. 548, 549.

48. It also appears in a letter from Sir Henry Torrens to Maj. Gen. Hislop, 16th Oct., 1815: P.R.0., Private Out letters of the Commander in Chief, ff. 163-66.

49. Moira to Chairman, 6th Aug., 1816: P.R.N.W., P. 994; Moira to Prince Regent, 29th July, 1815: Aspinall, Letters of George IV, vol. ii, p. 86.

50. Minute by Gov. Gen.: Mil. Cons., 22nd Dec., 1815, no. 1; Secret Letter from Lord Moira, 3lst Aug., 1815: Sec. Letters from Bengal, vol. 16, ff. 518-55; Secret Letter from Bengal, 30th March, 1816: P.R.N.W., Pp. 951-52; Moira to Chairman, 6th Aug., 1816: ibid., p. 997 .

51. Political Letter to Bengal, 13th Feb., 1817: ibid., p. 989.

52. Ibid., p. 991; Military Letter to Bengal, 26th Aug., 1818, para. 192.

53. Moira to Chairman, 6th Aug., 1816: P.R.N.W., P. 996; A.J., vol. i: June, 1816, pp. 529-30.

54. Minute by Gov. Gen., Mil. Cons., 22nd Dec., 1815, no. 1.

55. Military Letter to Bengal, 16th April, 1817, paras. 113, 119.

56. The first quotation is taken from Military Letter to Bengal, 7th Jan., 1817, para. 17; the second is cited by H. A. Young, Arsenals and Manufactories, p. 17. 
57. Military Letter to Bengal, 16th June, 1815, paras. 109-12.

58. Military Letter to Bengal, 7th Jan., 1817, para. 16.

59. Military Letter to Bengal, 16th April, 1817, paras. 113-119.

60. Cited by Barat, op. cit., p. 203. The same sort of parsimony seems to have regulated the size of the establishment of gun lascars. Sir John Horsford, Commandant of the Bengal Artillery, claimed that the Nepal war had shown an increase in the number of gun lascars to be essential. He wanted a special corps of store lascars "to attend on the march and arrange in the park on coming to the ground of encampment, all the ordnance stores carried in the field". The lack of such a corps made it necessary to send extra gun lascars whenever artillery companies were detached on service, with the result that companies remaining at the station in question were deprived of some of theirs. Consequently, if another train was ordered out, "which frequently happened in the late war with Nepal", recourse had to be made either to new recruits, untrained and inexperienced, or to the personnel of the magazine at the station. "Consequently, particularly in the late Nepal war, incessant complaints were received from the commissaries of ordnance of their men being detached... all this gross mischief at a time of the most active preparation in the respective magazines, and when every man of the establishment and twice their number were in requisition." - Memoir on Artillery, 1816.

Despite this emphatic recommendation, and despite subsequent increases in the corps of artillery, the number of lascars does not appear to have been increased. In 1827, in fact, it was considerably less than it had been in 1814 (Cardew, Bengal Native Army, p. 162), so that the proportion of lascars had decreased from one to each artillerist to one to every five.

61. The Englishman, 30th Oct., 1846. The author was Major William Hough. During the financial year 1814, a total of 9,791 sonaut rupees was paid to commanding officers on account of secret intelligence guides, and hiracarrahs. This was less than half the amount spent on stationery for the military department during the same period Bengal Annual Military Statement, f. 223.

62. Military Letter to Bengal, 16th April, 1817, paras. 139, 140, 141.

63. Mins. of Ev., 1832, Sec. 5, p. 89; Cardew, op. cit., pp. 139-40. 1825 took the form of irregular battalions - Lee Warner, Dalhousie, vol. ii, p. 281 .

64. See, for example, "Carnaticus", "A General View of Our India Army": A.J., vol. xi, no. 65, May, 1821, p. 432; Sketches of the Goorkha War, p. xi; Badenach, Inquiry, pp. 5, 9-10. Dalhousie was still pleading for an increase on the eve of the Mutiny - Lee Warner, op. cit., vol. ii, p. 283. Sir Henry Lawrence, on the other hand, stressed 
64.. that quality was more important than quantity alone - op. cit.,
p. 27 .

65. Barat, op. cit., pp. 106-07.

66. Lord Roberts of Kandahar, Forty One Years in India, vol. i, p. 436.

67. Ibid., p. 437 , fn.

68. Military Letter to Bengal, 22nd March, 1816; Military Letter from Bengal, 27th Sept., 1816, para. 125; Mil. Cons., 13th Sept., 1816, nos. 41, 42; anecdotes entitled "From my Notebook": E.I.U.S.J., vol. iii, Aug., 1834, p. 91. By 1846 the design had been changed to "a tin with three divisions, to contain ten rounds each, and a wooden former to rest on the tin, to contain twenty-six rounds more": The Englishman, 30th Sept., 1846.

69. Political Letter to Bengal, 13th Oct., 1815: P.R.N.W., P. 548 .
My italics.

70. Sketches of the Goorkha War, pp. $x, 31,51$.

71. Major William Hough, in The Englishman, 27th Oct., 1846. .

72. Gov. Gen. to Vice Pres., 9th Feb., 1815: Sec. Cons., 2lst March,
1815, no. 1. para. 9. 


\section{BIBLIOGRAPHY}

\section{Manuscript Sources.}

a) India Office Records: Commonwealth Office, Orbit House, Blackfriars

Secret Letters from Bengal.

Military Letters from Bengal.

Military Letters to Bengal.

Enclosures to Secret Despatches from Bengal (E.S.D.B.)

Bengal Secret and Political Consultations (Sec. Cons.)

Bengal Political Consultations (Pol. Cons.)

Bengal Military Consultations (Mil. Cons.)

Home Miscellaneous Records (Home Misc.)

Personal Records

Maps and Plans. b) India Office Library Manuscripts, Commonwealth Office, Orbit House,

The Raffles Collection: MSS/EUR/C/34. Special Military Collections: L/Mil/5/391

The Papers of Lt. Col. John Lewis Stuart: MSS/EUR/D/668

Letters to John Adam and Charles Ricketts: MSS/EUR/D/585

The Moorcroft Papers: MSS/EUR/F/38

The Stubbs Papers: MSS/MISC/348/MR

MS History of Sikkim, compiled by Their Highnesses the Maharaja Sir Thutob Namgyal and Maharani Yeshay Dolma of Sikkim in 1908: MSS/EUR/E/78

"Regimental Histories of the Indian Army": a bibliography by M.A. Myers, 1957: MSS/EUR/C/142.

c) Library of the Royal United Services Institution, Whitehall, London. The Correspondence of Sir George Nugent: MM/181, and folder marked "Maps and Plans".

d) The University Library, Cambridge.

The Ludlow Papers: MSS AD $7450 / 1$ and AD $7450 / 2$.

e) Public Records Office, Chancery Lane, London.

Private Out-Letters of the Commander in Chief: MSS/WO/3/610. 
f) National Army Museum, Camberley, Surrey.

The Papers of Sir Jasper Nicolls (unclassified).

g) Regimental Muse'm of the King's Shropshire Light Infantry, Copthorne

Transcriptions by $W$. Rogerson of the private journals of Captain Henry Sherwood and Captain Charles Chepmell.

h) Library of the Royal Artillery Institution, Woolwich, London, S.E.

"Memoirs on Artillery, Referring to the Present Establishment of that Arm in the Bengal Presidency", by Major-General Sir John Horsford, K.C.B., 1801 and 1816: MS/15.

i) Library of the Royal Army Medical College, Millbank, London.

MS notebook entitled "Remarks and Observations on the Health of Troops and Metereological Observations" among the papers of John Francis Smet, Surgeon to H.M. 8th Dragoons.

j) National Archives of India, Janpath, New Delhi.

Bengal Annual Military Statement, 1813/1814, 1814/1815: 2861/68/R.

\section{Official Publications}

Papens Respecting the Nepaul War, Printed for the Court of Proprietors of the East India Company: London, 1824 (P.R.N.W.)

C.U. Aitchison, A Collection of Treaties, Engagements and Sanads Relating to India and Neighbouring Countries, volume XIV, revised edition: Calcutta, 1929.

Political Missions to Bootan: Bengal Secretariat Office, Calcutta, 1865.

Minutes of Evidence taken before the Committee of the Whole House and the Select Committee on the Affairs of the East India Company: ordered by the House of Commons to be printed, 1813 (Mins. of Ev., 1813).

IIIrd and IVth Reports from the Select Committee of the House of Commons on the Affairs of the East India Company (1811-12), 
Minutes of Evidence taken before the Select Committee of the House of Commons on the Affairs of the East India Company...1832: Printed by order of the Court of Directors, 1833. (Mins. of Ev., 1832)

Report on East India Affairs from the Select Committee of the House of Commons, 1832 (1832 Report).

The Marquis of Hastings' Summary of the Operations in India, with their Results, from the 30th April 1814 to the 31st January 1823: General Appendix II to 1832 Report.

Events at the Court of Ranjit Singh 1810-1817: Punjab Government Records Office Monograph no. 17, edited by G. T. Garrett: Lahore, 1939.

Selections from the Punjab Government Records, volume 2 (Records of the Ludhiana Agency, 1808-15): Lahore, 1911. (Ludhiana Records).

Army Lists.

Selections from the Records of the Government of Bengal, vol. xxvii: Calcutta, 1857 (S.R.G.B.)

The Panjab States Gazetteer, vol. viii (The Simla Hill States): Panjab Government Press, Lahore, 1911.

The East India Register.

Historical Papers Relating to Kumaun, 1809-1842, edited by B. P. Saksena: Government Record Office, Allahabad, 1956.

\section{Periodicals and Newspapers}

Asiatic Journal and Monthly Register, London. (A.J.)

Asiatick Researches, Calcutta. (A.R.)

Calcutta Monthly Joumal, Calcutta (‥M.J.)

Calcutta Review, Calcutta (C.R.)

East India United Services Journal and Military Magazine, Calcutta (E.I.U.S.J.)

The Englishman and Military Chronicle, Calcutta.

Gentleman's Magazine, London.

Imperial and Asiatic Quarterly Review, London. (I.A.Q.R.) 
Journal Asiatique, Paris. (J.A.)

Journal of the Royal Asiatic Society, London, (J.R.A.S.)

Journal of the Royal Asiatic Society of Bengal, Calcutta. (J.R.A.S.B.)

Journal of the Society for Army Historical Research, London. (J.S.A.H.R.)

Journal of the United Services Institute of India, (J.U.S.I.I.)

Journal of the Uttar Pradesh Historical Society, Lucknow. (J.U.P.H.S.)

$\frac{\text { Proceedings of the Meetings of the Indian Historical Records Commission, }}{\text { Calcutta. (P.I.H.R.C.) }}$

Regimental Journal of the King's Shropshire Light Infantry.

United Services Magazine, London. (U.S.M.)

\section{Other Works.}

Anon., Military Sketches of the Goorkha War in India in the Years 1814,
\[ 1815 \text { and 1816: London, } 1824 . \]

Anon., Memoir of Sir R.R. Gillespie: London, 1816.

Anon., Sketches of India, Written by an Officer for Fireside Travellers at Home, second edition: London, 1824. Aspinall, A. (ed.), The Letters of King George IV, 1812-1830: Cambridge,
1938. Atkinson, C. T., Regimental History of the South Wales Borderers, 1689-1937:
Cambridge, 1937 .

Atkinson, Edwin T., The Himalayan Districts of the North West Provinces of
India: Allahabad, 1884 .

Auber, Peter, Analysis of the Constitution of the East India Company:
London, 1826 . Badenach, Walter, An Inquiry into the State of the Indian Army: London,
1826.

Barat, Amiya, The Bengal Native Infantry, the Organization and Discipline
$\quad$ 1796-1852:

Basham, A.L., The Wonder that was India: London, 1954. 
Bastin, J., (Ed.), The Journal of Thomas Otho Travers, 1813-1820: Singapore, 1960 .

Boulger, Demetrius Charles, The Life of Sir Stamford Raffles: London, 1897.

Bute, the Marchioness of, (Ed.), The Private Journal of the Marquis of Hastings, London, 1858.

Camman, Schuyler, Trade through the Himalayas: Princeton, 1951.

Campbell, George, Modern India: A Sketch of the System of Civil Government: London, 1852.

Cannon, Richard, Historical Record of the 5 rd or Shropshire Regiment of Foot: London, 1849.

Historical Record of the 8th or King's Royal Irish Regiment of Hussars; London, 1837.

Cardew, F. G., A Sketch of the Services of the Bengal Native Army, revised edition: Calcutta, 1903.

Carey, W. H., The Good Old Days of Honorable John Company: Calcutta, 1906.

Chaudhuri, K. C., Anglo-Nepalese Relations from the Earliest Times of the British Rule in India till the Gurkha War: Calcutta, 1960.

Clark, T. W., Introduction to Nepali: Cambridge, 1963.

Compton, Herbert, A Particular Account of the European Military Adventurers Hindustan: London, 1892 .

Coomaraswamy, Ananda K., The Arts and Crafts of India and Ceylon (reprint): New York, 1964.

Crawford, D. G., A History of the Indian Medical Service: London, 1913.

Cunningham, J. D., History of the Sikhs, Indian reprint: Delhi, 1955.

Desgodins, C.H., Le Thibet, d'Apres la Correspondance des Missionaires, deuxieme edition: Paris, 1885 .

Dictionary of National Biography.

The East India Military Calendar, London, 1823.

Embree, Ainslee, Charles Grant and British Rule in India: London, 1962.

Fortescue, J. W., A History of the British Army, vol. XI: London, 1930. 
Fraser, J. B., Journal of a Tour through Part of the Snowy Range of the Himala Mountains and to the Sources of the Rivers Jumna and Ganges: London, 1820. Military Memoir of Lieutenant-Colonel James Skinner: London, 1851.

Gleig, G. R., Memoirs of the Life of the Right Honorable Warren Hastings: London, 1841.

Greenberg, Michael, British Trade and the Opening of China, 1800-1842: Cambridge, 1951.

Grey, C., and Garrett, G. T., European Adventurers of North India: Lahore, 1929.

Hadow Jenkins, L., General Frederick Young: London, 1923.

Hamilton, C. J., The Trade Relations between England and India: Calcutta, 1919.

Hamilton, Francis Buchanan, An account of the Kingdom of Nepaul and of the Territories annexed to this Dominion by the House of Gurkha: Edinburgh, 1819 .

Hamilton, Walter, Gazetteer of Hindustan and the Adjacent Countries, second edition: London, 1820.

Harvey Darton, F.J., (Ed.), The Life and Times of Mrs Sherwood: London, n.d.

Heber, R., Narrative of a Journey through the Upper Provinces of India: fourth edition: London, 1829.

Henry, Walter, Events of a Military Life, second edition: London, 1843.

Hodson, V. C. P., A List of the Officers of the Bengal Army, 1758-1834: London, 1927-1946.

Hough, William: The Practice of Courts Martial and other Military Courts: Calcutta, 1834 . to $1849:$ Lolitical and Military Events in British India from the Year 1756

Huc, E., Souvenirs d'un Voyage dans la Tartarie, le Tibet, et la Chine, Pendant les Annees 1844, 1845, et 1846: Paris, 1850.

Hutchison, J., and Vogel, J. Ph., History of the Panjab Hill States: Lahore, 1933.

Ilbert, Courtenay, The Government of India, second edition: Oxford, 1907. 
Jackson, Major Donovan, India's Army: London, 1940.

jNavali, Surya Vikram, Amar Singh Thapa 1748-1816: Darjeeling, Samvat 2000.

Kaye, J. W., The Life and Correspondence of Charles, Lord Metcalfe: London, 1854 .

- Selections from the Papers of Lord Metcalfe: London, 1855.

Lives of Indian Officers: London, 1867. - 1875 A History of the Sepoy War in India, seventh edition: London,

Kelly, Sophia, The Life of Mrs Sherwood: London, 1854.

Kincaid, Dennis: British Social Life in India: 1608-1937: London, 1938.

Kirkpatrick, W., An Account of the Kingdom of Nepaul: London, 1811.

Landon, Percival, Nepal: London, 1928.

Lawrence, H. M., Essays Military and Political, Written in India: London, 1859.

Lee-Warner, Sir William, The Life of the Marquis of Dalhousie: London, 1904.

Levi, Sylvain, Le Nepal: Etude Historique d'un Royaume Hindu: Paris, 1905-07.

Li, Tieh-Tseng, Tibet, Today and Yesterday: New York, 1960.

Lorraine Petre, F., The Royal Berkshire Regiment: Reading, 1925.

Low, C. R., Life and Correspondence of Field Marshall Sir George Pollock: London, 1873 .

Mackenzie, Alexander, The History of the Fraser's of Lovat: Inverness, 1894.

Malcolm, Sir John, Political History of India: London, 1826.

Markham, C. R. (Ed.), Narratives of the Mission of George Bogle to Tibet and of the Journey of Thomas Manning to Lhassa: London, 1876.

Maron, Stanley, Rose, Leo, et al, A Survey of Nepal Society: Human Relations area Files, South Asia Project, University of California, 1956.

Martin, Sir J. Ranald, The Sanitary History of the British Army in India, Past and Present: London, 1868. 
Martin, R. Montgomery, (Ed.), The Despatches, Minutes, and Correspondence of the Marquess Wellesley: London, 1836.

China: Political, Commercial, and Social: London, 1847.

Montague, Mrs. F. M., Memorials of the Family of Wood of Largo:

London, 1863 (privately printed).

Morse, H. B., The Chronicles of the East India Company Trading to China 1635-1834: Oxford, 1926 .

Murray, R. H., History of the King's Royal Irish Hussars: Cambridge, 1923.

Northey, W. Brook, and Morris, C. J., The Gurkhas: Their Manners, Customs, and Country: London, 1928.

Nugent, Maria, Lady, A Journal from the Year 1811 to the Year 1815: London, 1839.

Oldfield, Henry Ambrose: Sketches from Nipal: London, 1880.

Parks, Mrs. Fanny, Wanderings of a Pilgrim in Search of the Picturesque: London, 1850.

Parlby, Captain S., The British Indian Military Repository: Calcutta, 1823.

Pearse, Col. Hugh, The Hearseys: Five Generations of an Anglo-Indian Family: London, 1905.

Petech, Luciano, Medieval History of Nepal (Serie Orientale Roma, vol. x): Rome, 1958.

Prinsep, Henry, T., History of the Political and Military Transactions in India during the Administration of the Marquis of Hastings: London, 1825 .

Pryme, Jane Townley and Bayne, Alicia, Memorials of the Thackeray Family: London, 1879 (privately printed).

Roberts of Kandahar, Lord, Forty One Years in India: London, 1897.

Ross of Bladesburg, Major, The Marquis of Hastings, Oxford, 1900.

Ross, Charles, (Ed.), The Correspondence of Charles, First Marquis Cormwallis: London, 1859.

Rouire, D., La Rivalite Anglo-Russe an XIXe Siecle en Asie: Paris, 1908.

Royal Military Calendar, third edition: London, 1820.

Ram, Sita, From Sepoy to Subadar, translated by Lt. Col. Norgate, third edition, edited by D. C. Phillot: Calcutta, 1911. 
Shawe, W. B., History of the Second Regiment of Bengal Native Light Infantry: Julpigoree, 1872.

Shipp, John, Memoirs of the Extraordinary Military Career of John Shipp, A New Illustrated Edition with an Introduction by H. Manners Chichester: London, 1894.

Sinha, N.K., and Dasgupta, A. K., (Eds.), Selections from the Ochterlony Papers in the National Archives of India: Calcutta, 1964.

Sleeman, W. H., Rambles and Recollections of an Indian Official: London, 1844. A Journey through the Kingdom of Oude in 1849-50: London, 1858 .

Stubbs, F. W., A History of the Bengal Artillery: London, 1877.

Tucci, G., Preliminary Report on Two Scientific Expeditions in Nepal (Serie Orientale Roma, vol. $\mathrm{x}$ ): Rome, 1956.

Turner, R. L., Comparative and Etymological Dictionary of the Nepali Language: London, 1931.

Turner, Samuel, An Account of an Embassy to the Court of the Teshoo Lama in Tibet: London, 1800.

Twemlow, George, Considerations on Tactics and Strategy, second edition: London, 1855.

Wakeham, Eric, The Bravest Soldier: Sir Rollo Gillespie, 1786-1814: London, 1937.

I Wallaee, Lt. T, Fifteen Years in India, or Sketches of a Soldier's Life: London, $18 \overline{2} 3$.

Watkins, Walter Kendall, The Scotch Ancestry of Major-General Sir David Ochterlony, Bart., a Native of Boston in New England: Boston, 1902 (privately printed).

Webb, E. H., A History of the Services of the 17th (the Leicestershire) Regiment, second edition: London, 1912 .

Welsh, Col. James, Military Reminiscences: London, 1830.

Wheeler, J. Talboys, A Short History of India and the Frontier States of Afghanistan, Nipal and Burma: London, 1880.

White, George Francis, Views in India, Chiefly Among the Himalaya Mountains: London, 1837. 
Williams, G. R. C., Historical and Statistical Memoir of Dehra Doon: Roorkee, 1874.

Wilson, H. H., (Ed.), Travels in the Himalayan Provinces of Hindustan and the Panjab by William Moorcroft and George Trebeck from 1819 to 1825: London, 1841 .

The History of British India: London, 1845 .

Wilson, Minden, A History of the Behar Indigo Factories: Calcutta, 1908.

Woodyatt, Nigel, Regimental History of the 3rd, Queen Alexandra's Own, Gurkha Rifles: London, 1929.

Wright, Daniel (Ed.), History of Nepal, Indian reprint: Calcutta, 1958.

Wurtzburg, C. E., Raffles of the Eastern Isles: London, 1954.

Young, H.A., The East India Company's Arsenals and Manufactories: Oxford, 1937. 


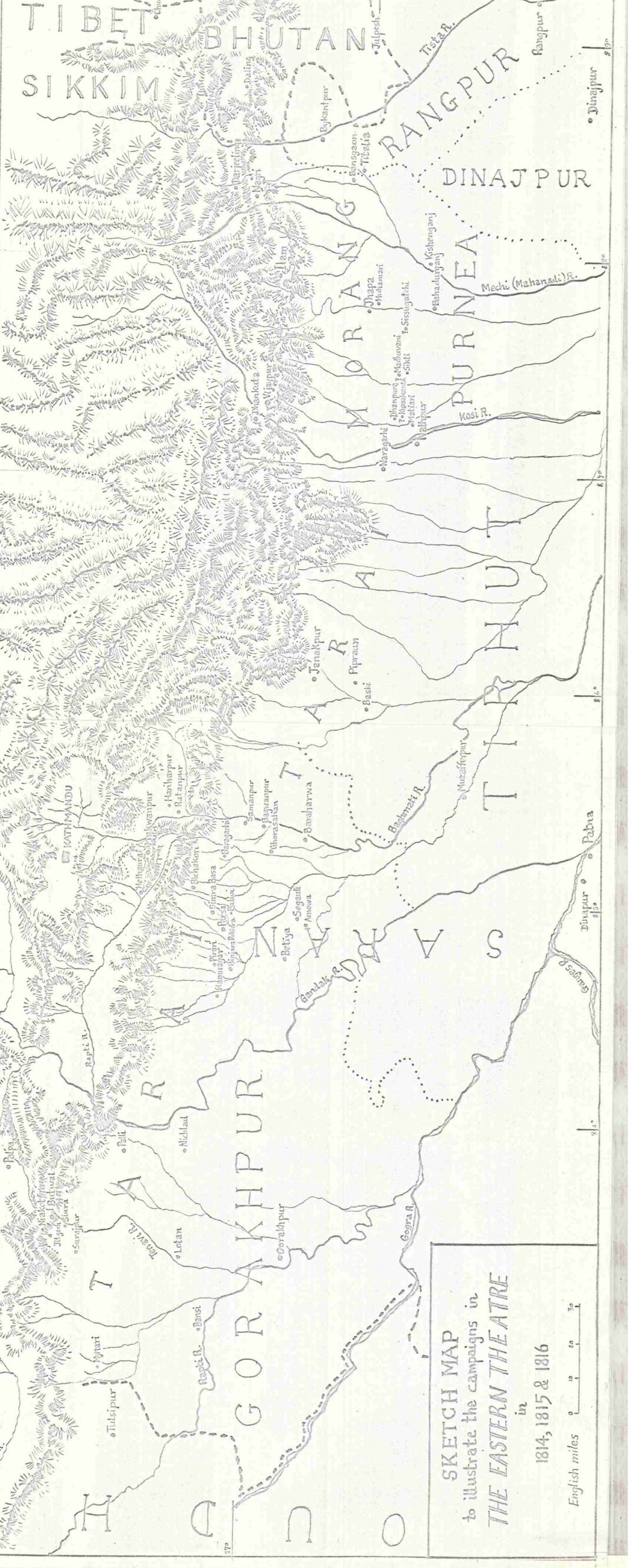


